\title{
RAND EDUCATION
}

THE ARTS

CHILD POLICY

CIVIL JUSTICE

EDUCATION

ENERGY AND ENVIRONMENT

HEALTH AND HEALTH CARE

INTERNATIONAL AFFAIRS

NATIONAL SECURITY

POPULATION AND AGING

PUBLIC SAFETY

SCIENCE AND TECHNOLOGY

SUBSTANCE ABUSE

TERRORISM AND HOMELAND SECURITY

TRANSPORTATION AND INFRASTRUCTURE

WORKFORCE AND WORKPLACE
This PDF document was made available from www.rand.org as a public service of the RAND Corporation.

Jump down to document $\nabla$

The RAND Corporation is a nonprofit research organization providing objective analysis and effective solutions that address the challenges facing the public and private sectors around the world.

\section{Support RAND}

Purchase this document

Browse Books \& Publications

Make a charitable contribution

\section{For More Information}

Visit RAND at www.rand.org

Explore RAND Education

View document details

\section{Limited Electronic Distribution Rights}

This document and trademark(s) contained herein are protected by law as indicated in a notice appearing later in this work. This electronic representation of RAND intellectual property is provided for noncommercial use only. Permission is required from RAND to reproduce, or reuse in another form, any of our research documents for commercial use. 
This product is part of the RAND Corporation technical report series. Reports may include research findings on a specific topic that is limited in scope; present discussions of the methodology employed in research; provide literature reviews, survey instruments, modeling exercises, guidelines for practitioners and research professionals, and supporting documentation; or deliver preliminary findings. All RAND reports undergo rigorous peer review to ensure that they meet high standards for research quality and objectivity. 


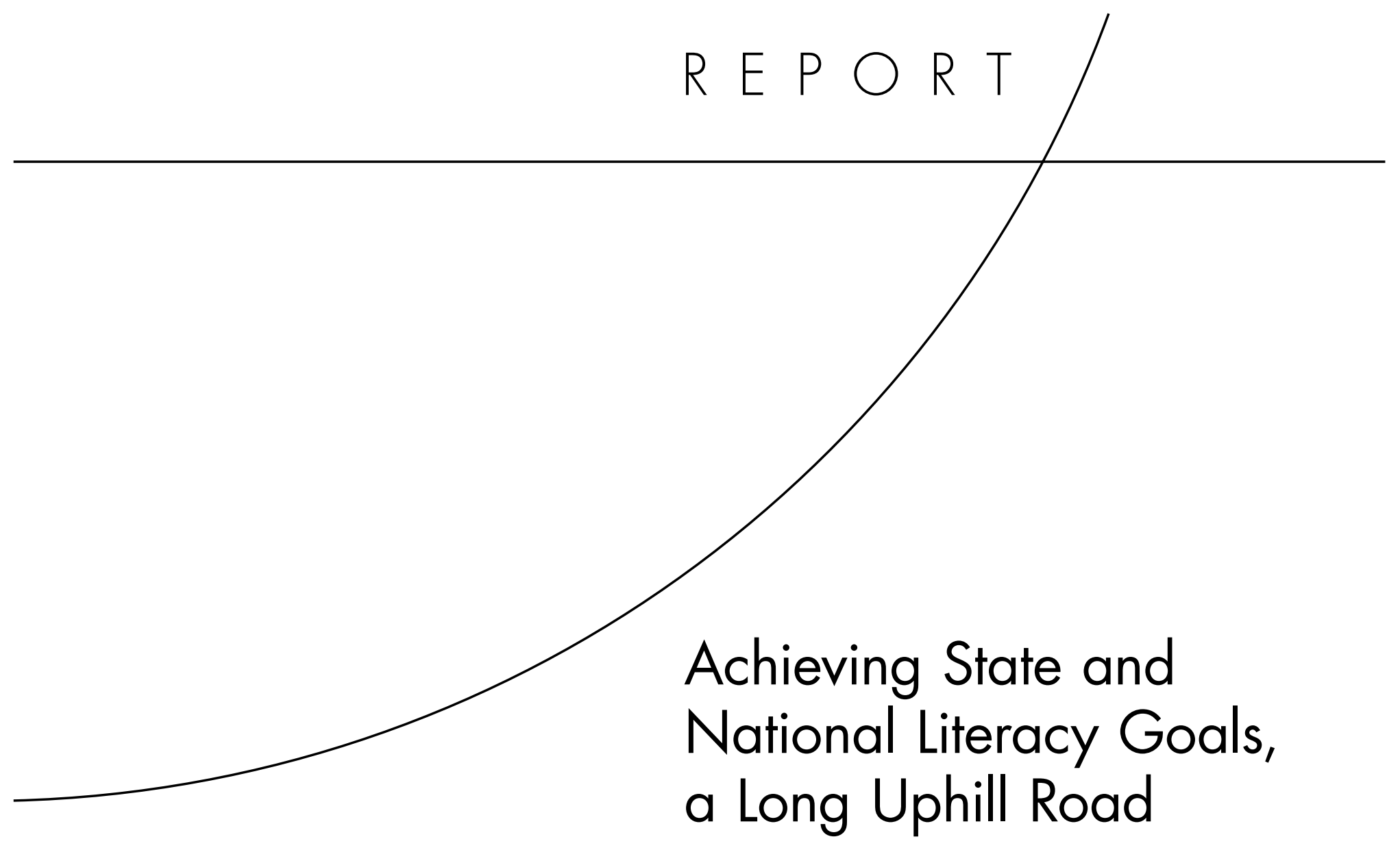

A Report to Carnegie Corporation of New York

Jennifer Sloan McCombs, Sheila Nataraj Kirby, Heather Barney, Hilary Darilek, Scarlett Magee

Prepared for Carnegie Corporation of New York 
The research described in this report was conducted within RAND Education for Carnegie Corporation of New York.

Library of Congress Cataloging-in-Publication Data

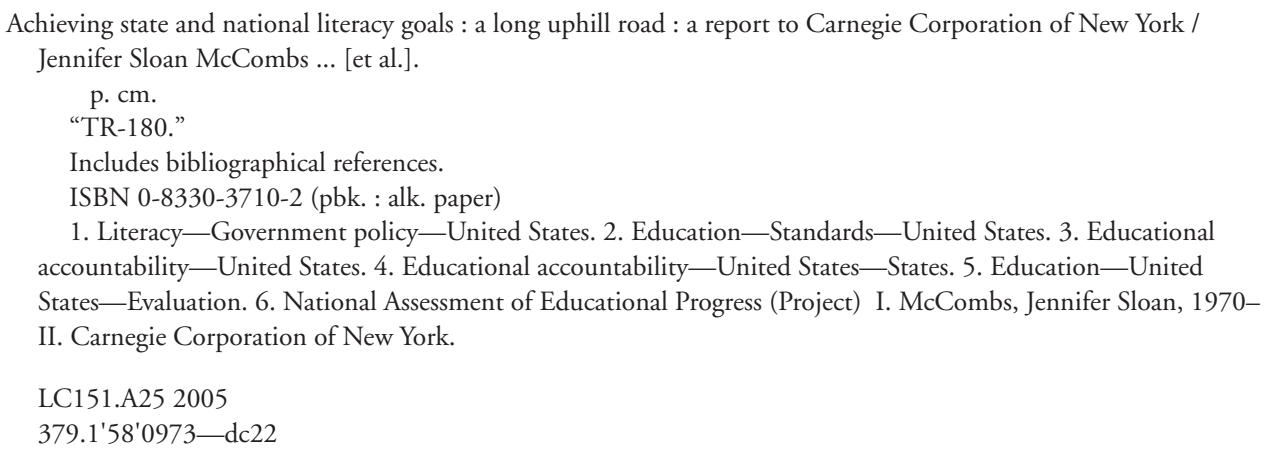

The RAND Corporation is a nonprofit research organization providing objective analysis and effective solutions that address the challenges facing the public and private sectors around the world. RAND's publications do not necessarily reflect the opinions of its research clients and sponsors.

RAND $^{\circledR}$ is a registered trademark.

(C) Copyright 2005 Carnegie Corporation of New York

All rights reserved. No part of this book may be reproduced in any form by any electronic or mechanical means (including photocopying, recording, or information storage and retrieval) without permission in writing from RAND.

Published 2005 by the RAND Corporation

1776 Main Street, P.O. Box 2138, Santa Monica, CA 90407-2138

1200 South Hayes Street, Arlington, VA 22202-5050

201 North Craig Street, Suite 202, Pittsburgh, PA 15213-1516

RAND URL: http://www.rand.org/

To order RAND documents or to obtain additional information, contact

Distribution Services: Telephone: (310) 451-7002;

Fax: (310) 451-6915; Email: order@rand.org 


\section{Preface}

To succeed in post-secondary education or employment, students must emerge from high school possessing literacy skills and critical-thinking skills so that they can extract and construct meaning from a variety of texts. Recent reform efforts have yielded positive results in improving reading achievement for the nation's children in the primary grades. However, many children are not moving beyond basic decoding skills_-deciphering and/or sounding out - to fluency and comprehension, even as they advance to the fourth grade and classes in history, mathematics, and science (deLeon, 2002).

In an effort to focus national attention on the problem of adolescent literacy, Carnegie Corporation of New York launched a new initiative, Advancing Literacy, to promote policy, practice, and research in the field of adolescent literacy, which encompasses reading and writing in grades 4 through 12 . Its new initiative was the result of a two-year review that showed that, although substantial attention had been devoted to grades $\mathrm{K}-3$, adolescent literacy remained "an orphaned responsibility in the K-12 world" (deLeon, 2002, p. 3). As part of this initiative, Carnegie decided to appoint an Advisory Council to propose promising strategies for the improvement of adolescent literacy. As a first step, Carnegie asked the RAND Corporation to convene a small study group for one year to lay the foundation for the work of the larger Advisory Council. Carnegie also asked RAND to produce a comprehensive, quantitative survey of the state of adolescent reading and writing achievement in the United States.

RAND gathered information from the 50 states and the District of Columbia (DC) on state assessment systems and on the performance of students in reading, English language arts, and writing on state assessments. To examine the relative performance of students against national standards, the RAND team also used data from the 2003 state component of the National Assessment of Educational Progress (NAEP) in reading and the 2002 state component of the NAEP in writing. This report documents the results of this research and provides a portrait of the condition of adolescent literacy as measured by these national and state assessments. The appendices contain individual state write-ups for the 50 states and the District of Columbia (DC) that describe the assessment systems; the content, format, and performance levels of reading, writing, and English language arts assessments between 4th and 12th grades; and student performance on those assessments.

Achieving State and National Literacy Goals, a Long Uphill Road: A Report to Carnegie Corporation of New York should be of interest to educational researchers and education policymakers at the national, state, and local levels who are working to improve educational opportunities and learning for all students. 
Achieving State and National Literacy Goals, a Long Uphill Road

This research was conducted within RAND Education, a division of the RAND Corporation, and reflects RAND Education's mission to bring accurate data and careful, objective analysis to the national debate on education policy. 


\section{Contents}

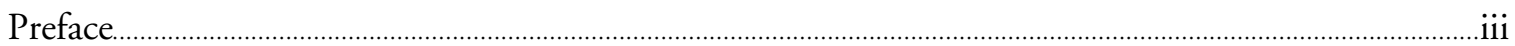

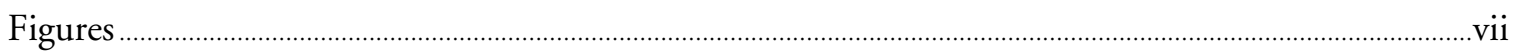

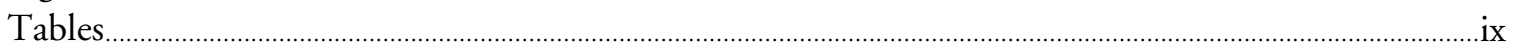

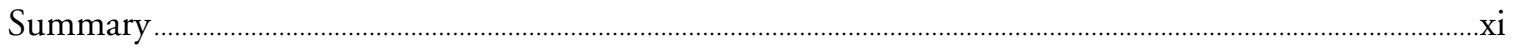

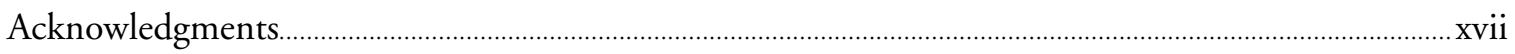

CHAPTER ONE

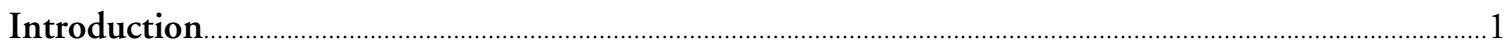

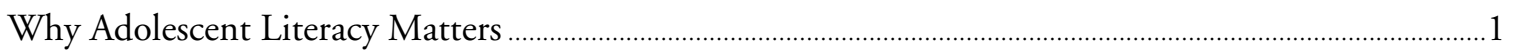

Teaching Students to Read to Learn: An "Orphaned Responsibility" in the K-12 World ......................2

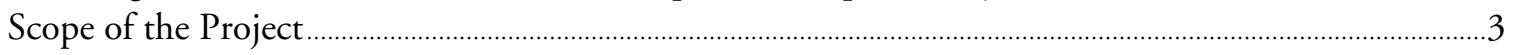

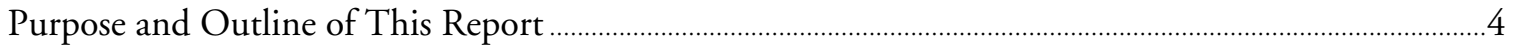

CHAPTER TWO

State and National Assessments of Adolescent Literacy ................................................................................

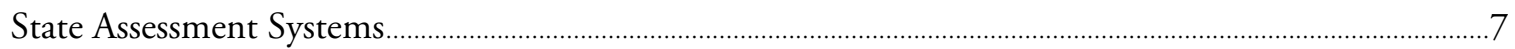

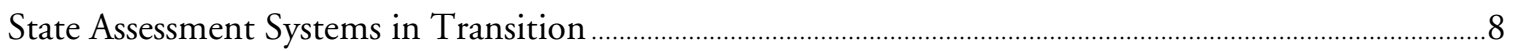

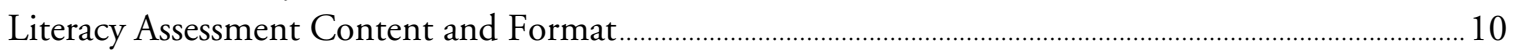

State Assessment Achievement Standards ............................................................................................................... 11

National Assessment of Educational Progress ............................................................................................. 12

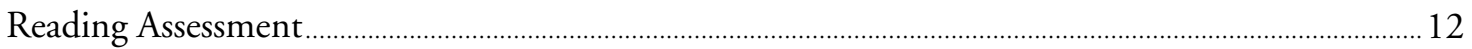

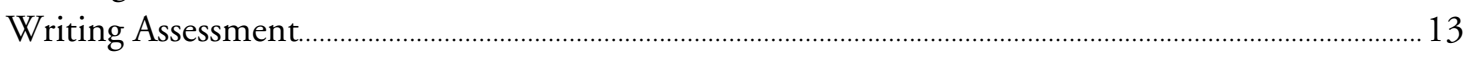

CHAPTER THREE

The Current State of Adolescent Literacy Achievement: Results from State Assessments ................. 17

What We Present in This Chapter ................................................................................................................................. 17

Performance of Elementary School Students.............................................................................................................2

Reading Assessments: Overall Pass Rates.............................................................................................................2

Reading Assessments: Differences in Performance Among Students, Disaggregated by

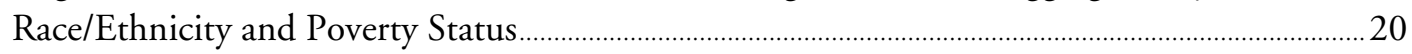

Writing Assessments.................................................................................................................................... 24

Performance of Middle School Students ........................................................................................................................2

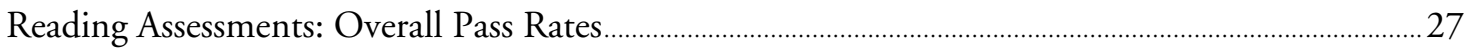

Reading Assessments: Differences in Performance Among Students, Disaggregated by

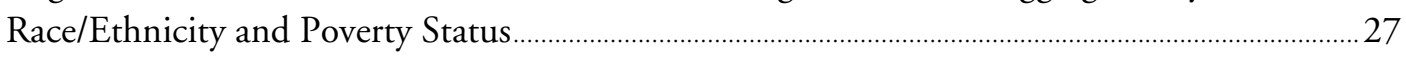




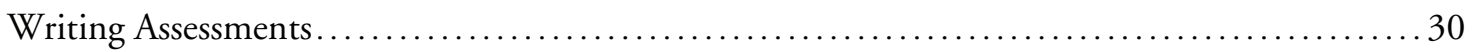

Performance of High School Students ............................................ 34

Student Performance on Graduation Assessments .................................... 34

Student Performance on High School Assessments Not Required for Graduation ............... 36

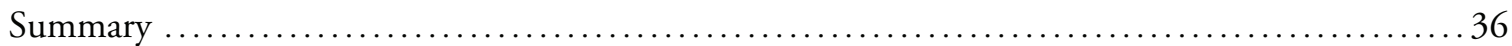

\section{CHAPTER FOUR}

The Current State of Adolescent Literacy Achievement: Results from the National Assessment of

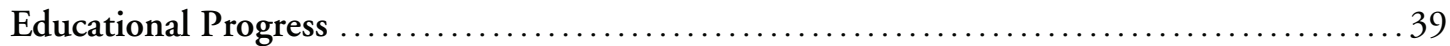

Performance of 4th-Graders ............................................................ 39

Reading Assessment: Overall Proficiency Rates ........................................ 39

Reading Assessment: Differences in Performance Among Students, Disaggregated by

Race/Ethnicity and Poverty Status ........................................... 39

Writing Assessment....................................................... 42

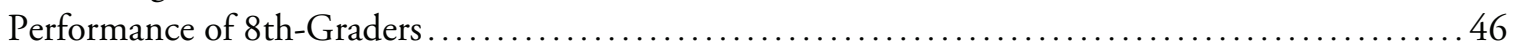

Reading Assessment: Overall Proficiency Rates .................................. 46

Reading Assessment: Differences in Performance Among Students, Disaggregated by

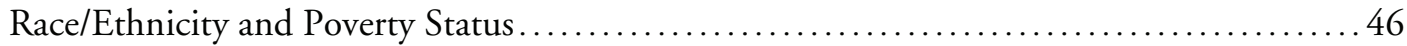

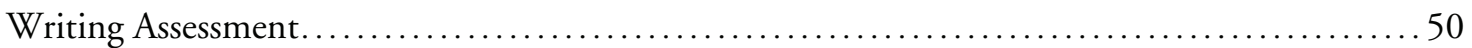

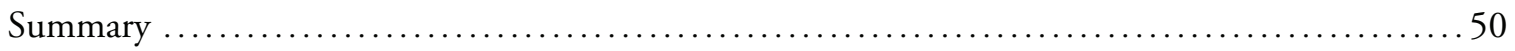

\section{CHAPTER FIVE}

The Current State of Adolescent Literacy Achievement: Reconciling Results from State and

National Assessments...................................................... 55

Overall Proficiency Rates ...................................................... 55

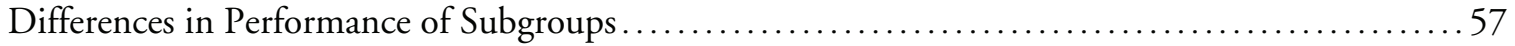

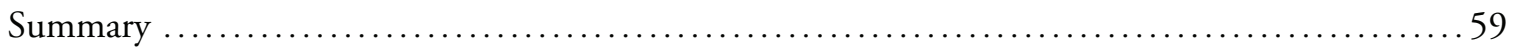

\section{CHAPTER SIX}

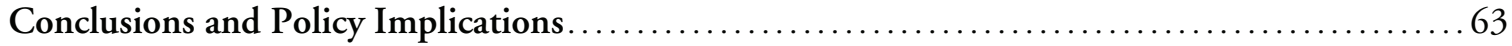

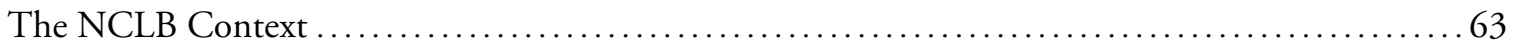

Meeting State and National Literacy Goals: A Long Uphill Road ............................. 64

Multiple Sources of Data Regarding Literacy Achievement Help Provide a More

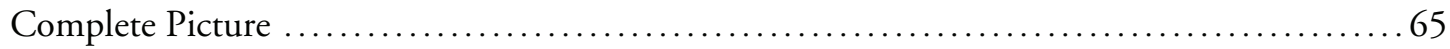

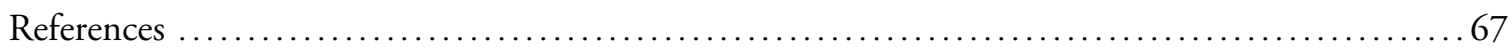




\section{Figures}

3.1. Pass Rates of Elementary School Students on State Reading Assessments, 2001-2002/2002-2003

3.2. Differences in Pass Rates of White and African American Elementary School Students on State Reading Assessments, 2001-2002/2002-2003

3.3. Differences in Pass Rates of White and Hispanic Elementary School Students on State Reading Assessments, 2001-2002/2002-2003.

3.4. Differences in Pass Rates of Economically Advantaged and Economically Disadvantaged Elementary School Students on State Reading Assessments, 2001-2002/2002-2003 _............25

3.5. Pass Rates of Elementary School Students on State Writing Assessments, 2001-2002/2002-2003

3.6. Pass Rates Of Middle School Students on State Reading Assessments, 2001-2002/2002-2003

3.7. Differences in Pass Rates of White and African American Middle School Students on State Reading Assessments, 2001-2002/2002-2003.

3.8. Differences in Pass Rates of White and Hispanic Middle School Students on State Reading Assessments, 2001-2002/2002-2003

3.9. Differences in Pass Rates of Economically Advantaged and Economically Disadvantaged Middle School Students on State Reading Assessments, 2001-2002/2002-2003.

3.10. Pass Rates of Middle School Students on State Writing Assessments, 2001-2002/ 2002-2003

4.1. Percentage of 4th-Grade Students Scoring "Proficient" and Above on the National Assessment of Educational Progress 2003 Reading Assessment. 40

4.2. Difference in Percentages of White and African American 4th-Grade Students Scoring "Proficient" and Above on the National Assessment of Educational Progress 2003 Reading Assessment.

4.3. Difference in Percentages of White and Hispanic 4th-Grade Students Scoring "Proficient" and Above on the National Assessment of Educational Progress 2003 Reading Assessment.

4.4. Difference in Percentages of Economically Advantaged and Disadvantaged 4th-Grade Students Scoring "Proficient" and Above on the National Assessment of Educational Progress 2003 Reading Assessment.

4.5. Percentage of 4th-Grade Students Scoring "Proficient" and Above on the National Assessment of Educational Progress 2002 Writing Assessment.

4.6. Percentage of 8th-Grade Students Scoring "Proficient" and Above on the National Assessment of Educational Progress 2003 Reading Assessment. 
4.7. Difference in Percentages of White and African American 8th-Grade Students Scoring "Proficient" and Above on the National Assessment of Educational Progress 2003

Reading Assessment

4.8. Difference in Percentages of White and Hispanic 8th-Grade Students Scoring "Proficient" and Above on the National Assessment of Educational Progress 2003

Reading Assessment.

4.9. Difference in Percentages of Economically Advantaged and Disadvantaged 8th-Grade Students Scoring "Proficient" and Above on the National Assessment of Educational Progress 2003 Reading Assessment.

4.10. Percentage of 8th-Grade Students Scoring "Proficient" and Above on the National Assessment of Educational Progress 2002 Writing Assessment

5.1. Differences in Proficiency Rates of 4th-Grade Students: State Reading Assessments National Assessment of Educational Progress 2003 Reading Assessment.

5.2. Differences in Proficiency Rates of 8th-Grade Students: State Reading Assessments National Assessment of Educational Progress 2003 Reading Assessment. 


\section{Tables}

S.1. Average Differences in Proficiency Rates of 4th- and 8th-Grade Students, Disaggregated by Race/Ethnicity and Poverty Status: State Reading Assessments and National Assessment of Educational Progress 2003 Reading Assessment ....................... xiv

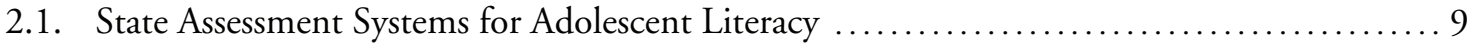

2.2. Achievement-Level Definitions for NAEP Reading Assessment, Grades 4 and $8 \ldots \ldots \ldots 13$

2.3. Achievement-Level Definitions for NAEP Writing Assessment, Grades 4 and $8 \ldots \ldots \ldots \ldots 15$

3.1. Elementary and Middle School Grades Reported for State Accountability Reading Assessments, by State .................................................. 18

3.2. Differences in Pass Rates of Elementary School Students, Disaggregated by Race/Ethnicity and Poverty Status: State Writing Assessments ................................ 26

3.3. Differences in Pass Rates of Middle School Students, Disaggregated by Race/Ethnicity and Poverty Status: State Writing Assessments ................................. 34

3.4. Results for First-Time Test Takers: High School Tests Required for Graduation,

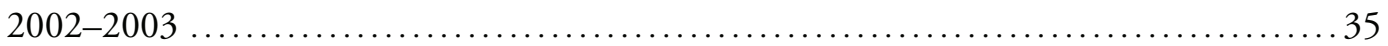

3.5. High School Results Not Linked to Graduation Requirements, 2002-2003 .............. 37

4.1. Differences in Proficiency Rates of 4th-Grade Students, Disaggregated by Race/Ethnicity and Poverty Status: 2002 National Assessment of Educational Progress Writing Assessment.

4.2. Differences in Proficiency Rates of 8th-Grade Students, Disaggregated by Race/Ethnicity and Poverty Status: National Assessment of Educational Progress 2002 Writing Assessment ......................................................... 53

5.1. Distribution of States by Percentage of 4th-Grade Students Scoring at the "Proficient" Level and Above on the State Reading Assessments and National Assessment of Educational Progress 2003 Reading Assessment ................................... 55

5.2. Distribution of States by Percentage of 8th-Grade Students Scoring at the "Proficient" Level and Above on the State Reading Assessments and National Assessment of Educational Progress 2003 Reading Assessment ....

5.3. Differences in Proficiency Rates of 4th-Grade Students, Disaggregated by Race/Ethnicity and Poverty Status: State Reading Assessments and National Assessment of Educational Progress 2003 Reading Assessment........................................... 59

5.4. Differences in Proficiency Rates of 8th-Grade Students, Disaggregated by Race/Ethnicity and Poverty Status: State Reading Assessments and National Assessment of Educational Progress 2003 Reading Assessment.............................................. 59

5.5. Differences in Proficiency Rates of 4th- and 8th-Grade Students, Disaggregated by Race/Ethnicity and Poverty Status: State Reading Assessments and National Assessment of Educational Progress 2003 Reading Assessment, Selected Samples .... 



\section{Summary}

Recent reform efforts in education have yielded positive results in improving reading achievement for the nation's children in the primary grades, but many children are not moving beyond basic decoding skills to fluency and comprehension, even as they advance to the fourth grade and classes in history, mathematics, and science. This lack of progress is especially troubling because adolescents are facing a post-secondary job market that demands high literacy skills.

In an effort to focus national attention on the problem of adolescent literacy, Carnegie Corporation of New York launched a new initiative, Advancing Literacy. Carnegie's objective is to advance adolescent literacy, which encompasses reading and writing in grades 4-12, by promoting policy, practice, and research in this field. As a first step, Carnegie asked the RAND Corporation to convene a small study group for one year to lay the foundation for the work of a larger Advisory Council and to undertake a study examining the state of adolescent achievement in literacy in the nation.

Our analysis focused on three research questions:

1. To what extent are adolescents (defined as students in the 4th through 12th grades) meeting state literacy goals, as measured by state assessments?

2. To what extent are adolescents meeting national literacy goals, as measured by the National Assessment of Educational Progress (NAEP)?

3. To what extent are the results from state assessments and the NAEP consistent with one another?

To answer these questions and to understand how states define and measure adolescent literacy and how students fare on assessments of those measures, we examined the state assessment systems adopted by the 50 states and the District of Columbia. ${ }^{1}$ For each state, we sought to briefly describe the assessments that are being used to measure literacy levels among adolescents, including how they are linked to content standards, the content and format of the assessments, and student performance on those assessments. We also describe how students are performing relative to national goals, as measured by the National Assessment of Education Progress (NAEP). We describe the NAEP reading and writing assessment, including the content and format, and student performance on that assessment. Our

\footnotetext{
1 The District of Columbia, being a large urban district, is quite different in nature from the states in terms of demographics, population, and educational governance. It offers a look at how students in a high-poverty, urban district perform and some of the challenges such districts face in trying to meet the No Child Left Behind (NCLB) goals.
} 
timeline did not allow for detailed analyses of these assessment or the results: Our purpose was simply to report publicly available data.

This report documents the results of RAND's research effort and provides a portrait of where the nation's adolescents stand relative to state and national literacy goals and how far we need to go to help our children achieve those goals.

\section{Under No Child Left Behind, All Students Should Become Proficient by 2014}

It is important to place the research in the context of the No Child Left Behind Act (NCLB), which requires states to adopt standards-based accountability systems that set challenging content and performance standards for all students. To ensure that students are meeting these standards, by 2005-2006, states must annually test all children in reading and math, in grades 3, 4, 5, 6, 7, 8, and at one grade in high school. By 2007-2008, states must test students in science at least once in grades 3-5, 6-9, and 10-12. States must establish goals for performance on the assessment and track performance for all students and subgroups of students (e.g., racial/ethnic groups, students with disabilities, migrant students). By the end of 12 years, all schools should have reached 100-percent proficiency-that is, all children in the school must pass the state test.

To meet these federal requirements, states are currently changing and expanding state testing programs, which will be used to hold schools accountable under the federal law. Schools that fail to make adequate yearly progress face escalating sanctions over time, such as being required to offer school choice or supplemental services and may include, among others, decreased decisionmaking; reconstituting the school staff; instituting a new curriculum based on scientifically based research; extending the school year or school day; and appointing an outside expert to advise the school. In addition, a growing number of states are holding students accountable by requiring that students pass high school assessments before they can graduate or to pass a given grade assessment to be promoted to the next grade.

\section{States Have a Long Way to Go to Meet State and National Literacy Goals}

We include data both from the NAEP and the state assessments to provide multiple indicators of student performance in the states and to show how students are faring with respect to national and state literacy goals. Note that, because of the differences in the tests themselves and the definitions of proficiency levels in the NAEP and state performance standards, these data are not directly comparable. While one could argue that state and national literacy goals should be reasonably similar, in reality there is debate regarding at what level standards should be set. For instance, there is debate about whether NAEP achievement standards are too ambitious and challenging (Linn, 2003). If NAEP achievement standards are indeed more rigorous and challenging than many state standards, then one would expect differences: Students would perform worse on the NAEP than on state assessments, and such differences would not imply that the data from state assessments are wrong or unreliable. Our purpose here is not to draw such inferences but simply to offer two different data points on adolescent literacy achievement measured against state and (arguably, more stringent) national literacy standards. We believe that it is important for state policymakers, practitioners, and parents to examine both sources of data and to make their own judgments regarding the rela- 
tive performance of their students against both sets of standards. In addition, under NCLB, states are now required to participate in the NAEP in order to help verify state results using a common measure; therefore, states need to become familiar with the NAEP, what it measures, and how this differs from their own assessments.

Our findings suggest some major concerns about the ability of states to meet the ambitious goal set by NCLB of 100-percent proficiency for all students.

First, in several states, fewer than half the students meet the state proficiency standards, and in no state do even half the students meet the NAEP national literacy standard of proficiency:

- The pass rates on the elementary-school state assessments (4th- or 5th-grade assessments) differed widely across states, ranging from 28 to 87 percent. In seven states, less than half of the students passed at the elementary level.

- Fourth-grade state proficiency rates on the 2003 NAEP Reading Assessment ranged from 10 to 43 percent, and the average state proficiency rate on the NAEP was 30 percent. Three states had proficiency rates of less than 20 percent; 15 states had proficiency rates of 20-29 percent; 30 states had proficiency rates of 30-39 percent. In only three states-Massachusetts, New Hampshire, and Connecticut-did the proportion of students scoring at the proficient level reach 40 percent and above.

- The pass rates on the middle-school state assessments ranged from 21 to 88 percent. Three states had pass rates of less than 30 percent. In 12 states, less than half of the students passed the reading assessment.

- Overall, between 10 and 43 percent of 8th-graders scored at the proficient level on the 2003 NAEP Reading Assessment. DC was the only jurisdiction to have a proficiency rate of less than 20 percent; New Hampshire and Massachusetts were the only states to have proficiency rates of 40 percent or higher. In 17 states, 20-29 percent of students scored proficient and above; in 31 states, 30-39 percent scored proficient and above. The average state proficiency rate of 8th-graders was 32 percent.

- Pass rates on the state and the NAEP writing assessments tended to be somewhat lower than on the reading assessments.

Second, the wide disparity in the achievement of subgroups of students makes reaching the 100-percent proficiency goal for all students a more challenging task for certain schools and districts. The NAEP and state assessments show large achievement gaps between subgroups of students disaggregated by race/ethnicity and poverty status (Table S.1). For example:

- At the 4th-grade level in reading, national and state assessments show, on average, a difference of 27 percentage points between the proficiency rates of white and African American students; 24-27 percentage points between white and Hispanic students; and 23-25 percentage points between economically advantaged and economically disadvantaged students.

- This is true at the 8th-grade level in reading as well, where we see a difference of 26-28 percentage points between the proficiency rates of white and African 
Table S.1

Average Differences in Proficiency Rates of 4th- and 8th-Grade Students, Disaggregated by Race/Ethnicity and Poverty Status: State Reading Assessments and National Assessment of Educational Progress 2003 Reading Assessment

\begin{tabular}{|c|c|c|}
\hline \multirow[b]{2}{*}{ Subgroups of Students } & \multicolumn{2}{|c|}{$\begin{array}{c}\text { Average Difference in Proficiency Rates } \\
\text { (percentage points) }\end{array}$} \\
\hline & State Assessments & NAEP \\
\hline \multicolumn{3}{|c|}{ 4th Grade } \\
\hline White and African American students & 27 & 27 \\
\hline White and Hispanic Students & 27 & 24 \\
\hline $\begin{array}{l}\text { Economically Advantaged and Economically } \\
\text { Disadvantaged Students }\end{array}$ & 23 & 25 \\
\hline \multicolumn{3}{|c|}{ 8thGrade } \\
\hline White and African American students & 28 & 26 \\
\hline White and Hispanic Students & 26 & 22 \\
\hline $\begin{array}{l}\text { Economically Advantaged and Economically } \\
\text { Disadvantaged Students }\end{array}$ & 24 & 22 \\
\hline
\end{tabular}

American students; 22-26 percentage points between white and Hispanic students; and 22-24 percentage points between economically advantaged and economically disadvantaged students.

- At all levels, students with limited English proficiency and students with disabilities trailed well behind their peers.

\section{Multiple Sources of Data Regarding Literacy Achievement Help Provide a More Complete Picture}

It is clear that while states are operating under a common mandate for proficiency, there are large differences in the rigor of the assessment and in performance levels that states consider "proficient" under NCLB_-proficiency cut-scores_leading to quite disparate outcomes. Compare, for instance, South Carolina, Wyoming, North Carolina, and Texas. At the 8thgrade level, 21 percent of students in South Carolina and 39 percent of students in Wyoming passed the state assessment, compared with 86-88 percent of 8th-graders in North Carolina and Texas. However, when one looks at the 8th-grade NAEP scores, 24 percent of students in South Carolina and 34 percent of students in Wyoming scored at the proficient level, compared with 26 percent of students in Texas and 29 percent of students in North Carolina. Clearly, even if each state were to meet its 100-percent proficiency goal for reading, students in those states would likely have quite dis parate abilities, knowledge, and skills.

Further, simply looking at proficiency rates on state assessments may not provide the public and parents with all the information they might want about student achievement. For example, in an examination of individual states, we see both similarities and marked differences in some states regarding what state assessments show about the relative performance of subgroups and what the NAEP shows. If state assessments show small performance gaps among these groups of students while the NAEP, arguably using a more challenging standard of literacy, shows large performance gaps, it is important for state policymakers and parents to reflect on what this disparity might imply for the likely future employment and education opportunities for these students. If we fail to give due attention to multiple sources of 
information regarding literacy achievement, we may fail to miss important problem areas and may end up shortchanging those most in need of assistance.

Overall, the data show that our nation faces a tremendous challenge to raise the literacy skills of our nation's adolescents. It is clear that simply mandating standards and assessments is not going to guarantee success. Unless we, as a nation, are prepared to focus attention and resources on this issue, our schools are likely to continue producing students who lack skills and are ill-prepared to deal with the demands of post-secondary education and the workplace. Policymakers, schools, and teachers need to step up and accept the "orphaned responsibility" of teaching students to read to learn. The costs of inattention are very high, both in personal and economic terms. 



\section{Acknowledgments}

The authors would like to thank Carnegie Corporation for funding this research. We particularly thank Andrés Henríquez, our project sponsor at Carnegie.

We are grateful to our reviewers, Laura Hamilton and Scott Naftel of RAND, for their critical and insightful reviews. Their recommended changes greatly improved the organization and clarity of the report. Both Dominic Brewer and Susan Bodilly also provided overall guidance for the project as directors of the program under which this report was produced.

We are also grateful to our editors, Marian Branch and Paul Arends, for their patient and careful editing.

We also thank our administrative assistant, Carolyn Rowe, for her work helping to create the tables in this report. 



\section{Introduction}

\section{Why Adolescent Literacy Matters}

Today's economy places a premium on knowledge and skills, and most jobs require at least a high school education. For example, in 1998, only 11 percent of blue-collar workers had not completed high school compared with 33 percent in 1973, and nearly half had acquired at least some post-secondary education (Carnevale, 2001). Even the military-historically a viable first career step for high school dropouts-now requires its recruits to be high school graduates. The U.S. Department of Labor (2001) estimates that 70 percent of the 30 fastestgrowing jobs will require some post-secondary education and 40 percent of all new jobs will require at least an associate's degree. The premium on knowledge and educational attainment translates into large and growing gaps in annual earnings, with college graduates earning more than twice as much as high school dropouts, and people with graduate or professional degrees earning three times as much as high school graduates (Alliance for Excellent Education, 2002).

As part of the American Diploma Project, Achieve (2004) recently delineated the content and skills that graduates need to have mastered by the time they leave high school if they expect to succeed in post-secondary education or in high-performance, high-growth jobs (see http://www.achieve.org/achieve.nsf/AmericanDiplomaProject?OpenForm). These skills include the ability to read and interpret a wide range of reference materials (e.g., periodicals, memoranda, and other documents that may contain technical information), to judge the credibility of sources, to evaluate arguments, to understand and convey complex information, and to communicate effectively in writing.

Given this information, it is important that our schools equip students with the knowledge and skills to succeed in post-secondary education and/or in the labor market. Unfortunately, many of our nation's students fail to acquire these skills and many fail to continue their schooling. According to a recent report from the National Center for Public Policy and Higher Education (2004), out of every 100 students who enter 9th grade, only 68 graduate from high school four years later. Of those, 40 enroll immediately in higher education. A year later, only 27 are still enrolled as sophomores. Allowing up to six years for completion of the bachelor's degree, and three for an associate's degree, only 18 of the original 100 9th-graders will have graduated with a college diploma in that time frame. Even factoring in those who eventually find their way into college after obtaining their high school (or equivalent) diploma and/or a period in the workforce, the reality is that only one American in three obtains a post-secondary degree by his or her mid-thirties. These figures are even lower for minority students. In fact, on-time high school graduation rates are 50 
percent for African American students, 51 percent for Native American students, and 53 percent for Hispanic students (Greene and Forester, 2003).

The data suggest that the leaks in our education pipeline are at least partially due to the fact that large numbers of young people reach high school without being able to read with sufficient fluency ${ }^{1}$ and comprehension to do serious academic work. In urban, highpoverty schools, a majority of incoming 9th-graders read at or below the 7th-grade level. Students in the bottom quartile of achievement are 20 times more likely to drop out than are students in the top quartile (Carnevale, 2001).

Students who manage to get a high school diploma but whose literacy skills are meager are likely to have difficulty as well. Of those heading to college, many require one or more remedial classes - not just in community colleges, but in selective four-year institutions as well. For example, in the California State University system, which routinely enrolls students graduating in the top-third of their high school class, almost half of students require remediation in English. Interestingly, the average high school GPA of these students was quite high-3.19 (http://iar.csumb.edu/campus_demographic/remediation/remediation_ entry.xls). Not surprisingly, students who enter college not ready to do college-level work graduate at significantly lower rates than do those not requiring remediation. Only a third of students assigned to a remedial reading course manage to obtain a degree (U.S. Department of Education, 2001).

Literacy matters, independent of credentials, and the costs of poor literacy skills are high. The National Adult Literacy Survey found a greater economic return for higher versus lower literacy skills for high school graduates, for those with some college, and for those with undergraduate and professional degrees (Kirsch et al., 1993). Over 40 percent of all adults with the lowest levels of literacy were living in poverty, compared with only 4 to 8 percent of those in the two highest proficiency levels.

\section{Teaching Students to Read to Learn: An "Orphaned Responsibility" in the K-12 World}

For a number of years, the federal government has made substantial investments in early reading, most recently through Reading First, which provides resources targeted to improve reading skills among children in kindergarten through third grade, and Early Reading First Grants, which provides resources for pre-reading skills of children from birth to age 5 . However, our nation has not made a commensurate effort to improve the literacy skills of students as they progress to fourth grade and beyond. ${ }^{2}$

Middle school and high school students build on the literacy strategies they learned in the early grades to make sense of abstract, complex subjects removed from their personal experiences. The need to guide adolescents to advanced stages of literacy is not necessarily the result of any teaching or learning failure in the preschool or primary years; rather, it is a

\footnotetext{
${ }^{1}$ Reading fluency encompasses the speed or rate of reading, as well as the ability to read materials with expression. Meyer and Felton (1999, p. 284) defined fluency as "the ability to read connected text rapidly, smoothly, effortlessly, and automatically with little conscious attention to the mechanics of reading, such as decoding."

${ }^{2}$ Over the past year, the federal government began to turn some attention to the question of adolescent literacy. The President's proposed Striving Readers program, which would target middle and high school students, would be a step forward toward turning attention and resources to adolescent literacy; however, at $\$ 100$ million, the funding still falls far short of the $\$ 1.26$ billion President Bush requested for the Reading First and Early Reading First grants.
} 
necessary next step in normal reading development. Many students need specific instruction in how to tackle texts of such disciplines as science and history, each of which contains a specific vocabulary and structure of written language.

It is clear that continual instruction beyond the early grades is needed. However, as deLeon (2002) eloquently points out, teaching students to read to learn is an "orphaned responsibility" in the K-12 system. Elementary schools traditionally emphasize literacy instruction, but middle and secondary schools shift attention to the disciplines, rarely overtly presenting instruction in reading and writing. The assumption that students will automatically learn to read more-complex, content-laden texts is particularly invalid for students who struggled when learning to read. As a nation, if we fail to properly address adolescent literacy, the reading gains achieved for Pre-K-3 students may be lost or diluted.

\section{Scope of the Project}

In an effort to focus national attention on the problem of adolescent literacy, Carnegie Corporation of New York launched a new initiative, Advancing Literacy. As part of this initiative, Carnegie decided to appoint an Advisory Council to propose promising strategies for the improvement of adolescent literacy. As a first step toward forming this council, Carnegie asked the RAND Corporation to convene a small study group for one year to lay the foundation for the work for the larger Advisory Council. Carnegie also asked RAND to examine data from reading and writing assessments and to summarize the state of adolescent literacy achievement in the United States as measured by these tests.

Our analysis focused on three research questions:

1. To what extent are adolescents (defined as students in the 4th through 12th grades) meeting state literacy goals, as measured by state assessments?

2. To what extent are adolescents meeting national literacy goals, as measured by the National Assessment of Educational Progress (NAEP)?

3. To what extent are the results from state assessments and the NAEP consistent with one another?

To answer these questions, we examined the state assessment systems adopted by the 50 states and the District of Columbia ${ }^{3}$ in order to understand how states define and measure adolescent literacy and how students fare on these assessments. For each state, we described the state standards-based assessment system, the content and format of the assessment, and student performance on those assessments. We collected data on the state assessment systems and student performance from state websites. The state assessment data presented in this report are from the 2003 assessment, with a few exceptions. For Connecticut, Minnesota, New Jersey, Ohio, Tennessee (writing scores), and Utah, we used the results of the 2002 administration because 2003 data were not available. We supplemented the assessment data with school-level data obtained from the National Longitudinal School-Level State Assessment Score Database (http://208.253.216.16/Assessment). We

\footnotetext{
${ }^{3}$ The District of Columbia, being a large urban district, is quite different from the states, which tend to have both rural and urban areas. It offers a look at how students in a high-poverty, urban district perform and some of the challenges such districts face in trying to meet No Child Left Behind (NCLB) goals.
} 
primarily used school-level data to examine the relative performance of urban, rural, and suburban schools. In addition, some states did not publish disaggregated data by student socioeconomic status; in these cases, we reported school-level performance data by school poverty status. Data regarding student demographics in the states were obtained from the 2002 NCES Common Core of Data (http://www.nces.ed.gov/ccd/).

To get a national picture and to understand whether and how student performance differed across the states, we examined data from the 2003 state NAEP in reading and the 2002 state NAEP in writing for 4th and 8th grades. ${ }^{4}$ The NAEP, known as "the Nation's Report Card," is the only nationally representative and continuing assessment of what America's students know and can do in various subject areas; the state NAEP provides representative estimates of student performance in participating states. NAEP does not provide scores for individual students or schools; instead, it offers results regarding subject-matter achievement for populations and subgroups of students (e.g., fourth-graders, female students, Hispanic students). In 2003, NAEP administered the reading assessment to approximately 343,000 students in grades 4 and 8 throughout the nation. The sample assessed students in approximately 7,143 schools at grade 4 and 5,714 schools at grade 8 across the nation.

\section{Purpose and Outline of This Report}

It is important to understand what this report does and does not do.

An important contribution of the report is that it brings together all available data on achievement in adolescent literacy, thus providing a portrait of how adolescents perform against state and national literacy goals. However, our timeline did not allow for detailed analyses of these assessments or the achievement results. Our mandate was simply to report publicly available data. As a result, the report is purely descriptive and perhaps raises more questions than it answers, particularly in the different pictures of adolescent literacy achievement offered by the state and the national assessments.

One important caveat to keep in mind is that, although we present data on the similarities and differences in the results of state assessments and the state NAEP, data from these two assessments are not directly comparable, because of the differences in the tests themselves and in the definitions of proficiency levels in the NAEP and state performance standards. 5 While one could argue that state and national literacy goals should be reasonably similar, in reality there is debate about whether NAEP achievement standards are too challenging. Indeed, Linn (2003) points out that the proficiency standard on the NAEP is an ambitious one, intended to encourage greater effort. The National Assessment Governing Board (NAGB), which sets the standards for the NAEP, notes that the proficiency level on the NAEP indicates that "students reaching this level have demonstrated competency over challenging subject matter" (http://www.nagb.org).

4 We do not present results from the 12th-grade NAEP assessments, because the state NAEP does not test grade 12 .

${ }^{5}$ See, for example, National Research Council. (1999). Uncommon Measures: Equivalence and Linkage Among Educational Tests. Washington, D.C.: National Academy Press; Linn, R. L. (2000). Assessments and Accountability. Educational Researcher. Vol. 29, No.2; Linn, R. L. (2003). Performance Standards: Utility for Different Uses of Assessments. Education Policy Analysis Archives. Vol. 11, No. 31. 
If NAEP achievement standards are indeed more rigorous and challenging than many state achievement standards, then one would expect fewer students to reach proficiency on the NAEP than on state assessments, and such differences would not imply that the data from state assessments are wrong or unreliable. Our purpose here is not to draw such inferences but to offer two different data points on adolescent literacy: achievement measured against state and achievement measured against (arguably more stringent) national literacy standards. We believe that it is important for state policymakers, practitioners, and parents to examine both sources of data and to make their own judgments regarding the relative performance of their students against both sets of standards. In addition, under No Child Left Behind (NCLB), states are now required to participate in the NAEP in order to help verify state results by using a common measure; therefore, states need to become familiar with the NAEP, what it measures, and how its assessment differs from their own assessments.

The report is organized into six chapters. The second chapter provides an overview of state assessments and the NAEP. The third and fourth chapters present summary data from the state assessments and the NAEP to paint a broad picture of adolescent literacy achievement across the nation. The fifth chapter looks at the similarities and differences between what the state NAEP and state assessments reveal about the performance of adolescents, subject to the caveat listed above. The final chapter offers some thoughts on the policy implications of these findings.

The appendices contain individual state write-ups that describe the assessment systems; the content, format, and performance levels of reading, writing, and English language arts assessments between 4th and 12th grades; and student performance results on those assessments. Given that the report encompasses 50 states and the District of Columbia, the sheer volume of the readily available and public information on state standards and assessments required us to make choices about what to include in the report. We focus on the reading, writing, or language arts assessment used for accountability purposes and report results at the elementary (grades 4-5), middle (grades 6-8), and high school (grades 9-12) levels. Thus, for a state that tests students in grades 3-12 in reading, we present findings for only three grades (i.e., grades 4, 8, and 11). When a choice of grades needed to be made, we selected grades 4 and 8 whenever possible so that we could examine those results in combination with NAEP data. Consequently, our state write-ups are intended to be illustrative, not exhaustive. Specifically, each state summary includes the following sections:

- State Assessment System-Information on the state's assessment system as a whole, including what tests are used for accountability, and if they are intended to measure state content standards.

- Assessment Format and Content-Information regarding the format and content of the selected assessments.

- Achievement-Level Descriptions-An overview of the achievement levels set by each state and what is considered "proficient" (or passing) under NCLB.

- Performance Results_-Data on student and school-level performance on the selected state reading and writing assessments. 



\section{State and National Assessments of Adolescent Literacy}

This chapter presents a description of state assessments in the context of NCLB used to measure student progress toward state academic goals in literacy ${ }^{1}$ and on the NAEP, which measures student performance against a set of national standards.

\section{State Assessment Systems}

After the nation's governors issued a call in 1989 for "world-class" standards to guide educational practice, in response to the poor performance of U.S. students on international comparative assessments (McKnight et al., 1987; National Governors Association, 1989; Travers and Westbury, 1989), state policymakers have steadily moved toward a system that emphasizes explicit performance standards, systematic standardized testing, and consequences for results. The National Research Council (1999, pp. 2-3) described the rationale for such a system:

The centerpiece of the system is a set of challenging standards. By setting these standards for all students, states would hold high expectations for performance; these expectations would be the same regardless of students' backgrounds or where they attended school. Aligned assessments to the standards would allow students, parents, and teachers to monitor student performance against the standards. Providing flexibility to schools would permit them to make the instructional and structural changes needed for their students to reach the standards. And holding schools accountable for meeting the standards would create incentives to redesign instruction toward the standards and provide appropriate assistance to schools that need extra help.

In the 1990s, most states were moving toward establishing systems of content standards and assessments. However, NCLB mandated that all states adopt standards-based accountability systems for all schools and, with its marked emphasis on sanctions for poor performance, raised the stakes for schools and students. As a consequence, state assessments are likely to exert significant influence over instruction.

Specifically, NCLB requires states to adopt standards-based accountability systems that set challenging content and performance standards for all students. To ensure that students are meeting these standards, by 2005-2006, states must annually test all children in reading and math, in grades 3, 4, 5, 6, 7, 8, and at one grade in high school. By 2007-2008,

\footnotetext{
${ }^{1}$ For details on individual state systems, see Appendices A through YY.
} 
states must test students in science at least once in grades 3-5, 6-9, and 10-12. States must establish goals for performance on the assessment and track performance for all students and subgroups of students (e.g., racial/ethnic groups, students with disabilities, migrant students). By the end of 12 years, all schools should have reached 100-percent proficiency-that is, all children in the school must pass the state test.

Schools that fail to make adequate yearly progress face escalating sanctions over time, such as being required to offer school choice or supplemental services and may include, among others, decreased decisionmaking; reconstituting the school staff; instituting a new curriculum based on scientifically based research; extending the school year or school day; and appointing an outside expert to advise the school. In addition, a growing number of states are holding students accountable by requiring that students pass high school assessments before they can graduate or to pass a given grade assessment to be promoted to the next grade.

Almost all states have content standards in the four major content areas-English language arts, mathematics, science, and social studies-and most have standards in a number of additional subjects as well. To support implementation of standards in the classroom, most states also have developed (at least in tested grades and subjects) grade-level expectations, which delineate specific learning goals by grade level, to support instruction (see state appendices for specific examples). There is, however, considerable variability in the depth and specificity of standards among the states (Linn, 1998).

All the states with criterion-referenced tests $(\mathrm{CRT})^{2}$ note that their assessments are aligned with their content standards, and many states detail the particular standards that form the basis for the assessments. Previous research indicates that, although state assessments do tend to be aligned with standards, the collection of items on a test tends to measure only a few of the less-challenging standards and objectives. As a result, few state tests can be said to be well-aligned assessments of challenging standards (Rothman et al., 2002).

\section{State Assessment Systems in Transition}

Because of NCLB, many state assessment systems are currently in flux. Table 2.1 details the grade levels at which states are currently testing in reading, English language arts, and writing, and the changes that will be made to these systems so that they meet the assessment requirements under NCLB.

All states currently administer state assessments in reading, English language arts, or writing in various grades, except for Nebraska, which requires districts to administer districtselected assessments in certain grades. Twenty-nine states assess writing in at least one grade, although these writing tests are not used for federal accountability purposes. Another 12 states include a writing section in the English language arts assessment.

To meet the testing requirements under NCLB, as of 2003, 36 states were planning to expand the number of grades tested and nine states were developing new CRTs. In 2003, only 15 states required no changes to comply with NCLB. Among them were such states as Maryland, which had already changed their assessment systems in response to NCLB.

\footnotetext{
${ }^{2}$ Criterion-referenced tests measure how well a person has learned a specified body of knowledge and skills.
} 
Table 2.1

State Assessment Systems for Adolescent Literacy

\begin{tabular}{|c|c|c|c|c|}
\hline State & $\begin{array}{c}\text { Grades Tested on } \\
\text { Reading/English } \\
\text { Language Arts }\end{array}$ & $\begin{array}{l}\text { Grades Tested } \\
\text { on Writing }\end{array}$ & $\begin{array}{c}\text { High School } \\
\text { Graduation Test }\end{array}$ & $\begin{array}{c}\text { Revisions Needed to Comply with } \\
\text { NCLB }\end{array}$ \\
\hline Alabama & $3-8$ & 5,7 & Yes & $\begin{array}{l}\text { New CRT in development; } \\
\text { expanding tested grades }\end{array}$ \\
\hline Alaska & $3,6,8$ & $3,6,8$ & Yes & $\begin{array}{l}\text { New CRT in development; } \\
\text { expanding tested grades }\end{array}$ \\
\hline Arizona & $3,5,8,10$ & $3,5,8,10$ & (class of 2006) & Expanding tested grades \\
\hline Arkansas & $4,6,8,11$ & $\begin{array}{l}\text { Part of literacy } \\
\text { exam }\end{array}$ & No & Expanding tested grades \\
\hline California & $3-11$ & Included in ELA & (class of 2006) & \\
\hline Colorado & $3-10$ & $3-10$ & No & \\
\hline Connecticut & $4,6,8,10$ & $4,6,8$ & No & Expanding tested grades \\
\hline Delaware & $2-10$ & $3-10$ & No & \\
\hline $\begin{array}{l}\text { District of } \\
\text { Columbia }\end{array}$ & $1-11$ & & No & New CRT in development \\
\hline Florida & $2-10$ & $4,8,10$ & Yes & \\
\hline Georgia & $1-11$ & & Yes & \\
\hline Hawaii & $5,8,10$ & $5,8,10$ & No & Expanding tested grades \\
\hline Idaho & $2-10$ & $5,7,9$ (in 2004) & (class of 2004) & \\
\hline Illinois & $3,5,8$ & $3,5,8$ & No & Expanding tested grades \\
\hline Indiana & $\begin{array}{l}3,6,8,10, \text { High } \\
\text { school EOG tests }\end{array}$ & & Yes & Expanding tested grades \\
\hline lowa & $4,8,11$ & $3-12$ & No & Expanding tested grades \\
\hline Kansas & $5,8,10$ & $\begin{array}{l}5,8,11 \text { (every } 2 \\
\text { years) }\end{array}$ & No & Expanding tested grades \\
\hline \multirow[t]{2}{*}{ Kentucky } & $4,7,10$ (CRT) & $4,7,12$ & No & \multirow{2}{*}{$\begin{array}{l}\text { Augmenting CTBS and adding } \\
\text { grade }\end{array}$} \\
\hline & $3,6,9$ (NRT) & & & \\
\hline Louisiana & $4,8,10$ & & Yes & Expanding tested grades \\
\hline Maine & 4,8 & 4,8 & No & $\begin{array}{l}\text { Developing new CRTs; expanding } \\
\text { tested grades }\end{array}$ \\
\hline Maryland & $3-8,10$ & & No & \\
\hline Massachusetts & $4,7,10$ & Included in ELA & Yes & Expanding tested grades \\
\hline Michigan & $4,7,11$ & Included in ELA & No & Expanding tested grades \\
\hline \multirow[t]{2}{*}{ Minnesota } & $3,5,7$ & 5 & Yes & Expanding tested grades \\
\hline & $\begin{array}{l}8,10 \text { (Basic Skills } \\
\text { Test) }\end{array}$ & & & \\
\hline Mississippi & $2-8, \mathrm{HS}$ & 4,7 & No & \\
\hline Missouri & $3,7,11$ & Included in ELA & No & Expanding tested grades \\
\hline Montana & $4,8,11$ & & No & $\begin{array}{l}\text { Developing new CRT; expanding } \\
\text { tested grades }\end{array}$ \\
\hline Nebraska & $\begin{array}{l}\text { Districts tests in } 4,8, \\
11\end{array}$ & $\begin{array}{l}\text { Districts tests in } \\
4,8,11\end{array}$ & No & Expanding tested grades \\
\hline Nevada & $\begin{array}{l}3,5,8(C R T)(4,7 \\
\text { NRT) }\end{array}$ & 4,8 & Yes & Expanding tested CRT grades \\
\hline
\end{tabular}


Table 2.1-Continued

\begin{tabular}{|c|c|c|c|c|}
\hline State & $\begin{array}{c}\text { Grades Tested on } \\
\text { Reading/English } \\
\text { Language Arts }\end{array}$ & $\begin{array}{l}\text { Grades Tested } \\
\text { on Writing }\end{array}$ & $\begin{array}{l}\text { High School } \\
\text { Graduation Test }\end{array}$ & $\begin{array}{l}\text { Revisions Needed to } \\
\text { Comply with NCLB }\end{array}$ \\
\hline New Hampshire & $3,6,10$ & Included in ELA & No & $\begin{array}{l}\text { New CRT in development; } \\
\text { expanding tested grades }\end{array}$ \\
\hline New Jersey & $4,8,11$ & Included in ELA & Yes & Expanding tested grades \\
\hline New Mexico & $3-9,10$ & $\begin{array}{l}\text { HS competency } \\
\text { test includes } \\
\text { writing }\end{array}$ & Yes & New CRT in development \\
\hline New York & $4,8, \mathrm{HS}$ & & Yes & Expanding tested grades \\
\hline North Carolina & $3-8,10$ & $\begin{array}{l}4,7,10 \text { (pilot } \\
2003)\end{array}$ & No & \\
\hline North Dakota & $4,8,12$ & & No & Expanding tested grades \\
\hline Ohio & $4,6,9$ & $4,6,9$ & Yes & Expanding tested grades \\
\hline Oklahoma & $5,8, \mathrm{HS}$ & & No & Expanding tested grades \\
\hline Oregon & $3,5,8,10$ & $5,8,10$ & No & Expanding tested grades \\
\hline Pennsylvania & $5,8,11$ & $6,9,11$ & No & Expanding tested grades \\
\hline Rhode Island & $4,8,10$ & Included in ELA & No & $\begin{array}{l}\text { New CRT in development; } \\
\text { expanding tested grades }\end{array}$ \\
\hline South Carolina & $3-8,10$ & Included in ELA & Yes & \\
\hline South Dakota & $3-8,11$ & 5,9 & No & \\
\hline Tennessee & $\mathrm{K}-8, \mathrm{HS}$ & $5,8,11$ & Yes & \\
\hline Texas & $3-11$ & Included in ELA & (class of 2004) & \\
\hline Utah & $1-11$ & 6,9 & (class of 2003) & \\
\hline Vermont & $4,8,10$ & Included in ELA & No & New CRT in development \\
\hline Virginia & $\begin{array}{l}3,5,8, \mathrm{HS}(\mathrm{CRT}) \\
4,6,9 \text { (NRT) }\end{array}$ & Included in ELA & Yes & $\begin{array}{l}\text { Expanding tested CRT } \\
\text { grades }\end{array}$ \\
\hline Washington & $\begin{array}{l}4,7,10 \text { (CRT) } \\
3,6,9 \text { (NRT) }\end{array}$ & $4,7,10$ & No & $\begin{array}{l}\text { Expanding tested CRT } \\
\text { grades }\end{array}$ \\
\hline West Virginia & $3-8,10$ & $4,7,11$ & No & \\
\hline Wisconsin & $4,8,10$ & & No & Expanding tested grades \\
\hline Wyoming & $4,8,11$ & $4,8,11$ & No & Expanding tested grades \\
\hline
\end{tabular}

In addition, a growing number of states require students to pass high school assessments in order to graduate. Twenty-two states will have this requirement in place by 2006. In all of these states, students who do not pass their graduation assessments the first time are provided multiple opportunities to retake the test. A few states are also requiring students to pass the assessments in certain grades in order to be promoted (not shown). For example, Georgia is phasing in new promotion policies that will require students to pass the state assessment before they can be promoted from third to fourth and from fifth to sixth grade.

\section{Literacy Assessment Content and Format}

As part of the individual state descriptions in the appendices, we provide an overview of the design and content of the literacy assessments, based on state-published information. It is difficult to provide a summary across the states regarding the content and competencies 
covered, for a number of reasons. First, states differ in the amount of detail provided about the assessments. Second, language used by the states differs considerably. Without an independent and detailed review, trying to interpret the differences may lead to erroneous conclusions regarding similarities and differences among the assessments. Such a content analysis would be enlightening but was beyond the scope of this project.

There are, however, a few general points worth noting.

First, the dominant form of state large-scale on-demand assessments is multiplechoice; however, almost all the states (except for four) included some sort of constructedresponse or writing section to their assessments.

Second, states with writing assessments or a direct writing section in their English language arts assessment generally reported requiring elementary students to respond to a descriptive or narrative prompt, which asked students to describe a situation or to tell a story, respectively. States reported that writing assessments for middle school and high school students required students to respond with expository or persuasive essays, which are intended to inform or influence the reader. However, the narrative form was an option on upper-grade assessments in many states as well, although this form of writing is the least likely to be used by students in post-secondary work and education.

Third, most of the states reported including both fiction and nonfiction reading passages on their assessments, and some states reported using specific content-area readings such as science or history. We do not know whether, in most cases, these are authentic texts that students are likely to encounter in their everyday lives or whether the passages are manufactured for the assessment. The question of whether these assessments actually test students on skills they need for post-secondary success is important, particularly in high-stakes assessment environments in which assessments influence classroom instruction in significant ways (Wolf and McIver, 1999; Borko and Elliott, 1999). In a recent study of high school graduation examinations in six states, Achieve (2004) found that, although the high school examinations did measure key skills without which students could not succeed, the examinations measured only a fraction of the skills and knowledge that colleges and employers report as being essential. Further, in both reading and mathematics, the majority of test questions tap basic skills, such as literal recall in English language arts.

\section{State Assessment Achievement Standards}

As of 2003, all but two states reported scores in state-set achievement (e.g., basic, proficient, advanced) levels, as required under NCLB. Although NCLB has set a common goal for all the states-100-percent proficiency in mathematics and reading - states have been given the latitude to set their own achievement levels. Previous research has shown that proficiency standards differ dramatically. For instance, the Northwest Evaluation Association found that proficiency standards in the 14 states they studied differed enough to cause dramatic differences in the percentage of students categorized as "proficient," even if students had the same skills. In addition, proficiency standards within individual states differ across grades enough that they may provide teachers with inconsistent indicators of student progress (Kingsbury et al., 2003). 


\section{National Assessment of Educational Progress}

The National Assessment of Educational Progress is the only nationally representative and continuing assessment of what America's students know and can do in various subject areas. With the passage of NCLB, NAEP's role has been expanded. All states will be required to participate in the NAEP, with the idea that it will be used to validate state assessment results in reading and mathematics.

Below, we describe the content and format of the NAEP reading and writing assessments for grades 4 and 8 that were used in this report.

\section{Reading Assessment}

The NAEP reading assessment measures the reading comprehension of 4th- and 8th-grade students. The assessment consists of multiple-choice and constructed-response questions. At least half of the questions are constructed-response, designed to test critical-thinking skills as opposed to simply testing recall. Materials used in the assessment are taken from sources that are typically available to students inside and outside of school, such as collections of stories, children's magazines, and informational books. Passages vary in length: Students in 4th grade read passages of 250 to 800 words; students in 8 th grade read passages of 400 to 1,000 words.

NAEP tests students in 4th and 8th grade in two contexts for reading: reading for literary experience (e.g., exploring events, characters, and plots, by reading literary texts); and reading for information. In addition, 8th-grade students are tested on their ability to perform a task, reading directions for repairs. In 2003, about half of 4th-grade questions tested reading for literacy experience; the other half tested reading for information. The 8th-grade test focused most heavily on reading for information (41 percent of questions), followed by reading to perform a task (30 percent) and reading for literary experience ( 28 percent) (http://www.nces.ed.gov/nationsreportcard/reading/distributequest.asp).

The NAEP framework also categorizes questions by particular aspects of reading: the ability to form a general understanding, develop an interpretation, evaluate text content and structure, and connect information in the text with knowledge and experience on all types of texts. The majority of the assessment items fall into forming a general understanding or developing an interpretation (56-61 percent), followed by evaluating text content and structure (22-26 percent) and connecting information (17-18 percent).

NAEP has established four achievement levels: advanced, proficient, basic, and below basic. ${ }^{3}$ Table 2.2 presents definitions that the National Assessment Governing Board has established to describe the advanced, proficient, and basic levels for 4th and 8th grades.

\footnotetext{
3 The 2001 reauthorization law requires that the achievement levels be used on a trial basis until the Commissioner of Education Statistics determines that the achievement levels are "reasonable, valid, and informative to the public." Until that determination is made, the law requires the Commissioner and the National Assessment Governing Board to state clearly the trial status of the achievement levels in all NAEP reports.
} 
Table 2.2

Achievement-Level Definitions for NAEP Reading Assessment, Grades 4 and 8

\begin{tabular}{|c|c|c|}
\hline $\begin{array}{l}\text { Achievement } \\
\text { Level }\end{array}$ & 4th Grade & 8th Grade \\
\hline Advanced & $\begin{array}{l}\text { Fourth-grade students performing at the } \\
\text { Advanced level should be able to generalize } \\
\text { about topics in the reading selection and } \\
\text { demonstrate an awareness of how authors } \\
\text { compose and use literary devices. When } \\
\text { reading text appropriate to fourth grade, they } \\
\text { should be able to judge text critically and, in } \\
\text { general, to give thorough answers that } \\
\text { indicate careful thought. }\end{array}$ & $\begin{array}{l}\text { Eighth-grade students performing at the } \\
\text { Advanced level should be able to describe the } \\
\text { more abstract themes and ideas of the overall } \\
\text { text. When reading text appropriate to eighth } \\
\text { grade, they should be able to analyze both } \\
\text { meaning and form and support their analyses } \\
\text { explicitly with examples from the text; they } \\
\text { should be able to extend text information by } \\
\text { relating it to their experiences and to world } \\
\text { events. At this level, student responses should } \\
\text { be thorough, thoughtful, and extensive. }\end{array}$ \\
\hline Proficient & $\begin{array}{l}\text { Fourth-grade students performing at the } \\
\text { Proficient level should be able to demonstrate } \\
\text { an overall understanding of the text, providing } \\
\text { inferential as well as literal information. When } \\
\text { reading text appropriate to fourth grade, they } \\
\text { should be able to extend the ideas in the text } \\
\text { by making inferences, drawing conclusions, } \\
\text { and making connections to their own } \\
\text { experiences. The connection between the text } \\
\text { and what the student infers should be clear. }\end{array}$ & $\begin{array}{l}\text { Eighth-grade students performing at the } \\
\text { Proficient level should be able to show an } \\
\text { overall understanding of the text, including } \\
\text { inferential as well as literal information. When } \\
\text { reading text appropriate to eighth grade, they } \\
\text { should be able to extend the ideas in the text } \\
\text { by making clear inferences from it, by drawing } \\
\text { conclusions, and by making connections to } \\
\text { their own experiences-including other reading } \\
\text { experiences. Proficient eighth-graders should } \\
\text { be able to identify some of the devices authors } \\
\text { use in composing text. }\end{array}$ \\
\hline Basic & $\begin{array}{l}\text { Fourth-grade students performing at the Basic } \\
\text { level should demonstrate an understanding of } \\
\text { the overall meaning of what they read. When } \\
\text { reading text appropriate for fourth-graders, } \\
\text { they should be able to make relatively obvious } \\
\text { connections between the text and their own } \\
\text { experiences and extend the ideas in the text by } \\
\text { making simple inferences. }\end{array}$ & $\begin{array}{l}\text { Eighth-grade students performing at the Basic } \\
\text { level should demonstrate a literal under- } \\
\text { standing of what they read and be able to } \\
\text { make some interpretations. When reading text } \\
\text { appropriate to eighth grade, they should be } \\
\text { able to identify specific aspects of the text that } \\
\text { reflect overall meaning, extend the ideas in the } \\
\text { text by making simple inferences, recognize } \\
\text { and relate interpretations and connections } \\
\text { among ideas in the text to personal experience, } \\
\text { and draw conclusions based on the text. }\end{array}$ \\
\hline
\end{tabular}

SOURCE: http://www.nces.ed.gov/nationsreportcard/writing/achieveall.asp.

These achievement levels are cumulative; therefore, students performing at the proficient level also display the competencies associated with the basic level, and students at the advanced level also demonstrate the skills and knowledge associated with both the basic and the proficient levels. As mentioned earlier in this chapter, the "proficient" standard on NAEP is widely considered to be an ambitious one, intended to encourage greater effort (Linn, 2002; http://www.nagb.org).

\section{Writing Assessment}

The NAEP writing assessment presents a broad view of the writing skills of America's students. The assessment tests students in three styles of writing: narrative, informative, and persuasive. The writing assessment was designed around six overarching objectives (http://www.nces.ed.gov/nationsreportcard/writing/whatmeasure.asp):

- Students should write for a variety of purposes: narrative, informative, and persuasive.

- Students should write on a variety of tasks and for many different audiences.

- Students should write from a variety of stimulus materials, and within various time constraints. 
- Students should generate, draft, revise, and edit ideas and forms of expression in their writing.

- Students should display effective choices in the organization of their writing. They should include detail to illustrate and elaborate their ideas, and use appropriate conventions of written English.

- Students should value writing as a communicative activity.

Similarly to the NAEP reading assessment, student writing assessment results fall into four achievement levels: advanced, proficient, basic, and below basic. Table 2.3 presents the achievement-level definitions for writing in grades 4 and 8.

The next chapter presents a discussion of the assessment results from the state assessments. 
Table 2.3

Achievement-Level Definitions for NAEP Writing Assessment, Grades 4 and 8

\begin{tabular}{|c|c|c|}
\hline $\begin{array}{l}\text { Achievement } \\
\text { Level }\end{array}$ & 4th Grade & 8th Grade \\
\hline \multirow[t]{11}{*}{ Advanced } & $\begin{array}{l}\text { Fourth grade students performing at the } \\
\text { Advanced level should: }\end{array}$ & $\begin{array}{l}\text { Eighth grade students performing at the } \\
\text { Advanced level should: }\end{array}$ \\
\hline & $\begin{array}{l}\text { create an effective and elaborated response } \\
\text { to the task in form, content, and language; }\end{array}$ & $\begin{array}{l}\text { create an effective and elaborated response } \\
\text { to the task in form, content, and language; }\end{array}$ \\
\hline & $\begin{array}{l}\text { express analytical, critical, and/or creative } \\
\text { thinking; }\end{array}$ & $\begin{array}{l}\text { express analytical, critical, and/or creative } \\
\text { thinking; }\end{array}$ \\
\hline & $\begin{array}{l}\text { have unity of form and content in response } \\
\text { to the task; }\end{array}$ & $\begin{array}{l}\text { have well-crafted, cohesive organization } \\
\text { appropriate to the task; }\end{array}$ \\
\hline & $\begin{array}{l}\text { demonstrate an awareness of the intended } \\
\text { audience; }\end{array}$ & $\begin{array}{l}\text { show sophisticated use of transitional } \\
\text { elements; }\end{array}$ \\
\hline & $\begin{array}{l}\text { use effective organization appropriate to } \\
\text { the task; }\end{array}$ & $\begin{array}{l}\text { use varied and elaborated supporting } \\
\text { details in appropriate, extended response; }\end{array}$ \\
\hline & show proficient use of transitional elements; & begin to develop a personal style or voice; \\
\hline & $\begin{array}{l}\text { elaborate and enhance the central idea with } \\
\text { descriptive and supportive details; }\end{array}$ & $\begin{array}{l}\text { demonstrate precise and varied use of } \\
\text { language; }\end{array}$ \\
\hline & $\begin{array}{l}\text { use language appropriate to the task and } \\
\text { intended audience; and }\end{array}$ & $\begin{array}{l}\text { use a variety of strategies such as analogies, } \\
\text { illustrations, examples, anecdotes, and }\end{array}$ \\
\hline & enhance meaning through control of & figurative language; and \\
\hline & $\begin{array}{l}\text { spelling, grammar, punctuation, and } \\
\text { capitalization. }\end{array}$ & $\begin{array}{l}\text { enhance meaning through control of } \\
\text { spelling, grammar, punctuation, and } \\
\text { capitalization. }\end{array}$ \\
\hline \multirow[t]{9}{*}{ Proficient } & $\begin{array}{l}\text { Fourth grade students performing at the } \\
\text { Proficient level should: }\end{array}$ & $\begin{array}{l}\text { Eighth grade students performing at the } \\
\text { Proficient level should: }\end{array}$ \\
\hline & $\begin{array}{l}\text { create an effective response to the task in } \\
\text { form, content, and language; }\end{array}$ & $\begin{array}{l}\text { create an effective response to the task in } \\
\text { form, content, and language; }\end{array}$ \\
\hline & $\begin{array}{l}\text { demonstrate an awareness of the intended } \\
\text { audience; }\end{array}$ & $\begin{array}{l}\text { express analytical, critical, and/or creative } \\
\text { thinking; }\end{array}$ \\
\hline & $\begin{array}{l}\text { use effective organization appropriate to } \\
\text { the task; }\end{array}$ & $\begin{array}{l}\text { demonstrate an awareness of the purpose } \\
\text { and intended audience; }\end{array}$ \\
\hline & $\begin{array}{l}\text { use sufficient elaboration to clarify and } \\
\text { enhance the central idea; }\end{array}$ & $\begin{array}{l}\text { have logical and observable organization } \\
\text { appropriate to the task; }\end{array}$ \\
\hline & $\begin{array}{l}\text { use language appropriate to the task and } \\
\text { intended audience: and }\end{array}$ & show effective use of transitional elements; \\
\hline & $\begin{array}{l}\text { intended audience; and } \\
\text { have few errors in spelling, grammar, }\end{array}$ & $\begin{array}{l}\text { use sufficient elaboration to clarify and } \\
\text { enhance the central idea; }\end{array}$ \\
\hline & $\begin{array}{l}\text { punctuation, and capitalization that } \\
\text { interfere with communication. }\end{array}$ & $\begin{array}{l}\text { use language (e.g., variety of word choice } \\
\text { and sentence structure) appropriate to the } \\
\text { task; and }\end{array}$ \\
\hline & & $\begin{array}{l}\text { have few errors in spelling, grammar, } \\
\text { punctuation, and capitalization that } \\
\text { interfere with communication. }\end{array}$ \\
\hline \multirow[t]{5}{*}{ Basic } & $\begin{array}{l}\text { Fourth grade students performing at the Basic } \\
\text { level should: }\end{array}$ & $\begin{array}{l}\text { Eighth grade students performing at the Basic } \\
\text { level should: }\end{array}$ \\
\hline & $\begin{array}{l}\text { demonstrate appropriate response to the } \\
\text { task in form, content, and language; }\end{array}$ & $\begin{array}{l}\text { demonstrate appropriate response to the } \\
\text { task in form, content, and language; }\end{array}$ \\
\hline & use some supporting details; & use some supporting details; \\
\hline & $\begin{array}{l}\text { demonstrate organization appropriate to } \\
\text { the task; and }\end{array}$ & $\begin{array}{l}\text { demonstrate organization appropriate to the } \\
\text { task; and }\end{array}$ \\
\hline & $\begin{array}{l}\text { demonstrate sufficient command of spelling, } \\
\text { grammar, punctuation, and capitalization to } \\
\text { communicate to the reader. }\end{array}$ & $\begin{array}{l}\text { demonstrate sufficient command of spelling, } \\
\text { grammar, punctuation, and capitalization to } \\
\text { communicate to the reader. }\end{array}$ \\
\hline
\end{tabular}

SOURCE: http://www.nces.ed.gov/nationsreportcard/reading/achieveall.asp. 



\section{The Current State of Adolescent Literacy Achievement: Results from State Assessments}

Data from state assessments, or results, are important because they measure progress against state-set goals, generally are taken seriously by teachers and schools, and are likely to influence instruction, particularly in high-stakes environments. However, these results cannot be compared across states, because states set differing goals for student performance in terms of content and appropriate achievement levels. This chapter focuses on results from the state assessments and examines overall proficiency levels, as well as differences in performance, for students disaggregated by race/ethnicity and by poverty status. ${ }^{1,2}$

\section{What We Present in This Chapter}

- We use data from the most recent state accountability assessment available on the state website. Generally, data are for the 2003 administration (school year 20022003); however, for a few states, we report data from 2001-2002. Because test scores tend to rise (for a number of reasons-growing familiarity with the test, regression to the mean, increased teaching of content that is on the test) over time, these scores may underestimate current student achievement levels.

- Data from state assessments were mapped to state definitions of "passing" for purposes of meeting the requirements of NCLB. This mapping allowed us to identify the "pass rate" for elementary and middle school students in each state. States that did not report such data on websites were automatically excluded from the analysis. For example, two states (Alabama and Tennessee) reported scores in average percentile ranks, not in proficiency levels.

-For pass rates of elementary students, we use 4th- or 5th-grade results. For reading, we use 4th-grade results, whenever available (see Table 3.1). Ten states did

\footnotetext{
${ }^{1}$ While the appendices detail student performance, where available, for students with disabilities and for students with limited English proficiency, we do not focus on these data in this chapter. We found large achievement gaps between these students and their peers at all grade levels and on all assessments. However, given the wide variety of student needs and abilities within these groups, the wide variety in accommodations across and sometimes within states, it is difficult to determine what these scores mean and at what level these students should be expected to perform. For an example of a state that provides detailed scores by language background and proficiency, see the entry for Colorado.

2 Data regarding the performance of schools by urbanicity are available in the appendices. In general, we found that findings regarding urbanicity were confounded with poverty levels. Students in areas with higher concentrations of highpoverty schools performed at lower levels than students in areas with lower-poverty rates.
} 
Table 3.1

Elementary and Middle School Grades Reported for State Accountability Reading Assessments, by State

\begin{tabular}{|c|c|c|}
\hline State & Elementary Grade & Middle School Grade \\
\hline Alabama $^{a}$ & 一* & -* \\
\hline Alaska & 一* & 8 \\
\hline Arizona $^{b}$ & - & 一* $^{*}$ \\
\hline Arkansas & 4 & 8 \\
\hline California & 4 & 8 \\
\hline Colorado & 4 & 8 \\
\hline Connecticut & 4 & 8 \\
\hline Delaware & 5 & 8 \\
\hline DC & 4 & 8 \\
\hline Florida & 4 & 8 \\
\hline Georgia & 4 & 8 \\
\hline Hawaii & 5 & 8 \\
\hline Idaho & 4 & 8 \\
\hline Illinois & 5 & 8 \\
\hline Indiana & -* & 8 \\
\hline lowa & 4 & 8 \\
\hline Kansas & 5 & 8 \\
\hline Kentucky & 4 & 7 \\
\hline Louisiana & 4 & 8 \\
\hline Maine & 4 & 8 \\
\hline Maryland & 5 & 8 \\
\hline Massachusetts & 4 & 7 \\
\hline Michigan & 4 & 7 \\
\hline Minnesota & 5 & 8 \\
\hline Mississippi & 4 & 8 \\
\hline Missouri & -* & 7 \\
\hline Montana & 4 & 8 \\
\hline Nebraskac & -* & 一* $^{*}$ \\
\hline Nevada & 5 & -* \\
\hline New Hampshire & -* & 6 \\
\hline New Jersey & 4 & 8 \\
\hline New Mexico & 4 & 8 \\
\hline New York ${ }^{d}$ & - $^{*}$ & -* \\
\hline North Carolina & 4 & 8 \\
\hline North Dakota & 4 & 8 \\
\hline Ohio & 4 & 6 \\
\hline Oklahoma & 5 & 8 \\
\hline
\end{tabular}


Table 3.1-Continued

\begin{tabular}{|c|c|c|}
\hline State & Elementary Grade & Middle School Grade \\
\hline Oregon & 5 & 8 \\
\hline Pennsylvania & 5 & 8 \\
\hline Rhode Island & 4 & 8 \\
\hline South Carolina & 4 & 8 \\
\hline South Dakota & 5 & 8 \\
\hline Tennessee $^{\mathrm{e}}$ & 一* $^{*}$ & 一 $^{*}$ \\
\hline Texas & 4 & 8 \\
\hline Utah & 4 & 8 \\
\hline Vermont & 4 & 8 \\
\hline Virginia & 5 & 8 \\
\hline Washington & 4 & 7 \\
\hline West Virginia ${ }^{f}$ & 一* & -* \\
\hline Wisconsin & 4 & 8 \\
\hline Wyoming & 4 & 8 \\
\hline \multicolumn{3}{|c|}{$\begin{array}{l}\text { NOTES: } \\
\text { * These states did not have readily available or reportable data for the selected grades and are } \\
\text { not included in the results presented in this section. } \\
\text { a Alabama's student-performance results are reported as national percentile ranks, not as profi- } \\
\text { ciency levels. } \\
\text { b Arizona reports its scores for two groups based on English-language proficiency, and all dis- } \\
\text { aggregated data are for non-English-language learners only. As a result, these are not compa- } \\
\text { rable with the scores reported by other states. } \\
\text { 'In Nebraska, each district administers its own assessment. As a result, there are no state-level } \\
\text { results. } \\
\text { d No data for New York were publicly available. } \\
\text { e Tennesee student-performance results are reported as national percentile ranks, not as profi- } \\
\text { ciency levels. } \\
\text { f In } 2003, \text { West Virginia did not report student scores for the performance levels by grade level. }\end{array}$} \\
\hline
\end{tabular}

not have readily available or reportable data. Of these, two states-Alaska and Indiana - did not test either 4th or 5th grades in 2003.

-For the middle school students, we report 6th-, 7th-, or 8th-grade results. For reading, we use 8 th-grade results for most states. We use 7 th-grade results for seven states and 6th-grade results for New Hampshire. An additional seven states did not have readily available or reportable data.

- For high school students, we report assessment results in two categories-those from high school assessments that are required for graduation and those from assessments that are not required for graduation.

We present data of pass rates from all the states in order to determine their progress toward meeting the 100-percent proficiency goal set by NCLB. However, these state pass rates are not comparable. State standards and assessments differ widely in format, rigor, and proficiency thresholds. The purpose of showing pass rates across the 50 states is simply to provide a broad-brush snapshot of adolescent literacy based on states' own definitions, tests, 
and standards. Differences in student performance shown below can be due to several factors-most particularly, differences in the content of the assessments; differences in the proficiency levels set by the states; and differences in student abilities. This report does not disentangle these differences; detailed or multivariate analyses were beyond the scope and timeline of the project. Consequently, one should not assume that a state with higher levels of passing on a state assessment has a greater percentage of students with advanced literacy skills than a state with lower passing rates.

\section{Performance of Elementary School Students}

\section{Reading Assessments: Overall Pass Rates}

Figure 3.1 shows the pass rates for elementary school students on the state assessments for the 40 states and DC that had readily available and reportable data in terms of percentages of students (in 4th or 5th grade) who scored at the passing level on the state assessment.

The average pass rate was 66 percent, and the pass rates for states in the middle half of the distribution ranged from 57 to 76 percent. The pass rates differed widely across states, ranging from a low of 29 percent in DC to a high of 87 percent in Colorado. Three states had a pass rate of below 40 percent-DC, South Carolina, and California; in seven states, less than half of the students passed at the elementary level. In contrast, eight states had pass rates of 80 percent or higher-Georgia, Utah, Wisconsin, Virginia, Mississippi, Texas, North Carolina, and Colorado.

\section{Reading Assessments: Differences in Performance Among Students, Disaggregated by Race/Ethnicity and Poverty Status}

Among states that reported data for students disaggregated by race/ethnicity, we find large differences in pass rates of white and African American students ( $n=32$ states) and white and Hispanic students ( $n=29$ states) (Figures 3.2 and 3.3).

The difference in pass rates of white and African American students ranged from a low of 12 percentage points in Hawaii to a high of 65 percentage points in DC (Figure 3.2). In eight states, the difference was 20 percentage points or less; in 11 states, it was 30 percentage points or more; and in three states-Minnesota, Pennsylvania, and DC-African American students trailed their white counterparts by 40 percentage points or more. ${ }^{3}$

We also find large performance gaps between white and Hispanic elementary school students. The smallest differences in pass rates were in Arkansas, Hawaii, and Texas-13 percentage points — and the largest difference was in DC—68 percentage points. In nine states, the achievement gap was 20 percentage points or less; in 10 states, the gap was 30 percentage points or more.

Of the twenty-seven states for which we have data on the pass rates of white, Hispanic, and African American students, African American students performed better than

\footnotetext{
${ }^{3}$ In some states, we found that while the achievement gap at the passing level is relatively small, particularly in those states with high overall pass rates such as Massachusetts and Colorado, there was a much larger achievement gap at the next-higher level of achievement. For example, in Massachusetts, at the next level of achievement, the achievement gap between white students and African American students jumped to 36 percentage points while the gap between white students and Hispanic students was 44 percent (see appendices for details).
} 
Figure 3.1

Pass Rates of Elementary School Students on State Reading Assessments, 2001-2002/2002-2003

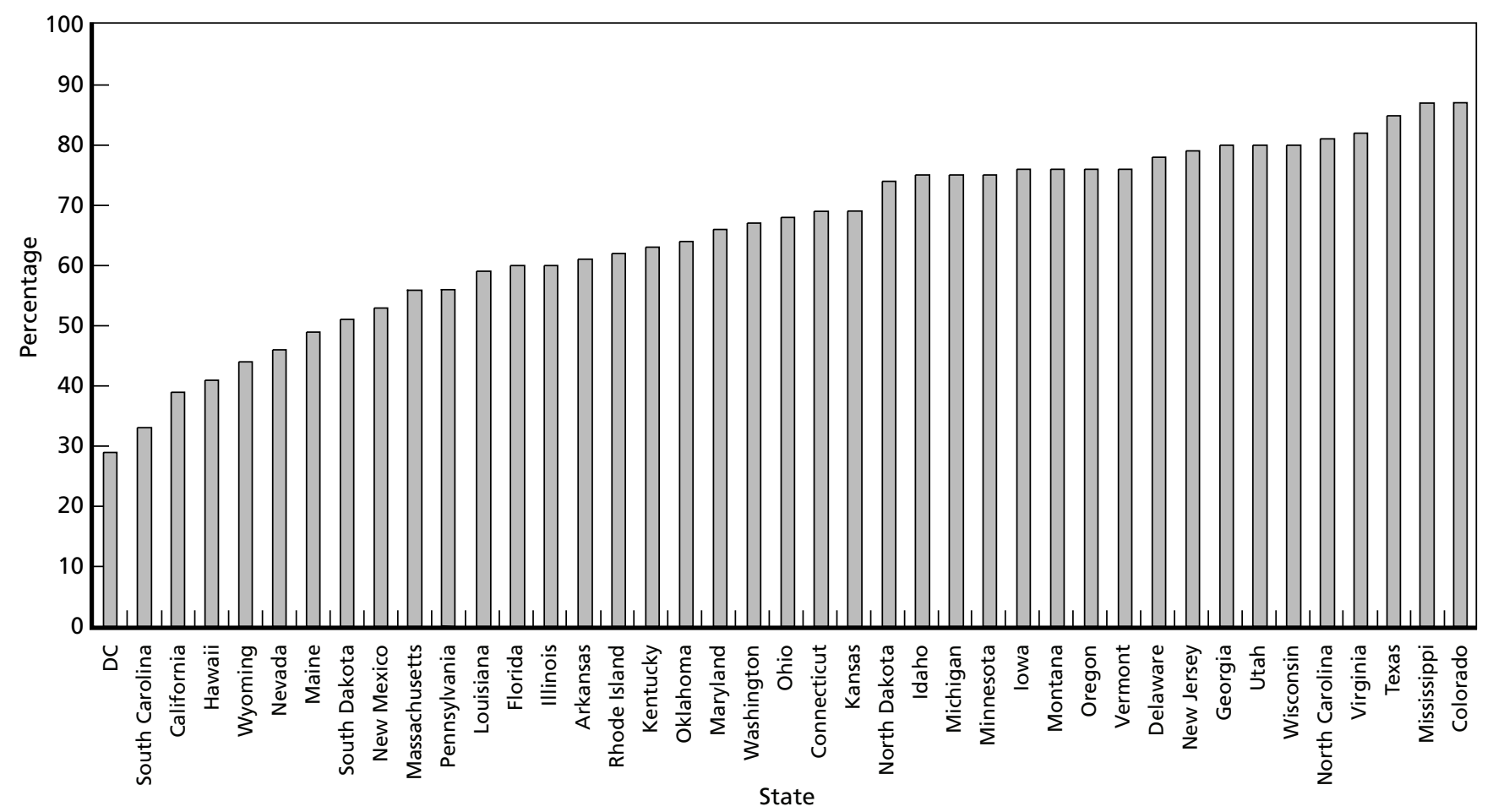

NOTE: Ten states are excluded from the figure because they did not have readily available and reportable data for grades 4-5.

RAND TR180-3.1 
Figure 3.2

Differences in Pass Rates of White and African American Elementary School Students on State Reading Assessments, 2001-2002/2002-2003

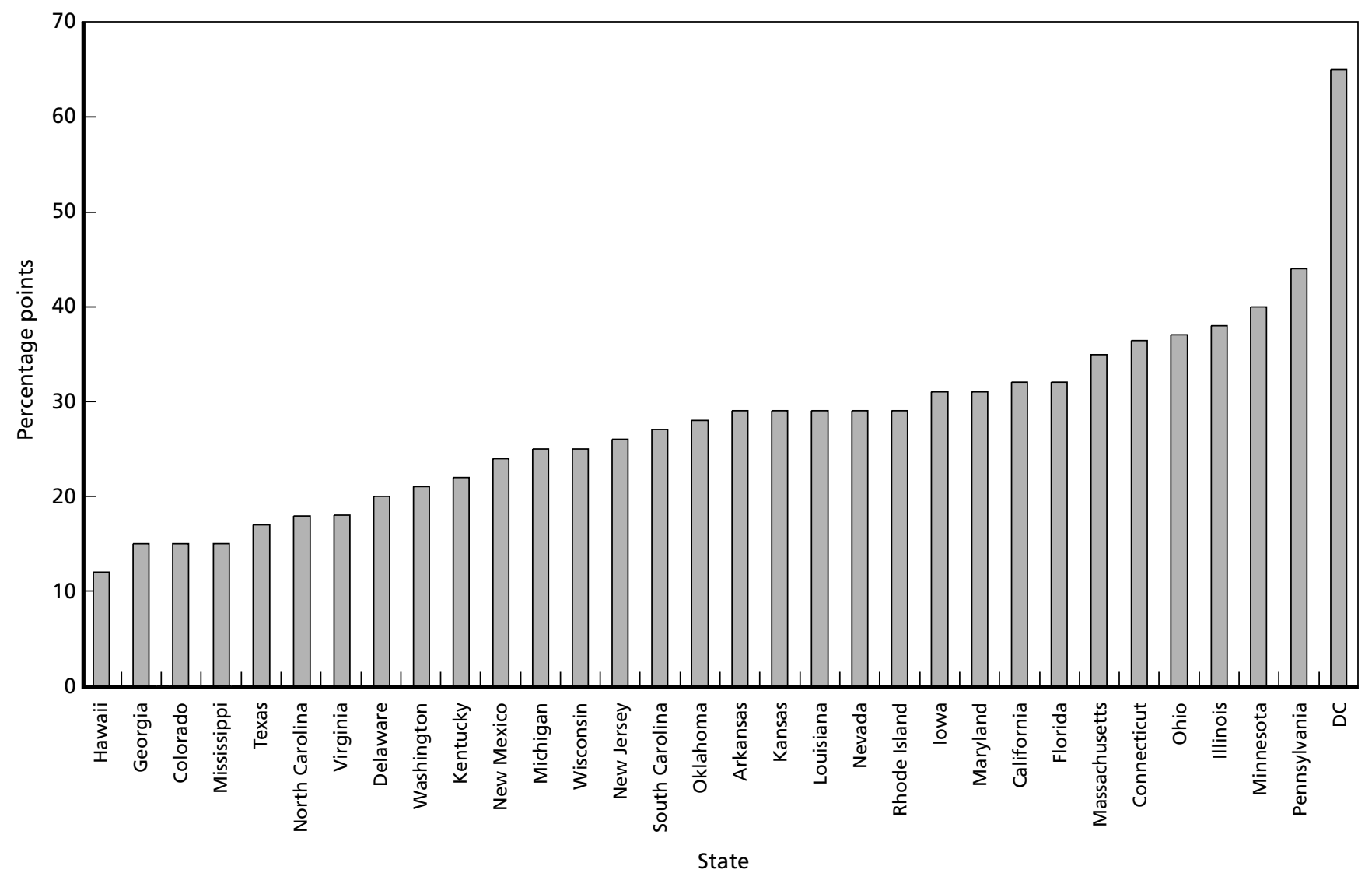

NOTE: Eighteen states did not have readily available and reportable data disaggregated for African American students in grades 4-5. RAND TR180-3.2 
Figure 3.3

Differences in Pass Rates of White and Hispanic Elementary School Students on State Reading Assessments, 2001-2002/2002-2003

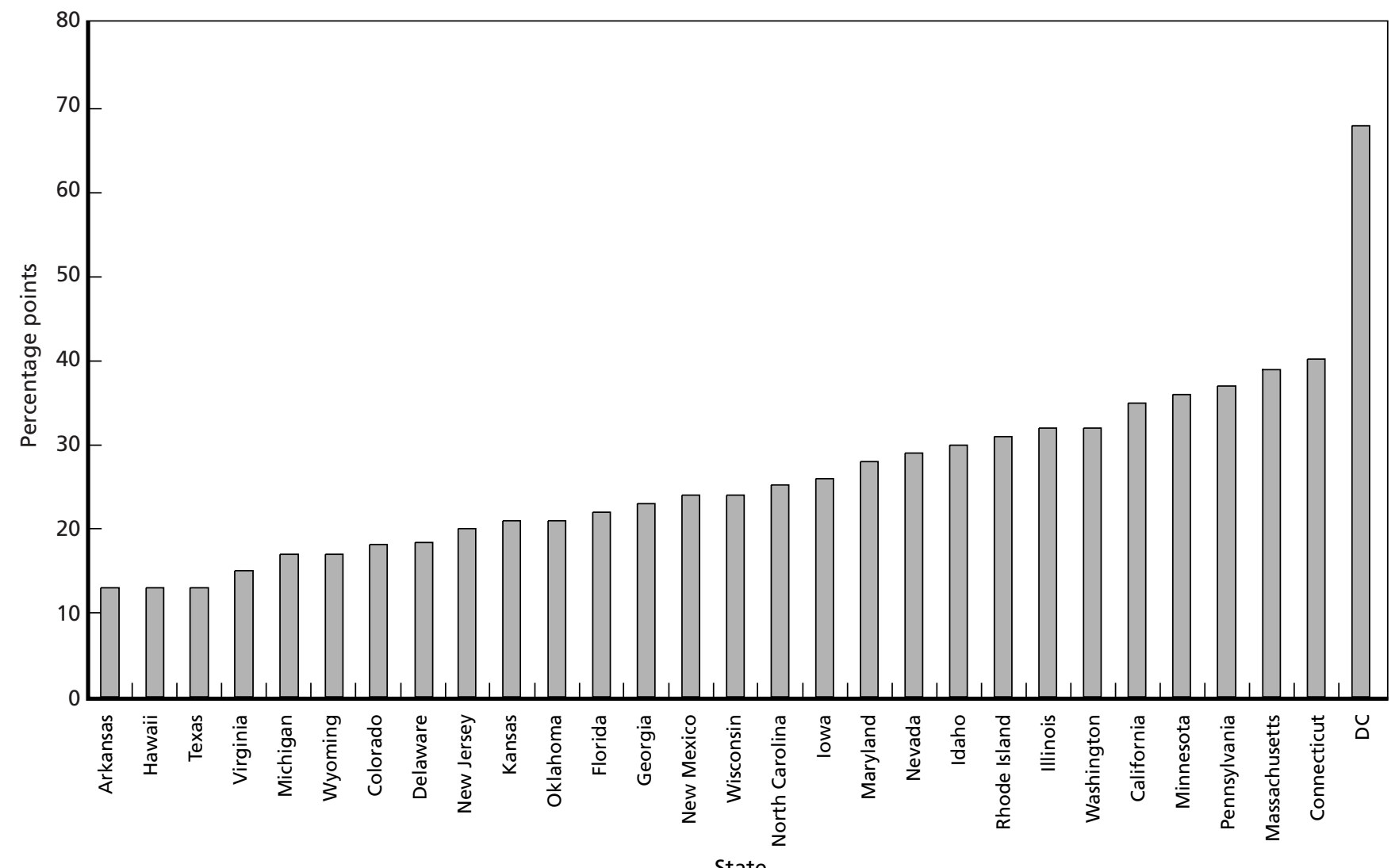

NOTE: Twenty-two states did not have readily available and reportable data disaggregated for Hispanic students in grades 4-5.

RAND TR180-3.3 
Hispanic students in 11 ; in 14 states, the opposite was true. However, generally, the difference in pass rates between the two groups was between -6 and +6 percentage points. There were some exceptions. In Arkansas, for example, Hispanic students outperformed African American students by 16 percentage points; in Washington, African Americans scored better than their Hispanic counterparts by about 11 percentage points.

Economically disadvantaged ${ }^{4}$ students lagged behind their counterparts who were not economically disadvantaged. As shown in Figure 3.4, 25 states provided data for students, disaggregated by poverty status. The achievement gap ranged from 15 to 37 percentage points. Ten states reported differences in pass rates of the two groups of 20 percentage points or less. In seven states-South Carolina, Minnesota, Vermont, Illinois, California, Pennsylvania, and Connecticut - the difference ranged from 30 to 37 percentage points. By and large, these performance gaps were somewhat smaller than those found among racial/ethnic groups. This lesser gap was particularly evident in DC: 18 percentage points among advantaged and disadvantaged students compared with over 65-68 percentage points between white and African American and white and Hispanic students.

\section{Writing Assessments}

Some states also gave writing assessments in the elementary grades. Pass rates on the writing assessments for the 18 states that had data with achievement levels are shown in Figure 3.5. Kentucky had the lowest passing rates: Only 9 percent of elementary school students passed the state writing assessment. Four states had pass rates of less than 30 percent, whereas five states had pass rates of 80 percent or higher. Between 81 and 91 percent of students in Ohio, Connecticut, Virginia, Texas, and Colorado passed the writing assessment at the elementary grade level. In many cases, the pass rates on the writing assessments were considerably lower than the pass rates on the state reading assessments. For example, in Kentucky, 63 percent of elementary students passed the reading assessment, compared with 9 percent passing the writing assessment. In Rhode Island, the percentage of students passing the reading assessment was exactly double the percentage that passed the writing assessment (62 percent versus 31 percent). Given that achievement levels can be set considerably differently across subjects, even within a state, this finding may not be surprising (Kingsbury et al., 2003).

At the top end of the distribution, pass rates on both assessments tended to be more comparable. For example, $82-85$ percent of students in Virginia passed both the reading and writing assessments; in Texas, $85-88$ percent of students did so.

Some states provided data on pass rates disaggregated by race/ethnicity and poverty status of students. Because these data largely mirror what we found on the reading assessments, we provide only a summary distribution of the achievement gaps in writing for the various subgroups of students (Table 3.2). The achievement gaps range from a low of 3 to a high of 26 percentage points. We divided the range into four categories: 0-9, 10-19, 20-29, and $30+$ percentage points and then tallied the number of states that fell into each group. There were three states in which the difference in pass rates between white and African American students was less than 10 percentage points, nine states in which the

\footnotetext{
${ }^{4}$ Most states used eligibility or receipt of free or reduced-price lunch as a proxy for economic disadvantage or poverty.
} 
Figure 3.4

Differences in Pass Rates of Economically Advantaged and Economically Disadvantaged

Elementary School Students on State Reading Assessments, 2001-2002/2002-2003

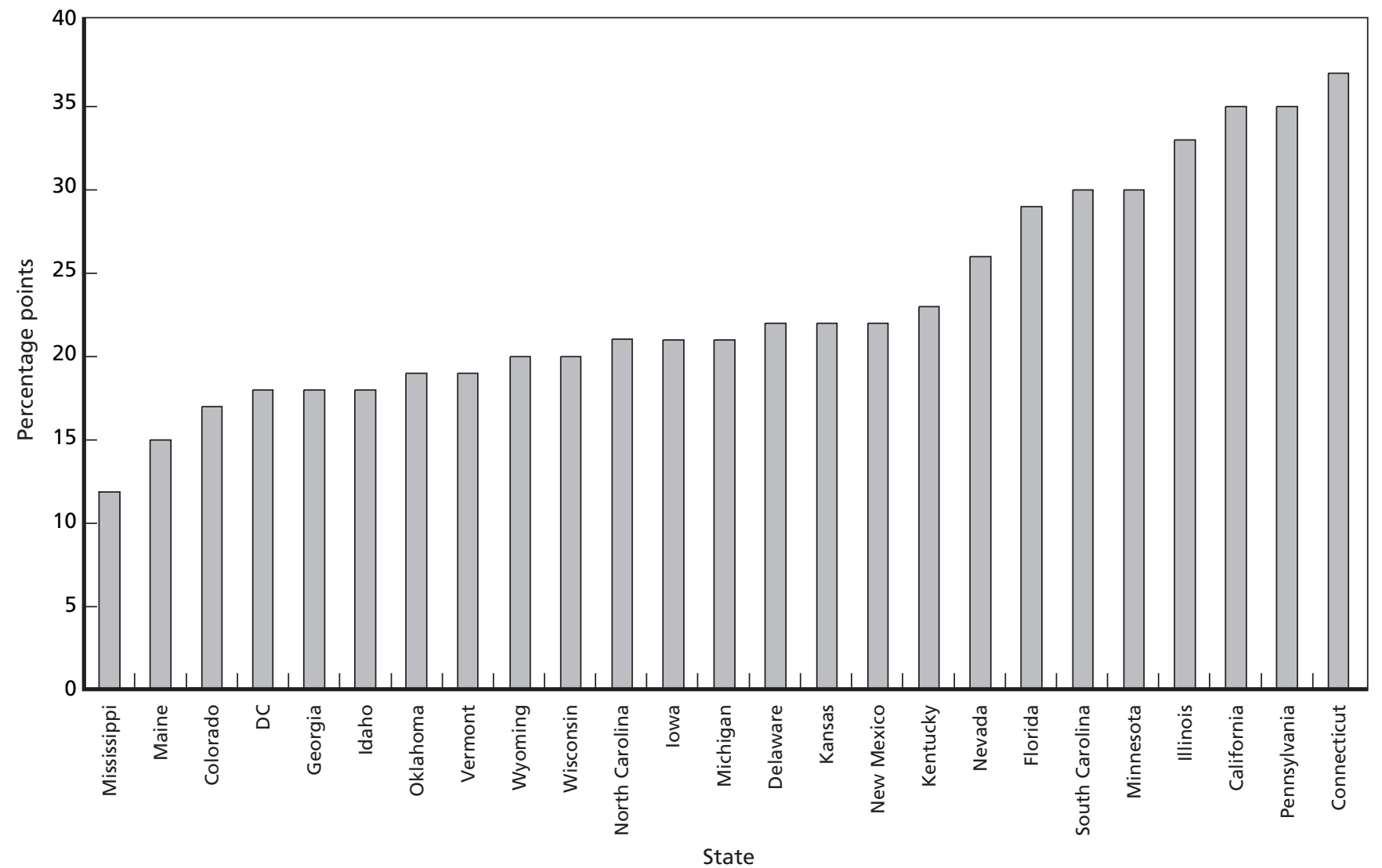

NOTE: Twenty-six states did not have readily available and reportable data disaggregated by poverty.

RAND TR180-3.4 
Figure 3.5

Pass Rates of Elementary School Students on State Writing Assessments, 2001-2002/2002-2003

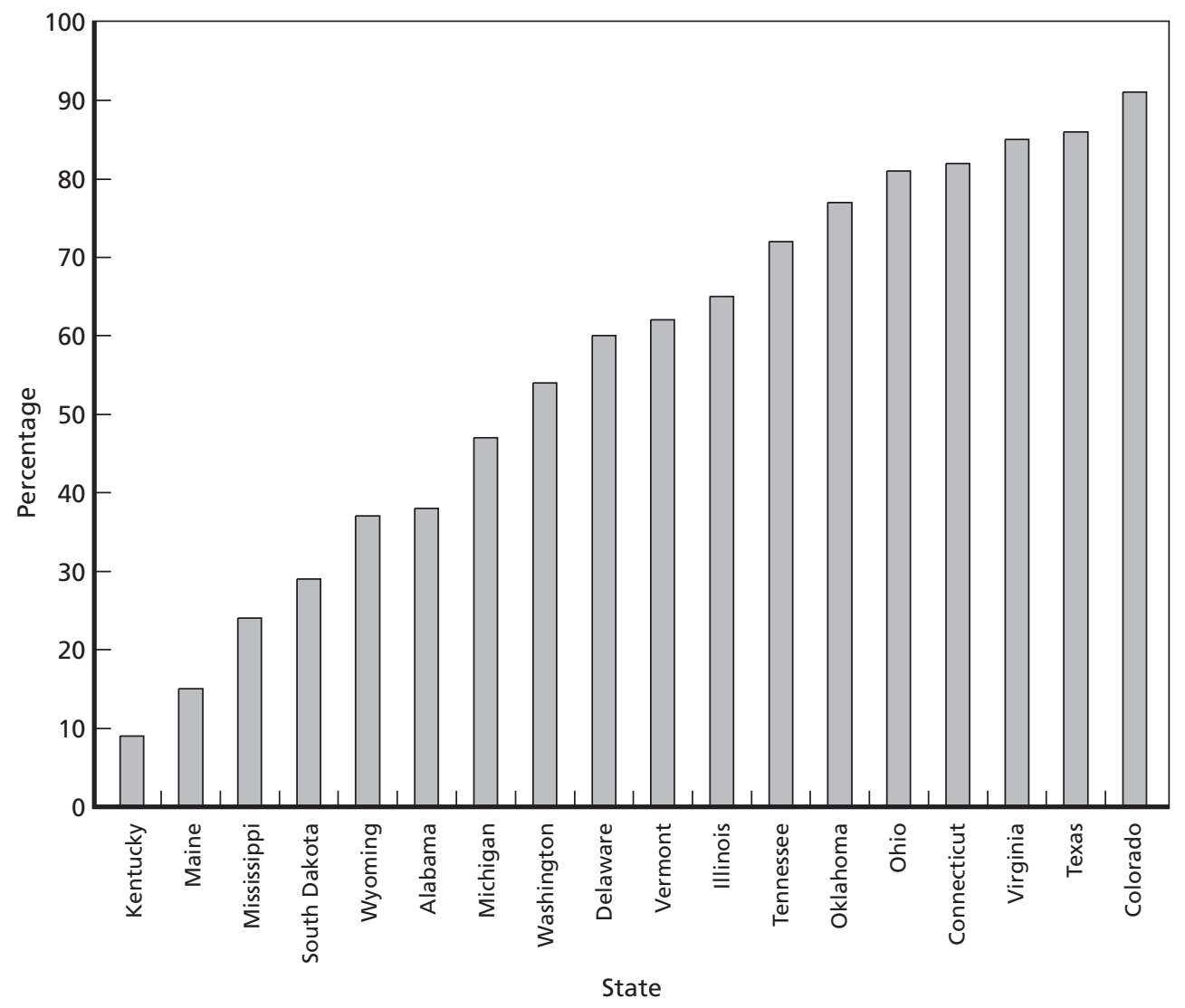

NOTE: Thirty-one states either did not administer a separate writing assessment or did not have reportable data at the elementary grade level.

RAND TR180-3.5

Table 3.2

Differences in Pass Rates of Elementary School Students, Disaggregated by Race/Ethnicity and Poverty Status: State Writing Assessments

\begin{tabular}{|c|c|c|c|}
\hline $\begin{array}{l}\text { Difference } \\
\text { Between } \\
\text { Pass Rates of } \\
\text { Selected } \\
\text { Subgroups of } \\
\text { Students }\end{array}$ & $\begin{array}{c}\text { White and } \\
\text { African American } \\
\text { Students } \\
(n=15)\end{array}$ & $\begin{array}{c}\text { White and } \\
\text { Hispanic Students } \\
(n=11)\end{array}$ & $\begin{array}{c}\text { Economically } \\
\text { Advantaged and } \\
\text { Economically } \\
\text { Disadvantaged } \\
\text { Students } \\
(n=12)\end{array}$ \\
\hline points) & \multicolumn{3}{|c|}{ Number of States } \\
\hline$\leq 10$ & 3 & 4 & 2 \\
\hline $10-19$ & 9 & 5 & 5 \\
\hline $20-29$ & 3 & 2 & 5 \\
\hline $30+$ & 0 & 0 & 0 \\
\hline
\end{tabular}


difference was between 10 and 19 percentage points, and three states in which the difference was between 20 and 29 percentage points.

The achievement gap between white and African American students on the writing assessments ranged from 3 to 26 percentage points. Kentucky, Oklahoma, and Maine reported the lowest achievement gap-less than 10 percentage points (Kentucky and Maine had very low pass rates overall); Connecticut, Ohio, and Illinois had an achievement gap of 20-29 percentage points.

Oklahoma, Tennessee, and Texas also showed a difference in pass rates of less than 10 percentage points between white students and Hispanic students. Connecticut's achievement gap between white students and Hispanic students was the highest, at 24 percentage points.

Two states-Kentucky and Maine-reported a difference in pass rates between economically advantaged and disadvantaged students of 5-8 percentage points; five states reported an achievement gap of 20-29 percentage points between the two groups.

\section{Performance of Middle School Students}

We now turn to data on the performance of middle school students.

\section{Reading Assessments: Overall Pass Rates}

Figure 3.6 presents the pass rates of middle school students on the state reading assessment for the 44 states that had readily available and reportable data. The pass rates range from 21 percent in South Carolina to 88 percent in Texas, and the average is 61 percent. Three states had pass rates of 30 percent or less. In 12 states, less than half of the students passed the reading assessment. Six states had pass rates of 80 percent and higher.

Middle school students had lower pass rates on reading assessments than did elementary school students in 27 of the 40 states for which we had data on pass rates for both elementary and middle school students. In 23 of the states, the difference was between 1 and 19 percentage points; in four states-Arkansas, Mississippi, Rhode Island, Vermont-the difference in pass rates was 20 percentage points or higher. In North Carolina, 86 percent of both sets of students passed the respective reading assessments. In 13 of the 40 states, middle school students passed at a higher rate than did elementary school students. In South Dakota, the difference was quite large: Pass rates of middle school students were 27 percentage points higher than those of elementary school students.

Among the states, for both sets of students, DC had the lowest pass rates, whereas Texas, North Carolina, and Colorado had pass rates of 80 percent or higher.

\section{Reading Assessments: Differences in Performance Among Students, Disaggregated by Race/Ethnicity and Poverty Status}

Figure 3.7 shows differences in pass rates of white and African American middle school students. These ranged from 12 percentage points in Colorado and Texas to 64 percentage points in DC. In eight states, the difference in performance was 20 percentage points or lower. In three states-Minnesota, Pennsylvania, and DC- the difference was 40 percentage points or higher. 
Figure 3.6

Pass Rates of Middle School Students on State Reading Assessments, 2001-2002/2002-2003

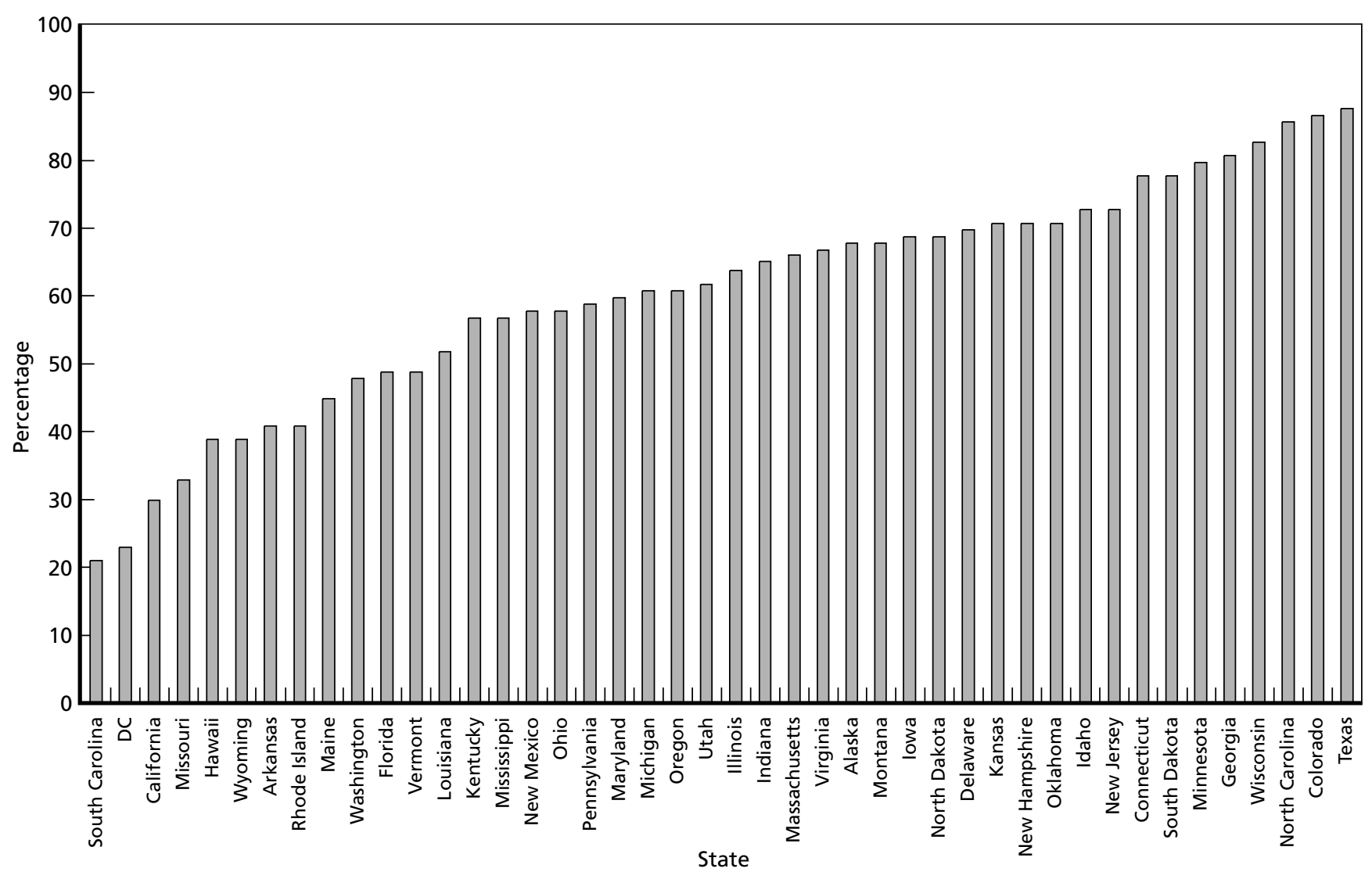

NOTE: Seven states are excluded from the figure because they did not have readily available and reportable data for grades 6-8.

RAND TR180-3.6 
Figure 3.7

Differences in Pass Rates of White and African American Middle School Students on State Reading Assessments, 2001-2002/2002-2003

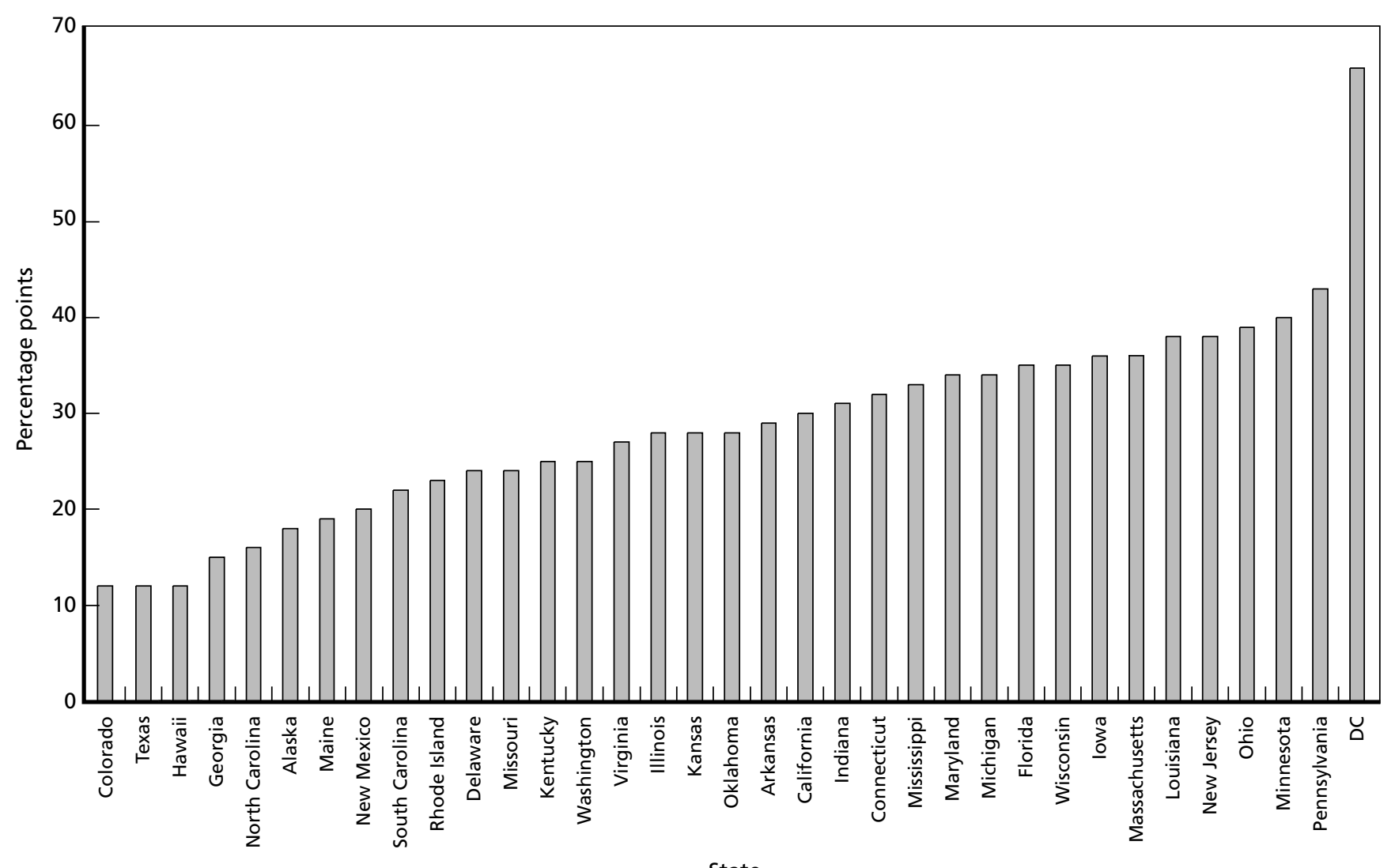

State

NOTE: Sixteen states are excluded from the figure because they did not have readily available and reportable data for African American students in grades 6-8.

RAND TR180-3.7 
Figure 3.8 shows data for white and Hispanic students. The smallest difference in performance was in Texas, where Hispanic students trailed white students by 11 percentage points, and the largest difference was in DC (65 percentage points). In five states, the difference in pass rates was 20 percentage points or lower. In eight states, the performance gap between white and Hispanic students was 30 percentage points or higher.

As with elementary school students, the performance of Hispanic and African American middle school students was relatively similar across states. With some exceptions, of the 29 states that published data on all three groups of students (whites, Hispanics, and African Americans), 17 had a difference in pass rates of between -6 and +6 percentage points. In four states-Arkansas, Florida, Michigan, Missouri-Hispanic pass rates were between 10 and 13 percentage points higher than those of African American students. In North Carolina, African American students outperformed Hispanic students by 11 percentage points. ${ }^{5}$

Twenty-seven states reported data for students that were disaggregated by poverty status (Figure 3.9). The achievement gap by poverty status ranged from 17 to 37 percentage points. Nine states reported differences in pass rates of 20 percentage points or less for the two groups. In three states-Florida, Connecticut, and Pennsylvania—-the difference ranged from 30 to 37 percentage points. Connecticut and Pennsylvania showed differences of over 35 percentage points between economically advantaged and disadvantaged students at both the elementary and middle school levels.

As with elementary school students, the performance gaps between students from low-income households and those from more-advantaged backgrounds were slightly smaller than those found among racial/ethnic groups, with one notable exception. In DC, students from low-income households trailed their counterparts by 15 percentage points compared with 59-64-percentage-point differences between white and Hispanic and African American students.

\section{Writing Assessments}

Twenty-one states reported writing assessment data with achievement levels in the middle grades (Figure 3.10). As with elementary school students, Kentucky had the lowest passing rate-only 17 percent of its middle school students passed the state writing assessment - and it was the only state with a pass rate lower than 30 percent. Six states had pass rates of 80 percent or higher-Connecticut, Tennessee, Texas, Ohio, Georgia, and Colorado-and the last two had pass rates of 90 percent. In 15 of the 21 states, over half the students passed the writing assessment.

In most states that reported pass rates on both the reading and writing assessments for middle school students, the pass rates tended to be fairly comparable ( \pm 7 percentage points). Of the remaining states, two (Kentucky and Mississippi) had considerably higher

\footnotetext{
5 There were also large achievement gaps between white students and minorities other than African Americans and Hispanics, such as Native Americans, Alaskan Natives, and Hawaiian natives. For instance, the percentages of Native American students scoring at the proficient level in middle school reading in Wyoming, Montana, South Dakota, and North Dakota were 27-38 percentage points lower than the proficiency rates of white students in those states. In Hawaii, the proportion of Hawaiian natives at the proficient level was 16 percent lower than the percentage of white students; in Alaska, the achievement gap between white students and Alaskan natives is 40 percentage points. These achievement gaps occurred in writing and in lower grades as well.
} 
Figure 3.8

Differences in Pass Rates of White and Hispanic Middle School Students on State Reading Assessments, 2001-2002/2002-2003

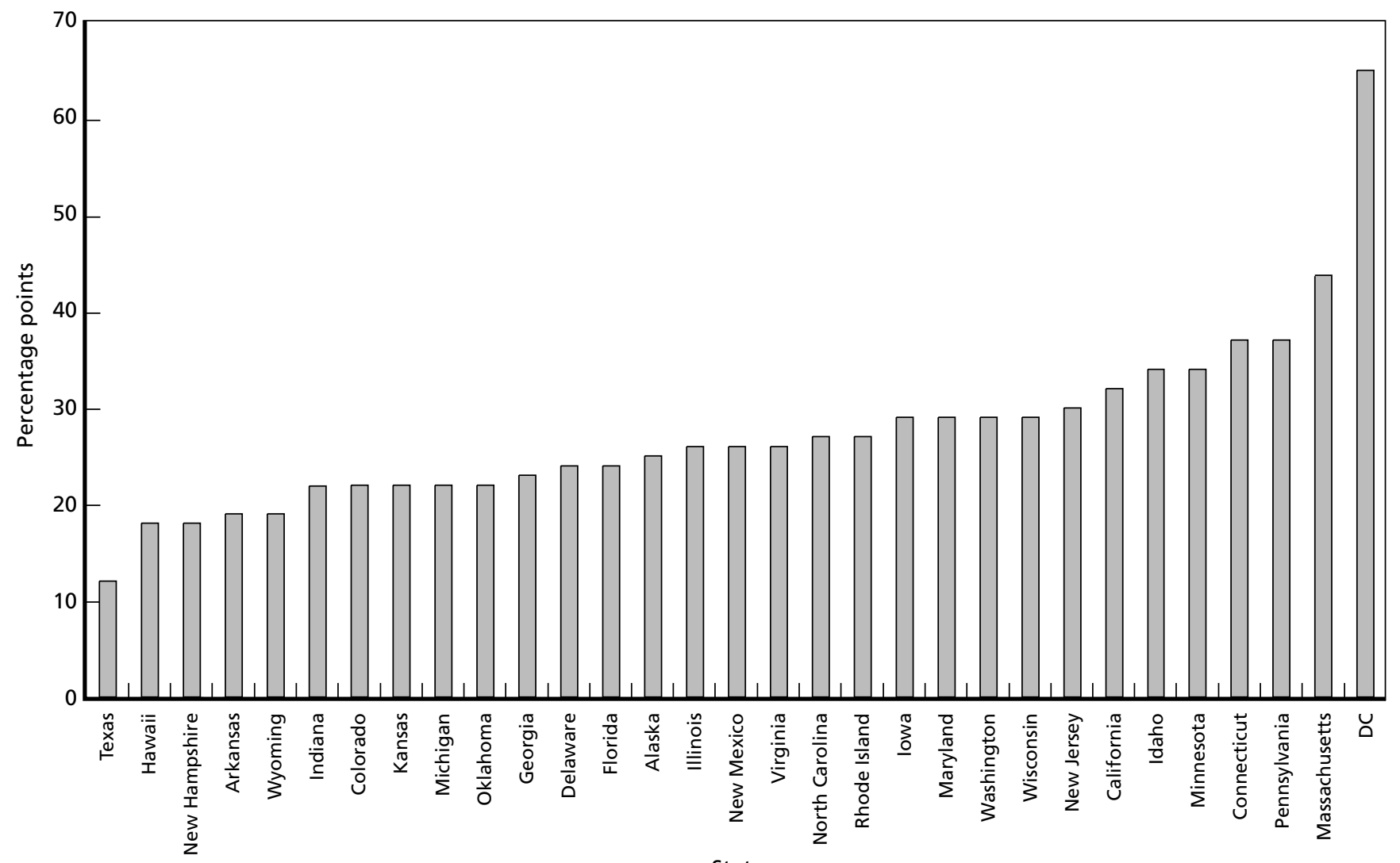

State

NOTE: Nineteen states are excluded from the figure because they did not have readily available and reportable data on Hispanic students in grades 6-8. RAND TR180-3.8 
Figure 3.9

Differences in Pass Rates of Economically Advantaged and Economically Disadvantaged

Middle School Students on State Reading Assessments, 2001-2002/2002-2003

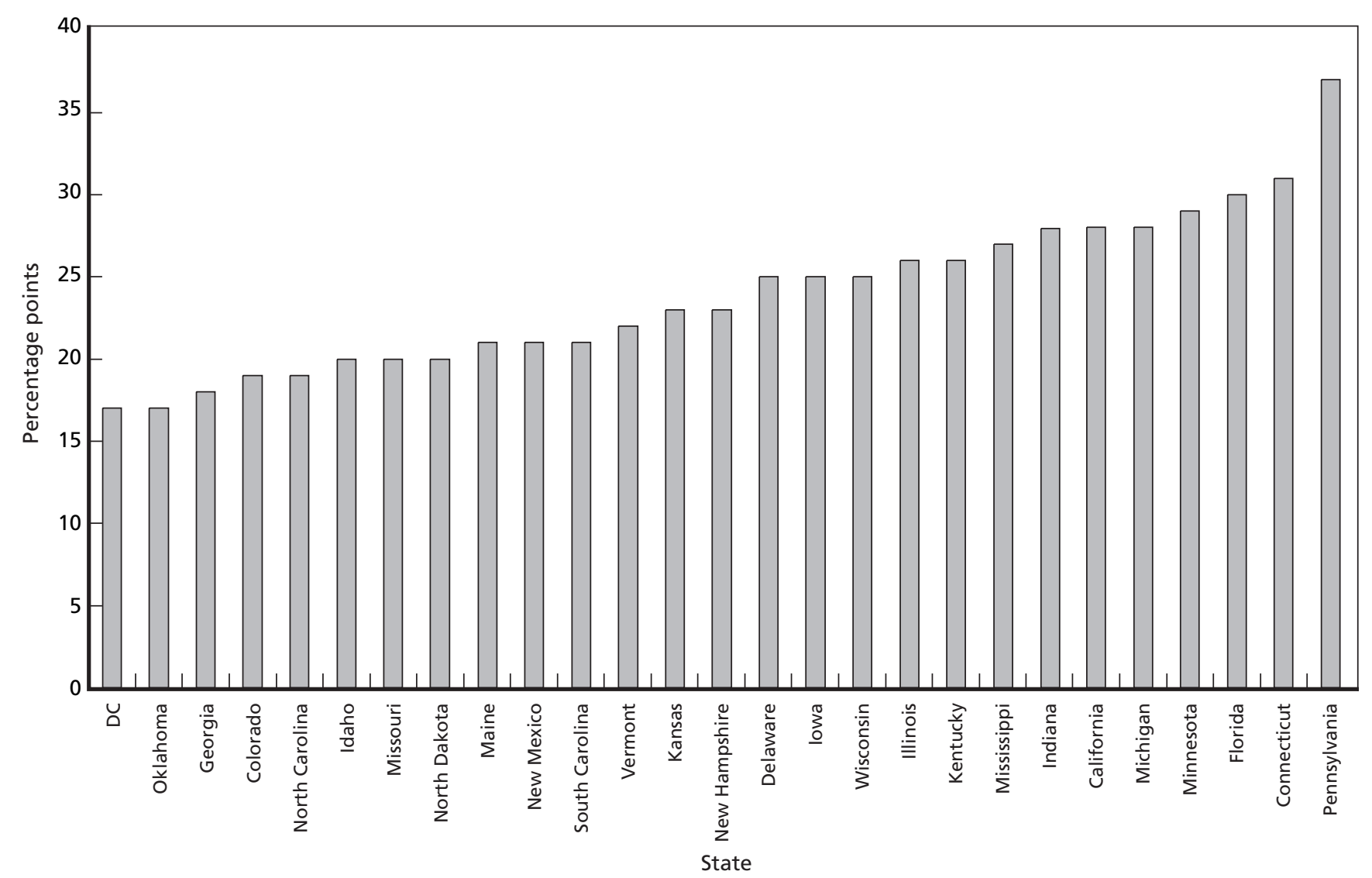

NOTE: Twenty-four states are excluded from the figure because they did not have readily available and reportable data on poverty status for grades 6-8. RAND TR180-3.9 
Figure 3.10

Pass Rates of Middle School Students on State Writing Assessments,

2001-2002/2002-2003

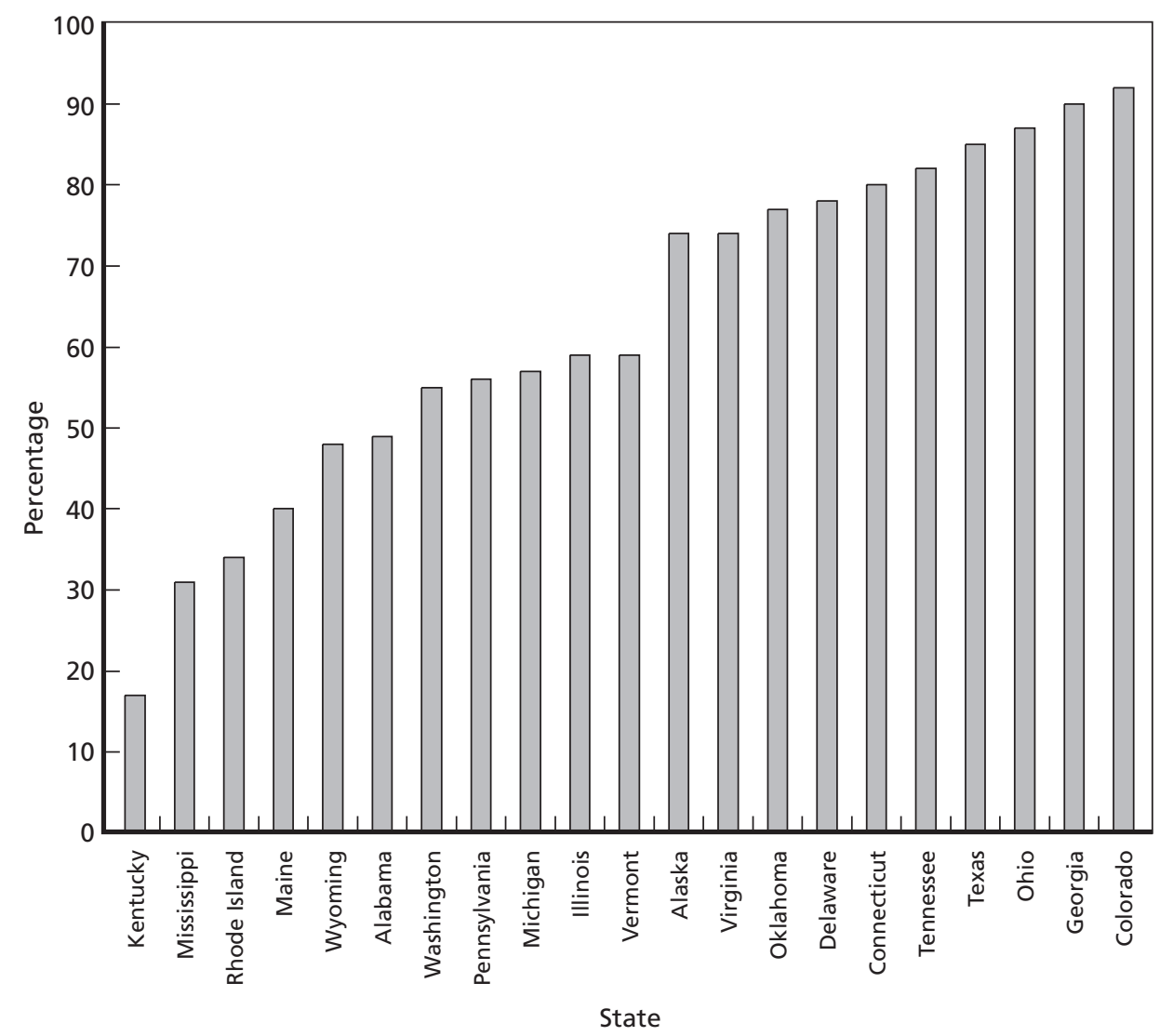

NOTE: Thirty states either did not administer writing assessments or did not have reportable data at the middle school level.

RAND TR180-3.10

pass rates on the reading assessment than on the writing assessment; in Ohio and Vermont, the opposite was true. The differences in pass rates ranged from 26 to 41 percentage points in these states. In three states, the pass rates were uniformly high on both assessments-78-80 percent of students in Connecticut; $85-88$ percent of students in Texas; and 87-92 percent of students in Colorado passed the reading and writing assessments.

As with the elementary school data, we provide only a summary distribution of the achievement gaps in writing for the various subgroups of students for the states that reported such data (Table 3.3). As before, we divided the range (6-34 percentage points in this case) into four categories: $0-9,10-19,20-29$, and $\geq 30$ percentage points and counted the number of states that fell into each group.

The achievement gap between white and African American students on the writing assessments ranged from 6 to 25 percentage points. Kentucky and Oklahoma reported the lowest achievement gaps (6-8 percentage points). Five states had an achievement gap of 20-29 percentage points-Alabama, Michigan, Connecticut, Virginia, and Illinois.

Oklahoma was the only state that reported a difference in pass rates between white students and Hispanic students of less than 10 percentage points, and it was the only state to 
Table 3.3

Differences in Pass Rates of Middle School Students, Disaggregated by Race/Ethnicity and Poverty Status: State Writing Assessments

\begin{tabular}{|c|c|c|c|}
\hline $\begin{array}{l}\text { Difference } \\
\text { Between } \\
\text { Pass Rates of } \\
\text { Selected } \\
\text { Subgroups of } \\
\text { Students }\end{array}$ & $\begin{array}{c}\text { White and } \\
\text { African American } \\
\text { Students } \\
(n=17)\end{array}$ & $\begin{array}{c}\text { White and } \\
\text { Hispanic Students } \\
(n=13)\end{array}$ & $\begin{array}{c}\text { Economically } \\
\text { Advantaged and } \\
\text { Economically } \\
\text { Disadvantaged } \\
\text { Students } \\
(n=12)\end{array}$ \\
\hline points) & \multicolumn{3}{|c|}{ Number of States } \\
\hline$\leq 10$ & 3 & 1 & 1 \\
\hline $10-19$ & 9 & 10 & 6 \\
\hline $20-29$ & 5 & 1 & 5 \\
\hline$\geq 30$ & 0 & 1 & 0 \\
\hline
\end{tabular}

report a difference in pass rates between economically advantaged and disadvantaged students of less than 10 percentage points. In contrast, in Connecticut the achievement gap between white students and Hispanic students was 30 percentage points, and the gap between economically disadvantaged students and their economically advantaged peers was 25 percentage points.

There was remarkable consistency in the results on the elementary and middle school writing assessments in terms of which states had the lowest and which had the highest achievement gaps by race/ethnicity and poverty status. For example, Connecticut showed large subgroup differences in both grades, whereas Kentucky (which had the lowest pass rates overall among both elementary and middle school students) tended to report much lower differences between groups at both grade levels.

\section{Performance of High School Students}

This section briefly examines some of the results on high school tests that are part of the states' accountability systems. We report the data for high school tests required for graduation separately from student performance on the assessments that do not carry high stakes for students.

\section{Student Performance on Graduation Assessments}

On the high school tests that are required for graduation, first-time pass rates tended to be relatively high-68-95 percent for all students (Table 3.4). ${ }^{6}$ It is not surprising that these scores would be higher than those found in typical state assessments, because graduation tests tend to heavily test basic skills rather than advanced skills (Achieve, 2004). For the three states that tested students in both reading and English language arts, the pass rates were quite similar on the two assessments - within 0 to 5 percentage points of one another.

For the six states with a separate writing assessment, students in Ohio, South Carolina, and Virginia had very similar pass rates on the assessments for reading (1-2percentage-point difference), while students in Minnesota and Alaska performed better on

\footnotetext{
${ }^{6}$ In all states with graduation examinations, students who do not pass the exam have multiple opportunities to retake the exam so that they can graduate. Thus, first-time pass rates on these examinations do not determine who will and who will not graduate.
} 
the writing assessment than on the reading assessment, and students in Georgia had higher language arts scores.

Table 3.4

Results for First-Time Test Takers: High School Tests Required for Graduation, 2002-2003

\begin{tabular}{|c|c|c|c|c|}
\hline State & $\begin{array}{l}\text { Average } \\
\text { Performance } \\
\text { in Reading }\end{array}$ & $\begin{array}{c}\text { Average } \\
\text { Performance } \\
\text { in Writing }\end{array}$ & $\begin{array}{c}\text { Average } \\
\text { Performance } \\
\text { in English } \\
\text { Language Arts }\end{array}$ & Achievement Gaps \\
\hline Alabama & All: $88 \%$ & & All: $83 \%$ & $\begin{array}{l}\text { SES: } 12-14 \% \\
\text { W-AA: } 14-18 \%\end{array}$ \\
\hline Alaska & All: $70 \%$ & All: $83 \%$ & & $\begin{array}{l}\text { W-AA: } 17-35 \% \\
\text { W-AN: } 22-37 \% \\
\text { W-H: } 14-19 \%\end{array}$ \\
\hline Florida $^{a}$ & All: $68 \%$ & & & $\begin{array}{l}\text { SES: } 26 \% \\
\text { W-AA: } 35 \% \\
\text { W-H: } 24 \%\end{array}$ \\
\hline Georgia & & All: $88 \%$ & All: $95 \%$ & $\begin{array}{l}\text { SES: } 7-14 \% \\
\text { W-AA: } 5-12 \% \\
\text { W-H: } 13-22 \%\end{array}$ \\
\hline Idaho** & All: $74 \%$ & & All: $74 \%$ & $\begin{array}{l}\text { SES: } 19 \% \\
\text { W-H: } 32-37 \%\end{array}$ \\
\hline Indiana & & & All: $69 \%$ & $\begin{array}{l}\text { SES: } 29 \% \\
\text { W-AA: } 35 \% \\
\text { W-H: } 31 \%\end{array}$ \\
\hline Louisiana $^{a}$ & & & All: $71 \%$ & W-AA: $32 \%$ \\
\hline Massachusetts ${ }^{a}$ & & & All: $89 \%$ & $\begin{array}{l}\text { W-AA: } 18 \% \\
\text { W-H: } 28 \%\end{array}$ \\
\hline Minnesota ${ }^{b}$ & All: $80 \%$ & All: $91 \%$ & & $\begin{array}{l}\text { SES: } 18-29 \% \\
\text { W-AA: } 32-40 \% \\
\text { W-H: } 24-34 \%\end{array}$ \\
\hline New Jersey & & & All: $81 \%$ & $\begin{array}{l}\text { W-AA: } 25 \% \\
\text { W-H: } 24 \%\end{array}$ \\
\hline New Mexico & $\begin{array}{l}\text { Passing data } \\
\text { not available }\end{array}$ & & $\begin{array}{l}\text { Passing data } \\
\text { not available }\end{array}$ & $\begin{array}{l}\text { SES: .4 standard } \\
\text { deviation } \\
\text { W-AA: .5 standard } \\
\text { deviation } \\
\text { W-H: } .5 \text { standard } \\
\text { deviation }\end{array}$ \\
\hline Ohio & All: $92 \%$ & All: $90 \%$ & & W-AA: $15-16 \%$ \\
\hline South Carolina & All: $84 \%$ & All: $83 \%$ & & $\begin{array}{l}\text { SES: } 20-21 \% \\
\text { W-AA: } 20-23 \%\end{array}$ \\
\hline Texas* & All: $72 \%$ & & & $\begin{array}{l}\text { W-AA: } 16 \% \\
\text { W-H: } 17 \%\end{array}$ \\
\hline Virginia & All: $93 \%$ & All: $91 \%$ & & $\begin{array}{l}\text { W-AA: 8-11\% } \\
\text { W-H: 9-19\% }\end{array}$ \\
\hline
\end{tabular}

NOTES:

All=all students; SES=achievement gap between non-economically disadvantaged students and economically disadvantaged students; $\mathrm{W}-\mathrm{AA}=$ achievement gap between white students and African American students; $\mathrm{W}-\mathrm{AN}=$ achievement gap between white students and Alaskan native students; W-NA=achievement gap between white students and Native American students; W-H: achievement gap between white students and Hispanic students.

* Required for graduation in 2004.

** Required for graduation in 2006.

a Performance level required for graduation is lower than that required to meet the requirements under NCLB.

${ }^{\mathrm{b}}$ Minnesota reading data are from the basic-skills test that students must take in 8 th grade. The writing basic-skills test is administered in 10th grade. The achievement gaps are larger in 8thgrade reading than in 10 th-grade reading. 
Similar to the elementary and middle school findings, there were large achievement gaps by socioeconomic status and by race/ethnicity. Economically disadvantaged students scored 7 to 30 percentage points below their peers. In New Mexico, these students scored .4 of a standard deviation below their more-advantaged peers. Differences based on race/ethnicity tended to be even larger. The achievement gap between white students and African American students ranged from 5 to 42 percentage points and 9 to 37 percentage points between white students and Hispanic students. In New Mexico, the achievement gaps equated to about half of a standard deviation.

\section{Student Performance on High School Assessments Not Required for Graduation}

On the high school reading, English language arts, and writing assessments that were not linked to graduation requirements, 13-93 percent of all students scored at the "proficient" level-a much wider range than what we found with required graduation tests (Table 3.5). For instance, for states that administered writing assessments, the proportion of students passing ranged from 24 percent in Rhode Island to almost all students in Mississippi and Colorado.

Again, there were significant achievement gaps by socioeconomic status, ranging from 2 percentage points (for the Mississippi writing assessment, which almost all students passed) to 36 percentage points. And similar to all other findings, the achievement gaps for race/ethnicity were even larger (2-72 percentage points).

\section{Summary}

There is considerable variability in proficiency rates among states, owing largely to differences in the content and rigor of the tests, the cut-scores used to determine achievement levels, and actual differences in student abilities. Given the great variability across states in the first two factors, one cannot make inferences regarding how well or how badly students in one state are doing relative to those in another.

However, these data are useful in highlighting how far states have to go to meet NCLB's ambitious goal of bringing all students up to the "proficient" level (even based on their own standards). For example, the average reading pass rate was between 61 and 66 percent at the elementary and middle school grades, with a range of 21 to 88 percent. In seven states, less than half of the students passed the reading assessment at the elementary level, and this was true of 12 states at the middle school level. In both reading and writing, African American and Hispanic students trailed significantly behind white students - and the performance gap is often quite large (30 percentage points or higher). Economically disadvantaged students lagged behind their counterparts who were not economically disadvantaged, although, by and large, these performance gaps were somewhat smaller than those found among racial/ethnic groups. With some exceptions, the pass rates on the writing assessments were lower than the pass rates on the state reading assessments.

We now turn to data on the performance of 4th- and 8th-graders on the National Assessment of Educational Progress. 
Table 3.5

High School Results Not Linked to Graduation Requirements, 2002-2003

\begin{tabular}{|c|c|c|c|c|}
\hline State & $\begin{array}{c}\text { Average } \\
\text { Performance } \\
\text { in Reading }\end{array}$ & $\begin{array}{l}\text { Average } \\
\text { Performance } \\
\text { in Writing }\end{array}$ & $\begin{array}{c}\text { Average } \\
\text { Performance in } \\
\text { English } \\
\text { Language Arts }\end{array}$ & Achievement Gaps \\
\hline Arkansas ${ }^{a}$ & - & - & All: $37 \%$ & $\begin{array}{l}\text { W-AA: } 35 \% \\
\text { W-H: } 29 \%\end{array}$ \\
\hline California & & & All: $33 \%$ & $\begin{array}{l}\text { SES: } 27 \% \\
\text { W-AA: } 31 \% \\
\text { W-H: } 33 \%\end{array}$ \\
\hline Colorado & All: $87 \%$ & All: $93 \%$ & & $\begin{array}{l}\text { SES: } 10-16 \% \\
\text { W-AA: 7-12\% } \\
\text { W-H: } 10-19 \%\end{array}$ \\
\hline Connecticut & All: $78 \%$ & All: $81 \%$ & & $\begin{array}{l}\text { SES: } 30 \% \\
\text { W-AA: } 33-37 \% \\
\text { W-H: } 35-37 \%\end{array}$ \\
\hline Delaware & All: $67 \%$ & All: $73 \%$ & & $\begin{array}{l}\text { SES: } 21-32 \% \\
\text { W-AA: } 19-30 \% \\
\text { W-H: } 20-32 \%\end{array}$ \\
\hline $\begin{array}{l}\text { District of } \\
\text { Columbia }\end{array}$ & All: $13 \%$ & & & $\begin{array}{l}\text { SES: } 12 \% \\
\text { W-AA: } 70 \% \\
\text { W-H: } 72 \%\end{array}$ \\
\hline Florida & & $\begin{array}{l}\text { Tested; no } \\
\text { proficiency } \\
\text { level set }\end{array}$ & & \\
\hline Hawaii & All: $40 \%$ & & & $\begin{array}{l}\text { W-AA: } 17 \% \\
\text { W-H: } 21 \%\end{array}$ \\
\hline Illinois & All: $56 \%$ & All: $59 \%$ & & $\begin{array}{l}\text { SES: } 31-36 \% \\
\text { W-AA: } 34-37 \% \\
\text { W-H: } 31-34 \%\end{array}$ \\
\hline lowa & All: $77 \%$ & & & $\begin{array}{l}\text { SES: } 21 \% \\
\text { W-AA: } 29 \% \\
\text { W-H: } 25 \%\end{array}$ \\
\hline Kansas & All: $61 \%$ & & & $\begin{array}{l}\text { SES: } 23 \% \\
\text { W-AA: } 31 \% \\
\text { W-H: } 22 \%\end{array}$ \\
\hline Kentucky & All: $31 \%$ & & & $\begin{array}{l}\text { SES: } 23 \% \\
\text { W-AA: } 18 \%\end{array}$ \\
\hline Maine & All: $46 \%$ & All: $37 \%$ & & $\begin{array}{l}\text { SES: } 20-26 \% \\
\text { W-AA: } 20-25 \%\end{array}$ \\
\hline Maryland & All: $61 \%$ & & & $\begin{array}{l}\text { W-AA: } 34 \% \\
\text { W-H: } 30 \%\end{array}$ \\
\hline Michigan & All: $71 \%$ & All: $50 \%$ & & $\begin{array}{l}\text { SES: } 21 \% \\
\text { W-AA: } 20-21 \% \\
\text { W-H: } 16-19 \%\end{array}$ \\
\hline Mississippi & All: $78 \%$ & All: $94-97 \%$ & & $\begin{array}{l}\text { SES: } 2-18 \% \\
\text { W-AA: } 2-22 \%\end{array}$ \\
\hline Missouri & & & All: $22 \%$ & $\begin{array}{l}\text { SES: } 14 \% \\
\text { W-AA: } 18 \% \\
\text { W-H: } 10 \%\end{array}$ \\
\hline Montana & & & All: $75 \%$ & W-NA: $31 \%$ \\
\hline $\begin{array}{l}\text { New } \\
\text { Hampshire }\end{array}$ & & & All: $69 \%$ & $\begin{array}{l}\text { SES: } 20 \% \\
\text { W-H: } 24 \%\end{array}$ \\
\hline
\end{tabular}


Table 3.5-Continued

\begin{tabular}{|c|c|c|c|c|}
\hline State & $\begin{array}{c}\text { Average } \\
\text { Performance } \\
\text { in Reading }\end{array}$ & $\begin{array}{c}\text { Average } \\
\text { Performance } \\
\text { in Writing }\end{array}$ & $\begin{array}{c}\text { Average } \\
\text { Performance in } \\
\text { English Language } \\
\text { Arts }\end{array}$ & Achievement Gaps \\
\hline $\begin{array}{l}\text { North } \\
\text { Carolina }\end{array}$ & All: $64 \%$ & & & $\begin{array}{l}\text { W-AA: } 32 \% \\
\text { W-NA: } 26 \% \\
\text { W-H: } 31 \%\end{array}$ \\
\hline North Dakota & All: $52 \%$ & & & W-NA: $30 \%$ \\
\hline Oklahomac $^{c}$ & All: $56 \%$ & All: $68 \%$ & & $\begin{array}{l}\text { SES: } 15-22 \% \\
\text { W-AA: } 21-31 \% \\
\text { W-NA: } 11-15 \% \\
\text { W-H: } 15-26 \%\end{array}$ \\
\hline Oregon & & & All: $52 \%$ & \\
\hline Pennsylvania & All: $59 \%$ & All: $70 \%$ & & $\begin{array}{l}\text { SES: } 28-32 \% \\
\text { W-AA: } 31-38 \% \\
\text { W-H: } 32-35 \%\end{array}$ \\
\hline Rhode Island $^{d}$ & & All: $24 \%$ & All: $43 \%$ & $\begin{array}{l}\text { W-AA: } 24 \% \\
\text { W-H: } 27 \%\end{array}$ \\
\hline South Dakota & All: $55 \%$ & & & W-NA: $24 \%$ \\
\hline Utah & All: $74 \%$ & & & \\
\hline Vermont & All: $49 \%$ & All: $60 \%$ & & SES: $21-23 \%$ \\
\hline Washington & All: $60 \%$ & All: $61 \%$ & & $\begin{array}{l}\text { W-AA: } 27-28 \% \\
\text { W-H: } 30-32 \% \\
\text { W-NA: } 22 \%\end{array}$ \\
\hline Wisconsin & All: $71 \%$ & & All: $70 \%$ & $\begin{array}{l}\text { SES: } 26-30 \% \\
\text { W-AA: } 42 \% \\
\text { W-H: } 33-34 \%\end{array}$ \\
\hline Wyoming & All: $47 \%$ & All: $62 \%$ & & $\begin{array}{l}\text { SES: } 17-18 \% \\
\text { W-H: } 17-18 \% \\
\text { W-NA: } 25-27 \%\end{array}$ \\
\hline
\end{tabular}

NOTES:

All=all students; SES=achievement gap between non-economically disadvantaged students and economically disadvantaged students; $\mathrm{W}-\mathrm{AA}=$ achievement gap between white students and African American students; $\mathrm{W}-\mathrm{NA}=$ achievement gap between white students and Native American students; $\mathrm{W}-\mathrm{H}=$ achievement gap between white students and Hispanic students.

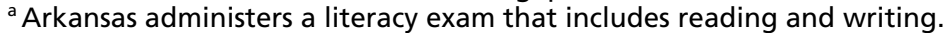

b Mississippi reports scores for reading and language convention, as well as two writing scores-narrative essay and informative essay.

'Racial/ethnic and SES achievement gaps are for general-education students only.

${ }^{\mathrm{d}}$ Disaggregated data for the writing assessment were not available. 


\section{The Current State of Adolescent Literacy Achievement: Results from the National Assessment of Educational Progress}

The advantage of the National Assessment of Educational Progress is that it allows us to compare the performance of states with one another and view the performance of the nation on a common metric. The weakness of NAEP is that it may not align well with state goals; therefore, students may not feel as much pressure to "do their best" on the assessment because it carries no consequences for students, teachers, or schools. ${ }^{1}$ This chapter presents results from the NAEP for 4th- and 8th-graders and looks at the relative performance of groups of students disaggregated by race/ethnicity and poverty status.

\section{Performance of 4th-Graders}

\section{Reading Assessment: Overall Proficiency Rates}

Figure 4.1 shows the percentage of 4th-graders who scored "proficient" and above on the 2003 NAEP Reading Assessment. Proficiency rates ranged from a low of 10 in DC to a high of 43 in Connecticut. Three states had proficiency rates of less than 20 percent; 15 states had proficiency rates of 20-29 percent; 30 states had proficiency rates of 30-39 percent. In only three states-Massachusetts, New Hampshire, and Connecticut-did the proportion of students scoring at the "proficient" level reach 40 percent and above.

\section{Reading Assessment: Differences in Performance Among Students, Disaggregated by Race/Ethnicity and Poverty Status}

Figure 4.2 shows the achievement gap between white and African American 4th-graders on the NAEP. The smallest difference was in Oregon (14 percentage points), and the largest difference was in DC (63 percentage points). Of the 42 states for which we had data, ten exhibited differences in performance of the two groups of between 20 and 29 percentage points; ten states exhibited a performance gap that was less than 20 percentage points; and another ten states exhibited a gap of 30 percentage points or higher.

\footnotetext{
${ }^{1}$ In the future, NAEP will be used to validate gains on state assessments under NCLB. As a consequence, schools, students, and teachers are likely to view it much more seriously than is currently the case.
} 
Figure 4.1

Percentage of 4th-Grade Students Scoring "Proficient" and Above on the National Assessment of Educational Progress 2003 Reading Assessment

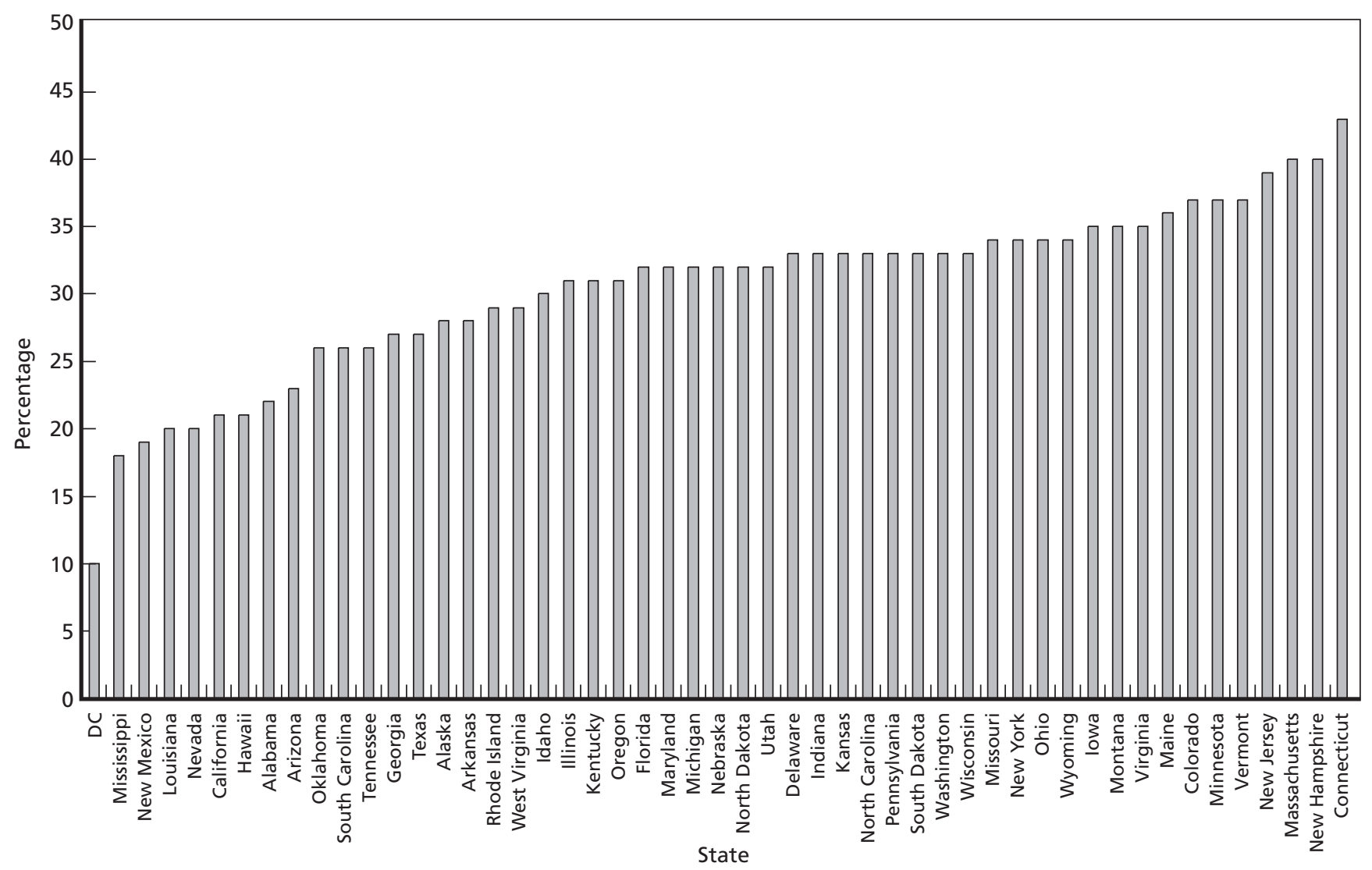


Figure 4.2

Difference in Percentages of White and African American 4th-Grade Students Scoring "Proficient" and Above on the National Assessment of Educational Progress 2003 Reading Assessment

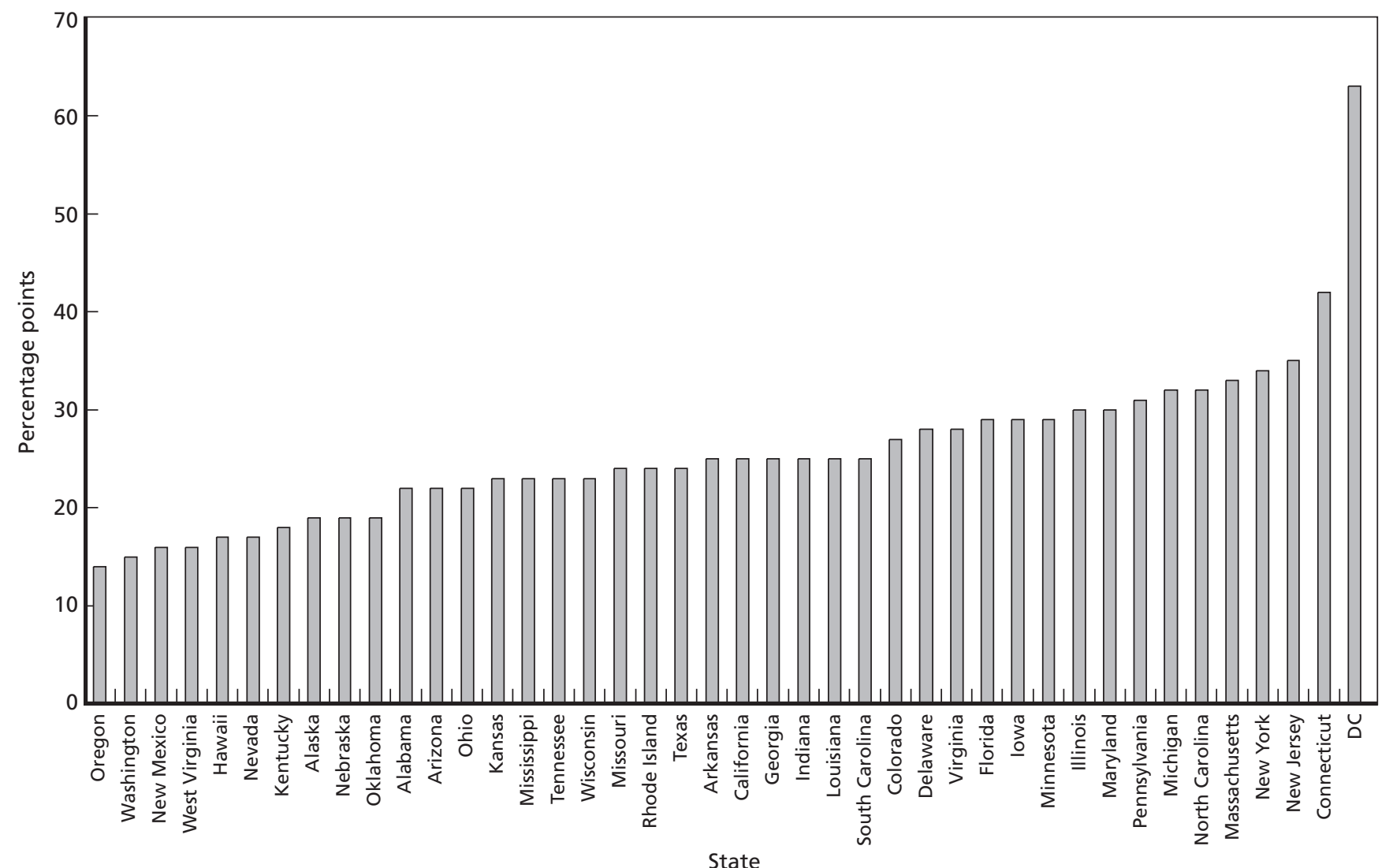

NOTE: Data were not available for nine states—Idaho, Maine, Nebraska, New Hampshire, North Dakota, South Dakota, Utah, Vermont, and Wyoming RAND TR180-4.2 
Figure 4.3 shows the difference in performance of white and Hispanic students at the 4th-grade level. In general, these differences were somewhat smaller than the ones shown above between white and African American students. In Tennessee, Missouri, and Indiana, Hispanic students trailed their white counterparts by 5-10 percentage points. Once again, the performance gap was the highest in DC (62 percentage points). Of the 40 states for which we had data, 22 exhibited differences in performance of the two groups of between 20 and 29 percentage points. In 15 states, the performance gap was less than 20 percentage points; in three states, the gap was 30 percentage points or higher.

The achievement gap between students from economically advantaged and disadvantaged backgrounds ranged from a low of 16 percentage points in Hawaii to 36 percentage points in Connecticut (Figure 4.4). In about two-thirds (33 out of 51) of the states, the gap was between 20 and 29 percentage points; in 12 states, it was between 10 and 19 percentage points; and in the remaining six states, it was 30 percentage points or higher.

\section{Writing Assessment}

Forty-four states participated in the 2002 4th-grade writing assessment. The proficiency scores, shown in Figure 4.5, ranged from 10 percent (DC) to 49 percent (Connecticut). In 12 states, less than 20 percent of 4 th-grade students scored at the "proficient" level and above; 21 states had proficiency scores of 20-29 percent; nine had scores of 30-39 percent; and only two (Massachusetts and Connecticut) had proficiency rates of 40 percent and higher.

The differences in proficiency scores between white and African American and Hispanic students and between economically advantaged and disadvantaged students are shown in Table 4.1.

A total of 36 states had data on the performance of white and African American students; 30 states had data on the performance of white and Hispanic students. All 44 states had data disaggregated by poverty status of students.

In three states-West Virginia, Hawaii, and Arizona-the achievement gap between the white and African American students was less than 10 percentage points; in 21 states, the gap was between 10 and 19 percentage points; in ten states, the gap was between 20 and 29 percentage points. In Connecticut, 58 percent of white students scored at the "proficient" level compared with 22 percent of African American students-a performance gap of 36 percentage points. In DC, the performance gap was even larger- 56 percentage points.

The pattern is very similar for Hispanic students. In three states-Connecticut, Massachusetts, and DC- the difference in proficiency rates of white and Hispanic students was over 30 percentage points. In DC, the difference was 54 percentage points, similar to the difference in performance between white and African American students. Hawaii, Wyoming, and Florida exhibited the smallest differences in the relative performance of the two groups-6-9 percentage points.

In 24 states, the difference between the proficiency rates of the economically advantaged and disadvantaged students ranged from 10 to 19 percentage points, and in 16 states, the performance gap was between 20 and 29 percentage points. Two states-North Dakota and Wyoming-posted the smallest difference (8 percentage points), while Connecticut and Massachusetts showed the largest gap in the relative performance of the two groups of students—30 percentage points. 
Figure 4.3

Difference in Percentages of White and Hispanic 4th-Grade Students Scoring "Proficient" and Above on the National Assessment of Educational Progress 2003 Reading Assessment

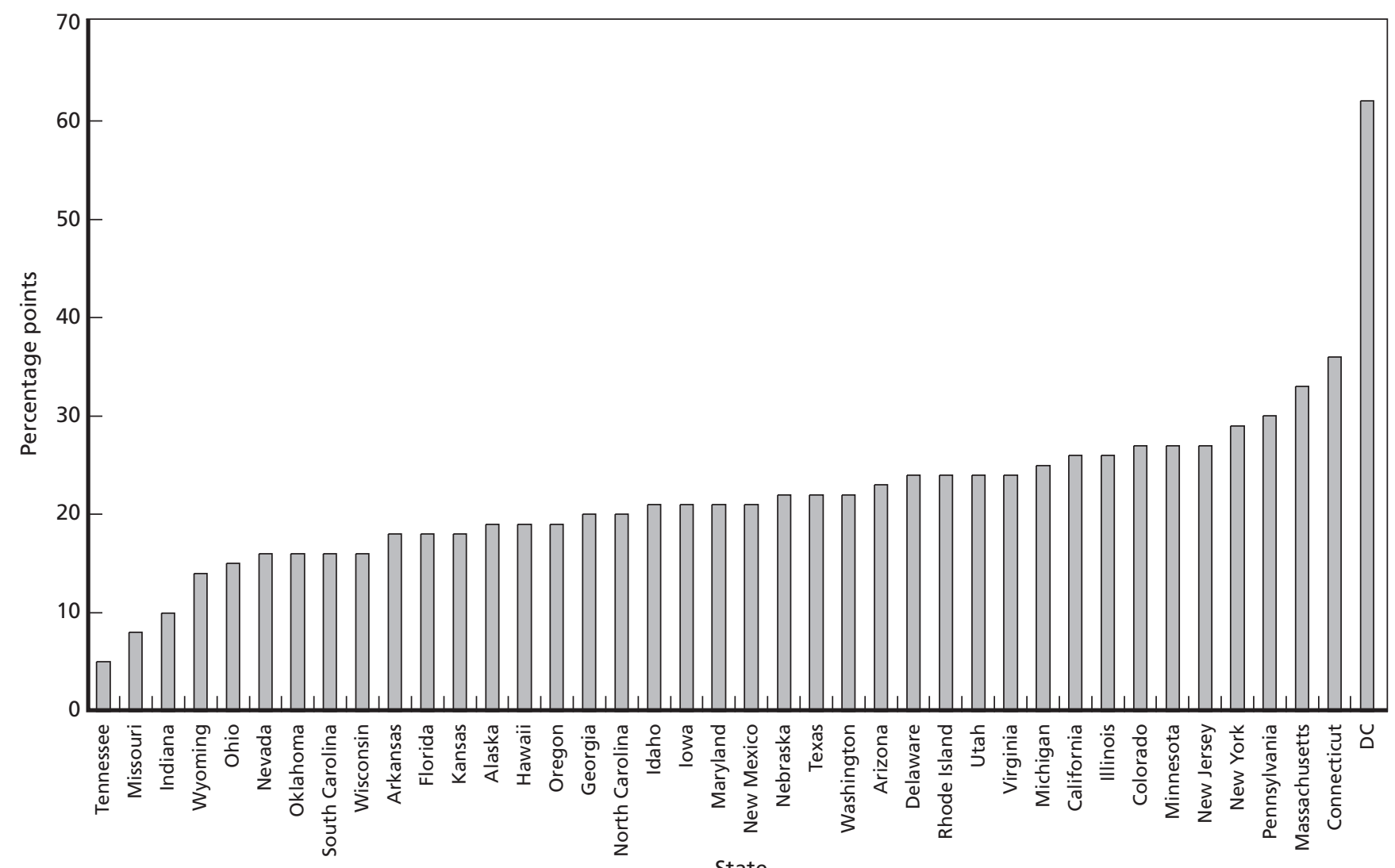

NOTE: Data were not available for 11 states—Alabama, Kentucky, Louisiana, Maine, Mississippi, Montana, New Hampshire, North Dakota, South Dakota Vermont, and West Virginia.

RAND TR180-4.3 
Figure 4.4

Difference in Percentages of Economically Advantaged and Disadvantaged 4th-Grade Students Scoring "Proficient" and Above on the National Assessment of Educational Progress 2003 Reading Assessment

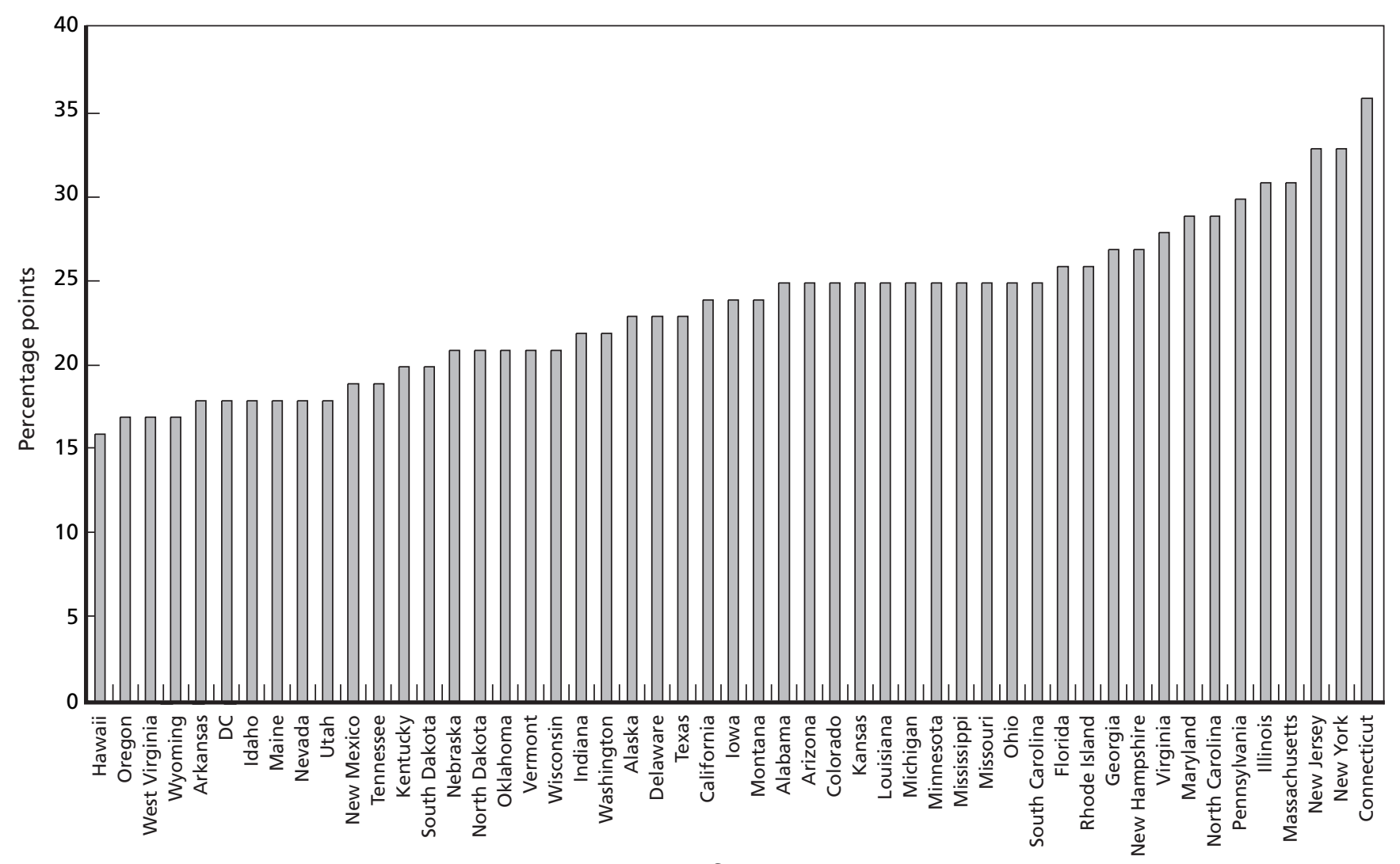

RAND TR180-4.4

State 
Figure 4.5

Percentage of 4th-Grade Students Scoring "Proficient" and Above on the National Assessment of Educational Progress 2002 Writing Assessment

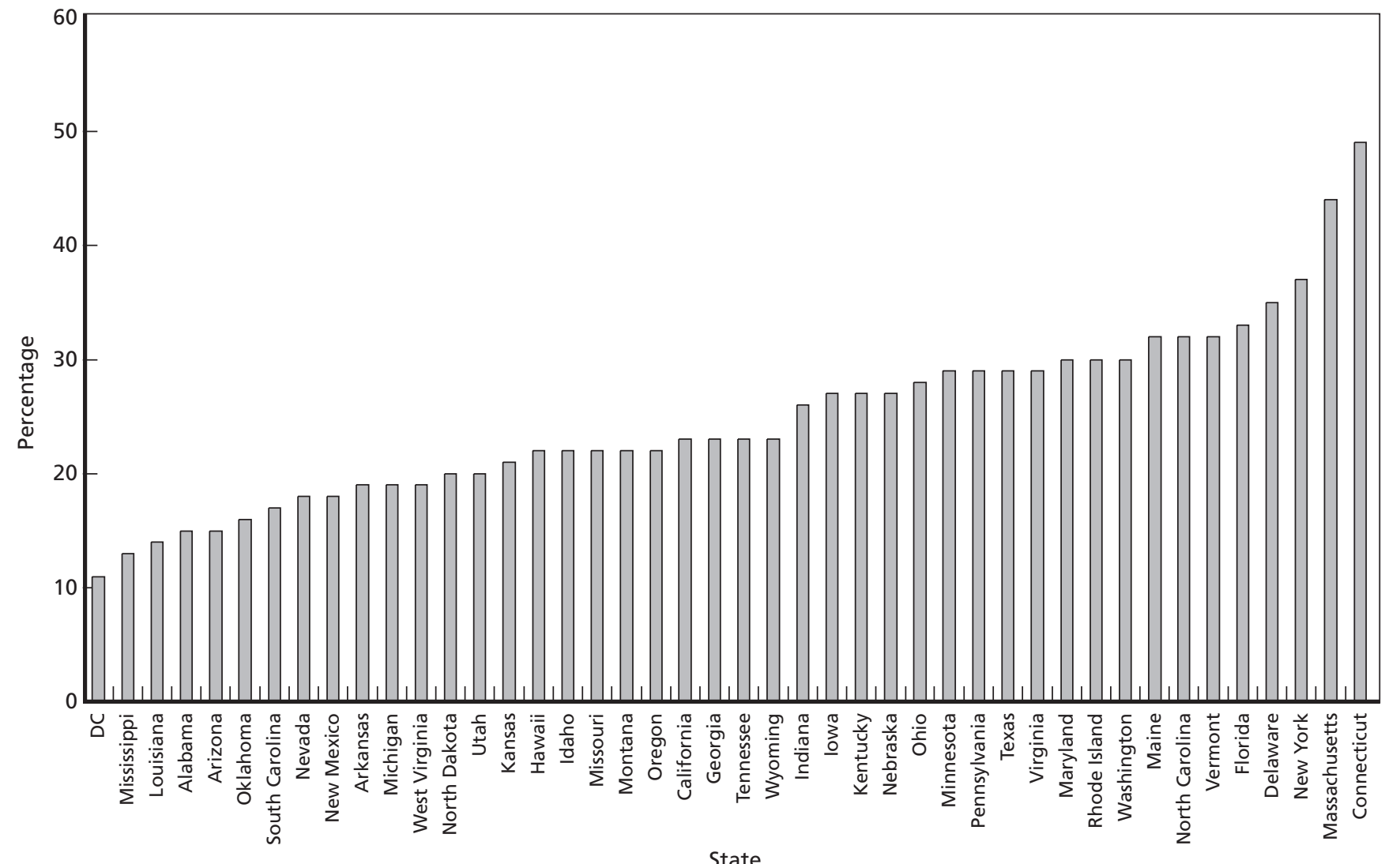

NOTE: Data were not available for seven states-Alaska, Colorado, Illinois, lowa, New Hampshire, New Jersey, South Dakota, and Wisconsin

RAND TR180-4.5 
Table 4.1

Differences in Proficiency Rates of 4th-Grade Students, Disaggregated by Race/Ethnicity and Poverty Status: 2002 National Assessment of Educational Progress Writing Assessment

\begin{tabular}{|c|c|c|c|}
\hline \multirow{2}{*}{$\begin{array}{l}\text { Range } \\
\text { (percentage } \\
\text { points) }\end{array}$} & $\begin{array}{l}\text { Difference Between } \\
\text { Proficiency Rates of } \\
\text { White and African } \\
\text { American Students } \\
(n=36)\end{array}$ & $\begin{array}{c}\text { Difference Between } \\
\text { Proficiency Rates of } \\
\text { White and Hispanic } \\
\text { Students } \\
(n=30)\end{array}$ & $\begin{array}{c}\text { Difference Between } \\
\text { Proficiency Rates of } \\
\text { Economically } \\
\text { Advantaged and } \\
\text { Economically } \\
\text { Disadvantaged } \\
\text { Students } \\
(n=44)\end{array}$ \\
\hline & \multicolumn{3}{|c|}{ Number of States } \\
\hline $\begin{array}{l}\leq 10 \\
10-19 \\
20-29 \\
\geq 30\end{array}$ & $\begin{array}{r}3 \\
21 \\
10 \\
2\end{array}$ & $\begin{array}{r}3 \\
15 \\
9 \\
3\end{array}$ & $\begin{array}{r}2 \\
24 \\
16 \\
2\end{array}$ \\
\hline
\end{tabular}

\section{Performance of 8th-Graders}

\section{Reading Assessment: Overall Proficiency Rates}

Overall, between 10 and 43 percent of 8th-graders scored at the "proficient" level on the 2003 NAEP Reading Assessment (Figure 4.6). DC was the only jurisdiction to have a proficiency rate of less than 20 percent; New Hampshire and Massachusetts were the only states to have proficiency rates of 40 percent or higher. In 17 states, 20-29 percent of students scored "proficient" and above on the 2002 assessment; in 31 states, 30-39 percent scored "proficient" and above.

There appeared to be little difference between the performance of 4th- and 8thgraders on the NAEP. In 12 states, the same percentage of 4th-and 8th-graders scored "proficient"; in 14 states, 4th-graders did a little better than 8th-graders; and in the remaining 25 states, they did a little worse. In all cases, the differences in proficiency rates were between -6 and +6 percentage points.

\section{Reading Assessment: Differences in Performance Among Students, Disaggregated by Race/Ethnicity and Poverty Status}

Differences between the proficiency rates of white and African American students on the NAEP were between 13 and 34 percentage points. The lowest differences were in West Virginia, and the highest were in New York (Figure 4.7). Four states posted differences of less than 20 percentage points; in seven states, the performance gap was 30 percentage points or higher. In the majority of the states $(n=29)$, African American students lagged behind their white counterparts by 20-29 percentage points.

Figure 4.8 shows similar data for white and Hispanic 8th-graders. Data were available for only 36 states. The difference in the percentages of white and Hispanic students scoring at or above the "proficient" level on the 2003 NAEP was less than 10 percentage points in three states_-Ohio, Hawaii, and Arkansas-and 30 percentage points or higher in 


\section{Figure 4.6}

Percentage of 8th-Grade Students Scoring "Proficient" and Above on the

National Assessment of Educational Progress 2003 Reading Assessment

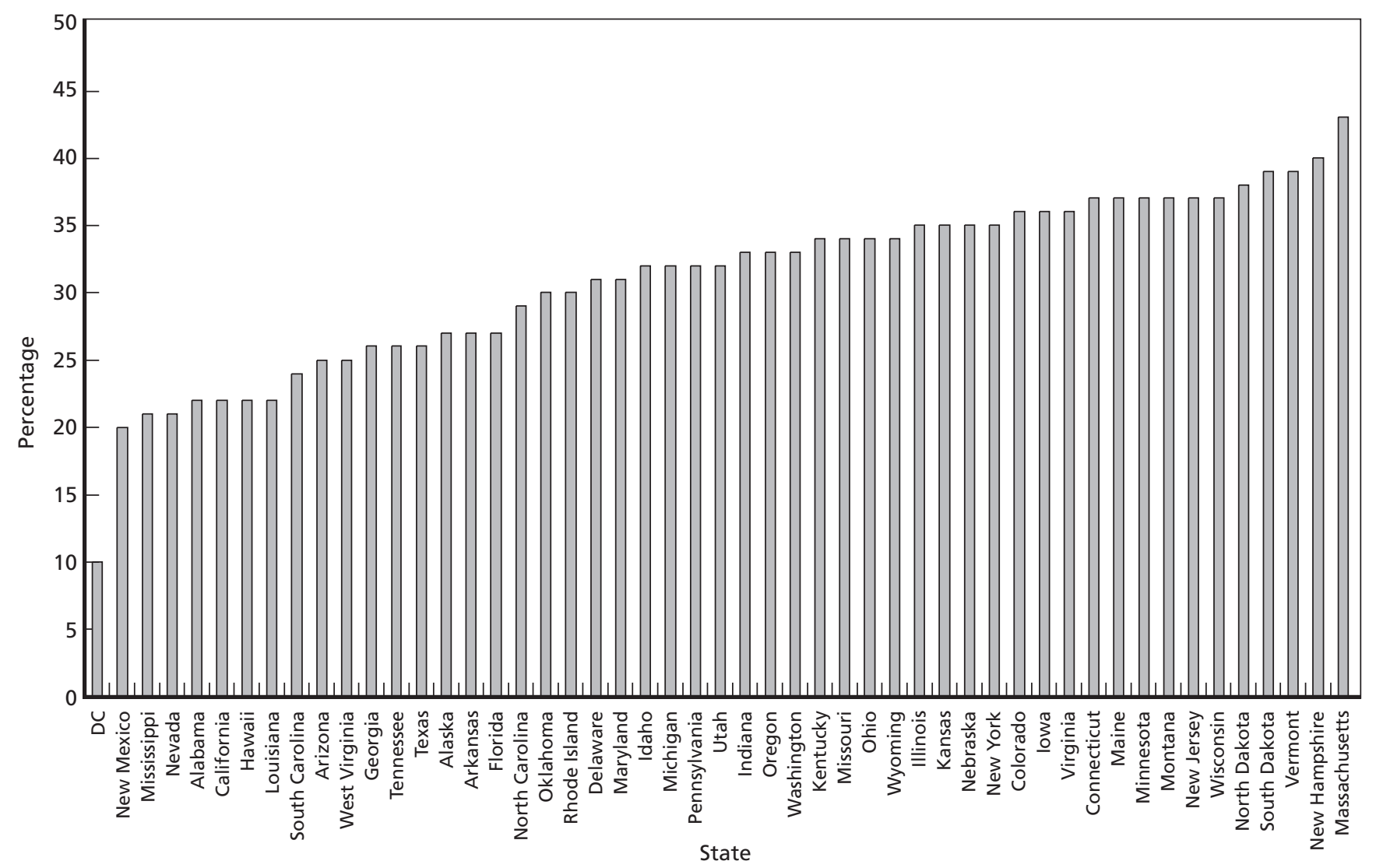

RAND TR180-4.6 


\section{Figure 4.7}

Difference in Percentages of White and African American 8th-Grade Students Scoring "Proficient" and Above on the National Assessment of Educational Progress 2003 Reading Assessment

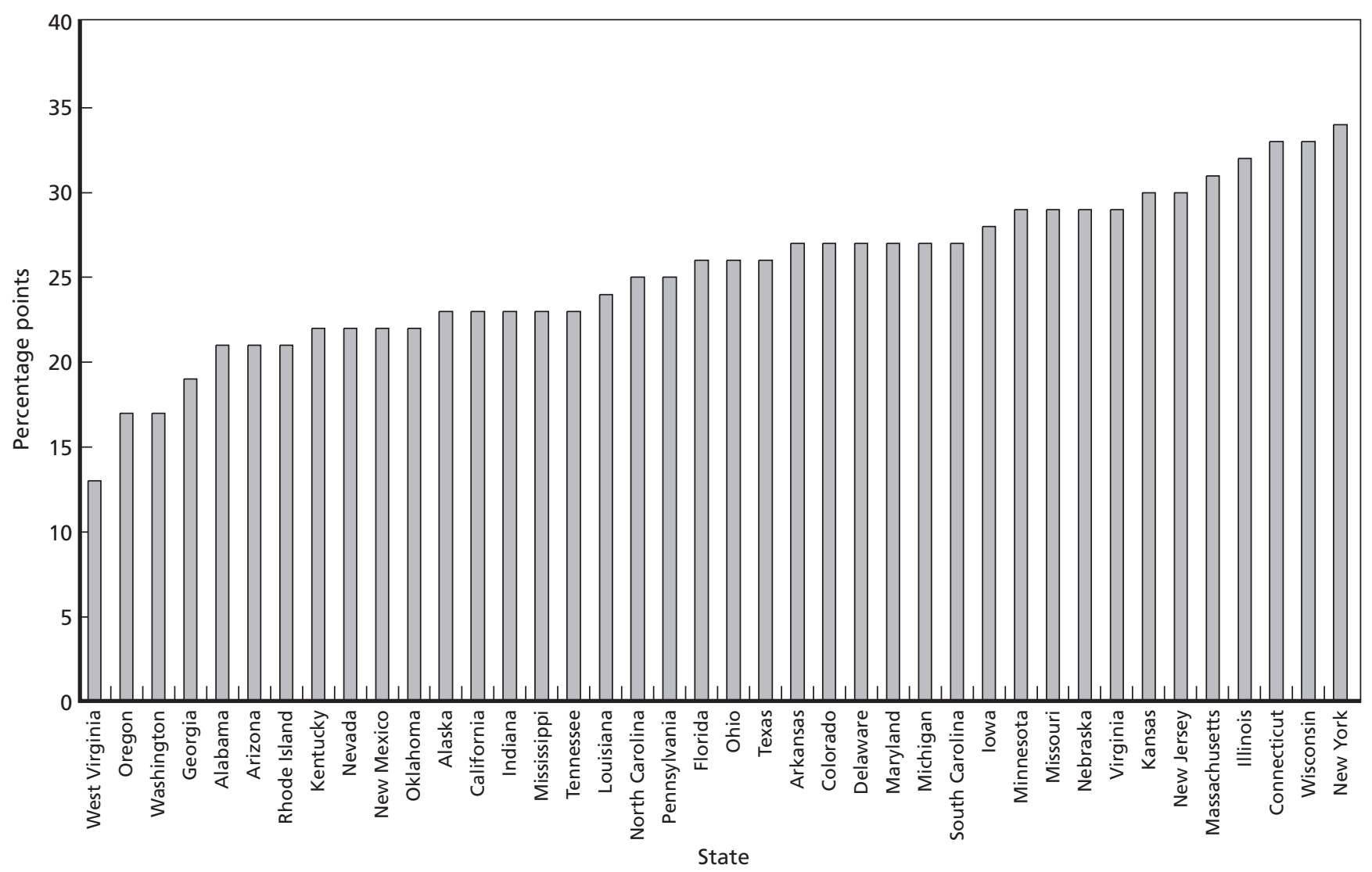

NOTE: Data were not available for 11 states—DC, Hawaii, Idaho, Maine, Montana, New Hampshire, North Dakota, South Dakota, Utah, Vermont, and Wyoming.

RAND TR180-4.7 
Figure 4.8

Difference in Percentages of White and Hispanic 8th-Grade Students Scoring "Proficient" and Above on the National Assessment of Educational Progress 2003 Reading Assessment

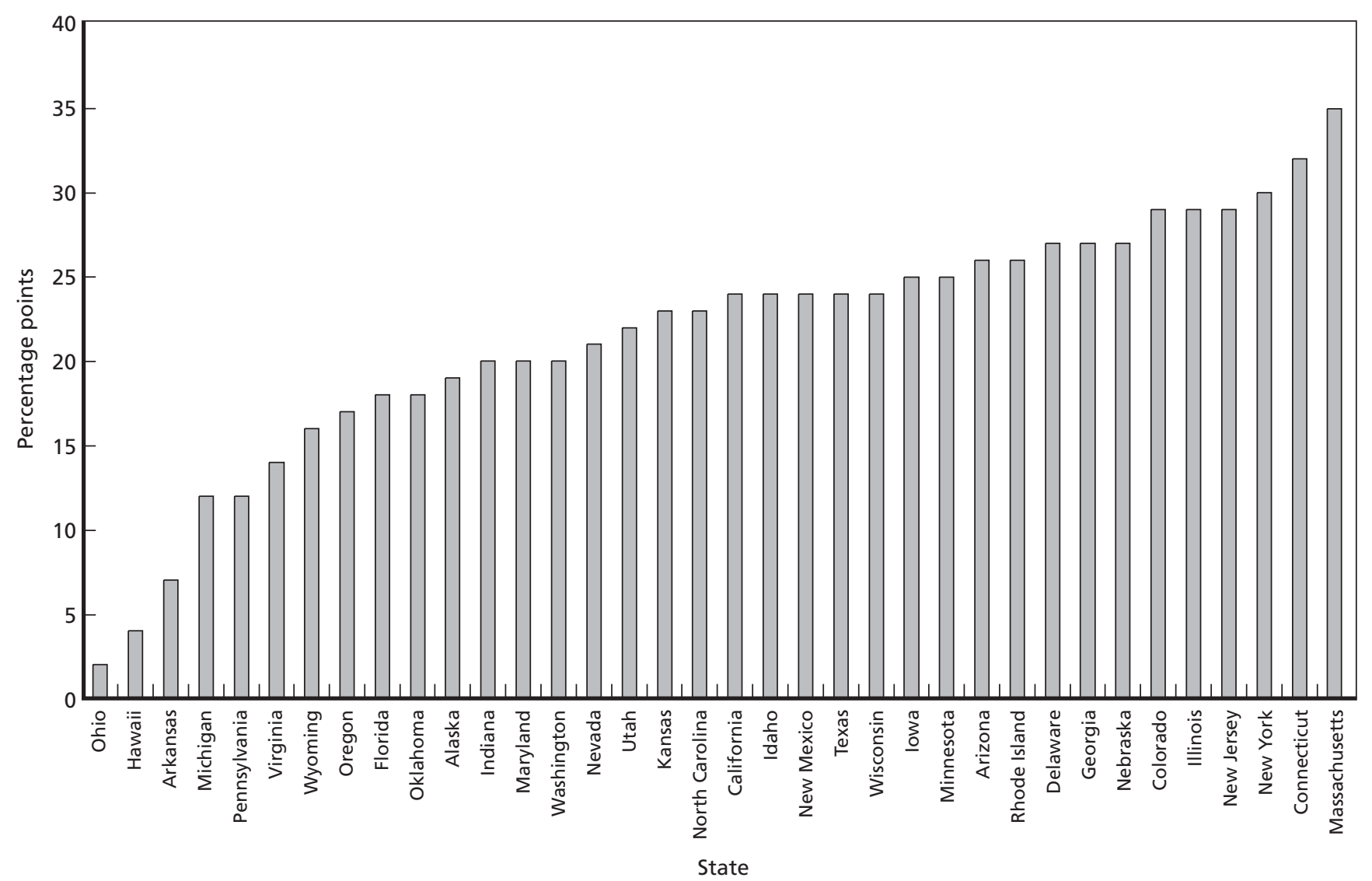

NOTE: Data were not available for 15 states—Alabama, DC, Kentucky, Louisiana, Maine, Mississippi, Missouri, Montana, New Hampshire, North Dakota, South Carolina, South Dakota, Tennessee, Vermont, and West Virginia.

RAND TR180-4.8 
three states-New York, Connecticut, and Massachusetts. The range was between 2 and 35 percentage points. Of the 36 states, 22 had performance gaps of between 20 and 29 percentage points.

The proficiency rates of economically disadvantaged students were between 11 and 33 percentage points lower than those of their 8th-grade counterparts who were not from economically disadvantaged backgrounds (Figure 4.9). The smallest differences were in DC and Nevada; Massachusetts had the largest difference. In 21 states, the performance gap was between 10 and 19 percentage points; in 26 states, 20-29 percentage points; and in four states (Connecticut, Illinois, New York, and Massachusetts), 30-33 percentage points.

\section{Writing Assessment}

Forty-two states had reportable data for the 2002 8th-grade NAEP Writing Assessment. Of these, the lowest score was in DC, where only 10 percent of students scored at the "proficient" and above levels (Figure 4.10). Seven states had proficiency scores of less than 20 percent, and only three states-Vermont, Massachusetts, and Connecticut-had proficiency rates of between 40 and 45 percent. In 18 states, the proficiency rates were 20-29 percent; about 30-39 percent of students were judged proficient in writing in 14 states.

Table 4.2 shows differences in the relative performance of 8 th-grade students, disaggregated by race/ethnicity and poverty status. Among the 31 states reporting data on white and African American students, 12 states showed a difference in relative proficiency rates of 10-19 percentage points, and 14 states showed a difference of 20-29 percentage points. In Hawaii and West Virginia, the difference in proficiency rates was 4 and 8 percentage points, respectively; these two states also had the smallest achievement gap among white and African American students on the 4th-grade writing assessment. Connecticut reported the largest performance gap: 40 percentage points. Pennsylvania and Massachusetts had performance gaps of 30 and 31 percentage points, respectively.

Among the 25 states with data on the performance of white and Hispanic students, 22 showed a difference of proficiency rates between the two groups of 10-29 percentage points. In three states-Texas, Connecticut, and Massachusetts-Hispanic students trailed white students by 30-39 percentage points.

Nineteen states reported differences in proficiency rates of economically advantaged and disadvantaged students of between 10 and 19 percentage points. In 21 states, the difference was larger: 20-29 percentage points. Connecticut and Massachusetts showed the largest difference in the relative performance of the two groups-30 and 32 percentage points, respectively.

\section{Summary}

Between 10 and 43 percent of 4th- and 8th-graders scored "proficient" on the NAEP reading assessments. DC had the lowest proficiency rates, and Connecticut and Massachusetts had the highest proficiency rates. The results were similar on the writing assessments.

As with the state assessments, there were large achievement gaps by race/ethnicity and poverty status on both the NAEP reading and writing assessments, some of which were quite significant. In the majority of states for which we had disaggregated data, minority students 
Figure 4.9

Difference in Percentages of Economically Advantaged and Disadvantaged 8th-Grade Students Scoring "Proficient" and Above on the National Assessment of Educational Progress 2003 Reading Assessment

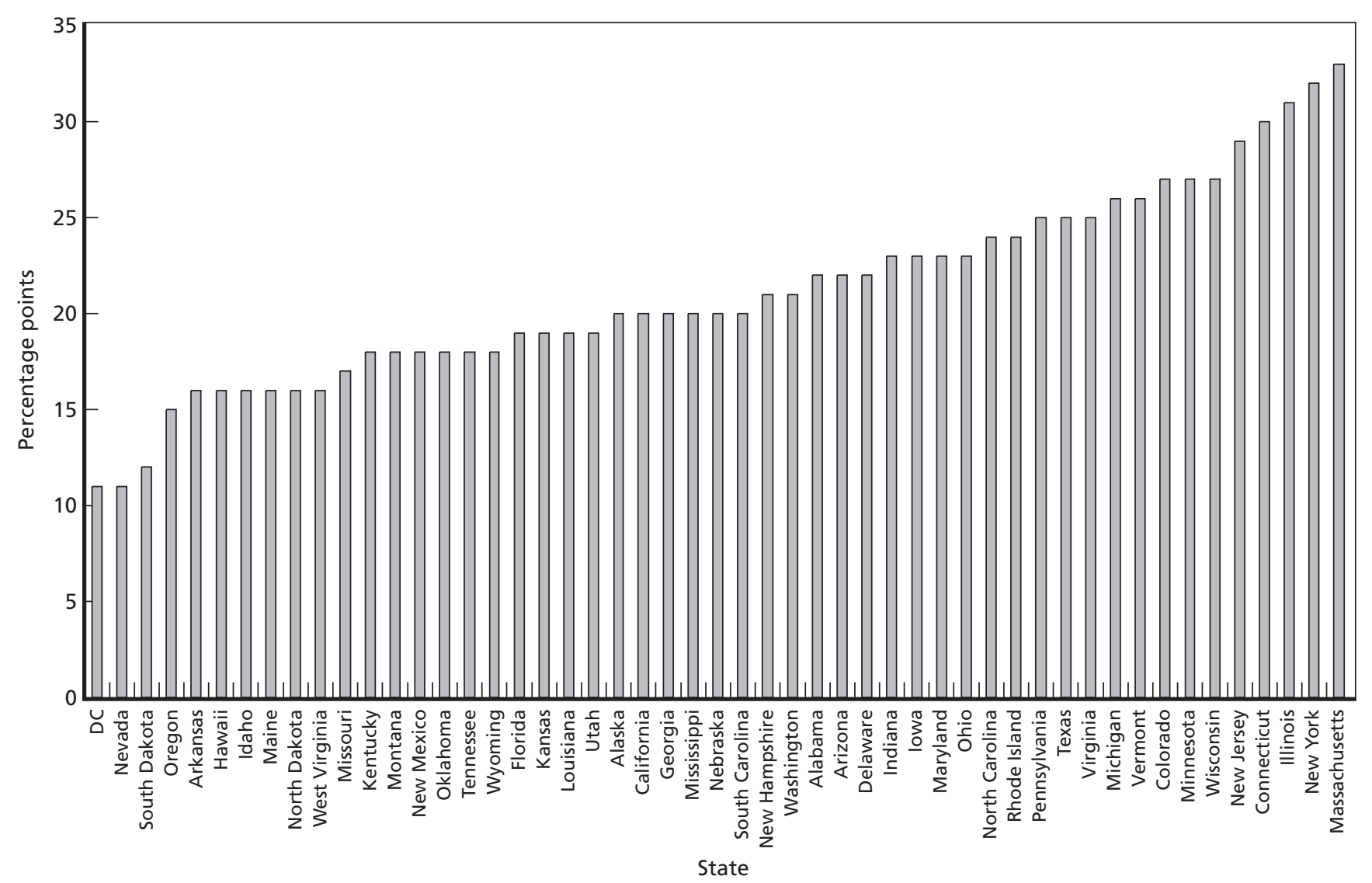

RAND TR180-4.9 
Figure 4.10

Percentage of 8th-Grade Students Scoring "Proficient" and Above on the

National Assessment of Educational Progress 2002 Writing Assessment

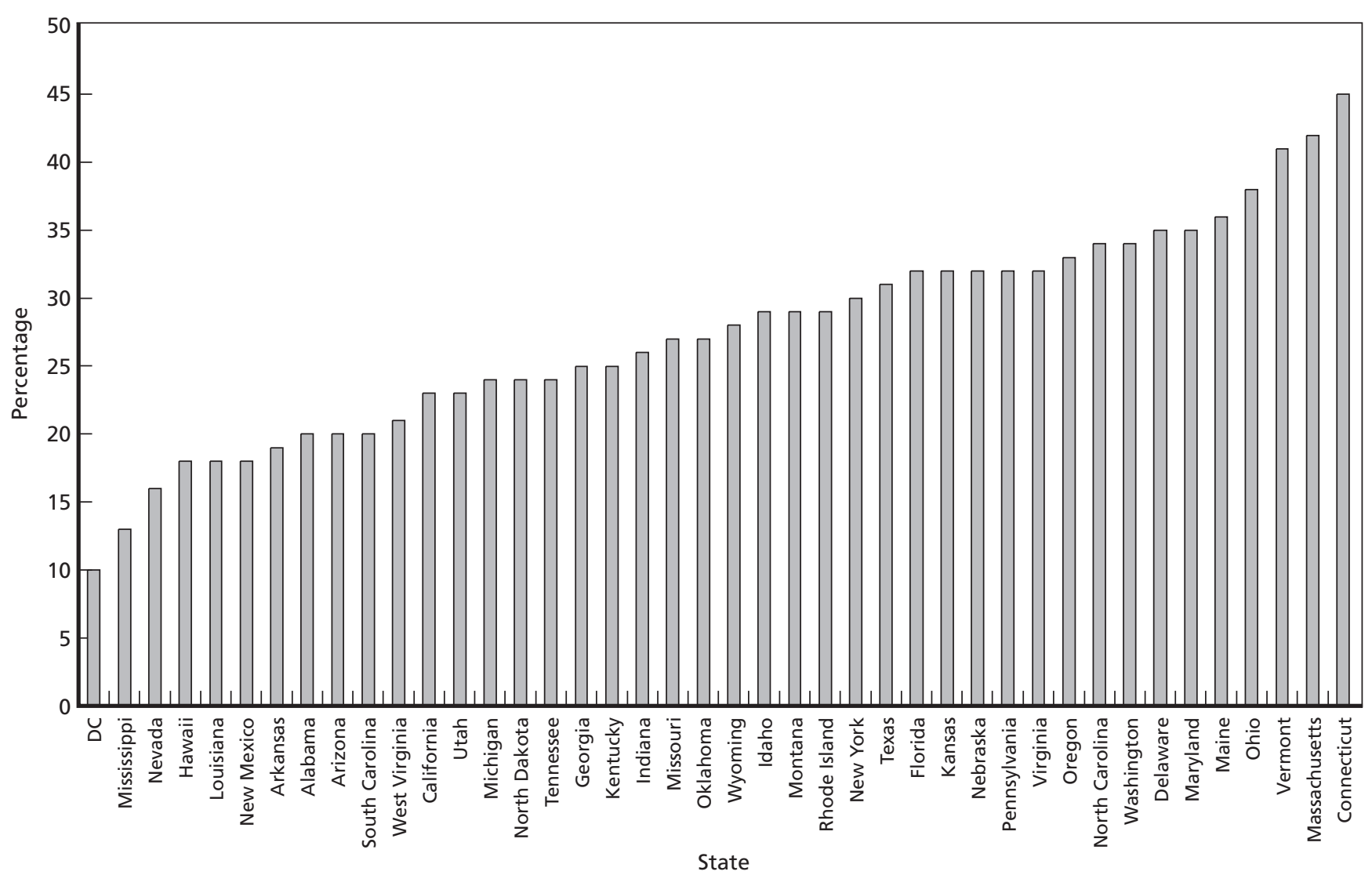

NOTE: Data were not available for nine states—Alaska, Colorado, Illinois, lowa, Minnesota, New Hampshire, New Jersey, South Dakota, and Wisconsin RAND TR180-4.10 
Table 4.2

Differences in Proficiency Rates of 8th-Grade Students, Disaggregated by Race/Ethnicity and Poverty Status: National Assessment of Educational Progress 2002 Writing Assessment

\begin{tabular}{|c|c|c|c|}
\hline \multirow{2}{*}{$\begin{array}{l}\text { Range } \\
\text { (percentage } \\
\text { points) }\end{array}$} & $\begin{array}{c}\text { Difference } \\
\text { Between } \\
\text { Proficiency Rates } \\
\text { of White and } \\
\text { African American } \\
\text { Students } \\
(n=31) \\
\end{array}$ & $\begin{array}{c}\text { Difference } \\
\text { Between } \\
\text { Proficiency Rates } \\
\text { of White and } \\
\text { Hispanic Students } \\
(n=25)\end{array}$ & $\begin{array}{c}\text { Difference Between } \\
\text { Proficiency Rates of } \\
\text { Economically } \\
\text { Advantaged and } \\
\text { Economically } \\
\text { Disadvantaged } \\
\text { Students } \\
(n=42)\end{array}$ \\
\hline & \multicolumn{3}{|c|}{ Number of States } \\
\hline$\leq 10$ & 2 & 0 & 0 \\
\hline $10-19$ & 12 & 10 & 19 \\
\hline $20-29$ & 14 & 12 & 21 \\
\hline$\geq 30$ & 3 & 3 & 2 \\
\hline
\end{tabular}

trailed white students by 20-29 percentage points, and similar performance gaps existed between economically advantaged and disadvantaged students.

As mentioned in Chapter Two, NAEP standards of proficiency are considered to be challenging, so these fairly low levels of proficiency may not necessarily be cause for alarm in and of themselves. However, they become more troubling when we consider the kinds of skills that Achieve (2004) identified as necessary for high school graduates to succeed in postsecondary education or in high-performance, high-growth jobs. If our students - particularly minority and low-income students - are failing to achieve a high level of proficiency in reading and writing, then their post-secondary education and job opportunities may be severely curtailed.

The next chapter attempts to reconcile what the NAEP and state assessment data tell us about the state of adolescent literacy achievement. 



\section{The Current State of Adolescent Literacy Achievement: Reconciling Results from State and National Assessments}

We begin this chapter by reiterating the caveat given in the Introduction: proficiency rates on the NAEP and the state assessments are not directly comparable. The tests differ in content and in how achievement levels are defined. However, the two data sources provide two data points for the level of adolescent literacy in the nation, measured by state and national standards. Therefore, it is useful to examine whether the two provide a consistent picture and also to understand what the differences imply for policymakers.

\section{Overall Proficiency Rates}

Fourth-grade state proficiency rates on the NAEP ranged from 10 to 43 percent; in marked contrast, proficiency rates on the state assessments ranged from 21 to 87 percent. Table 5.1 shows the distribution of scores on the 4th-grade reading state assessments and the NAEP.

All 29 states for which we had data for 4th-graders from both the state assessments and the NAEP had proficiency scores of less than 50 percent on the NAEP; this was true of only five states on the state assessment. Although no state had a proficiency score of over 43 percent on the NAEP, in 21 of the 29 states, between 60 and 90 percent of students scored at the "proficient" level on the state assessments.

The difference between proficiency rates of 4th-graders on the two assessments is shown in Figure 5.1. In no state were proficiency scores on the NAEP higher than those on the state assessment, and only South Carolina and Wyoming posted differences of 10 percent

Table 5.1

Distribution of States by Percentage of 4th-Grade Students

Scoring at the "Proficient" Level and Above on the State

Reading Assessments and National Assessment of Educational Progress 2003 Reading Assessment

\begin{tabular}{l|c|c}
\hline $\begin{array}{l}\text { Range } \\
\text { (percentage } \\
\text { points) }\end{array}$ & $\begin{array}{c}\text { NAEP "Proficient" and } \\
\text { Above }\end{array}$ & $\begin{array}{c}\text { State "Proficient" and } \\
\text { Above }\end{array}$ \\
\cline { 2 - 3 } & \multicolumn{2}{|c}{ Number of States } \\
\hline $10-19$ & 3 & 0 \\
$20-29$ & 7 & 1 \\
$30-39$ & 17 & 2 \\
$40-49$ & 2 & 2 \\
$50-59$ & 0 & 3 \\
$60-69$ & 0 & 7 \\
$70-79$ & 0 & 7 \\
$80+$ & 0 & 7 \\
\hline
\end{tabular}


Figure 5.1

Differences in Proficiency Rates of 4th-Grade Students: State Reading Assessments - National Assessment of Educational Progress 2003 Reading Assessment

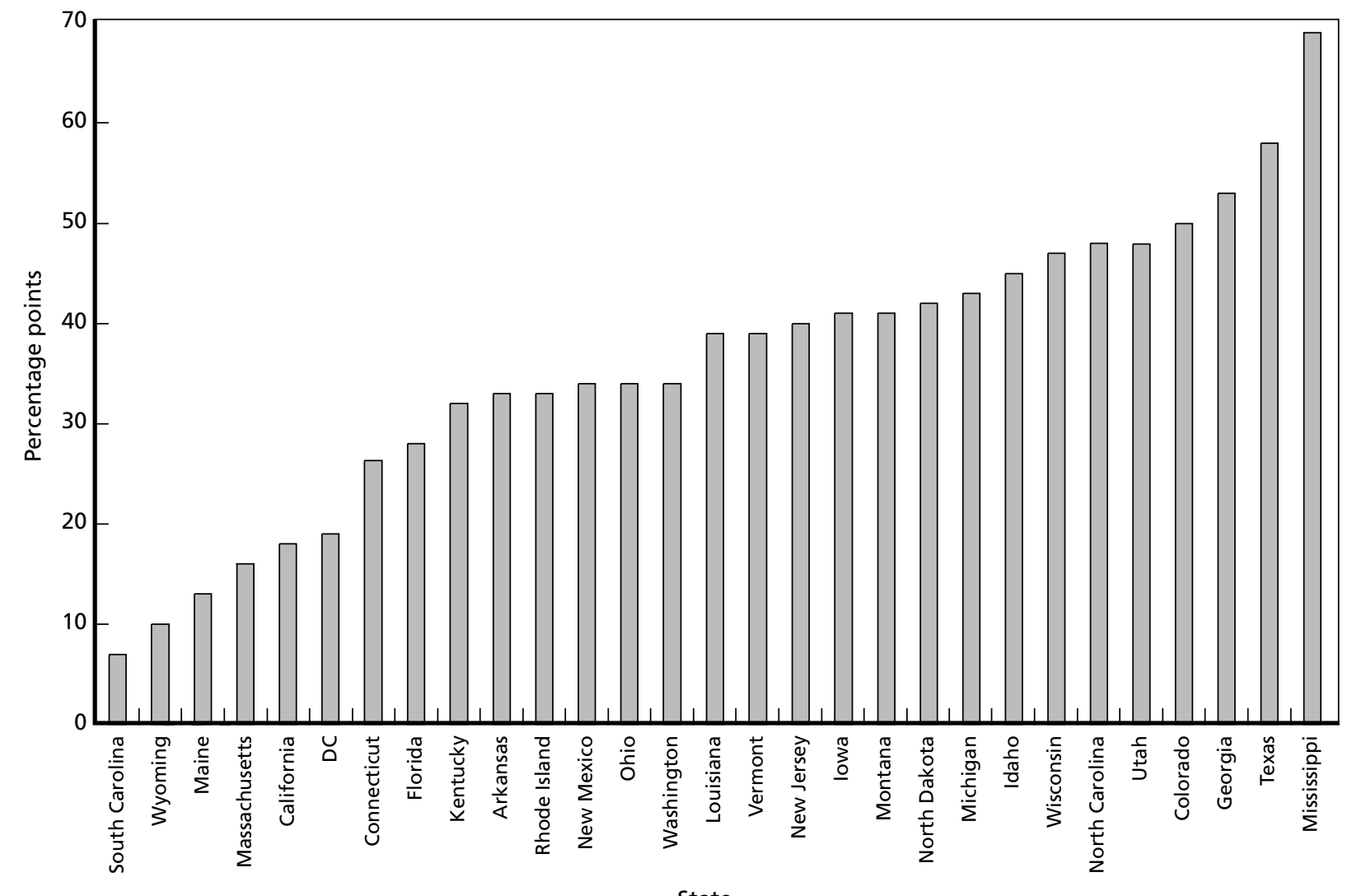

RAND TR180-5.1

State 
or less. The largest difference between proficiency rates on the state assessment and the NAEP was in Mississippi-69 percentage points. While 87 percent of 4th-graders in Mississippi passed the state assessment by scoring at the "proficient" level and above, only 18 percent of them were judged "proficient" on the NAEP.

As with the 4th-grade scores, Table 5.2 shows the distribution of scores on the state assessments and the NAEP for 8th-graders for the 37 states for which we had data on both assessments. For these states, eighth-grade state proficiency rates on the NAEP were similar to those of fourth-grade students and ranged from 10 to 39 percent compared with 21 to 88 percent on the state assessments. The average proficiency rate of 8th-graders was 31 percent on the NAEP versus 61 percent on the state assessment. All 37 states had proficiency rates of less than 50 percent on the NAEP compared with 11 states on the state assessment. Over 60 percent of students scored at the "proficient" level on the state assessments in 23 of the 37 states.

The difference between proficiency rates of 8th-graders on the two assessments is shown in Figure 5.2. In one state-South Carolina-the proficiency rate on the NAEP was higher than that on the state assessment. The largest differences between proficiency rates on the state assessment and the NAEP were in North Carolina and Texas-57 and 62 percentage points, respectively. In 23 states, the difference in proficiency rates on the two assessments was 30 percentage points or larger.

Table 5.2

Distribution of States by Percentage of 8th-Grade Students Scoring at the "Proficient" Level and Above on the State Reading Assessments and National Assessment of Educational Progress 2003 Reading Assessment

\begin{tabular}{l|c|c}
\hline \multirow{2}{*}{$\begin{array}{l}\text { Range } \\
\text { (percentage } \\
\text { points) }\end{array}$} & $\begin{array}{c}\text { NAEP “Proficient" and } \\
\text { Above }\end{array}$ & $\begin{array}{c}\text { State "Proficient "and } \\
\text { Above }\end{array}$ \\
\cline { 2 - 3 } $10-19$ & \multicolumn{2}{|c}{ Number of States } \\
$20-29$ & 1 & 0 \\
$30-39$ & 12 & 2 \\
$40-49$ & 24 & 3 \\
$50-59$ & 0 & 5 \\
$60-69$ & 0 & 4 \\
$70-79$ & 0 & 10 \\
$80+$ & 0 & 7 \\
\hline
\end{tabular}

\section{Differences in Performance of Subgroups}

Both assessments showed large achievement gaps between subgroups of students, disaggregated by race/ethnicity and poverty status. Tables 5.3 and 5.4 show the average achievement gap between white and African American students, white and Hispanic students, and economically advantaged and economically disadvantaged students on the two assessments at the 4th- and 8th-grade levels, respectively. 
Figure 5.2

Differences in Proficiency Rates of 8th-Grade Students: State Reading Assessments - National Assessment of Educational Progress 2003 Reading Assessment

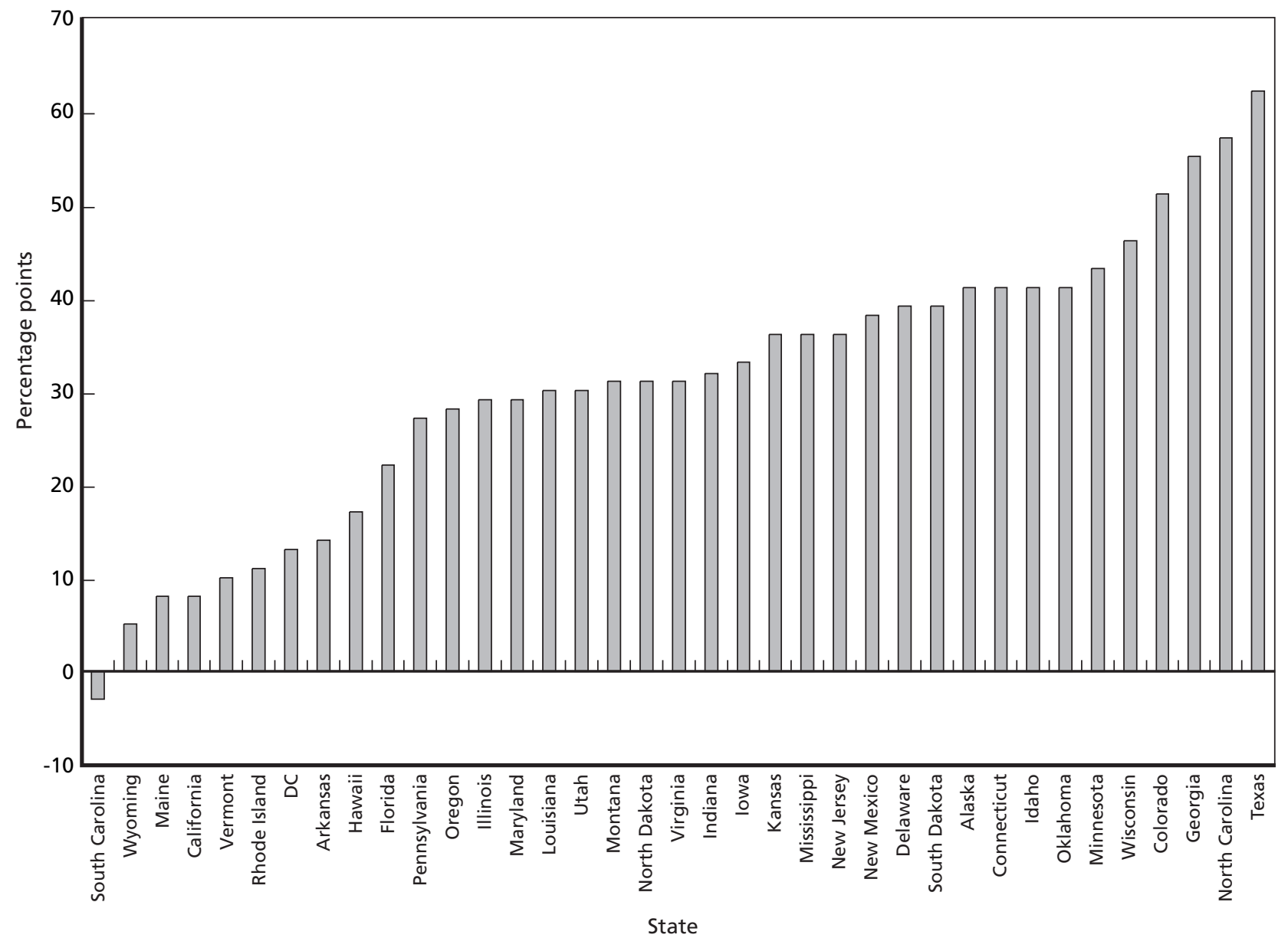

RAND TR180-5.2

State 
Table 5.3

Differences in Proficiency Rates of 4th-Grade Students, Disaggregated by Race/Ethnicity and Poverty Status: State Reading Assessments and National Assessment of Educational Progress 2003 Reading Assessment

\begin{tabular}{l|cc}
\hline & \multicolumn{2}{|c}{ Average Difference in Proficiency Rates } \\
\cline { 2 - 3 } Subgroups of Students & State Assessments & NAEP \\
\hline White and African American Students & 27 & 27 \\
White and Hispanic Students & 27 & 24 \\
Economically Advantaged and Economically & 23 & 25 \\
Disadvantaged Students & & \\
\hline
\end{tabular}

Table 5.4

Differences in Proficiency Rates of 8th-Grade Students, Disaggregated by Race/Ethnicity and Poverty Status: State Reading Assessments and National Assessment of Educational Progress 2003 Reading Assessment

\begin{tabular}{l|cc}
\hline & \multicolumn{2}{|c}{ Average Difference in Proficiency Rates } \\
\cline { 2 - 3 } Subgroups of Students & State Assessments & NAEP \\
\hline White and African American Students & 28 & 26 \\
White and Hispanic Students & 26 & 22 \\
Economically Advantaged and Economically & 24 & 22 \\
Disadvantaged Students & & \\
\hline
\end{tabular}

Despite the differences we had seen earlier with respect to overall proficiency scores on the two assessments, the overall distribution of the achievement gap is fairly similar on both assessments. Indeed, the average difference in proficiency rates is remarkably similar in magnitude. For example, at the 4th -grade level, the two assessments show, on average, a difference of 27 percentage points between the proficiency rates of white and African American students; $24-27$ percentage points between white and Hispanic students; and 23-25 percentage points between economically advantaged and economically disadvantaged students. These trends are found at the 8th-grade level as well.

However, when examining individual states, we see both similarities and marked differences in some states about what the state assessments show about the relative performance of subgroups and what the NAEP shows. We selected a few examples to show the wide range of differences reported on the two assessments (Table 5.5):

- DC-Both assessments show large differences in achievement of African American and Hispanic 4th-grade students compared with white students (over 60 percentage points).

- California, Florida, and Washington-The performance gap is larger on the state assessments than on the NAEP.

- Mississippi and Texas-The performance gap is larger on the NAEP than on the state assessments.

\section{Summary}

This chapter has offered a look at the portraits of the condition of adolescent literacy that state assessments and the state NAEP offer. In general, the state assessments offer a much more optimistic picture of overall proficiency levels - and not necessarily an inaccurate picture. The two sets of assessments use different standards of proficiency and different 
formats and test content. We believe that it is important to examine both sets of data to understand how students rank against others in the nation, using national literacy standards, and against others in their state.

Simply to elevate all student scores up to state proficiency standards remains a tremendous challenge. In particular, there is remarkable consistency across the state and national assessments in the magnitudes of the performance gaps between minority and economically disadvantaged students and their peers. On average, minority students and low-income students trail their peers by $22-28$ percentage points. 
Table 5.5

Differences in Proficiency Rates of 4th- and 8th-Grade Students, Disaggregated by Race/Ethnicity and Poverty Status: State Reading Assessments and National Assessment of Educational Progress 2003 Reading Assessment, Selected Examples

\begin{tabular}{|c|c|c|c|c|c|c|}
\hline \multirow[b]{3}{*}{ Selected States } & \multicolumn{2}{|c|}{$\begin{array}{c}\text { White and African American } \\
\text { Students }\end{array}$} & \multicolumn{2}{|c|}{ White and Hispanic Students } & \multicolumn{2}{|c|}{$\begin{array}{c}\text { Economically Advantaged } \\
\text { and Economically } \\
\text { Disadvantaged Students }\end{array}$} \\
\hline & $\begin{array}{c}\text { State } \\
\text { Assessments }\end{array}$ & NAEP & $\begin{array}{c}\text { State } \\
\text { Assessments }\end{array}$ & NAEP & $\begin{array}{c}\text { State } \\
\text { Assessments }\end{array}$ & NAEP \\
\hline & \multicolumn{6}{|c|}{ Percentage of Students Scoring at the "Proficient "Level and Above } \\
\hline \multicolumn{7}{|c|}{ 4th-grade level } \\
\hline $\begin{array}{l}\text { California } \\
\text { DC }^{\text {a }} \\
\text { Florida } \\
\text { Texas } \\
\text { Washington }\end{array}$ & $\begin{array}{l}32 \\
65 \\
32 \\
17 \\
21\end{array}$ & $\begin{array}{l}25 \\
63 \\
29 \\
24 \\
15\end{array}$ & $\begin{array}{l}35 \\
68 \\
22 \\
13 \\
32 \\
\end{array}$ & $\begin{array}{l}26 \\
62 \\
18 \\
22 \\
22\end{array}$ & $\begin{array}{r}35 \\
18 \\
29 \\
-* \\
-*\end{array}$ & $\begin{array}{r}25 \\
26 \\
27 \\
-* \\
-*\end{array}$ \\
\hline \multicolumn{7}{|c|}{ 8th-grade level } \\
\hline $\begin{array}{l}\text { California } \\
\text { Connecticut } \\
\text { Florida } \\
\text { Texas }\end{array}$ & $\begin{array}{l}30 \\
32 \\
35 \\
12\end{array}$ & $\begin{array}{l}23 \\
33 \\
26 \\
26\end{array}$ & $\begin{array}{l}32 \\
37 \\
24 \\
11\end{array}$ & $\begin{array}{l}24 \\
32 \\
18 \\
24\end{array}$ & $\begin{array}{r}28 \\
31 \\
30 \\
-*\end{array}$ & $\begin{array}{l}20 \\
30 \\
19 \\
-*\end{array}$ \\
\hline
\end{tabular}
NOTES:

-* Data not available.

${ }^{\text {a }}$ No data were available at the 8 th-grade level.

The last chapter offers some thoughts on the policy implications of our findings. 



\section{Conclusions and Policy Implications}

\section{The NCLB Context}

It is important to place the findings presented here in the larger context of NCLB. As discussed in Chapter Two, NCLB requires states to adopt standards-based accountability systems that set challenging content and performance standards for all students. To ensure that students are meeting these standards, states must annually test all children in reading and math in grades 3, 4, 5, 6, 7, and 8, and once in high school, by 2005-2006, and in science at least once in grades 3-5, 6-9, and grades $10-12$ by $2007-2008$. By the end of 12 years, all schools in the state should have reached 100-percent proficiency, meaning that all the children in the school pass the state test.

Schools that fail to meet adequate yearly progress for two years are identified as being "in need of improvement." Schools that fail to make such progress for two or more years will be confronted with a number of escalating consequences.

To meet these requirements under federal law, states are currently changing and expanding state testing programs that will be used to hold schools accountable under the federal law. In addition, a growing number of states are holding students accountable by requiring that students pass high school assessments in order to graduate or to pass a given grade assessment for promotion to the next grade.

For the theory of action underlying NCLB to be realized, state standards and assessments need to be rigorous and well aligned, data from assessments need to be used to diagnose problems and to improve instruction, and effective interventions need to be known and widely disseminated.

Unfortunately, as research has shown, these conditions are difficult to meet. Previous research has shown a great variety in the depth and specificity of state standards among the states (Linn, 1998). And while state assessments tend to be aligned to standards, the collection of items included in a test tends to measure only a few of the less-challenging standards and objectives. As a result, few state tests can be said to be well-aligned assessments of challenging standards (Rothman et al., 2002). However, given the high stakes attached to student performance on these assessments, states face disincentives to maintain (let alone increase) the difficulty of their assessments or to set high standards for the definition of proficiency. Research also suggests that state assessment data may not be used in ways that effectively diagnose students' difficulties and improve instruction. For example, Valencia and Buly (2003) found that a standard approach was used to provide assistance to students who performed poorly on Washington State's assessment, despite the fact that the reasons why they failed the assessment were diverse. For example, some of the students they examined displayed the word-identification skills of a ninth-grader, yet they could not pass the fourth- 
grade reading assessment. A uniform approach that emphasized word identification would miss the point. Such students would be better served by instruction that focused on meaning. Without combining state data with better diagnostic assessments, remedial instruction provided to students may fail to meet student needs.

\section{Meeting State and National Literacy Goals: A Long Uphill Road}

We used two different data sources to paint a broad-brush portrait of the condition of adolescent literacy achievement in the nation. Despite the caveats about the comparability of the two assessments, the data presented in this report lead to major concerns about the ability of states to meet the ambitious goal set by NCLB-100-percent proficiency for all students.

First, if we simply take the state assessment scores at face value, which in many states were much higher than scores on the NAEP, the majority of states are not even close to reaching 100-percent proficiency. In fact, at the middle school level, 11 states and the District of Columbia had proficiency rates under 50 percent. Further, in no state did even half the students meet the NAEP national literacy standard of proficiency.

Also, the wide disparity in the achievement of subgroups of students makes reaching the 100-percent-proficiency goal even more difficult, particularly for states, districts, and schools with large proportions of such subgroups. Both the NAEP and state assessments show large achievement gaps between subgroups of students, disaggregated by race/ethnicity and poverty status. For example:

- At the 4th-grade level, the two assessments show, on average, a difference of 27 percentage points between the proficiency rates of white and African American students; 24-27 percentage points between white and Hispanic students; and 23-25 percentage points between economically advantaged and economically disadvantaged students.

- These differences hold at the 8th-grade level as well, where we see a difference of 26-28 percentage points between the proficiency rates of white and African American students; 22-26 percentage points between white and Hispanic students; and 22-24 percentage points between economically advantaged and economically disadvantaged students.

- At both grade levels, students with limited English proficiency and students with disabilities trailed well behind their peers.

Second, it is clear that while states are operating under a common mandate for proficiency, there are large differences in the rigor of assessments and in how states define proficiency and set cut-scores, leading to quite disparate outcomes. Compare, for instance, South Carolina, Wyoming, North Carolina, and Texas. At the 8th-grade level, 21 percent of students in South Carolina and 39 percent of students in Wyoming passed the state assessment, compared with 86-88 percent of 8th-graders in North Carolina and Texas. However, when one looks at the 8th-grade NAEP scores, 24 percent of students in South Carolina and 34 percent of students in Wyoming scored at the proficient level, compared with 26 percent of students in Texas and 29 percent of students in North Carolina. 
Clearly, even if each state were to meet its 100-percent proficiency goal for reading, students in those states would likely have strikingly different abilities, knowledge, and skills.

\section{Multiple Sources of Data Regarding Literacy Achievement Help Provide a More Complete Picture}

Simply looking at proficiency rates on state assessments may not provide the public and parents all the information they might want about student achievement. For example, when examining individual states, we see both similarities and marked differences in some states in what the state assessments show about the relative performance of subgroups and what the NAEP shows. If state assessments show small performance gaps between these subgroups of students, while the NAEP (arguably using a more challenging standard of literacy) shows large performance gaps, it is important for state policymakers and parents to reflect on what this information might imply for the likely future employment and education opportunities for these students. If we fail to give due attention to multiple sources of information regarding literacy achievement, we may fail to miss important problem areas and may end up shortchanging those most in need of assistance.

Overall, these are sobering statistics. It is clear that simply mandating standards and assessments is not going to guarantee success. Unless we, as a nation, are prepared to focus attention and resources on the issue of adolescent literacy, our schools are likely to continue producing students who lack skills and who are ill-prepared to deal with the demands of post-secondary education and the workplace. Policymakers, schools, and teachers need to step up and accept the "orphaned responsibility" of teaching students to read to learn. The costs of inattention are very high, both in personal and economic terms. 



\section{References}

Achieve. (2004). American Diploma Project. Available online at http://www.achieve.org/achieve.nsf/ AmericanDiplomaProject?OpenForm; last accessed on October 5, 2004.

Alliance for Excellent Education. (2002). Every Child a Graduate: A Framework for an Excellent Education for all Middle and High School Students. Washington, D.C.: Alliance for Excellent Education. Available online at http://www.all4ed.org/publications/EveryChildAGraduate/index.html. Last accessed on October 15, 2004.

Borko, H., and Elliott, R. (1999). "Hands-on” Pedagogy vs. "Hands-off” Accountability: Tensions Between Competing Commitments for Exemplary Teachers of Mathematics in Kentucky. Phi Delta Kappan. Vol. 80, pp. 394-400.

Carnevale, Anthony. (2001). Help Wanted ... College Required. Princeton, New Jersey: Educational Testing Service.

deLeon, Anne Grosso. (2002). Moving Beyond Storybooks: Teaching Our Children to Read to Learn. Carnegie Reporter. Fall, Vol. 2, No. 1.

Greene, J. P., and G. Forster. (2003). Public High School Graduation and College Readiness Rates in the United States. New York: Manhattan Institute for Policy Research.

Kingsbury, G. G., Olson, A., Cronin, J., Hauser, C., and Houser, R. (2003). The State of Standards: Research Investigating Proficiency Levels in Fourteen States. Lake Oswego, Oregon: Northwest Evaluation Association. Available online at http://www.nwea.org/assets/research/national/State\% $20 \mathrm{of} \% 20$ State $\% 20$ standards\%20-\%20complete\%20report.pdf. Last accessed on October 15, 2004.

Kirsch, I., Jungeblut, A., Jenkins, L., and Kolstad, A. (1993). Adult Literacy in America: A First Look at the Findings of the National Adult Literacy Survey. Washington, D.C.: National Center for Education Statistics.

Linn, R. (1998). Assessments and Accountability. C.S.E. Technical Report. Los Angeles: National Center for Research on Evaluation, Standards, and Student Testing.

Linn, R. (2000). Assessment and Accountability. Educational Researcher. March, pp. 4-16.

Linn, R. (2003). Performance Standards: Utility for Different Uses of Assessments. Education Policy Analysis Archives. Vol. 11, No. 31. Available online at http://epaa.asu.edu/epaa/v11n31/. Last accessed on October 15, 2004.

McKnight, C. C., Crosswhite, F. J., Dossey, J. A., Kifer, E., Swafford, J. O., Travers, K. J., and Cooney, T. J. (1987). The Underachieving Curriculum: Assessing U.S. School Mathematics from an International Perspective. Champaign, Ill.: Stipes.

National Center for Public Policy and Higher Education. (2004). Policy Alert: The Educational Pipeline: Big Investment, Big Returns: Educational Success Rate. Washington, D.C., April 6, 2004. 
National Governors Association. (1989). Results in Education: 1989. The Governors 1991 Report on Education. Washington, D.C.

National Research Council. (1999). Uncommon Measures: Equivalence and Linkage Among Educational Tests. Washington, D.C.: National Academy Press.

Rothman, R., Slattery, J. B., Vranek, J. L., and Resnick, L. B. (2002). Benchmarking and Alignment of Standards and Testing. Los Angeles, Calif.: University of California, National Center for Research on Evaluation, Standards, and Student Testing (CRESST), CSE Tech. Rep. No. 566.

Travers, K., and Westbury, I. (1989). The IEA Study of Mathematics I: Analysis of Mathematics Curricula. New York: Pergamon.

Valencia, S. W., and M. R. Buly. (2003). Meeting the Needs of Failing Readers: Cautions and Considerations for State Policy. Available online at http://depts.washington.edu/ctpmail/AbstractMNF.html. Last accessed on October 15, 2004.

Wolf, S. A., and McIver, M.C. (1999). When Progress Becomes Policy: The Paradox of Kentucky School Reform for Exemplary Teachers. Phi Delta Kappan. Vol. 80, pp. 401-406.

U.S. Department of Education. (2001). The Condition of Education. Washington, D.C.: U.S. Department of Education.

U.S. Department of Labor. (2001). The Outlook for College Graduates 1998-2008 (cited in Youth at the Crossroads: Facing High School and Beyond. Washington, D.C.: The Education Trust). 


\section{PREFACE}

The appendices contain individual state write-ups that describe the assessment systems; the content, format, and performance levels of reading, writing, and English language arts assessments between $4^{\text {th }}$ and $12^{\text {th }}$ grades; and student performance results on those assessments. Given that the report encompasses 50 states and the District of Columbia, the sheer volume of the readily available and public information on state standards and assessments required us to make choices about what to include in the report. We focus on the reading, writing, or language arts assessment used for accountability purposes and report results at the elementary (grades 4-5), middle (grades 6-8), and high school (grades 9-12) levels. Thus, for a state that tests students in grades 3-12 in reading, we present findings for only three grades (i.e., grades 4,8 , and 11). When a choice of grades needed to be made, we selected grades 4 and 8 whenever possible so that we could examine those results in combination with National Assessment of Educational Progress (NAEP) data. Consequently, our state write-ups are intended to be illustrative, not exhaustive.

Specifically, each state summary contained in the appendices includes the following sections:

- State Assessment System-Information on the state's assessment system as a whole, including what tests are used for accountability, and if they are intended to measure state content standards.

- Assessment Format and Content-Information regarding the format and content of the selected assessments.

- Achievement-Level Descriptions-An overview of the achievement levels set by each state and what is considered "proficient" (or passing) under NCLB.

- Performance Results-Data on student and school-level performance on the selected state reading and writing assessments.

The information presented in the appendices is based on publicly-available data from Web sites gathered in the winter and spring of 2003. 


\section{APPENDIX A. ALABAMA}

\section{State Assessment System}

Like many states, Alabama is implementing a new student assessment system. For the 2002-03 school year, Alabama's state assessment system consisted of three tests:

- The Stanford Achievement Test, 10 $^{\text {th }}$ edition (SAT10) is a norm-referenced exam published by Harcourt, a national assessment company. All students in grades 3 through 8 take the reading, mathematics, and language subtests; in addition, students in grades 5 and 7 take the science subtest and students in grade 6 take the social studies subtest.

- The Direct Assessment of Writing (DAW) is a criterion-referenced assessment of student writing performance for students in grades 5 and 7.

- The Alabama High School Graduation Exam (AHSGE) is a criterion-referenced exam based on state standards in reading, mathematics, science, and social studies. Students have as many as six opportunities in grades 10,11, and 12 to take and pass each subject-area test in order to graduate (for more information on state accountability, see http://www.alsde.edu/html/sections/documents.asp?section=57\&sort=1\&footer=sections).

The state is currently in the process of developing and implementing new criterion-referenced tests (CRTs) for grades 1-8 that will align with Alabama's content standards and will attempt to reflect National Assessment of Educational Progress (NAEP)-type rigor, format, and reporting. The $\mathrm{K}-2$ reading CRTs were implemented in the fall of 2003; new reading/language arts and mathematics CRTs for grades 4, 6, and 8 will be introduced statewide in the spring of 2004, along with a new DAW for grade 10. CRTs in reading/language arts and mathematics for grades 3, 5, and 7 will be rolled out for the 2004-05 school year. The K-2 mathematics CRTs, science CRTs for grades 5 and 7, and a social studies CRT for grade 6 will be implemented in the following three school years.

Alabama has published content standards in English language arts, mathematics, science, social studies, and arts. The standards present minimum required content for each grade level in the areas of comprehension, which includes reading, listening, and viewing; and expression, which includes writing, speaking, and presenting. Each standard also presents skills and knowledge that students should be introduced to, but are not necessarily required to master, at that grade level. The state's Pathways for Learning publications provide teachers with materials and resources, including creative classroom activities linked to each content standard and sample test items and item specifications for the student assessments. 


\section{Test Format and Content}

As our focus is on adolescent literacy, the rest of this discussion focuses on the reading and language subtests of the SAT10, the AHSGE, and the DAW (for further assessment information, see http://www.alsde.edu/html/sections/section detail.asp?section=54).

$\underline{\text { SAT10 }}$

The SAT10 is composed of multiple-choice questions, and the tests are untimed. The reading subtest measures a number of reading components, including sound recognition, word identification, vocabulary skills; and comprehension, including initial understanding, interpretation, critical analysis, and awareness and usage of reading strategies.

The SAT10 language subtest measures word- and sentence-level skills to whole composition. The language subtest measures proficiency in mechanics, including capitalization, punctuation, usage, language expression, and sentence structure.

\section{$\underline{\text { DAW }}$}

The DAW consists of one writing prompt that students read and respond to during a 50-minute testing period. Students receive one of three prompts directing them to write in either a descriptive, narrative, or expository/persuasive mode. Student responses are scored using both a focused holistic rubric and analytic rubrics judging writing mechanics, sentence formation, and grammar and usage.

\section{$\underline{\text { AHSGE }}$}

The AHSGE reading subject-area test includes 84 multiple-choice questions, while the language test consists of 100 multiple-choice questions. The test is untimed, but it takes approximately three hours.

For the AHSGE, the reading subject-area test measures students' ability to demonstrate literal understanding, interpret passages, apply critical analysis strategies, and utilize strategies that enhance comprehension. Passages include textual, functional, and recreational material, such as articles, poems, editorials, and manuals. The language subject-area test measures students' knowledge of mechanics and expression, including their ability to recognize and use correct grammar, demonstrate appropriate word choice, recognize correct sentence structure, use correct capitalization, and use appropriate organizational skills for writing and revising. Both the reading and language tests are written at the $11^{\text {th }}$-grade level. Although the standards and objectives for the AHSGE are not directly aligned one-to-one with the content standards identified in the 
Course of Study, the state has produced assessment correlation tables mapping the two sets of standards against each other to illustrate linkages.

\section{Achievement-Level Definitions}

The SAT10 is reported in national percentile ranks. Student results on the DAW are divided into four achievement levels according to students' understanding of the writing task: Level I-Does not meet standard, Level II-Partially meets standard, Level III-Meets standard, and Level IVExceeds standard. Scoring rubrics include detailed descriptions of the four levels for each of the four scoring areas. For aggregate reporting purposes, Levels I and II are grouped together as "Not meeting standards," while Levels III and IV are grouped as "Meeting standards."

Alabama has defined minimum passing scores on the AHSGE, and scores are divided into two achievement levels: "passing" and "not passing."

\section{Performance Results}

\section{Student Performance}

Table A1 provides data on student performance for all students, general education students, special education students, economically disadvantaged students, and racial/ethnic groups ${ }^{1}$ for reading and language from the 2003 SAT10. Overall, Alabama's $4^{\text {th }}$-and $7^{\text {th }}$-grade students' average scores were at the $55^{\text {th }}$ and $54^{\text {th }}$ percentile on the SAT1O reading subtest, slightly above the national norm. On the language subtest, $4^{\text {th-grade }}$ performance was even better, with an average score at the $63^{\text {rd }}$ percentile; however, the average language score for $7^{\text {th }}$-graders was at the $55^{\text {th }}$ percentile. White students outscored African American students in $4^{\text {th }}$ and $7^{\text {th }}$-grade reading and language by large margins, between 21 and 29 percentile points. Students who were not economically disadvantaged averaged scores between the $67^{\text {th }}$ and $76^{\text {th }}$ percentile, while economically disadvantaged students performed much lower-between the $39^{\text {th }}$ and the $51^{\text {st }}$ percentile on the tests. Special education students in the $4^{\text {th }}$-grade scored at the $23^{\text {rd }}$ and $27^{\text {th }}$ percentiles on the reading and language tests, respectively, while $7^{\text {th }}$-grade special education students scored only at the $18^{\text {th }}$ percentile on both reading and language.

Table A2 shows results for $5^{\text {th }}$ and $7^{\text {th }}$-grade students on the DAW. In addition to providing the holistic score, which represents an overall score on the assessment, the table also provides scores

${ }^{1}$ Approximately 61 percent of students in Alabama are white, and 37 percent are African American. No other racial/ethnic group accounts for 2 percent of the population. Almost half of students (49 percent) are eligible for the free or reduced-price lunch program, and 13 percent have Individual Education Programs (IEPs). 
for skills tested, including grammar and usage, sentence formation, and writing mechanics. On the $5^{\text {th }}$ - and $7^{\text {th }}$-grade DAW, only 41 percent of $5^{\text {th }}$-graders and 39 percent of $7^{\text {th }}$-graders met state standards. Fifth-grade students particularly struggled with their grammar and usage and sentence-formation skills; however, scores for these skills at the $7^{\text {th }}$ grade were comparatively better. Only 10-13 percent of special education students passed the writing assessments. Again on the writing assessments, there was a substantial achievement gap between white students and African American students (17-21 percentage points) and non-economically disadvantaged students and economically disadvantaged students (21-23 percentage points).

\section{Table A1. Performance of $4^{\text {th- }}$ and $7^{\text {th }}$-Graders on 2003 Reading and Language} SAT10, by Student Characteristics

\begin{tabular}{lcccc}
\hline & \multicolumn{2}{c}{$\mathbf{4}^{\text {th }}$ Grade } & \multicolumn{2}{c}{$7^{\text {th }}$ Grade } \\
\cline { 2 - 5 } & \multicolumn{1}{c}{ Reading } & Language & Reading & Language \\
\cline { 2 - 5 } & 55 & 63 & 54 & 55 \\
\hline Average Percentile Rank & \\
General education students & 60 & 68 & 59 & 61 \\
Special education students & 23 & 27 & 18 & 18 \\
Economically disadvantaged & 41 & 51 & 39 & 42 \\
students & & & & 67 \\
Non-economically & 71 & 76 & 67 & \\
disadvantaged students & & & & 42 \\
African American students & 37 & 50 & 37 & 63 \\
White students & 66 & 71 & 64 & \\
\hline
\end{tabular}

Source:

http://www.alsde.edu/Accountability/Accountability.asp?system=0\&sch=0\&SchoolYear=20022003\&Rep= $2 \& V i e w=2$

Overall, the majority of $11^{\text {th }}$-grade students passed the AHSGE: 88 percent passed the reading section, and 83 percent passed the language section (Table A3). All students performed better in reading than in language, a situation that was particularly true for special education students: 59 percent passed the reading section, while only 46 percent passed in language. Again, similar to the other assessments, white students outperformed African American students by significant margins (14-18 percentage points) and non-economically disadvantaged students outperformed economically disadvantaged students (12-14 percentage points).

Also not surprisingly, students in special education scored well below students in general education. For example, on average, $4^{\text {th }}$-grade special education students scored 37 percentiles lower on the SAT10 than did general education students in reading, and 41 percentiles lower in language. This gap was slightly wider in $7^{\text {th }}$ grade, where the average reading score for special 
education students was 41 percentiles lower than the average for general education students, and the average language score was 43 percentiles lower.

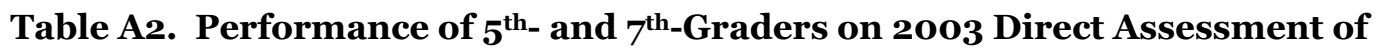
Writing, by Student Characteristics

\begin{tabular}{|c|c|c|c|c|}
\hline & $\begin{array}{c}\text { Holistic } \\
\text { (Overall } \\
\text { Score) }\end{array}$ & $\begin{array}{l}\text { Writing } \\
\text { Mechanics }\end{array}$ & $\begin{array}{l}\text { Sentence } \\
\text { Formation }\end{array}$ & $\begin{array}{l}\text { Grammar } \\
\text { and Usage }\end{array}$ \\
\hline & \multicolumn{4}{|c|}{ Percentage Meeting Standard } \\
\hline \multicolumn{5}{|l|}{$5^{\text {th }}$ Grade } \\
\hline All students & 41 & 42 & 35 & 33 \\
\hline General education students & 45 & 46 & 39 & 36 \\
\hline Special education students & 13 & 13 & 11 & 11 \\
\hline $\begin{array}{l}\text { Economically disadvantaged } \\
\text { students }\end{array}$ & 31 & 33 & 26 & 23 \\
\hline $\begin{array}{l}\text { Non-economically disadvantaged } \\
\text { students }\end{array}$ & 52 & 53 & 47 & 45 \\
\hline African American students & 29 & 33 & 24 & 19 \\
\hline White students & 48 & 47 & 42 & 41 \\
\hline \multicolumn{5}{|l|}{$7^{\text {th }}$ Grade } \\
\hline All students & 39 & 53 & 55 & 47 \\
\hline General education students & 43 & 58 & 60 & 51 \\
\hline Special education students & 10 & 16 & 18 & 15 \\
\hline $\begin{array}{l}\text { Economically disadvantaged } \\
\text { students }\end{array}$ & 27 & 44 & 43 & 34 \\
\hline $\begin{array}{l}\text { Non-economically disadvantaged } \\
\text { students }\end{array}$ & 50 & 62 & 66 & 59 \\
\hline African American students & 26 & 45 & 41 & 32 \\
\hline White students & 47 & 59 & 63 & 56 \\
\hline
\end{tabular}

Source:

http://www.alsde.edu/Accountability/Accountability.asp?system=0\&sch=0\&SchoolYear=20022003\&Rep= $2 \& \mathrm{View}=2$

White students outscored African American students on all assessments. In $4^{\text {th }}$ and $7^{\text {th }}$ grade, this achievement gap was larger in reading than in language, but in $11^{\text {th }}$ grade the gap was larger in language. For example, African American students scored 27 to 29 percentiles below white students on the $4^{\text {th }}$ and $7^{\text {th }}$-grade SAT1O reading subtest, but scored 21 percentiles lower on the language subtest. Economically disadvantaged students scored markedly lower than other students. For example, in $4^{\text {th }}$-grade reading, economically disadvantaged students scored 30 percentiles below full-price- lunch students, and in $7^{\text {th }}$ grade they scored 28 percentiles lower. As we saw in the racial breakdown, economically disadvantaged students faced larger achievement gaps in reading than in language in $4^{\text {th }}$ and $7^{\text {th }}$ grades, but scored closer to their peers in language 
than in reading on the $11^{\text {th }}$-grade AHSGE. On the DAW, the gap between the percentage of economically disadvantaged students passing the assessment and the percentage of noneconomically disadvantaged students passing was 20-21 percentage points in $5^{\text {th }}$ grade and 21-22 percentage points in $7^{\text {th }}$ grade.

\section{Table A3. Performance of $11^{\text {th }}$-Graders on 2003 Reading and Language AHSGE, by Student Characteristics}

\begin{tabular}{|c|c|c|}
\hline & Reading & Language \\
\hline & \multicolumn{2}{|c|}{ Percentage Passing } \\
\hline All students & 88 & 83 \\
\hline General education students & 90 & 85 \\
\hline Special education students & 59 & 46 \\
\hline $\begin{array}{l}\text { Economically disadvantaged } \\
\text { students }\end{array}$ & 80 & 73 \\
\hline $\begin{array}{l}\text { Non-economically disadvantaged } \\
\text { students }\end{array}$ & 92 & 87 \\
\hline African American students & 79 & 71 \\
\hline White students & 93 & 89 \\
\hline
\end{tabular}

Source:

http://www.alsde.edu/Accountability/Accountability.asp?system=0\&sch=0\&SchoolYear=20022003\&Rep= $2 \&$ View $=2$

\section{$\underline{\text { School Performance }}$}

We are also able to report school-level data by urbanicity for the 2002 administration of the DAW and the AHSGE. Because $4^{\text {th- }}$ and $7^{\text {th-grade }}$ students took the SAT9 in 2002, which is normed differently than the SAT10, we do not report these scores, as they are not comparable to the 2003 scores.

Of schools in Alabama, 39 percent are suburban, 37 percent are rural, and 24 percent are urban. Suburban schools outperformed rural and urban schools on the $5^{\text {th }}$ - and $7^{\text {th }}$-grade DAW by $6-14$ percentage points (Table A4). Suburban schools also outperformed the rest on the $11^{\text {th }}$-grade AHSGE, but by slightly smaller margins, 4-7 percentage points (Table A5). These results are not surprising, as 66 percent of rural schools are high-poverty schools (defined as schools with 50 percent or more students eligible for free or reduced-price lunch), as are 68 percent of urban schools, while only 34 percent of suburban schools are high-poverty. 


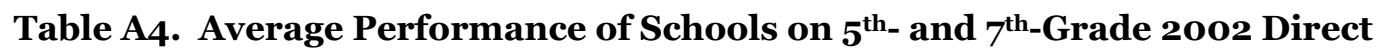
Assessment of Writing, by Urbanicity

\begin{tabular}{lcccc}
\hline & Holistic & $\begin{array}{c}\text { Writing } \\
\text { Mechanics }\end{array}$ & $\begin{array}{c}\text { Sentence } \\
\text { Formation }\end{array}$ & $\begin{array}{c}\text { Grammar } \\
\text { and Usage }\end{array}$ \\
\cline { 2 - 5 } Average Passing Percentage \\
\hline Grade 5 & \multicolumn{5}{c}{. } & 44 & 38 & 34 \\
Rural schools & 27 & 51 & 47 & 44 \\
Suburban school & 33 & 45 & 37 & 34 \\
Urban schools & 26 & 55 & 56 & 41 \\
Grade 7 & & 59 & 63 & 49 \\
Rural schools & 33 & 54 & 49 & 39 \\
Suburban schools & 41 & 30 & &
\end{tabular}

Table A5. Average Performance of Schools on $1^{\text {th }}$-Grade Reading and Language 2002 AHSGE, by Urbanicity

\begin{tabular}{lcc}
\hline & Reading & Language \\
\cline { 2 - 3 } & \multicolumn{1}{c}{ Average Passing } & Percentage \\
\hline Rural schools & 84 & 82 \\
Suburban schools & 88 & 86 \\
Urban schools & 83 & 79 \\
\hline
\end{tabular}




\section{APPENDIX B. ALASKA}

\section{State Assessment System}

Alaska began implementing its statewide assessment system in 1998. Currently, the state administers three exams as part of its accountability system:

- The Benchmark Tests are criterion-referenced exams that the state reports as being linked to state performance standards. Students in grades 3,6 , and 8 take the tests in reading, writing, and mathematics.

- The Terra Nova CAT/6 is a nationally norm-referenced assessment published by CTB/ McGraw-Hill. Districts administer the Terra Nova reading, writing, and mathematics assessments in grades 4, 5, 7, and 9, and they have the option of testing in science and social studies as well.

- The High School Graduation Qualifying Exam (HSGQE) is a criterion-referenced exam linked to state performance standards in reading, writing, and mathematics. Students have five opportunities to take the exam in grades 10, 11, and 12 and must pass in order to graduate (for additional information on state accountability see http://www.eed.state.ak.us/ nclb/home.html).

In 1994-95, Alaska adopted content standards that define what students should know and be able to do as a result of their public schooling. The state has content standards in English language arts, mathematics, science, geography, government and citizenship, history, arts, world languages, technology, information literacy, and skills for healthy living. In broad terms, the content standards for English language arts state that a student:

A. should be able to speak and write well for a variety of purposes and audiences

B. should be a competent and thoughtful reader, listener, and viewer of literature, technical materials, and other information

C. should be able to identify and select from multiple strategies in order to complete projects independently and cooperatively

D. should be able to think logically and reflectively in order to present and explain positions based on relevant and reliable information

E. should understand and respect the perspectives of others in order to communicate effectively (www.eed.state.ak.us/contentstandards/English.html).

In 1999, the content standards in English language arts were linked with performance standards in reading and writing that lay out specific expectations for what students should know and be able to do in four age groups $-5-7,8-10,11-14$, and 15-17-and that are assessed in grades 3,6 , 
8, and 10 on the aligned Benchmark Tests. The performance standards focus on content standards B, D, and E. For instance, writing performance standards for ages 11-14, which are assessed in grade 8 , include:

- Write a coherent composition that includes a thesis statement, supporting evidence, and a conclusion.

- Select and use appropriate forms of fiction and non-fiction to achieve different purposes when writing for different purposes when writing for different audiences.

- Use the conventions of Standard English including grammar, sentence structure, paragraph structure, punctuation, spelling and usage in written work.

- Revise writing to improve organization, word choice, paragraph development, and voice appropriate to the purpose

- Form and explain own standards or judgments of quality writing.

- List and document sources using a given format (http://www.eed.state.ak.us/tls/PerformanceStandards/).

Since 2003, the state has been working to develop grade-level expectations (GLEs) that will align with the performance standards and will use "assessable" language. ${ }^{2}$ The GLEs will offer grade-bygrade standards rather than the age-group standards in the performance standards. Draft GLEs were released in February 2004 (see http://www.eed.state.ak.us/tls/ assessment/GLEHome.html).

The state recently signed a new six-year contract with Data Recognition Corporation to develop and administer the statewide assessment program. In addition to continuing the HSGQE, the contract calls for new criterion-referenced exams for grades 3 through 9 that will be tied directly to the GLEs in English language arts, writing, and math, and will include both constructedresponse and multiple-choice questions. The new assessment for grades 3-9 will be introduced in the spring of 2005. Discussions are still ongoing as to whether or not the state will continue to give a norm-referenced test once the new exam is in place. Alaska also hopes to eventually move the new assessments to electronic formats to allow remote testing and faster scoring.

\section{Test Format and Content}

Because the Terra Nova is not specifically linked to Alaska's content and performance standards, the rest of the discussion will focus on the Benchmark Tests and the HSGQE. To examine trends

${ }^{2}$ For example, GLEs will use such words as "selects," "identifies," "locates," or "restates" instead of such performance-standard words as "knows" and "understands." 
in adolescent literacy, we will concentrate on reading and writing for grades 6, 8, and 10 (more information on the assessments can be found at (http://www.eed.state.ak.us/tls/ assessment/).

\section{Benchmark Test}

The reading and writing portions of the Benchmark Test consist of 36 questions apiece: 29-30 multiple-choice questions, $5-6$ short-response questions, and 1 extended-response question. Tests are not timed, but they are expected to take about two or three hours.

The questions on the reading exam cover all performance standards with similar emphasis, except those related to reading aloud and making cultural connections, which are not tested. The writing assessment places primary emphasis on short and extended writing tasks covering the first two performance standards (write about a topic and write for a variety of purposes and audiences); these five questions account for 38 percent of the available raw-score points. Writing and editing receive slightly less emphasis (36 percent), followed by revising writing (14 percent). Using resources and citing sources are not tested.

\section{HSGQE}

The HSGQE for reading consists of 50 questions: 35 multiple choice and 15 short response. The writing assessment includes 35 questions: 26 multiple choice, eight short response, and one extended response.

The HSGQE reading test places 24 percent of its emphasis on summarizing information and making connections, and it also assesses performance standards covering supporting main ideas and critiquing arguments, reading and applying multistep directions, making and supporting assertions, and analyzing and evaluating themes at 16 to 19 percent of emphasis each. Using contextual clues accounts for the remaining 6 percent. On the writing exam, short and extended writing tasks make up more than half the exam emphasis and assess students' ability to write compositions and demonstrate elements of discourse. Also tested are students' use of conventional English (27 percent of total) and their ability to revise writing (19 percent of total).

\section{Achievement-Level Definitions}

Scores on the Benchmark Tests are divided into four achievement levels: advanced, proficient, below proficient, and far below proficient. To pass the exam, students most score at the proficient or advanced levels. Scores on the HSGQE are reported in two levels: proficient and not proficient. 


\section{Performance Results}

\section{$\underline{\text { Student Performance }}$}

Alaska provides student-level data on student performance on the Benchmark Tests and the HSGQE for all students, students with disabilities, students with limited-English proficiency, and economically disadvantaged students. It also provides scores for racial/ethnic groups. ${ }^{3}$ Table B1 shows the reading and writing performance results from the 2003 administration of the $6^{\text {th- }}$ and $8^{\text {th }}$-grade Benchmark Tests; Table B2 provides results from the HSGQE for $10^{\text {th }}$-grade students, disaggregated by these same student characteristics.

Overall, 68-70 percent of students scored proficient or better on the Benchmark reading assessments, and 74-75 percent did so in writing. With one exception (African American students), the percentage of students reaching proficiency on the Benchmark assessment was slightly lower in grade 8 than in grade 6.

Table B1. Performance of $6^{\text {th- }}$ and $8^{\text {th }}$-Graders on 2003 Reading and Writing Benchmark Assessments, by Student Characteristics

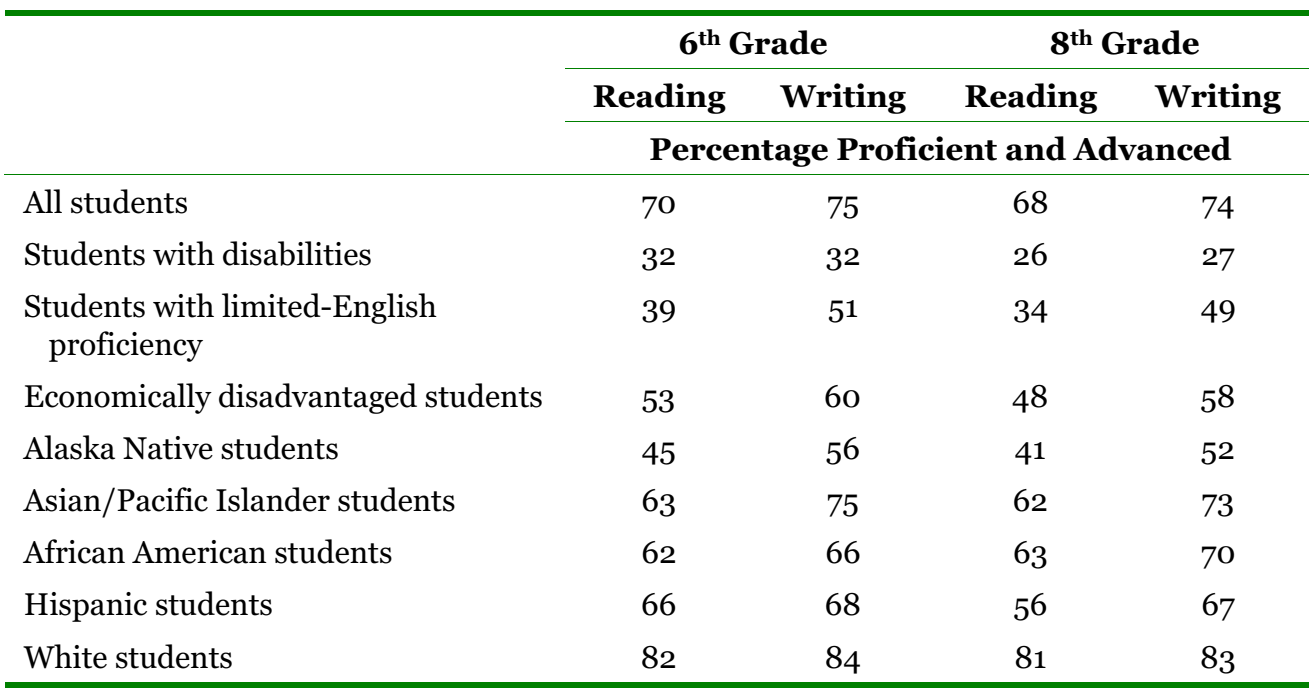

Source: http://www.eed.state.ak.us/tls/assessment/results.html

Pass rates on the reading assessment were considerably lower among students with disabilities, students with limited-English proficiency, and economically disadvantaged students. Only 26-32 percent of students with disabilities, 34-39 percent of students with limited-English proficiency,

3Approximately 60 percent of students in Alaska are white; 26 percent are Alaska Native; 6 percent are Asian/Pacific Islander; 5 percent are African American; and 4 percent are Hispanic. One-fourth of students are eligible for the free or reduced-price lunch program; 15 percent are enrolled in limited-Englishproficiency programs, and 13 percent have Individual Education Programs (IEPs). 
and 48-53 percent of economically disadvantaged students scored proficient or better on the Benchmark Assessments for reading.

While students with disabilities scored marginally higher in writing than in reading at the $8^{\text {th }}$ grade level, students with limited-English proficiency had notably better success in writing (4951 percent passing) than in reading at both grade levels. Between 58 and 60 percent of economically disadvantaged students scored proficient or better on the writing test.

\section{Table B2. Performance of $10^{\text {th }}$-Graders on 2003 Reading and Writing High School Graduation Qualifying Examination, by Student Characteristics}

\begin{tabular}{lcc}
\hline & Reading & Writing \\
\cline { 2 - 3 } & \multicolumn{2}{c}{ Percentage Passing } \\
\hline All students & 70 & 83 \\
Students with disabilities & 24 & 39 \\
Students with limited-English proficiency & 32 & 62 \\
Economically disadvantaged students & 47 & 70 \\
Alaska Native students & 45 & 68 \\
Asian/Pacific Islander students & 58 & 83 \\
African American students & 47 & 73 \\
Hispanic students & 63 & 76 \\
White students & 82 & 90 \\
\hline
\end{tabular}

Source: http://www.eed.state.ak.us/tls/assessment/results.html

Among the different racial/ethnic groups, white students scored notably higher than all other groups on both tests at all three grade levels. In reading, 81-82 percent of white students scored proficient or above, and in writing 83-84 percent were at the proficient level. Between 56 and 66 percent of African American, Hispanic, or Asian/Pacific Islander students scored at the proficient level in reading and between 67 and 75 percent did so in writing. Alaska Native students scored markedly below all other groups in both subjects, with proficiency levels of 41-45 percent in reading and $52-56$ percent in writing.

We find similar results for $10^{\text {th }}$-grade students on the HSGQE. Seventy percent of students passed in reading and 83 percent passed in writing. While all groups of students passed writing at higher rates than reading, the difference was particularly large for students with limitedEnglish proficiency (62 percent compared with 32 percent). On the HSGQE, white students had much higher pass rates than did other racial/ethnic groups, and Alaskan Natives performed far below other groups: only 45 percent passed in reading, and 68 percent passed in writing. Unlike trends for student performance on the Benchmark Assessment in the lower grades, African 
American students performed more in range with Alaskan Native students on the HSGQE, rather than with Hispanic and Asian students.

\section{$\underline{\text { School Performance }}$}

We are also able to report school-level data by urbanicity for the 2001-02 $6^{\text {th }}$ - and $8^{\text {th }}$-grade Benchmark Assessment (Table B3). Most of the schools in Alaska were in rural areas (74 percent), while 18 percent of schools were urban and 6 percent were suburban. Rural schools were more likely to be high-poverty schools: 35 percent of rural schools were high-poverty compared with 10 percent of suburban schools and 14 percent of urban schools.

Rural schools performed considerably worse than suburban or urban schools, with average proficiency levels in both reading and writing that are 20-25 percentage points lower in the $6^{\text {th }}$ grade and $15^{-25}$ percentage points lower in the $8^{\text {th }}$ grade.

Table B3. School Performance on $6^{\text {th- }}$ and $8^{\text {th }}$-Grade 2002 Reading and Writing Benchmark Assessment, by Urbanicity

\begin{tabular}{lcc}
\hline & \multicolumn{1}{c}{ Reading } & Writing \\
\cline { 2 - 3 } & \multicolumn{2}{c}{ Average Percentage Proficient and } \\
Above \\
\hline 6 $^{\text {th }}$ Grade \\
Rural schools & 50 & 60 \\
Suburban schools & 75 & 81 \\
Urban schools & 75 & 80 \\
$\mathbf{8}^{\text {th }}$ Grade & & \\
Rural schools & 58 & 51 \\
Suburban schools & 81 & 62 \\
Urban schools & 83 & 66 \\
\hline
\end{tabular}




\section{APPENDIX C. ARIZONA}

\section{State Assessment System}

In 2002-03, Arizona administered two assessments as part of its accountability system:

- Arizona's Instrument to Measure Standards (AIMS) is a criterion-referenced test that the state reports being aligned with state standards. Students in grades 3, 5, and 8 take the tests in reading, writing, and mathematics. High school students also take the AIMS in $10^{\text {th }}$ grade, and, beginning with the class of 2006, must pass in order to graduate.

- The Stanford Achievement Test $9^{\text {th }}$ edition (SAT9) is a nationally norm-referenced assessment published by Harcourt. Students take the SAT9 in language, mathematics, and reading in grades 2 through 9.

In response to No Child Left Behind (NCLB), Arizona is expanding the AIMS program to cover all grades from 3 through 8 . Newly developed criterion-referenced AIMS tests for grade 4, 6, and 7 will be field-tested in the spring of 2004 and should be operational in the spring of 2005 (for additional information regarding state accountability, see http://www.ade.state.az.us/azlearns/).

The state introduced the Arizona Academic Standards in 1996, in language arts, mathematics, science, social studies, the arts, foreign language, technology, workplace skills, and comprehensive health and physical education. For the language arts, the four standards of reading, writing, listening and speaking, and viewing and presenting define what students should know and be able to do by the end of $12^{\text {th }}$ grade. These standards are made more specific by providing specific examples of what students should know and be able to do in five grade clusters: Readiness (Kindergarten), Foundations (Grades 1-3), Essentials (Grades 4-8) Proficiency (Grades 9-12), and Distinction (Honors).

In 2003, the state published refined standards in reading that are articulated separately for all grade levels in accordance with the requirements of NCLB. These standards are divided into three content strands that include component concepts broadly describing what students should know and be able to do. The Reading Process strand includes six concepts (print concepts, phonemic awareness, phonics, vocabulary, fluency, and comprehension), the Comprehending Literary Text strand includes two concepts (elements of literature, and historical and cultural aspects of literature), and the Comprehending Informational Text strand includes three concepts (expository text, functional text, and persuasive text). Each concept is further defined by performance objectives, which describe specific knowledge and tasks appropriate to each grade. 


\section{Test Format and Content}

Because the SAT9 is not specifically linked to Arizona's content and performance standards, the rest of the discussion will focus on the AIMS (additional information on the AIMS can be found through (http://www.ade.state.az.us/standards/). To examine trends in adolescent literacy, we concentrate on reading and writing for grades 5,8 , and 10.

For 2004, the AIMS reading assessment consists of approximately 40 multiple-choice questions and asks students to read and respond to both passages from fiction, such as stories and poems, and passages from nonfiction, such as informational articles, directions, user's guides, a map, or a chart. The tests are not timed but are expected to take one to two hours to complete.

The AIMS reading assessment covers five concepts at each grade level. Using comprehension strategies, analyzing literary elements, and identifying an author's persuasive techniques are tested at all grade levels. Evaluating an instructional manual is tested in grades 5 and 8, while evaluating technical and workplace documents is tested in grade 10. Students in grades 5 and 8 are tested on using structural-analysis skills to decode unfamiliar words, and students in grade 10 are tested on analyzing literary works. Table $\mathrm{C} 1$ shows the relative weight these concepts carry in the assessments across the grade levels. Decoding receives less emphasis in the $8^{\text {th }}$ grade than in the $5^{\text {th }}$ grade, while identifying an author's perspective carries a bit more weight in the later grades than in the $5^{\text {th }}$ grade.

Table C1. Weights of Concepts Tested on AIMS in $5^{\text {th }}, 8^{\text {th }}$, and $10^{\text {th }}$ Grades

\begin{tabular}{lccc}
\hline \multirow{2}{*}{ Concept } & Grade 5 & Grade 8 & Grade 10 \\
\cline { 2 - 4 } & \multicolumn{2}{c}{ Percentage of Available Points } \\
\hline Using comprehension strategies & $26-33$ & $21-29$ & $30-44$ \\
Analyzing literary elements & $23-29$ & $14-21$ & $15-23$ \\
$\begin{array}{l}\text { Evaluating an instructional manual (grades 5 and 8) or } \\
\text { technical and workplace documents (grade 10) }\end{array}$ & $14-21$ & $21-29$ & $9-21$ \\
Using structural-analysis skills to decode unfamiliar & $12-17$ & $10-17$ & NT \\
words & & & \\
Analyzing literary works & NT & NT & $9-21$ \\
Identifying an author's persuasive techniques & $9-14$ & $12-21$ & $13-21$ \\
\hline
\end{tabular}

Source: http://www.ade.state.az.us/standards/aims/blueprints/default.asp

$\mathrm{NT}=$ not tested.

The writing portion of AIMS, which has previously included multiple-choice and short-answer questions in addition to an extended writing exercise, will be changed to include only extended writing as of the 2004 test administration. Students have 2-3 hours to complete the test and are given time to plan, draft, revise, edit, and write a final copy of their composition. 
For the 2003 AIMS writing assessment, the $5^{\text {th }}$-grade exam focused on writing personalexperience narrative or creative stories, allocating 38-41 percent of the available points to these exercises. Other concepts that were tested included using correct spelling, punctuation, capitalization, grammar, and usage; demonstrating research skills using reference materials; writing formal communications; and writing reports that convey point of view and develop topics. The $8^{\text {th }}$-grade test placed the most emphasis on writing expository essays (31-37 percent of available points) and also tested correct spelling, punctuation, capitalization, grammar, and usage; writing summaries; writing reports that convey point of view and develop topics; demonstrating research skills using reference materials; writing formal communications; and writing personal-experience narratives or creative stories. At the high school level, writing persuasive essays received the most emphasis, at 25-35 percent of the available points, but also tested crafting a cohesive research document, writing formal communications, writing a narrative or story, writing literary analyses, and using literary devices.

Extended responses on the AIMS writing assessment were judged using the Six Trait Analytical Rubric developed by the Northwest Regional Educational Laboratory. The rubric applies for all grade levels and modes of writing, and defines six achievement levels in each of the six traits: ideas and content, organization, voice, word choice, sentence fluency, and conventions. The overall score is an average of the scores on the six traits, with each trait receiving equal weighting.

\section{Achievement-Level Definitions}

Results on the AIMS are divided into four achievement levels: falls far below the standard, approaches the standard, meets the standard, and exceeds the standard. Students meeting or exceeding the standard are considered to be "proficient" for accountability purposes. The state has published general AIMS achievement-level descriptors that apply for all grade levels and all subjects. These descriptors are further detailed by grade- and subject-specific descriptors of general and specific essentials, which stipulate what students at each level should know and be able to do. Table $\mathrm{C} 2$ shows the general $\mathrm{K}-12$ achievement-level descriptors; Table $\mathrm{C}_{3}$ presents grade-specific descriptors for $8^{\text {th }}$-grade reading, as an example. 
Table C2. AIMS Achievement-Levels Grades K-12

\begin{abstract}
Falls far below the standard

This level denotes insufficient evidence of the prerequisite skills to approach meeting the standards. Students who perform at this level have serious gaps in knowledge and skills. They, in all likelihood, require a considerable amount of additional work and remediation in the basic skills that are prerequisite to the challenging work expected at the current grade level.

Approaches the standard This level denotes partial understanding of the knowledge and application of the skills that are fundamental for proficient work. Students who approach the standard demonstrate competency in the prerequisites necessary to begin working on challenging content required of students who meet the standards, but do not demonstrate full understanding of that challenging content.

Meets the standard This level denotes demonstration of solid academic performance on challenging subject matter reflected by the content standards. This performance includes subject-matter knowledge, application of such knowledge to real-world situations, and content-relevant analytical skills. Students who perform at this level are well prepared to begin work on even more challenging material that is required for the next grade level. Attainment of at least this level is the goal for all students.

Exceeds the standard This level denotes demonstration of superior academic performance evidenced by achievement substantially beyond the goal for all students.
\end{abstract}

Source: http://www.ade.state.az.us/standards/aims/PerformanceStandards/performancelevels.asp

\title{
Performance Results
}

\section{Student Performance}

The Arizona Department of Education provides data on student performance by categories that roughly correlate with English-language learners and non-English-language learners, and by racial/ethnic groups within those categories. 4 Table $\mathrm{C} 4$ shows 2003 AIMS reading and writing results for students in grades 5,8 , and 10 , disaggregated by student characteristics. Note that data for racial/ethnic groups are for those students with English-language proficiency. More than half of Arizona's English-proficient $5^{\text {th }}$-grade students passed the AIMS reading and writing assessments in 2003 by scoring at or above the "meets standards" level. Eleven percent scored in the "exceeds standard" level in reading, and 8 percent did so in writing. Eighth-grade

4Approximately 51 percent of students in Arizona are white; 35 percent are Hispanic; 7 percent are American Indian; 5 percent are African American; and 2 percent are Asian. About 16 percent of students are enrolled in limited-English proficiency programs, and 11 percent have Individual Education Programs (IEPs).

Arizona's Category 2 includes all students whose first language is not English and who are in the process of learning English, regardless of how long they have been classified as English Learners. Category 1 in grades 5 and 8 includes students whose first language is English or who have met the requirements needed to exit from an English Learner program or who have been identified as an English Learner for four years or more. For high school students, Category 1 includes all students who take AIMS without modifications. Note that the two categories are not mutually exclusive. 
students scored similarly in reading, with 55 percent passing and 15 percent exceeding the standard, but they did not score as well as $5^{\text {th }}$-grade students in writing: Only 46 percent passed the test, and just 1 percent exceeded the standard. Tenth-graders did better than $5^{\text {th-graders and }}$ $8^{\text {th }}$-graders at the "passing" level in both subjects-59 percent met or exceeded standards in reading, and 67 percent did so in writing-but while 10 percent of $10^{\text {th }}$-graders exceeded the standards in reading, none scored at this level on the writing exam.

Table C3. Achievement-Level Descriptors-Grade-8 Reading

\begin{tabular}{|c|c|c|}
\hline $\begin{array}{l}\text { Approaches the } \\
\text { Standard }\end{array}$ & Meets the Standard & Exceeds the Standard \\
\hline \multicolumn{3}{|c|}{ General Reading Achievement-Level Descriptors } \\
\hline $\begin{array}{l}\text { Students who are } \\
\text { "Approaching the } \\
\text { Standard" demonstrate a } \\
\text { basic understanding of } \\
\text { fiction, nonfiction, and } \\
\text { poetry. They are able to } \\
\text { use basic reading } \\
\text { strategies to identify the } \\
\text { main ideas, to find } \\
\text { supporting details, and } \\
\text { to interpret meaning } \\
\text { through context clues. } \\
\text { Students are able to } \\
\text { identify author's } \\
\text { purpose and to } \\
\text { recognize some } \\
\text { organizational patterns, } \\
\text { including cause and } \\
\text { effect and sequencing. } \\
\text { Students are able to } \\
\text { identify and locate } \\
\text { details from } \\
\text { informational sources. }\end{array}$ & $\begin{array}{l}\text { Students who "Meet the } \\
\text { Standard" are able to } \\
\text { comprehend and respond } \\
\text { to text both literally and } \\
\text { inferentially. Students } \\
\text { demonstrate an } \\
\text { understanding of the use } \\
\text { of figurative, idiomatic, } \\
\text { and technical language. } \\
\text { Students distinguish fact } \\
\text { from opinion and draw } \\
\text { conclusions from stated } \\
\text { details. Students describe } \\
\text { events and/or character } \\
\text { motivations, apply prior } \\
\text { knowledge in interpreting } \\
\text { concepts, and draw } \\
\text { conclusions based on } \\
\text { stated information } \\
\text { according to style and } \\
\text { meaning. Students } \\
\text { identify author bias, use } \\
\text { details to support and } \\
\text { explain author's purpose } \\
\text { or bias, and recognize } \\
\text { persuasive strategies. } \\
\text { Students identify details of } \\
\text { instructional manuals or } \\
\text { guides (e.g., business } \\
\text { brochures, advertising, } \\
\text { menus, work manuals). }\end{array}$ & $\begin{array}{l}\text { Students who "Exceed the } \\
\text { Standard" are able to } \\
\text { identify theme and infer } \\
\text { conclusions from } \\
\text { challenging texts. At this } \\
\text { level, students are able to } \\
\text { apply structural-analysis } \\
\text { skills to confirm meaning } \\
\text { of complex language. } \\
\text { Students are able to } \\
\text { recognize literary } \\
\text { elements such as theme, } \\
\text { plot sequence, and word } \\
\text { relationships. Students } \\
\text { can analyze details from } \\
\text { information sources and } \\
\text { recognize when } \\
\text { information is either } \\
\text { extraneous or missing. } \\
\text { Finally, students are able } \\
\text { to interpret or explain an } \\
\text { author's use of persuasive } \\
\text { strategies. }\end{array}$ \\
\hline
\end{tabular}


Table C3. (cont.)

\begin{tabular}{|c|c|c|c|}
\hline \multicolumn{4}{|c|}{ Specific Reading Achievement-Level Descriptors } \\
\hline & $\begin{array}{l}\text { Approaches the } \\
\text { Standard }\end{array}$ & Meets the Standard & Exceeds the Standard \\
\hline $\begin{array}{l}\text { Apply } \\
\text { comprehension } \\
\text { strategies }\end{array}$ & $\begin{array}{l}\text { Predict outcome based } \\
\text { on events. } \\
\text { Identify main idea. } \\
\text { Compare and contrast } \\
\text { text ideas. }\end{array}$ & $\begin{array}{l}\text { Draw conclusions from } \\
\text { stated details. } \\
\text { Identify cause-and-effect } \\
\text { relationships. } \\
\text { Support conclusions with } \\
\text { evidence from text. }\end{array}$ & $\begin{array}{l}\text { Infer conclusions from } \\
\text { challenging texts. } \\
\text { Make clear distinctions } \\
\text { using comparisons. } \\
\text { Distinguish fact from } \\
\text { opinion. }\end{array}$ \\
\hline $\begin{array}{l}\text { Analyze literary } \\
\text { elements }\end{array}$ & $\begin{array}{l}\text { Interpret information } \\
\text { from fiction, nonfiction, } \\
\text { and poetry. } \\
\text { Identify author's point of } \\
\text { view. }\end{array}$ & $\begin{array}{l}\text { Interpret events and/or } \\
\text { character motivations. } \\
\text { Apply prior knowledge in } \\
\text { interpreting an idea. } \\
\text { Draw conclusions based } \\
\text { on stated information } \\
\text { Identify critical details. }\end{array}$ & $\begin{array}{l}\text { Identify theme in a } \\
\text { challenging text. } \\
\text { Recognize the relationship } \\
\text { between two or more } \\
\text { terms. } \\
\text { Analyze elements of plot. } \\
\text { Interpret events and } \\
\text { character motivations. } \\
\text { Explain interactions of } \\
\text { characters }\end{array}$ \\
\hline $\begin{array}{l}\text { Use structural- } \\
\text { analysis skills to } \\
\text { decode unfamiliar } \\
\text { words }\end{array}$ & \multirow[t]{2}{*}{$\begin{array}{l}\text { Use context clues to } \\
\text { determine figurative } \\
\text { language. }\end{array}$} & $\begin{array}{l}\text { Demonstrate an } \\
\text { understanding of the use } \\
\text { of figurative, idiomatic, } \\
\text { and technical language. }\end{array}$ & $\begin{array}{l}\text { Apply structural-analysis } \\
\text { skills to confirm meaning } \\
\text { of figurative, idiomatic, } \\
\text { and technical language. }\end{array}$ \\
\hline $\begin{array}{l}\text { Identify the } \\
\text { author's persuasive } \\
\text { techniques }\end{array}$ & & & $\begin{array}{l}\text { Interpret and explain an } \\
\text { author's use of persuasive } \\
\text { strategies, supported by } \\
\text { evidence from text. }\end{array}$ \\
\hline $\begin{array}{l}\text { Evaluate an } \\
\text { instructional } \\
\text { manual }\end{array}$ & $\begin{array}{l}\text { Identify components of } \\
\text { informational source. } \\
\text { Locate information from } \\
\text { print and illustration. }\end{array}$ & $\begin{array}{l}\text { Identify critical details in } \\
\text { instructional guides. }\end{array}$ & $\begin{array}{l}\text { Analyze details from } \\
\text { informational sources. } \\
\text { Recognize when } \\
\text { information is either } \\
\text { extraneous or missing. }\end{array}$ \\
\hline \multicolumn{4}{|c|}{$\begin{array}{l}\text { Source: } \\
\text { http://www.ade.state.az.us/standards/aims/PerformanceStandards/8thGradePerformanceStandards.pdf }\end{array}$} \\
\hline \multicolumn{4}{|c|}{$\begin{array}{l}\text { English-language learners scored substantially below English-proficient students in both subjects } \\
\text { and at all grade levels. In fact, the percentage of English-proficient students passing the AIMS } \\
\text { was } 3-4.5 \text { times as large as the percentage of English-language learners who met or exceeded the } \\
\text { standards. The percentage of English-language learners who met the level "approaches the } \\
\text { standard" ranged from } 31-45 \text { percent, meaning that the majority of English-language learners fell } \\
\text { into the lowest achievement level. }\end{array}$} \\
\hline
\end{tabular}


Table C4: Performance of $5^{\text {th }}$, $8^{\text {th }}$, and $10^{\text {th }}$-Graders on the 2003 AIMS Reading and Writing, by Student Characteristics

\begin{tabular}{|c|c|c|c|c|c|c|}
\hline & \multicolumn{3}{|c|}{ Reading } & \multicolumn{3}{|c|}{ Writing } \\
\hline & $\begin{array}{l}\text { Approaches } \\
\text { Standard } \\
\text { and Above }\end{array}$ & $\begin{array}{c}\text { Meets } \\
\text { Standard } \\
\text { and } \\
\text { Above }\end{array}$ & $\begin{array}{l}\text { Exceeds } \\
\text { Standard }\end{array}$ & $\begin{array}{l}\text { Approaches } \\
\text { Standard } \\
\text { and Above }\end{array}$ & $\begin{array}{c}\text { Meets } \\
\text { Standard } \\
\text { and } \\
\text { Above }\end{array}$ & $\begin{array}{l}\text { Exceeds } \\
\text { Standard }\end{array}$ \\
\hline & \multicolumn{6}{|c|}{ Percentage } \\
\hline \multicolumn{7}{|l|}{$5^{\text {th }}$ Grade } \\
\hline $\begin{array}{l}\text { English-proficient } \\
\text { students (Category 1) }\end{array}$ & 81 & 57 & 11 & 82 & 55 & 8 \\
\hline $\begin{array}{l}\text { English-language } \\
\text { learners (Category 2) }\end{array}$ & 43 & 16 & 1 & 45 & 16 & 1 \\
\hline $\begin{array}{l}\text { African American } \\
\text { students }^{\mathrm{a}}\end{array}$ & 72 & 44 & 5 & 74 & 43 & 4 \\
\hline $\begin{array}{l}\text { American Indian } \\
\text { students }^{\text {a }}\end{array}$ & 61 & 30 & 3 & 61 & 29 & 2 \\
\hline Hispanic studentsa & 72 & 42 & 5 & 74 & 42 & 4 \\
\hline White students ${ }^{\text {a }}$ & 90 & 70 & 16 & 90 & 67 & 11 \\
\hline \multicolumn{7}{|l|}{$8^{\text {th }}$ Grade } \\
\hline $\begin{array}{l}\text { English-proficient } \\
\text { students (Category 1) }\end{array}$ & 75 & 55 & 15 & 83 & 46 & 1 \\
\hline $\begin{array}{l}\text { English-language } \\
\text { learners (Category 2) }\end{array}$ & 31 & 12 & 1 & 41 & 9 & o \\
\hline $\begin{array}{l}\text { African American } \\
\text { students }^{\mathrm{a}}\end{array}$ & 62 & 38 & 7 & 75 & 31 & o \\
\hline $\begin{array}{l}\text { American Indian } \\
\text { students }^{\text {a }}\end{array}$ & 54 & 29 & 4 & 66 & 23 & o \\
\hline Hispanic students ${ }^{\mathrm{a}}$ & 63 & 38 & 6 & 73 & 30 & o \\
\hline White students ${ }^{\mathrm{a}}$ & 85 & 68 & 21 & 90 & 56 & 1 \\
\hline \multicolumn{7}{|l|}{ 10 $^{\text {th }}$ Grade } \\
\hline $\begin{array}{l}\text { English-proficient } \\
\text { students (Category 1) }\end{array}$ & 82 & 59 & 10 & 80 & 67 & o \\
\hline $\begin{array}{l}\text { English-language } \\
\text { learners (Category 2) }\end{array}$ & 44 & 13 & o & 32 & 22 & o \\
\hline $\begin{array}{l}\text { African American } \\
\text { students }^{\mathrm{a}}\end{array}$ & 75 & 44 & 4 & 74 & 61 & o \\
\hline $\begin{array}{l}\text { American Indian } \\
\text { students }^{\mathrm{a}}\end{array}$ & 70 & 35 & 2 & 61 & 45 & o \\
\hline Hispanic students ${ }^{\mathrm{a}}$ & 69 & 38 & 3 & 64 & 50 & o \\
\hline White students ${ }^{\mathrm{a}}$ & 91 & 74 & 15 & 91 & 79 & o \\
\hline
\end{tabular}

Source: http://www.ade.state.az.us/profile/publicview

Note: ${ }^{a}$ Results for racial/ethnic groups are for English proficient students only. 
White students were notably more successful on the AIMS than most other groups. On all assessments except $8^{\text {th }}$-grade writing, where only 56 percent passed the test, more than twothirds of white students met or exceeded the standard. In contrast, only 30-50 percent of Hispanic students passed the assessments, and the achievement gap between white and Hispanic students ranged from 28 to 36 percentage points in reading and 25 to 29 percentage points in writing. The gap was slightly larger at higher grade levels in both subjects. While 3-6 percent of Hispanic students were able to exceed the standards in reading, and 4 percent exceeded the standards in writing in $5^{\text {th }}$ grade, none scored at that level in $8^{\text {th }}$ - or $10^{\text {th }}$-grade writing. It is important to note that this achievement gap is between English-proficient white students and English-proficient Hispanic students, so it tends to overstate the performance of all Hispanic students, since a substantial proportion are classified in Category 2.

The performance of African American students was similar to that of Hispanic students in $5^{\text {th }}$ and $8^{\text {th }}$ grades, but these students had considerably higher pass rates than did Hispanic students at the $10^{\text {th }}$-grade level -44 percent in reading and 61 percent in writing compared with 38 and 50 percent, respectively. The percentage of African American students passing the writing assessment in $10^{\text {th }}$ grade was much higher than in $5^{\text {th }}$ or $8^{\text {th }}$ grade. The achievement gap between white and African American students was 26-30 percentage points in reading, but only 18-25 percentage points in writing.

American Indian students also trailed white students by a substantial margin. The achievement gap was $39-40$ percentage points in reading, and $33-38$ percentage points in writing. The gap was somewhat narrower in $10^{\text {th }}$ grade than in $5^{\text {th }}$ grade. As with Hispanic students, a sizable proportion of American Indian students are English-language learners, so these results for English-proficient students tend to overstate the performance of the overall group.

\section{$\underline{\text { School Performance }}$}

Although Arizona does not report AIMS performance by poverty or urbanicity at the student level, school-level data are available for the 2002 AIMS administration for grades 5 and 8 . However, over 20 percent of poverty data is missing on schools; as a result, we do not report these data. About 49 percent of Arizona's schools are urban, 33 percent are suburban, and 19 percent are rural.

Table $\mathrm{C}_{5}$ provides information about school performance for rural, suburban, and urban schools. The average $5^{\text {th }}$-grade passing rate in suburban schools was 8 percentage points higher than that of rural schools in reading and 12 percentage points higher in writing. Urban schools also scored lower than suburban schools by about $4-5$ percentage points, but were very similar to suburban 
schools in the percentage of students exceeding standards. At grade 8, there appears to be little difference among the different types of schools by urbanicity.

Table C5. Performance of Schools on $5^{\text {th- }}$ and $8^{\text {th-Grade }} 2002$ AIMS Reading and Writing, by Urbanicity

\begin{tabular}{|c|c|c|c|c|c|c|}
\hline & \multicolumn{3}{|c|}{ Reading } & \multicolumn{3}{|c|}{ Writing } \\
\hline & $\begin{array}{l}\text { Approaches } \\
\text { Standard } \\
\text { and Above }\end{array}$ & $\begin{array}{c}\text { Meets } \\
\text { Standard } \\
\text { and Above }\end{array}$ & $\begin{array}{l}\text { Exceeds } \\
\text { Standard }\end{array}$ & $\begin{array}{l}\text { Approaches } \\
\text { Standard and } \\
\text { Above }\end{array}$ & $\begin{array}{c}\text { Meets } \\
\text { Standard } \\
\text { and } \\
\text { Above }\end{array}$ & $\begin{array}{l}\text { Exceeds } \\
\text { Standard }\end{array}$ \\
\hline & \multicolumn{6}{|c|}{ Average Percentage } \\
\hline \multicolumn{7}{|l|}{$5^{\text {th }}$ Grade } \\
\hline Rural schools & 73 & 51 & 10 & 78 & 47 & 11 \\
\hline $\begin{array}{l}\text { Suburban } \\
\text { schools }\end{array}$ & 79 & 59 & 15 & 84 & 59 & 16 \\
\hline Urban schools & 76 & 55 & 15 & 81 & 54 & 15 \\
\hline \multicolumn{7}{|l|}{$8^{\text {th }}$ Grade } \\
\hline Rural schools & 73 & 50 & 12 & 82 & 35 & 1 \\
\hline $\begin{array}{l}\text { Suburban } \\
\text { schools }\end{array}$ & 73 & 51 & 13 & 82 & 37 & 1 \\
\hline Urban schools & 69 & 49 & 13 & 78 & 36 & 1 \\
\hline
\end{tabular}





\section{APPENDIX D. ARKANSAS}

\section{State Assessment System}

The Arkansas Comprehensive Testing, Assessment \& Accountability Program (ACTAAP) was adopted in 1999 in conjunction with the state's Smart Start and Smart Step initiatives. Through ACTAAP, Arkansas administers a set of assessments that includes two types of assessments:

- The Benchmark Examination is a criterion-referenced exam in mathematics and literacy that students take in grades 4,6 , and 8.

- The End-of-Course Examinations are criterion-referenced assessments in Algebra, Geometry, and Literacy that students take in high school. The literacy exam is given at the end of $11^{\text {th }}$ grade.

Arkansas also administers a nationally norm-referenced exam to students in other grade levels; however, the Benchmark Examinations and the End-of-Course Examinations are the tests used to reward and sanction schools under the state accountability system. Arkansas is expanding testing to grades 3-8 in literacy and mathematics to meet testing requirements under No Child Left Behind (NCLB) (for additional information regarding state accountability, see http://arkedu.state.ar.us/accountability/index.html).

The Benchmark and End-of-Course Examinations are meant to measure Arkansas' content standards. Arkansas' English Language Arts Curriculum Framework defines content standards and student expectations within four strands: oral and visual communications, writing, reading, and inquiring and researching. Table D1 shows the standards for each strand. Each standard is further divided into component domains. For example, the reading comprehension standard includes using prior knowledge to create meaning, using connections to make meaning, using visualization to make meaning, using questioning and monitoring to make meaning, using inferences to make meaning, determining importance to make meaning, and summarizing and synthesizing for meaning. Within each domain are listed a number of student learning expectations that outline what students should know and be able to do at each grade level (see http://arkedu.state.ar.us/pdf/English language arts\%20Framework\%202003.pdf). 
Table D1. English/Language Arts Curriculum Framework Strands and Standards

\begin{tabular}{|c|c|}
\hline \multicolumn{2}{|r|}{ Oral and Visual Communications } \\
\hline 1. Speaking & $\begin{array}{l}\text { Students shall demonstrate effective oral communication skills to express } \\
\text { ideas and to present information. }\end{array}$ \\
\hline 2. Listening & $\begin{array}{l}\text { Students shall demonstrate effective listening skills in formal and informal } \\
\text { settings to facilitate communications. }\end{array}$ \\
\hline 3. Media literacy & $\begin{array}{l}\text { Students shall demonstrate knowledge and understanding of media as a mode } \\
\text { of communication. }\end{array}$ \\
\hline \multicolumn{2}{|r|}{ Writing } \\
\hline 4. Process & $\begin{array}{l}\text { Students shall employ a wide range of strategies as they write, using the } \\
\text { writing process appropriately. }\end{array}$ \\
\hline $\begin{array}{l}\text { 5. Purpose, topics, forms } \\
\text { and audiences }\end{array}$ & $\begin{array}{l}\text { Students shall demonstrate competency in writing for a variety of purposes, } \\
\text { topics, and audiences, employing a wide range of forms. }\end{array}$ \\
\hline 6. Conventions & $\begin{array}{l}\text { Students shall apply knowledge of Standard English conventions in written } \\
\text { work. }\end{array}$ \\
\hline 7. Craftsmanship & $\begin{array}{l}\text { Students shall develop personal style and voice as they approach the } \\
\text { craftsmanship of writing. }\end{array}$ \\
\hline \multicolumn{2}{|r|}{ Reading } \\
\hline $\begin{array}{l}\text { 8. Foundations of } \\
\text { reading }\end{array}$ & $\begin{array}{l}\text { Students shall apply concepts of print, acquire knowledge of spoken words, } \\
\text { and understand the relationship of speech to print as they develop a } \\
\text { foundation for literacy. }\end{array}$ \\
\hline 9. Comprehension & $\begin{array}{l}\text { Students shall apply a variety of strategies to read and comprehend printed } \\
\text { material. }\end{array}$ \\
\hline 10. Variety of text & $\begin{array}{l}\text { Students shall read, examine, and respond to a wide range of texts for a } \\
\text { variety of purposes. }\end{array}$ \\
\hline $\begin{array}{l}\text { 11. Vocabulary, word } \\
\text { study, and fluency }\end{array}$ & $\begin{array}{l}\text { Students shall acquire and apply skills in vocabulary development and word } \\
\text { analysis to be able to read fluently. }\end{array}$ \\
\hline \multicolumn{2}{|r|}{ Inquiring/Researching } \\
\hline $\begin{array}{l}\text { 12. Research/inquiry } \\
\text { process }\end{array}$ & $\begin{array}{l}\text { Students shall engage in inquiry and research to address questions, to make } \\
\text { judgments about credibility, and to communicate ideas in ways that suit the } \\
\text { purpose and audience. }\end{array}$ \\
\hline
\end{tabular}

Source: http://arkedu.state.ar.us/pdf/ELA\%20Framework\%202003.pdf

\section{Test Format and Content}

To examine trends in adolescent literacy, the rest of the discussion will focus on the literacy Benchmark Examinations for grades 4 and 8 and the End-of-Course Examination in literacy for grade 11 (for more information regarding the assessments, see http://arkedu.state.ar.us/actaap/student_assessment/student_assessment_p1.htm).

Both the Benchmark Examination and the End-of-Course Examination literacy assessments consist of two sections, one on reading and one on writing. Each section takes approximately two hours to complete. The reading section on the Benchmark Examination features three reading passages-one literary, one content, and one practical-each followed by eight multiple-choice questions and one open-response item. The format of the End-of-Course Examination is identical, but there are twice as many reading passages and questions. The multiple-choice and 
open-response portions receive equal weight, because the multiple-choice questions are worth two points apiece and the open-response items are worth 16 points apiece. The writing section consists of two extended-response writing tasks.

For the Benchmark Examination literacy test, 43 percent of the available points are allocated to the reading section and 57 percent to the writing section. On the $4^{\text {th-grade }}$ exam, 30 percent of the reading questions test students' use of comprehension strategies, and 11 percent assess their use of strategies for visual organization. Items on print concepts, cuing systems, vocabulary, critical thinking, fluency, and textual purposes account for 7 percent each, while use of prior knowledge, use of textual relationships, selection of appropriate reading materials, and understanding of the purpose of reading are assessed on 4 percent of the questions in each.

In the $8^{\text {th }}$ grade, analyzing main ideas and supportive details accounts for one-third of the reading questions, while analyzing literature for purpose and style makes up 15 percent. Using patterns of organization, following directions, and employing comprehension strategies each count for 11 percent apiece. Applying cues to decode, comparing literary elements, establishing purpose for reading, and using reference skills each account for 4 percent apiece

In the writing section, the two writing tasks are weighted equally and are judged on five domains: content, style, sentence formation, usage, and mechanics. For each domain, students are scored from 1 (little or no control of the domain) to 4 (consistent control of the domain). Scores for style are weighted twice as heavily as scores for sentence formation, usage, and mechanics; scores for content count three times as much. In 2003, the $4^{\text {th }}$-grade prompts directed students to write an expository essay and a narrative story, while the $8^{\text {th }}$-grade prompts called for students to write two expository essays.

On the literacy End-of-Course Examination, the majority of the multiple-choice and openresponse questions (53 percent) test students' ability to apply comprehension strategies. Other student-learning expectations addressed on the exam include articulating the theme of a text (11 percent of questions), applying critical-thinking skills (11 percent), integrating information from the text and other sources (9 percent), understanding different points of view (4 percent), using structures and features of the text (4 percent), analyzing a diversity of ideas ( 2 percent), and reading for a variety of purposes (2 percent). On the 2003 exam, the two extended-response writing prompts directed students to write a personal communication and a persuasive essay. As on the Benchmark Examination, student compositions are scored on five domains using a scale from one to four. 


\section{Achievement-Level Definitions}

Results on the assessments are reported using four achievement levels:

- Below Basic: Below basic students fail to show sufficient mastery of skills in mathematics or reading and writing to attain the basic level.

- Basic: Basic students show substantial skills in mathematics or reading and writing; however, they only partially demonstrate the abilities to apply these skills. They demonstrate a need for some additional assistance, commitment, or study to reach the proficient level.

- Proficient: Proficient students demonstrate solid academic performance for the grade tested and are well prepared for the next level of schooling. They can use Arkansas' established mathematics or reading and writing skills and knowledge to solve problems and complete tasks on their own. Students can tie ideas together and explain the ways their ideas are connected.

- Advanced: Advanced students demonstrate superior performance well beyond proficient grade-level performance. They can apply Arkansas' established mathematics or reading and writing skills to solve complex problems and complete demanding tasks on their own. They can make insightful connections between abstract and concrete ideas and provide wellsupported explanations and arguments.

Students must score at the "proficient" level or above to be considered "passing" under state accountability provisions.

\section{Performance Results}

\section{Student Performance}

The Arkansas Department of Education provides student-level data on performance for all students, general education students, students with limited-English proficiency, economically disadvantaged students, and groups of students categorized by race/ethnicity.5 Table D2 shows literacy results from the 2003 ACTAAP for students in grades 4 and 8, and Table D3 shows literacy results from the 2003 ACTAAP for students in grade 11.

\footnotetext{
5Approximately 71 percent of students in Arkansas are white; 24 percent are African American; and 4 percent are Hispanic. No other racial/ethnic group comprises 2 percent of the student population. About 47 percent of students are eligible for the free or reduced-price lunch program; 3 percent are in limited-Englishproficiency programs; and 13 percent have Individual Education Programs (IEPs).
} 
Table D2. Performance of $4^{\text {th- }}$ and $8^{\text {th }}$-Graders on 2003 Literacy Benchmark Examination, by Student Characteristics

\begin{tabular}{lccc}
\hline & $\begin{array}{c}\text { Basic and } \\
\text { Above }\end{array}$ & $\begin{array}{c}\text { Proficient } \\
\text { and Above }\end{array}$ & Advanced \\
\cline { 2 - 4 } & & Percentage \\
\hline $\mathbf{4}^{\text {th }}$ Grade & 85 & 61 & 7 \\
All students & 92 & 69 & 8 \\
General education students & 36 & 11 & 0 \\
Special education students & 75 & 39 & 2 \\
Students with limited-English proficiency & 68 & 49 & 27 \\
Economically disadvantaged students & 73 & 40 & 2 \\
African American students & 84 & 56 & 3 \\
Hispanic students & 90 & 69 & 9 \\
White students & & & 4 \\
$\mathbf{8}^{\text {th }}$ Grade & 78 & 41 & 5 \\
All students & 87 & 48 & 0 \\
General education students & 24 & 3 & 0 \\
Special education students & 57 & 18 & 2 \\
Students with limited-English proficiency & 68 & 27 & 1 \\
Economically disadvantaged students & 61 & 21 & 2 \\
African American students & 71 & 31 & 6 \\
Hispanic students & 86 & 50 & \\
White students & & & 4 \\
\hline
\end{tabular}

Source: www.as-is.org/indicators/search_actap.php

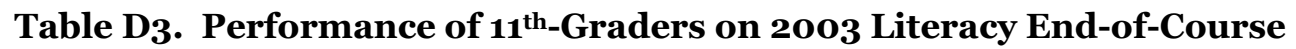
Examination, by Student Characteristics

\begin{tabular}{lccc}
\hline & $\begin{array}{c}\text { Basic and } \\
\text { Above }\end{array}$ & $\begin{array}{c}\text { Proficient } \\
\text { and Above }\end{array}$ & Advanced \\
\cline { 2 - 4 } & & Percentage & \\
\hline $\mathbf{1 1}^{\text {th }}$ Grade & 78 & 37 & 1 \\
All students & 86 & 43 & 2 \\
General education students & 23 & 2 & 0 \\
Special education students & 39 & 10 & 0 \\
Students with limited-English & 68 & 23 & 1 \\
$\quad$ proficiency & 64 & 16 & 0 \\
Economically disadvantaged students & 66 & 22 & 1 \\
African American students & 89 & 51 & 3 \\
Hispanic students & & & \\
White students & & & \\
\hline
\end{tabular}

Source: www.as-is.org/indicators/search_actap.php 
Overall, between 78 and 85 percent of all students scored at or above the basic level. However, these percentages were considerably higher for general education students. For example, 92 percent of general education students in $4^{\text {th }}$ grade, 87 percent in $8^{\text {th }}$ grade, and 86 percent in $11^{\text {th }}$ grade scored at or above the basic level. The percentages of students reaching higher levels of performance were much lower: $43-69$ percent at or above the proficient level, and just 2-8 percent at the advanced level. Students in higher grades had lower levels of performance than those in lower grades across all levels of performance. For example, while 61 percent of all students in the $4^{\text {th }}$ grade scored at the proficient level, only 41 percent of $8^{\text {th }}$-graders and 37 percent of $11^{\text {th-graders }}$ did so.

Students with limited-English proficiency and special education students scored well below general education students at all grade levels.

There was a large gap in achievement levels of African American students compared with both Hispanic and white students. The gap between African American and white students ranged from 17 to 25 percentage points at the basic level and 29 to 35 percentage points at the proficient level. The proportion of Hispanic students scoring at the basic level was between 10 and 11 percentage points higher than the percentages of African American students at the $4^{\text {th }}$ and $8^{\text {th }}$ grades but only 2 percentage points higher at the $11^{\text {th }}$ grade. The gap was larger at the proficient level: $6-16$ percentage points across the three grades.

\section{School Performance}

The data available for urbanicity on the 2002 ACTAAP are limited to $8^{\text {th }}$-grade scores (Table D4). Almost 60 percent of schools in Arkansas are located in rural areas, while the remaining 40 percent of schools are split fairly evenly among urban and suburban areas. These data show that rural and suburban schools are outperforming urban schools by $6-8$ percentage points at the basic level and 2-5 percentage points at or above the proficient level.

Table D4. Average School Performance on $8^{\text {th }}$-Grade 2002 Literacy Benchmark Assessment, by Urbanicity

\begin{tabular}{lccc}
\hline & \multicolumn{1}{c}{$\begin{array}{c}\text { Basic and } \\
\text { Above }\end{array}$} & $\begin{array}{c}\text { Proficient } \\
\text { and Above }\end{array}$ & Advanced \\
\cline { 2 - 4 } & \multicolumn{3}{c}{ Average Percentage } \\
\hline $8^{\text {th Grade }}$ & 85 & 30 & 3 \\
Rural schools & 87 & 33 & 2 \\
Suburban schools & 79 & 28 & 3 \\
Urban schools & & & \\
\hline
\end{tabular}




\section{APPENDIX E. CALIFORNIA}

\section{State Assessment System}

California's Standardized Testing and Reporting (STAR) program was adopted in 1997 as part of Senate Bill 376. Currently, the program consists of two assessments for general education students:

- The California Standards Tests (CSTs) are criterion-referenced assessments the state reports as aligned with state standards. Students in grades 3-11 take the tests in mathematics and English/language arts. In addition, students in grades 8, 10, and 11 are tested in history and social science, and students in grades $5,9,10$, and 11 take tests in various fields of science.

- The California Achievement Test, 6th edition (CAT/6) is a nationally norm-referenced assessment published by CTB/McGraw-Hill. Students in grades 2-11 take the test in reading, language, and mathematics. Students in grades 2-8 also take the spelling assessment, while students in grades 9-11 take the science exam.

In addition, the state administers the California High School Exit Examination, a criterionreferenced assessment that the state reports as aligned with state standards, for students in grade 10 or higher. Beginning with the class of 2006, students must pass the exam in mathematics and English/language arts to earn a high school diploma. Students will be permitted five opportunities to retake the exam after the initial administration in 1oth grade (for additional information on state accountability, see http://www.cde.ca.gov/nclb/index.asp).

California reports that CST exams are aligned with the content standards, and published CST blueprints trace items back to specific standards. California's adopted content standards outline the skills, knowledge, and abilities that all students should master at each grade level of their public schooling for a number of content areas, including (among others) English/language arts, mathematics, science, history and social science, and visual and performing arts. For instance, the English/language arts content standards are organized by grade level and are categorized under four skill areas: reading, writing, written and oral English-language conventions, and listening and speaking. Each standard is further defined by a number of component domains. For example, word analysis, fluency, and systematic vocabulary development may include concepts about print, phonemic awareness, decoding and word recognition, vocabulary, and concept development, depending on the grade level. Under these domains are listed specific skills and knowledge that students should have mastery of at each grade level. Table E1 provides an 
example for the $7^{\text {th }}$-grade subdomain under reading comprehension, with a focus on

informational texts.

Table E1. Skills and Knowledge for $7^{\text {th-Grade Reading Comprehension, Focus on }}$ Informational Texts

Reading Comprehension: Students read and understand grade-level-appropriate material. They describe and connect the essential ideas, arguments, and perspectives of the text by using their knowledge of text structure, organization, and purpose. The selections in Recommended Readings in Literature, Kindergarten Through Grade Eight illustrate the quality and complexity of the materials to be read by students. In addition, by grade eight, students read one million words annually on their own, including a good representation of grade-level-appropriate narrative and expository text (e.g., classic and contemporary literature, magazines, newspapers, online information). In grade seven, students make substantial progress toward this goal.

\section{Skills, Knowledge, and Abilities}

Structural features of informational materials

Comprehension and analysis of grade-level-appropriate text

Expository critique
- Understand and analyze the differences in structure and purpose between various categories of informational materials (e.g., textbooks, newspapers, instructional manuals, signs).

- Locate information by using a variety of consumer, workplace, and public documents.

- Analyze text that uses the cause-and-effect organizational pattern.

- Identify and trace the development of an author's argument, point of view, or perspective in text.

- Understand and explain the use of a simple mechanical device by following technical directions.

- $\quad$ Assess the adequacy, accuracy, and appropriateness of the author's evidence to support claims and assertions, noting instances of bias and stereotyping.

Source: http://www.cde.ca.gov/be/st/ss/index.asp

\section{Test Format and Content}

To examine trends in adolescent literacy, the rest of the discussion focuses on the CST in English/language arts for grades 4, 8, and 11 (for additional information regarding the CST assessment, see http://www.cde.ca.gov/ta/tg/sr/resources.asp).

The English/language arts assessment in grades 4 and 8 includes two multiple-choice sections and a direct writing portion. The multiple-choice questions account for 90 percent of the English/language arts total score, while the writing assessment accounts for 10 percent. The $11^{\text {th }}$ grade English/language arts CST is entirely a multiple-choice examination. The tests are untimed, but the multiple-choice sections typically take 85 minutes; the writing portion generally takes an hour.

All CST English/language arts exams include 75 multiple-choice questions. The multiple-choice sections of the CST for all grade levels assess students' knowledge and skills around five standards

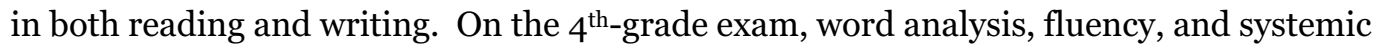


vocabulary development account for 24 percent of the multiple-choice items, and written and oral English-language conventions account for another 24 percent. Reading comprehension and writing strategies make up 20 percent each, while literary response and analysis account for the remaining 12 percent. For $8^{\text {th }}$-graders, the major focus is on reading comprehension, with a special emphasis on informational materials, which accounts for 24 percent of the multiple-choice questions. Writing strategies make up 23 percent of the test; written and oral English-language conventions, 21 percent; literary response and analysis, 20 percent; and word analysis, fluency, and systematic vocabulary development, 11 percent. The $11^{\text {th }}$-grade test places the most emphasis on writing strategies, which account for 27 percent of the questions. Reading comprehension makes up 24 percent of the points; literary response and analysis, 21 percent; written and oral English-language conventions, 17 percent; and word analysis, fluency, and systematic vocabulary development, 11 percent.

The direct writing exercise on the $4^{\text {th- }}$ and $8^{\text {th }}$-grade tests requires students to compose a first draft of an essay on a specified topic. For $4^{\text {th }}$-graders, possible writing modes that may be tested include a narrative, a summary of information, or a response to literature. Eighth-graders may be asked to write a fictional or autobiographical narrative, a response to literature, a persuasive essay, or a summary of information. Student essays are judged using a four-point holistic rubric that includes general criteria related to writing strategies and conventions, as well as specific criteria for the particular mode of writing.

\section{Achievement-Level Definitions}

Results on the CST are reported in five achievement levels: Far Below Basic, Below Basic, Basic, Proficient, and Advanced. Students scoring at or above the proficient level are considered to be "proficient” under the state's accountability system.

\section{Performance Results}

\section{$\underline{\text { Student Performance }}$}

California's STAR program provides data on student performance for all students and by a variety of student characteristics, including disability status, poverty status, English fluency, and racial/ethnic group. ${ }^{6}$ Table E2 shows results from the 2003 CST English/language arts exam for students in grades 4,8 , and 10 .

\footnotetext{
${ }^{6}$ Approximately 45 percent of students in California are Hispanic; 35 percent are white; 11 percent are Asian/Pacific Islander; and 8 percent are African American. About 47 percent of students are eligible for the free or reduced-price lunch program; 25 percent are in limited-English-proficiency programs; and 11 percent have Individual Education Programs (IEPs).
} 
Table E2. Performance of $4^{\text {th }}$, $8^{\text {th }}$, and $10^{\text {th }}$-Graders on 2003 English/Language Arts CST, by Student Characteristics

\begin{tabular}{|c|c|c|c|}
\hline & $\begin{array}{l}\text { Basic and } \\
\text { Above }\end{array}$ & $\begin{array}{c}\text { Proficient and } \\
\text { Above }\end{array}$ & Advanced \\
\hline & & Percentage & \\
\hline \multicolumn{4}{|l|}{$4^{\text {th }}$ Grade } \\
\hline All students & 74 & 39 & 15 \\
\hline Students with no disabilities & 78 & 42 & 17 \\
\hline Students with disabilities & 38 & 14 & 5 \\
\hline English-language learner students & 56 & 15 & 3 \\
\hline Fluent English-language students & 83 & 50 & 21 \\
\hline Economically disadvantaged students & 64 & 24 & 6 \\
\hline Non-economically disadvantaged students & 87 & 59 & 28 \\
\hline African American students & 66 & 27 & 8 \\
\hline Asian students & 88 & 61 & 32 \\
\hline Hispanic students & 64 & 24 & 6 \\
\hline White students & 88 & 59 & 28 \\
\hline \multicolumn{4}{|l|}{$8^{\text {th }}$ Grade } \\
\hline All students & 64 & 30 & 8 \\
\hline Students with no disabilities & 70 & 33 & 9 \\
\hline Students with disabilities & 21 & 5 & 1 \\
\hline English-language learner students & 32 & 4 & 0 \\
\hline Fluent English-language students & 73 & 37 & 10 \\
\hline Economically disadvantaged students & 50 & 15 & 2 \\
\hline Non-economically disadvantaged students & 77 & 43 & 13 \\
\hline African American students & 51 & 17 & 3 \\
\hline Asian students & 80 & 49 & 19 \\
\hline Hispanic students & 51 & 15 & 2 \\
\hline White students & 80 & 47 & 15 \\
\hline \multicolumn{4}{|l|}{ 10 $^{\text {th }}$ Grade } \\
\hline All students & 63 & 33 & 11 \\
\hline Students with no disabilities & 68 & 36 & 12 \\
\hline Students with disabilities & 19 & 5 & 1 \\
\hline English-language learner students & 28 & 4 & o \\
\hline Fluent English-language students & 71 & 39 & 13 \\
\hline Economically disadvantaged students & 48 & 16 & 3 \\
\hline Non-economically disadvantaged students & 73 & 43 & 16 \\
\hline African American students & 49 & 19 & 4 \\
\hline Asian students & 77 & 49 & 21 \\
\hline Hispanic students & 50 & 17 & 3 \\
\hline White students & 78 & 50 & 19 \\
\hline
\end{tabular}

Source: http://star.cde.ca.gov/star2003/viewreport.asp 
Overall, roughly two-thirds of students (63 to 74 percent) scored at the basic level or above on the CST English/language arts assessment. Between 30 and 39 percent scored at the "proficient" level or above, as required to pass the test, and only 9-15 percent scored at the "advanced" level. Students with disabilities had the lowest percentages of students scoring at the basic level and above of any reporting group $-19-38$ percent. Only 5-14 percent of students with disabilities scored at the proficient level, and few reached the advanced level (1-5 percent).

Students who were economically disadvantaged scored lower on the CST English/language arts assessment than their non-economically disadvantaged counterparts. Between 48 and 64 percent of economically disadvantaged students scored at the basic level or above, 16-24 percent at the proficient level or above, and 2-6 percent at the advanced level. The gap at the basic level and above between economically disadvantaged students and other students was 23-27 percentage points across the three grades. The gap at the proficient level and above was somewhat larger that at the basic level: In the $4^{\text {th }}$ grade, economically disadvantaged students trailed their peers by 35 percentage points; in the $8^{\text {th }}$ grade, by 28 percentage points; and in the $10^{\text {th }}$ grade, by 27 percentage points. Only 6 percent of economically disadvantaged students scored at the advanced level in the $4^{\text {th }}$ grade compared with 28 percent of students who were not economically disadvantaged-a difference of 22 percentage points. The gap was smaller at the higher grades $-11-13$ percentage points.

The percentage of English-language learners scoring at the basic level and above declined markedly between the $4^{\text {th }}$ and higher grades, from 56 percent to $28-32$ percent. English-language learners scored much lower than their fluent English peers, and the gap in performance increased substantially across the grades. Few English-language learners passed the assessment by scoring at or above the proficient level-15 percent in $4^{\text {th }}$ grade and 4 percent in $8^{\text {th }}$ and $10^{\text {th }}$ grades.

White students and Asian students outperformed all other racial/ethnic groups, with 78-88 percent scoring at the basic level, 47-61 percent scoring at the proficient level, and 15-32 percent scoring at the advanced level. African American and Hispanic students had similar performance to one another, but trailed their white and Asian counterparts by sizable margins. For example, 66 percent of African American students and 64 percent of Hispanic students scored at the basic level and above compared with 88 percent of white students in the $4^{\text {th }}$ grade. The gap at the basic level between white students and African American and Hispanic students was somewhat larger in $8^{\text {th }}$ and $10^{\text {th }}$ grades-28-29 percentage points as opposed to 22-24 percentage points in $4^{\text {th }}$ grade. While 47-59 percent of white students scored at the proficient level, only 17-27 percent of African American students and 15-24 percent of Hispanic students did so, an achievement gap of 30-35 points. Eight percent of African American students and 6 percent of Hispanic students 
scored at the advanced level in $4^{\text {th }}$ grade, and the percentage was even smaller in the higher grades $-2-4$ percent.

\section{$\underline{\text { School Performance }}$}

School-level data on the CRT assessments were not available. 


\section{APPENDIX F. COLORADO}

\section{State Assessment System}

The Colorado Student Assessment Program (CSAP) has been in place since 1997. The CSAP assessments are criterion-referenced and are administered to students in the following subjects and grades:

- Reading and writing in grades 3-10

- Mathematics in grades $5^{-10}$

- $\quad$ Science in grade 8 (http://www.cde.state.co.us/cdeunified/nclb.htm).

The Colorado Model Content Standards, on which CSAP is based, were developed by educators and community members and were adopted in 1995. The reading and writing content standards define what students should know and be able to do in order to read, write, and speak fluently; communicate effectively; recognize and use the power of language; and communicate in an increasingly technological world. The six standards state that students should:

1. read and understand a variety of materials

2. write and speak for a variety of purposes and audiences

3. write and speak using conventional grammar, usage, sentence structure, punctuation, capitalization, and spelling

4. apply thinking skills to their reading, writing, speaking, listening, and viewing

5. read to locate, select, and make use of relevant information from a variety of media, reference, and technological sources

6. read and recognize literature as a record of human experience.

Each standard is made more specific by a set of expectations outlining what students should know and be able to do to meet the content standard, along with a rationale that explains the standard's importance to learning and life outcomes. Specific expectations are given in three grade clusters $(\mathrm{K}-4,5-8,9-12)$. The expectations for grades 9-12 also include non-mandatory skills and knowledge for students who extend their English/language arts education beyond the standards. In 2000, the state published a further elaboration of the content standards in English/language arts that defines student expectations at each grade level. For instance, under standard 1 (students read and understand a variety of materials) $7^{\text {th }}$-grade students are expected to:

- compare and contrast texts with similar characters, plots, and/or themes

- summarize texts read, such as newspaper and magazine articles, technical writing, stories, and poetry

- determine the main idea or essential message in a text 
- make reasonable inferences from information that is implied but not directly stated

- infer by making connections between separated sections of a text

- find support in the text for main ideas

- use word-recognition skills to comprehend text (for example, roots, prefixes, and suffixes)

- find the sequence of steps in a technical publication

(http://www.cde.state.co.us/cdeassess/standards/pdf/reading.pdf).

\section{Test Format and Content}

To examine trends in adolescent literacy, the rest of the discussion will focus on the CSAP reading and writing exams for grades 4,8 , and 10. Both the reading and writing assessments are administered over three testing sessions of approximately one hour apiece.

The reading portion of the CSAP tests students on content standards 1, 4, 5, and 6, which address reading comprehension, thinking skills, use of literary information, and literature, respectively. The test includes multiple-choice and constructed-response items. Multiple-choice questions count for one point each, while constructed-response items are worth between one and four points. The $4^{\text {th-, }} 8^{\text {th-}}$, and $10^{\text {th }}$-grade assessments consist of $59-60$ multiple-choice and $13^{-15}$

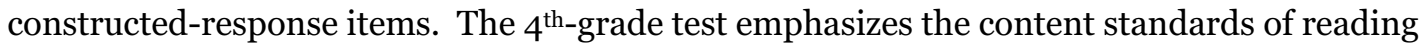
comprehension, thinking skills, and literature equally, at 26-27 percent of points each. Use of literary information accounts for the remaining 20 percent. On the $8^{\mathrm{h}}$ grade test, reading comprehension is weighted most heavily, followed by use of literary information, literature, and thinking skills. At the $10^{\text {th }}$-grade level, the assessment places the most emphasis on reading comprehension and literature, each of which accounts for 27 percent of available points, thinking skills (20 percent), and using literary information (20 percent). Students at all grade levels are required to read fiction, poetry, and nonfiction passages and are also tested on vocabulary.

The CSAP writing assessment in grades 4,8 , and 10 includes one extended-writing task worth 11 points, three short paragraph-writing exercises worth four points each, one editing task worth six points, and 38-40 multiple-choice questions worth one point each. The assessment tests students on content standards 2 and 3: writing for a wide variety of purposes, and writing using conventions, which includes skills such as paragraph writing, extended writing, grammar and usage, and mechanics.

The majority of the multiple-choice items focus on grammar and usage. The short-paragraph items are scored on a four-point holistic rubric that includes criteria related to content and organization, and style and fluency. The extended-writing task is scored using a set of analytic rubrics. Content and organization, and style and fluency are scored on a scale of $0-4$, language 
and usage are scored together on a scale of $0-2$, and planning is scored from $0-1$ (additional information regarding the assessments can be found at http://www.cde.state.co.us/ index_assess.htm).

\section{Achievement-Level Definitions}

Scores on the CSAP are reported using four achievement levels: unsatisfactory, partially proficient, proficient, and advanced. The state has published definitions of the achievement levels for each grade level and subject. Table F1 shows the achievement-level definitions for $4^{\text {th }}$-grade reading for the four tested reading standards as an example. Students scoring at or above the partially proficient level are considered to have met the academic requirements under NCLB.

\section{Performance Results}

\section{$\underline{\text { Student Performance }}$}

Colorado provides data on student performance for all students and by a variety of student characteristics, including disability status, poverty, English proficiency, and racial/ethnic group.7 Table F2 shows results from the 2003 CSAP English/language arts exam for students in grades 4, 8 , and 10 by most student characteristics, and Table F3 provides detailed results for students based on relative English-proficiency levels.

Overall, the vast majority of Colorado's students passed the CSAP reading assessment by scoring at or above the partially proficient level-87 percent across all three grades. Between 63 and 67 percent of students scored at or above the proficient level, and 10 percent or less reached the advanced level. On the writing assessment, between 91 and 93 percent passed the test. However, the percentage scoring at the proficient level was only 49-53 percent, somewhat lower than on the reading test. Between 9 and 10 percent of students achieved the advanced level in writing. Economically disadvantaged students scored well below non-economically disadvantaged students in reading and writing, particularly at the proficient level, at which the achievement gap was between 30 and 37 percentage points.

Between 44 percent and 52 percent of students with disabilities passed the reading assessment, and 63-70 percent passed in writing. However, this rate fell to 17-22 percent in reading and 714 percent in writing at the proficient level.

7Approximately 67 percent of students in Colorado are white; 23 percent are Hispanic; 6 percent are African American; and 3 percent are Asian/Pacific Islander. About 28 percent of students are eligible for the free or reduced-price lunch program, 10 percent are in limited-English-proficiency programs, and 10 percent have Individual Education Programs (IEPs). 
Table F1. CSAP Fourth-Grade Reading Achievement Levels

\begin{tabular}{|c|c|c|c|c|}
\hline & $\begin{array}{c}\text { Read and } \\
\text { Understand a } \\
\text { Variety of Materials }\end{array}$ & $\begin{array}{l}\text { Apply Thinking } \\
\text { Skills to Reading, } \\
\text { Writing, Speaking, } \\
\text { Listening and } \\
\text { Viewing }\end{array}$ & $\begin{array}{c}\text { Read to Locate, } \\
\text { Select, and Make Use } \\
\text { of Relevant } \\
\text { Information from a } \\
\text { Variety of Sources }\end{array}$ & $\begin{array}{l}\text { Read and Recognize } \\
\text { Literature as a Record } \\
\text { of Human Experience }\end{array}$ \\
\hline Unsatisfactory & $\begin{array}{l}\text { May demonstrate } \\
\text { evidence of minimal or } \\
\text { very general } \\
\text { comprehension (i.e., } \\
\text { gist) of a text that has } \\
\text { substantial textual or } \\
\text { visual support or clues }\end{array}$ & $\begin{array}{l}\text { May give inconsistent } \\
\text { responses to specific } \\
\text { tasks when predicting or } \\
\text { drawing conclusions } \\
\text { using text and/or visual } \\
\text { clues }\end{array}$ & $\begin{array}{l}\text { May demonstrate } \\
\text { limited accuracy in the } \\
\text { identification and use of } \\
\text { facts presented in the } \\
\text { text }\end{array}$ & $\begin{array}{l}\text { May respond to simple story } \\
\text { elements (e.g,, character, } \\
\text { setting, and plot) at a literal } \\
\text { level }\end{array}$ \\
\hline $\begin{array}{l}\text { Partially } \\
\text { Proficient }\end{array}$ & $\begin{array}{l}\text { Demonstrates use of } \\
\text { limited strategies to } \\
\text { comprehend reading } \\
\text { materials by: using } \\
\text { context clues to } \\
\text { comprehend word } \\
\text { meanings, recalling } \\
\text { details to answer } \\
\text { questions, skimming to } \\
\text { locate a limited number } \\
\text { of details }\end{array}$ & $\begin{array}{l}\text { Demonstrates analysis } \\
\text { of a text by using a } \\
\text { graphic organizer to } \\
\text { categorize facts }\end{array}$ & $\begin{array}{l}\text { Demonstrates accurate } \\
\text { identification and use of } \\
\text { information presented } \\
\text { in the text }\end{array}$ & $\begin{array}{l}\text { Demonstrates the ability to } \\
\text { read and respond to } \\
\text { literature by: classifying } \\
\text { vocabulary in a basic way, } \\
\text { understanding a text (e.g., } \\
\text { poem) at a literal level, } \\
\text { recalling details to answer } \\
\text { questions }\end{array}$ \\
\hline Proficient & $\begin{array}{l}\text { Demonstrates } \\
\text { comprehension of a } \\
\text { variety of reading } \\
\text { selections by using } \\
\text { multiple strategies: } \\
\text { context and visual clues; } \\
\text { word parts (prefixes and } \\
\text { suffixes); multiple word } \\
\text { meanings and idiomatic } \\
\text { expressions; factual } \\
\text { recall and } \\
\text { discrimination; } \\
\text { sequencing; main idea; } \\
\text { inference; written } \\
\text { summary with factual } \\
\text { support }\end{array}$ & $\begin{array}{l}\text { Responds to a specific } \\
\text { text by: understanding } \\
\text { and following directions, } \\
\text { recognizing the author's } \\
\text { point of view and } \\
\text { purpose, expressing a } \\
\text { character's reactions or } \\
\text { explaining a reaction to } \\
\text { the text, locating } \\
\text { relevant information, } \\
\text { defining a problem or a } \\
\text { solution, making } \\
\text { predictions and drawing } \\
\text { conclusions based on } \\
\text { the information }\end{array}$ & $\begin{array}{l}\text { Demonstrates accurate } \\
\text { use of information from } \\
\text { a variety of sources by: } \\
\text { differentiating among } \\
\text { printed materials, } \\
\text { reading for information } \\
\text { that contains multiple } \\
\text { steps, analyzing and } \\
\text { discriminating among } \\
\text { various media, } \\
\text { identifying details from } \\
\text { relevant information, } \\
\text { extracting information } \\
\text { from a complex source } \\
\text { (e.g., graph, chart, table, } \\
\text { or text) }\end{array}$ & $\begin{array}{l}\text { Demonstrates the ability to } \\
\text { read and respond to } \\
\text { literature by: identifying } \\
\text { characters' reactions and } \\
\text { motives for their actions, } \\
\text { identifying sequence and } \\
\text { several details to adequately } \\
\text { answer a question, support } \\
\text { an opinion with general } \\
\text { ideas from text, classify } \\
\text { familiar vocabulary in new } \\
\text { ways, interpret poetry in a } \\
\text { concrete manner with a } \\
\text { limited understanding of } \\
\text { figurative language (e.g., } \\
\text { personification) }\end{array}$ \\
\hline Advanced & $\begin{array}{l}\text { Uses multiple strategies } \\
\text { to read a variety of } \\
\text { selections to } \\
\text { demonstrate a deeper } \\
\text { understanding (e.g., } \\
\text { insight into text) by: } \\
\text { writing a complete, } \\
\text { thorough summary, } \\
\text { completing complex } \\
\text { non-linear sequencing; } \\
\text { recalling details with } \\
\text { inference (e.g., making } \\
\text { connections between } \\
\text { details or ideas); using } \\
\text { context clues for words } \\
\text { with unusual or abstract } \\
\text { meanings }\end{array}$ & $\begin{array}{l}\text { Responds to a specific } \\
\text { text by: thoroughly } \\
\text { categorizing facts and } \\
\text { details using a graphic } \\
\text { organizer, } \\
\text { differentiating fact from } \\
\text { opinion, evaluating the } \\
\text { main idea, defining both } \\
\text { a problem and a } \\
\text { solution, defending and } \\
\text { thoroughly supporting a } \\
\text { reaction to a text, } \\
\text { interpreting the author's } \\
\text { style }\end{array}$ & $\begin{array}{l}\text { Demonstrates skill in } \\
\text { finding and using } \\
\text { information from a } \\
\text { complex variety of } \\
\text { sources by: identifying } \\
\text { and using the } \\
\text { organizational features } \\
\text { of a book (e.g., glossary, } \\
\text { index, or table of } \\
\text { contents), following a } \\
\text { complex set of } \\
\text { instructions, } \\
\text { discriminating among a } \\
\text { wide variety of reference } \\
\text { materials, applying } \\
\text { reasoning skills, } \\
\text { interpreting factual } \\
\text { material displayed in a } \\
\text { non-traditional way }\end{array}$ & $\begin{array}{l}\text { Demonstrates the ability to } \\
\text { read and respond to } \\
\text { literature by: generating } \\
\text { character traits and motives } \\
\text { for characters' actions, } \\
\text { identifying many details } \\
\text { from context to thoroughly } \\
\text { answer a question, } \\
\text { supporting an opinion with } \\
\text { specific details from text, } \\
\text { classifying vocabulary in } \\
\text { abstract ways, interpreting } \\
\text { poetry and folk tales in a } \\
\text { more abstract manner with } \\
\text { a more complete } \\
\text { understanding of figurative } \\
\text { language (e.g., } \\
\text { personification, symbolism) }\end{array}$ \\
\hline
\end{tabular}

Source: www.cde.state.co.us/cdeassess/csap/2003/G3-8_GTIo3.pdf 
Table F2. Performance of $4^{\text {th }}$, $8^{\text {th }}$, and $10^{\text {th }}$-Graders on 2003 English/Language Arts CSAP, by Student Characteristics

\begin{tabular}{|c|c|c|c|c|c|c|}
\hline & \multicolumn{3}{|c|}{ Reading } & \multicolumn{3}{|c|}{ Writing } \\
\hline & $\begin{array}{c}\text { Partially } \\
\text { Proficient } \\
\text { and Above }\end{array}$ & $\begin{array}{l}\text { Proficient } \\
\text { and Above }\end{array}$ & Advanced & $\begin{array}{c}\text { Partially } \\
\text { Proficient } \\
\text { and Above }\end{array}$ & $\begin{array}{l}\text { Proficient } \\
\text { and Above }\end{array}$ & Advanced \\
\hline & \multicolumn{6}{|c|}{ Percentage } \\
\hline \multicolumn{7}{|l|}{ 4th Grade } \\
\hline All students & 87 & 63 & 7 & 91 & 52 & 10 \\
\hline General education students & 90 & 68 & 8 & 93 & 56 & 11 \\
\hline Students with disabilities & 52 & 22 & 1 & 63 & 14 & 1 \\
\hline $\begin{array}{l}\text { Economically } \\
\text { disadvantaged students }\end{array}$ & 75 & 41 & 2 & 81 & 31 & 3 \\
\hline $\begin{array}{l}\text { Non-economically } \\
\text { disadvantaged students }\end{array}$ & 92 & 74 & 9 & 95 & 62 & 13 \\
\hline $\begin{array}{l}\text { Asian/Pacific Islander } \\
\text { students }\end{array}$ & 89 & 65 & 9 & 95 & 59 & 14 \\
\hline African American students & 77 & 43 & 2 & 85 & 35 & 3 \\
\hline Hispanic students & 74 & 40 & 2 & 80 & 30 & 3 \\
\hline White students & 92 & 74 & 9 & 95 & 62 & 13 \\
\hline \multicolumn{7}{|l|}{ 8th Grade } \\
\hline All students & 87 & 66 & 10 & 92 & 49 & 9 \\
\hline General education students & 91 & 72 & 11 & 95 & 54 & 10 \\
\hline Students with IEPs & 49 & 19 & 1 & 66 & 7 & o \\
\hline $\begin{array}{l}\text { Economically } \\
\text { disadvantaged students }\end{array}$ & 73 & 41 & 2 & 84 & 24 & 2 \\
\hline $\begin{array}{l}\text { Non-economically } \\
\text { disadvantaged students }\end{array}$ & 92 & 76 & 13 & 95 & 58 & 11 \\
\hline $\begin{array}{l}\text { Asian/Pacific Islander } \\
\text { students }\end{array}$ & 88 & 70 & 14 & 94 & 57 & 14 \\
\hline African American students & 80 & 49 & 3 & 89 & 33 & 3 \\
\hline Hispanic students & 70 & 39 & 2 & 82 & 23 & 2 \\
\hline White students & 92 & 77 & 13 & 95 & 58 & 11 \\
\hline
\end{tabular}


Table F2. (cont.)

\begin{tabular}{|c|c|c|c|c|c|c|}
\hline & \multicolumn{3}{|c|}{ Reading } & \multicolumn{3}{|c|}{ Writing } \\
\hline & $\begin{array}{c}\text { Partially } \\
\text { Proficient } \\
\text { and Above }\end{array}$ & $\begin{array}{l}\text { Proficient } \\
\text { and Above }\end{array}$ & Advanced & $\begin{array}{c}\text { Partially } \\
\text { Proficient } \\
\text { and Above }\end{array}$ & $\begin{array}{l}\text { Proficient } \\
\text { and Above }\end{array}$ & Advanced \\
\hline & \multicolumn{6}{|c|}{ Percentage } \\
\hline \multicolumn{7}{|l|}{ loth Grade } \\
\hline All students & 87 & 67 & 9 & 93 & 52 & 9 \\
\hline General education students & 90 & 72 & 10 & 96 & 56 & 10 \\
\hline Students with disabilities & 50 & 18 & o & 64 & 7 & o \\
\hline $\begin{array}{l}\text { Economically } \\
\text { disadvantaged students }\end{array}$ & 73 & 42 & 3 & 85 & 27 & 2 \\
\hline $\begin{array}{l}\text { Non-economically } \\
\text { disadvantaged students }\end{array}$ & 89 & 72 & 11 & 95 & 57 & 11 \\
\hline $\begin{array}{l}\text { Asian/Pacific Islander } \\
\text { students }\end{array}$ & 91 & 67 & 11 & 94 & 53 & 11 \\
\hline African American students & 79 & 48 & 3 & 88 & 31 & 3 \\
\hline Hispanic students & 72 & 40 & 2 & 85 & 25 & 2 \\
\hline White students & 91 & 76 & 12 & 95 & 61 & 11 \\
\hline
\end{tabular}

Source: http://www.cde.state.co.us/cdeassess/results/2003/as_results_CSAP03.htm

African American and Hispanic students scored below white students, and Hispanic students scored slightly below African American students. The differences ranged from 12-25 percentage points in reading at the passing level and from 28-39 percentage points in reading at or above the proficient level. The gap was much smaller in writing at the partially proficient level, ranging from 5 to 15 percentage points, but increased substantially at or above the proficient level (25-36 percentage points).

Colorado provides detailed scores by language background and proficiency (Table F3). As would be expected, non-English-proficient students scored lowest-9-20 percent passed in reading and 17-30 percent passed in writing. Non-English-proficient students scored lower in the later grades than in $4^{\text {th }}$ grade. About 47-6o percent of students with limited-English proficiency passed in reading and 64-82 percent passed in writing. Students from non-English-language backgrounds who have reached English proficiency scored at almost the same levels as native English-speaking students (83-89 percent passing in reading and 89-96 percent passing in writing). However, an achievement gap still exists among these groups at or above the proficient level, at which native English speakers outscore non-native but proficient English students by 1120 percentage points in reading and 8-21 percentage points in writing. This achievement gap is lower in the $4^{\text {th }}$ grade than in the $7^{\text {th }}$ and $10^{\text {th }}$ grades. 
Table F3. Performance of $4^{\text {th }}$, $8^{\text {th-}}$, and $10^{\text {th }}$-Graders on 2003 English/Language Arts CSAP, by Language Background and Proficiency

\begin{tabular}{|c|c|c|c|c|c|c|}
\hline & \multicolumn{3}{|c|}{ Reading } & \multicolumn{3}{|c|}{ Writing } \\
\hline & $\begin{array}{c}\text { Partially } \\
\text { Proficient } \\
\text { and Above }\end{array}$ & $\begin{array}{l}\text { Proficient } \\
\text { and Above }\end{array}$ & Advanced & $\begin{array}{l}\text { Partially } \\
\text { Proficient } \\
\text { and Above }\end{array}$ & $\begin{array}{l}\text { Proficient } \\
\text { and } \\
\text { Above }\end{array}$ & Advanced \\
\hline \multicolumn{7}{|c|}{ Percentage } \\
\hline \multicolumn{7}{|l|}{ 4th Grade } \\
\hline $\begin{array}{l}\text { English-language- } \\
\text { background students }\end{array}$ & 90 & 68 & 8 & 93 & 56 & 11 \\
\hline \multicolumn{7}{|c|}{ Non-English-Language Background } \\
\hline $\begin{array}{l}\text { Non-English- } \\
\text { proficient students }\end{array}$ & 20 & 5 & o & 30 & 3 & o \\
\hline $\begin{array}{l}\text { Students with limited- } \\
\text { English proficiency }\end{array}$ & 60 & 19 & o & 71 & 13 & o \\
\hline $\begin{array}{l}\text { Fluent English } \\
\text { students }\end{array}$ & 89 & 57 & 4 & 92 & 48 & 6 \\
\hline \multicolumn{7}{|l|}{$8^{\text {th }}$ Grade } \\
\hline $\begin{array}{l}\text { English-language- } \\
\text { background students }\end{array}$ & 90 & 71 & 11 & 94 & 52 & 10 \\
\hline \multicolumn{7}{|c|}{ Non-English-Language Background } \\
\hline $\begin{array}{l}\text { Non-English- } \\
\text { proficient students }\end{array}$ & 11 & 1 & o & 30 & 1 & o \\
\hline $\begin{array}{l}\text { Students with limited- } \\
\text { English proficiency }\end{array}$ & 57 & 17 & o & 80 & 9 & o \\
\hline $\begin{array}{l}\text { Fluent English } \\
\text { students }\end{array}$ & 87 & 54 & 3 & 94 & 37 & 5 \\
\hline \multicolumn{7}{|l|}{ 10 $^{\text {th }}$ Grade } \\
\hline $\begin{array}{l}\text { English-language- } \\
\text { background students }\end{array}$ & 88 & 70 & 10 & 91 & 55 & 10 \\
\hline \multicolumn{7}{|c|}{ Non-English-Language Background } \\
\hline $\begin{array}{l}\text { Non-English } \\
\text { proficient students }\end{array}$ & 12 & 1 & o & 17 & o & o \\
\hline $\begin{array}{l}\text { Students with limited- } \\
\text { English proficiency }\end{array}$ & 57 & 14 & o & 64 & 7 & o \\
\hline $\begin{array}{l}\text { Fluent English } \\
\text { students }\end{array}$ & 88 & 51 & 3 & 89 & 34 & 4 \\
\hline
\end{tabular}

Source: www.cde.state.co.us/cdeassess/results/2003/as_results_CSAPo3.htm

$\underline{\text { School Performance }}$

School performance on the $4^{\text {th }}$, $8^{\text {th-}}$, and $10^{\text {th }}$-grade 2002 English Language Arts CSAP is reported by urbanicity in Table F4. Forty-three percent of schools in Colorado are suburban; the remaining 57 percent of schools are relatively evenly split between urban and rural areas. On average, rural and suburban schools outperformed urban schools by about 6-8 percentage points 
in reading at the passing level and 1-6 percentage points in writing. The gap was somewhat

larger at or above the proficient level in both subjects, ranging from 3-11 percentage points. This

is not surprising, because 41 percent of urban schools are high-poverty schools, compared with 26 percent of rural schools and 11 percent of suburban schools.

Table F4. Average School Performance for $4^{\text {th-}}$, $8^{\text {th }}$, and $10^{\text {th }}-$ Grade 2002 English/Language Arts CSAP, by Urbanicity

\begin{tabular}{|c|c|c|c|c|c|c|}
\hline & \multicolumn{3}{|c|}{ Reading } & \multicolumn{3}{|c|}{ Writing } \\
\hline & $\begin{array}{l}\text { Partially } \\
\text { Proficient } \\
\text { and Above }\end{array}$ & $\begin{array}{l}\text { Proficient } \\
\text { and Above }\end{array}$ & Advanced & $\begin{array}{l}\text { Partially } \\
\text { Proficient } \\
\text { and Above }\end{array}$ & $\begin{array}{l}\text { Proficient } \\
\text { and Above }\end{array}$ & Advanced \\
\hline & \multicolumn{6}{|c|}{ Average Percentage } \\
\hline \multicolumn{7}{|l|}{$4^{\text {th }}$ Grade } \\
\hline Rural schools & 88 & 65 & 6 & 93 & 51 & 7 \\
\hline Suburban schools & 87 & 64 & 7 & 92 & 53 & 9 \\
\hline Urban schools & 80 & 55 & 6 & 87 & 45 & 7 \\
\hline \multicolumn{7}{|l|}{$8^{\text {th }}$ Grade } \\
\hline Rural schools & 89 & 68 & 6 & 94 & 50 & 8 \\
\hline Suburban schools & 87 & 67 & 8 & 93 & 51 & 8 \\
\hline Urban schools & 81 & 60 & 9 & 89 & 46 & 8 \\
\hline \multicolumn{7}{|l|}{$10^{\text {th }}$ Grade } \\
\hline Rural schools & 87 & 64 & 6 & 90 & 48 & 6 \\
\hline Suburban schools & 85 & 63 & 6 & 89 & 47 & 6 \\
\hline Urban schools & 79 & 53 & 5 & 84 & 39 & 6 \\
\hline
\end{tabular}




\section{APPENDIX G. CONNECTICUT}

\section{State Assessment System}

Connecticut's state assessment system encompasses two examinations:

- The Connecticut Mastery Test (CMT) is a criterion-referenced test administered to students in grades 4,6 , and 8 in mathematics, reading, and writing.

- The Connecticut Academic Performance Test (CAPT) is a criterion-referenced test administered to students in grade 10 in mathematics, reading across the curriculum, writing across the curriculum, and science.

These assessments are used for school accountability. In addition, starting with the class of 2006, local boards of education will be required to use CAPT results in developing criteria for graduation (although failure on the CAPT cannot be the sole reason for denying graduation to a student). The state also awards Certification of Mastery in each tested subject based on CAPT results, and scores are listed on students' high school transcripts. Students may retake the test in grades 11 and 12 to earn Certification of Mastery.

An optional version of the CMT for grades 3, 5, and 7 is also available at no cost to districts that wish to provide feedback to educators on student achievement. This version is not currently aligned with state standards, as standards have not been articulated for these grade levels. Scores on the optional CMT are currently not reported to the state. However, beginning in 2005-06, the mandatory state assessment system will be expanded to include grades 3, 5, and 7 (for additional information on state accountability, see http://www.csde.state.ct.us/public/der/nclb/index.htm). Connecticut reports that the CMT reading and writing assessments are aligned with the Connecticut Curriculum Frameworks and the National Assessment of Educational Progress (NAEP) reading and writing framework. Connecticut's Curriculum Frameworks provide guidance to schools and districts in thinking about the knowledge and skills that students should have. Frameworks have been developed for language arts, mathematics, science, social studies, the arts, world languages, technology education, learning resource and information technology, health and safety education, and physical education. Each Curriculum Framework consists of Program Goals that students should achieve by the end of grade 12. In language arts, the Curriculum Framework Program Goals state that by the end of grade 12, students will:

- read, write, speak, listen, and view to construct meaning of written, visual, and oral texts

- read with understanding and respond thoughtfully to a variety of texts

- write and speak English proficiently to communicate ideas clearly 
- create works using the language arts in visual, oral, and written texts

- choose and apply strategies that enhance the fluent and proficient use of language arts

- understand and appreciate texts from many literary periods and cultures

- employ the language arts for lifelong learning, work, and enjoyment.

Content standards describe what students should know and be able to do by the end of grade 12 and identify the most important content domains within the subject. Finally, performance standards indicate how students should be able to demonstrate progress toward the content standards in grade clusters $(\mathrm{K}-4,5-8,9-12)$.

The language arts section of the curriculum framework is under revision. A draft of the new framework was circulated in 2003. If approved, the new framework will include grade-by-grade performance standards for grades 3 though 8 , in addition to clustered performance standards for PK-2 and 9-12. The draft framework also updates the content standards and domains from the 1998 version. In addition, the state is developing guides to $\mathrm{K}-12$ program development for each of the subject areas, with ideas for classroom activities, prototype assessments, exemplars of student work, and other resources.

\section{Test Format and Content}

To examine trends in adolescent literacy, the rest of the discussion will focus on the CMT and CAPT reading and writing exams for grades 4,8 , and 10 (http://www.csde.state.ct.us/ public/der/s-t/index.htm).

\section{CMT Reading and Writing Assessments}

The CMT reading assessment is split into two tests: Reading Comprehension and Degrees of Reading Power ${ }^{\circledR}$. Each test counts for 50 percent of the total reading score.

The Reading Comprehension test includes both multiple-choice and open-ended questions related to three reading passages. Fourth-grade students answer 19 multiple-choice and six short-answer questions, while $8^{\text {th }}$-grade students answer 14 multiple-choice and eight shortanswer questions. Students are given 70 minutes to complete the test. The Reading Comprehension tests assess students on three strands of reading literacy: forming an initial understanding, developing an interpretation, and developing a critical stance. For $4^{\text {th }}$-graders, the passages contain $400-500$ words, while the $8^{\text {th }}$-grade exam includes passages of $800-1,000$ words. Passages include original works representing various types of literature, including fiction, poetry, nonfiction, and functional texts.

The Degrees of Reading Power ${ }^{\circledR}$ test is designed to assess students' ability to understand the meaning of a textual passage. The test consists of a number of informational passages of 325-350 
words, with words deleted at varying intervals. Several word choices for each deletion are given in the margins of the passage, and students must select the best one. The sentences are written such that any of the choices makes sense if the sentence is taken in isolation; thus, students must read the sentence in the context of the whole paragraph or passage to be able to identify the best choice. In grade 4, students read eight passages and select words for 56 deletions in 70 minutes. In grade 8 , students read 11 passages and select words for 77 deletions in 70 minutes.

The writing assessment also is split into two tests: the Direct Assessment of Writing, and Editing and Revising. The Direct Assessment of Writing counts for 60 percent of the total writing score, and Editing and Revising counts for the remaining 40 percent.

For the Direct Assessment of Writing, students have 45 minutes to create a first draft of a response to a prompt. Fourth-grade students are prompted to write in narrative prose, while $8^{\text {th }}$ grade students are prompted to write persuasive prose. Students' responses are judged holistically on a six-point scale that emphasizes students' ability to communicate a whole message, rather than their use of English-language conventions and grammar.

The Editing and Revising test assesses students' ability to proofread another students' writing. Students answer multiple-choice questions related to errors embedded in one-page texts. The items address both composing and revising, which include making appropriate and effective content choices, organizing for clarity, and revising for diction; and editing, which includes capitalization, punctuation, and spelling. Fourth-grade students answer 32 multiple-choice questions, while $8^{\text {th }}$-grade students answer 40 multiple-choice items. The test takes 60 minutes.

\section{$\underline{\text { CAPT Reading and Writing Assessments }}$}

As with the CMT reading tests, the CAPT Reading Across the Curriculum assessment is split into two tests: the Response to Literature test and the Reading for Information test.

The Response to Literature test consists of four open-ended questions that students answer by responding to a four- to five-page short story. The four items assess students' ability to demonstrate basic understanding of the text, interpret or explain the text, connect to the text, and make judgments about the quality of the text. The student responses are scored holistically on a six-point scale. Students have 70 minutes to complete the test.

The Reading for Information test consists of three nonfiction passages that students respond to in 12 multiple-choice and six open-ended questions. The items assess students' ability to develop interpretation and to demonstrate a critical stance. The tests take 45 minutes. 
As with the others, the CAPT Writing Across the Curriculum assessment is split into two tests: Interdisciplinary Writing, and Editing and Revising. On the Interdisciplinary Writing test, students complete two extended-writing tasks by reading three short informational articles on a controversial issue, and writing a first draft of a persuasive letter explaining and supporting their position on the issue. Students' responses are judged on five dimensions: taking a position, support, comprehensiveness, organization, and fluency. Responses are scored holistically on a six-point scale. Students have 25 minutes for reading and planning and 30 minutes for writing on each task.

The CAPT Editing and Revising test is similar to the CMT Editing and Revising test, with 18 multiple-choice items related to three reading passages that are samples of student writing and have errors embedded within them. Items assess composing and revising, which include content, organization and tone, syntax, and word choice; and editing, which includes capitalization, punctuation, usage, and spelling. The test takes 25 minutes.

\section{Achievement-Level Definitions}

Scores on the CMT and CAPT are reported in five achievement levels: below basic, basic, proficient, goal, and advanced. While the state is hoping to get students to goal and above, the achievement levels proficient and above are considered "passing” under NCLB.

\section{Performance Results}

\section{$\underline{\text { Student Performance }}$}

Connecticut provides data on student performance for all students and by a variety of student characteristics, including disability status, economic disadvantage, English fluency, and racial/ethnic group. ${ }^{8}$ Table G2 shows results from the 2002 CMT English/language arts exam for students in grades 4 and 8.

Overall, 59 percent of $4^{\text {th }}$-grade students scored at or above the proficient level in reading, 46 percent met the goal, and 19 percent scored at the advanced level. Writing scores were higher at the first two levels, with 82 percent of students scoring at the proficient level and 62 percent meeting the goal. However, only 20 percent scored at the advanced level in writing, similar to the reading score.

\footnotetext{
${ }^{8}$ Approximately 69 percent of students in Connecticut are white; 14 percent are African American; 14 percent are Hispanic; and 3 percent are Asian/Pacific Islander. Only 4 percent of students are in limited-Englishproficiency programs, and 13 percent have Individual Education Programs (IEPs).
} 
Eighteen percent of students with limited-English proficiency reached the proficient level in $4^{\text {th }}$ grade reading. Only 30 percent of these students reached the basic level, meaning that approximately 70 percent of them fell into the lowest achievement level (not shown). However,

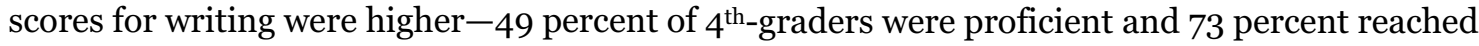
the basic level.

About 42 percent of economically disadvantaged students in the $4^{\text {th }}$ grade scored at the proficient level in reading, and only 27 percent of them met the goal compared with 79 and 67 percent, respectively, of non-economically disadvantaged students-a difference of 37-40 percentage points. In writing, the gap was smaller-22-30 percentage points. Very few economically disadvantaged students (4-6 percent) scored at the advanced level in reading and writing compared with 24-25 percent of non-economically disadvantaged students.

There were large differences in achievement by race/ethnicity, larger in reading than in writing. Asian and white students seemed to have similar scores in reading across the different levels, but African American and Hispanic students scored well below these two groups. For example, while 79-81 percent of Asian and white students scored at the proficient level, only 42 percent of African American students and 39 percent of Hispanic students did so. The achievement gap ranged from 37 to 42 percentage points at the proficient and met the goal levels in reading and from 21 to 39 percentage points in writing. Only about 4 percent of African American and Hispanic students scored at the advanced level in reading, and 6-7 percent did so in writing. In general, African American students scored somewhat higher than Hispanic students by about 2-4 percentage points.

At the $8^{\text {th }}$-grade level, $78-80$ percent of students met the proficiency standard in reading and writing, and between 60 and 68 percent met the goal in the two subjects. Overall, 21-23 percent were at the advanced level, similar to the $19-20$ percent in the $4^{\text {th }}$ grade.

We find differences of similar magnitude in proficiency levels of $8^{\text {th }}$ grade students disaggregated by poverty, special education, and limited-English proficiency status. For example, only 11 percent of limited-English-proficiency students, 39 percent of economically disadvantaged students, and 26 percent of special education students met the goal in reading compared with 6975 percent of their counterparts. The differences by race/ethnicity are equally pronounced, with differences in proficiency levels between Asian and white students and African American and Hispanic students ranging from 23 to 40 percentage points in reading and 32 to 43 percentage points in writing at the proficient and met the goal levels. 


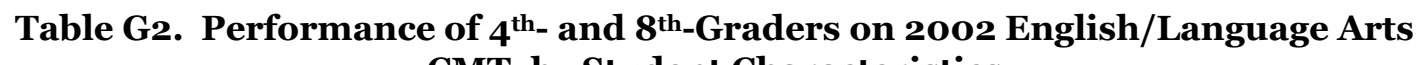
CMT, by Student Characteristics

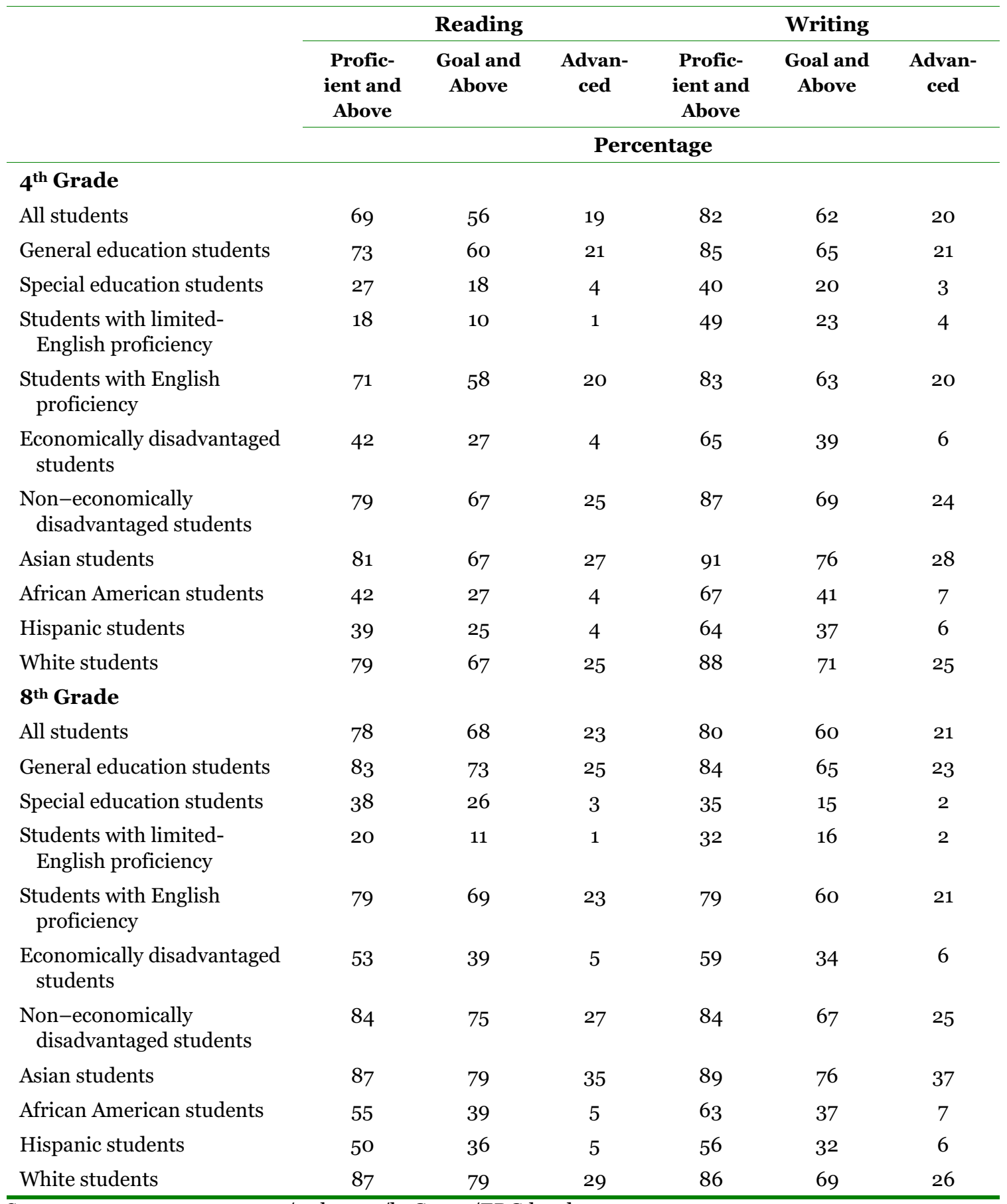

Source: www.captreports.com/web2003/byGroup/ERG.html

Table G3 provides results from the 2003 CMT Degrees of Reading Power ${ }^{\circledR}$ test that give information regarding the types of texts students are able to read. While between 72 and 86

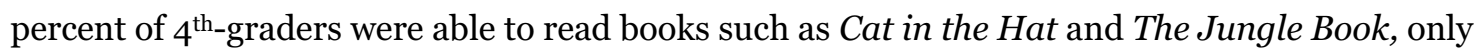


53 percent were able to read a typical elementary school textbook, and only 42 percent could read such books as James and the Giant Peach. Eighth-graders did better than the $4^{\text {th }}$-graders in their ability to read grade-appropriate fiction books, and about 70 percent were able to read the typical high school textbook. However, only 59 percent could read an average article in the newspaper.

\section{Table G3. Percentage of Students Who Can Read Specific Types of Materials at an Instructional Level, from 2003 CMT Degrees of Reading Power Scores}

\begin{tabular}{lc}
\hline Students who can read... & Percentage \\
\cline { 2 - 2 } $\mathbf{4}^{\text {th }}$ Grade & 86 \\
Books like Cat in the Hat & 72 \\
Books like The Jungle Book & 53 \\
Typical elementary school textbook & 42 \\
Books like James and the Giant Peach & \\
$\mathbf{8}^{\text {th }}$ Grade & 91 \\
Books like Where the Red Fern Grows & 84 \\
Books like To Kill a Mockingbird & 70 \\
Typical high school textbook & 59 \\
Average article in a Connecticut newspaper &
\end{tabular}

The $10^{\text {th }}$-grade 2003 CAPT English-language results are shown in Table G4. About 80 percent (78-81 percent) of $10^{\text {th }}$-graders were at the proficient level in reading or writing across the disciplines, but only 47-53 percent met the goal. Between 19 and 21 percent were at the advanced level.

While only 28 percent of limited-English-proficiency students were scored at or above the proficient level in reading and 31 percent scored so in writing, 62-63 percent of these students did reach the basic level (not shown); thus, less than 40 percent of limited-English-proficiency students scored at the lowest achievement level, a substantial improvement over the earlier grades.

Similar to trends in the earlier grades, economically disadvantaged students scored below their peers (33-36 percentage points in reading and $28-36$ percentage points in writing), and Asian and white students outperformed African American and Hispanic students by between 24 and 41 percentage points at the proficient and goal levels. 
Table G4. Performance of $1^{\text {th }}$-Graders on 2003 English-Language CAPT, by Student Characteristics

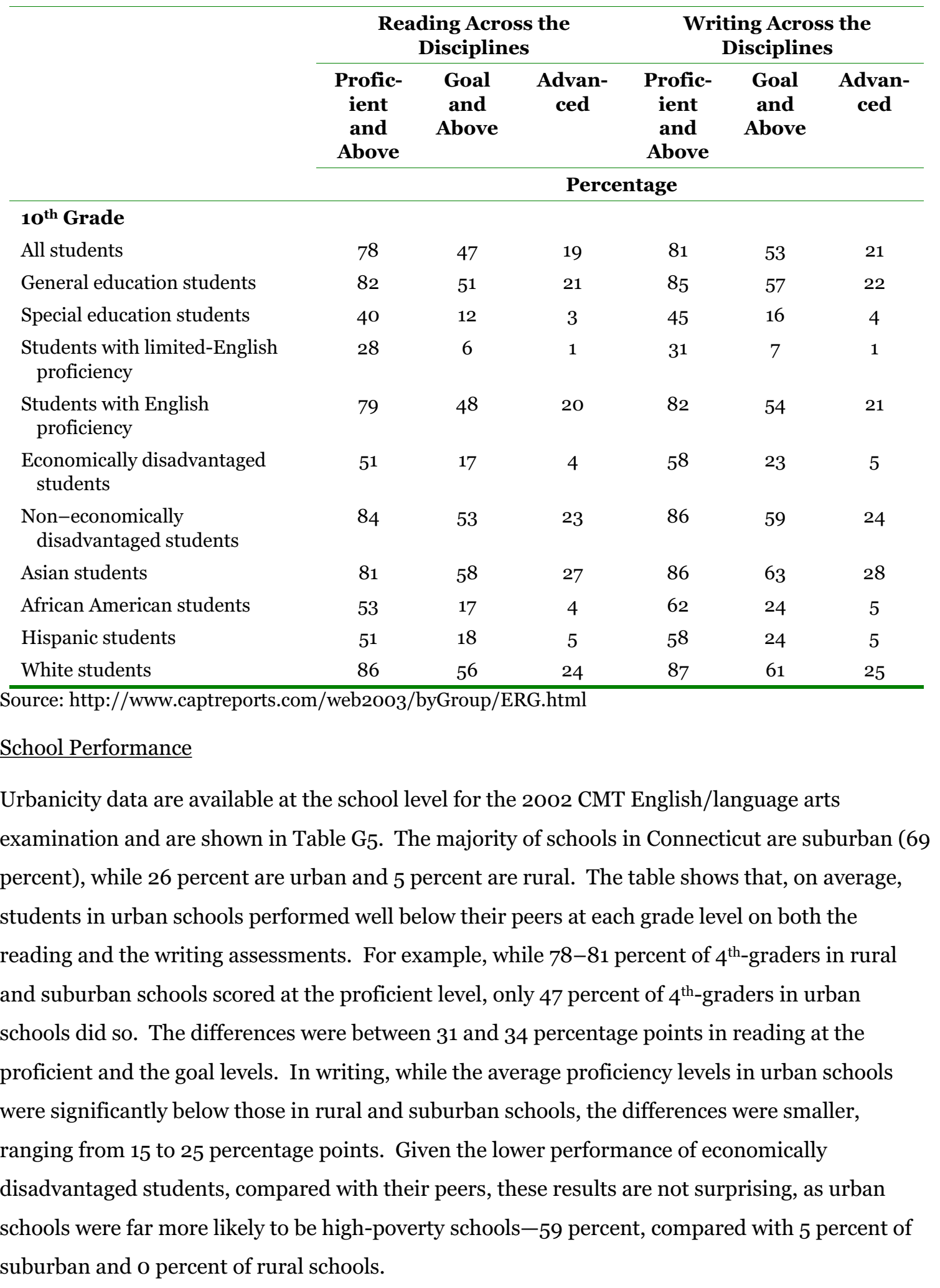


Table G5. Average School Performance on $4^{\text {th- }}$ and $8^{\text {th }}$-Grade 2002 English/Language Arts CMT, by Urbanicity

\begin{tabular}{lcccccc}
\hline & \multicolumn{3}{c}{ Reading } & \multicolumn{3}{c}{ Writing } \\
\cline { 2 - 7 } & $\begin{array}{c}\text { Basic } \\
\text { and } \\
\text { Above }\end{array}$ & $\begin{array}{c}\text { Proficient } \\
\text { and Above }\end{array}$ & $\begin{array}{c}\text { Goal } \\
\text { and } \\
\text { Above }\end{array}$ & $\begin{array}{c}\text { Basic } \\
\text { and } \\
\text { Above }\end{array}$ & $\begin{array}{c}\text { Proficient } \\
\text { and Above }\end{array}$ & $\begin{array}{c}\text { Goal } \\
\text { and } \\
\text { Aberage Percentage }\end{array}$ \\
\cline { 2 - 7 } & \multicolumn{7}{c}{} & & \\
\hline $\mathbf{4}^{\text {th }}$ Grade & 89 & 81 & 67 & 96 & 84 & 62 \\
Rural schools & 87 & 78 & 65 & 95 & 86 & 67 \\
Suburban schools & 61 & 47 & 33 & 88 & 69 & 42 \\
Urban schools & & & & & & \\
$\mathbf{8}^{\text {th Grade }}$ & 90 & 84 & 75 & 93 & 82 & 61 \\
Rural schools & 90 & 83 & 74 & 93 & 83 & 65 \\
Suburban schools & 67 & 55 & 41 & 82 & 65 & 40 \\
Urban schools & & & & & & \\
\hline
\end{tabular}





\section{APPENDIX H. DELAWARE}

\section{State Assessment System}

The Delaware Student Testing Program (DSTP) is Delaware's statewide assessment system, which was initiated 1998, and tested students in grades 3, 5, 8, and 10 in reading, writing, and mathematics. Testing has been expanded and now students in grades 2 through 10 take the DSTP tests in reading and mathematics and students in grades 3-10 take the DSTP in writing. Students in grades 4, 6, 8, and 11 are also assessed in science and social studies. The tests include a mix of norm-referenced and criterion-referenced items aligned with the state content standards. Student scores in reading and mathematics are used for school accountability, as well as to determine whether or not individual students are required to have an Individual Improvement Plan for the next school year, which may include attendance at summer school as a mandatory component (for additional information regarding state accountability, see http://www.doe.state.de.us/AAB/DSTP_School_Accountability.html).

The state reports that the DSTP measures Delaware's content standards. Delaware adopted content standards in English/language arts, mathematics, science, and social studies in 1995. The four English/language arts standards are broad, end-point goals for what students in Delaware public schools should be able to do. The standards are:

1. Use written and oral English appropriate for various purposes and audiences.

2. Construct, examine, and extend the meaning of literary, informative, and technical texts through listening, reading, and viewing.

3. Access, organize, and evaluate information gained through listening, reading, and viewing.

4. Use literary knowledge accessed through print and visual media to connect self to society and culture.

Performance indicators linked to standards describe proficient student performance in four grade-level clusters $-\mathrm{K}-3,4-5,6-8$, and $9-10$. Table $\mathrm{H} 1$ shows the performance descriptors for content standard 2 for grades $6-8$ as an example. The standards also include a number of "vignettes" for each standard and grade cluster, describing effective classroom activities used by Delaware teachers. 


\section{Table H1. ${ }^{\text {th }}-8^{\text {th }}-$ Grade Performance Standards for English/Language Arts Standard 2}

Content Standard 2: Students will construct, examine, and extend the meaning of literary, informative, and technical texts through listening, reading, and viewing.

By the completion of grade 8, using appropriate text, students will be able to:

1. select and apply efficient, effective decoding and other word-recognition strategies to comprehend printed texts

2. develop an increasingly extensive vocabulary and actively seek the meaning of unknown words as an important facet of comprehending texts and messages by

- $\quad$ using context clues to determine the meaning of words

- $\quad$ using reference works, technology, and human resources to learn the meaning of unknown words (e.g., dictionaries, thesauruses, computer software)

3. self-monitor comprehension while listening, reading, and viewing by

- $\quad$ generating a purpose for reading, listening, or viewing

- $\quad$ assimilating information with prior knowledge to revise predictions and understandings, and to make inferences

- $\quad$ taking appropriate actions (e.g., rereading to make sense, adjusting rate of reading, seeking the meaning of unknown vocabulary) to enhance understanding of oral and written text

4. demonstrate an overall understanding of oral and printed texts by

- making and revising predictions as needed

- $\quad$ identifying the story elements (e.g., characters, setting, plot)

- $\quad$ identifying and interpreting figurative language and literary devices (e.g., simile, metaphor, allusion)

- $\quad$ retelling a story or restating an informative text through speaking and/or writing

- $\quad$ organizing the important points of the text via summaries, outlines, and/or graphic organizers

- identifying the author's purpose

- $\quad$ comparing information between texts and within text

- discriminating between fact and opinion

- drawing conclusions

- $\quad$ accepting or rejecting the validity of the information and giving supportive evidence

- relating the content of the text to real-life situations

- critically analyzing and evaluating information and messages presented through print, speech, and mass media by

-connecting and synthesizing information from many sources

- formulating and expressing opinions

-responding to questions requiring critical thinking

-drawing conclusions

- recognizing the impact of non-literal or figurative words or expressions

-recognizing discrepancies between speaker's verbal and non-verbal messages

-explaining ambiguity in words or expressions

- acknowledging the possibility of a variety of interpretations of the same text

- evaluating texts and media presentations for bias and misinformation

-recognizing a variety of persuasive and propaganda techniques and how they are used in a variety of forms (e.g., advertising, campaigns, news formats)

- evaluating expository and technical texts and media presentations for their completeness, accuracy, and clarity of communications

- evaluating the literary merit of various texts and media presentations. 


\section{Table H1. (cont.)}

5. extend meaning by:

- offering a personal response to texts

- applying information from printed, electronic, and oral texts to complete authentic tasks

- using divergent thinking

6. recognize the presence and role of the mass media in their lives by:

- evaluating how the content, techniques, and form of electronic, print, and cinematic messages affect them artistry).

-identifying the underlying purposes of media messages (e.g., profit, humanitarianism, support of

Source: http://www.doe.state.de.us/Standards/English/ELA_Standards.html

\section{Test Format and Content}

For the purposes of this document, we now turn our focus to the DSTP reading and assessments in grades 5,8 , and 10 (information regarding content of the assessments can be found through http://www.doe.state.de.us/AAB/).

The DSTP reading assessment tests students on content standards 2 and 4: constructing, examining, and extending the meaning of literary, informative, and technical texts through listening, reading, and writing; and using literary knowledge accessed through print and visual media to connect self to society and culture. The assessment includes literary, informative, and technical reading passages. Technical passages receive the least weight, accounting for 23 percent of the available points on the $5^{\text {th }}$-grade exam and 19 percent on the $8^{\text {th }}$ - and $10^{\text {th }}$-grade exams. In grades 5 and 8 , informative passages receive the most emphasis -42 and 46 percent of the available points in the two grades, respectively. Literary passages account for 35 percent of the points at both grade levels. In $10^{\text {th }}$ grade, literary passages account for 48 percent of the score, and informative passages make up the remaining 33 percent. Questions ask students to determine, interpret, or extend meaning.

The test includes a mix of multiple-choice, short-answer, and extended-response questions. Several of the multiple-choice items are drawn from the Stanford Achievement Test, $9^{\text {th }}$ edition (SAT9) reading subtest. Thirty of these items are used to create a national percentile-rank score for each student. Other SAT9 items that are aligned with the state content standards are combined with Delaware-created items to make up the standard-based score. The extendedresponse item requires students to respond to an attached reading passage. This essay counts for both the reading and writing scores. For reading, it is scored using the four-point Delaware General Reading Rubric.

The DSTP writing assessment tests students on content standard 1, using written and oral English for a variety of purposes and audiences. The assessment is composed of the text-based writing 
prompt, described above, and a stand-alone writing prompt, which is administered separately from the reading exam. The stand-alone prompt may ask students to use any one of three discourses: expressive (author oriented), informative (subject oriented), or persuasive (audience oriented). Students have three hours to complete their essays, divided between 20 minutes for prewriting, 45 minutes for composing a first draft, and 60 minutes for revising and writing a second draft, in addition to time for directions and a break. Both the text-based and the standalone prompts are scored for writing using the Delaware General Writing Rubric. The standalone prompt response is scored by two readers, whose scores are summed and then added to the score from one reader for the text-based prompt; thus, the stand-alone prompt counts twice as much in the writing score as the text-based prompt.

\section{Achievement-Level Definitions}

DSTP reports student scores in five achievement levels: Well Below the Standard, Below the Standard, Meets the Standard, Exceeds the Standard, and Distinguished Performance. The state describes the levels as "needs significant improvement," "needs improvement," "good," "very good," and "exemplary performance," respectively. Scores of meeting the standards and above are considered "proficient” under NCLB.

\section{Performance Results}

\section{Student Performance}

Delaware provides data on student performance for all students and by a variety of student characteristics, including disability, economic disadvantage, English fluency, and racial/ethnic group. 9 Table H2 displays $5^{\text {th- }}$ and $8^{\text {th }}$-grade 2003 DSTP English/language arts test results. Between 70 and 78 percent of all $5^{\text {th }}$ and $8^{\text {th }}$-graders met the standard in reading. In writing, only 60 percent of $5^{\text {th }}$ graders met the standard compared with 78 percent of $8^{\text {th }}$-graders. The percentages achieving higher proficiency levels (exceeds the standard, distinguished performance) tail off rather quickly. A little under one-quarter (23 percent) of $5^{\text {th }}$ graders exceeded the standard in reading, and only 9 percent scored at the distinguished achievement level. A much smaller percentage (9 percent) of $8^{\text {th }}$-graders exceeded the standard in reading and very few (3 percent) achieved the distinguished performance category. In writing, the trend was reversed, with few $5^{\text {th }}$-graders exceeding standards (4 percent) compared with 15 percent of $8^{\text {th }}$

\footnotetext{
9Approximately 60 percent of students in Delaware are white; 31 percent are African American; 7 percent are Hispanic; and 2 percent are Asian/Pacific Islander. About 35 percent of students are eligible for the free or reduced-price lunch program; 3 percent are in limited-English-proficiency programs; and 14 percent have Individual Education Programs (IEPs).
} 
graders. No $5^{\text {th }}$-graders scored at the distinguished achievement level, and only 2 percent of $8^{\text {th }}$ graders did so.

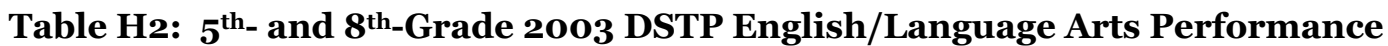

\begin{tabular}{|c|c|c|c|c|c|c|}
\hline & \multicolumn{3}{|c|}{ Reading } & \multicolumn{3}{|c|}{ Writing } \\
\hline & $\begin{array}{l}\text { Meets the } \\
\text { Standard } \\
\text { or Above }\end{array}$ & $\begin{array}{l}\text { Exceeds } \\
\text { the } \\
\text { Standard } \\
\text { or Above }\end{array}$ & $\begin{array}{l}\text { Dis- } \\
\text { tinguished } \\
\text { Perform- } \\
\text { ance }\end{array}$ & $\begin{array}{l}\text { Meets the } \\
\text { Standard } \\
\text { or Above }\end{array}$ & $\begin{array}{l}\text { Exceeds } \\
\text { the } \\
\text { Standard } \\
\text { or Above }\end{array}$ & $\begin{array}{c}\text { Dis- } \\
\text { tinguished } \\
\text { Perform- } \\
\text { ance }\end{array}$ \\
\hline & \multicolumn{6}{|c|}{ Percentage } \\
\hline \multicolumn{7}{|l|}{$5^{\text {th }}$ Grade } \\
\hline All students & 78 & 23 & 9 & 60 & 4 & o \\
\hline $\begin{array}{l}\text { General education } \\
\text { students }\end{array}$ & 82 & 25 & 9 & 67 & 5 & o \\
\hline $\begin{array}{l}\text { Special education } \\
\text { students }\end{array}$ & 35 & 4 & 2 & 16 & o & o \\
\hline $\begin{array}{l}\text { Economically } \\
\text { disadvantaged } \\
\text { students }\end{array}$ & 65 & 10 & 3 & 46 & 1 & o \\
\hline $\begin{array}{l}\text { Non-economically } \\
\text { disadvantaged } \\
\text { students }\end{array}$ & 87 & 32 & 12 & 70 & 6 & o \\
\hline $\begin{array}{l}\text { African American } \\
\text { students }\end{array}$ & 64 & 11 & 3 & 49 & 2 & o \\
\hline Asian students & 91 & 43 & 24 & 79 & 12 & 2 \\
\hline Hispanic students & 69 & 9 & 3 & 49 & 2 & o \\
\hline White students & 87 & 31 & 12 & 67 & 5 & o \\
\hline \multicolumn{7}{|l|}{$8^{\text {th }}$ Grade } \\
\hline All students & 70 & 9 & 3 & 78 & 15 & 2 \\
\hline $\begin{array}{l}\text { General education } \\
\text { students }\end{array}$ & 76 & 10 & 3 & 85 & 17 & 2 \\
\hline $\begin{array}{l}\text { Special education } \\
\text { students }\end{array}$ & 26 & 1 & 1 & 37 & 2 & $\mathrm{o}$ \\
\hline $\begin{array}{l}\text { Economically } \\
\text { disadvantaged } \\
\text { students }\end{array}$ & 54 & 2 & 1 & 65 & 7 & o \\
\hline $\begin{array}{l}\text { Non-economically } \\
\text { disadvantaged } \\
\text { students }\end{array}$ & 79 & 12 & 4 & 85 & 19 & 2 \\
\hline $\begin{array}{l}\text { African American } \\
\text { students }\end{array}$ & 55 & 3 & 1 & 68 & 8 & o \\
\hline Asian students & 86 & 27 & 13 & 91 & 42 & 9 \\
\hline Hispanic students & 55 & 3 & 1 & 67 & 8 & 1 \\
\hline White students & 79 & 12 & 4 & 84 & 18 & 2 \\
\hline
\end{tabular}

Source: http://dstp.doe.state.de.us/DSTPmart/default.asp. 
At the $5^{\text {th }}$ grade, 35 percent of special education students met the standards in reading and 16 percent did so in writing. The percentage of these students reaching proficiency was higher in $8^{\text {th }}$ grade writing (37 percent), but lower in reading (26 percent).

Economically disadvantaged students scored well below their counterparts in both reading and writing, and the proportion meeting standards were 20-25 percentage points lower in both grades. For example, only 54 percent of economically disadvantaged $8^{\text {th }}$-grade students met the standard in reading compared with 79 percent of their advantaged counterparts. With the exception of $5^{\text {th }}$-grade reading, the performance gap was smaller at the "exceeds standards" achievement level, 5-12 percentage points.

Asian students scored the highest of all racial/ethnic groups, outperforming white students by between 4 and 12 percentage points in meeting the standards in both reading and writing in the $5^{\text {th }}$ grade and between 2 and 12 percentage points at higher achievement levels. At the $8^{\text {th }}$-grade level, the proportion of Asian students who exceeded the standard was 15 percentage points higher in reading and 24 percentage points higher in writing than that of white students. For example, 42 percent of Asian students exceeded the standard in writing compared with 18 percent of white students and 8 percent of African American and Hispanic students. In general, the proportions of African American and Hispanic students who met standards in reading and writing were between 16 and 24 percentage points lower than those of white students. The gap was smaller at the higher proficiency levels, partly because much smaller percentages of students scored at those levels. For example, only 5 percent of white students exceeded the standard in writing in the $5^{\text {th }}$ grade, as did 2 percent of African American and Hispanic students.

Table $\mathrm{H} 3$ shows the results for the $10^{\text {th }}$-grade English-language assessment. Overall, 67-73 percent of students met the standard in reading and writing across the disciplines; only 5 percent exceeded the standard in reading, and 22 percent did so in writing. Few students (1 percent in reading and 4 percent in writing) scored at the "distinguished" achievement level.

We see similar trends to those found on the $5^{\text {th- }}$ and $8^{\text {th }}$-grade assessments: Economically disadvantaged students scored well below their peers who were not from economically disadvantaged households; small percentages of special education met the standard; Asian students outperformed all other racial/ethnic categories; and there were large differences (30-32 percentage points in reading and 19-20 percentage points in writing) between the proportions of African American and Hispanic and white students who met standards. 


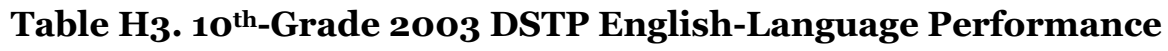

\begin{tabular}{|c|c|c|c|c|c|c|}
\hline & \multicolumn{3}{|c|}{ Reading Across the Disciplines } & \multicolumn{3}{|c|}{ Writing Across the Disciplines } \\
\hline & $\begin{array}{l}\text { Meets the } \\
\text { Standard } \\
\text { or Above }\end{array}$ & $\begin{array}{l}\text { Exceeds } \\
\quad \text { the } \\
\text { Standard } \\
\text { or Above }\end{array}$ & $\begin{array}{l}\text { Dis- } \\
\text { tinguished } \\
\text { Perform- } \\
\text { ance }\end{array}$ & $\begin{array}{l}\text { Meets the } \\
\text { Standard } \\
\text { or Above }\end{array}$ & $\begin{array}{l}\text { Exceeds } \\
\quad \text { the } \\
\text { Standard } \\
\text { or Above }\end{array}$ & $\begin{array}{l}\text { Dis- } \\
\text { tinguished } \\
\text { Perform- } \\
\text { ance }\end{array}$ \\
\hline & \multicolumn{6}{|c|}{ Percentage } \\
\hline \multicolumn{7}{|l|}{$10^{\text {th }}$ Grade } \\
\hline All students & 67 & 5 & 1 & 73 & 22 & 4 \\
\hline $\begin{array}{l}\text { General education } \\
\text { students }\end{array}$ & 73 & 5 & 1 & 79 & 24 & 4 \\
\hline $\begin{array}{l}\text { Special education } \\
\text { students }\end{array}$ & 13 & o & o & 24 & 1 & o \\
\hline $\begin{array}{l}\text { Economically } \\
\text { disadvantaged } \\
\text { students }\end{array}$ & 43 & 1 & o & 57 & 10 & 1 \\
\hline $\begin{array}{l}\text { Non-economically } \\
\text { disadvantaged } \\
\text { students }\end{array}$ & 75 & 6 & 1 & 78 & 26 & 4 \\
\hline $\begin{array}{l}\text { African American } \\
\text { students }\end{array}$ & 46 & 1 & o & 60 & 13 & 1 \\
\hline Asian students & 82 & 13 & 4 & 84 & 45 & 7 \\
\hline Hispanic students & 44 & 2 & $\mathrm{O}$ & 59 & 15 & 1 \\
\hline White students & 76 & 6 & 1 & 79 & 25 & 5 \\
\hline
\end{tabular}

Source: http://dstp.doe.state.de.us/DSTPmart/default.asp

\section{School Performance}

School-level performance data are available by urbanicity for the 2002 DSTP administration.

Delaware has 168 schools, 57 percent of which are suburban. The remaining 43 percent are fairly evenly split among rural and urban schools. While urban schools were most likely to be highpoverty schools (40 percent), 24 percent of rural schools were high-poverty, compared with 9 percent of suburban schools. Due to the small sample size of middle and high schools in rural and urban areas, Table $\mathrm{H}_{4}$ provides information about school performance for rural, suburban, and urban schools only for grade 5 . Rural and suburban schools outperform urban schools by 8-10 percentage points at the "meets standards" level, with rural schools outperforming suburban schools by small amounts. 


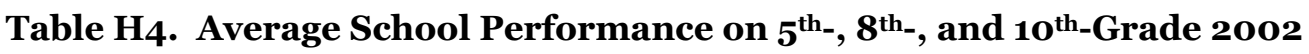
English/Language Arts DSTP, by Urbanicity

\begin{tabular}{|c|c|c|c|c|c|c|}
\hline & \multicolumn{3}{|c|}{ Reading } & \multicolumn{3}{|c|}{ Writing } \\
\hline & $\begin{array}{l}\text { Meets the } \\
\text { Standard } \\
\text { or Above }\end{array}$ & $\begin{array}{c}\text { Exceeds } \\
\text { the } \\
\text { Standard } \\
\text { or Above }\end{array}$ & $\begin{array}{l}\text { Distinguished } \\
\text { Performance }\end{array}$ & $\begin{array}{l}\text { Meets the } \\
\text { Standard } \\
\text { or Above }\end{array}$ & $\begin{array}{c}\text { Exceeds } \\
\text { the } \\
\text { Standard } \\
\text { or Above }\end{array}$ & $\begin{array}{l}\text { Distinguished } \\
\text { Performance }\end{array}$ \\
\hline & \multicolumn{6}{|c|}{ Average Percentage } \\
\hline \multicolumn{7}{|l|}{$5^{\text {th }}$ Grade } \\
\hline Rural schools & 83 & 26 & 11 & 55 & 10 & 1 \\
\hline $\begin{array}{l}\text { Suburban } \\
\text { schools }\end{array}$ & 82 & 24 & 11 & 52 & 9 & 1 \\
\hline Urban schools & 73 & 18 & 8 & 45 & 6 & o \\
\hline
\end{tabular}




\section{APPENDIX I. DISTRICT OF COLUMBIA}

\section{State Assessment System}

The District of Columbia Public School system (DCPS) administers the Stanford Achievement Test, ${ }^{\text {th }}$ edition (SAT9) in reading and mathematics twice each year (fall and spring administrations) to students in grades 1-11. The fall test is used only as a tool to measure where students are as they begin a new school year. The spring test measures how much they have learned during the year. DCPS is currently having criterion-referenced tests developed in order to meet requirements under NCLB (http://www.ed.gov/about/contacts/state/dc.html).

DCPS has developed content and performance standards in English/language arts, math, music, science, social studies, and visual arts for grades $\mathrm{K}-8$ and for specific courses in those subjects (e.g., English I) for grades 9-12. These standards are linked to essential skills and technology tools that students should know and understand. In the written standards, DCPS indicates which standards are assessed through the SAT9.

The four major content standards for the secondary English language arts are:

1. Students comprehend and compose a wide range of written, oral, and visual texts in the process of making meaning.

2. Students respond in many ways to a rich variety of literary texts and relate them to their own lives and the lives of others.

3. Students use language and symbol systems (e.g., time lines, maps, graphs, and charts) to define indicated problems; retrieve, interpret, and organize information; and communicate that information to defined audiences.

4. Students use language in a variety of social contexts, participate in a number of language communities, and understand the social and cultural influences on text.

Table I1 provides an example from the grade 8 English language arts standards for content standard 2 that links to performance standards, essential skills, and technology. 


\section{Table I1. Performance Standards, Essential Skills, and Technology Integration for}

English Language Arts Content Standard Two, Grade 8

Content Standard 2: Students respond in many ways to a rich variety of literary texts and relate them to their own lives and the lives of others.

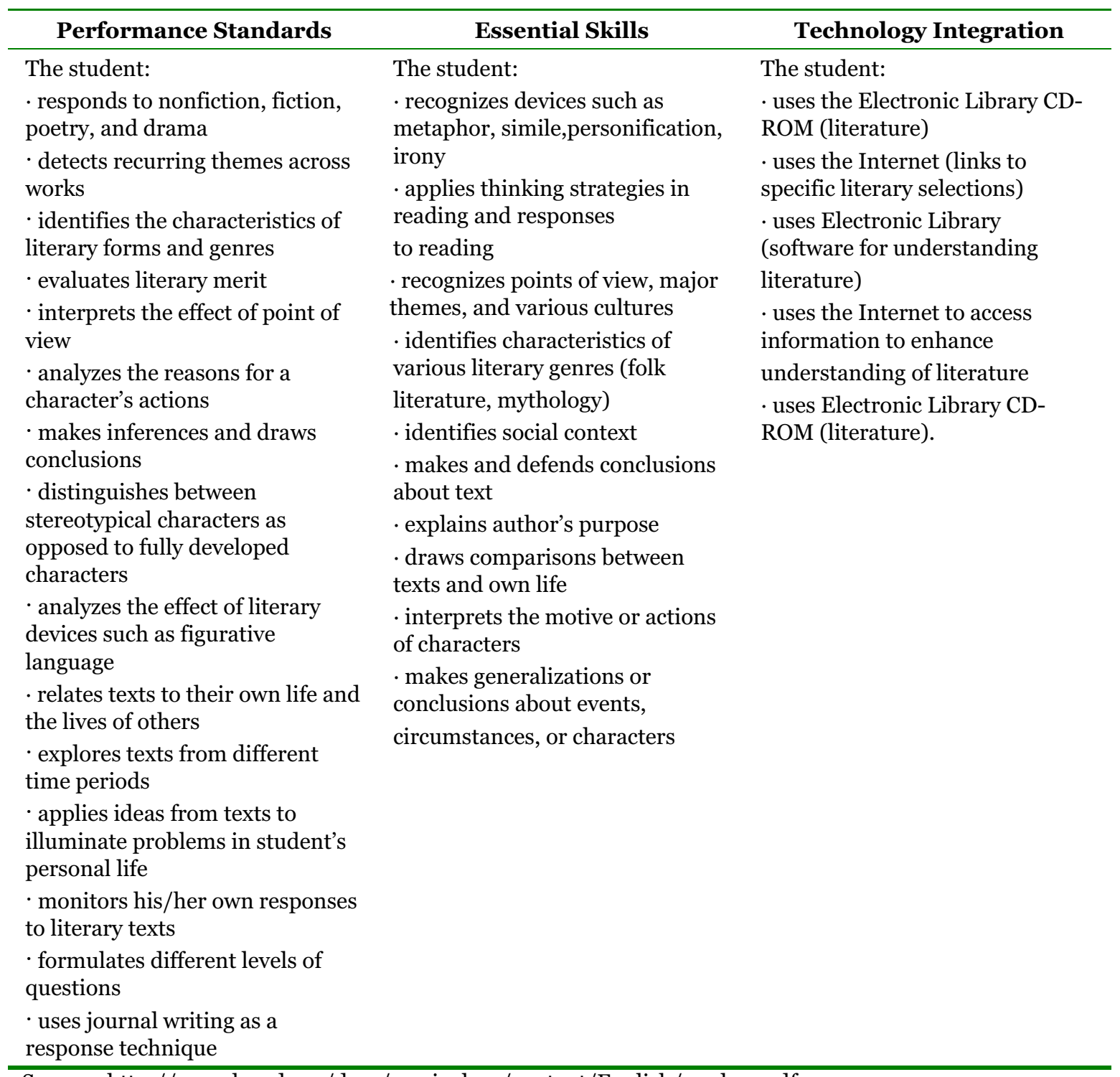

Source: http://www.k12.dc.us/dcps/curriculum/content/English/s-rela-7.pdf

\section{Test Format and Content}

For the purposes of this document, we focus on the reading/language arts section of the SAT9 taken by $4^{\text {th-, }} 8^{\text {th-}}$, and $10^{\text {th }}$-graders. The SAT9 is a multiple-choice nationally normed test Tested areas that relate to adolescent literacy in the SAT9 are reading, language, spelling, and vocabulary. 


\section{Achievement-Level Definitions}

DCPS has defined four achievement levels-advanced, proficient, basic, and below basic.

Students must score at or above the $4 \mathrm{O}^{\text {th }}$ percentile on the SAT9 in order to reach the proficient level. Scores of proficient or above are considered passing for accountability purposes.

\section{Student Performance}

DCPS provides data on student performance for all students and for students disaggregated by race/ethnicity, by English-proficiency status, disability status, ${ }^{10}$ and socio-economic status..$^{11}$ We present reading SAT9 data for grades 4, 8, and 10 in Table I2.

Only 29 percent of $4^{\text {th }}$-graders, 23 percent of $8^{\text {th }}$-graders, and 13 percent of $10^{\text {th }}$-graders, reached the proficient level. Very few student scores fell into the advanced category (2-8 percent). Sixtynine percent reached the basic level or above in $4^{\text {th }}$ and $8^{\text {th }}$ grades, but only 45 percent reached the basic level in $10^{\text {th }}$ grade.

Very small percentages of students with limited-English proficiency reached the proficient level in grades 4 and 8 (12 percent and 2 percent, respectively), and none did in the $10^{\text {th }}$ grade. While 65 percent of students with limited-English proficiency scored at the basic level or above in $4^{\text {th }}$ grade, this percentage was much lower in $8^{\text {th }}$ grade ( 46 percent) and $11^{\text {th }}$ grade (11 percent).

Small percentages of special education students with learning disabilities reached the proficient level in any grade (1-3 percent), and only between 9 and 25 percent of these students reached the basic level.

There were very large achievement gaps between white students and nonwhite students. White students outscored African American students by 66-70 percentage points and Hispanic students by $65-72$ percentage points at the proficient level and above. These achievement gaps were larger in the $10^{\text {th }}$ grade than in the $4^{\text {th }}$ grade. There were persistent achievement gaps at the basic level and above as well. For example, at the basic level and above, white students outscored African American students by 30 percentage points in the $4^{\text {th }}$ grade, 29 percentage points in the $8^{\text {th }}$ grade, and 49 percentage points at the $10^{\text {th }}$ grade.

\footnotetext{
${ }^{10}$ DCPS had disaggregated data for its special education population by disability. For the purposes of this report, we provide data about special education students with learning disabilities.

${ }^{11}$ Approximately 85 percent of students in the District of Columbia are African American; 9 percent are Hispanic; 5 percent are white; and 2 percent are Asian. Sixty-one percent of students are eligible for the free or reduced-price lunch program, 11 percent are in limited-English-proficiency programs, and 17 percent have Individual Education Programs (IEPs).
} 
Table I2. Performance of $4^{\text {th- }}$, $7^{\text {th- }}$, and $10^{\text {th }}-$ Graders on 2003 Reading SAT9, by Student Characteristics

\begin{tabular}{|c|c|c|c|}
\hline & $\begin{array}{l}\text { Basic and } \\
\text { Above }\end{array}$ & $\begin{array}{l}\text { Proficient } \\
\text { and Above }\end{array}$ & Advanced \\
\hline & \multicolumn{3}{|c|}{ Percentage } \\
\hline \multicolumn{4}{|l|}{$4^{\text {th }}$ Grade } \\
\hline All students & 69 & 29 & 8 \\
\hline Special education students with learning disability & 23 & 3 & o \\
\hline Students who are not English proficient & 37 & 6 & 3 \\
\hline Students with limited-English proficiency & 65 & 12 & 1 \\
\hline Students with full English proficiency & 96 & 59 & 16 \\
\hline Economically disadvantaged students & 67 & 26 & 6 \\
\hline Non-economically disadvantaged students & 80 & 44 & 19 \\
\hline African American students & 68 & 26 & 6 \\
\hline Asian students & 81 & 52 & 10 \\
\hline Hispanic students & 68 & 23 & 5 \\
\hline White students & 98 & 91 & 61 \\
\hline \multicolumn{4}{|l|}{$8^{\text {th }}$ Grade } \\
\hline All students & 69 & 23 & 3 \\
\hline Special education students with learning disability & 25 & 2 & o \\
\hline Students who are not English proficient & 15 & 3 & o \\
\hline Students with limited-English proficiency & 46 & 2 & o \\
\hline Students with full English proficiency & 93 & 43 & 4 \\
\hline Economically disadvantaged students & 64 & 17 & 2 \\
\hline Non-economically disadvantaged students & 77 & 34 & 6 \\
\hline African American students & 68 & 20 & 1 \\
\hline Asian students & 70 & 33 & 3 \\
\hline Hispanic students & 63 & 21 & 1 \\
\hline White students & 97 & 86 & 42 \\
\hline \multicolumn{4}{|l|}{$10^{\text {th }}$ Grade } \\
\hline All students & 45 & 13 & 2 \\
\hline Special education students with learning disability & 6 & 1 & o \\
\hline Students who are not English proficient & 9 & o & o \\
\hline Students with limited-English proficiency & 11 & o & o \\
\hline Students with full English proficiency & 74 & 22 & 2 \\
\hline Economically disadvantaged students & 39 & 8 & 2 \\
\hline Non-economically disadvantaged students & 55 & 20 & 4 \\
\hline African American students & 44 & 10 & 1 \\
\hline Asian students & 43 & 15 & 1 \\
\hline Hispanic students & 34 & 8 & o \\
\hline White students & 93 & 80 & 32 \\
\hline
\end{tabular}

Source: http://silicon.k12.dc.us/apds/APDSSummaryReports.asp 
There are also achievement gaps between economically disadvantaged and non-economically disadvantaged students, although these are not as large as those found by race/ethnicity-12-18 percent at the proficient level and 11-16 percent at the basic level across all three grades.

\section{$\underline{\text { School Performance }}$}

Since all schools in the District of Columbia are urban schools, we do not report school-level urbanicity data. 



\section{APPENDIX J. FLORIDA}

\section{State Assessment System}

The Florida Comprehensive Assessment Test (FCAT) is Florida's primary test for student assessment and accountability. Florida introduced the FCAT in 1998 and expanded it to include additional grades in 2002 and additional subjects in 2003. Students take the FCAT in:

- Grades 3-10 in reading and mathematics

- Grades 4, 8, and 10 in writing

- Grades 5, 8, and 10 in science.

The FCAT is used to hold schools accountable. In addition, beginning with the class of 2003, high school students are required to earn a passing score on the reading and writing sections of the $10^{\text {th }}$-grade FCAT to graduate; students who do not pass in grade 10 are given multiple opportunities to retake the test before their $12^{\text {th }}$-grade graduation. Students in all grade levels may earn a certificate of achievement for scoring at the highest achievement level in reading and mathematics. Students in $4^{\text {th }}$ and $8^{\text {th }}$ grades may also earn certificates of achievement for outstanding performance on the writing exam (see http://www.fldoe.org/NCLB/ for additional information regarding state accountability).

The FCATs are intended to measure student performance toward Florida's Sunshine State Standards (SSS), which identify what students should know and be able to do in language arts, mathematics, science, social studies, the arts, health and physical education, and foreign language. The SSS include benchmarks for developmental grade clusters (PK-2, 3-5, 6-8, 9-12), which have been further elaborated with student expectations at all grade levels from $\mathrm{K}-8$. The language arts SSS are categorized under five content strands: reading; writing; listening, viewing, and speaking; language; and literature. Each content strand has two or three content standards that are elaborated by benchmarks and grade-level expectations. Table J1 provides an example of benchmarks for grades 6-8 for the content standards under the reading strand.

Florida has published a number of tools to aid schools and districts in implementing the SSS at the classroom level. The Florida Curriculum Frameworks provide sample performance descriptions and overviews of best practices in a variety of areas. The Curriculum Planning Tools is software to help teachers create learning activities related to the standards. The state also requires publishers to correlate instructional materials to the state standards, and it offers training programs for teachers and administrators to increase awareness of the standards initiative. 
Table J1. Florida Sunshine State Standards and Benchmarks for Reading Content Strand, Grades 6-8

\section{Strand A: Reading}

Standard 1:

The student uses the reading process effectively.
1. The student uses background knowledge of the subject and text structure knowledge to make complex predictions of content, purpose, and organization of the reading selection. 2. The student uses a variety of strategies to analyze words and text, draw conclusions, use context and word-structure clues, and recognize organizational patterns.

3. The student demonstrates consistent and effective use of interpersonal and academic vocabularies in reading, writing, listening, and speaking.

4. The student uses strategies to clarify meaning, such as rereading, note taking, summarizing, outlining, and writing a grade-level-appropriate report.
Standard 2:

The student constructs meaning from a wide range of texts.
1. The student determines the main idea of the essential message in a text and identifies relevant details and facts and patterns of organizations.

2. The student identifies the author's purpose and/or point of view in a variety of texts and uses the information to construct meaning.

3. The student recognizes logical, ethical, and emotional appeals in texts.

4. The student uses a variety of reading materials to develop personal preferences in reading.

5. The student locates, organizes, and interprets written information for a variety of purposes, including classroom research, collaborative decisionmaking, and performing a school or real-world task.

6. The student uses a variety of reference materials, including indexes, magazines, newspapers, and journals, and tools, including card catalogs and computer catalogs, to gather information for research topics.

7. The student synthesizes and separates collected information into useful components, using a variety of techniques such as sources cards, note cards, spreadsheets, and outlines.

8. The student checks the validity and accuracy of information obtained from research in such ways as differentiating fact and opinion, identifying strong vs. weak arguments, and recognizing that personal values influence the conclusions an author draws.

Source: http://www.firn.edu/doe/curric/prek12/pdf/langgle6.pdf

\section{Test Format and Content}

To examine trends in adolescent literacy, the rest of the discussion will focus on the FCAT reading and writing exams for grades 4,8 , and 10 .

The FCAT reading assessment combines a criterion-referenced section aligned with the state content standards, called the Sunshine State Standards Test, and a norm-referenced section based on a test by one of the major national testing companies-currently, the Stanford Achievement Test, $9^{\text {th }}$ edition, from Harcourt. Students receive separate scores for the two sections. The reading assessment includes a variety of question types. ${ }^{12}$ Students in grades 4,8 ,

${ }^{12}$ The test for grades $3,5,6,7$, and 9 includes only multiple-choice questions. 
and 10 answer $45-50$ multiple-choice and 5-8 short-response items on the Sunshine State Standards Test, and 50-55 multiple-choice questions on the norm-referenced test. Shortresponse and extended-response items are scored using a two- or four-point reading rubric. Reading passages include both literary excerpts and informational texts, such as magazine or newspaper articles, editorials, and biographies. The $4^{\text {th }}$-grade test is split evenly, with 50 percent literary and 50 percent informational passages, while the $8^{\text {th }}$ - and $10^{\text {th }}$-grade tests have 60 and 70 percent informational texts, respectively. Fourth-grade passages average 400 words; $8^{\text {th }}$-grade passages, 700 words; and $10^{\text {th }}$-grade passages, 900 words. The Sunshine State Standards section tests students on comprehension skills and processes related to standards 1 and 2 from the reading strand (using the reading process effectively and constructing meaning from a variety of texts) and standards 1 and 2 from the literature strand (understanding the common features of a variety of literary forms and responding critically to fiction, nonfiction, poetry, and drama).

Content on the norm-referenced test is intended to measure initial understanding, interpretation, critical analysis, and strategies. Types of materials used in this section include recreational, textual (e.g., classroom textbooks), and functional texts. On the $4^{\text {th-grade }}$ test, 50 percent of the items are designed to measure students' knowledge and comprehension, while the other 50 percent measure skill at analysis, synthesis, and evaluation. Sixty percent of the items on the $8^{\text {th }}$ grade test and 70 percent of the items on the $10^{\text {th }}$-grade test measure analysis, synthesis, and evaluation.

The FCAT writing assessment asks students to write an essay in response to a specific prompt; 50 percent of students in the $4^{\text {th }}$ grade are assigned either an expository or a narrative prompt; in the $8^{\text {th }}$ and $10^{\text {th }}$ grades, students are assigned either an expository or a persuasive essay. Student responses are scored using a six-point, grade-specific rubric that evaluates the students' use of focus, organization, support, and conventions, and also judges the essay holistically (additional information regarding the assessments can be found through http://www.firn.edu/ doe/sas/fcat/fcatpub1.htm).

\section{Achievement-Level Definitions}

Student scores on the FCAT are reported using five achievement levels:

- Level 5: Performance at this level indicates that the student has success with the most challenging content of the Sunshine State Standards. A Level 5 student answers most of the test questions correctly, including the most challenging questions.

- Level 4: Performance at this level indicates that the student has partial success with the challenging content of the Sunshine State Standards. A Level 4 student answers most of the 
questions correctly but may have only some success with questions that reflect the most challenging content.

- Level 3: Performance at this level indicates that the student has partial success with the challenging content of the Sunshine State Standards, but performance is inconsistent. A Level 3 student answers many of the questions correctly but is generally less successful with questions that are most challenging.

- Level 2: Performance at this level indicates that the student has limited success with the challenging content of the Sunshine State Standards.

- Level 1: Performance at this level indicates that the student has little success with the challenging content of the Sunshine State Standards (http://www.firn.edu/doe/sas/fcat/pdf/fcatlevl.pdf).

Under NCLB, students scoring level 3 and above are considered to be "proficient."

\section{Performance Results}

\section{Student Performance}

Florida provides data on student performance for all students and for students disaggregated by race/ethnicity, English-proficiency status, disability status, and poverty status. ${ }^{13}$ Table J2 shows results from the 2003 FCAT English reading exam for students in grades 4, 8, and 10 as the percentages of students scoring at Levels 2, 3, 4, and 5. Table J3 presents the results on the 2003 FCAT writing expository and narrative or persuasive assessments. ${ }^{14}$

We discuss the reading results first. Overall, about 68-75 percent of students scored at Level 2 or higher on the reading assessment. There was a substantial drop-off in the percentages of students scoring at Level 3 (the proficient level) in the higher grades. For example, in $8^{\text {th }}$ grade, the proportion of students scoring at Level 3 was only 49 percent compared with 75 percent who scored at Level 2; the decrease was even larger in the $10^{\text {th }}$ grade, in which the difference between students scoring at Level 2 was 32 percentage points higher than at Level 3. The percentages of

\footnotetext{
13Approximately 53 percent of students in Florida are white; 25 percent are African American; and 20 percent are Hispanic. No other racial/ethnic group comprises 2 percent of the student population. Fortyfive percent of students are eligible for the free or reduced-price lunch program, 8 percent are in limitedEnglish-proficiency programs, and 15 percent have Individual Education Programs (IEPs).

${ }^{14} \mathrm{On}$ the state writing assessment, half of the students in the state are assigned a narrative or persuasive prompt and half are assigned an expository prompt.
} 
students scoring at or above Level 4 ranged from 16 to 29 percent across the three grades. Few students scored at Level 5 (3-8 percent).

Table J2: Performance of $4^{\text {th-, }} 8^{\text {th-}}$, and $10^{\text {th }}$-Graders on 2003 Reading FCAT, by Student Characteristics

\begin{tabular}{|c|c|c|c|c|}
\hline & $\begin{array}{l}\text { Level } 2 \text { or } \\
\text { Above }\end{array}$ & $\begin{array}{l}\text { Level } 3 \text { or } \\
\text { Above }\end{array}$ & $\begin{array}{l}\text { Level } 4 \text { or } \\
\text { Above }\end{array}$ & Level 5 \\
\hline & \multicolumn{4}{|c|}{ Percentage } \\
\hline \multicolumn{5}{|l|}{$4^{\text {th }}$ Grade } \\
\hline All students & 75 & 60 & 29 & 6 \\
\hline General education students & 82 & 67 & 34 & 7 \\
\hline Special education students (ESE) & 42 & 28 & 9 & 1 \\
\hline Students with limited-English proficiency & 38 & 22 & 6 & 1 \\
\hline Economically disadvantaged students & 66 & 48 & 19 & 3 \\
\hline $\begin{array}{l}\text { Non-economically disadvantaged } \\
\text { students }\end{array}$ & 88 & 77 & 45 & 11 \\
\hline African American students & 60 & 41 & 14 & 2 \\
\hline Hispanic students & 67 & 51 & 22 & 4 \\
\hline White students & 85 & 73 & 40 & 9 \\
\hline \multicolumn{5}{|l|}{$8^{\text {th }}$ Grade } \\
\hline All students & 75 & 49 & 19 & 3 \\
\hline General education students & 80 & 54 & 21 & 3 \\
\hline Special education students (ESE) & 36 & 15 & 3 & o \\
\hline Students with limited-English proficiency & 30 & 9 & 1 & o \\
\hline Economically disadvantaged students & 62 & 33 & 9 & 1 \\
\hline $\begin{array}{l}\text { Non-economically disadvantaged } \\
\text { students }\end{array}$ & 86 & 63 & 27 & 4 \\
\hline African American students & 57 & 27 & 7 & 1 \\
\hline Hispanic students & 65 & 38 & 12 & 1 \\
\hline White students & 85 & 62 & 26 & 4 \\
\hline \multicolumn{5}{|l|}{ 10 $^{\text {th }}$ Grade } \\
\hline All students & 68 & 36 & 16 & 8 \\
\hline General education students & 73 & 40 & 18 & 9 \\
\hline Special education students (ESE) & 33 & 10 & 3 & 1 \\
\hline Students with limited-English proficiency & 18 & 4 & 1 & o \\
\hline Economically disadvantaged students & 51 & 20 & 7 & 3 \\
\hline $\begin{array}{l}\text { Non-economically disadvantaged } \\
\text { students }\end{array}$ & 77 & 44 & 21 & 11 \\
\hline African American students & 45 & 15 & 5 & 2 \\
\hline Hispanic students & 56 & 24 & 9 & 4 \\
\hline White students & 80 & 47 & 22 & 11 \\
\hline
\end{tabular}

Source: http://www.fcatresults.com/demog/ 
Few students with limited-English proficiency reached the proficient Level 3 in reading, and the proportion was lower in $8^{\text {th }}$ and $10^{\text {th }}$ grades than in $4^{\text {th }}$ grade $(9$ percent and 4 percent, compared with 22 percent). The majority of students with limited-English proficiency scored at the very bottom proficiency level-Level 1: 62 percent of students in $4^{\text {th }}$ grade, 70 percent of students in $8^{\text {th }}$ grade, and 82 percent of students in $10^{\text {th }}$ grade did so. We find similar trends for special education students as well: 28 percent, 15 percent, and 10 percent scored at Level 3 or above in grades 4, 8, and 10, respectively; 33-42 percent scored at Level 2 or above.

There was a substantial gap between proficiency levels of African American and Hispanic students

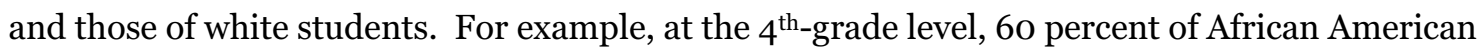
students and 67 percent of Hispanic students scored at Level 2 compared with 85 percent of white students. The differences were even more pronounced at Level 3: 32 percentage points between African American and white students and 22 percentage points between Hispanic and white students. We find gaps of a similar size in the $8^{\text {th }}$ and $10^{\text {th }}$ grades. For example, 47 percent of white students scored at or above Level 3 in the $10^{\text {th }}$ grade compared with 15 percent of African American and 24 percent of Hispanic students, a difference of 32 and 23 percentage points, respectively. In general, Hispanic students outperformed African American students.

The difference in proficiency levels of economically disadvantaged students and noneconomically disadvantaged students ranged from 23 to 30 percentage points at Levels 2 and 3 across the three grades.

Florida also provides data for the mean percentage correct on the different content areas tested in the FCAT SSS reading test for all students (Table J3). Students in the three grades do equally well on words/phrases and comparisons, whereas the higher grades do better on recognizing the main idea/purpose. Eighth-graders do not fare well on the reference and research section, scoring only 45 percent correct compared with 60 percent for the $4^{\text {th }}$-graders and 56 percent for the $10^{\text {th }}$-graders.

Table J3. Performance of $4^{\text {th- }}, 8^{\text {th }}$, , and $10^{\text {th }}$-Graders on FCAT Sunshine State Standards Reading Test, by Content

\begin{tabular}{lccc}
\hline & $4^{\text {th }}$ Grade & $\mathbf{8}^{\text {th }}$ Grade & $\mathbf{1 0}^{\text {th }}$ Grade \\
\cline { 2 - 4 } & 71 & 67 & 67 \\
\hline Words and Phrases & 57 & 68 & 64 \\
Main Idea and Purpose & 56 & 60 & 54 \\
Comparisons & 60 & 45 & 56 \\
Reference and Research & &
\end{tabular}

Source: http://www.fcatresults.com/demog/ 
Table $\mathrm{J} 4$ shows the performance on the writing assessment for the three grades. Almost all students in the three grades scored a 3 or higher in both the expository and the narrative and persuasive portions of the assessment. The percentage of $4^{\text {th }}$-graders who scored a 4 or better on the expository portion was considerably lower than the percentage of $8^{\text {th }}$ or $10^{\text {th }}$-graders $(40$ percent compared with 62 percent) and this was true for the higher proficiency levels as well. The $4^{\text {th }}$-graders did equally well on the narrative portion of the assessment as the $8^{\text {th }}$ and $10^{\text {th }}$-graders did on the persuasive. For example, between 54 and 60 percent received a 4 or higher on this section regardless of grade.

There are also much smaller differences on the writing FCAT than the reading FCAT in the relative performance of African Americans and Hispanics compared with whites. For example, on

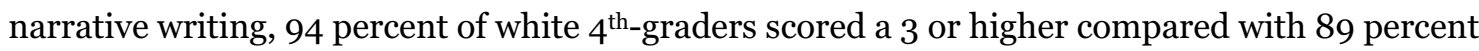
of African American and Hispanic students. The gap widens at higher proficiency levels but it is nowhere as large as on the reading assessment.

Economically disadvantaged students tended to score lower than their counterparts-the difference in proficiency rates at almost every level and across the three grades ranged from 10 to 20 percentage points, except for Level 6, where the percentage of any students scoring at this level was quite small.

\section{$\underline{\text { School Performance }}$}

School-level data on relative performance by urbanicity are available for the 2002 FCAT administration for grades 4, 8, and 10 (Tables J5 and J6). Sixty-three percent of schools in Florida are suburban, 27 percent are urban, and 10 percent are rural. Approximately 59 percent of rural schools were high-poverty schools, as were 45 percent of suburban schools and 55 percent of urban schools.

There was relatively little difference in the percentages of students scoring at the different proficiency levels in the three types of schools in reading-generally on the order of 1-5 percentage points. In writing, rural schools seem to be somewhat behind urban and suburban schools at higher proficiency levels. For example, while 55-57 percent of $8^{\text {th }}$-graders in urban and suburban schools scored at or above level 4 , the corresponding percentage in rural schools was 48 percent. 
Table J4. Performance of $4^{\text {th-, }} 8^{\text {th }}$, and $10^{\text {th }}$-Graders on 2003 Writing FCAT, by Student Characteristics

\begin{tabular}{|c|c|c|c|c|c|c|c|c|}
\hline & \multicolumn{4}{|c|}{ Expository } & \multicolumn{4}{|c|}{ Narrative } \\
\hline & $\begin{array}{c}3 \text { or } \\
\text { Above }\end{array}$ & $\begin{array}{c}4 \text { or } \\
\text { Above }\end{array}$ & $\begin{array}{c}5 \text { or } \\
\text { Above }\end{array}$ & 6 & $\begin{array}{c}3 \text { or } \\
\text { Above }\end{array}$ & $\begin{array}{c}4 \text { or } \\
\text { Above }\end{array}$ & $\begin{array}{c}5 \text { or } \\
\text { Above }\end{array}$ & 6 \\
\hline & \multicolumn{8}{|c|}{ Percentage } \\
\hline \multicolumn{9}{|l|}{$4^{\text {th }}$ Grade } \\
\hline All students & 88 & 40 & 5 & o & 91 & 55 & 10 & 1 \\
\hline $\begin{array}{l}\text { General education } \\
\text { students (not ESE) }\end{array}$ & 93 & 44 & 5 & o & 96 & 62 & 12 & 2 \\
\hline $\begin{array}{l}\text { Special education } \\
\text { students (ESE) }\end{array}$ & 63 & 17 & 1 & o & 70 & 27 & 3 & o \\
\hline $\begin{array}{l}\text { Students with limited- } \\
\text { English proficiency }\end{array}$ & 71 & 23 & 1 & o & 78 & 35 & 3 & o \\
\hline $\begin{array}{l}\text { Economically } \\
\text { disadvantaged } \\
\text { students }\end{array}$ & 85 & 33 & 3 & o & 89 & 48 & 7 & 1 \\
\hline $\begin{array}{l}\text { Non-economically } \\
\text { disadvantaged } \\
\text { students }\end{array}$ & 94 & 51 & 9 & 1 & 96 & 66 & 16 & 2 \\
\hline $\begin{array}{l}\text { African American } \\
\text { students }\end{array}$ & 86 & 33 & 3 & o & 89 & 46 & 6 & 1 \\
\hline Hispanic students & 86 & 39 & 4 & o & 89 & 53 & 8 & 1 \\
\hline White students & 90 & 44 & 6 & o & 94 & 61 & 14 & 2 \\
\hline & \multicolumn{4}{|c|}{ Expository } & \multicolumn{4}{|c|}{ Persuasive } \\
\hline \multicolumn{9}{|l|}{$8^{\text {th }}$ Grade } \\
\hline All students & 91 & 62 & 18 & 2 & 89 & 54 & 14 & 1 \\
\hline $\begin{array}{l}\text { General education } \\
\text { students (not ESE) }\end{array}$ & 96 & 69 & 22 & 3 & 94 & 59 & 16 & 1 \\
\hline $\begin{array}{l}\text { Special education } \\
\text { students (ESE) }\end{array}$ & 69 & 29 & 4 & o & 64 & 20 & 2 & o \\
\hline $\begin{array}{l}\text { Students with limited- } \\
\text { English proficiency }\end{array}$ & 65 & 26 & 3 & o & 63 & 20 & 2 & o \\
\hline $\begin{array}{l}\text { Economically } \\
\text { disadvantaged } \\
\text { students }\end{array}$ & 86 & 52 & 12 & 1 & 84 & 43 & 8 & o \\
\hline $\begin{array}{l}\text { Non-economically } \\
\text { disadvantaged } \\
\text { students }\end{array}$ & 95 & 72 & 25 & 4 & 95 & 64 & 20 & 2 \\
\hline $\begin{array}{l}\text { African American } \\
\text { students }\end{array}$ & 87 & 52 & 11 & 1 & 84 & 42 & 7 & o \\
\hline Hispanic students & 87 & 56 & 13 & 1 & 87 & 49 & 11 & 1 \\
\hline White students & 95 & 70 & 24 & 3 & 92 & 60 & 18 & 2 \\
\hline
\end{tabular}


Table J4. (cont.)

\begin{tabular}{|c|c|c|c|c|c|c|c|c|}
\hline & $\begin{array}{c}3 \text { or } \\
\text { Above }\end{array}$ & $\begin{array}{c}4 \text { or } \\
\text { Above }\end{array}$ & $\begin{array}{c}5 \text { or } \\
\text { Above }\end{array}$ & 6 & $\begin{array}{c}3 \text { or } \\
\text { Above }\end{array}$ & $\begin{array}{c}4 \text { or } \\
\text { Above }\end{array}$ & $\begin{array}{c}5 \text { or } \\
\text { Above }\end{array}$ & 6 \\
\hline & \multicolumn{4}{|c|}{ Expository } & \multicolumn{4}{|c|}{ Persuasive } \\
\hline & \multicolumn{8}{|c|}{ Percentage } \\
\hline 10 ${ }^{\text {th }}$ Grade & & & & & & & & \\
\hline All students & 92 & 62 & 11 & 1 & 86 & 60 & 10 & 1 \\
\hline $\begin{array}{l}\text { General education } \\
\text { students (not ESE) }\end{array}$ & 93 & 66 & 12 & 1 & 90 & 65 & 11 & 1 \\
\hline $\begin{array}{l}\text { Special education } \\
\text { students (ESE) }\end{array}$ & 69 & 28 & 1 & o & 59 & 27 & 1 & $\mathrm{O}$ \\
\hline $\begin{array}{l}\text { Students with limited- } \\
\text { English proficiency }\end{array}$ & 59 & 21 & 1 & O & 51 & 21 & 1 & $\mathrm{O}$ \\
\hline $\begin{array}{l}\text { Economically } \\
\text { disadvantaged } \\
\text { students }\end{array}$ & 85 & 49 & 5 & $\mathrm{O}$ & 78 & 47 & 5 & $\mathrm{O}$ \\
\hline $\begin{array}{l}\text { Non-economically } \\
\text { disadvantaged } \\
\text { students }\end{array}$ & 95 & 70 & 15 & 2 & 90 & 66 & 11 & 1 \\
\hline $\begin{array}{l}\text { African American } \\
\text { students }\end{array}$ & 85 & 48 & 5 & o & 79 & 49 & 5 & $\mathrm{O}$ \\
\hline Hispanic students & 88 & 57 & 9 & 1 & 81 & 53 & 5 & $\mathrm{O}$ \\
\hline White students & 95 & 69 & 15 & 2 & 90 & 66 & 12 & 1 \\
\hline
\end{tabular}


Table J5. Average School Performance on $4^{\text {th }}$, $8^{\text {th }}$, and $10^{\text {th }}-$ Grade 2002 Reading FCAT, by Urbanicity

\begin{tabular}{lcccc}
\hline & $\begin{array}{c}\text { Level 2 or } \\
\text { Above }\end{array}$ & $\begin{array}{c}\text { Level 3 or } \\
\text { Above }\end{array}$ & $\begin{array}{c}\text { Level 4 or } \\
\text { Above }\end{array}$ & Level 5 \\
\cline { 2 - 5 } & \multicolumn{4}{c}{ Average Percentage } \\
\hline $\mathbf{4}^{\text {th }}$ Grade & 68 & 52 & 23 & 5 \\
Rural schools & 69 & 54 & 27 & 6 \\
Suburban schools & 67 & 51 & 25 & 6 \\
Urban schools & & & & \\
$\mathbf{8}^{\text {th }}$ Grade & 69 & 42 & 14 & 2 \\
Rural schools & 67 & 41 & 15 & 3 \\
Suburban schools & 65 & 40 & 15 & 3 \\
Urban schools & & & & 6 \\
10 $^{\text {th }}$ Grade & 64 & 30 & 12 & 6 \\
Rural schools & 63 & 31 & 13 & 6 \\
Suburban schools & 59 & 29 & 12 & \\
Urban schools & & & & \\
\hline
\end{tabular}

Table J6. Average School Performance on $4^{\text {th-, }} 8^{\text {th }}$, and $10^{\text {th }}$-Grade 2002 Writing FCAT, by Urbanicity

\begin{tabular}{|c|c|c|c|c|}
\hline & 3 or Above & 4 or Above & 5 or Above & 6 \\
\hline & \multicolumn{4}{|c|}{ Average Percentage } \\
\hline \multicolumn{5}{|l|}{$4^{\text {th }}$ Grade } \\
\hline Rural schools & 77 & 34 & 7 & 0 \\
\hline Suburban schools & 81 & 39 & 10 & 1 \\
\hline Urban schools & 79 & 37 & 9 & 1 \\
\hline \multicolumn{5}{|l|}{$8^{\text {th }}$ Grade } \\
\hline Rural schools & 81 & 48 & 12 & 1 \\
\hline Suburban schools & 86 & 55 & 15 & 2 \\
\hline Urban schools & 86 & 57 & 16 & 2 \\
\hline \multicolumn{5}{|l|}{ 10 $^{\text {th }}$ Grade } \\
\hline Rural schools & 86 & 56 & 9 & 1 \\
\hline Suburban schools & 87 & 60 & 12 & 1 \\
\hline Urban schools & 85 & 58 & 11 & 1 \\
\hline
\end{tabular}




\section{APPENDIX K. GEORGIA}

\section{State Assessment System}

Georgia's state assessment system includes the following components:

- The Criterion Referenced Competency Tests (CRCT), which are criterion-referenced exams that are intended to align with state content standards. Students in grades 1-8 take the CRCT in reading, English language arts, and mathematics, while students in grades $3-8$ also take the CRCT in science and social studies. New promotion policies are being phased in that will require students to pass the CRCT before they can be promoted from third to fourth grade and from fifth to sixth grade.

- End-of-Course Tests (EOCT), which high school students take in a variety of subject areas, including Algebra, Geometry, United States History, Economics/Business/Free Enterprise, Biology, Physical Science, Ninth Grade Literature and Composition, and American Literature and Composition. All students enrolled in an EOCT course take the tests at the completion of the course, regardless of their grade level.

- The Georgia High School Graduation Tests (GHSGT), which are curriculum-based assessments of knowledge and skills that constitute a high school education. Students in grades 11 take the GHSGT in English language arts, mathematics, science, and social studies, and they are required to pass all four sections, in addition to the writing exam described below, to graduate. They have four opportunities to retake the exam if they do not pass.

- A number of writing assessments, including the Grade Three Writing Assessment; the Grade Five Writing Assessment; the Middle Grades Writing Assessment (MGWA), given in grade 8; and the Georgia High School Writing Test (GHSWT), given in grade 11 (for additional information regarding state accountability, see http://www.doe.k12.ga.us/support/plan/nclb.asp).

Georgia's state standards are contained in the Quality Core Curriculum (QCC), which outlines skills and knowledge that students should possess in English language arts, mathematics, science, social studies, foreign languages, fine arts, health, physical education, technology/career education, and agriculture. The QCC gives grade-by-grade standards for grades $\mathrm{K}-8$ and grade cluster standards for 9-12. The English language arts standards are grouped under seven content strands: grammar and usage, listening, literature, reading, reference and study skills, speaking, and writing. Table K1 shows the standards under the reading strand for the $8^{\text {th }}$ grade, as an example. 
Table K1. Georgia $8^{\text {th }}$-Grade English Language Arts QCC Standards for the Reading Strand

\begin{tabular}{|c|c|}
\hline Strand & Standards \\
\hline Reading & $\begin{array}{ll}\text { - } & \text { Reads a variety of materials for information } \\
\text { - } & \text { Reads a variety of materials for pleasure } \\
\text { - } & \text { Expands reading vocabulary } \\
\text { - } & \text { Applies word-recognition strategies (e.g., roots, affixes, and compound words) to acquire new } \\
\text { - } & \text { vocabulary } \\
\text { - } & \text { Intes context clues to determine meanings of unknown words } \\
\text { - } & \text { Recognizes semantic and syntactic relationships } \\
\text { - } & \text { Adjusts reading speed according to purpose and rereads for comprehension } \\
\text { - } & \text { Interprets written instructions } \\
\text { - } & \text { Analyzes explicit and implicit main ideas, details, sequence of events, and cause-effect relationships } \\
\text { - } & \text { Makes comparisons, predictions, and generalizations and draws conclusions } \\
\text { - } & \text { Analyzes relevance of data } \\
\text { - } & \text { Analyzes fact and opinion, persuasion technique, bias, and stereotyping } \\
\text { - } & \text { Applies reading strategies (e.g., literal comprehension, context clues, and main ideas) to specific content } \\
\text { - } & \text { Anaterial and subject matter }\end{array}$ \\
\hline
\end{tabular}

Georgia released a draft version of a new revision of the English language arts QCC in January 2004. It is expected that the new QCCs will have fewer standards with more depth. The draft is currently under review, and the new QCCs are expected to be rolled out over a two-year period beginning in the fall of 2004. The draft standards include benchmarks as well as a number of aligned sample student tasks, a sample reading list, and more thorough paragraph-length descriptors of the overall QCC and each content strand.

Georgia has published sample lesson plans and student activities, and lists of Web resources to help teachers teach to the standards. In addition, the state's CRCT Item Banking System provides students and teachers access to sample test items online for self-assessment and/or the creation of customized classroom assessments.

\section{Test Format and Content}

To examine trends in adolescent literacy, the rest of the discussion will focus on the CRCT reading and English language arts exams for grades 4 and 8; the English language arts GHSGT for grade 11; and the writing assessment for grades 8 and 11.

The current CRCT reading and English language arts exams consist entirely of multiple-choice questions. Domains tested on the reading exam include reading for vocabulary improvement, reading for locating and recalling information, reading for meaning, and reading for critical 
analysis. The English language arts exam covers sentence construction and revision, paragraph content and organization, grammar and mechanics, and research process.

The GHSGT English language arts exam consists entirely of multiple-choice questions that measure knowledge and recall, comprehension and interpretation, and problem solving and analysis. Almost half of the questions cover standards related to reading and literature, 37-39 percent cover critical thinking, and 14-16 percent cover writing, usage, and grammar.

The MGWA and GHSWT require students to respond to an assigned prompt. Eighth-grade students may be asked to write a narrative, persuasive, or expository essay, while all $11^{\text {th }}$-graders write a persuasive essay. Essays are judged using several four-point analytic scales that are weighted and summed to produce the final score. For the MGWA, students are judged on content/organization, style, sentence formation, usage, and mechanics. Content/organization counts three times as much as the other three domains and style counts twice as much. On the GHSWT, students are judged on content/organization, style, conventions of written language, and sentence formation. Content/organization counts twice as much as the other three domains (additional information regarding the assessments can be found through http://www.doe.k12.ga.us/curriculum/testing/index.asp).

\section{Achievement-Level Definitions}

Student scores on the CRCT are reported using three achievement levels: Exceeds the Standard, Meets the Standard, and Does Not Meet the Standard. Students scoring at the "meets the standard level" or above are considered "proficient” for accountability purposes. Achievement level descriptors are defined separately for each grade level and subject. Table K2 shows the descriptors for $8^{\text {th }}$-grade reading as an example.

Scores on the GHSGT and the GHSWT are reported as "passing" or "failing," while scores on the MGWA are reported as Below Target, On Target, and Exceeds Target. 


\section{Table K2. CRCT Achievement-Level Descriptors, $8^{\text {th-Grade }}$ Reading}

\begin{tabular}{|c|c|}
\hline Does Not Meet the Standard & $\begin{array}{l}\text { The student's overall performance in reading a variety of eighth-grade- } \\
\text { appropriate materials is below the standard set for students in this grade. } \\
\text { Students performing at this level are inconsistent in the application of their } \\
\text { reading skills. They typically have a limited understanding of text and tend } \\
\text { to read at a literal level. They may find it difficult to locate and use } \\
\text { information from the text to respond to questions. They demonstrate a } \\
\text { limited ability to identify the text type and purpose. Students display a basic } \\
\text { knowledge of literary elements and techniques. They demonstrate a basic } \\
\text { ability to examine and interpret text. They are limited in their reading } \\
\text { strategies and vocabulary skills. }\end{array}$ \\
\hline Meets the Standard & $\begin{array}{l}\text { The student's overall performance in reading a variety of eighth-grade- } \\
\text { appropriate materials meets the standard set for students in the grade. } \\
\text { Most of the students performing at this level apply reading skills } \\
\text { appropriately. They typically understand what they read and go beyond the } \\
\text { literal meaning of text. They use information from the text to correctly } \\
\text { respond to questions. They locate and recall information from the text. } \\
\text { They recognize many text types, identify the purpose of most text, and } \\
\text { recognize some text organizational structures. Students can identify and } \\
\text { use literary elements and techniques to aid comprehension. They examine } \\
\text { and interpret text information. Students apply reading strategies and } \\
\text { vocabulary skills while reading. }\end{array}$ \\
\hline Exceeds the Standard & $\begin{array}{l}\text { The student's overall performance in reading a variety of eighth-grade- } \\
\text { appropriate materials exceeds the standards set for students in this grade. } \\
\text { Most of the students performing at this level consistently apply their reading } \\
\text { skills to a variety of texts, particularly to expository text. They have a clear } \\
\text { understanding of what they read and go beyond the literal meaning of text. } \\
\text { They understand text in which the meaning is implicit, synthesizing or } \\
\text { making inferences from the text to accurately respond to questions. } \\
\text { Students summarize, interpret, and analyze relevant information from a } \\
\text { variety of texts. They recognize different text types, such as poetry and } \\
\text { drama, and understand that text can be organized in a variety of ways and } \\
\text { for different purposes. Students recognize and analyze literary elements, } \\
\text { such as theme and point of view, and literary techniques, such as alliteration } \\
\text { and metaphors, to enhance comprehension. They read critically by } \\
\text { examining and interpreting text information in order to draw conclusions, } \\
\text { make predictions and generalizations about text, analyze characters, and } \\
\text { distinguish between facts and opinions. Students apply a variety of effective } \\
\text { reading strategies and vocabulary skills while reading. }\end{array}$ \\
\hline
\end{tabular}

Source: http://www.doe.k12.ga.us/_documents/curriculum/testing/crct_score_interpretation.pdf

\section{Performance Results}

\section{Student Performance}

Table K3 shows results from the 2003 CRCT English language arts and reading exams for students in grades 4 and 8, disaggregated by selected characteristics: race/ethnicity, disability status, English-proficiency status, and economically disadvantaged status. ${ }^{15}$

15Approximately 54 percent of students in Georgia are white; 38 percent are African American; 6 percent are Hispanic; and 2 percent are Asian/Pacific Islander. About 44 percent of students are eligible for the free or 
Overall, $75^{-81}$ percent of all $4^{\text {th }}$ - and $8^{\text {th }}$-grade students met the standard in reading and English language arts. However, while 44-46 percent of students exceeded the standard in reading, only 18 percent did so in English language arts at the $4^{\text {th }}$-grade level and 28 percent at the $8^{\text {th }}$-grade level.

Less than half of students with limited-English proficiency met or exceeded standards in reading or language arts in the $4^{\text {th }}$ or $8^{\text {th }}$ grade. In general, most students with disabilities did not meet or exceed standards in these subjects either. At the $8^{\text {th }}$ grade, 43 percent of students with disabilities met or exceeded the standards in reading, and 31 percent did so in language arts.

There were substantial differences between the proficiency levels of African American and Hispanic students and those of white students $-15^{-23}$ percentage points in the $4^{\text {th }}$ grade at the "meets standard" level to 26-30 percentage points at the "exceeds standard" level. The differences tended to be equally large or larger at the $8^{\text {th }}$-grade level. For example, while 88 percent of white students met the standard in reading, only 73 percent of African American students and 65 percent of Hispanic students did so. With one exception, African American students did better than Hispanic students at both proficiency levels, and in both grades and both subjects.

Students from economically disadvantaged backgrounds scored lower than their advantaged counterparts by between 18-19 percentage points in reading and English language arts. However, in reading, the differences were even larger at the "exceeds standard" level-28-29 percentage points.

Turning now to the $8^{\text {th }}$-grade writing assessment performance (Table K4), we see that 90 percent of all students, 94-95 percent of white and Asian students, 85 percent of African American students, and 79 percent of Hispanic students passed the test. However, the proportion who exceeded the target were quite low-18 percent overall, 25-30 percent of white and Asian students, and only 8-9 of African American and Hispanic students. Students with limitedEnglish proficiency had pass rates of 64 percent and very few (4 percent) exceeded the target. Almost all $11^{\text {th }}$-graders passed the English language arts test, and 63 percent scored at the "pass plus" level (Table $\mathrm{K}_{5}$ ). Unlike what we had seen in reading, white students outperformed Asian students at the higher proficiency level. African American students had pass rates very close to that of all students but were still behind all students at the "pass plus" level. For example, 47

reduced-price lunch program; 4 percent are in limited-English-proficiency programs; and 12 percent have Individual Education Programs (IEPs). 
percent of African American students scored at the "pass plus" level compared with 73 percent of whites. Hispanic students scored lower than African American students.

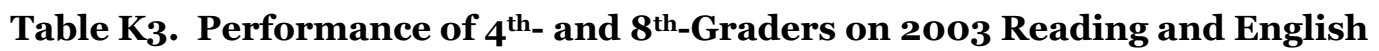
Language Arts CRCT, by Student Characteristics

\begin{tabular}{|c|c|c|c|c|}
\hline & \multicolumn{2}{|c|}{ Reading } & \multicolumn{2}{|c|}{ English Language Arts } \\
\hline & $\begin{array}{l}\text { Meets the } \\
\text { Standard } \\
\text { and Above }\end{array}$ & $\begin{array}{l}\text { Exceeds the } \\
\text { Standard }\end{array}$ & $\begin{array}{c}\text { Meets the } \\
\text { Standard and } \\
\text { Above }\end{array}$ & $\begin{array}{l}\text { Exceeds the } \\
\text { Standard }\end{array}$ \\
\hline & \multicolumn{4}{|c|}{ Percentage } \\
\hline \multicolumn{5}{|l|}{$4^{\text {th }}$ Grade } \\
\hline All students & 80 & 44 & 78 & 18 \\
\hline Students with disabilities & 51 & 19 & 47 & 6 \\
\hline Students without disabilities & 84 & 48 & 83 & 20 \\
\hline $\begin{array}{l}\text { Students with limited-English } \\
\text { proficiency }\end{array}$ & 47 & 13 & 46 & 4 \\
\hline $\begin{array}{l}\text { Economically disadvantaged } \\
\text { students }\end{array}$ & 71 & 30 & 69 & 10 \\
\hline $\begin{array}{l}\text { Non-economically disadvantaged } \\
\text { students }\end{array}$ & 89 & 58 & 87 & 27 \\
\hline African American students & 73 & 31 & 71 & 11 \\
\hline Asian students & 87 & 56 & 87 & 32 \\
\hline Hispanic students & 65 & 27 & 64 & 9 \\
\hline White students & 88 & 57 & 86 & 25 \\
\hline \multicolumn{5}{|l|}{$8^{\text {th }}$ Grade } \\
\hline All students & 81 & 46 & 75 & 28 \\
\hline Students with disabilities & 43 & 13 & 31 & 4 \\
\hline Students without disabilities & 86 & 51 & 81 & 31 \\
\hline $\begin{array}{l}\text { Students with limited-English } \\
\text { proficiency }\end{array}$ & 46 & 14 & 37 & 8 \\
\hline $\begin{array}{l}\text { Economically disadvantaged } \\
\text { students }\end{array}$ & 71 & 30 & 64 & 15 \\
\hline $\begin{array}{l}\text { Non-economically disadvantaged } \\
\text { students }\end{array}$ & 89 & 59 & 83 & 37 \\
\hline African American students & 73 & 31 & 67 & 16 \\
\hline Asian students & 88 & 60 & 86 & 47 \\
\hline Hispanic students & 65 & 28 & 55 & 14 \\
\hline White students & 88 & 59 & 83 & 37 \\
\hline
\end{tabular}

Source: http://reportcard.gaosa.org/k12/reports.asp?TestType=QCC\&ID=ALL:ALL

Students with disabilities and limited-English proficiency had much lower pass rates. Students from economically disadvantaged backgrounds had a high pass rate of 90 percent, but they fell 
behind at the "pass plus" proficiency level: 44 percent scored at this level compared with 70 percent of students who did not come from economically disadvantaged backgrounds.

Table K4. Performance of $8^{\text {th }}$-Graders on 2003 Middle Grades Writing Assessment, by Student Characteristics

\begin{tabular}{lcc}
\hline & On Target or Above & Exceeds Target \\
\cline { 2 - 3 } & \multicolumn{2}{c}{ Percentage } \\
\hline All students & 90 & 18 \\
Students with disabilities & 61 & 3 \\
Students without disabilities & 94 & 20 \\
Students with limited-English proficiency & 64 & 4 \\
Economically disadvantaged students & 84 & 8 \\
Non-economically disadvantaged students & 95 & 25 \\
African American students & 85 & 8 \\
Asian students & 94 & 30 \\
Hispanic students & 79 & 9 \\
White students & 95 & 25 \\
\hline
\end{tabular}

Source: http://reportcard.gaosa.org/k12/reports.asp?TestType=QCC\&ID=ALL:ALL

Table K5: Performance of $1^{\text {th }}$-Graders on 2003 English Language Arts GHSGT, by Student Characteristics

\begin{tabular}{lcc}
\hline & Passing & Passing Plus \\
\cline { 2 - 3 } & \multicolumn{2}{c}{ Percentage } \\
\hline First-Time Test Takers & 95 & 63 \\
All students & 74 & 50 \\
Students with disabilities & 97 & 31 \\
Students without disabilities & 67 & 22 \\
Students with limited-English proficiency & 90 & 44 \\
Economically disadvantaged students & 97 & 70 \\
Non-economically disadvantaged students & 92 & 47 \\
African American students & 93 & 62 \\
Asian students & 84 & 41 \\
Hispanic students & 97 & 73 \\
White students & 97
\end{tabular}

Source: http://reportcard.gaosa.org/k12/reports.asp?TestType=QCC\&ID=ALL:ALL 
Pass rates on the Grade 11 writing assessment (Table K6) were also high-88 percent overall. Hispanic students had much lower pass rates of 72 percent, and fewer than half of the students with limited-English proficiency passed (44 percent).

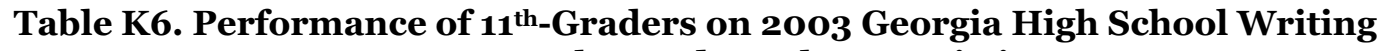
Assessment, by Student Characteristics

\begin{tabular}{lc}
\hline & Percentage Passing \\
\hline All students & 88 \\
Students with disabilities & 56 \\
Students without disabilities & 91 \\
Students with limited-English proficiency & 44 \\
Economically disadvantaged students & 79 \\
Non-economically disadvantaged students & 93 \\
African American students & 82 \\
Asian students & 86 \\
Hispanic students & 72 \\
White students & 94 \\
\hline ortcard.gaosa.org/k12/reports.asp?TestType=QCC\&ID=ALL:ALL
\end{tabular}

Source: http://reportcard.gaosa.org/k12/reports.asp?TestType=QCC\&ID=ALL:ALL

\section{$\underline{\text { School Performance }}$}

School-level data for the 2002 administration of the assessments for grades 4, 8, and 11 are available by urbanicity. Tables K7 through K9 provide information about school performance for rural, suburban, and urban schools. Almost half of schools in Georgia are located in suburban areas, 34 percent are rural, and 16 percent are urban. Over three-fourths ( 78 percent) of urban schools are high-poverty schools, compared with 64 percent of rural schools and 31 percent of suburban schools.

Urban schools scored lower than either rural or suburban schools at the $4^{\text {th }}$ and $8^{\text {th }}$ grades in reading, English language arts, and writing at both proficiency levels. For example, at the $4^{\text {th }}$ grade, on average, 82 percent of students in suburban schools and 79 percent of students in rural schools met the standard in reading; the passing rate in urban schools was 73 percent. At the higher proficiency level, there was a difference between urban and suburban schools of 13 percentage points in the proportion of students exceeding the standard in reading. We see similar patterns in English language arts and in writing.

At the $11^{\text {th }}$-grade level, passing rates were uniformly high in English language arts-between 92 and 96 percent and somewhat lower in writing (82-87 percent). While suburban schools did 
better than either rural or urban schools, the differences were small. At the $11^{\text {th }}$-grade level, there is little difference in the passing rates of urban and rural schools.

Table K7. Average School Performance on $4^{\text {th- }}$ and $8^{\text {th-Grade }} 2002$ Reading and English Language Arts CRCT, by Urbanicity

\begin{tabular}{lcccc}
\hline & \multicolumn{2}{c}{ Reading } & \multicolumn{2}{c}{ English Language Arts } \\
\cline { 2 - 5 } & $\begin{array}{c}\text { Meets the } \\
\text { Standard and } \\
\text { Above }\end{array}$ & $\begin{array}{c}\text { Exceeds the } \\
\text { Standard }\end{array}$ & $\begin{array}{c}\text { Meets the } \\
\text { Standard and } \\
\text { Above }\end{array}$ & $\begin{array}{c}\text { Exceeds the } \\
\text { Standard }\end{array}$ \\
\cline { 2 - 5 } & \multicolumn{4}{c}{ Average Percentage } \\
\hline $\mathbf{4}^{\text {th Grade }}$ & 79 & 35 & 75 & 13 \\
Rural schools & 82 & 42 & 79 & 17 \\
Suburban schools & 73 & 29 & 71 & 11 \\
Urban schools & & & & \\
8 $^{\text {th Grade }}$ & 76 & 36 & 69 & 20 \\
Rural schools & 82 & 46 & 73 & 26 \\
Suburban schools & 75 & 35 & 65 & 17 \\
Urban schools & & &
\end{tabular}

Table K8. Average School Performance on 2002 Middle Grades Writing Assessment, by Urbanicity

\begin{tabular}{lcc}
\hline & \multicolumn{1}{c}{ On Target or Above } & Exceeds Target \\
\cline { 2 - 3 } Middle Grades & \multicolumn{2}{c}{ Average Percentage } \\
\cline { 2 - 3 } Rural schools & 83 & 8 \\
Suburban schools & 87 & 14 \\
Urban schools & 80 & 7 \\
\hline
\end{tabular}

Table K9. Average School Performance on $1^{\text {th }}$-Grade English Language Arts GHSGT and High School Writing Assessment, by Urbanicity

\begin{tabular}{|c|c|c|}
\hline & $\begin{array}{c}\text { English Language } \\
\text { Arts }\end{array}$ & Writing \\
\hline 11 $^{\text {th }}$ Grade & \multicolumn{2}{|c|}{ Average Passing Percentage } \\
\hline Rural schools & 92 & 82 \\
\hline Suburban schools & 96 & 87 \\
\hline Urban schools & 92 & 83 \\
\hline
\end{tabular}




\section{APPENDIX L. HAWAII}

\section{State Assessment System}

As part of its assessment system, Hawaii administers the Hawaii Content and Performance Standards, Second Edition (HCPS II) in grades 3, 5, 8, and 10 in reading, writing, and mathematics. The reading and mathematics assessments include two sets of test questions: the first set is based on an abbreviated version of the Stanford Achievement Test, $9^{\text {th }}$ Edition (SAT9); the second set is a criterion-referenced section based on the state standards. The writing assessments are made up solely of criterion-referenced questions. Assessments are being developed in additional grades in order to meet the testing requirements under NCLB.

Performance on the HCPS II is used to hold schools accountable under the state system. In addition, students may be retained in grade based on their performance on the assessment (for additional information regarding state accountability, see http://arch.k12.hi.us/school/NCLB/default.html).

The assessments are intended to measure student progress on the state standards. Hawaii has established content and performance standards that describe what students should know and be able to do in 10 content areas: language arts, mathematics, science, social studies, career and life skills, educational technology, fine arts, health, physical education, and world languages. These content standards are further defined by grade-span benchmarks. The English language arts content standards are organized under three components: reading and literature, writing, and oral communications. As an example, Table L1 presents the 6-8 grade-span benchmarks for reading and literature.

\section{Test Format and Content}

For the purposes of examining what the HCPS II reveals about adolescent literacy, the rest of the discussion focuses on the reading and writing tests students take in grades 5,8 , and 10 (additional information on the HCPS II can be found at http://www.hawaiiassessmentmatters.org/HCPSII_parent.pdf).

HCPS II standards-based assessments contain three types of questions:

- Multiple-choice questions.

- Constructed-response questions, which require students to create a one- or two-paragraph response in writing or in the form of a narrative or a chart, table, diagram, illustration, or graph, as appropriate.

- Essay questions, which require students to respond by creating a written composition. 


\section{Table L1. Benchmarks for Language Arts Reading Literature, Grades 6-8}

\begin{tabular}{|c|c|}
\hline Content Standards & Benchmarks \\
\hline $\begin{array}{l}\text { Students will read a range of literary } \\
\text { and informative texts for a variety of } \\
\text { purposes. }\end{array}$ & $\begin{array}{l}\text { - Read a broad range of traditional contemporary and young-adult texts across } \\
\text { genres. } \\
\text { Read to understand human experience and the range of choices and } \\
\text { possibilities in life. } \\
\text { - Read to research an inquiry question, theme, or hypothesis, using technological } \\
\text { and traditional informational resources. } \\
\text { Read to solve problems and perform functional tasks (e.g., bus schedule, } \\
\text { consumer information, instructions, directions). }\end{array}$ \\
\hline $\begin{array}{l}\text { Students will use strategies within } \\
\text { the reading processes to construct } \\
\text { meaning. }\end{array}$ & $\begin{array}{l}\text { - Use strategies for constructing meaning that include annotating, interpreting, } \\
\text { connecting, and analyzing. } \\
\text { Revise interpretations in light of new information from reading, prior } \\
\text { knowledge, and discussion with others. } \\
\text { - Interpret text(s) from multiple perspectives (e.g., historical, cultural, gender, } \\
\text { political). } \\
\text { Evaluate and synthesize information within a text and across texts. }\end{array}$ \\
\hline $\begin{array}{l}\text { Students will apply knowledge of } \\
\text { the conventions of language and } \\
\text { texts to construct meaning. }\end{array}$ & $\begin{array}{l}\text { - Apply knowledge of genre conventions to analyze and interpret texts. } \\
\text { - Apply knowledge of figurative language and symbols to analyze and interpret } \\
\text { texts. }\end{array}$ \\
\hline $\begin{array}{l}\text { Students will respond to texts from } \\
\text { a range of stances: initial } \\
\text { understanding, personal, } \\
\text { interpretive, and critical. }\end{array}$ & $\begin{array}{l}\text { - Support own interpretation of imagery, plot, and character. } \\
\text { - Support a conclusion or response based on facts, ideas, and/or arguments } \\
\text { within the text and between texts. } \\
\text { - } \quad \text { Respond to text critically by analyzing the author's craft and message. }\end{array}$ \\
\hline $\begin{array}{l}\text { Students will demonstrate } \\
\text { confidence as readers and find value }\end{array}$ & $\begin{array}{l}\text { Engage intellectually with texts, think divergently, visualize characters or } \\
\text { scenes, express opinions, and raise questions. }\end{array}$ \\
\hline
\end{tabular}

and satisfaction in reading and

sharing reading experiences with

others.

Students will interact thoughtfully and respectfully with texts that represent diversity in language, perspective, and/or culture.

\section{Source:}

http://165.248.2.55/HCPS/L2/hcps6.nsf/d6824640c79oeod38a2569c40oo8cd78/259c1936obac98128a25 69c80082de66/\$FILE/Language\%20Arts\%20Content\%20Stds.pdf

The HCPS II reading test questions measure comprehension processes, conventions and skills, and response. The writing test measures conventions and skills, and rhetoric. The HCPS II Stanford 9 abbreviated reading assessment allocates 28 minutes to read six passages and answer 30 multiple-choice questions. The criterion-referenced reading section incorporates a variety of age-appropriate literary pieces, such as stories and poems, information pieces, such as textbooklike selections, and functional pieces, such as directions and consumer material; itallocates two hours for answering multiple-choice and constructed-response questions.

On the writing assessment, students write a response to a given prompt. The prompt specifies the type of essay a student should write. The writing segment allocates about two hours for students 
to plan, draft, edit, and write one expository, narrative, or persuasive essay. Table L2 provides sample prompts from the $5^{\text {th- }}$ and $10^{\text {th }}$-grade writing assessment.

\section{Table L2. Sample $5^{\text {th- }}$ and $10^{\text {th }}$-Grade HCPS II Writing Assessment Prompts}

\begin{tabular}{ll}
\hline $\begin{array}{l}\text { Grade } 5 \\
\text { Writing } \\
\text { Prompt }\end{array}$ & $\begin{array}{l}\text { Imagine that one day you can trade places with someone you would like to be. This person, } \\
\text { real or imaginary, can be from the past, present, or future. Tell who that person is and why } \\
\text { you would like to trade places with him or her. Write about what you would do as that } \\
\text { person for one day and how you would feel about it. }\end{array}$ \\
\hline $\begin{array}{l}\text { Grade 10 } \\
\text { Writing } \\
\text { Prompt }\end{array}$ & $\begin{array}{l}\text { Imagine that your school needs some new computers. As president of the student council, } \\
\text { you have been asked to write to the president of a local computer company and request a } \\
\text { company to grant your request. }\end{array}$ \\
\hline Source: http://www.hawaiiassessmentmatters.org/HCPSI__parent.pdf
\end{tabular}

\section{Achievement-Level Definitions}

Test results are reported using four achievement levels:

- Well below proficiency - the student demonstrated little or no knowledge and skills in the content standards for this grade.

- Approaches proficiency - the student demonstrated some knowledge and skills in the content standards for this grade and, with more support and effort, the student should be able to reach the proficient level.

- Meets proficiency - the student demonstrated the knowledge and skills required to meet the content standards for this grade. The student is ready to work on higher levels of this content area.

- Exceeds proficiency - the student has demonstrated knowledge and skills that exceed the content standards for this grade. The student is ready for more-advanced work in the content area.

For NCLB accountability purposes, students scoring at or above the "meets proficiency" level are considered "proficient."

\section{Results}

\section{Student Performance}

The Hawaii HCPS II provides student-level data on performance for all students, students with limited-English proficiency (designated as ESLL - English for Second Language Learner), students with disabilities, racial/ethnic groups, and economically disadvantaged students ${ }^{16}$. Table

\footnotetext{
${ }^{16}$ Approximately 72 percent of students in Hawaii are Asian/Pacific Islander; 20 percent are white; 5 percent are Hispanic; and 2 percent are African American. About 42 percent of students are eligible for free or
} 
L3 shows reading performance results from the 2003 HCPS II test for students in grades 5, 8, and 10.

Overall, 41 percent of $5^{\text {th-graders, }} 39$ percent of $8^{\text {th }}$-graders, and 40 percent of $10^{\text {th }}$-graders scored at the "proficient" level and a very small percentage-1 percent-exceeded proficiency standards. The percentage of students falling into the lowest achievement level (well below standards, not shown in table) was larger in $5^{\text {th }}$ grade than in $8^{\text {th }}$ or $10^{\text {th }}$ grade for all student groups.

Among students with limited-English proficiency and students with disabilities, only a small percentage (4-7 percent) met proficiency standards, and none of them exceeded proficiency standards. Less than 30 percent of economically disadvantaged students scored at the "proficient" level across all three grade levels, and none of these students exceeded proficiency standards.

White $5^{\text {th- }}, 8^{\text {th }}$, and $10^{\text {th }}$-grade students outperformed Asian/Pacific Islander, African American, and Hispanic students at all three grade levels. A little over half of white $5^{\text {th }}, 8^{\text {th }}$, and $10^{\text {th }}$ graders met proficiency standards, compared with 31-40 percent of Asian/Pacific Islander, African American, and Hispanic students.

\section{$\underline{\text { School Level Performance }}$}

School-level data by ubanicity are available for performance for $5^{\text {th-, }} 8^{\text {th }}$, and $10^{\text {th }}$-graders $(T a b l e$ L4) for the 2002 administration of the reading HCPS II. Approximately 38 percent of schools in Hawaii are suburban, 35 percent are rural, and 27 percent are urban. On average, rural schools were slightly more likely to be high-poverty schools--46 percent--compared with 43 percent of suburban schools and 38 percent of urban schools.

Between 84 and 88 percent of schools scored at the "approaches proficiency" level at all grade levels, and there was little difference among schools. However, at the "proficient" level, urban schools did better than either rural or suburban schools at all grade levels, and the difference in the average ranged from 4-8 percentage points.

reduced-price lunch; 9 percent are in limited-English-proficiency programs; and 12 percent have Individual Education Programs (IEPs). 
Table L3. Performance of $5^{\text {th-}}$, $8^{\text {th }}$, and $1^{\text {th }}$-Graders on 2003 Reading HCPS II, by Student Characteristics

\begin{tabular}{|c|c|c|c|}
\hline & $\begin{array}{c}\text { Approaches } \\
\text { Proficiency and } \\
\text { Above }\end{array}$ & $\begin{array}{c}\text { Meets } \\
\text { Proficiency } \\
\text { and Above }\end{array}$ & $\begin{array}{l}\text { Exceeds } \\
\text { Proficiency }\end{array}$ \\
\hline & & Percentage & \\
\hline \multicolumn{4}{|l|}{$5^{\text {th }}$ Grade } \\
\hline All students & 84 & 41 & 1 \\
\hline Students with disabilities & 37 & 6 & o \\
\hline $\begin{array}{l}\text { Students with limited-English } \\
\text { proficiency }\end{array}$ & 52 & 6 & o \\
\hline Economically disadvantaged students & 77 & 28 & 0 \\
\hline African American students & 88 & 40 & 1 \\
\hline Asian/Pacific Islander students & 83 & 39 & 1 \\
\hline Hispanic students & 83 & 39 & 1 \\
\hline White students & 91 & 52 & 1 \\
\hline \multicolumn{4}{|l|}{$8^{\text {th }}$ Grade } \\
\hline All students & 90 & 39 & 1 \\
\hline Students with disabilities & 54 & 5 & o \\
\hline $\begin{array}{l}\text { Students with limited-English } \\
\text { proficiency }\end{array}$ & 63 & 4 & o \\
\hline Economically disadvantaged students & 85 & 25 & o \\
\hline African American students & 93 & 38 & o \\
\hline Asian/Pacific Islander students & 89 & 36 & 1 \\
\hline Hispanic students & 90 & 34 & 1 \\
\hline White students & 93 & 52 & 1 \\
\hline \multicolumn{4}{|l|}{$10^{\text {th }}$ Grade } \\
\hline All students & 91 & 40 & 1 \\
\hline Students with disabilities & 53 & 5 & 0 \\
\hline $\begin{array}{l}\text { Students with limited-English } \\
\text { proficiency }\end{array}$ & 67 & 7 & o \\
\hline Economically disadvantaged students & 85 & 26 & 0 \\
\hline African American students & 91 & 35 & o \\
\hline Asian/Pacific Islander students & 91 & 38 & 1 \\
\hline Hispanic students & 87 & 31 & 1 \\
\hline White students & 94 & 52 & 1 \\
\hline
\end{tabular}

Source: http://arch.k12.hi.us/pdf/NCLB/NCLB2003StateAssmtByGde.pdf 
Table L4. Average School Performance for $5^{\text {th-, }} 8^{\text {th-}}$, and $10^{\text {th }}$-Grade 2002 Reading HCPS II, by Urbanicity

\begin{tabular}{lccc}
\hline & $\begin{array}{c}\text { Approaches } \\
\text { Proficiency and } \\
\text { Above }\end{array}$ & $\begin{array}{c}\text { Meets } \\
\text { Proficiency } \\
\text { and Above }\end{array}$ & $\begin{array}{c}\text { Exceeds } \\
\text { Proficiency }\end{array}$ \\
\cline { 2 - 4 } & \multicolumn{3}{c}{ Average Percentage } \\
\hline $\mathbf{5}^{\text {th }}$ Grade & 86 & 39 & 2 \\
Rural schools & 87 & 41 & 3 \\
Suburban schools & 88 & 47 & 3 \\
Urban schools & & & \\
$\mathbf{8}^{\text {th }}$ Grade & 84 & 37 & 3 \\
Rural schools & 85 & 40 & 1 \\
Suburban schools & 85 & 44 & 3 \\
Urban schools & & & $\mathbf{1}$ \\
10 & & & 1 \\
Rural schools & 87 & 39 & 2 \\
Suburban schools & 86 & 47 & \\
Urban schools & 85 & & \\
\hline
\end{tabular}





\section{APPENDIX M. IDAHO}

\section{State Assessment System}

The Idaho Comprehensive Assessment Plan includes:

- The K-3 Idaho Reading Indicator (IRI)

- The Direct Mathematics Assessment in grades 4, 6, and 8

- The Direct Writing Assessments in grades 5, 7, and 9. These assessments will be administered officially for the first time in 2004.

- Idaho Standards Achievement Test (ISAT) in grades 2-10 in reading, language usage (grades 2-9)/language arts (grade 10), and mathematics. The ISAT is administered in the fall and spring, allowing student progress to be measured during the school year.

The ISAT measures student progress toward state standards and carries consequences for schools and students. Beginning with the graduating class of 2006, students must pass the $10^{\text {th }}$-grade ISAT in order to graduate; however, students will be provided multiple opportunities to do so (for additional information regarding the state accountability system, see http://www.sde.state.id.us/dept/testreports.asp).

Idaho has developed Achievement Standards for students that are grade-specific for K-8 and for the grade-span 9-12 in language arts/communication (Reading, Writing, Listening, Speaking, and Viewing), math, science, social studies, health, and the humanities. Each standard is more fully defined by a set of content knowledge and skills. For instance, for the $7^{\text {th }}$-grade content standard-read and respond to a variety of literature to compare and contrast the many dimensions of human experience-the content knowledge and skills delineated include:

a. Describe characteristics of the following genres: fiction, nonfiction, poetry, biography/autobiography, legend, fable, myth, and reference materials.

b. Activate and draw upon prior experiences to connect to reading selections.

c. Relate social, cultural, and historical aspects of literature to reader's personal experience.

d. Analyze narrative literature according to the following text elements: Character; Setting; Conflict; Plot structure; Theme; Point of view.

e. Demonstrate an understanding of how reading can provide enrichment and information, as well as serve as a tool for lifelong learning.

(http://www2.state.id.us/adm/adminrules/rules/idapao8/o203.pdf) 
While the state has developed these standards, districts are encouraged to develop additional, more rigorous local standards as well.

\section{Test Format and Content}

For the purposes of examining adolescent literacy, the rest of the discussion will focus on the grade 4, 8, and 10 spring 2003 reading and language usage ISAT (for additional information regarding the ISAT, see http://www.sde.state.id.us/admin/standards/).

The ISAT reading and language assessments are untimed and contain two types of questions:

- Selected-response questions

- Constructed-response questions, which require students to create a one- or two-paragraph response.

Students take the ISAT in a fixed format (pen and pencil test); an achievement format (computerized version that adapts questions based on student responses), or a blended format, which combines the preceding two formats. For the spring administration in 2003, students in grades 4 and 8 took the blended test; the fixed form was given to $10^{\text {th }}$-graders.

Student's skills are evaluated in six categories in the ISAT Reading assessment:

- Vocabulary

- Word analysis: the ability to understand relationships between words and use component structures and clues from context to decipher word meaning

- Literal comprehension: the ability to recall, identify, classify, and sequence details, facts, and stated main ideas from a variety of written materials and interpret directions

- Interpretive comprehension: the ability to make reasonable predictions before, during, and after reading; the ability to draw inferences necessary for understanding, recognize causeeffect relationships, and summarize and synthesize information from a variety of written materials

- Evaluative comprehension: the ability to understand fact, opinion, bias, assumptions, and elements of persuasion and evaluate the quality and validity of written material, ability to compare works, evaluate conclusions and apply what is learned to real life experiences

- Literary analysis: the ability to respond to stories based on well-know characters, themes, plots and settings.

Students' skills are evaluated in six different categories in the ISAT Language assessment: composition and the writing process (ability to use writing, drafting, revising, editing, and 
proofreading skills), composition and structure (ability to work with sentences and paragraphs, use the correct writing form, and understand composition forms), grammar and usage (show understanding of basic sentence patterns, phrases and clauses, word forms, verb tenses, subjectverb agreement, and pronoun-antecedent agreement), punctuation, capitalization, and spelling.

\section{Achievement-Level Definitions}

Test results reported across the state are broken into four achievement levels, which are consistent across grade levels:

- Advanced (exceeds standards)--demonstrate thorough mastery of skills and knowledge that allow them to function independently and above their current educational level.

- Proficient (meets standards)--demonstrate skills and knowledge that allow them to function independently on all major skills and concepts related to their education level.

- Basic (below standards)--demonstrate basic skills and knowledge, but cannot operate independently using grade-level skills and concepts. They require assistance and remediation to complete tasks without significant errors.

- Below basic (critically below standards)--demonstrate significant lack of knowledge and skills and are unable to complete basic knowledge sets or skills without significant remediation. (http://www.sde.state.id.us/admin/docs/isat/proficiency-levels-definitions.htm)

Students scoring at the "proficient" level and above are considered to be "proficient" under accountability provisions of NCLB.

\section{Performance Results}

\section{Student-Level Performance}

The Idaho Department of Education (DOE) provides student-level data, disaggregated by English-proficiency status, disability status, socioeconomic status, and racial/ethnic groups ${ }^{17}$. Table M1 provides reading and language assessment results from the spring 2003 ISAT administration for $4^{\text {th }}, 8^{\text {th }}$, and $10^{\text {th }}$-grade students, by student characteristics.

Overall, $71-79$ percent of $4^{\text {th }}$-, $8^{\text {th }}$, and $10^{\text {th }}$-grade students met or exceeded proficiency standards in reading or language arts. The percentage of students scoring at the advanced level was lower in

\footnotetext{
${ }^{17}$ Approximately 85 percent of students in Idaho are white, and 11 percent are Hispanic; no other racial/ethnic group comprises 2 percent of the population. About 36 percent of students are eligible for the free or reduced-price lunch program; 7 percent are in limited-English-proficiency programs; and 12 percent have Individual Education Programs (IEPs).
} 
the upper grades. For example, in language arts, 30 percent of $4^{\text {th }}$-graders scored at the advanced level, compared with 17 percent of $8^{\text {th }}$-graders and 20 percent of $10^{\text {th }}$-graders.

About 19-44 percent of students with disabilities and 28-51 percent of students with limitedEnglish proficiency reached the proficient level across subjects and grades. The percentage of students with disabilities and students with limited-English proficiency scoring at or above the proficient level was lower in the later grades. For example, the percentage of students with disabilities reaching proficiency levels in language arts was 44 percent in $4^{\text {th }}$ grade, 20 percent in $8^{\text {th }}$ grade, and 19 percent in $10^{\text {th }}$ grade. Similarly, the percentage of students with limited-English proficiency scoring at or above the proficient level in language arts was 51 percent in grade 4, 38 percent in grade 8 , and 35 percent in grade 10.

Economically disadvantaged students scored far below their peers. The achievement gap ranged between 12-21 percentage points at both the proficient and above level and the advanced level. For example, in $8^{\text {th }}$-grade reading, 60 percent of economically disadvantaged students reached the proficient level and 20 percent reached the advanced level, compared with 80 percent and 41 percent of students who are not economically disadvantaged.

White students outperformed Hispanic students at all three grade levels in both reading and language. The achievement gap ranged from 25-37 percentage points at the proficient and above level and from $15^{-31}$ percentage points at the advanced level.

\section{$\underline{\text { School-Level Performance }}$}

Idaho implemented the ISAT in 2002-03. As a result, we do not report any school-level data from 2002. 
Exhibit M1. Performance of $4^{\text {th- }}, 8^{\text {th }}$, and $10^{\text {th }}$-Graders on Spring 2003 Reading and Language ISAT, by Student Characteristics

\begin{tabular}{|c|c|c|c|c|}
\hline & \multicolumn{2}{|c|}{ Reading } & \multicolumn{2}{|c|}{ Language } \\
\hline & $\begin{array}{l}\text { Proficient } \\
\text { and Above }\end{array}$ & Advanced & $\begin{array}{l}\text { Proficient } \\
\text { and Above }\end{array}$ & Advanced \\
\hline & \multicolumn{4}{|c|}{ Percentage } \\
\hline \multicolumn{5}{|l|}{$4^{\text {th }}$ Grade } \\
\hline All students & 75 & 39 & 79 & 30 \\
\hline Students with disabilities & 34 & 9 & 44 & 7 \\
\hline Students without disabilities & 80 & 43 & 84 & 32 \\
\hline $\begin{array}{l}\text { Students with limited-English } \\
\text { proficiency }\end{array}$ & 38 & 8 & 51 & 6 \\
\hline Students with English proficiency & 77 & 41 & 81 & 31 \\
\hline Economically disadvantaged students & 64 & 27 & 70 & 19 \\
\hline $\begin{array}{l}\text { Non-economically disadvantaged } \\
\text { students }\end{array}$ & 82 & 47 & 85 & 36 \\
\hline Hispanic students & 49 & 14 & 58 & 11 \\
\hline White students & 79 & 43 & 83 & 33 \\
\hline \multicolumn{5}{|l|}{$8^{\text {th }}$ Grade } \\
\hline All students & 73 & 34 & 71 & 17 \\
\hline Students with disabilities & 26 & 4 & 20 & 1 \\
\hline Students without disabilities & 78 & 37 & 76 & 18 \\
\hline $\begin{array}{l}\text { Students with limited-English } \\
\text { proficiency }\end{array}$ & 35 & 7 & 38 & 4 \\
\hline Students with English proficiency & 75 & 35 & 72 & 18 \\
\hline Economically disadvantaged students & 60 & 21 & 57 & 9 \\
\hline $\begin{array}{l}\text { Non-economically disadvantaged } \\
\text { students }\end{array}$ & 80 & 41 & 78 & 21 \\
\hline Hispanic students & 43 & 10 & 45 & 4 \\
\hline White students & 77 & 37 & 74 & 19 \\
\hline \multicolumn{5}{|l|}{$10^{\text {th }}$ Grade } \\
\hline All students & 74 & 27 & 74 & 20 \\
\hline Students with disabilities & 23 & 3 & 19 & 1 \\
\hline Students without disabilities & 78 & 29 & 78 & 22 \\
\hline $\begin{array}{l}\text { Students with limited-English } \\
\text { proficiency }\end{array}$ & 28 & 3 & 35 & 3 \\
\hline Students with English proficiency & 75 & 28 & 75 & 21 \\
\hline Economically disadvantaged students & 59 & 16 & 59 & 11 \\
\hline $\begin{array}{l}\text { Non-economically disadvantaged } \\
\text { students }\end{array}$ & 78 & 30 & 78 & 23 \\
\hline Hispanic students & 40 & 6 & 45 & 5 \\
\hline White students & 77 & 29 & 77 & 22 \\
\hline
\end{tabular}





\section{APPENDIX N. ILLINOIS}

\section{State Assessment System}

Illinois' statewide assessment system includes two main tests:

- The Illinois Standards Achievement Test (ISAT) is a criterion-referenced exam for students in grades $3-8$. Students in grades 3,5 , and 8 take the ISAT in reading, writing, and mathematics, while students in grades 4 and 7 take the test in science, social studies, fine arts, and physical development and health.

- The Prairie State Achievement Examination (PSAE) is a criterion-referenced test in reading, writing, mathematics, social studies, and science for students in grade 11.

These assessments are used for school accountability. In addition, students who score well on the various portions of the exam may earn the Prairie State Achievement Award in each subject area. PSAE scores are also reported on student transcripts, and they may be used in the collegeadmissions process. Students who wish to improve their PSAE scores may retake the entire exam in the fall of their $12^{\text {th }}$-grade year.

Illinois is currently in the process of revamping its statewide assessment system. Beginning with the 2005-06 school year, students in grades 3-8 in reading and mathematics will take a newly revised ISAT assessment that will include both norm-referenced and criterion-referenced items. The writing assessment will expand to include grades $3,4,6$, and 8 . The science assessment will move to grades 3 and 7; the social studies and fine arts assessments, to grades 5 and 8; and the physical development and health assessment, to grades 4 and 7 (for additional state accountability information, see http://www.isbe.net/nclb/default.htm).

The ISAT and PSAE are intended to measure student progress toward mastering Illinois' content standards. Illinois has defined content standards in English language arts, mathematics, science, social studies, foreign language, fine arts, and physical development and health, in the Illinois Learning Standards. The English language arts standards were adopted in 1997. They are organized under five broad goals: reading, literature, writing, listening and speaking, and research. Each goal encompasses up to four learning standards, which define what all students should know and be able to do as a result of their public school experience. Each learning standard is broken down into specific benchmarks for each of five levels of schooling: early elementary, late elementary, junior high/middle school, early high school, and late high school. Table N1 shows the learning standards for the reading goal and benchmarks for the early high school level, as an example. 
Table N1. Illinois Learning Standards for English Language Arts, Reading Goal

\begin{tabular}{|c|c|}
\hline $\begin{array}{l}\text { Learning } \\
\text { Standard } \\
\end{array}$ & Early High School Benchmark \\
\hline \multirow{2}{*}{$\begin{array}{l}\text { Apply word } \\
\text { analysis and } \\
\text { vocabulary skills to } \\
\text { comprehend } \\
\text { selections }\end{array}$} & $\begin{array}{l}\text { Expand knowledge of words' origins and derivations and use idioms, analogies, } \\
\text { metaphors, and similes to extend vocabulary development }\end{array}$ \\
\hline & $\begin{array}{l}\text { Compare the meaning of words and phrases and use analogies to explain the } \\
\text { relationships among them }\end{array}$ \\
\hline \multirow{3}{*}{$\begin{array}{l}\text { Apply reading } \\
\text { strategies to } \\
\text { improve } \\
\text { understanding and } \\
\text { fluency }\end{array}$} & $\begin{array}{l}\text { Preview reading materials, clarify meaning, analyze overall themes and coherence, and } \\
\text { relate reading to information from other sources }\end{array}$ \\
\hline & $\begin{array}{l}\text { Analyze, interpret, and compare a variety of texts for purpose, structure, content, } \\
\text { detail, and effect }\end{array}$ \\
\hline & Read age-appropriate materials with fluency and accuracy \\
\hline \multirow{6}{*}{$\begin{array}{l}\text { Comprehend a } \\
\text { broad range of } \\
\text { reading materials }\end{array}$} & Use questions and predictions to guide reading \\
\hline & Explain and justify an interpretation of a text \\
\hline & $\begin{array}{l}\text { Interpret, evaluate, and apply information from a variety of sources to other situations } \\
\text { (e.g., academic, vocational, technical, personal) }\end{array}$ \\
\hline & $\begin{array}{l}\text { Summarize and make generalizations from content and relate them to the purpose of } \\
\text { the material }\end{array}$ \\
\hline & $\begin{array}{l}\text { Analyze how authors and illustrators use text and art to express and emphasize their } \\
\text { ideas (e.g., imagery, multiple points of view) }\end{array}$ \\
\hline & Interpret tables, graphs, and maps in conjunction with related text \\
\hline
\end{tabular}

Source: http://www.isbe.net/ils/ela/pdf/goal1.pdf

Illinois has also defined a set of performance standards that complement the "what" of the content standards with descriptions of "how well" students should perform at each grade level.

The five levels of schooling are further divided into ten stages with overlapping grade levels:

- $\quad$ Stage A - Grades 1 and 2

- $\quad$ Stage B - Grades 1, 2, and 3

- $\quad$ Stage C - Grades 2, 3, and 4

- $\quad$ Stage D - Grades 3, 4, and 5

- Stage E - Grades 4, 5, and 6

- $\quad$ Stage F - Grades 5, 6, and 7

- $\quad$ Stage G-Grades 6, 7, and 8

- $\quad$ Stage H - Grades7, 8, and 9

- $\quad$ Stage I - Grades 8, 9, and 10

- $\quad$ Stage $J$ - Grades 11 and 12

Each performance standard is linked to a content standard and is stage-specific. The performance standards are expressed through performance descriptors that describe how students can demonstrate the knowledge and skills they have acquired. Table N2 shows the 
performance descriptors for the three learning standards in reading for stage I (grades 8, 9, and 10), as an example.

\section{Table N2. Illinois Performance Standards for Learning Standards in Reading, Stage I (Grades 8-10)}

\section{Apply word analysis and vocabulary skills to comprehend selections}

Students who meet the standard can apply word analysis and vocabulary skills to comprehend selections.

1. Expand knowledge of word origins and derivations.

2. Use idioms, analogies, metaphors, and similes to extend vocabulary development.

3. Apply knowledge of roots and affixes to comprehend the meaning of unfamiliar or difficult words, terms, or phrases.

4. Identify and analyze the meanings of specialized vocabulary/terminology

5. Analyze the structure and function of words in context.

6. Analyze and interpret word usage in traditional and contemporary sources (e.g., books, lyrics, speeches).

7. Interpret American idioms to strengthen comprehension.

8. Identify analogy in text and use analogy to explain a relationship.

Apply reading strategies to improve understanding and fluency

Students who meet the standard can apply reading strategies to improve understanding and fluency.

1. Use previewing and predicting before reading, and questioning during reading.

2. Relate reading to information from other sources (e.g., prior knowledge, personal experience, other reading) using a variety of strategies.

3. Analyze a variety of texts for purpose, structure, content, detail, and effect.

4. Interpret and compare a variety of texts for purpose, structure, content, detail, and effect.

5. Analyze overall themes and discover coherence.

6. Clarify meaning of text by focusing on the key ideas presented explicitly or implicitly.

7. Identify how different content areas require different organizational structures (e.g., science text, literary text).

8. Demonstrate fluency by reading aloud a variety of materials (e.g., dialogue, dramatizations).

9. Select and read books for recreation.

\section{Comprehend a broad range of reading materials}

Students who meet the standard can comprehend a broad range of reading materials.

1. Ask questions before, during, and after reading that demonstrate that understanding of the reading has progressed.

2. Use topic, theme, organizational patterns, context, and point of view to guide interpretation.

3. Interpret concepts or make connections through analysis, evaluation, inference, and/or comparisons.

4. Analyze how authors and illustrators use text and art to express and emphasize their ideas (e.g., imagery, multiple points of view).

5. Identify and use criteria for evaluating the accuracy of text information.

6. Summarize and make generalizations from content and relate them to the purpose of the material.

7. Recognize kinds of writing (e.g., expository, persuasive, narrative).

8. Explain and justify an interpretation of the text using relevant, accurate references.

9. Challenge ideas presented in a text through questions about specific parts of the text.

10. Interpret tables, graphs, diagrams, and maps in conjunction with related text by drawing conclusions to support text.

Source: http://www.isbe.net/ils/ela/stage_I/descriptor.htm

In addition to the performance descriptors, achievement levels describe how well students have achieved the standards in terms of the range, frequency, facility, depth, creativity, and quality of their knowledge and skills. Accompanying classroom assessment tasks linked to the performance standards describe specific activities that allow students to demonstrate that they have met the 
standards and teachers to evaluate the levels of students' performance. Student work samples for the assessment tasks help to illustrate the different achievement levels.

\section{Test Format and Content}

To examine trends in adolescent literacy, the rest of the discussion will focus on the ISAT for reading and writing for grades 5 and 8, and the reading and writing portions of the PSAE for grade 11 (additional information regarding the assessments can be found through

http://www.isbe.net/assessment/default.htm).

$\underline{\text { ISAT }}$

The reading portion of the ISAT includes approximately 68 items, with a mix of both multiplechoice and extended-response items. The exam assesses students in five areas: comprehension of literary works; comprehension of informational sources; explicit ideas, application of strategies; inferences from text; and vocabulary. Reading passages include both literary and informational selections. The extended-response items are graded using a four-point rubric. The test is administered in three 40-minute sessions. The first features a longer passage followed by $20-25$ multiple-choice questions; the other two each contain one shorter passage followed by $15-20$ multiple-choice questions and one extended-response item.

The ISAT writing exam asks students to write two essays, one in response to an assigned prompt used statewide and one in response to a prompt selected by the student from a list of two. Prompts may require expository, persuasive, or narrative modes of writing. Students' responses are scored using both a holistic rubric and a set of analytic rubrics, all of which are grade-specific. Three six-point rubrics judge essays' focus, support, and organization, and a two-point rubric is used for writing conventions. Finally, a six-point holistic rubric is used to assess the overall integration of the essays. The total score for each essay is the sum of the four analytic scores plus twice the holistic score. A student's score for the entire writing assessment is the average of the scores from the two essays, rounded up to the nearest whole number.

$\underline{\text { PSAE }}$

The PSAE in reading consists of two distinct tests: the ACT college-entrance exam reading test and the WorkKeys Assessment in Reading for Information. Similarly, the PSAE writing assessment includes two tests: the ACT English language arts test and a separate writing exam developed by the Illinois State Board of Education. For each subject area, the two component tests count equally toward the final score in that subject. Scores on the ACT portion of the PSAE are accepted by nearly all colleges and universities as part of their application processes. 
The ACT reading exam consists of four reading passages - one science content reading, one social studies content reading, one prose fiction selection, and one nonfiction humanities selection each followed by ten multiple-choice items. Skills tested on the exam include determining main ideas, locating and interpreting details, understanding sequences of events, making comparisons, comprehending cause-effect relationships, determining the meaning of context-dependent material, generalizing, and analyzing authors' voice and methods. Students have 35 minutes to complete the 40-question exam.

The WorkKeys Reading for Information Assessment is part of a series of tests from the publishers of the ACT, which makes up a comprehensive job analysis and assessment system. The test consists of 15 reading samples from procedural texts, such as memos, letters, directions, signs, notices, bulletins, policies, regulations, and other materials that might be encountered in the workplace. Each passage is followed by one to three multiple-choice questions that assess students' ability to choose main ideas or details, understand word meanings, apply instructions, and apply information and reasoning. Students have 45 minutes to complete the 33-question exam.

The ACT English language arts exam consists of 75 multiple-choice items designed to assess writing usage/mechanics, including punctuation, grammar and usage, and sentence structure, and rhetorical skills, including strategies, organization, and style. The exam includes five reading passages followed by multiple-choice items that ask students to select the most appropriate alternative (if any) to the underlined portion of the preceding text. Students have 45 minutes to complete the test.

Finally, the Illinois State Board of Education-developed writing assessment asks students to respond to one writing prompt in either an expository or persuasive essay. The scoring categories and procedures are identical to those for the ISAT writing exam, except that the scoring rubrics are specific to $11^{\text {th }}$-grade writing.

\section{Achievement-Level Definitions}

Student scores on the ISAT and PSAE are reported using four achievement levels - Exceeds Standards, Meets Standards, Below Standards, and Academic Warning. Students scoring at the Meets Standards level or above are considered to have met academic requirements under NCLB. Table N3 shows the state's general performance descriptors, along with grade- and subject-

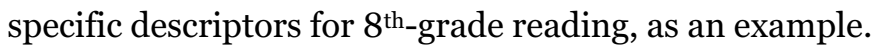


Table N3. Illinois Achievement-Level Descriptors, $8^{\text {th}}$-Grade Reading

\begin{tabular}{|c|c|c|}
\hline & $\begin{array}{l}\text { General } \\
\text { Descriptor }\end{array}$ & $8^{\text {th-Grade Reading Descriptor }}$ \\
\hline \multirow[t]{4}{*}{$\begin{array}{l}\text { Exceeds } \\
\text { Standards }\end{array}$} & \multirow{4}{*}{$\begin{array}{l}\text { Student work } \\
\text { demonstrates } \\
\text { advanced knowledge } \\
\text { and skills in the } \\
\text { subject. Students } \\
\text { creatively apply } \\
\text { knowledge and skills } \\
\text { to solve problems and } \\
\text { evaluate the results. }\end{array}$} & $\begin{array}{l}\text { The readers who exceed state standards comprehend a variety of } \\
\text { types of literary and informational grade-appropriate texts. They } \\
\text { can consistently understand and identify the important ideas in the } \\
\text { text and can support their ideas with relevant information from the } \\
\text { text and their own knowledge and experience. }\end{array}$ \\
\hline & & $\begin{array}{l}\text { Readers in the "exceeds standards" level consistently use knowledge } \\
\text { of text structure to recall and understand important information. } \\
\text { They consistently identify explicit main ideas and supporting details, } \\
\text { and infer logical conclusions using evidence in the text and their own } \\
\text { knowledge. }\end{array}$ \\
\hline & & $\begin{array}{l}\text { These readers consistently understand the broad meanings of a text, } \\
\text { such as theme or author's purpose, and are able to recognize } \\
\text { multiple perspectives and interpretations. They consistently use } \\
\text { clues in the text to understand basic and complex character traits } \\
\text { and motives. "Exceeds standards" readers read grade-appropriate } \\
\text { texts fluently, apply word analysis skills when needed to recognize } \\
\text { words, and use a variety of strategies to determine the meaning of } \\
\text { words in the text. }\end{array}$ \\
\hline & & $\begin{array}{l}\text { Finally, readers at the "exceeds standards" level consistently } \\
\text { understand and evaluate the use of a range of literary devices (e.g., } \\
\text { word choice, language structure, figurative language, point of view) }\end{array}$ \\
\hline \multirow[t]{4}{*}{$\begin{array}{l}\text { Meets } \\
\text { Standards }\end{array}$} & \multirow{4}{*}{$\begin{array}{l}\text { Student work } \\
\text { demonstrates } \\
\text { proficient knowledge } \\
\text { and skills in the } \\
\text { subject. Students } \\
\text { effectively apply } \\
\text { knowledge and skills } \\
\text { to solve problems. }\end{array}$} & $\begin{array}{l}\text { The readers who meet state standards comprehend a variety of types } \\
\text { of literary and informational grade-appropriate texts. They can } \\
\text { understand and identify a majority of the important ideas in the text } \\
\text { and can frequently support their ideas with relevant information } \\
\text { from the text and their own knowledge and experience. }\end{array}$ \\
\hline & & $\begin{array}{l}\text { Readers in the "meets standards" level usually use knowledge of text } \\
\text { structure to recall and understand important information. They } \\
\text { usually identify explicit main ideas and several supporting details, } \\
\text { infer implicit main ideas, and use details as supporting evidence. } \\
\text { Readers at this level usually draw logical conclusions using evidence } \\
\text { in the text and their own knowledge. }\end{array}$ \\
\hline & & $\begin{array}{l}\text { These readers usually understand the broad meanings of a text, such } \\
\text { as theme or author's purpose, and use clues in the text to understand } \\
\text { basic character traits and motives. "Meets standards" readers read } \\
\text { grade-appropriate texts fluently, apply word-analysis skills when } \\
\text { needed to recognize words, and use a variety of strategies to } \\
\text { determine the meaning of words in the text. }\end{array}$ \\
\hline & & $\begin{array}{l}\text { Finally, readers at the "meets standards" level usually understand } \\
\text { and evaluate the use of a range of literary devices (e.g., word choice, } \\
\text { language structure, figurative language, point of view) }\end{array}$ \\
\hline
\end{tabular}


Table N3. (cont.)

\begin{tabular}{ll}
\hline & $\begin{array}{l}\text { General } \\
\text { Descriptor }\end{array}$ \\
\hline Below & Student work \\
Standards & demonstrates basic \\
& knowledge and skills \\
in the subject. \\
& However, because of \\
& gaps in learning, \\
students apply \\
knowledge and skills \\
in limited ways.
\end{tabular}

$8^{\text {th-Grade Reading Descriptor }}$

The readers who do not meet state standards have difficulty

comprehending a variety of types of literary and informational gradeappropriate texts. They can understand and identify some of the important ideas in the text and will inconsistently support their ideas with relevant information from the text and their own knowledge and experience. They frequently rely more on their own knowledge and ideas than on the text. Errors in comprehension and overgeneralizations are often the result of this overreliance on their own knowledge.

Readers in the "below standards" level inconsistently use knowledge of text structure to recall and understand important information. They identify some explicit main ideas and some supporting details; however, they seldom infer implicit main ideas. They use few supporting ideas, and the supporting ideas they do use may be inappropriate or irrelevant. They often have difficulties distinguishing between main ideas and details, and rely too much on specific pieces of information, since they are easily misled by irrelevant details.

Readers at this level occasionally draw logical conclusions using evidence in the text and their own knowledge. Readers at this level overgeneralize concepts and ideas or rely on specific episodes or details rather than extending these to understand themes or author's purpose. They rely too much on their own knowledge and inconsistently use clues in the text to understand basic character traits and motives.

"Below standards" readers seldom apply word-analysis skills to recognize words, but may occasionally use a variety of strategies to determine the meaning of words in the text. Finally, readers at this level generally lack awareness of literary devices (e.g., word choice, language structure, figurative language, point of view), but may occasionally understand and evaluate the use of a limited range of literary devices.

Academic

Student work

Warning demonstrates limited

The readers at the "academic warning" level have significant difficulty knowledge and skills in the subject. Because of major gaps in learning, students apply knowledge and skills ineffectively. comprehending a variety of types of literary and informational gradeappropriate texts. They understand and identify few of the important ideas in the text and are rarely able to support their ideas with relevant information from the text and from their own knowledge and experience. They frequently rely more on their own knowledge and ideas than on the text.

Readers at the "academic warning" level seldom use knowledge of text structure to recall and understand important information. They identify few explicit main ideas and supporting details, rely too much on specific pieces of information, are easily misled by irrelevant details, and rarely identify implicit main ideas. Readers at this level overgeneralize concepts and ideas. These readers rely on specific episodes or details, rather than extending these to understand themes or author purpose. They rely too much on their own knowledge and rarely use clues in the text to understand basic character traits and motives. "Academic warning" readers inconsistently apply word analysis skills to recognize words, and skip unfamiliar words or phrases essential to the understanding of the text. Finally, readers at this level lack awareness of literary devices (e.g., word choice, language structure, figurative language, point of view)

Source: http://www.isbe.net/assessment/readperfdef.html 


\section{Performance Results}

\section{$\underline{\text { Student Performance }}$}

Illinois provides data on student performance on the ISAT and PSAE for all students and for students disaggregated by race/ethnicity, English-proficiency status, disability status, and socioeconomic status. ${ }^{18}$ Table $\mathrm{N} 4$ provides $5^{\text {th }}$ - and $8^{\text {th }}$-grade reading ISAT performance for these groups of students.

Overall, in reading and writing, 59-65 percent of $5^{\text {th- }}$ and $8^{\text {th }}$-grade students met or exceeded standards. Few students exceeded standards in writing (4 percent in $5^{\text {th }}$ and $8^{\text {th }}$ grades), and only 10 percent of $8^{\text {th }}$-grade students exceeded standards in reading. However, 23 percent of $5^{\text {th }}$-grade students exceeded standards. Few students fell into the lowest performance category (academic warning) - only 6 percent in grades 5 and 8 in writing and 1 percent or less in reading (not shown in table).

Less than 15 percent of students with limited-English proficiency (12 percent in $5^{\text {th }}$ grade and 14 percent in $8^{\text {th }}$ grade) met or exceeded standards in reading. However, their performance in writing was higher: 35 percent of $5^{\text {th }}$-graders and 24 percent of $8^{\text {th }}$-graders met or exceeded standards. One-fourth of $5^{\text {th }}$-grade students with Individual Education Programs (IEPs) met or exceeded the standards in reading, and almost a third (32 percent) met the standard in writing. Performance of $8^{\text {th }}$-graders with IEPs was a bit lower: 20 percent met or exceeded standards in reading, and 19 percent met this level in writing.

There was a large achievement gap between economically disadvantaged students and their peers: about 22-33 percentage points across subjects and grades at the meets or exceeds standards level.

White students outperformed African American and Hispanic students at all grade levels and in all subjects - by 24-38 percentage points for African Americans and 17-32 percentage points for Hispanics. Asian students outperformed all other racial/ethnic groups and outperformed white students by $5^{-12}$ percentage points.

\footnotetext{
${ }^{18}$ Approximately 59 percent of students in Illinois are white; 21 percent are African American; 16 percent are Hispanic; and 4 percent are Asian/Pacific Islander. About 35 percent of students are eligible for the free or reduced-price lunch program; 7 percent are in limited-English-proficiency programs; and 14 percent have Individual Education Programs (IEPs).
} 


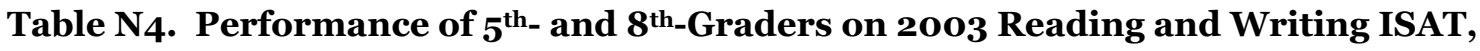
by Student Characteristics

\begin{tabular}{|c|c|c|c|c|}
\hline & \multicolumn{2}{|c|}{ Reading } & \multicolumn{2}{|c|}{ Writing } \\
\hline & $\begin{array}{c}\text { Meeting } \\
\text { Standards } \\
\text { or Above } \\
\end{array}$ & $\begin{array}{l}\text { Exceeding } \\
\text { Standards }\end{array}$ & $\begin{array}{c}\text { Meeting } \\
\text { Standards } \\
\text { or Above }\end{array}$ & $\begin{array}{l}\text { Exceeding } \\
\text { Standards }\end{array}$ \\
\hline & \multicolumn{4}{|c|}{ Percentage } \\
\hline \multicolumn{5}{|l|}{$5^{\text {th }}$ Grade } \\
\hline All students & 60 & 23 & 65 & 4 \\
\hline Students with IEPs & 25 & 5 & 32 & 1 \\
\hline Non-disabled students & 66 & 26 & 70 & 4 \\
\hline $\begin{array}{l}\text { Students with limited-English } \\
\text { proficiency }\end{array}$ & 12 & 1 & 35 & 1 \\
\hline Economically disadvantaged students & 40 & 9 & 50 & 1 \\
\hline $\begin{array}{l}\text { Non-economically disadvantaged } \\
\text { students }\end{array}$ & 73 & 32 & 74 & 5 \\
\hline Asian/Pacific Islander students & 79 & 38 & 81 & 9 \\
\hline African American students & 36 & 7 & 47 & 1 \\
\hline Hispanic students & 42 & 10 & 56 & 2 \\
\hline White students & 74 & 32 & 73 & 5 \\
\hline \multicolumn{5}{|l|}{$8^{\text {th }}$ Grade } \\
\hline All students & 64 & 10 & 59 & 4 \\
\hline Students with IEPs & 20 & 1 & 19 & o \\
\hline Non-disabled students & 71 & 11 & 66 & 5 \\
\hline $\begin{array}{l}\text { Students with limited-English } \\
\text { proficiency }\end{array}$ & 14 & 1 & 24 & o \\
\hline Economically disadvantaged students & 46 & 3 & 44 & 1 \\
\hline $\begin{array}{l}\text { Non-economically disadvantaged } \\
\text { students }\end{array}$ & 72 & 13 & 66 & 6 \\
\hline Asian/Pacific Islander students & 80 & 20 & 78 & 10 \\
\hline African American students & 45 & 3 & 42 & 1 \\
\hline Hispanic students & 47 & 3 & 49 & 1 \\
\hline White students & 73 & 13 & 66 & 6 \\
\hline
\end{tabular}

On the PSAE, 56 percent of $11^{\text {th }}$-graders met or exceeded standards in reading and 59 percent did so in writing (Table N5). Only 12 percent and 9 percent of students exceeded standards in reading and writing, respectively. Just 17-19 percent of students with limited-English proficiency met or exceeded the standards, and 1-2 percent exceeded the standard. Students with IEPs also struggled on the PSAE: 14-15 percent met or exceeded the standards, and 1-2 percent reached the highest achievement level and exceeded the standards. 
Similar to what we found on the ISAT, economically disadvantaged students scored far behind their peers - an achievement gap of 31-36 percent at the meets or exceeds standards level and 911 percent at the exceeds standards level. Whites outperformed African American and Hispanic students by large margins - 31-37 percentage points at the meets or exceeds standards level and 10-13 percent at the exceeds standards level. Asian students tended to outperform white students, but not by large margins $-0-5$ percent at the meets or exceeds standards level and 2-6 percent at the exceeds standards level.

Table N5. Performance of $11^{\text {th }}-$ Graders on the 2003 Reading and Writing PSAE, by Student Characteristics

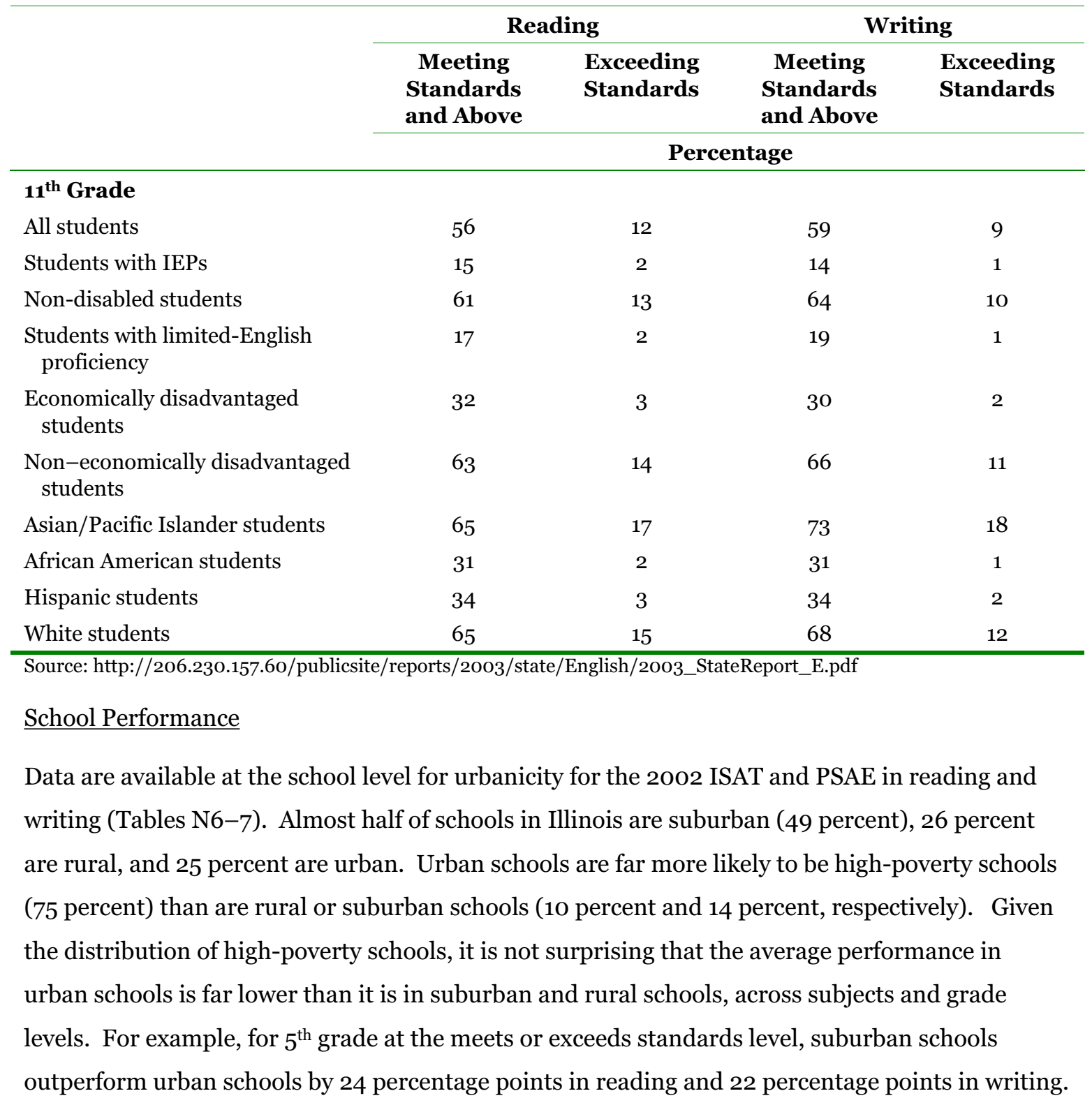


Suburban schools also outperform rural schools by smaller margins. On the $11^{\text {th }}$-grade PSAE on average, suburban schools outperform rural schools by 4-9 percentage points.

Table N6. Average School Performance for $5^{\text {th- }}$ and $8^{\text {th-Grade }} 2002$ Reading and Writing ISAT, by Urbanicity

\begin{tabular}{lcccc}
\hline & \multicolumn{2}{c}{ Reading } & \multicolumn{2}{c}{ Writing } \\
\cline { 2 - 5 } & $\begin{array}{c}\text { Meeting } \\
\text { Standards } \\
\text { or Above }\end{array}$ & $\begin{array}{c}\text { Exceeding } \\
\text { Standards }\end{array}$ & $\begin{array}{c}\text { Meeting } \\
\text { Standards } \\
\text { or Above }\end{array}$ & $\begin{array}{c}\text { Exceeding } \\
\text { Standards }\end{array}$ \\
\cline { 2 - 5 } & \multicolumn{5}{c}{ Average Percentage } \\
\hline $\mathbf{5}^{\text {th }}$ Grade & 65 & 23 & 57 & 3 \\
Rural schools & 67 & 28 & 67 & 6 \\
Suburban schools & 43 & 12 & 45 & 3 \\
Urban schools & & & & \\
$\mathbf{8}^{\text {th }}$ Grade & 70 & 8 & 58 & 4 \\
Rural schools & 72 & 12 & 66 & 6 \\
Suburban schools & 56 & 5 & 51 & 3 \\
Urban schools & \multicolumn{5}{c}{} \\
\hline
\end{tabular}

Table N7. Average School Performance for $1^{\text {th }}$-Grade 2002 Reading and Writing PSAE, by Urbanicity

\begin{tabular}{lcccc}
\hline & \multicolumn{2}{c}{ Reading } & \multicolumn{2}{c}{ Writing } \\
\cline { 2 - 5 } & $\begin{array}{c}\text { Meeting } \\
\text { Standards } \\
\text { or Above }\end{array}$ & $\begin{array}{l}\text { Exceeding } \\
\text { Standards }\end{array}$ & $\begin{array}{c}\text { Meeting } \\
\text { Standards } \\
\text { or Above }\end{array}$ & $\begin{array}{c}\text { Exceeding } \\
\text { Standards }\end{array}$ \\
\cline { 2 - 5 } & \multicolumn{4}{c}{ Average Percentage } \\
\hline $\mathbf{1 1}^{\text {th }}$ Grade & 57 & 10 & 54 & 5 \\
Rural schools & 61 & 13 & 63 & 10 \\
Suburban schools & 37 & 6 & 35 & 4 \\
Urban schools & \multicolumn{3}{c}{} \\
\hline
\end{tabular}





\section{APPENDIX O. INDIANA}

\section{State Assessment System}

In 2002-03, Indiana's accountability system, ISTEP+, assessed students in the following grades and subjects:

- Students in grades 3, 6, and 8 took the ISTEP+ in English language arts and mathematics in the fall.

- Students in grade 10 took the ISTEP+ Graduation Qualifying Examination (GQE) in English language arts and mathematics. A passing score on the GQE is a requirement for graduation; however, students failing the GQE have multiple opportunities to retake the assessment.

In 2003-04, testing was expanded so that students in grades 3-9 will take the ISTEP+ in English language arts and mathematics. Also, Indiana plans to adopt science and social studies tests for grades 5, 7, and 9. The ISTEP+ is the state's accountability test for NCLB; consequently, schools can be rewarded or sanctioned based on student performance on the assessment. In addition, as part of Indiana's school-accountability system, students take Core 40 End-of-Course Assessments, which are final exams measuring what students know and are able to do upon completion of targeted Core 40 courses (additional information on state accountability can be found through http://www.doe.state.in.us/asap/accountability.html).

Indiana reports that the ISTEP+ and the GQE measure student performance on state standards. Indiana has adopted grade-specific standards in English language arts, mathematics, science, social studies, music, business, visual arts, family and consumer science, and physical education (http://www.doe.state.in.us/asap/academicstandards.html). Table O1 shows the English language arts standards for $8^{\text {th }}$ grade as an example. Indiana also makes available curriculum frameworks and classroom assessments to support implementation of the standards.

\section{Test Format and Content}

For the purposes of examining what Indiana assessments reveal about adolescent literacy, the rest

of the discussion will focus on the English language arts sections of the ISTEP+ in grades 6 and 8 and the GQE (additional information regarding these assessments can be found through http://www.doe.state.in.us/istep/welcome.html). 
Table O1. English Language Arts Standards, Grade 8

\begin{tabular}{|c|c|}
\hline Standard & Definition \\
\hline $\begin{array}{l}\text { Standard } 1 \text { Reading: Word } \\
\text { Recognition, Fluency, and Vocabulary } \\
\text { Development }\end{array}$ & $\begin{array}{l}\text { Students use their knowledge of word parts and word } \\
\text { relationships, as well as context clues, to determine the meaning } \\
\text { of specialized vocabulary and to understand the precise meaning } \\
\text { of grade-level-appropriate words. }\end{array}$ \\
\hline Standard 2 Reading: Comprehension & $\begin{array}{l}\text { Students read and understand grade-level-appropriate material. } \\
\text { They describe and connect the essential ideas, arguments, and } \\
\text { perspectives of the text by using their knowledge of text structure, } \\
\text { organization, and purpose. Students read a variety of grade-level- } \\
\text { appropriate narrative and expository texts. }\end{array}$ \\
\hline $\begin{array}{l}\text { Standard } 3 \text { Reading: Literary } \\
\text { Response and Analysis }\end{array}$ & $\begin{array}{l}\text { Students read and respond to grade-level-appropriate historically } \\
\text { or culturally significant works of literature that enhance their } \\
\text { study of history and social science. They clarify the ideas and } \\
\text { connect them to other literary works. }\end{array}$ \\
\hline Standard 4 Writing: Writing Process & $\begin{array}{l}\text { Students discuss and keep a list of writing ideas. They write clear, } \\
\text { coherent, and focused essays. Students progress through the } \\
\text { stages of the writing process and proofread, edit, and revise } \\
\text { writing. }\end{array}$ \\
\hline $\begin{array}{l}\text { Standard } 5 \text { Writing: Writing } \\
\text { Applications }\end{array}$ & $\begin{array}{l}\text { Students write narrative, expository, persuasive, and descriptive } \\
\text { texts of } 500 \text { to } 700 \text { words. Students are introduced to } \\
\text { biographical and autobiographical narratives and to writing } \\
\text { summaries of grade-level-appropriate reading materials. Student } \\
\text { writing demonstrates a command of Standard English and uses } \\
\text { the research, organizational, and drafting strategies outlined in } \\
\text { Standard } 4 \text {. Writing demonstrates an awareness of the audience } \\
\text { and purpose for writing. }\end{array}$ \\
\hline $\begin{array}{l}\text { Standard } 6 \text { Writing: Written English } \\
\text { Language Conventions }\end{array}$ & $\begin{array}{l}\text { Students write using Standard English conventions appropriate to } \\
\text { this grade level. }\end{array}$ \\
\hline $\begin{array}{l}\text { Standard } 7 \text { Listening and Speaking: } \\
\text { Listening/Speaking Skills, Strategies, } \\
\text { and Applications }\end{array}$ & $\begin{array}{l}\text { Students deliver focused, coherent presentations that convey } \\
\text { ideas clearly and relate to the background and interests of the } \\
\text { audience. They evaluate the content of oral communication. } \\
\text { Students deliver well-organized formal presentations using } \\
\text { traditional speech strategies, including narration, exposition, } \\
\text { persuasion, and description. Students use the same Standard } \\
\text { English conventions for oral speech that they use in their writing. }\end{array}$ \\
\hline
\end{tabular}

Source: http://www.doe.state.in.us/istep/2003/pdf/progman2003.pdf

ISTEP+ assessments consist of two major components: the basic skills assessment, which is entirely multiple choice, and the applied skills assessment, which asks students to respond in essays or short answers.

The GQE was designed to measure students' mastery of Indiana Academic Standards and their applications in real-life situations; these skills are set to $9^{\text {th-grade }}$ standards. The GQE covers basic and applied skills, including reading ability, reading comprehension, vocabulary, and writing skills. 


\section{Proficiency Levels}

Grade 6 and 8 ISTEP+ results are reported in three categories of student achievement: Pass+, Pass, and Did Not Pass. Grade 10 GQE results are reported as "Above Standard” (passed) and "Below Standard" (did not pass). Students scoring at or above the passing level on the ISTEP+ and "above standard" on the GQE are considered to have met the academic requirements under NCLB.

\section{Performance Results}

\section{$\underline{\text { Student Performance }}$}

Indiana provides student-level data disaggregated by disability status, English proficiency status, income status, and racial/ethnic groups. ${ }^{19}$. Table $\mathrm{O} 2$ shows performance results from the 2002o3 reading ISTEP+ for students in grades 6 and 8, broken down by these students' characteristics, and Table $\mathrm{O}_{3}$ shows performance results for first-time test-takers on the $10^{\text {th }}$-grade GQE.

Sixty-nine percent of $6^{\text {th }}$-graders and 65 percent of $8^{\text {th }}$-graders passed the English language arts ISTEP+. Seven percent of students in both grades reached the pass- plus level. Students with disabilities had much lower pass rates -27 percent in $6^{\text {th }}$ grade and 20 percent in $8^{\text {th }}$ grade. Less than half of students with limited-English proficiency passed the assessment (47 percent and 40 percent, respectively).

Non-economically disadvantaged students outperformed economically disadvantaged students by $25-28$ percentage points at the passing level. There were also large racial/ethnic achievement gaps. The achievement gap between white students and African American students was 31 percentage points; that between white students and Hispanic students was smaller but still substantial, ranging from 22 to 24 percentage points at the passing level.

The pass rate for first-time $10^{\text {th }}$-grade test-takers on the GQE was 69 percent. Again, we found large achievement gaps between economically disadvantaged students and their peers (29 percentage points), white students and African American students (35 percentage points), and white students and Hispanic students (31 percentage points).

19 Approximately 83 percent of students in Indiana are white; 12 percent are African American; and 4 percent are Hispanic. About 31 percent of students are eligible for the free or reduced-price lunch program; 4 percent are in limited-English-proficiency programs; and 16 percent have Individual Education Programs (IEPs). 


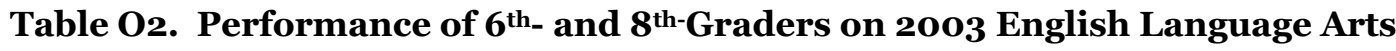
ISTEP+, by Student Characteristics

\begin{tabular}{lcc}
\hline & Pass & Pass + \\
\cline { 2 - 3 } & \multicolumn{2}{c}{ Percentage } \\
\hline 6 $^{\text {th Grade }}$ & 69 & 7 \\
All Students & 76 & 8 \\
General education students & 27 & 1 \\
Special education students & 47 & 3 \\
Students with limited-English proficiency & 70 & 7 \\
Students with English proficiency & 53 & 3 \\
Economically disadvantage students & 78 & 10 \\
Non-economically disadvantaged students & 43 & 1 \\
African American students & 50 & 3 \\
Hispanic students & 74 & 8 \\
White students & & \\
8 $^{\text {th Grade }}$ & 65 & 7 \\
All Students & 72 & 8 \\
General education students & 20 & 0 \\
Special education students & 40 & 3 \\
Students with limited-English proficiency & 65 & 7 \\
Students with English proficiency & 45 & 2 \\
Economically disadvantaged students & 73 & 9 \\
Non-economically disadvantaged students & 38 & 1 \\
African American students & 47 & 2 \\
Hispanic students & 69 & 8 \\
White students & Sumpdf & \\
\hline
\end{tabular}

Source: http://ideanet.doe.state.in.us/istep/2003/reports/Fo3_Disag_Sum.pdf

Table O3. Performance of $10^{\text {th }}$-Graders on 2003 English Language Arts GQE, by Student Characteristics

\begin{tabular}{lc}
\hline $\mathbf{1 0}^{\text {th }}$ Grade & $\begin{array}{c}\text { Percentage } \\
\text { Passing }\end{array}$ \\
\hline All students & 69 \\
Economically disadvantaged students & 48 \\
Non-economically disadvantaged students & 77 \\
African American students & 40 \\
Hispanic students & 44 \\
White students & 75 \\
\hline Tht.doe.state.in.us/istep/2003/reports/Fo3_Disag_Sum.pdf
\end{tabular}


$\underline{\text { School Performance }}$

School-level data by urbanicity were available for the 2002 ISTEP+ and GQE administration

(Table O4). Approximately 43 percent of schools in Indiana were located in suburban areas; 32

percent were rural; and 25 percent were urban. Urban schools were significantly more likely to be high-poverty than were suburban and rural schools (55 percent, compared with 11 percent and 9 percent).

While the average pass rates of suburban and rural schools were relatively similar at all grades (13-percentage-point difference), at all grades, the average pass rates at suburban and rural schools were higher than those at urban schools. The achievement gap between urban schools and their suburban and rural counterparts ranged between 14 and 20 percentage points.

Table 04. Average School Performance on the 2001-02 $6^{\text {th }}$ and $8^{\text {th }}$-Grade ISTEP+ and the $10^{\text {th }}$-Grade GQE, by Urbanicity

\begin{tabular}{lc}
\hline & $\begin{array}{c}\text { Percentage } \\
\text { Passing }\end{array}$ \\
\hline 6 $^{\text {th }}$-Grade ISTEP+ & \\
Rural & 54 \\
Suburban & 57 \\
Urban & 40 \\
$\mathbf{8}^{\text {th }}$-Grade ISTEP+ & \\
Rural & 70 \\
Suburban & 72 \\
Urban & 56 \\
10 $^{\text {th-Grade GQE }}$ & \\
Rural & 70 \\
Suburban & 71 \\
Urban & 51 \\
\hline
\end{tabular}





\section{APPENDIX P. IOWA}

\section{State Assessment System}

The Iowa Tests of Basic Skills (ITBS) and the Iowa Tests of Educational Development (ITED) are the two norm-referenced achievement tests used as the primary academic assessments for Iowa students. The ITBS assesses K-8 students, and the ITED assesses 9-12 students. For the 200103 biennium, ${ }^{20}$ students were tested in the following grades and subjects:

- Grade 4 - ITBS Reading Comprehension and Mathematics

- Grade 8 - ITBS Reading Comprehension, Mathematics and Science

- Grade 11 - ITED Reading Comprehension, Mathematics and Science.

The state allows districts to administer the ITBS and ITED any time during the year, but recommends that the assessments be administered in the fall in order to allow teachers to use the assessment data to inform their instruction.

In addition, Iowa administers the Iowa Writing Assessment (IWA) to students in grades 3-12. However, only the ITBS/ITED scores are used for school-accountability purposes (for additional information regarding state accountability, see http://www.state.ia.us/ educate/ecese/nclb/assessments.html).

Iowa is expanding its assessment requirements to meet NCLB standards. Thus, the ITBS assessments will also be given in grades 3, 5, 6, and 7 starting in 2005-06. However, districts will be provided the option of administering a different assessment as long as they can demonstrate that the other tests are valid, reliable, aligned to the core content standards and benchmarks corresponding to the ITBS, and produce score scales that equate to the ITBS score scales (http://www.state.ia.us/educate/ecese/nclb/doc/annualletter.doc).

Iowa has established content standards for reading and mathematics. The state reports that these standards align with the ITBS and ITED. These standards include benchmarks for specific gradespans (3-5, 6-9, and 10-12). For reading, Iowa's content standard is that students must comprehend what they read in a variety of literary and informational texts. For example, benchmarks for grades 6-9 stipulate students can:

- understand stated information they have read

${ }^{20}$ Iowa combines scores for pairs of consecutive years for the biennium reporting. All Iowa schools have not always tested every year in each of the three grades used for reporting (4, 8, and 11); thus, annual data are subject to fluctuations due to these inconsistent annual testing patterns. Two-year averages help overcome this problem. 
- determine the meaning of new words from their context

- draw conclusions, make inferences, and deduce meaning

- infer traits, feelings, and motives of characters

- interpret information in new contexts

- interpret nonliteral language

- determine the main idea of a text

- identify the author's views or purpose and analyze text style or structure (http://www.state.ia.us/educate/ecese/nclb/doc/ccsb.html).

Further, to meet NCLB requirements, each local school district will be required to have standards and benchmarks or grade-level expectations at grades $3,4,5,6,7,8$, and 11 for reading and/or language arts, mathematics, and science. The state core-content standards and benchmarks must be incorporated into local standards and benchmarks.

\section{Test Format and Content}

For the purposes of examining what Iowa assessments reveal about adolescent literacy, the rest of the discussion will focus on the ITBS (grades 4 and 8) and ITED (grade 11) Reading Comprehension tests (additional information regarding ITBS and ITED can be found at http://www.sde.state.id.us/admin/standards/). ITBS and ITED Reading Comprehension assessments contain only multiple-choice/selected-response questions.

In grades 4 and 8 , the reading comprehension ITBS section presents students with a variety of tasks, including using print, context, and picture cues to identify unfamiliar words; completing sentences that tell about a picture by choosing a word for filling in a blank; and answering multiple-choice questions after reading a brief story. The questions associated with pictures and stories often ask students to make inferences or to generalize about what they have read.

On the reading comprehension ITED, students read five types of passages taken from previously published materials: a fiction or narrative passage; an article about a social studies topic; an article about a science topic; another nonfiction passage, which may be from a biography or memoir, from an essay, or from the general-interest domain; and a poem. The prose passages range in length from 440 to 650 words. The questions associated with each passage require students to demonstrate factual understanding, inference and interpretation, and analysis and generalization. The greatest emphasis is on questions that address the higher-level objectives of inferring, analyzing, and generalizing. 


\section{Achievement-Level Definitions}

Test results reported across the state are broken into three achievement levels: low, intermediate, and high. For accountability purposes, Iowa uses the national percentile rank scale from the ITBS and ITED: "low performance" is 1-40 percent; "intermediate" is 41-89 percent; and "high" is 9099 percent. Scores in the intermediate and high levels are proficient; low performance is less than proficient.

\section{Performance Results}

\section{Student Performance}

Iowa reports ISAT and ITED student-level data for all students and by disability status, Englishproficiency status, socioeconomic status, and race/ethnicity. ${ }^{21}$ Table P1 shows the reading comprehension performance results from the 2001-03 biennium for students in grades 4,8 , and 11 , broken out by these students' characteristics.

Table P1. Performance of $4^{\text {th- }}$ and $8^{\text {th }}$-Graders on 2001-o3 Reading Comprehension ITBS and $1^{\text {th }}$-Graders on the 2001-03 Reading Comprehension ITED, by Student Characteristics

\begin{tabular}{lccc}
\hline & $4^{\text {th }}$ Grade & $\mathbf{8}^{\text {th }}$ Grade & $\mathbf{1 1}^{\text {th }}$ Grade \\
\cline { 2 - 4 } & \multicolumn{2}{c}{ Percentage Proficient or Above } \\
\hline All students & 76 & 69 & 77 \\
Students with disabilities & 29 & 23 & 28 \\
Students without disabilities & 84 & 77 & 82 \\
English-language-learner students & 41 & 27 & 32 \\
English-proficient students & 77 & 70 & 78 \\
Economically disadvantaged students & 61 & 50 & 61 \\
Non-economically disadvantaged & 82 & 75 & 80 \\
students & & & \\
African American students & 48 & 36 & 50 \\
Hispanic students & 53 & 43 & 54 \\
White students & 79 & 72 & 79 \\
\hline http://www.state.ia.us/educate/fis/pre/coer/doc/stuo3.pdf & &
\end{tabular}

Source: http://www.state.ia.us/educate/fis/pre/coer/doc/stuo3.pdf

Overall, 76 percent of $4^{\text {th }}$-graders, 69 percent of $8^{\text {th }}$-graders, and 77 percent of $11^{\text {th }}$-graders

performed at the proficient level and higher. Across the grades, fewer than 30 percent of students

${ }^{21}$ Approximately 90 percent of students in Iowa are white; 4 percent are African American; and 4 percent are Hispanic. About 27 percent of students are eligible for the free and reduced-price lunch program; 3 percent are in limited-English-proficiency programs; and 15 percent have Individual Education Programs (IEPs). 
with disabilities reached the proficient level or above. In $4^{\text {th }}$ grade, 41 percent of students with limited-English proficiency reached the proficient level or above; 27 percent of $8^{\text {th }}$-graders and 32 percent of $11^{\text {th }}$-graders did so.

Economically disadvantaged students performed much lower than their advantaged peers. For example, 50 percent of economically disadvantaged $8^{\text {th }}$-graders reached the proficient level, compared with 75 percent of non-economically disadvantaged $8^{\text {th }}$-graders. There were also significant achievement gaps between the three main ethnic groups at all grade levels. White students outperformed African American students by 29-36 percentage points and Hispanics by 25-29 percentage points.

$\underline{\text { School Performance }}$

No school-level data were available for the 2002 administration of the ITBS or ITED in Iowa. 


\section{APPENDIX Q. KANSAS}

\section{State Assessment System}

The Kansas Assessment Program (KAP) is a criterion-referenced system that aims to link curriculum, standards, and assessments. Under KAP, students are tested in the following grades and subjects:

- Grade 4-Mathematics, Science

- $\quad$ Grade 5 - Reading

- Grade 6 - Social Studies

- Grade 7 - Mathematics, Science

- Grade 8 - Reading, Social Studies

- Grade 10 - Mathematics, Science

- $\quad$ Grade 11 - Reading, Social Studies.

In addition, every two years student in grades 5,8 , and 11 take a writing assessment. The next administration of the writing assessment will be in 2003-04. Kansas will be expanding its testing in mathematics and reading to grades 3-8 to meet the requirements of NCLB. While performance on the KAP assessments is used to hold schools accountable, these assessments currently do not carry consequences for individual students or teachers (for additional information regarding state accountability, see http://www.ksbe.state.ks.us/ Welcome.html).

Kansas has standards in ten content areas: communication arts (reading and writing), foreign language, environmental education, library media, mathematics, music, physical education, science, social studies, and visual arts. The general standards are broad statements outlining what students should know and be able to do at different grade levels, including benchmarks and indicators that further define the content standard. The indicators note whether the skill is to be assessed at the state or local level. Kansas is revising its curriculum standards so that they will map to the new assessments. Table Q1 lists the $8^{\text {th }}$-grade benchmarks and performance indicators for one of the reading standards as an example. 


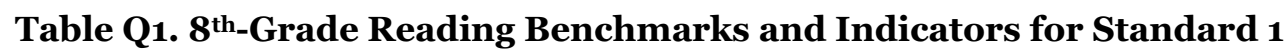

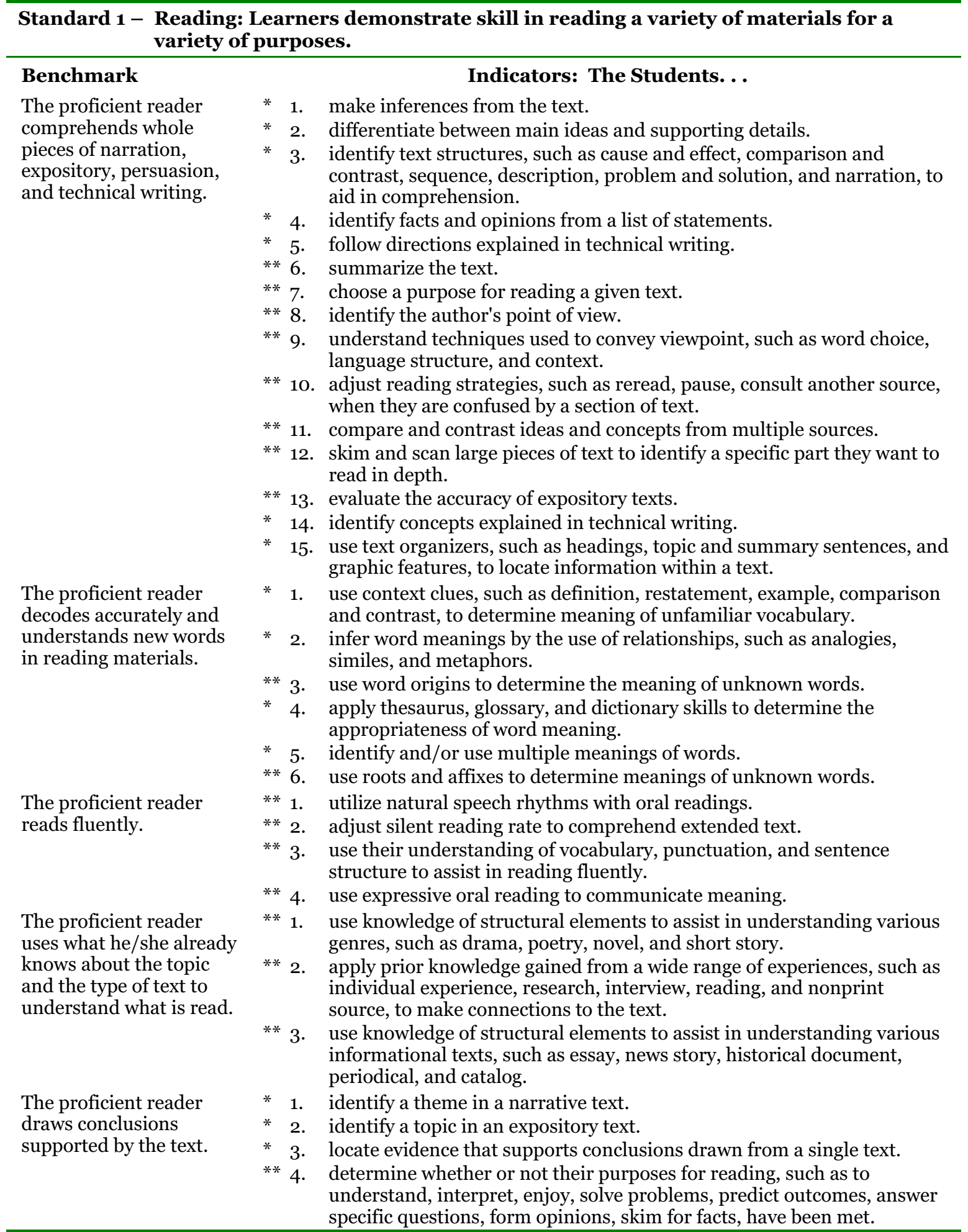

Notes: *Recommendation for state assessment; ** Recommendation for local assessment. 


\section{Test Format and Content}

For the purposes of examining what the Kansas Assessments reveal about adolescent literacy, we focus on the reading tests that students take in grades 5,8 , and $11 .{ }^{22}$

The Kansas reading assessments contain a maximum of 60 multiple-choice and yes/no questions that students answer in response to given reading passages. However, there are plans to add performance and other types of questions to the assessments in 2005-06. There is no set time limit for the test; however, four $45-$ minute sessions are recommended. The test includes narrative, expository, technical, and persuasive texts. Approximately 25 percent of the questions on the test come from each type of text (http://www.ksde.org/pre/assessmentpp_11_14.pdf).

\section{Achievement-Level Definitions}

Test results are reported on five general achievement levels that apply across subject areas and grade levels:

- Exemplary - Consistently demonstrates high performance. These students have welldeveloped ability to apply knowledge and skills in all situations. Their work is superior.

- Advanced - Frequently demonstrates high performance. These students effectively demonstrate the ability to apply knowledge and skills in most situations. They have a command of difficult, rigorous, and challenging material.

- Proficient - Demonstrates a mastery of core skills. These students exhibit competence in applying knowledge and skills in problem situations. They show evidence of solid performance.

- Basic - Shows partial mastery of fundamental skills. These students have a basic knowledge of content, but struggle in applying knowledge and skills in problem situations.

- Unsatisfactory - Demonstrates a lack of core knowledge, skills, and concepts. These students' command of the contents is very limited, and their ability to apply knowledge or demonstrate understanding is minimal (http://online.ksde.org/rcard/definitions.aspx?org_no=\%\&rpt_type=3).

Students scoring at or above the proficient level are considered to have met the academic requirements for proficiency under NCLB.

\footnotetext{
${ }^{22}$ We do not report on the writing assessment because administration and grading of this assessment differ across the state. As a result, test scores are not comparable across districts.
} 


\section{Performance Results}

\section{$\underline{\text { Student Performance }}$}

Kansas provides student-level data disaggregated by disability status, English-proficiency status, socioeconomic status, and racial/ethnic groups. ${ }^{23}$ Table Q2 shows the performance results from the 2003 reading assessment for students in grades 5,8 , and 11, disaggregated by these student characteristics.

Sixty-nine percent and 71 percent of $5^{\text {th }}$ - and $8^{\text {th }}$-graders passed the reading assessment, respectively, and 42-46 percent scored at the advanced level. The percentages of $11^{\text {th }}$-graders who scored at or above the proficient and advanced levels were somewhat lower, 61 percent and 36 percent, respectively. Nineteen percent of the $5^{\text {th-graders and } 11-12}$ percent of students in the higher grades scored at the exemplary level.

About 50 percent of students with disabilities performed at or above the proficient level in $5^{\text {th }}$ grade; however, the proportion of students with disabilities performing at this level was much lower in $8^{\text {th }}$ and $11^{\text {th }}$ grades -39 percent and 28 percent, respectively.

About half of English-language learners reached the proficient level in all grades; and 30-34 percent scored at the advanced or above level. The scores of English-language learners at the proficient and above level was less than the passing rate of all students by between 10 and 19 percentage points. However, the differences were much smaller at the advanced level and in the higher grades. For example, 29 percent of $5^{\text {th }}$-graders who were English-language learners scored at the advanced level compared with 46 percent of all students; at the $11^{\text {th }}$-grade level, 34 percent of English-language learners scored at the advanced level compared with 36 percent of all students-a difference of only 2 percentage points. At the exemplary level, we see a remarkable reversal, with English-language learners scoring higher than all students in the $8^{\text {th }}$ and $11^{\text {th }}$ grades. For example, 16 percent of English-language learners scored at the exemplary level compared with only 11 percent of all students in the $8^{\text {th }}$ grade. While we can hypothesize regarding what might be driving this unusually high performance, we are unable to know for certain.

\footnotetext{
23 Approximately 78 percent of students in Kansas are white; 10 percent are Hispanic; 9 percent are African American; and 2 percent are Asian/Pacific Islander. About one-third (34 percent) are eligible for the free and reduced-price lunch program; 4 percent are in limited-English-proficiency programs; and 13 percent have Individual Education Programs (IEPs).
} 
Table Q2. Performance of $5^{\text {th }}$, $8^{\text {th-}}$, and $1^{\text {th }}$-Graders on 2003 Reading Assessment, by Student Characteristics

\begin{tabular}{|c|c|c|c|}
\hline & $\begin{array}{l}\text { Proficient and } \\
\text { Above }\end{array}$ & $\begin{array}{l}\text { Advanced and } \\
\text { Above }\end{array}$ & Exemplary \\
\hline & \multicolumn{3}{|c|}{ Percentage } \\
\hline \multicolumn{4}{|l|}{$5^{\text {th }}$ Grade } \\
\hline All students & 69 & 46 & 19 \\
\hline Students without disabilities & 72 & 49 & 20 \\
\hline Students with disabilities & 49 & 29 & 12 \\
\hline $\begin{array}{l}\text { Students who are English-language } \\
\text { learners }\end{array}$ & 51 & 30 & 10 \\
\hline Economically disadvantaged students & 55 & 31 & 10 \\
\hline $\begin{array}{l}\text { Non-economically disadvantaged } \\
\text { students }\end{array}$ & 77 & 55 & 24 \\
\hline African American students & 45 & 24 & 7 \\
\hline Hispanic students & 53 & 28 & 9 \\
\hline White students & 74 & 51 & 21 \\
\hline \multicolumn{4}{|l|}{$8^{\text {th }}$ Grade } \\
\hline All students & 71 & 42 & 11 \\
\hline Students without disabilities & 75 & 45 & 11 \\
\hline Students with disabilities & 39 & 18 & 5 \\
\hline $\begin{array}{l}\text { Students who are English-language } \\
\text { learners }\end{array}$ & 53 & 33 & 16 \\
\hline Economically disadvantaged students & 55 & 26 & 6 \\
\hline $\begin{array}{l}\text { Non-economically disadvantaged } \\
\text { students }\end{array}$ & 78 & 50 & 13 \\
\hline African American students & 47 & 19 & 4 \\
\hline Hispanic students & 53 & 25 & 7 \\
\hline White students & 75 & 47 & 12 \\
\hline \multicolumn{4}{|l|}{$1^{\text {th }}$ Grade } \\
\hline All students & 61 & 36 & 12 \\
\hline Students without disabilities & 64 & 38 & 13 \\
\hline Students with disabilities & 28 & 15 & 6 \\
\hline $\begin{array}{l}\text { Students who are English-language } \\
\text { learners }\end{array}$ & 51 & 34 & 17 \\
\hline Economically disadvantaged students & 43 & 21 & 7 \\
\hline $\begin{array}{l}\text { Non-economically disadvantaged } \\
\text { students }\end{array}$ & 66 & 40 & 14 \\
\hline African American students & 33 & 15 & 3 \\
\hline Hispanic students & 42 & 22 & 8 \\
\hline White students & 64 & 39 & 13 \\
\hline
\end{tabular}

Source: http://online.ksde.org/rcard/ 
African American and Hispanic students tended to score well below white students at all grade levels, with differences ranging between 17 and 31 percentage points in the proportion of students scoring at or above the proficient and advanced achievement levels. Hispanic students scored higher than African American students by between 4 and 9 percentage points. For example, 42 percent of Hispanic $11^{\text {th }}$-graders passed the reading assessment compared with 33 percent of African American $11^{\text {th }}$-graders.

\section{$\underline{\text { School Performance }}$}

School-level data disaggregated by urbanicity are available for the 2002 Reading Assessment administration. Table Q3 provides information about school performance for rural, suburban, and urban schools. Approximately 58 percent of Kansas' schools are rural, 24 percent are suburban, and 18 percent are urban. Urban schools were far more likely to enroll high proportions of economically disadvantaged students. Fifty-two percent of urban schools were high-poverty schools, compared with 19 percent of rural schools and 8 percent of suburban schools.

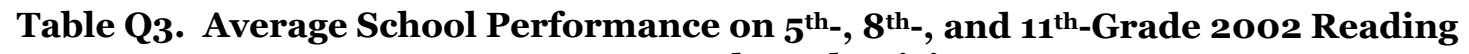
Assessment, by Urbanicity

\begin{tabular}{lccc}
\hline & $\begin{array}{c}\text { Satisfactory and } \\
\text { Above }\end{array}$ & $\begin{array}{c}\text { Proficient and } \\
\text { Above }\end{array}$ & Advanced \\
\cline { 2 - 4 } & \multicolumn{3}{c}{ Average Percentage } \\
\hline $\mathbf{5}^{\text {th Grade }}$ & 38 & 13 \\
Rural schools & 62 & 46 & 18 \\
Suburban schools & 69 & 33 & 12 \\
Urban Schools & 55 & & 8 \\
$\mathbf{8}^{\text {th Grade }}$ & & 37 & 11 \\
Rural schools & 67 & 41 & 7 \\
Suburban schools & 70 & 30 & \\
Urban schools & 56 & & 9 \\
$\mathbf{1 1}^{\text {th }}$ Grade & & 29 & 10 \\
Rural schools & 54 & 32 & 7 \\
Suburban schools & 57 & 22 & \\
Urban schools & 41 & & \\
\hline
\end{tabular}

Note that the achievement-level classifications for the school-level urbanicity data are different from those for the student-level data because the achievement-level names changed from the 2001-02 to the 2002-03 assessments. In 2001-02, the five achievement levels were as follows: 
Below Basic, Basic, Satisfactory, Proficient, and Advanced, compared with Unsatisfactory, Basic, Proficient, Advanced, and Exemplary for the 2002-03 school year.

The average percentage of students scoring at the satisfactory level declined across grade levels and was much lower in urban schools than in rural or suburban schools. For example, on average, 62-69 percent of students in rural and suburban schools scored at the satisfactory level in the $5^{\text {th }}$ grade compared with 55 percent of students in urban schools; at the $11^{\text {th }}$ grade, the average proportions scoring at the satisfactory level declined to 54-57 percent in rural and suburban schools and 41 percent in urban schools. The difference in the average proportion of students scoring at the proficient level in urban versus suburban schools ranged from 10 to 13 percentage points. Rural schools also scored lower than suburban schools at the satisfactory and proficient levels in all three grades, with differences ranging between 3 and 8 percentage points. The proportions of students scoring at the exemplary level declined between $5^{\text {th }}$ and $8^{\text {th }}$ grades but remained fairly stable between grades 8 and 11. 


\section{APPENDIX R. KENTUCKY}

\section{State Assessment System}

The Commonwealth Accountability Testing System (CATS) is designed to improve teaching and student learning in Kentucky. CATS includes the Kentucky Core Content Test (KCCT), a nationally norm-referenced test, the Comprehensive Test of Basic Skills (CTBS)/ 5 Survey Edition, writing portfolios, on-demand writing assessments, and the alternate portfolio for students with severe to profound disabilities. Specifically, students take the following tests:

- CTBS in reading, language arts, and mathematics in grades 3, 6, and 9

- $\quad$ KCCT in reading and science in grades 4,7 , and 10

- KCCT in mathematics, social studies, and arts and humanities in grades 5, 8, and 11

- KCCT in practical living and vocational studies in grades 5,8 , and 10

- $\quad$ On-demand writing assessment in grades 4, 7, and 12.

In addition, students submit writing portfolios in grades 4, 7, and 12. The CTBS, KCCT, and ondemand writing test are used for state accountability purposes in Kentucky. To fulfill the testing requirements under NCLB, Kentucky plans to administer an augmented version of the CTBS to students in grades and subjects not covered by the KCCT (for additional information regarding state accountability, see http://www.education.ky.gov/KDE/

Administrative+Resources/Testing+and+Reporting+/default.htm).

The goal of the KCCT24 is to measure students' performance against the state standards.

Kentucky outlines six general learning goals that are further defined by academic indicators.

Each academic indicator has an attached list of demonstrators at the elementary, middle, and high school levels that describe how students would demonstrate achieving the academic indicator. In addition, Kentucky has developed a program of studies for communication arts (reading and writing), mathematics, science, social studies, arts and humanities, and practical living and vocational studies that further defines content standards and describes skills that students should acquire as they progress through primary, intermediate, middle, and high school levels.

(http://www.education.ky.gov/KDE/Instructional+Resources/Curriculum+Documents+and+Res ources/default.htm)

\footnotetext{
24 A matrix design is used to ensure that the test provides complete coverage of the Core Content each year. Six different, equivalent test forms are administered each year, which limits test time for students and provides maximum instructional program feedback to schools.
} 


\section{Test Format and Content}

To see what the KCCT reveals about adolescent literacy, the rest of the discussion focuses on the reading tests students take in grades 4,7 , and 10 and on the on-demand writing assessments students take in grades 4, 7, and 12 (for additional information regarding assessment content, see http://www.education.ky.gov/NR/rdonlyres/

epspsvkn4t66ypkz2oi2bp7dv7dzmqksjxjqxip7vybag6csqswfwd4x405zvrw33nbsutbaia6phqg3x2c 47rfcy4c/2002TestinginKyPt1.pdf).

The reading assessment is untimed and includes 24 multiple-choice items and six open-response questions (limited to one-page responses) that follow reading passages. Students are tested on reading skills, literary reading, persuasive reading, and practical or workplace reading. Table R1 outlines the grade $7 \mathrm{KCCT}$ reading assessment content related to these reading areas, as an example.

Reading skills are tested more heavily in the early grades; reading for information gets more weight in the later grades.

The on-demand writing assessment requires students to produce one response to a prompt, which defines an audience, the purpose, and the writing form (narrative, persuasive, or descriptive). Two writing prompts are provided in each test booklet, and students respond to the prompt of their choice. Grade 4 students respond in the form of a letter or article; grade 7 students respond by writing a letter, article, or editorial; and grade 12 students write a letter, article, editorial, or speech. 
Table R1. KCCT Reading Assessment Content for $7^{\text {th }}$ Grade

\begin{tabular}{|c|c|}
\hline & Description \\
\hline $\begin{array}{l}\text { Reading skills } \\
\text { (assessed across } \\
\text { all reading } \\
\text { types) }\end{array}$ & $\begin{array}{l}\text { Reading Skills enable students to comprehend all types of reading materials. } \\
\text { - Identify an author's purpose in literary, informational, persuasive, and practical/workplace } \\
\text { - } \text { materials. } \\
\text { - Ise knowledge of synonyms, antonyms, and homonyms to comprehend a passage. } \\
\text { - } \quad \text { Know the meanings of common prefixes and suffixes to comprehend unfamiliar words. } \\
\text { - Formulate questions to guide reading. } \\
\text { - Scan to find key information. } \\
\text { - Skim to get the general meaning of a passage. } \\
\text { - Make predictions, draw conclusions, and make generalizations about what is read. } \\
\text { - Reflect on and evaluate what is read. } \\
\text { - Connect information from a passage to students' lives and/or real-world issues. }\end{array}$ \\
\hline Literature & $\begin{array}{l}\text { Literary Reading includes whole texts and excerpts from materials such as short stories, novels, essays, poetry, } \\
\text { plays and scripts. The reading materials represent various historical and cultural perspectives. } \\
\text { - Explain the meaning of a passage taken from texts appropriate for middle-level students. } \\
\text { - Identify characteristics of short stories, novels, poetry, and plays. } \\
\text { - Describe literary elements (e.g., characterization, setting, plot, theme, point of view) in a passage. } \\
\text { - } \quad \text { Analyze the relationship between events in a story and a character's behavior. } \\
\text { - Explain how a conflict in a passage is resolved. } \\
\text { - Identify literary devices such as foreshadowing, imagery, and figurative language (e.g., similes, } \\
\text { metaphors, personification, hyperbole). }\end{array}$ \\
\hline Information & $\begin{array}{l}\text { Informational Reading includes whole texts and excerpts from materials such as journals, magazines, } \\
\text { newspaper articles, letters, brochures, reference materials, essays, nonfiction books, and electronic texts. } \\
\text { - Use text features (e.g., lists, charts, graphs, tables of contents, indexes, glossaries, captions, } \\
\text { diagrams, headings) to understand a passage. } \\
\text { - Apply knowledge of organizational patterns (e.g., cause and effect, comparison, contrast, } \\
\text { - } \quad \text { Idequence) to understand a passage. } \\
\text { - Summarize information from a passage. }\end{array}$ \\
\hline Persuasion & $\begin{array}{l}\text { Persuasive Reading includes whole texts and excerpts from materials such as magazine and newspaper } \\
\text { articles, brochures, letters, proposals, speeches, editorials, electronic texts, essays, opinion columns, and } \\
\text { advertisements. } \\
\text { - Distinguish between informative and persuasive passages. } \\
\text { - Identify an author's opinion about a subject. } \\
\text { - Apply knowledge of organizational patterns (e.g., cause and effect, comparison, contrast, } \\
\text { - } \text { sequence) to understand a passage. } \\
\text { - Idistinguish between fact and opinion. } \\
\text { - Identify the argument and supporting evidence. } \\
\text { - } \text { Identify commonly used persuasive techniques (e.g., expert opinion, statistics, testimonial, } \\
\text { Identify bias and/or misinformation. }\end{array}$ \\
\hline $\begin{array}{l}\text { Practical or } \\
\text { workplace }\end{array}$ & $\begin{array}{l}\text { Practical/Workplace Reading includes whole texts and excerpts from materials such as articles, letters, } \\
\text { memos, brochures, electronic texts, warranties, recipes, forms, consumer texts, manuals, schedules, and } \\
\text { directions. } \\
\text { - Locate and apply information for a specific purpose (e.g., following directions, completing a task). } \\
\text { - Identify the sequence of activities needed to carry out a procedure. } \\
\text { - } \quad \text { Explain how organizational patterns and/or text features (e.g., pictures, charts, graphs, format) } \\
\text { relate to the content of a practical/workplace passage. } \\
\text { - Interpret the meaning of specialized vocabulary. }\end{array}$ \\
\hline
\end{tabular}


Source:

http://www.education.ky.gov/NR/rdonlyres/epspsvkn4t66ypkz2oi2bp7dv7dzmqksjxjqxip7vybag6csqswfwd 4x405zvrw33nbsutbaia6phqg3x2c47rfcy4c/2002TestinginKyPt1.pdf

\section{Achievement-Level Definitions}

Students are categorized into one of four achievement levels according to their test results:

- $\quad$ Novice

- Apprentice

- Proficient

- Distinguished

Students scoring at or above the proficient level are considered to have met proficiency requirements under NCLB.

\section{Performance Results}

\section{$\underline{\text { Student Performance }}$}

Table R2 shows student performance on the 2002-03 reading assessment for students in grades 4, 7, and 10, and Table $\mathrm{R} 3$ shows student performance on the 2002-03 writing assessment for students disaggregated by disability status, socioeconomic status, and racial/ethnic groups. ${ }^{25}$ Looking first at the reading assessment, we find that the percentage of students achieving proficiency falls sharply across grades. For example, 63 percent of $4^{\text {th-graders scored }}$ at or above the proficient level on the reading assessment, compared with 57 percent of $7^{\text {th }}$-graders and only 31 percent of the $10^{\text {th }}$-graders. Few reached the distinguished level ( $7-8$ percent) in any grade. Among students with disabilities, 43 percent scored at the proficient level in the $4^{\text {th }}$ grade, 19 percent in $7^{\text {th }}$ grade, and 8 percent in the $10^{\text {th }}$ grade.

There was a 23-26-percentage-point gap in the proficiency levels of economically disadvantaged students and those not economically disadvantaged in the three grades, but a much smaller gap of between 6 and 8 percentage points at the distinguished level. The differences between African American and white students scoring at the proficient level ranged from 18 percentage points in the $10^{\text {th }}$ grade to 25 percentage points in the $7^{\text {th }}$ grade. Again, the differences in the proportions achieving at the distinguished level were considerably smaller-4-6 percentage points.

25 Approximately 88 percent of students in Kentucky are white, and 10 percent are African American. No other racial/ethnic group comprises 2 percent of the student population. Almost half of students (49 percent) are eligible for the free and reduced-price lunch program; less than 1 percent are in limited-Englishproficiency programs; and 15 percent have Individual Education Programs (IEPs). 


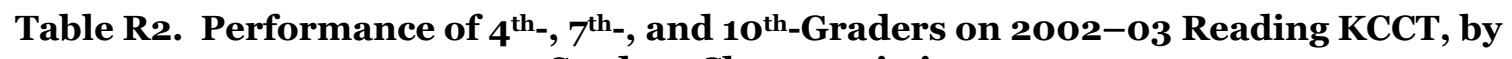
Student Characteristics

\begin{tabular}{|c|c|c|}
\hline & $\begin{array}{c}\text { Proficient and } \\
\text { Above }\end{array}$ & Distinguished \\
\hline & \multicolumn{2}{|c|}{ Percentage } \\
\hline \multicolumn{3}{|l|}{$4^{\text {th }}$ Grade } \\
\hline All students & 63 & 7 \\
\hline Students with disabilities & 43 & 6 \\
\hline Students without disabilities & 65 & 7 \\
\hline Economically disadvantaged students & 51 & 4 \\
\hline Non-economically disadvantaged students & 74 & 10 \\
\hline African American students & 43 & 3 \\
\hline White students & 65 & 7 \\
\hline \multicolumn{3}{|l|}{$7^{\text {th }}$ Grade } \\
\hline All students & 57 & 7 \\
\hline Students with disabilities & 19 & 2 \\
\hline Students without disabilities & 63 & 8 \\
\hline Economically disadvantaged students & 43 & 3 \\
\hline Non-economically disadvantaged students & 69 & 11 \\
\hline African American students & 35 & 2 \\
\hline White students & 60 & 8 \\
\hline \multicolumn{3}{|l|}{$1^{\text {th }}$ Grade } \\
\hline All students & 31 & 8 \\
\hline Students with disabilities & 8 & 3 \\
\hline Students without disabilities & 34 & 9 \\
\hline Economically disadvantaged students & 16 & 3 \\
\hline Non-economically disadvantaged students & 39 & 11 \\
\hline African American students & 15 & 3 \\
\hline White students & 33 & 9 \\
\hline
\end{tabular}

Source: http://apps.kde.state.ky.us/secure_cats_reports_03/index.cfm?action=display_regionstate.

Scores on the writing assessment were much lower than on the reading assessment, with only 9 percent of $4^{\text {th }}$-graders and 17-18 percent of $7^{\text {th }}$ - and $12^{\text {th }}$-graders scoring at or above the proficient level. Overall, only 1 percent of $4^{\text {th }}$-graders and none of the $7^{\text {th }}$ or $12^{\text {th }}$-graders reached the distinguished level. The gap between the proficiency levels of economically disadvantaged students and others was 5 percentage points in the $4^{\text {th }}$ grade, 12 percentage points in the $7^{\text {th }}$ grade, and 9 percentage points in the $12^{\text {th }}$ grade. The differences between African American and white students were much smaller than those seen earlier in reading, ranging from 3-6 percentage points. 
Table R3. Performance of $4^{\text {th-, }} 7^{\text {th- }}$, and $12^{\text {th }}$-Graders on 2002-03 On-Demand Writing KCCT, by Student Characteristics

\begin{tabular}{|c|c|c|}
\hline & $\begin{array}{l}\text { Proficient and } \\
\text { Above }\end{array}$ & Distinguished \\
\hline & \multicolumn{2}{|c|}{ Percentage } \\
\hline \multicolumn{3}{|l|}{$4^{\text {th }}$ Grade } \\
\hline All students & 9 & 1 \\
\hline Students with disabilities & 11 & 3 \\
\hline Students without disabilities & 8 & o \\
\hline Economically disadvantaged students & 6 & 1 \\
\hline $\begin{array}{l}\text { Non-economically disadvantaged } \\
\text { students }\end{array}$ & 11 & 1 \\
\hline African American students & 6 & 1 \\
\hline White students & 9 & 1 \\
\hline \multicolumn{3}{|l|}{$7^{\text {th }}$ Grade } \\
\hline All students & 17 & o \\
\hline Students with disabilities & 7 & 2 \\
\hline Students without disabilities & 19 & o \\
\hline Economically disadvantaged students & 11 & o \\
\hline $\begin{array}{l}\text { Non-economically disadvantaged } \\
\text { students }\end{array}$ & 23 & o \\
\hline African American students & 12 & o \\
\hline White students & 18 & o \\
\hline \multicolumn{3}{|l|}{$1^{\text {th }}$ Grade } \\
\hline All students & 18 & o \\
\hline Students with disabilities & 9 & 4 \\
\hline Students without disabilities & 20 & o \\
\hline Economically disadvantaged students & 12 & 1 \\
\hline $\begin{array}{l}\text { Non-economically disadvantaged } \\
\text { students }\end{array}$ & 21 & o \\
\hline African American students & 13 & 1 \\
\hline White students & 19 & o \\
\hline
\end{tabular}

Source: $\overline{\text { http://apps.kde.state.ky.us/secure_cats_reports_03/index.cfm?action=display_regionstate. }}$

\section{$\underline{\text { School Performance }}$}

School-level data on urbanicity are available for the 2002 administration of the reading KCCT.

Data on the writing assessment were not available. Table R4 reports the average school performance of rural, suburban, and urban schools. Approximately 58 percent of schools in Kentucky are rural, 28 percent are suburban, and 12 percent are urban. Over half of rural schools and urban schools were high-poverty schools (69 percent and 55 percent, respectively), while a little over a third ( 36 percent) of suburban schools were high-poverty schools. 
There is little difference (between 1 and 3 percentage points) in the average proficiency levels of students in rural, suburban, and urban schools at both the proficient and distinguished levels for grades 4 and 7.

Table R4. Average School Performance on 2001-02 $4^{\text {th }}$, $7^{\text {th }}$, and $10^{\text {th }}-$ Grade KCCT Reading Assessment, by Urbanicity

\begin{tabular}{|c|c|c|}
\hline & $\begin{array}{c}\text { Proficient and } \\
\text { Above }\end{array}$ & Distinguished \\
\hline & \multicolumn{2}{|c|}{ Average Percentage } \\
\hline \multicolumn{3}{|l|}{$4^{\text {th }}$ Grade } \\
\hline Rural schools & 63 & 7 \\
\hline Suburban schools & 65 & 8 \\
\hline Urban schools & 63 & 7 \\
\hline \multicolumn{3}{|l|}{$7^{\text {th }}$ Grade } \\
\hline Rural schools & 56 & 6 \\
\hline Suburban schools & 59 & 7 \\
\hline Urban schools & 59 & 8 \\
\hline \multicolumn{3}{|l|}{$1^{\text {th }}$ Grade } \\
\hline Rural schools & 26 & 6 \\
\hline Suburban schools & 30 & 8 \\
\hline Urban schools & $*$ & * \\
\hline
\end{tabular}

Note: " Grade 10 results for urban schools are not reported because of the small sample size. 


\section{APPENDIX S. LOUISIANA}

\section{State Assessment System}

The Louisiana School and District Accountability System is a standards-based accountability system that aims to link standards, curriculum, and assessments and carries consequences for schools and students. The Louisiana Educational Assessment Program for the $21^{\text {st }}$ Century (LEAP 21) and the Graduation Exit Examination for the 21 ${ }^{\text {st }}$ Century (GEE 21) make up Louisiana's Criterion-Referenced Testing (CRT) program. For the 2003-04 school year, students are tested in the following grades and subjects:

- Grade 4 - LEAP 21 English Language Arts (ELA), Mathematics, Science, and Social Studies

- $\quad$ Grade 8 - LEAP 21 ELA, Mathematics, Science, and Social Studies

- Grade 10 - GEE 21 ELA and Mathematics

- Grade 11 - GEE 21 Science and Social Studies

The LEAP 21 and GEE 21 are high-stakes assessments that carry consequences for students (e.g., students must pass the exams to be promoted from grades 4 to 5 and 8 to $9^{26}$ and to graduate ${ }^{27}$ ) and for schools (for additional information on state accountability, see http://www.doe.state.la.us/lde/ssa/home.html).

The LEAP 21 and GEE 21 are intended to measure student progress toward mastering Louisiana's content standards. Louisiana approved standards in English language arts, mathematics, science, social studies, arts, health, physical education, and foreign languages in May 1997. In March 2004, the Louisiana Department of Education revised its English language arts standards for curriculum development. Louisiana has defined five foundation skills that apply to students in all disciplines (see http://www.doe.state.la.us/lde/uploads/4331.doc). There are seven ELA content standards:

\footnotetext{
${ }^{26}$ Starting in spring 2000, $4^{\text {th }}$ - and $8^{\text {th }}$-grade students could not be promoted if they did not receive an Approaching Basic or above score on both the LEAP 21 ELA and Mathematics tests. Starting in spring 2004, $4^{\text {th }}$-grade students must score Basic or above on either the ELA or the Mathematics test and Approaching Basic or above on the other test to advance to the $5^{\text {th }}$ grade. Students in the $8^{\text {th }}$ grade must achieve Approaching Basic or above on both the ELA and Mathematics LEAP 21 tests until the 2005-2006 school year, at which time they must score a combination of at least Basic or above and Approaching Basic or above on both the ELA and Mathematics test. Students that fail these tests have the opportunity to take intensive summer remediation and to retest after remediation ends.

${ }^{27} \mathrm{High}$ school students take the GEE 21 and have test-score requirements to graduate. To be eligible to graduate and obtain a standard high school diploma, students who were first-time $10^{\text {th }}$-graders in 20002001 were required to score Approaching Basic or above on only the ELA and Mathematics tests, while firsttime $10^{\text {th }}$-graders in 2001-2002 and thereafter are required to score Approaching Basic or above on the ELA and Mathematics tests and on either the Social Studies or Science test. If they fail, students are given additional chances to retake the test in the summer and fall.
} 
1. Students read, comprehend, and respond to a range of materials, using a variety of strategies for different purposes.

2. Students write competently for a variety of purposes and audiences.

3. Students communicate using Standard English grammar, usage, sentence structure, punctuation, capitalization, spelling, and handwriting.

4. Students demonstrate competence in speaking and listening as tools for learning and communicating.

5. Students locate, select, and synthesize information from a variety of texts, media, references, and technological sources to acquire and communicate knowledge.

6. Students read, analyze, and respond to literature as a record of life experiences.

7. Students apply reasoning and problem-solving skills to reading, writing, speaking, listening, viewing, and visually representing (http://www.doe.state.la.us/lde/uploads/4331.doc).

These standards are further defined by grade-span benchmarks. Table $\mathrm{S} 1$ contains the grade $5^{-8}$ benchmarks for standard 1, as an example.

Table S1. Grades 5-8 English Language Arts Benchmarks for Content Standard 1

Standard One: Students read, comprehend, and respond to a range of materials, using a variety of strategies for different purposes.

- Using knowledge of word meaning and developing basic and technical vocabulary using various strategies (e.g., context clues, idioms, affixes, etymology, multiple-meaning words).

- Using the conventions of print (e.g., left-to-right directionality, top-to-bottom, one-to-one matching, sentence framing). Conventions of print are enhanced through application across grade levels.

- Adjusting speed of reading (e.g., appropriate pacing, intonation, expression) to suit the difficulty of materials and the purpose for reading (e.g., enjoying, learning, problem solving). Speed of reading is enhanced through application across grade levels.

- Interpreting story elements (e.g., mood, tone, style) and literary devices (e.g., flashback, metaphor, foreshadowing, symbolism) within a selection.

- Reading, comprehending, and responding to written, spoken, and visual texts in extended passages (e.g., ranging from 500-1,000 words).

- Interpreting (e.g., paraphrasing, comparing, contrasting) texts with supportive explanations to generate connections to real-life situations and other texts (e.g., business, technical, scientific).

- Adjusting reading rate according to texts and purposes for reading (e.g., problem solving, evaluating, researching).

Source: http://www.doe.state.la.us/lde/uploads/4331.doc

\section{Test Format and Content}

For the purposes of examining trends in adolescent literacy, the rest of the discussion will focus on the ELA tests that students take in grades 4,8 , and 10 (see

http://www.doe.state.la.us/lde/uploads/3779.pdf for additional assessment information).

The LEAP 21 and GEE 21 assessments contain four types of questions: 
- Multiple-choice questions

- Short-answer questions, which require students to write a word or phrase or to create a oneor two-sentence response

- Open-response questions, requiring students to create a one- or two-paragraph response in writing

- Writing prompts, requiring students to respond by creating a written composition.

The LEAP 21 and GEE 21 ELA tests contain four parts: writing, using information resources, reading and responding, and proofreading:

- The writing section requires students to produce one composition about an assigned topic. Grade 4 students are given a minimum of one hour to write either a narrative or descriptive essay, and grade 8 students are given a minimum of an hour and a half to write one narrative or expository essay. The GEE 21 allocates a minimum of 90 minutes for $10^{\text {th }}$-grade students to write a persuasive or expository essay. This is the only test session during which students are allowed to use dictionaries and thesauruses.

- The using information resources section requires students to locate, evaluate, and synthesize information from four to six texts, media, references, or technological sources to answer multiple-choice and short-answer questions. Fourth-grade students are given no more than 40 minutes to answer five multiple-choice and two short-answer items. Eighth-grade students are given no more than 40 minutes to answer eight multiple-choice and shortanswer questions. Tenth-grade students are given 40 minutes to answer five multiple-choice questions and two short-answer questions.

- The reading and responding section requires students to read, compare, and contrast four grade-appropriate, complete, authentic reading passages (fiction, nonfiction, poem, and a fourth passage of any genre or form) and respond to multiple-choice and short-answer questions. Grade 4 students are given at least one hour to complete 20 multiple-choice questions and eight short-answer items. Grade 4 students have fiction passages of 450-1000 words and nonfiction passages of 450-850 words. Poems and the fourth passage may be no more than 450 words. Grade 8 students are given a minimum of an hour and a half to answer 20 multiple-choice questions and eight short-answer items and write one essay in response to two reading passages. Grade 8 students have fiction and nonfiction passages of 500-1000 words and a maximum 500-word poem and fourth passages. Grade 10 students are given 90 minutes to answer 20 multiple-choice, eight short-answer, and one essay question. Grade 10 fiction and nonfiction passages are 600-1500 words, and the final two passages (e.g. poems, letter to editor) are a maximum of 600 words each. 
- The proofreading section utilizes a multiple-choice format to test student's ability to read a text (letter, narrative, editorial, or expository piece) and correct grammar, usage, and mechanics errors. The grade 4 reading passage is $100-150$ words long; the grade 8 and grade 10 students' reading passage is $100-250$ words. Grade 4,8 , and 10 students are given a minimum of 30 minutes to answer multiple-choice questions pertaining to eight sentences with underlined items.

The reading and responding section is weighted most heavily-55-58 percent of the total score. Writing accounts for 17-18 percent of the total score, while the proofreading and using information resources sections account for 12-14 percent of the score each.

\section{Achievement-Level Definitions}

Test results reported across the state are broken into five achievement levels:

- Advanced - Superior performance beyond the proficient level of mastery

- Mastery (exceeding the standard) - Competency over challenging subject matter and is well prepared for the next level of schooling

- Basic (meeting the standard) - Only fundamental knowledge and skills needed for the next level of schooling

- Approaching Basic (approaching the standard) - Only partially demonstrated the fundamental knowledge and skills needed for the next level of schooling

- Unsatisfactory - Did not demonstrate fundamental knowledge and skills needed for the next level of schooling.

Students scoring at or above the basic level on the LEAP are considered to have met the academic requirements under NCLB. However, students need to score only at or above the approaching basic level on the GEE21 in order to graduate.

\section{Performance Results}

\section{$\underline{\text { Student Performance }}$}

Table S2 shows the spring 2003 ELA LEAP performance results for students in grades 4 and 8, disaggregated by disability status and race/ethnicity; student-level data by poverty were not available. ${ }^{28}$

\footnotetext{
${ }^{28}$ Approximately 49 percent of students in Louisiana are white and 48 percent are African American. No other racial/ethnic group comprises 2 percent of the population. About 59 percent of students are eligible for the free and reduced-price lunch program; less than 2 percent are in limited-English-proficiency programs; and 13 percent have Individual Education Programs (IEPs).
} 
Fifty-nine percent of $4^{\text {th }}$-grade students and 52 percent of $8^{\text {th }}$-grade students performed at or above the basic level on the English language arts LEAP21. About 14-15 percent achieved at or above the mastery level, and only 1 percent reached the advanced level. Only 30 percent of $4^{\text {th }}$ grade and 13 percent of $8^{\text {th }}$-grade special education students achieved at or above the basic level, and only 2-4 percent reached the mastery level.

There was a large achievement gap at both grade levels. White students scored 29-38 percentage points higher than African American students at the basic level and 17-19 percentage points higher at the mastery level.

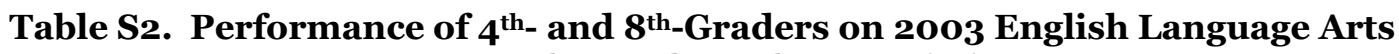
LEAP21, by Student Characteristics

\begin{tabular}{lccc}
\hline & $\begin{array}{c}\text { Basic and } \\
\text { Higher }\end{array}$ & $\begin{array}{c}\text { Mastery and } \\
\text { Higher }\end{array}$ & Advanced \\
\cline { 2 - 4 } & & Percentage & \\
\hline $\mathbf{4}^{\text {th }}$ Grade & 59 & 14 & 1 \\
All students & 67 & 17 & 1 \\
General education students & 30 & 4 & 0 \\
Special education students & 45 & 6 & 0 \\
African American students & 74 & 23 & 2 \\
White students & 52 & & 1 \\
$\mathbf{8}^{\text {th }}$ Grade & 58 & 15 & 1 \\
All students & 13 & 2 & 0 \\
General education students & 32 & 5 & 0 \\
Special education students & 70 & 24 & 1 \\
African American students & & & \\
White students & & &
\end{tabular}

Table S3 presents 2003 ELA GEE 21 results for $10^{\text {th }}$-graders. To pass the test for graduation, students must score at or above the approaching basic level. Seventy-one percent of all students passed the assessment upon the first attempt. However, initial pass rates were very low for special education students (18 percent), and African American students had much lower pass rates than did white students ( 55 percent compared with 87 percent). About 47 percent of all students achieved at or above basic, 10 percent achieved at or above mastery, and o percent reached the advanced level. 
Table S3. Performance of $10^{\text {th }}$-Graders on 2003 English Language Arts GEE 21, by Student Characteristics

\begin{tabular}{lcccc}
\hline & $\begin{array}{c}\text { Approaching } \\
\text { Basic and } \\
\text { Above }\end{array}$ & $\begin{array}{c}\text { Basic and } \\
\text { Above }\end{array}$ & $\begin{array}{c}\text { Mastery and } \\
\text { Above }\end{array}$ & Advanced \\
\cline { 2 - 5 } & \multicolumn{4}{c}{ Percentage } \\
\hline $\mathbf{1 0}^{\text {th }}$ Grade & 71 & 47 & 10 & 0 \\
All students & 79 & 54 & 12 & 1 \\
General education students & 18 & 6 & 1 & 0 \\
Special education students & 55 & 27 & 3 & 0 \\
African American students & 87 & 66 & 17 & 1 \\
White students & & & \\
\hline
\end{tabular}

Source: http://www.doe.state.la.us/lde/uploads/3779.pdf

\section{$\underline{\text { School Performance }}$}

Table S4 presents school-level data for the 2002 administration of the English language arts LEAP 21 and GEE 21 for urbanicity and for poverty (since these data were not available at the student level). Forty percent of schools in Louisiana were suburban, 32 percent were rural, and 28 percent were urban. Approximately 70 percent of schools were high-poverty schools.

Suburban schools were slightly less likely to serve high proportions of economically disadvantaged students than were urban and suburban schools (62 percent compared with 75 percent and 78 percent, respectively).

At all grade levels, high-poverty schools' performance was lower than that of the low- and medium-poverty schools -19 percentage points lower for $8^{\text {th }}$ and $11^{\text {th }}$ grades and 25 percentage points lower for $4^{\text {th }}$ grade at or above the basic level.

Suburban schools outperformed rural and urban schools at all grades and achievement levels, except at the advanced level in $10^{\text {th }}$ grade. However, rural schools also outperformed urban schools at the basic and above level. For instance, at grade 8, an average of 50 percent of students in suburban schools scored at or above the basic level compared with 49 percent in rural schools and 29 percent in urban schools. 
Table S4: Average School Performance on 2001-02 $4^{\text {th- }}$ and $8^{\text {th }}$-Grade English

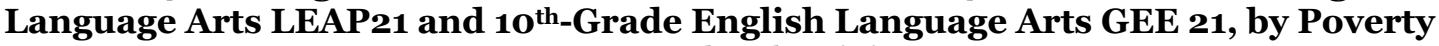
Status and Urbanicity

\begin{tabular}{lccc}
\hline & $\begin{array}{c}\text { Basic and } \\
\text { Above }\end{array}$ & $\begin{array}{c}\text { Mastery and } \\
\text { Above }\end{array}$ & Advanced \\
\cline { 2 - 4 } & & & Average Percentage \\
\hline $\mathbf{4}^{\text {th }}$ Grade & 52 & 14 & 2 \\
High-poverty schools & 77 & 32 & 7 \\
Low- and medium-poverty schools & 58 & 17 & 2 \\
Rural schools & 64 & 21 & 4 \\
Suburban schools & 48 & 15 & 3 \\
Urban schools & & & 1 \\
$\mathbf{8}^{\text {th Grade }}$ & 38 & 12 & 2 \\
High-poverty schools & 57 & 22 & 1 \\
Low- and medium-poverty schools & 49 & 16 & 2 \\
Rural schools & 50 & 17 & 1 \\
Suburban schools & 29 & 10 & \\
Urban schools & & & 1 \\
10 & & & \\
High-poverty schools & 42 & 17 & 2 \\
Low- and medium-poverty schools & 61 & 12 & 1 \\
Rural schools & 53 & 14 & 1 \\
Suburban schools & 56 & 12 & \\
Urban schools & 40 & & 1 \\
\hline
\end{tabular}





\section{APPENDIX T. MAINE}

\section{State Assessment System}

As part of Maine's Comprehensive Assessment System (MeCAS), which includes local- and statelevel measures to ensure accountability, the Maine Education Assessment (MEA) tests students in grades 4, 8, and 11 in reading, writing, mathematics, and science/technology. ${ }^{29}$ Maine is working to expand its assessment system so that it meets the federal requirement for all students to be tested in grades 3-8 in reading and mathematics by 2005-06. While the MEA carries consequences under state and federal accountability systems for schools, it does not have consequences for students or teachers (for more information regarding the state accountability system, see http://www.maine.gov/education/lsalt/compassess.htm).

The MEA is intended to measure student progress toward mastery of the state content standards. Maine has established standards in English language arts, health and physical education, mathematics, science and technology, social studies, career preparation, modern and classical languages, and visual and performing arts. There are eight English language arts standards across four content areas: writing, reading, speaking, and listening:

A. Students will use the skills and strategies of the reading process to comprehend, interpret, evaluate, and appreciate what they have read.

B. Students will use reading, listening, and viewing strategies to experience, understand, and appreciate literature and culture.

C. Students will demonstrate an understanding of how words and images communicate.

D. Students will apply reading, listening, and viewing strategies to information texts across all areas of curriculum.

E. Students will demonstrate the ability to use the skills and strategies of the writing process.

F. Students will write and speak correctly, using conventions of standard written and spoken English.

G. Students will use stylistic and rhetorical aspects of writing and speaking to explore ideas, to present lines of thought, to represent and reflect on human experience, and to communicate feelings, knowledge, and opinions.

\footnotetext{
29 Before 2003-04, MEA testing also included the visual and performing arts, health, physical science, and social studies. However, these content areas will now be tested at the local level.
} 
H. Students will work, write, and speak effectively in connection with research in all content areas.

For each of the eight standards, performance indicators are identified by grade spans (http://www.state.me.us/education/lres/ela.htm). Table T1 shows the grade 5-8 English language arts performance indicators for content standard $\mathrm{D}$, as an example.

Table T1. $5^{\text {th }}-8^{\text {th }}-$ Grade English Language Arts Learning Results Standards and Performance Indicators

Standard D. Informational Texts: Students will apply reading, listening, and viewing strategies to informational texts across all areas of curriculum.

When reading, listening, and viewing critically, students will ask pertinent questions, recognize assumptions and implications, and evaluate information and ideas. In a world that surrounds them with information, they have to be able to connect with this information and make sense of it.

Performance Indicators:

1. Seek appropriate assistance when attempting to comprehend challenging text.

2. Identify useful information-organizing strategies.

3. Identify both the author's purpose and the author's point of view when reading expository information.

4. Identify different ways in which informational texts are organized.

5. Produce and support generalizations acquired from informational text.

6. Describe new knowledge presented in informational texts and how it can be used.

7. Identify common technical terms used in informational texts.

8. Use the various parts of a text (index, table of contents, glossary) to locate specific information.

Source: http://www.state.me.us/education/lres/ela.htm

\section{Test Format and Content}

For the purposes of examining what the MEA reveals about adolescent literacy, the rest of the discussion will focus on the English language arts (Reading and Writing) tests that students take in grades 4, 8, and 11 (see http://www.state.me.us/education/mea/tdmenu.htm for additional detail).

MEA English language arts assessments contain three types of questions: multiple-choice, constructed-response, and writing prompts. All MEA test items are released to the public after administration. In addition, sample MEA tests items reference the standards, indicating which standards correspond with the questions asked on the tests.

The English language arts writing assessment includes three writing tasks (formerly two) divided into one 45-minute test session and one 40-minute test session. In the first session, students respond to a long writing prompt. The second session is dedicated to two writing tasks.

The English language arts reading test includes four sessions. A total of 42 multiple-choice questions (10 of which are field-test items, and therefore do not count towards the final score) 
and ten constructed-response questions (two of which are field-test items) are administered, for a total of 64 points. Standards A (Process of Reading), B (Literature and Culture), and D (Informational Texts) are tested in the MEA common items (not including field-test items) in grades 4, 8, and 11, as follows: Standard A (12, 31, and 19 percent, respectively), Standard B (47, 33, and 41 percent respectively), and Standard D (41, 36 and 41 percent respectively). Students at all grade levels read fiction, short stories, and informational reading selections (e.g., newspaper articles, informational essays, textbook passages). Students' constructed-response answers are judged on their comprehension of the text as well as their use of reading strategies, language, and analysis.

\section{Achievement-Level Definitions}

Test results are reported for four achievement levels:

- Exceeds Standards - exemplary accomplishment in understanding and application skills.

- Meets Standards - consistency in understanding and application skills.

- Partially Meets the Standards - inconsistent understanding and application skills.

- Does Not Meet Standards - limited understanding and application skills.

Scores at or above the meets standards level are considered proficient for the accountability provisions of NCLB.

\section{Performance Results}

\section{$\underline{\text { Student Performance }}$}

Table T2 provides student-level data for $4^{\text {th }}$, $8^{\text {th }}$, and $11^{\text {th }}$-grade reading and writing, disaggregated by disability status and racial/ethnic groups. ${ }^{30}$ It also provides disaggregated results by whether a student had Internet access at home, which Maine used as a proxy for poverty. ${ }^{11}$

\footnotetext{
$3^{30}$ Approximately 96 percent of students in Maine are white, and 2 percent are African American; less than 1 percent are Hispanic, Asian, and Native American. About 30 percent of students are eligible for the free and reduced-price lunch program; 1 percent are in limited-English-proficiency programs; and 16 percent have Individual Education Programs (IEPs).

${ }^{31}$ Eligibility for the free and reduced-price lunch program will be a student poverty category in the future.
} 
Table T2. Performance of $4^{\text {th-, }} 8^{\text {th }}$, and $1^{\text {th }}$-Graders on 2003 Reading and 2002 Writing MEA, by Student Characteristics

\begin{tabular}{|c|c|c|}
\hline & Reading & Writing \\
\hline & \multicolumn{2}{|c|}{$\begin{array}{c}\text { Percentage Meeting Standards } \\
\text { and Above }\end{array}$} \\
\hline \multicolumn{3}{|l|}{$4^{\text {th }}$ Grade } \\
\hline All students & 49 & 15 \\
\hline Students with disabilities & 10 & 1 \\
\hline Non-disabled students & 55 & 14 \\
\hline Students with Internet access at home & 54 & 14 \\
\hline Students with no Internet access at home & 39 & 8 \\
\hline African American students & 30 & 3 \\
\hline White students & 50 & 12 \\
\hline \multicolumn{3}{|l|}{ 8 $^{\text {th }}$ Grade } \\
\hline All students & 45 & 40 \\
\hline Students with disabilities & 7 & 6 \\
\hline Non-disabled students & 50 & 46 \\
\hline Students with Internet access at home & 48 & 44 \\
\hline Students with no Internet access at home & 27 & 25 \\
\hline African American students & 26 & 24 \\
\hline White students & 45 & 42 \\
\hline \multicolumn{3}{|l|}{ 11 $^{\text {th }}$ Grade } \\
\hline All students & 46 & 37 \\
\hline Students with disabilities & 5 & 4 \\
\hline Non-disabled students & 51 & 36 \\
\hline Students with Internet access at home & 51 & 36 \\
\hline Students with no Internet access at home & 25 & 16 \\
\hline African American students & 22 & 13 \\
\hline White students & 47 & 33 \\
\hline
\end{tabular}

Source: Results for student characteristics other than "All” were obtained from the Maine Department of Education.

Overall, between 45 and 49 percent of all students met standards on the reading assessment. Very few students exceeded standards, less than 1-2 percent (not shown in table). Passing rates on the writing assessment were lower, particularly at the $4^{\text {th }}$-grade level, at which only 15 percent of students met the standards. Only $5-10$ percent of students with disabilities met standards in reading, and 1-6 percent met standards in writing.

Students with Internet access at home clearly had an advantage over students without such access. With one exception ( $4^{\text {th }}$-grade writing), the passing rates of students with Internet access 
at home were between 15 and 26 percentage points higher on both the reading and writing assessments across the grade levels.

There was a substantial gap between the passing rates of African American students and those of white students. For example, only 30 percent of African American students met standards in $4^{\text {th }}$ grade reading compared with 50 percent of white students. The gap in achievement was largest at the $11^{\text {th }}$ grade in both reading and writing (25 percentage points and 20 percentage points, respectively).

\section{$\underline{\text { School Performance }}$}

Table T3 presents school-level data disaggregated by urbanicity for the 2002 MEA administration for grades 4, 8, and 11. Approximately three-fourths of schools in Maine are rural; 19 percent are suburban; and 6 percent are urban. About 29 percent of rural and urban schools are high-poverty schools, compared with 3 percent of suburban schools.

Table T3. Average School Performance on $4^{\text {th }}-, 8^{\text {th }}$, and $11^{\text {th }}$-Grade 2002 Reading and Writing MEA, by Urbanicity

\begin{tabular}{lcc}
\hline & \multicolumn{1}{c}{ Reading } & Writing \\
\cline { 2 - 3 } & \multicolumn{2}{c}{$\begin{array}{c}\text { Average Meeting Standards and } \\
\text { Above Percentage }\end{array}$} \\
\hline $\mathbf{4}^{\text {th }}$ Grade & & \\
Rural schools & 44 & 12 \\
Suburban schools & 55 & 16 \\
Urban schools & 48 & 16 \\
$\mathbf{8}^{\text {th }}$ Grade & & \\
Rural schools & 41 & 36 \\
Suburban schools & 45 & 42 \\
Urban schools & $*$ & $*$ \\
11 $^{\text {th }}$ Grade & & \\
Rural schools & 50 & 34 \\
Suburban schools & 53 & 39 \\
Urban schools & $*$ & $*$ \\
\hline
\end{tabular}

Note: *No results are reported for grade 11 because of small sample sizes: There are only eight middle schools and five high schools in urban areas.

On average, the passing rates in suburban schools on the reading assessment were higher than those in rural schools by about 11 percentage points in grade 4 and 3-4 percentage points in the higher grades. On the writing assessment, the passing rates were between 4 and 6 percentage points higher in suburban schools than in rural and urban schools. 
We report data at the $4^{\text {th }}$-grade level for urban schools. Suburban schools had higher passing rates than urban schools in $4^{\text {th }}$-grade reading but there was no difference in writing. 


\section{APPENDIX U. MARYLAND}

\section{State Assessment System}

Maryland currently administers the Maryland School Assessment (MSA) and the High School Assessments (HSAs) in order to track student and school progress. The MSA was implemented in 2002-03 in response to NCLB requirements. Previously, Maryland used the Maryland School Performance Assessment Program (MSPAP) to fulfill the 1994 reauthorized Elementary and Secondary Education Act. However, the MSPAP produced scores for schools rather than for individual students; thus, it needed to be replaced to meet the new federal testing requirements. For the 2003-04 school year, students in grades 3-8 took the MSA in reading and mathematics and students in grade 10 took it in reading. ${ }^{32}$ The MSA is an augmented form of the Stanford Achievement Test - 10 (grades 3-8) or the Terra Nova (grade 10). Thus, the MSA produces norm-referenced scores and criterion-referenced scores. The criterion-referenced scores are what the state uses to measure student progress toward standards and to hold schools accountable (see http://www.marylandpublicschools.org/MSDE/testing/testing_overview.htm for additional information regarding the state assessment system).

In addition, Maryland administers the HSAs, which are end-of-course tests that students take as they complete the appropriate high school-level course. All students, including middle school students taking any one of the five high school-level courses, must take the HSA after they complete the appropriate course. These courses include English I, government, algebra/data analysis, geometry, and biology. These scores are reported on students' transcripts.

These assessments are used to track student progress toward mastering state standards. Maryland has standards in reading/English language arts, mathematics, science and social studies for preK -8 students and for $10^{\text {th }}$-grade students. Maryland is developing a voluntary statewide curriculum that will detail what should be taught at each grade in relation to the content standards. The English language arts curriculum framework is based on six Content Standards: Reading Processes (Fluency and Vocabulary), Reading Comprehension, Comprehension of Information Text, Comprehension of Literary Text, Writing, and Listening. (see http://mdk12.org/instruction/curriculum/reading/index.html). Indicator statements and

\footnotetext{
${ }^{32}$ In 2002-03, only students in grades 3, 5, 8 and 10 were given the MSA Reading assessment. In 2003-04 all students in grades 3-8 and 10 are given the MSA Reading assessment, however only scores for students in grades 3, 5, 8 and 10 will be available in the spring 2004. Scores for grades 4, 6 and 7 will be given after performance standards are set in the summer 2004. Starting as early as March 2008, science assessments will be added to grades 3,5 and 8 .
} 
objectives detail what students should be able to do to achieve/meet the content standards at each grade level. Table U1 contains an example from the Grade 8 indicators and objectives for fluency.

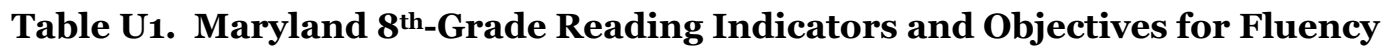

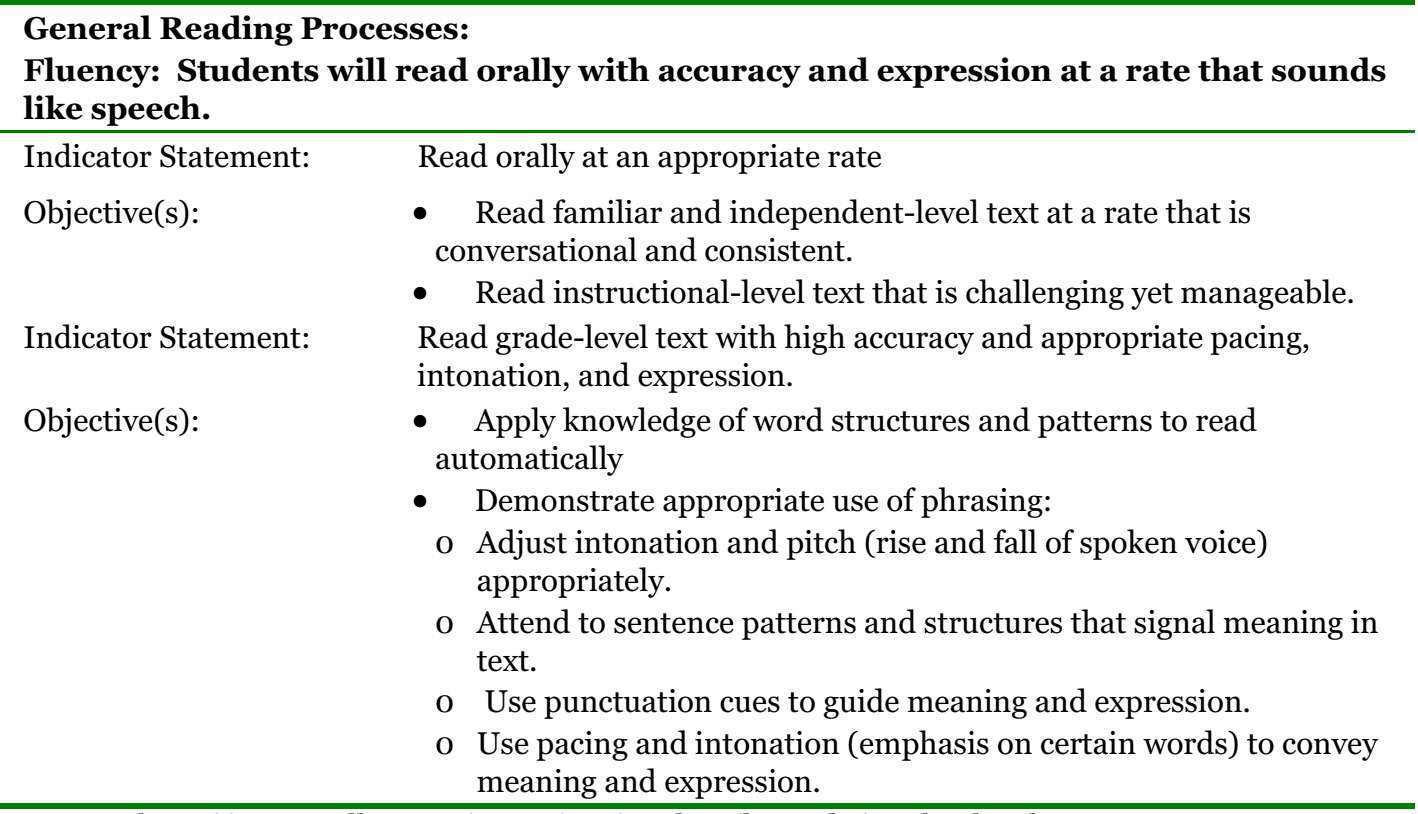

Source: http://www.mdk12.org/mspp/vsc/reading/bygrade/grade8.html

\section{Test Format and Content}

For the purposes of examining about adolescent literacy, the rest of the discussion will focus on the reading MSA. For the reading MSA, students are asked to read informational and literary texts and respond to selected-response or brief constructed-response questions that pertain to the text. The MSA assesses word study, vocabulary, and reading comprehension (http://msde.state.md.us/testing/MSAReading.pdf).

\section{Achievement-Level Definitions}

Maryland reports tests results by three achievement levels:

- Advanced - Students at this grade level can regularly read above-grade-level text and demonstrate the ability to comprehend complex literature and informational passages.

- Proficient - Students at this level can read appropriate text and demonstrate the ability to comprehend literature and informational passages.

- Basic - Students at this level are unable to read and adequately comprehend gradeappropriate literature and informational passages. 
Scores at or above the "proficient" level are considered proficient under the accountability provisions of NCLB.

\section{Performance Results}

\section{$\underline{\text { Student Performance }}$}

The Maryland Department of Education (DOE) provides student-level data, disaggregated by disability status, English-proficiency status, income status, and racial/ethnic groups. ${ }^{33}$ Table U2 shows performance results from the 2002-03 reading MSA for students in grades 5,8 , and 10, broken down by these students' characteristics.

Sixty percent or more of students in grades 5,8 , and 10 achieved at or above the proficient level on the MSA reading assessment; and 26 percent of $5^{\text {th- }}$ and $8^{\text {th }}$-graders scored at the advanced level, as did 30 percent of $10^{\text {th }}$-grade students. A low percentage of special education students reached the proficient level in all grades; however, the percentage was much lower in $8^{\text {th }}$ and $10^{\text {th }}$ grades (20 percent and 22 percent, respectively), compared with $5^{\text {th }}$ grade (35 percent). We find this same trend for students with limited-English-proficiency as well: 24 percent reach the proficient level in $5^{\text {th }}$ grade, compared with 12 percent and 15 percent in $8^{\text {th }}$ grade and 10 th grade, respectively.

Asian students and white students outperformed African American and Hispanic students by large margins-28-34 percentage points at the proficient level and 25-34 percent at the advanced level. Hispanic students outperformed African American students by small margins (35 percentage points at the proficient level and 2-4 percent at the advanced level). For instance, in grade 8, 74 percent of Asian and white students reached the proficient level, compared with 45 percent of Hispanic students and 40 percent of African American students. While white students performed at the same level as Asian students at the proficient level, a lower percentage of white students reached the advanced level (3-5 percentage points).

\footnotetext{
33 Approximately 52 percent of students in Maryland are white; 38 percent are African American; 5 percent are Hispanic; and 5 percent are Asian/Pacific Islander. About 30 percent of students are eligible for the free and reduced-price lunch program; 4 percent are in limited-English-proficiency programs; and 13 percent have Individual Education Programs (IEPs).
} 


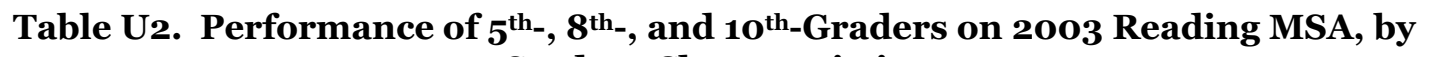
Student Characteristics

\begin{tabular}{|c|c|c|}
\hline & $\begin{array}{c}\text { Proficient and } \\
\text { Above }\end{array}$ & Advanced \\
\hline & \multicolumn{2}{|c|}{ Percentage } \\
\hline \multicolumn{3}{|l|}{$5^{\text {th }}$ Grade } \\
\hline All students & 66 & 26 \\
\hline Special education students & 35 & 7 \\
\hline Students with limited-English proficiency & 24 & 3 \\
\hline Economically disadvantaged students & 45 & 9 \\
\hline Asian/Pacific Islander students & 80 & 43 \\
\hline African American students & 48 & 11 \\
\hline Hispanic students & 51 & 13 \\
\hline White students & 79 & 38 \\
\hline \multicolumn{3}{|l|}{$8^{\text {th }}$ Grade } \\
\hline All students & 60 & 26 \\
\hline Special education students & 20 & 4 \\
\hline Students with limited-English proficiency & 12 & 2 \\
\hline Economically disadvantaged students & 36 & 8 \\
\hline Asian/Pacific Islander students & 74 & 40 \\
\hline African American students & 40 & 10 \\
\hline Hispanic students & 45 & 12 \\
\hline White students & 74 & 37 \\
\hline \multicolumn{3}{|l|}{$10^{\text {th }}$ Grade } \\
\hline All students & 61 & 30 \\
\hline Special education students & 22 & 5 \\
\hline Students with limited-English proficiency & 15 & 1 \\
\hline Economically disadvantaged students & 38 & 10 \\
\hline Asian/Pacific Islander students & 75 & 46 \\
\hline African American students & 41 & 12 \\
\hline Hispanic students & 45 & 16 \\
\hline White students & 75 & 42 \\
\hline
\end{tabular}

Source: http://www.mdk12.org/data/msa_data/index.asp?K=99AAAA

\section{$\underline{\text { School Performance }}$}

We do not report school-level performance by urbanicity because the MSA was not administered in 2002. 


\section{APPENDIX V. MASSACHUSETTS}

\section{State Assessment System}

The Massachusetts Comprehensive Assessment System (MCAS) is Massachusetts' standardsbased accountability system. For the 2003-04 school year, students took MCAS assessments in the following grades and subjects:

- $\quad$ Grade 3 - reading

- Grade 4-English language arts composition, English language arts language and literature, mathematics

- Grade 5 - science and technology/engineering

- Grade 6 - mathematics

- Grade 7 - English language arts composition, English language arts language and literature

- $\quad$ Grade 8 - mathematics, science and technology/engineering

- $\quad$ Grade 9 - High School End of Course, science and technology/engineering (also introductory physics and technology/engineering)

- Grade 10 - English language arts composition, English language arts language and literature, mathematics, High School End of Course assessments for biology, chemistry, introductory physics and technology/engineering.

Performance on the MCAS is used to measure school progress for accountability purposes. In addition, students must pass the $10^{\text {th }}$-grade mathematics and English Language Arts tests in order to graduate. Students may retake the $10^{\text {th }}$-grade MCAS assessments until they pass (see http://www.doe.mass.edu/Assess/ for additional information regarding state accountability and assessment).

The MCAS is intended to measure student progress toward mastering state content standards. Massachusetts has standards in English language arts, mathematics, science and technology/engineering, history and social science, arts, comprehensive health, and foreign languages.

Educators, consultants, and staff at the Massachusetts Department of Education (DOE) developed the current English Language Arts Curriculum Framework in 2001. English language arts standards are based on ten guiding principles (see http://www.doe.mass.edu/frameworks/ela/o601.pdf). The 27 general content standards follow the guiding principles across four content areas: language, reading and literature, composition, and media. The general standards provide broad statements outlining what students should know and be able to do. These standards are explicated by learning standards that detail what students in various grade ranges $-\mathrm{PreK}-2,3-4,5-6,7-8,9-10$, and 11-12-should master. In 
addition, standards for vocabulary, reading and composition have been further divided into PreK-K and 1-2 clusters. Table V1 presents an example of these grade-level expectations for grades 7-8 around content standard 8 , which focuses on understanding text.

Table V1. Grade-Level Expectations for $7^{\text {th- }}$ and $8^{\text {th-Grade English Language Arts for }}$ Standard 8: Understanding Text

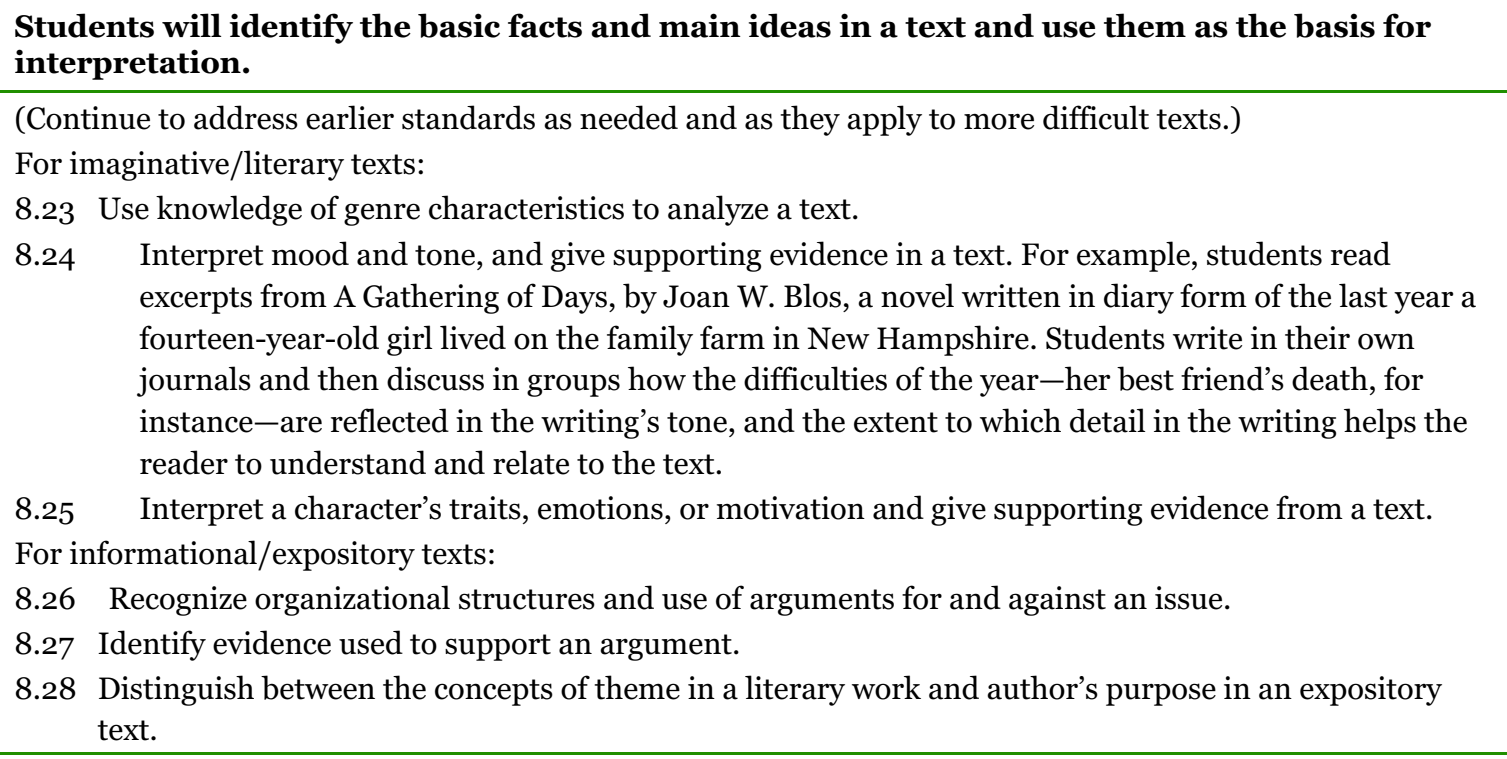

Source: http://www.doe.mass.edu/frameworks/ela/o601.pdf

Massachusetts' English language arts curriculum framework also provides examples that demonstrate how teachers might address standards in their classrooms.

\section{Test Format and Content}

For the purposes of examining what the MCAS reveals about adolescent literacy, the rest of the discussion will focus on the English language arts tests that students take in grades 4, 7, and 10 (see http://www.doe.mass.edu/mcas/ for further details on test format and content).

The MCAS English language arts tests contain two parts: the English language arts composition test and the English language arts language and literature test. In 2001, approximately 8 percent of the total score was from the language strand; 64 percent was from the literature strand; and 28 percent was from the composition strand.

The English language arts composition test includes two 45-minute test sessions. During the first session, students respond to a writing prompt by preparing a first draft of their writing. During the second session, students revise the first draft into a second draft, which is submitted for scoring. At grade 4, students write a narrative account that chronicles or describes an event or experience. At grade 7, the test assesses students' skill at persuasive writing, writing in an informative mode that shares knowledge and conveys messages, instructions, and ideas. At the $10^{\text {th }}$-grade level, the test assesses literary analysis---knowledge of literary elements, themes, and 
structures to analyze an excerpt from a literary text. Students' responses are judged on their focus and development and use of Standard English conventions.

The English language arts language and literature test includes multiple-choice and openresponse questions. It is administered in three 45-minute test sessions. During these sessions, developmentally appropriate reading passages are followed by either a small set (3-4 multiplechoice and 1 open-response) or a large set (6-8 multiple choice and 1 open-response) of related questions. A range of literary and nonliterary texts are used as reading passages, to include short stories, novel excerpts, poetry, plays, myths/legends/fables, biographies/autobiographies, essays, speeches, editorials, interviews, letters, diary entries, newspaper articles, reviews, instructions, and advertisements. Students' answers are judged on their comprehension of the text and their familiarity and understanding of literary genres, techniques, structures, and elements.

\section{Achievement-Level Definitions}

Test results reported across the state are broken into four achievement levels. For grades 4 through 8, the achievement levels are: Advanced, Proficient, Needs Improvement, and Warning. Students scoring at or above the proficient level are considered to have fully met the academic requirements under NCLB. For grade 10, MCAS results are reported by: Advanced, Proficient, Needs Improvement, and Failing. Students scoring at or above the needs improvement level are considered to have passed the exam, which is required for graduation.

Massachusetts has created general descriptions for each achievement level that apply across subject areas and grade levels. The subject-specific descriptions of each level are provided for English Language Arts in Table V1. (Note that the levels are not further defined by grade level.) 
Table V1. MCAS English Language Arts Achievement Levels, by Subject Area

\begin{tabular}{|c|c|c|c|}
\hline & $\begin{array}{l}\text { Needs Improvement On } \\
\text { MCAS, a student at this } \\
\text { level: }\end{array}$ & $\begin{array}{l}\text { Proficient On MCAS, a } \\
\text { student at this level: }\end{array}$ & $\begin{array}{l}\text { Advanced On MCAS, a } \\
\text { student at this level: }\end{array}$ \\
\hline $\begin{array}{l}\text { Language/ } \\
\text { vocabulary }\end{array}$ & $\begin{array}{l}\text { Demonstrates a modest } \\
\text { reading vocabulary and } \\
\text { partial understanding of } \\
\text { word parts and word } \\
\text { relationships (e.g., prefixes, } \\
\text { roots, suffixes, synonyms, } \\
\text { antonyms) }\end{array}$ & $\begin{array}{l}\text { Demonstrates a solid } \\
\text { reading vocabulary and } \\
\text { general understanding of } \\
\text { word parts and word } \\
\text { relationships (e.g., } \\
\text { prefixes, roots, suffixes, } \\
\text { synonyms, antonyms) }\end{array}$ & $\begin{array}{l}\text { Demonstrates a } \\
\text { comprehensive reading } \\
\text { vocabulary and in-depth } \\
\text { understanding of word } \\
\text { parts and word } \\
\text { relationships (e.g., prefixes, } \\
\text { roots, suffixes, synonyms, } \\
\text { antonyms) }\end{array}$ \\
\hline Comprehension & $\begin{array}{l}\text { Demonstrates an } \\
\text { understanding of concrete } \\
\text { ideas, but only partial } \\
\text { understanding of abstract } \\
\text { or implied ideas, in grade- } \\
\text { appropriate texts } \\
\text { Connects some ideas } \\
\text { within texts }\end{array}$ & $\begin{array}{l}\text { Demonstrates an } \\
\text { understanding of many } \\
\text { concrete ideas, and most } \\
\text { abstract and implied } \\
\text { ideas, in grade- } \\
\text { appropriate texts } \\
\text { Connects ideas within } \\
\text { texts and provides } \\
\text { supporting evidence }\end{array}$ & $\begin{array}{l}\text { Demonstrates an in-depth } \\
\text { understanding of concrete } \\
\text { and abstract ideas and } \\
\text { complex meanings in } \\
\text { grade-appropriate texts } \\
\text { Connects complex ideas } \\
\text { within texts and provides } \\
\text { well-reasoned and well- } \\
\text { supported arguments }\end{array}$ \\
\hline $\begin{array}{l}\text { Text elements } \\
\text { and techniques }\end{array}$ & $\begin{array}{l}\text { Shows partial } \\
\text { understanding of how } \\
\text { structure and genre } \\
\text { enhance the author's } \\
\text { purpose or theme } \\
\text { Identifies obvious } \\
\text { examples of some } \\
\text { techniques authors use } \\
\text { (e.g., repetition, } \\
\text { exaggeration, and } \\
\text { figurative language) }\end{array}$ & $\begin{array}{l}\text { Shows clear } \\
\text { understanding of } \\
\text { structure and elements of } \\
\text { genre and how they } \\
\text { support the author's } \\
\text { purpose or theme } \\
\text { Identifies more subtle } \\
\text { examples of techniques } \\
\text { authors use in a variety of } \\
\text { texts (e.g., repetition, } \\
\text { exaggeration, and } \\
\text { figurative language) as } \\
\text { grade-appropriate }\end{array}$ & $\begin{array}{l}\text { Critically evaluates how } \\
\text { structure and elements of } \\
\text { genre support the author's } \\
\text { purpose or theme } \\
\text { Identifies and critically } \\
\text { evaluates techniques } \\
\text { authors use in a wide } \\
\text { variety of texts (e.g., } \\
\text { repetition, exaggeration, } \\
\text { and figurative language) }\end{array}$ \\
\hline Composition & $\begin{array}{l}\text { Writes partially organized } \\
\text { compositions with } \\
\text { modestly developed ideas, } \\
\text { some supporting detail, } \\
\text { and some demonstration of } \\
\text { focus } \\
\text { Uses simplistic language } \\
\text { and sentence structure }\end{array}$ & $\begin{array}{l}\text { Writes well-organized } \\
\text { compositions with } \\
\text { logically developed ideas, } \\
\text { adequate detail, and clear } \\
\text { focus } \\
\text { Engages reader's interest } \\
\text { through use of a variety of } \\
\text { language choices and } \\
\text { sentence structures }\end{array}$ & $\begin{array}{l}\text { Writes well-organized, } \\
\text { richly developed } \\
\text { compositions with ideas } \\
\text { that are clearly expressed } \\
\text { and supported by extensive } \\
\text { detail } \\
\text { Provokes and sustains the } \\
\text { reader's interest through } \\
\text { effective and precise } \\
\text { language, sentence } \\
\text { structure, and vocabulary }\end{array}$ \\
\hline $\begin{array}{l}\text { Writing } \\
\text { conventions }\end{array}$ & $\begin{array}{l}\text { Writes compositions with } \\
\text { partial control of the } \\
\text { Standard English } \\
\text { conventions of grammar, } \\
\text { spelling, punctuation, and } \\
\text { usage }\end{array}$ & $\begin{array}{l}\text { Writes compositions with } \\
\text { solid control of the } \\
\text { Standard English } \\
\text { conventions of grammar, } \\
\text { spelling, punctuation, and } \\
\text { usage }\end{array}$ & $\begin{array}{l}\text { Writes compositions with } \\
\text { sophisticated control of the } \\
\text { Standard English } \\
\text { conventions of grammar, } \\
\text { spelling, punctuation, and } \\
\text { usage }\end{array}$ \\
\hline
\end{tabular}

Source: http://www.doe.mass.edu/mcas/mcaspld.html 


\section{Performance Results}

\section{Student Performance}

The Massachusetts DOE provides student-level data disaggregated by disability status, Englishlanguage-proficiency status, and race/ethnicity. ${ }^{1}$ Table V2 shows the English language arts performance results from the 2003 MCAS administration for students in grades 4, 7, and 10, disaggregated by these students' characteristics.

Overall, 56 percent of $4^{\text {th }}$-grade students and 66 percent of $7^{\text {th }}$-grade students scored at or above the proficient level. Far fewer, 10 percent and 8 percent, respectively, scored at the advanced level. Eighty-nine percent of $10^{\text {th }}$-grade students passed the English language arts tests by scoring at or above the needs improvement level; 61 percent scored at or above the advanced level; and 20 percent scored at the advanced level.

About 5 percent of students in Massachusetts are classified as limited-English proficient. Sixteen percent of students with limited-English proficiency met proficiency standards on the English language arts MCAS in $4^{\text {th }}$ grade, and 19 percent did so in $7^{\text {th }}$ grade. While only 12 percent of $10^{\text {th }}$ grade students with limited-English proficiency scored at or above the proficient level, 42 percent reached or exceeded the needs improvement level and passed this section of the MCAS on the first attempt.

White students outperformed African American and Hispanic students at all three grade levels.

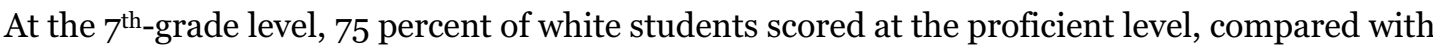
39 percent of African American students (36-percentage-point gap) and 31 percent of Hispanic students (44-percentage-point gap).

The same trends exist at the $4^{\text {th }}$ and $10^{\text {th }}$ grades. For example, only 76 percent of African American students and 66 percent of Hispanic students passed the $10^{\text {th }}$-grade English language arts test, compared with 94 percent of white students, an achievement gap of 18 and 28 percentage points, respectively. At the advanced level, the gap is the largest at the $10^{\text {th }}$-grade level, 18-20 percentage points, compared with 8-11 percentage points at grades 4 and 7 .

\footnotetext{
${ }^{1}$ Approximately 76 percent of students in Massachusetts are white; 11 percent are Hispanic; 9 percent are African American; and 5 percent are Asian/Pacific Islander. About one-fourth of students are eligible for the free and reduced-price lunch program; 5 percent are in limited-English-proficiency programs; and 15 percent have Individual Education Programs (IEPs).
} 
Table V2. Performance of $4^{\text {th-, }} 7^{\text {th-}}$, and $10^{\text {th }}$-Graders on 2003 English Language Arts MCAS, by Student Characteristics

\begin{tabular}{|c|c|c|c|}
\hline & $\begin{array}{c}\text { Needs } \\
\text { improvement } \\
\text { and above }\end{array}$ & $\begin{array}{l}\text { Proficient and } \\
\text { above }\end{array}$ & Advanced \\
\hline & & Percentage & \\
\hline \multicolumn{4}{|l|}{$4^{\text {th }}$ Grade } \\
\hline All students & 90 & 56 & 10 \\
\hline General education students & 95 & 64 & 13 \\
\hline Students with disabilities & 76 & 26 & 2 \\
\hline $\begin{array}{l}\text { Students with limited-English } \\
\text { proficiency }\end{array}$ & 57 & 16 & 1 \\
\hline African American students & 79 & 30 & 2 \\
\hline Asian/Pacific Islander students & 91 & 58 & 14 \\
\hline Hispanic students & 73 & 26 & 2 \\
\hline White students & 95 & 65 & 13 \\
\hline \multicolumn{4}{|l|}{$7^{\text {th }}$ Grade } \\
\hline All students & 94 & 66 & 8 \\
\hline General education students & 98 & 75 & 10 \\
\hline Students with disabilities & 80 & 29 & 1 \\
\hline $\begin{array}{l}\text { Students with limited-English } \\
\text { proficiency }\end{array}$ & 63 & 19 & 1 \\
\hline African American students & 87 & 39 & 2 \\
\hline Asian/Pacific Islander students & 94 & 69 & 14 \\
\hline Hispanic students & 79 & 31 & 1 \\
\hline White students & 97 & 75 & 10 \\
\hline \multicolumn{4}{|l|}{ 10 $^{\text {th }}$ Grade } \\
\hline All students & 89 & 61 & 20 \\
\hline General education students & 95 & 69 & 24 \\
\hline Students with disabilities & 70 & 26 & 3 \\
\hline $\begin{array}{l}\text { Students with limited-English } \\
\text { proficiency }\end{array}$ & 42 & 12 & 1 \\
\hline African American students & 76 & 35 & 6 \\
\hline Asian/Pacific Islander students & 88 & 58 & 24 \\
\hline Hispanic students & 66 & 26 & 4 \\
\hline White students & 94 & 69 & 24 \\
\hline
\end{tabular}

Source: http://www.doe.mass.edu/mcas/results.html?yr=03 


\section{$\underline{\text { School Performance }}$}

Although Massachusetts does not report MCAS performance by poverty status or urbanicity at the student level, school-level data are available for the 2002 MCAS administration (Table V3). About 24 percent of schools in Massachusetts were high-poverty schools. The majority of schools (64 percent) were located in suburban areas; 30 percent were urban; and 6 percent were rural. Urban schools were significantly more likely to be high-poverty than were suburban or rural schools (71 percent compared with 4 percent and 6 percent, respectively).

Without exception, low- and medium-poverty schools outperformed high-poverty schools at all achievement levels and all grade levels. For example, at the $7^{\text {th }}$ grade, on average 72 percent of students in low- and medium-poverty schools scored at or above the proficient level on the English language arts MCAS, compared with 37 percent of students in high-poverty schools (35percentage-point difference). At the needs improvement level, the differential is 24 percentage points in the $10^{\text {th }}$ grade.

Suburban schools outperformed urban schools at all grade and achievement levels. For instance, at grade 7, 73 percent of students scored at or above the proficient level, and 12 percent scored at the advanced level, compared with 42 percent and 2 percent, respectively, in urban schools. 
Table V3. Average School Performance on $4^{\text {th }}-, 7^{\text {th }}$, and $10^{\text {th }}-$ Grade English Language Arts 2002 MCAS, by School Poverty and Urbanicity

\begin{tabular}{|c|c|c|c|}
\hline & $\begin{array}{c}\text { Needs } \\
\text { Improvement } \\
\text { and Above }\end{array}$ & $\begin{array}{l}\text { Proficient and } \\
\text { Above }\end{array}$ & Advanced \\
\hline & \multicolumn{3}{|c|}{ Average Percentage } \\
\hline \multicolumn{4}{|l|}{$4^{\text {th }}$ Grade } \\
\hline $\begin{array}{l}\text { Low- and medium-poverty } \\
\text { schools }\end{array}$ & 95 & 62 & 10 \\
\hline High-poverty schools & 79 & 29 & 2 \\
\hline Rural schools & 93 & 51 & 7 \\
\hline Suburban schools & 95 & 63 & 10 \\
\hline Urban schools & 81 & 33 & 3 \\
\hline \multicolumn{4}{|l|}{$7^{\text {th }}$ Grade } \\
\hline $\begin{array}{l}\text { Low- and medium-poverty } \\
\text { schools }\end{array}$ & 95 & 72 & 11 \\
\hline High-poverty schools & 80 & 37 & 2 \\
\hline Rural schools & 94 & 65 & 6 \\
\hline Suburban schools & 96 & 73 & 12 \\
\hline Urban schools & 81 & 42 & 2 \\
\hline \multicolumn{4}{|l|}{$1^{\text {th }}$ Grade } \\
\hline $\begin{array}{l}\text { Low- and medium-poverty } \\
\text { schools }\end{array}$ & 89 & 63 & 21 \\
\hline High-poverty schools & 65 & 28 & 4 \\
\hline Rural schools & 88 & 59 & 18 \\
\hline Suburban schools & 92 & 66 & 22 \\
\hline Urban schools & 70 & 37 & 8 \\
\hline
\end{tabular}




\section{APPENDIX W. MICHIGAN}

\section{State Assessment System}

Michigan administers the Michigan Education Assessment Program (MEAP) to students in the following grades and subjects:

- Grade 4-English language arts35 and mathematics

- Grade 5-science and social studies

- Grade 7-English language arts

- Grade 8-mathematics, science, and social studies

- Grade 11-mathematics, science, social studies, and English language arts

Grade 11 assessments are administered in the spring, while all other grades are tested in the winter (late January to mid-February). The MEAP assessments are used to track school performance for state accountability purposes. While the MEAP assessment does not carry sanctions for individual teachers or students, the MEAP high school tests are used by students to qualify for the Michigan Merit Award, which provides scholarship money for students to attend state colleges and universities. ${ }^{6}$ In addition, students receive an endorsement level on their diploma based on their MEAP assessment scores. This endorsement is designed to give colleges and businesses an idea of a diploma's worth (see http://www.michigan.gov/mde/o,1607,7-14022709---,oo.html for additional information on state accountability and assessment).

The MEAP assessments are designed to determine student progress toward mastering specific content in the Michigan Curriculum Framework. Recently, Michigan adopted grade-level content expectations.

\section{Test Format and Content}

We now focus on the required assessments related to adolescent literacy: grades 4, 7, and 11 combined English language arts writing and reading from knowledge and experience (see http://www.michigan.gov/mde/o,1607,7-140-22709_31168_31773-97184--,oo.html for additional information on test format and content).

MEAP English language arts assessments contain three types of questions: multiple-choice or selected response, constructed-response, and a written response to a prompt. All sections of the

35Winter 2003 was the first year that grade 4 and grade 7 students took a new, combined English language arts test that includes reading, writing, and a voluntary listening component.

${ }^{36}$ Details of the Merit Award Program are available at http://www.meritaward.state.mi.us. 
MEAP tests are student-paced: There are established testing time frames, which are given below, but students are given as much time as needed during the same continuous session to complete each section of a test.

The Writing from Knowledge and Experience section requires students to write one essay in response to a theme-related prompt. Students may choose to answer in one of five styles, either narrative, descriptive, persuasive, expository, or their own form. Students in grades 4 and 7 take this assessment in two sessions (approximately 45 minutes per session); grade 11 students have one 80-minute session. At all grade levels, the writing section assesses students' skill at clear, engaging, focused writing with precise word choice, strong content organization, and smooth flow through the text, with a six-point rubric.

The Reading from Knowledge and Experience section has two parts. One requires students to read two selections and respond to multiple-choice questions regarding the texts. Students in $4^{\text {th }}$ and $7^{\text {th }}$ grades are given approximately 50 minutes to answer ten multiple-choice questions about two reading selections, five multiple-choice cross-text questions, and an additional 25 multiplechoice items. For the second part of the reading section, grade 4 students answer one direct question about the theme of the reading selection and $7^{\text {th }}$-grade students write about a scenario in response to a question related to the theme. Approximately 50 minutes are allocated to this section. Eleventh-grade students are given approximately 60 minutes to answer nine multiplechoice questions about two reading selections, seven multiple-choice cross-text questions, an additional 25 multiple-choice items, and one question related to a themed scenario.

At all grade levels, for the constructed-response items, students are expected to clearly and effectively choose key ideas from the reading that support their position on the question and make a clear connection between the reading selections. Students must demonstrate a mastery of language, strong relationships among ideas, and have no misconceptions about the reading selections, and they must provide appropriate examples and details that thoroughly support their position and the connection between the two.

In 2002-2003, the total scores for the $4^{\text {th- }}$ and $7^{\text {th }}$-grade mandatory English language arts sections included approximately 28 percent from Writing from Knowledge and Experience and 72 percent from Reading from Knowledge and Experience.

\section{Achievement-Level Definitions}

MEAP assessment results are reported using four achievement levels for elementary and middle school grades:

- Level 1-Exceeded Michigan standards 
- Level 2-Met Michigan standards

- Level 3-At Basic level

- Level 4-Apprentice.

High school scores are reported along four levels, as well:

- Level 1-Endorsed exceeded Michigan standards

- Level 2-Endorsed at met Michigan standards

- Level 3-Endorsed at basic level

- Level 4-Not Endorsed.

Students scoring at or above level 2 are considered to have met the academic requirements under NCLB.

\section{Performance Results}

\section{Student Performance}

Table W1 presents the reading, writing, and combined English language arts performance for the $4^{\text {th }}, 7^{\text {th }}$, and $11^{\text {th }}$ grades, disaggregated by disability status, English-proficiency status, 37 socioeconomic status, and race/ethnicity..$^{8}$

Higher percentages of all $4^{\text {th-}}, 7^{\text {th-}}$, and $11^{\text {th }}$-grade students met and exceeded reading standards $(75,61$, and 71 percent, respectively) than met and exceeded writing standards $(47,57$, and 50 percent, respectively). Approximately 60 percent met and exceeded the combined English language arts standards.

Not surprisingly, students with limited-English proficiency scored far below their peers in all three grades in the reading assessment and the combined English language arts assessments. The differences in the relative percentages of students meeting or exceeding standards ranged from 20 to 41 percentage points and increased substantially in the higher grades. In writing, there was a small achievement gap of 5-7 percentage points for grades 4 and 7 , but the gap increased to 22 percentage points in grade 11 .

The percentage of special education students who met or exceeded the standard decreased as the grade levels increased. For instance, on the combined English language arts assessment, 31

37In 2003, limited-English-proficiency students were offered an alternate MEAP; however, starting in 2004, all limited-English-proficiency students will take the standard MEAP with accommodations.

${ }^{38}$ Approximately 73 percent of students in Michigan are white; 20 percent are African American; 4 percent are Hispanic; and 2 percent are Asian/Pacific Islander. About 31 percent of students are eligible for the free and reduced-price lunch program; 3 percent are in limited-English-proficiency programs; and 13 percent have Individual Education Programs (IEPs). 
Table W1. Performance of $4^{\text {th }}$, $7^{\text {th }}$, and $11^{\text {th }}$-Graders on 2003 Reading, Writing, and Combined English Language Arts MEAP, by Student Characteristics

\begin{tabular}{|c|c|c|c|}
\hline & Reading & Writing & Combined \\
\hline & \multicolumn{3}{|c|}{$\begin{array}{c}\text { Percentage Meeting or Exceeding } \\
\text { Standards }\end{array}$} \\
\hline \multicolumn{4}{|l|}{$4^{\text {th }}$ Grade } \\
\hline All students & 75 & 47 & 60 \\
\hline General education students & 78 & 49 & 62 \\
\hline Special education students & 48 & 27 & 31 \\
\hline Students with limited-English proficiency & 55 & 42 & 43 \\
\hline Students with English proficiency & 75 & 47 & 60 \\
\hline Economically disadvantaged students & 61 & 37 & 44 \\
\hline Non-economically disadvantaged students & 82 & 52 & 67 \\
\hline African American students & 56 & 33 & 39 \\
\hline Hispanic students & 64 & 40 & 48 \\
\hline White students & 81 & 51 & 66 \\
\hline \multicolumn{4}{|l|}{$7^{\text {th }}$ Grade } \\
\hline All students & 61 & 57 & 58 \\
\hline General education students & 65 & 60 & 62 \\
\hline Special education students & 24 & 23 & 18 \\
\hline Students with limited-English proficiency & 32 & 50 & 31 \\
\hline Students with English proficiency & 62 & 57 & 58 \\
\hline Economically disadvantaged students & 41 & 44 & 37 \\
\hline Non-economically disadvantaged students & 69 & 62 & 66 \\
\hline African American students & 35 & 41 & 31 \\
\hline Hispanic students & 47 & 49 & 43 \\
\hline White students & 69 & 61 & 66 \\
\hline \multicolumn{4}{|l|}{ 11 $^{\text {th }}$ Grade } \\
\hline All students & 71 & 50 & 63 \\
\hline General education students & 75 & 53 & 67 \\
\hline Special education students & 25 & 12 & 16 \\
\hline Students with limited-English proficiency & 31 & 28 & 27 \\
\hline Students with English proficiency & 72 & 50 & 64 \\
\hline Economically disadvantaged students & 53 & 32 & 43 \\
\hline Non-economically disadvantaged students & 74 & 53 & 67 \\
\hline African American students & 54 & 33 & 44 \\
\hline Hispanic students & 56 & 37 & 47 \\
\hline White students & 75 & 53 & 67 \\
\hline
\end{tabular}

Source: The 2003 MEAP test results used in this report were found at: http://tres-

secure.state.mi.us/meritaward/mma/results/wino3/StatewideDemographicsSummary.pdf. The 11th-grade test results were not available online and were obtained from the MEAP office. 
Note: Operational test results were used in this report. Alternate limited-English-proficiency student tests were administered in 2003; those results are not compiled in this report.

percent met or exceeded standards in $4^{\text {th }}$ grade, compared with 18 percent in $7^{\text {th }}$ grade and 16 percent in $11^{\text {th }}$ grade.

White students had higher scores than African American and Hispanic students at all grade levels. In the $7^{\text {th }}$ grade, 69 percent of white students met or exceeded standards in reading, 61 percent did so in writing, and 66 percent did so on the combined English language arts score, compared with 31-41 percent of African American students. The proficiency levels of Hispanic students were higher than those of African American students in all three subjects by between 7 and 12 percentage points at the $4^{\text {th }}$ - and $7^{\text {th }}$-grade levels. The difference in performance shrank to 2-4 percentage points by grade 11 .

Students who did not come from economically disadvantaged backgrounds had higher proficiency levels than economically disadvantaged students in reading. At the $4^{\text {th-grade level, the gap in }}$ proficiency rates was 21-23 percentage points in reading and the combined English language arts and 15 percentage points in writing. The performance gap widens in the higher grades. For example, for the $7^{\text {th }}$ grade, the gap was $28-29$ percentage points in reading and the combined English language arts and 18 percentage points in writing.

\section{$\underline{\text { School Performance }}$}

School-level performance data by urbanicity are available for the 2002 MEAP administration for grades 4, 7, and 11. Table W2 provides information about school performance for rural, suburban, and urban schools. Fifty-six percent of Michigan schools are suburban, 23 percent are rural, and 21 percent are urban. The majority of urban schools are high-poverty schools (72 percent), compared with 23 percent of rural schools and 12 percent of suburban schools.

The pass rates (percentage of students who met or exceeded standards) in reading in urban schools were significantly lower than those of suburban and rural schools. The difference in the pass rate was 22-24 percentage points at the $4^{\text {th }}$ and $7^{\text {th }}$ grades and $12-16$ percentage points at the $11^{\text {th }}$ grade. The proportion of $11^{\text {th }}$-graders who met or exceeded standards in writing in urban schools was 35 percent--12 percentage points lower than the 47 percent who did so in suburban schools. 
Table W2. Average School Performance on the $4^{\text {th-}}, 7^{\text {th- }}$, and $11^{\text {th-Grade }} 2002$ Reading and Writing MEAP, by Student Characteristics39

\begin{tabular}{lcc}
\hline & Reading & Writing \\
\cline { 2 - 3 } & \multicolumn{2}{c}{$\begin{array}{c}\text { Average Percentage } \\
\text { Meeting or Exceeding } \\
\text { Standards }\end{array}$} \\
\hline $\mathbf{4}^{\text {th }}$ Grade & \multicolumn{2}{c}{} \\
Rural schools & 61 & $*$ \\
Suburban schools & 39 & $*$ \\
Urban schools & & $*$ \\
$7^{\text {th }}$ Grade & 54 & $*$ \\
Rural schools & 53 & $*$ \\
Suburban schools & 30 & $*$ \\
Urban schools & & \\
$\mathbf{1 1}^{\text {th }}$ Grade & 49 & 41 \\
Rural schools & 53 & 47 \\
Suburban schools & 37 & 35 \\
\hline Urban schools & & \\
\hline
\end{tabular}

*The school-level performance database does not include writing data for $4^{\text {th }}$ - or $7^{\text {th }}$-grade students

39Recall that the combined English language arts test was not administered until Winter 2003. The schoollevel results are for the 2002 administration of the test and therefore do not have combined English language arts data. 


\section{APPENDIX X. MINNESOTA}

\section{State Assessment System}

Under the Minnesota Comprehensive Assessment (MCA) system, students are assessed in the following grades and subjects:

- Grade 3-Reading and mathematics

- Grade 5-Reading, writing, and mathematics

- $\quad$ Grade 7-Reading and mathematics

By 2006, reading and mathematics MCAs will also be administered in grades 4,6 , and 8 , and a science MCA will be operational in 2008 in order to meet the requirements under NCLB.

In addition, the state administers the Basic Skills Test (BST) in reading and mathematics at grade 8 and in writing at grade 10. Students must pass the BST assessments in order to graduate. Those failing the assessment have multiple opportunities to retake it (see http://education.state.mn.us/html/intro_testing.htm for additional information regarding the state assessment system).

Minnesota adopted academic standards in language arts, mathematics, and the arts in 2003, and the 2006 MCAs will be the first tests to assess and report on the new reading and mathematics standards. Michigan has also drafted standards in science and social studies, which are under review. The Language Arts curriculum framework articulates standards in reading and literature, writing, and speaking, listening, and viewing. For each of these areas, Minnesota has created broad statements regarding what students should know and do (e.g., The student will read and understand grade-appropriate English-language text.) These statements are further defined by grade (though grades 9-12 are treated as a grade-span), with standards and benchmarks. Table $\mathrm{X} 1$ provides an example of these standards and expectations for $7^{\text {th }}$-grade reading and literature.

\section{Test Format and Content}

For the purposes of examining adolescent literacy, the rest of the discussion will focus on the reading tests that students take in grades 5 and 7 and the writing assessments they take in grades 5 and 10.

The MCA reading assessments are untimed and incorporate multiple-choice and constructedresponse questions. Students are required to read fiction and nonfiction works such as poems, recipes, short stories, directions, or a textbook passage. Students are then asked to answer questions about concepts and skills, such as the main idea, the sequence of events, chart or graph 
details, retelling a story in their own words, fact and opinion, the author's bias, analysis or evaluation of the text, and specialized vocabulary in context.

Table X1. $7^{\text {th }}$-Grade Language Arts Standards for Reading and Literature

\section{READING AND LITERATURE: The student will read and understand grade-appropriate English-language text.}

A. Word Recognition, Analysis and Fluency

Standard: The student will read with accuracy and fluency.

\section{B. Vocabulary Expansion}

Standard: The student will use a variety of strategies to expand reading, listening, and speaking vocabularies.

\section{Comprehension}

Standard: The student will understand the meaning of texts, using a variety of strategies, and will demonstrate literal, interpretive, inferential, and evaluative comprehension.
The student will:

1. read unfamiliar complex and multi-syllabic words using cueing systems, advanced phonetic analysis, and structural analysis

2. read narrative and expository text with fluency, accuracy, and comprehension at an appropriate silent-reading rate

3. apply correct word pronunciation and inflection.

The student will:

1. acquire, understand and use new vocabulary through explicit vocabulary instruction and independent reading

2. analyze word structure and use context clues to understand new words

3. recognize and interpret words with multiple meanings

4. recognize the influences of other languages on the English language

5. apply knowledge of Greek and Latin roots, prefixes, and suffixes to understand content-area vocabulary and assist pronunciation

6. identify and explain analogies, similes, and metaphors

7. determine pronunciation, meanings, and alternate choices through the use of dictionaries, thesauruses, and electronic tools.

The student will:

1. comprehend, interpret, and evaluate text by asking and answering questions

2. recall and use prior learning and preview text to prepare for reading

3. use knowledge of narrative and expository text structures and subject specific texts to summarize content

4. make inferences and draw conclusions based on explicit and implied information from texts

5. create outlines, logical notes, and summaries across content areas

6. use texts' structural organizers, such as graphics, illustrations, references, notes, introductions, boldface type, and subheadings to aid comprehension

7. distinguish statements of fact from opinion and give examples from text

8. critically read and evaluate to determine the author's purpose, point of view, audience, and message

9. follow written directions in technical reading

10. Scan a passage to determine relevant information and skim the text to locate specific information

11. identify devices used in persuasive text. 
Table X1. (cont.)

\footnotetext{
D. Literature

Standard: The student will actively engage in the reading process and read, understand, respond to, analyze, interpret, evaluate, and appreciate a wide variety of fiction, poetic, and nonfiction texts.
}

The student will:

1. read a variety of high-quality, traditional, classical, and contemporary literary works specific to America, as well as significant works from other countries

2. identify and analyze various genres and sub-genres as forms with distinct characteristics and purposes

3. identify and analyze the relationships among elements of fiction, including setting, character, plot, conflict/resolution, theme, and tone

4. identify and analyze the effect of characters' traits on the plot and resolution of the conflict

5. analyze how figurative language and literary devices contribute to the meaning of a text

6. identify and discuss the effect of the speaker and recognize the difference between first- and third-person point of view

7. relate a given literary work to historical events (place, time, and custom)

8. explain how form and stylistic devices convey the meaning of a poem

9. identify and understand recurring themes across literary works, citing evidence from the texts

10. respond to literature using ideas and details from the text to support reactions and make literary connections

11. read from and respond to a variety of fiction, poetic, and nonfiction texts of increasing complexity for personal enjoyment.

Source: http://education.state.mn.us/content/o09200.pdf

Grade 5 tests may include up to 8 selections (with at least one of the following: fictional story, poem, nonfiction text, nonfiction informative selection, and one chart, table, or graph) ranging from 250 to 1,000 words in length. The test includes 46 multiple-choice questions and three constructed-response questions worth 4 points each, for a total of 58 points. An additional ten multiple-choice questions and one constructed-response question are included in the test as fieldtest items. The field-test questions are not part of the student's test scores (http://education.state.mn.us/content/G5RSpecs.pdf).

Grade 7 tests include six reading selections (two nonfiction, three fiction, and one technical), with a total of 3,600 to 4,200 words and a maximum of 850 words per selection. There are 40 multiple-choice questions and a total of 12 points of open-response questions, for a total of 52 raw-score points (http://education.state.mn.us/content/G7RSpecs.pdf).

On the BST, the $10^{\text {th }}$-grade reading test includes 5 to 7 passages (one technical, one or two expository passages, one to three contemporary intellectual essays, and one or two historical essays); each passage includes 400-1,000 words (no length requirement for technical selections), with a total test word count of 3,000-4,000. There are 42 multiple-choice questions with 12 
points of open-response questions, for a total of 54 raw-score points

(http://education.state.mn.us/content/G1oRSpecs.pdf).

The writing assessments require students to write one narrative, clarification, problem solution, or descriptive composition based on a prompt. Students respond to only one of four possible prompts. The writing assessments are scored on a six-point rubric based on clarity of central idea, coherent focus, organization, detail support or elaboration of ideas, and correct language conventions (spelling, grammar, punctuation, etc.).

The 2003 grade 5 prompts were

- Descriptive-Describe a favorite town or city to someone who has never been there.

- Narrative-Imagine that you go to school and see a character from your favorite book sitting at a desk in your classroom. Write a story about what happens.

- Problem Solution-The students in your school are unhappy with the time that school begins. Write a letter to your principal describing the problem and suggesting ways to solve it.

- Clarification-If you could live any place in the world, where do you think the best place would be? Explain your choice. (http://education.state.mn.us/content/o10662.pdf)

\section{Achievement-Level Definitions}

Test results reported across the state are broken into five achievement levels. $4^{4}$

- Level I (below basic)-Scores indicate that the student has significant gaps in the knowledge and skills necessary for satisfactory grade-level work.

- Level IIa (basic)-Scores represent partial knowledge and skills required for successful gradelevel achievement.

- Level IIb (proficient)-Scores represent state expectations for achievement of all students. Students at this level are working successfully on grade-level material.

- Level III (advanced)-Scores represent successful work with challenging, above-grade-level material.

- Level IV (beyond advanced)-Scores represent superior, advanced academic performance, well beyond what is expected at the grade level.

Scores at or above the proficient level are considered proficient under NCLB accountability requirements.

40The 2003 and previous grade 5 Writing MCAs were graded on a scale of Level I, Level IIa, Level IIb, Level III, and Level IV. In 2004, the achievement levels became 1-5: I=1, IIa = 2, IIb = 3, III = 4, and IV = 5. 


\section{Performance Results}

\section{$\underline{\text { Student Performance }}$}

Tables $\mathrm{X}_{2}$ and $\mathrm{X}_{3}$ presents data on student performance, disaggregated by disability status, English-proficiency status, socioeconomic status, and racial/ethnic groups for the $5^{\text {th }}$-grade 2002 MCA in reading and writing. ${ }^{41}$ Table $\mathrm{X}_{4}$ shows the $20028^{\text {th }}$-grade reading and $10^{\text {th }}$-grade writing BST results for students, broken down by these characteristics. ${ }^{42}$

Overall, 75 percent of $5^{\text {th }}$-grade students reached the proficient level, 64 percent scored at or above the advanced level, and 25 percent reached the highest level of proficiency-beyond advanced. Almost 40 percent of special education students scored at or above the proficient level, as did 25 percent of students with limited-English proficiency.

Economically disadvantaged students scored far below their peers-30 percentage points at or above the proficient level, 34 percentage points at or above the advanced level, and 22 percentage points at the beyond advanced level. There were also large achievement gaps between white students and African American students (40 percentage points), Asian students (33 percentage points), and Hispanic students (36 percentage points) at the proficient level or above. These gaps persisted at the advanced and beyond advanced levels as well.

Minnesota reports data for student performance on each of the four writing prompts. Overall, 74-87 percent of students performed at or above the proficient level on the various prompts. Between 44 and 62 percent of special education students reached the proficient level on the various writing assessments, as did 43-69 percent of students with limited-English proficiency. Overall, students performed best on the problem solution prompt and not quite as well on the narrative and descriptive prompts. Similar to what we found in reading, there were large achievement gaps between economically disadvantaged students and their peers and between white students and Asian students, Hispanic students, and African American students. Eighty percent of $8^{\text {th }}$-graders passed the reading BST, and 91 percent of $10^{\text {th }}$-graders passed the writing BST. Forty percent of special education students passed the $8^{\text {th }}$-grade reading test, and 63 percent passed the $10^{\text {th }}$-grade writing test, as did 31 percent and 48 percent of students with limited-English proficiency, respectively. There were achievement gaps of 18-29 percentage

\footnotetext{
${ }^{41}$ Approximately 82 percent of students in Minnesota are white; 7 percent are African American; 5 percent are Asian/Pacific Islander; and 4 percent are Hispanic. About 26 percent of students are eligible for the free and reduced-price lunch program; 6 percent are in limited-English-proficiency programs; and 13 percent have Individual Education Programs (IEPs).

${ }^{42}$ Test results for 2003 were not available because of concerns about data accuracy.
} 
points between non-economically disadvantaged students and economically disadvantaged students, and even larger achievement gaps by race/ethnicity (in most cases). White students outperformed African American students by 32-40 percentage points, Hispanic students by 2434 percentage points, and Asian students by $15^{-25}$ percentage points.

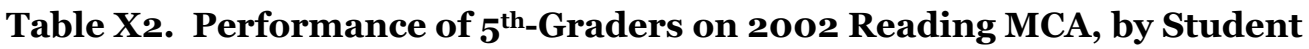
Characteristics

\begin{tabular}{lccc}
\hline & $\begin{array}{c}\text { Proficient } \\
\text { and Above }\end{array}$ & $\begin{array}{c}\text { Advanced } \\
\text { and Above }\end{array}$ & $\begin{array}{c}\text { Beyond } \\
\text { Advanced }\end{array}$ \\
\cline { 2 - 4 } & & & \\
\hline $\mathbf{5}^{\text {th }}$ Gercentage \\
All students & 75 & 64 & 25 \\
General education students & 80 & 69 & 28 \\
Special education students & 39 & 29 & 8 \\
Students with limited-English proficiency & 25 & 15 & 2 \\
Students with English proficiency & 78 & 67 & 27 \\
Economically disadvantaged students & 54 & 40 & 10 \\
Non-economically disadvantaged & 84 & 74 & 32 \\
$\quad$ students & 42 & 29 & 6 \\
African American students & 49 & 38 & 12 \\
Asian/Pacific Islander students & 46 & 34 & 9 \\
Hispanic students & 82 & 71 & 29 \\
White students & & & \\
\hline : http:/education_state.mn.us/html/intro_mde_analysis.htm & & & \\
\hline
\end{tabular}

Source: http://education.state.mn.us/html/intro_mde_analysis.htm 
Table X3. Performance of $5^{\text {th }}$-Graders on 2002 Writing MCA, by Student Characteristics

\begin{tabular}{|c|c|c|c|c|}
\hline & $\begin{array}{c}\text { Writing } \\
\text { Narrative }\end{array}$ & $\begin{array}{l}\text { Writing } \\
\text { Problem } \\
\text { Solution } \\
\end{array}$ & $\begin{array}{c}\text { Writing } \\
\text { Descriptive }\end{array}$ & $\begin{array}{c}\text { Writing } \\
\text { Clarification } \\
\end{array}$ \\
\hline & \multicolumn{4}{|c|}{ Percentage Proficient or Above } \\
\hline \multicolumn{5}{|l|}{$5^{\text {th }}$ Grade } \\
\hline All students & 74 & 87 & 74 & 78 \\
\hline General education students & 79 & 90 & 78 & 82 \\
\hline Special education students & 44 & 62 & 44 & 49 \\
\hline $\begin{array}{l}\text { Students with limited-English } \\
\text { proficiency }\end{array}$ & 50 & 69 & 43 & 56 \\
\hline Students with English proficiency & 76 & 88 & 76 & 79 \\
\hline $\begin{array}{l}\text { Economically disadvantaged } \\
\text { students }\end{array}$ & 60 & 77 & 57 & 64 \\
\hline $\begin{array}{l}\text { Non-economically disadvantaged } \\
\text { students }\end{array}$ & 80 & 91 & 81 & 84 \\
\hline African American students & 48 & 72 & 46 & 56 \\
\hline Asian/Pacific Islander students & 68 & 85 & 63 & 72 \\
\hline Hispanic students & 56 & 70 & 53 & 62 \\
\hline White students & 78 & 89 & 79 & 81 \\
\hline
\end{tabular}

Table X4. Performance of $8^{\text {th }}-$ Graders on 2002 Reading BST and $10^{\text {th }}$-Graders on 2002 Writing BST, by Student Characteristics

\begin{tabular}{lcc}
\hline & $\begin{array}{c}\mathbf{8}^{\text {th }} \text {-Grade } \\
\text { Reading }\end{array}$ & $\begin{array}{c}\mathbf{1 0}^{\text {th }} \text { Writing } \\
\text { Write }\end{array}$ \\
\cline { 2 - 3 } & Percentage & Passing \\
\hline All students & 80 & 91 \\
General education students & 86 & 94 \\
Special education students & 40 & 63 \\
Students with limited-English proficiency & 31 & 48 \\
Students with English proficiency & 83 & 93 \\
Economically disadvantaged students & 59 & 77 \\
Non-economically disadvantaged students & 88 & 95 \\
African American students & 46 & 62 \\
Asian/Pacific Islander students & 61 & 79 \\
Hispanic students & 52 & 70 \\
White students & 86 & 94 \\
\hline
\end{tabular}

Source: http://education.state.mn.us/html/intro_mde_analysis.htm 
$\underline{\text { School Performance }}$

Data on student performance on the MCA/BST by urbanicity are available for the 2002 administrations of the MCA and the BST (Tables $\mathrm{X}_{5}$ and X6). Forty-one percent of schools in Minnesota were suburban, 40 percent were rural, and 18 percent were urban. Urban schools were far more likely to be high-poverty schools-65 percent, compared with 16 percent of rural schools and 4 percent of suburban schools. The average performance of students in rural and suburban schools was quite similar, although suburban schools did outperform rural schools by small margins in $5^{\text {th }}$-grade reading (3-6 percentage points across achievement levels). However, the average performance of students in urban schools was far below that of rural and suburban schools -26 to 29 percentage points across grade levels at the passing or proficient level.

Table X5. Average School Performance on $5^{\text {th-Grade } 2002}$ Reading MCA, by Urbanicity

\begin{tabular}{lccc}
\hline & $\begin{array}{c}\text { Proficient } \\
\text { and Above }\end{array}$ & $\begin{array}{c}\text { Advanced } \\
\text { and Above }\end{array}$ & $\begin{array}{c}\text { Beyond } \\
\text { Advanced }\end{array}$ \\
\cline { 2 - 4 } & \multicolumn{3}{c}{ Average Percentage } \\
\hline Rural schools & 76 & 65 & 23 \\
Suburban schools & 79 & 69 & 29 \\
Urban schools & 50 & 39 & 14 \\
\hline
\end{tabular}

Table X6. Average School Performance on $8^{\text {th }}$-Grade 2002 Reading BST and $10^{\text {th }}$ Grade 2002 Writing BST, by Urbanicity

\begin{tabular}{lcc}
\hline & $\begin{array}{c}\mathbf{8}^{\text {th }} \text {-Grade } \\
\text { Reading }\end{array}$ & $\begin{array}{c}\mathbf{1 0}^{\text {th }} \text {-Grade } \\
\text { Writing }\end{array}$ \\
\cline { 2 - 3 } & Average Percentage Passing \\
\hline Rural schools & 79 & 91 \\
Suburban schools & 80 & 90 \\
Urban schools & 52 & 68 \\
\hline
\end{tabular}




\section{APPENDIX Y. MISSISSIPPI}

\section{State Assessment System}

Mississippi's assessment system consists of a number of assessments:

- $\quad$ The Mississippi Curriculum Tests (MCT) in reading, language, and mathematics in grades 2 through 8.

- Writing assessment in grades 4 and 7.

- A norm-referenced test in reading/language arts and mathematics in grade 6.

- Subject Area Test Program (SATP) assessments, which are end-of-course tests in Algebra I, Biology, English II, and U.S. History from 1877.

In addition, Mississippi is developing science assessments in grades 5 and 8 (see http://www.mde.k12.ms.us/account/SAM/SAM.htm for additional information on the state assessment and accountability system).

Mississippi's criterion-referenced tests aim to measure the state's content standards and curriculum frameworks. The language arts framework describes what students in grades $\mathrm{K}-12$ should be able to do in English, language arts, and reading.. The framework is grade-specific and links competencies with suggested objectives, teaching strategies, and assessment methods.

Table Y1 presents an example of one competency-communicating through writing-for grade 8.

\section{Table Y1. Language Arts Framework for Communicating through Writing, $8^{\text {th }}$ Grade}

Communicate for a variety of purposes through different forms of writing, using processes of reading, writing, listening, and viewing for an expanding audience.

Objectives:

- Accomplish a writing process through planning, drafting, revising, editing, publishing, and self-reflecting on written communications, such as various short papers (narrative, descriptive, expository, persuasive), essay test questions and responses, character analysis, for different audiences and purposes, with increasing independence. (Each teacher will determine the appropriate number of products to be taken through a writing process.)

- Write with increasing complexity in various forms, such as poetry, anecdotes, fables, tall tales, myths, skits, plays, stories.

- Write a reaction to, interpretation of, or summary of what has been read or heard.

- $\quad$ Revise to ensure effective introductions, wording, topic sentences, supporting details, and conclusions.
Suggested Teaching Strategies:

- Students will write persuasive compositions, trying to alter a school rule, schedule, course offerings, etc. (e.g., trying to get music and art included in the junior high curriculum). (Assessment uses rubric instrument.)

- At the beginning of a new calendar year, students will construct calendars listing not only months, days, holidays, but also original poems, anecdotes, etc., for each month. (Assessment uses rubric instrument.)

Source: http://marcopolo.mde.k12.ms.us/downloads/lang_arts/la_o8.pdf 


\section{Test Format and Content}

Below we discuss the tests that assess literacy skills in adolescents - the MCTs in reading and language; the writing assessments; and the English II subject-area test (see http://www.mde.k12.ms.us/acad/osa/ for additional information regarding test content and format).

\section{$\underline{\mathrm{MCT}}$}

The reading and language tests contain 45 multiple-choice questions and four open-ended questions. Each multiple-choice item is worth 1 point. The value of each open-ended item depends upon the item: most are worth one or two points, and a few are worth three points.

The following curriculum objectives are measured by the MCT:

\section{Reading}

- Context Clues - Items in this category assess students' ability to determine the meaning of unfamiliar words by utilizing picture and context clues; decode unknown words using the three-cueing system; and use multiple meanings of words in context.

- Word Structure - Items in this category assess students' ability to recognize and comprehend prefixes, suffixes, compound words, root words, and contractions; distinguish between contractions and possessives; and extend syntactic patterns.

- Word Patterns - Items in this category assess students' ability to recognize vowel sounds; decode words using phonetic generalizations; and extend phonetic patterns.

- Vocabulary - Items in this category assess students' ability to recognize and comprehend synonyms, antonyms, homonyms, and homographs.

- Main Idea - Items in this category assess students' ability to comprehend the meaning of text by identifying main ideas, details, stated cause and effect, and story elements; distinguishing fact and opinion; and summarizing main ideas.

- Expanded Comprehension - Items in this category assess students' ability to expand the meaning of text by drawing conclusions and making inferences; determining implied cause and effect; making predictions; comparing and contrasting; identifying author's purpose and tone; analyzing and describing story elements; connecting literature to real-life situations; and recognizing and interpreting figurative language.

- Workplace Data - Items in this category assess students' ability to utilize text features, such as visual aids, maps, graphs, charts, captions, headings, and subheadings; utilize parts of books; identify a sequence of steps or activities; follow directions; locate and apply information; identify information that provides additional clarity; and interpret specialized vocabulary. 


\section{Language}

- Capitalization and Punctuation - Items in this category assess students' ability to recognize the correct use of grade-level-appropriate punctuation marks and capitalization in sentences, paragraphs, and letters. Constructed-response items also have students proofread a given sentence or paragraph and correct a specified number of errors.

- Spelling - Items in this category assess students' ability to recognize and correct spelling of grade-level spelling words given in context by means of a sentence or a phrase.

- Sentence Structure - Items in this category assess students' ability to recognize sentences that are complete and that follow Standard English conventions. Students distinguish complete sentences from fragments and run-on sentences; recognize subject/verb and pronoun agreement, correct adjective and adverb forms, appropriate verb tense, and general common syntax; and concisely and accurately combine related sentences. Constructed-response items also have students write simple and compound sentences.

- Meaning - Items in this category assess students' ability to identify the elements of a cohesive paragraph. Students identify appropriate topic sentences, choose relevant information to include in a paragraph, put sentences in order, and choose traditional words to relate sentences to one another. In constructed-response items, students also write sentences or paragraphs in response to prompts, short sets of instructions, letters, and information to fill in a form or application (http://www.mde.k12.ms.us/acad/osa/mctobj.pdf).

\section{Writing Assessments}

In grades 4 and 7, students respond to a prompt designed to elicit either narrative, informative, or persuasive responses. The writing assessments are scored using a four-point holistic rubric.

\section{English II Subject Area Test}

The English II Subject Area Test measures knowledge of language conventions, reading comprehension, and effective writing skills according to competencies found in the Language Arts Curriculum Framework. The assessment consists of two separately administered tests: English II Multiple-choice and English II Writing. For the writing section, students write an informative essay and a narrative essay. Students have approximately two hours for the assessment; however, students needing additional time will be accommodated.

\section{Achievement-Level Definitions}

Proficiency levels for the English language arts MCTs and the English II component of the SATP are advanced, proficient, basic, and minimal. Definitions of these levels on these assessments are 
provided in Table Y2. Scores at or above the proficient level are considered "passing" for accountability purposes.

\section{Table Y2. Achievement-Level Definitions for the English Language Arts MCTs and English II SATP}

\begin{tabular}{lll}
\hline $\begin{array}{c}\text { Achievement } \\
\text { Level }\end{array}$ & \multicolumn{1}{c}{ MCT } & \multicolumn{1}{c}{ SATP English Test II } \\
\hline Advanced & $\begin{array}{l}\text { Students at the advanced level consistently } \\
\text { perform in a manner clearly beyond that } \\
\text { required to be successful at the next grade. }\end{array}$ & $\begin{array}{l}\text { Students at the advanced level consistently } \\
\text { perform in a manner clearly beyond that } \\
\text { required to be successful in a more } \\
\text { advanced course in the content area. }\end{array}$ \\
Proficient & $\begin{array}{l}\text { Students at the proficient level } \\
\text { demonstrate solid academic performance } \\
\text { and mastery of the content-area }\end{array}$ & $\begin{array}{l}\text { Students at the proficient level demonstrate } \\
\text { solid academic performance and mastery of } \\
\text { the knowledge and skills required for }\end{array}$ \\
& $\begin{array}{l}\text { knowledge and skills required for success } \\
\text { at the next grade. Students who perform } \\
\text { at this level are well prepared to begin } \\
\text { work on even more challenging material } \\
\text { than is required at the next grade. }\end{array}$ & $\begin{array}{l}\text { content area. } \\
\text { Basic }\end{array}$ \\
& $\begin{array}{l}\text { Students at the basic level demonstrate } \\
\text { partial mastery of the content-area } \\
\text { knowledge and skills required for success } \\
\text { at the next grade. Remediation may be } \\
\text { necessary for these students. }\end{array}$ & $\begin{array}{l}\text { Students at the basic level demonstrate } \\
\text { partial mastery of the knowledge and skills } \\
\text { in the course and may experience difficulty } \\
\text { in a more advanced course in the content } \\
\text { area. }\end{array}$ \\
& $\begin{array}{l}\text { Students at the minimal level are below } \\
\text { basic and do not demonstrate mastery of } \\
\text { the content-area knowledge and skills } \\
\text { required for success at the next grade. } \\
\text { These students require additional } \\
\text { instruction and remediation in the basic } \\
\text { skills that are necessary for success at the } \\
\text { grade tested. }\end{array}$ & $\begin{array}{l}\text { Students at the minimal level are below } \\
\text { basic and do not demonstrate mastery of } \\
\text { the knowledge and skills required for } \\
\text { success in the course. }\end{array}$ \\
& & \\
Minimal & &
\end{tabular}

Source:

http://www.mde.k12.ms.us/acad/osa/MCT_Proficiency_Levels.pdf;http://www.mde.k12.ms.us/acad/osa/ English2.html

\section{Performance Results}

\section{$\underline{\text { Student Performance }}$}

Student test results are reported for all students, and for students disaggregated by disability status, race/ethnicity, and economic disadvantage status. 43 Table $\mathrm{Y}_{3}$ provides $5^{\text {th }}$ and $8^{\text {th }}$-grade results for these groups of students on the English language arts MCT.

43Approximately 51 percent of students in Mississippi are African American; 47 percent are white; and no other racial/ethnic group comprises 1 percent of the student population. About 65 percent of students are eligible for the free and reduced-price lunch program; less than 1 percent are in limited-English-proficiency programs; and 13 percent have Individual Education Programs (IEPs). 
The large majority of students-over 90 percent-scored at the basic level in grade 4 reading and language, and there were relatively small differences among students grouped by disability status, race/ethnicity, and economic disadvantage status. In what follows, we focus on those scoring at the proficient level and above.

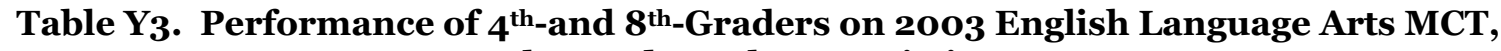
by Student Characteristics

\begin{tabular}{|c|c|c|c|c|}
\hline & \multicolumn{2}{|c|}{ Reading } & \multicolumn{2}{|c|}{ Language } \\
\hline & $\begin{array}{l}\text { Basic and } \\
\text { above }\end{array}$ & $\begin{array}{l}\text { Proficient } \\
\text { and above }\end{array}$ & $\begin{array}{l}\text { Basic and } \\
\text { above }\end{array}$ & $\begin{array}{l}\text { Proficient } \\
\text { and above }\end{array}$ \\
\hline & \multicolumn{4}{|c|}{ Percentage } \\
\hline \multicolumn{5}{|l|}{$4^{\text {th }}$ Grade } \\
\hline All students & 94 & 87 & 90 & 68 \\
\hline Students without disabilities & 95 & 87 & 91 & 69 \\
\hline Students with disabilities & 92 & 83 & 87 & 62 \\
\hline Economically disadvantaged students & 92 & 82 & 87 & 59 \\
\hline $\begin{array}{l}\text { Non-economically disadvantaged } \\
\text { students }\end{array}$ & 96 & 94 & 95 & 81 \\
\hline African American students & 91 & 80 & 86 & 57 \\
\hline White students & 96 & 95 & 96 & 81 \\
\hline \multicolumn{5}{|l|}{$8^{\text {th }}$ Grade } \\
\hline All students & 81 & 57 & 93 & 53 \\
\hline Students without disabilities & 82 & 57 & 93 & 54 \\
\hline Students with disabilities & 64 & 42 & 77 & 33 \\
\hline Economically disadvantaged students & 73 & 43 & 90 & 41 \\
\hline $\begin{array}{l}\text { Non-economically disadvantaged } \\
\text { students }\end{array}$ & 89 & 70 & 95 & 65 \\
\hline African American students & 71 & 40 & 89 & 39 \\
\hline White students & 91 & 73 & 96 & 67 \\
\hline
\end{tabular}

Source: http://www.mde.k12.ms.us/account/RC3A/HTML/Sooooooo.HTM

Note: Mississippi reports scores of 96-100 percent together in their report. We report the lower bound in this range in the table ( 96 percent).

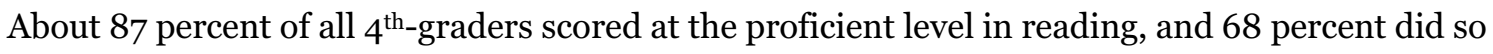
in language. There were small differences between the performance of students with and without disabilities (4-7 percentage points). The achievement differences by race were larger: 15 percentage points in reading and 24 percentage points in language. Economically disadvantaged students also had proficiency rates that were significantly lower than those of other students, by 12 percentage points in reading and 22 percentage points in language.

While the percentage of students scoring at the basic level was also quite high at the $8^{\text {th }}$ grade, the percentage of those scoring at the proficient level was much lower: 57 percent in reading and 53 
percent in language. The differences in proficiency rates among different groups of students were much larger in the $8^{\text {th }}$ grade: $15^{-21}$ percentage points between students with and without disabilities; 28-33 percentage points between African American and white students; and 24-27 percentage points between economically disadvantaged students and other students.

Table $\mathrm{Y}_{4}$ shows the $4^{\text {th- }}$ and $7^{\text {th }}$-grade writing scores for the same groups of students. While between 93 and 96 percent of students scored at the basic level and above, the proportions who were judged proficient were considerably smaller-24 percent of $4^{\text {th }}$-graders and 31 percent of $7^{\text {th }}$ graders. The differences between African American and white students were smaller than those seen in reading and language and ranged from 11 percentage points in grade 4 to 18 percentage points in grade 7. Similarly, differences in proficiency rates of economically disadvantaged students and their counterparts were smaller than those reported earlier-10-14 percentage points.

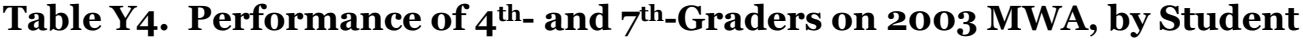 Characteristics}

\begin{tabular}{|c|c|c|c|c|}
\hline & \multicolumn{2}{|c|}{$4^{\text {th }}$ Grade } & \multicolumn{2}{|c|}{$7^{\text {th }}$ Grade } \\
\hline & $\begin{array}{l}\text { Basic and } \\
\text { above }\end{array}$ & $\begin{array}{l}\text { Proficient } \\
\text { and above }\end{array}$ & $\begin{array}{l}\text { Basic and } \\
\text { above }\end{array}$ & $\begin{array}{l}\text { Proficient } \\
\text { and above }\end{array}$ \\
\hline & \multicolumn{4}{|c|}{ Percentage } \\
\hline All students & 96 & 24 & 93 & 31 \\
\hline Students without disabilities & 96 & 24 & 94 & 32 \\
\hline Students with disabilities & 94 & 20 & 87 & 25 \\
\hline $\begin{array}{l}\text { Economically disadvantaged } \\
\text { students }\end{array}$ & 96 & 20 & 92 & 25 \\
\hline $\begin{array}{l}\text { Non-economically } \\
\text { disadvantaged students }\end{array}$ & 96 & 30 & 96 & 39 \\
\hline African American students & 96 & 19 & 91 & 22 \\
\hline White students & 96 & 30 & 96 & 40 \\
\hline
\end{tabular}

Source: http://www.mde.k12.ms.us/account/RC3A/HTML/Sooooooo.HTM

Note: Mississippi reports scores of $96-100$ percent together in their report. We report the lower bound in this range in the table ( 96 percent).

Table $Y_{5}$ presents the percentage of high school students passing the English II SATP in the first attempt for 2003. The reading and language-convention test appeared to be more difficult than the narrative and informative essay for students to pass -78 percent passed the former in the first attempt compared with the 94-97 percent who passed the essay portions of the test. Less than half of students with disabilities passed the reading and language-convention section compared with 80 percent of students without disabilities; the difference in pass rates was much smaller for the two essay sections. There was a 22-percentage-point gap in the pass rates of African 
American and white students in the reading and language-convention section compared with a 25-percentage-point gap in the essay sections. Similarly, there was a difference of 18 percentage points in the pass rates of economically disadvantaged and other students in the reading and language-convention section, compared with 2-4 percentage points in the two essay sections.

\section{Table Y5. Student Performance on 2003 English II SATP, by Student Characteristics}

\begin{tabular}{lccc}
\hline & $\begin{array}{c}\text { Reading } \\
\text { and } \\
\text { language } \\
\text { convention }\end{array}$ & $\begin{array}{c}\text { Narrative } \\
\text { essay }\end{array}$ & $\begin{array}{c}\text { Informative } \\
\text { essay }\end{array}$ \\
\cline { 2 - 4 } & \multicolumn{2}{c}{ Percentage Passing First Attempt } \\
\hline All students & 78 & 94 & 97 \\
Students without disabilities & 80 & 94 & 97 \\
Students with disabilities & 45 & 88 & 90 \\
Economically disadvantaged students & 68 & 92 & 96 \\
Non-economically disadvantaged & & 96 & 98 \\
$\quad$ students & 86 & 92 & 96 \\
African American students & 67 & 97 & 98 \\
White students & 89 & 96 \\
\hline
\end{tabular}

Source: http://www.mde.k12.ms.us/account/RC3A/HTML/Sooooooo.HTM

Note: Mississippi reports scores of $96-100$ percent together in their report. We report the lower bound in this range in the table ( 96 percent).

\section{$\underline{\text { School Performance }}$}

School-level data by urbanicity are available for the 2002 MCT administration for grades 5 and 8 for English language arts and the 2002 MWA for grades 4 and 7 (Tables Y6 and Y7).

Approximately 64 percent of schools in Mississippi were rural; 24 percent were suburban; and 12 percent were urban. 44 Over 80 percent were high-poverty schools: Almost all rural and urban schools were high-poverty (95 percent and 100 percent, respectively), while 43 percent of suburban schools were high-poverty schools.

In reading, language, and writing, at all grades and achievement levels, average school scores in suburban schools were higher than those in urban and rural schools--with one exception (performance of suburban and urban schools was equal at the basic level for $4^{\text {th }}$ grade). For instance, for grade 8 reading at the proficient level, suburban schools outperformed rural schools by an average of 8 percentage points and urban schools by an average of 10 percentage points.

\footnotetext{
44 Data for urbanicity and poverty status were missing for approximately 6 percent of schools.
} 
Table Y6. Average School Performance on $5^{\text {th- }}$ and $8^{\text {th }}$-Grade 2002 English Language Arts MCT, by Urbanicity

\begin{tabular}{lcccc}
\hline & \multicolumn{2}{c}{ Reading } & \multicolumn{2}{c}{ Language } \\
\cline { 2 - 5 } & $\begin{array}{c}\text { Basic and } \\
\text { Above }\end{array}$ & $\begin{array}{c}\text { Proficient } \\
\text { and Above }\end{array}$ & $\begin{array}{c}\text { Basic and } \\
\text { Above }\end{array}$ & $\begin{array}{c}\text { Proficient } \\
\text { and Above }\end{array}$ \\
\cline { 2 - 5 } & \multicolumn{5}{c}{ Average Percentage } \\
\hline $\mathbf{5}^{\text {th }}$ Grade & 86 & 75 & 87 & 59 \\
Rural schools & 81 & 82 & 90 & 66 \\
Suburban schools & 89 & 79 & 91 & 64 \\
Urban schools & & & & 40 \\
$\mathbf{8}^{\text {th }}$ Grade & 73 & 45 & 90 & 46 \\
Rural schools & 79 & 53 & 92 & 39 \\
Suburban schools & 70 & 43 & 86 & \\
Urban schools & & & & \\
\hline
\end{tabular}

Table Y7. Average School Performance on $4^{\text {th- }}$ and $7^{\text {th-Grade }} 2002$ MWA, by Urbanicity

\begin{tabular}{lcccc}
\hline & \multicolumn{2}{c}{$\mathbf{4}^{\text {th }}$ Grade } & \multicolumn{2}{c}{$\mathbf{7}^{\text {th }}$ Grade } \\
\cline { 2 - 5 } & $\begin{array}{c}\text { Basic and } \\
\text { Above }\end{array}$ & $\begin{array}{c}\text { Proficient } \\
\text { and Above }\end{array}$ & $\begin{array}{c}\text { Basic and } \\
\text { Above }\end{array}$ & $\begin{array}{c}\text { Proficient } \\
\text { and Above }\end{array}$ \\
\cline { 2 - 5 } & \multicolumn{4}{c}{ Average Percentage } \\
\hline Rural schools & 90 & 41 & 91 & 29 \\
Suburban schools & 93 & 49 & 94 & 35 \\
Urban schools & 93 & 41 & 93 & 29 \\
\hline
\end{tabular}




\section{APPENDIX Z. MISSOURI}

\section{State Assessment System}

The Missouri Assessment Program (MAP) is designed to measure student progress in meeting the Show-Me Standards. The 73 Show-Me Standards, adopted by the State Board of Education in 1996, describe what Missouri students must know and be able to do.

As of spring 2003, Missouri required that districts administer assessments in communication arts for grades 3,7 , and 11 and in mathematics for grades 4,8 , and 10. Districts may also voluntarily administer the science assessment in grades 3,7 , and 10 and the social studies assessment in grades 4,8 , and 11. The department uses the information obtained through MAP to monitor the progress of Missouri's students in meeting the state standards, to inform the public and the state legislature about students' performance, to help make informed decisions about educational issues, and, now, to hold schools accountable under NCLB (see http://dese.mo.gov/divimprove/assess/for additional assessment and accountability information).

In future years, Missouri will be adding to and revising assessments so that all students in grades 3-8 are tested annually in reading/language arts and mathematics in order to meet the testing requirements of NCLB.

Missouri's academic standards in all subjects are grouped around four goals:

- Goal 1-Students in Missouri public schools will acquire the knowledge and skills to gather, analyze, and apply information and ideas.

- Goal 2-Students in Missouri public schools will acquire the knowledge and skills to communicate effectively within and beyond the classroom.

- Goal 3-Students in Missouri public schools will acquire the knowledge and skills to recognize and solve problems.

- Goal 4-Students in Missouri public schools will acquire the knowledge and skills to make decisions and act as responsible members of society (http://dese.mo.gov/standards/process.html).

Standards, then, provide an overview of what knowledge and skills Missouri public school students should acquire. These are not grade-specific. For example, the standards for communication arts specify that students in Missouri public schools will acquire a solid foundation, which includes knowledge of and proficiency in: 
1. Speaking and writing Standard English (including grammar, usage, punctuation, spelling, capitalization).

2. Reading and evaluating fiction, poetry, and drama.

3. Reading and evaluating nonfiction works and material (such as biographies, newspapers, technical manuals).

4. Writing formally (such as reports, narratives, essays) and informally (such as outlines, notes).

5. Comprehending and evaluating the content and artistic aspects of oral and visual presentations (such as storytelling, debates, lectures, multi-media productions).

6. Participating in formal and informal presentations and discussions of issues and ideas.

7. Identifying and evaluating relationships between language and culture (http://dese.mo.gov/standards/comarts.html).

To help districts determine what students should learn and be able to do in accordance with these standards in various grades, the state has developed grade-level expectations or curriculum frameworks for students in three grade spans: $1-4,5-8$, and 9-12. The curriculum frameworks for each of the six content areas include:

- An overview of education in Missouri in that content area

- A listing of what students should know and be able to do at the elementary, middle, and high school levels

- Suggested learning activities to develop pertinent knowledge and skills

- Discussion of relevant educational issues and practices (http://dese.mo.gov/standards/comarts.html).

Table $Z 1$ presents an example from the communication arts grades $5-8$ expectations for goal 3 of Missouri Education-Recognizing and Solving Problems. 
Table Z1. Grade-Level Expectations and Sample Learning Activities, Communication Arts 5-8, Goal 3-Recognizing and Solving Problems

By the end of $8^{\text {th }}$ grade, all students should know how to: Apply communication strategies to identify, understand, and solve problems.

\begin{tabular}{|c|c|}
\hline What All Students Should be Able to Do & Sample Learning Activities \\
\hline 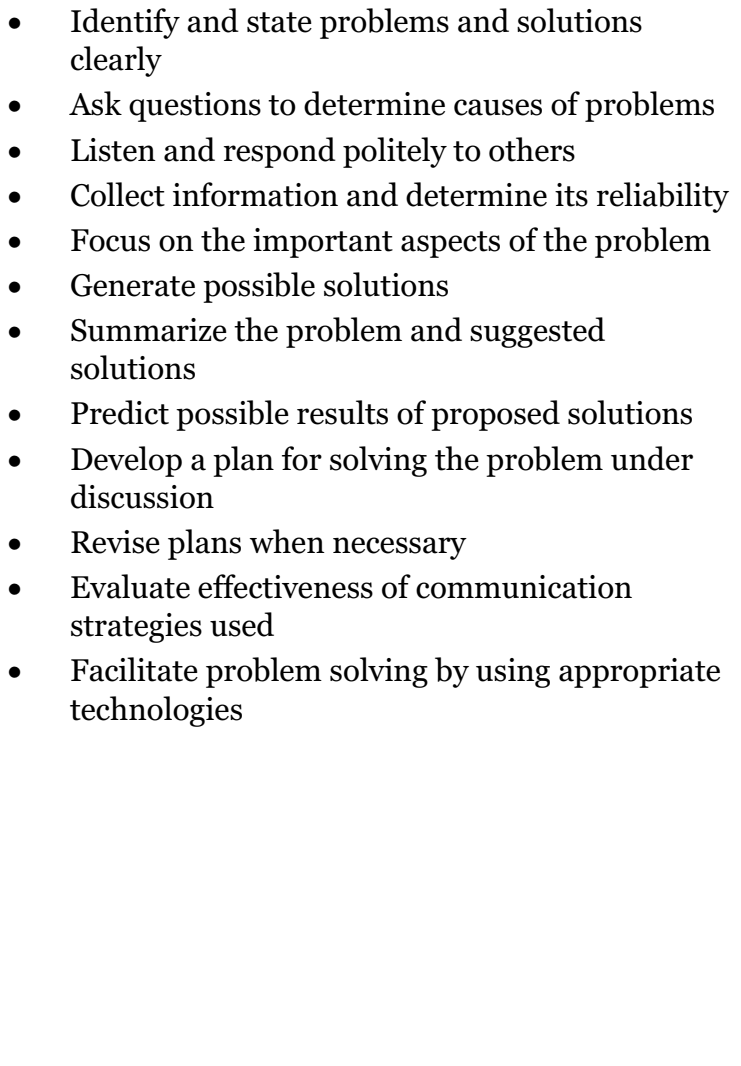 & $\begin{array}{l}\text { Research a school or community problem and } \\
\text { propose solutions; then write a persuasive letter } \\
\text { to the appropriate audience, requesting specific } \\
\text { action. } \\
\text { Design a desired school improvement or project } \\
\text { with classmates; brainstorm possible problems } \\
\text { that might arise. Devise strategies to counter } \\
\text { these problems or alter plans to avoid certain } \\
\text { problems. } \\
\text { Identify at least three groups who have different } \\
\text { opinions concerning a current issue or problem. } \\
\text { Write a feature story that presents how each } \\
\text { group might solve the problem. } \\
\text { Create a pamphlet, poster, or other visual } \\
\text { display to inform others and present ideas for } \\
\text { solving or avoiding a specific problem by } \\
\text { recommending health, safety, or technological } \\
\text { procedures. } \\
\text { Create a multimedia presentation to persuade a } \\
\text { specific audience to take action to avoid, } \\
\text { prevent, or help solve a problem. } \\
\text { Write a real or simulated letter to a company, } \\
\text { explaining a problem with a product or service } \\
\text { and requesting action; then evaluate the } \\
\text { response to decide whether the action taken will } \\
\text { resolve the problem satisfactorily. If not, decide } \\
\text { what follow-up steps must be taken. }\end{array}$ \\
\hline
\end{tabular}

Source: http://dese.mo.gov/standards/comarts.html

\section{Test Format and Content}

For purposes of examining adolescent literacy, the remainder of the discussion focuses on the communication arts MAP that students take in grades 7 and 11. The communication arts assessment contains multiple-choice and constructed-response questions, and a writingperformance event. The multiple-choice section of the communication arts assessment is taken from the TerraNova. The constructed-response questions typically ask students to write a paragraph or two to answer a question regarding a reading passage. The writing prompt is an open-ended item that requires students to demonstrate their writing proficiency. Writing is scored holistically, using a four-point scoring guide. Students complete the assessment, which consists of four sessions over three days. The tests are not timed, but are expected to take about 60 minutes per section (http://dese.mo.gov./divimprove/assess/ca.html). 


\section{Proficiency Levels}

Missouri currently reports state assessment results in terms of five achievement levels: step 1, progressing, nearing proficiency, proficient, and advanced. Table Z2 presents the definitions of these proficiency levels for communication arts in grades 7 and 11.

For purposes of NCLB, a passing score is set at the proficient level, which Missouri considers rigorous. Missouri's starting points for determining annual Adequate Yearly Progress (AYP) targets are based on 2002 MAP scores and the overall student proficiency rate in the school at the 20th percentile of total public school enrollment. Thus, for example, the AYP goal for schools in communication arts in 2003 was set at 19.4 percent of all students being proficient. Missouri notes that it will likely adjust and realign the proficiency level when the new annual tests are implemented, starting in 2005-06.

\section{Performance Results}

\section{Student Performance}

Missouri provides student-level data on student performance on the MAP for all students, students with individual education plans, students with limited-English proficiency, and economically disadvantaged students. It also provides scores for racial/ethnic groups. 45 Table Z3 shows the communication arts performance of all students in grades 7 and 11 on the 2003 MAP administration, disaggregated by various student characteristics.

About $64-65$ percent of $7^{\text {th }}$ and 11 graders scored at the nearing proficiency and above level; however, only 33 percent of $7^{\text {th }}$-graders and 22 percent of $11^{\text {th }}$-graders scored at or above the proficient level, and very few ( 2 percent of $7^{\text {th }}$-graders and none of the $11^{\text {th }}$-graders) scored at or above the advanced level.

About a quarter (23-26 percent) of students with limited-English proficiency scored at or above the nearing proficiency level in $7^{\text {th }}$ and $11^{\text {th }}$ grades, and less than 10 percent ( 8 percent and 2 percent, respectively) reached the proficient level. Few students with disabilities scored at the proficient level (1-6 percent), and 27 percent scored at or above the nearing proficient level in $7^{\text {th }}$ grade, while 16 percent did so in $11^{\text {th }}$ grade.

\footnotetext{
45Approximately 79 percent of students in Missouri are white; 18 percent are African American; and 2 percent are Hispanic. About 35 percent of students are eligible for the free and reduced-price lunch program; less than 1 percent are in limited-English proficiency programs; and 15 percent have Individual Education Programs (IEPs).
} 
Table Z2. Proficiency Levels for Communication Arts, $7^{\text {th }}$ and $11^{\text {th }}$ Grades

\begin{tabular}{|c|c|c|}
\hline $\begin{array}{l}\text { Proficiency } \\
\text { Level }\end{array}$ & $7^{\text {th }}$ Grade & 11 $^{\text {th }}$ Grade \\
\hline Step 1 & $\begin{array}{l}\text { Reading-Students comprehend literal } \\
\text { information in fiction and nonfiction and } \\
\text { attempt to use context clues to determine } \\
\text { meaning. } \\
\text { Writing-Students minimally address } \\
\text { the topic; attempt to write complete } \\
\text { sentences; and demonstrate minimal } \\
\text { knowledge of Standard English. }\end{array}$ & $\begin{array}{l}\text { Reading-Students extract main ideas from } \\
\text { fiction and nonfiction; recognize basic patterns } \\
\text { and organize information in a provided form; } \\
\text { and use context clues to determine literal } \\
\text { meaning and recognize problems. } \\
\text { Writing-Students address a topic; show } \\
\text { evidence of purpose; respond in generalities; } \\
\text { and display a limited vocabulary and } \\
\text { knowledge of Standard English. }\end{array}$ \\
\hline Progressing & $\begin{array}{l}\text { Reading-Students comprehend main } \\
\text { ideas in fiction and nonfiction; recognize } \\
\text { obvious similarities, simple cause-effect } \\
\text { relationships, literary elements, and } \\
\text { author's purpose; organize information; } \\
\text { and use text to initiate research. } \\
\text { Writing-Students use simple sentences } \\
\text { with minimal details and organization; } \\
\text { and demonstrate knowledge of Standard } \\
\text { English. }\end{array}$ & $\begin{array}{l}\text { Reading-Students comprehend simple } \\
\text { fiction and nonfiction; initiate research; } \\
\text { compare source accuracy and reliability; } \\
\text { identify author's purpose, main idea, and basic } \\
\text { literary elements; organize information; and } \\
\text { recognize consequences. } \\
\text { Writing-Students write for intended purpose } \\
\text { and audience; generally support main idea; } \\
\text { demonstrate organization; and begin to use } \\
\text { proper sentence structure and Standard } \\
\text { English. }\end{array}$ \\
\hline $\begin{array}{l}\text { Nearing } \\
\text { proficiency }\end{array}$ & $\begin{array}{l}\text { Reading-Students comprehend a } \\
\text { variety of fiction and nonfiction works; } \\
\text { support conclusions; use context clues; } \\
\text { compare and contrast; create graphic } \\
\text { organizers; understand literary elements; } \\
\text { recognize figurative language; explain } \\
\text { cause and effect; and recognize problem- } \\
\text { solving processes. } \\
\text { Writing-Students use complete } \\
\text { sentences, supporting details, basic } \\
\text { transitions, and apply rules of Standard } \\
\text { English. }\end{array}$ & $\begin{array}{l}\text { Reading-Students comprehend a variety of } \\
\text { fiction and nonfiction; develop research ideas; } \\
\text { identify author's techniques; question } \\
\text { accuracy; discover relationships within and } \\
\text { between texts; create graphic organizers; } \\
\text { identify strategies, solutions and consequences; } \\
\text { and explain reasoning. } \\
\text { Writing-Students write for variety of } \\
\text { purposes and audiences; support main idea } \\
\text { with general details; and apply rules of } \\
\text { Standard English. }\end{array}$ \\
\hline Proficient & $\begin{array}{l}\text { Reading-Students interpret and } \\
\text { explain fiction and nonfiction works, } \\
\text { figurative language, mood, and theme; } \\
\text { identify implied cause and effect; infer } \\
\text { and predict; evaluate problem-solving } \\
\text { strategies and solutions; develop research } \\
\text { ideas. } \\
\text { Writing-Students use precise language, } \\
\text { supporting details, varied sentences; } \\
\text { write for a variety of purposes, audiences; } \\
\text { and demonstrate control of Standard } \\
\text { English. }\end{array}$ & $\begin{array}{l}\text { Reading-Students analyze fiction and } \\
\text { nonfiction; create organizers; explain research } \\
\text { ideas; evaluate accuracy and relationships; } \\
\text { predict; use details to support inferences; and } \\
\text { identify multiple perspectives and effectiveness } \\
\text { of strategies and solutions; } \\
\text { Writing-Students use organization, specific } \\
\text { support, precise language, transitions, } \\
\text { individual style and voice; demonstrate control } \\
\text { of sentences and Standard English. }\end{array}$ \\
\hline Advanced & $\begin{array}{l}\text { Reading-Students analyze fiction and } \\
\text { nonfiction, literary elements, techniques, } \\
\text { theme, mood, author's purpose and } \\
\text { perspective, and characters' motivation; } \\
\text { apply information to new situations; } \\
\text { explain reliability of sources; and identify } \\
\text { and evaluate alternative solutions. } \\
\text { Writing-Students use vivid language } \\
\text { and clearly demonstrate a command of } \\
\text { Standard English. }\end{array}$ & $\begin{array}{l}\text { Reading-Students evaluate fiction and } \\
\text { nonfiction; analyze literary elements; evaluate } \\
\text { reliability of sources; make complicated } \\
\text { inferences; analyze and evaluate strategies and } \\
\text { solutions from multiple perspectives; and } \\
\text { create organizers for analysis and presentation. } \\
\text { Writing-Students use vivid details; advanced } \\
\text { stylistic techniques; and clearly demonstrate a } \\
\text { command of sentence structure and Standard } \\
\text { English. }\end{array}$ \\
\hline
\end{tabular}


Source: http://dese.mo.gov./divimprove/assess/Descriptors/Abbreviated/Communication_Arts.html

Table Z3. Performance of $7^{\text {th }}$ - and $1^{\text {th }}-$ Graders on 2003 Communication Arts MAP, by Student Characteristics

\begin{tabular}{|c|c|c|c|c|}
\hline & $\begin{array}{l}\text { Progressing } \\
\text { and Above }\end{array}$ & $\begin{array}{l}\text { Nearing } \\
\text { Proficient } \\
\text { and Above }\end{array}$ & $\begin{array}{l}\text { Proficient } \\
\text { and Above }\end{array}$ & Advanced \\
\hline & \multicolumn{4}{|c|}{ Percentage } \\
\hline \multicolumn{5}{|l|}{$7^{\text {th }}$ Grade } \\
\hline All students & 86 & 64 & 33 & 2 \\
\hline Student with individual education plans & 60 & 27 & 6 & o \\
\hline Students with limited-English proficiency & 50 & 23 & 8 & o \\
\hline Economically disadvantaged students & 76 & 47 & 18 & 1 \\
\hline Non-economically disadvantaged students & 91 & 73 & 38 & 3 \\
\hline African American students & 67 & 36 & 11 & o \\
\hline Hispanic students & 82 & 56 & 24 & 1 \\
\hline White students & 90 & 70 & 35 & 2 \\
\hline \multicolumn{5}{|l|}{$1^{\text {th }}$ Grade } \\
\hline All students & 83 & 65 & 22 & o \\
\hline Student with individual education plans & 41 & 16 & 1 & o \\
\hline $\begin{array}{l}\text { Students with limited-English proficiency } \\
\text { students }\end{array}$ & 47 & 26 & 2 & o \\
\hline Economically disadvantaged students & 72 & 48 & 10 & o \\
\hline Non-economically disadvantaged students & 86 & 69 & 24 & 1 \\
\hline African American students & 63 & 37 & 6 & o \\
\hline Hispanic students & 78 & 57 & 14 & o \\
\hline White students & 86 & 69 & 24 & o \\
\hline
\end{tabular}

Source: http://dese.mo.gov/divimprove/assess/springo3modisaggregatemaptotals.html

African American students scored considerably below white students and Hispanic students. For

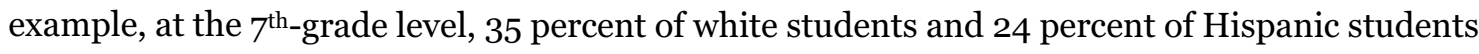
scored at the proficient level, compared with only 11 percent of African American students. The differences were even larger at the nearing proficient level: 34 percentage points between African American and white students and 20 percentage points between African American and Hispanic students. The achievement gap between white and Hispanic students was smaller-10-14 percentage points across the two achievement levels and the two grades.

A little less than half of economically disadvantaged students scored at the nearing proficient level compared with 69-73 percent of their counterparts who were not economically disadvantaged.

The difference in the percentage of economically disadvantaged and other students scoring at the 
proficient level was 20 percentage points in the $7^{\text {th }}$ grade and 14 percentage points in the $11^{\text {th }}$ grade.

\section{$\underline{\text { School-Level Performance }}$}

School-level data by urbanicity are available for the 2002 MAP administration for grades 7 and 11 (Table Z4). Approximately 44 percent of schools in Missouri are rural, 38 percent are suburban, and 19 percent are urban. Urban schools were far more likely to be high-poverty schools-62 percent, compared with 40 percent of rural schools and 13 percent of suburban schools.

Despite having a higher percentage of high-poverty schools, rural schools tended to perform as well or, in some cases, slightly better than suburban schools. Urban schools performed substantially below rural and suburban schools. For example, the average percentage of $7^{\text {th }}$ graders scoring at the nearing proficient level in urban schools was 44 percent compared with 64 percent in rural and suburban schools, and the differences were somewhat larger at the $11^{\text {th }}$-grade level (22-25 percentage points). At the proficient and above level, the differences were somewhat smaller, ranging from $10-12$ percentage points in the $7^{\text {th }}$ grade to $7-9$ percentage points in the $11^{\text {th }}$ grade.

Table Z4. Average School Performance on $7^{\text {th- }}$ and $11^{\text {th }}-$ Grade 2002 Communication Arts MAP, by Urbanicity

\begin{tabular}{lcccc}
\hline & $\begin{array}{c}\text { Progressing } \\
\text { and Above }\end{array}$ & $\begin{array}{c}\text { Nearing } \\
\text { Proficient } \\
\text { and Above }\end{array}$ & $\begin{array}{c}\text { Proficient } \\
\text { and Above }\end{array}$ & Advanced \\
\cline { 2 - 5 } Average Percentage \\
\hline $7^{\text {th Grade }}$ & \multicolumn{4}{c}{} \\
Rural schools & 88 & 64 & 29 & 2 \\
Suburban schools & 87 & 64 & 31 & 2 \\
Urban schools & 71 & 44 & 19 & 1 \\
$\mathbf{1 1}^{\text {th Grade }}$ & & & & 0 \\
Rural schools & 83 & 64 & 19 & 1 \\
Suburban schools & 81 & 61 & 21 & 0 \\
Urban schools & 59 & 39 & 12 & 0 \\
\hline
\end{tabular}





\section{APPENDIX AA. MONTANA}

\section{State Assessment System}

Montana administers the Iowa Test of Basic Skills (ITBS) to students in grades 4 and 8 and the Iowa Test of Educational Development (ITED) to students in grade 11, during one week in the spring, in reading, language arts, mathematics, social studies, and science. The ITBS and ITED are norm-referenced tests published by the University of Iowa.

As in many states, Montana's assessment system is in flux. Starting in spring 2004, Montana will also administer the Progress Towards Standards (PTS), criterion-referenced tests that will meet the assessment requirements under NCLB. PTS is an off-the-shelf test that will also contain Montana-specific items. The PTS assessments will be explicitly linked to Montana's content and performance standards and will be phased in over time. By spring 2008, students in grades 3-8 will be tested in reading and mathematics, and students in grades $4-8$ and grade 10 will be tested in science:

- In spring 2004, students in grades 4,8 , and 10 start taking the PTS in reading and mathematics.

- In spring 2006, students in grades 3, 5, 6, and 7 will start taking the PTS in reading and mathematics.

- In spring 2008, students in grades 4-8 and 10 will start taking the PTS in science.

As of spring 2004, Montana had not yet decided whether it would continue to use the normreferenced exams after the PTS assessments are implemented.

Schools' assessment scores on the ITBS and ITED were used as the basis for determining adequate yearly progress under NCLB through 2002-03; once the new criterion-referenced tests are administered in 2003-04, those scores will be used to compute adequate yearly progress for all schools in Montana. Performance on the assessment does not carry consequences for individual teachers or students (see http://www.opi.state.mt.us/ for additional information regarding assessment and accountability).

Montana has content standards in communications arts, which includes reading, literature, media literacy, speaking and listening, and writing; mathematics; science; social studies;

technology; arts; career and vocational-technical education; health enhancement; library media; world languages; and workplace competencies. These standards are general statements of what children should know, and they contain end-of-grade benchmarks in grades 4 , 8, and 12 . In addition, Montana has recently created grade-level learning expectations in reading and 
mathematics in grades $3-8,10$, and 12 . These expectations define levels of performance at the advanced, proficient, nearing proficient, and novice levels. Table AA1 provides an example from the reading learning expectations about making predictions and inferences in grades 4,8 , and 10, by achievement level (http://www.opi.state.mt.us/Standards/index.html).

\section{Table AA1. Learning Expectations About Making Predictions and Inferences for $4^{\text {th }}, 8^{\text {th }}$, and $10^{\text {th }}$ Grades, by Achievement Level}

\begin{tabular}{|c|c|c|c|}
\hline & $4^{\text {th }}$ Grade & $8^{\text {th }}$ Grade & $10^{\text {th }}$ Grade \\
\hline Advanced & $\begin{array}{l}\text { Makes predictions, } \\
\text { describes complex } \\
\text { connections between new } \\
\text { material and previous } \\
\text { information/experiences }\end{array}$ & $\begin{array}{l}\text { Consistently makes and } \\
\text { revises predictions and } \\
\text { articulates complex and } \\
\text { inferred connections } \\
\text { between new material } \\
\text { and prior knowledge }\end{array}$ & $\begin{array}{l}\text { Makes, confirms, and } \\
\text { revises predictions, } \\
\text { compares and contrasts } \\
\text { inferences, and articulates } \\
\text { complex and inferred } \\
\text { connections between new } \\
\text { material and prior } \\
\text { knowledge }\end{array}$ \\
\hline Proficient & $\begin{array}{l}\text { Makes predictions and } \\
\text { connections between new } \\
\text { material and previous } \\
\text { information/experiences }\end{array}$ & $\begin{array}{l}\text { Makes predictions and } \\
\text { connections between } \\
\text { new material and prior } \\
\text { knowledge }\end{array}$ & $\begin{array}{l}\text { Makes and revises } \\
\text { predictions and identifies } \\
\text { relationships when } \\
\text { reading }\end{array}$ \\
\hline Nearing Proficient & $\begin{array}{l}\text { Makes obvious predictions } \\
\text { and simple connections } \\
\text { between new material and } \\
\text { previous information/ } \\
\text { experiences }\end{array}$ & $\begin{array}{l}\text { Makes obvious } \\
\text { predictions and simple } \\
\text { connections between } \\
\text { new material and prior } \\
\text { knowledge }\end{array}$ & $\begin{array}{l}\text { Makes and revises } \\
\text { predictions and identifies } \\
\text { relationships when } \\
\text { reading }\end{array}$ \\
\hline Novice & $\begin{array}{l}\text { Sometimes makes obvious } \\
\text { predictions and simple } \\
\text { connections between new } \\
\text { material and previous } \\
\text { information/experiences }\end{array}$ & $\begin{array}{l}\text { Usually makes obvious } \\
\text { predictions and simple } \\
\text { connections between } \\
\text { new material and prior } \\
\text { knowledge }\end{array}$ & $\begin{array}{l}\text { Makes simple predictions } \\
\text { and inferences, but often } \\
\text { does not grasp the } \\
\text { meaning of causal } \\
\text { relationships when } \\
\text { reading material } \\
\text { appropriate to twelfth } \\
\text { grade }\end{array}$ \\
\hline
\end{tabular}

Source: http://www.opi.state.mt.us/Standards/index.html

\section{Test Format and Content}

For the purposes of this report, we now turn to discussing reading and language arts ITBS (grades 4 and 8) and ITED (grade 11) (see http://www.education.uiowa.edu/itp/site_index.htm for more information regarding the ITBS and ITED).

\section{ITBS/ITED}

The ITBS and ITED are multiple-choice assessments. The ITBS and ITED are vertically scaled and co-normed with one another, providing schools the opportunity to trace student achievement growth across the grades.

In grades 4 and 8, the reading and English Language Arts sections of the ITBS include: 
- Vocabulary. Approximately equal numbers of nouns, verbs, and modifiers are tested at all levels.

- Word Analysis. These questions assess how well students can recognize letters and lettersound relationships.

- Reading Comprehension: The Reading test presents students with a variety of tasks, including using print, context, and picture cues to identify unfamiliar words; completing sentences that tell about a picture by choosing a word for filling in a blank; and answering multiple-choice questions after reading a brief story. The questions associated with pictures and stories often ask students to make inferences or to generalize about what they have read.

- Listening. Short oral scenarios are presented, and then one or more multiple-choice questions are read. Since all response options are pictorial, the scores from this test do not depend on students' reading abilities. Students' abilities to demonstrate literal and inferential understanding, follow directions, understand sequences, and predict outcomes are measured.

- Language. A major portion of the test deals with skills in spelling, capitalization, punctuation, and skills in usage and expression in writing.

The reading and English language arts sections of the ITED test students on:

- Vocabulary. The words tested represent a cross section of vocabulary encountered in reading, writing, and listening. Technical words and specialized vocabulary are not included.

- Reading Comprehension. Students read five types of passages taken from previously published materials: a fiction or narrative passage; an article about a social studies topic and one about a science topic; another nonfiction passage, which may be from a biography or memoir, from an essay, or from the general-interest domain; and a poem. The prose passages range in length from 440 to 650 words. The questions associated with each passage require students to demonstrate factual understanding, inference and interpretation, and analysis and generalization. The greatest emphasis is on questions that address the higher-level objectives of inferring, analyzing, and generalizing.

- Language: Revising Written Materials. This asks students to make revision choices concerning focus, organization, diction and clarity, sentence structure, usage, mechanics, and spelling. All test questions are based on four relatively long, complete texts (ranging from 125 to 450 words) that are patterned after student writing in content and style. The corresponding questions pose alternatives that may correct or improve the underlined portions. In some cases, there is a clear-cut error in mechanics or usage, sometimes the consideration is one of fluency or clarity, and occasionally it is the appropriateness of the content for the task that is at issue. 
- Spelling. This is a 10-minute, 30-question test. Each question presents four words, one of which may be misspelled, and a fifth option, No mistakes, allowing students to indicate that they believe all four words are spelled correctly.

\section{$\underline{\text { PTS }}$}

The reading PTS will consist of 3 sessions. Each asks students to respond to approximately 24 multiple-choice questions and one constructed-response question. The sessions are not timed, but are expected to take 45 minutes. The PTS contains literary and information passages (http://www.opi.state.mt.us/assessment/crt.html).

\section{Achievement-Level Definitions}

Montana has developed four achievement categories: advanced, proficient, nearing proficiency, and novice. It will use these categories for the PTS. The scores for the ITBS/ITED are percentile ranks, and cut-scores are used to map the percentile ranks into the achievement categories:

- Novice: $1^{\text {st }-23^{\text {rd }}}$ percentile

- Nearing proficiency: $24^{\text {th }}-40^{\text {th }}$ percentile

- Proficient: $41^{\text {st }}-89^{\text {th }}$ percentile

- Advanced: $90^{\text {th }}-99^{\text {th }}$ percentile

Scores at or above the proficient level are considered "passing" for accountability purposes under NCLB.

\section{Performance Results}

\section{Student Performance}

The Montana Office of Public Instruction provides student-level data on student performance for all students and for students disaggregated by various characteristics: disability status, limitedEnglish-proficiency status, major racial/ethnic groups, and socioeconomic status. ${ }^{46}$ Table AA2 shows the English language arts performance results from the 2003 ITBS/ITED administration for students in grades 4,8 , and 10 , for these various groups of students. It provides the national percentile rank for these groups, as well as the percentage of students scoring at different achievement levels.

\footnotetext{
${ }^{46}$ Approximately 86 percent of students in Montana are white and 11 percent are American Indian. No other racial/ethnic group comprises 2 percent of the student population. About 32 percent of students are eligible for the free and reduced-price lunch program; 5 percent are in limited-English- proficiency programs; and 13 percent have Individual Education Programs (IEPs).
} 
Table AA2. Performance of $4^{\text {th }}$, $8^{\text {th-}}$, and $11^{\text {th }}$-Graders on 2003 Language Arts ITBS/ITED, by Student Groups

\begin{tabular}{|c|c|c|c|c|}
\hline & $\begin{array}{c}\text { National } \\
\text { Percentile } \\
\text { Rank }\end{array}$ & $\begin{array}{c}\text { Nearing } \\
\text { Proficiency } \\
\text { and Above }\end{array}$ & $\begin{array}{l}\text { Proficient } \\
\text { and Above }\end{array}$ & Advanced \\
\hline & Percentile & & Percentage & \\
\hline \multicolumn{5}{|l|}{$4^{\text {th }}$ Grade } \\
\hline All students & 68 & 89 & 76 & 18 \\
\hline Students without disabilities & 71 & 92 & 80 & 19 \\
\hline Students with disabilities & 35 & 61 & 37 & 4 \\
\hline $\begin{array}{l}\text { Students with limited-English } \\
\text { proficiency }\end{array}$ & 31 & 56 & 35 & 3 \\
\hline Economically disadvantaged students & 56 & 82 & 64 & 9 \\
\hline Native American students & 46 & 74 & 52 & 6 \\
\hline White students & 70 & 91 & 80 & 20 \\
\hline \multicolumn{5}{|l|}{$8^{\text {th }}$ Grade } \\
\hline All students & 57 & 85 & 68 & 12 \\
\hline Students without disabilities & 61 & 90 & 73 & 13 \\
\hline Students with disabilities & 22 & 43 & 17 & o \\
\hline $\begin{array}{l}\text { Students with limited-English } \\
\text { proficiency }\end{array}$ & 25 & 49 & 22 & 1 \\
\hline Economically disadvantaged students & 44 & 75 & 52 & 5 \\
\hline Native American students & 38 & 68 & 43 & 3 \\
\hline White students & 60 & 88 & 71 & 13 \\
\hline \multicolumn{5}{|l|}{ 11 $^{\text {th }}$ Grade } \\
\hline All students & 61 & 91 & 75 & 16 \\
\hline Students without disabilities & 64 & 94 & 80 & 18 \\
\hline Students with disabilities & 28 & 54 & 25 & 1 \\
\hline $\begin{array}{l}\text { Students with limited-English } \\
\text { proficiency }\end{array}$ & 35 & 71 & 36 & 2 \\
\hline Economically disadvantaged students & 50 & 83 & 61 & 8 \\
\hline Native American students & 42 & 77 & 48 & 4 \\
\hline White students & 64 & 92 & 79 & 18 \\
\hline
\end{tabular}

Source: http:// www.opi.state.mt.us

Overall, students in Montana performed above the national average. Fourth-graders scored at the $68^{\text {th }}$ percentile; $8^{\text {th }}$ - and $11^{\text {th }}$-graders are at the $57^{\text {th }}$ and $61^{\text {st }}$ percentiles, respectively. Between $68-$ 76 percent of students scored at the proficient level, and only 12-18 percent scored at the advanced level. Scores of $8^{\text {th }}$-graders were generally lower than those of $4^{\text {th }}$ and $11^{\text {th }}$-graders.

As would be expected, students with disabilities scored lower than students without disabilities $22^{\text {nd }}-35^{\text {th }}$ percentile, compared with $61^{\text {st }-} 71^{\text {st }}$ percentile. While 37 percent of $4^{\text {th }}$-grade students 
with disabilities scored at the proficient level, only 17 percent of $8^{\text {th }}$-grade and 25 percent of $11^{\text {th }}$ grade students with disabilities did so.

Students with limited-English proficiency scored at the $31^{\text {st }}$ percentile in $4^{\text {th }}$ grade, $25^{\text {th }}$ percentile in $8^{\text {th }}$ grade, and $35^{\text {th }}$ percentile in $11^{\text {th }}$ grade, and only 22-36 percent obtained a proficient score. A much higher percentage of $11^{\text {th }}$-graders scored at the near proficient level compared with $4^{\text {th }}$ and $8^{\text {th }}$-graders ( 71 percent versus $49-56$ percent). However, it is unclear whether this result was due to increased proficiency in reading or English or an effect of higher dropout rates among these students.

White students outperformed Native American students by large margins. While the average white students scored between the $60^{\text {th }}$ and $70^{\text {th }}$ percentile, depending on grade, on average, Native American students scored between the $38^{\text {th }}$ and $46^{\text {th }}$ percentile. The gap between white and Native American scores at or above the proficient level was quite large as well: 28 percentage point at the $4^{\text {th }}$ grade, 28 percentage points at the $8^{\text {th }}$ grade, and 31 percentage points at the $11^{\text {th }}$ grade. Overall, only about half of Native American students were considered proficient or above. Only 3-6 percent of Native American students across the grade levels reach advanced status, compared with 13-20 percent of white students.

Economically disadvantaged students scored at the $56^{\text {th }}$ percentile in $4^{\text {th }}$ grade, $44^{\text {th }}$ percentile in $8^{\text {th }}$ grade, and $50^{\text {th }}$ percentile in $11^{\text {th }}$ grade, far below the average for all students. In the $4^{\text {th }}$ grade, 64 percent of economically disadvantaged students received a proficient score or better compared with 76 percent of all students. We find similar achievement gaps in the $8^{\text {th }}$ and $11^{\text {th }}$ grades.

\section{$\underline{\text { School Performance }}$}

Data on performance on the ITBS/ITED by urbanicity are available for the 2002 administration of the test at the school level. However, the vast majority of schools (85 percent) in Montana are rural, while only 8 percent are suburban and 7 percent are urban. Table AA3 reports student performance for $4^{\text {th }}$-grade language arts for rural, suburban, and urban schools. The sample sizes of schools in the urban and rural categories at the secondary level were too small to report.

Urban elementary schools outperformed rural and suburban elementary schools at all levels, but the differences were only between 1 and 6 percentage points. For instance, on average urban schools had 79 percent of students at or above the proficient level and 23 percent at the advanced level, compared with 76 percent and 17 percent of students in rural schools, respectively. 


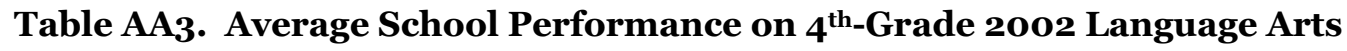
ITBS/ITED, by Urbanicity

\begin{tabular}{lccc}
\hline & $\begin{array}{c}\text { Nearing } \\
\text { Proficiency and } \\
\text { Above }\end{array}$ & $\begin{array}{c}\text { Proficient and } \\
\text { Above }\end{array}$ & Advanced \\
\cline { 2 - 4 } & \multicolumn{3}{c}{ Average Percentage } \\
\hline 4th Grade & 89 & 76 & 17 \\
Rural schools & 87 & 75 & 19 \\
Suburban schools & 90 & 79 & 23 \\
Urban schools & & & \\
\hline
\end{tabular}





\section{APPENDIX BB. NEBRASKA}

\section{State Assessment System}

During the 2000 session, Nebraska's legislature established the School-based Teacher-led Assessment and Reporting System (STARS) to implement standards, assessment, and accountability reporting for public school districts in Nebraska. Under this system, the state required that each public school district 1) adopt measurable, quality academic content standards in reading, writing, mathematics, science, social studies, and history that are equal to or more rigorous than the state standards; 2) assess students using a local assessment in reading and mathematics; and 3) administer a statewide writing assessment to students in grades 4, 8, and 11 . As part of STARS, the state measures the quality of district assessments and the performance of students in the district. The Nebraska Department of Education rates the assessment systems on the following: their ability to measure the standards; students' opportunity to learn the content; reliability; absence of bias; appropriateness of mastery levels; and age appropriateness. Districts either receive an Exemplary, Very Good, Good, Acceptable but Needs Improvement, or Unacceptable rating on each of these factors. Many districts use standardized achievement tests in combination with locally developed tests for their assessments. In addition to this state system, Nebraska is meeting the federal accountability provisions set under NCLB and is tracking the performance of student subgroups on the assessments as well (http://www.nde.state.ne.us/stars/pdf/STARSbooklet.pdf).

While Nebraska has state K-12 standards with sample indicators of mastery for reading and writing, mathematics, science, social studies, and history (among others), districts and schools may develop and use their own local standards, as long as the state board agrees that the standards are equal to or more rigorous than the state standards. Table BB1 provides an example of state reading and writing standards for grade 4 . 
Table BB1. Nebraska End-of-Grade Reading/Writing Standards, $4^{\text {th }}$ Grade

\begin{tabular}{|c|c|}
\hline Standard & Sample Indicators \\
\hline \multicolumn{2}{|l|}{ By the end of $4^{\text {th }}$ grade: } \\
\hline $\begin{array}{l}\text { Students will demonstrate the use of } \\
\text { multiple strategies in reading } \\
\text { unfamiliar words and phrases. }\end{array}$ & $\begin{array}{l}\text { - Use phonics and word structure to read. } \\
\text { - } \quad \text { Use context clues to confirm the accuracy of their reading. }\end{array}$ \\
\hline $\begin{array}{l}\text { Students will identify the main idea } \\
\text { and supporting details in what they } \\
\text { have read. }\end{array}$ & $\begin{array}{l}\text { - Identify and use meanings associated with common } \\
\text { prefixes, suffixes, and roots. } \\
\text { - Identify and use antonyms, synonyms, compounds, } \\
\text { homophones, and homographs. } \\
\text { - Use a dictionary to learn and confirm word meanings. }\end{array}$ \\
\hline $\begin{array}{l}\text { Students will identify the main idea } \\
\text { and supporting details in what they } \\
\text { have read. }\end{array}$ & $\begin{array}{l}\text { - Identify purpose for reading, recall prior knowledge, and } \\
\text { preview illustrations and headings to make predictions. } \\
\text { - } \quad \text { Interpret information from diagrams, charts, and graphs. } \\
\text { - Answer literal, inferential/interpretive, and critical } \\
\text { questions. }\end{array}$ \\
\hline $\begin{array}{l}\text { Students will identify the resource } \\
\text { appropriate for a specific purpose, } \\
\text { and use the resource to locate } \\
\text { information. }\end{array}$ & $\begin{array}{l}\text { Use general reference materials (dictionary, thesaurus, } \\
\text { encyclopedia, atlas, telephone book, almanac). } \\
\text { Use electronic resources (CD-ROM, software programs, } \\
\text { online resources). } \\
\text { - Use library resources (card or electronic catalog). } \\
\text { - Identify and use parts of a book (title page, table of } \\
\text { contents, glossary, index). }\end{array}$ \\
\hline $\begin{array}{l}\text { Students will identify and use } \\
\text { characteristics to classify different } \\
\text { types of text. }\end{array}$ & $\begin{array}{l}\text { Distinguish among common forms of literature, such as } \\
\text { fiction, nonfiction, poetry, and drama. } \\
\text { Identify characteristics of different types of fiction } \\
\text { (folktales, fairytales, tall tales, realistic fiction, science } \\
\text { fiction, historical fiction). } \\
\text { - Identify characteristics of different types of nonfiction } \\
\text { (autobiography, biography, informational text). }\end{array}$ \\
\hline $\begin{array}{l}\text { Students will identify and apply } \\
\text { knowledge of the structure, elements, } \\
\text { and literary techniques to analyze } \\
\text { fiction. }\end{array}$ & $\begin{array}{l}\text { - Identify the structure (e.g., beginning, middle, end). } \\
\text { Identify the elements (e.g., characters, plot, setting, } \\
\text { problem, events, solution). } \\
\text { Identify the literary techniques (e.g., simile, metaphor, } \\
\text { onomatopoeia, alliteration, idioms, hyperbole). }\end{array}$ \\
\hline $\begin{array}{l}\text { Students will identify and apply } \\
\text { knowledge of the text structure and } \\
\text { organizational elements to analyze } \\
\text { nonfiction or informational text. }\end{array}$ & 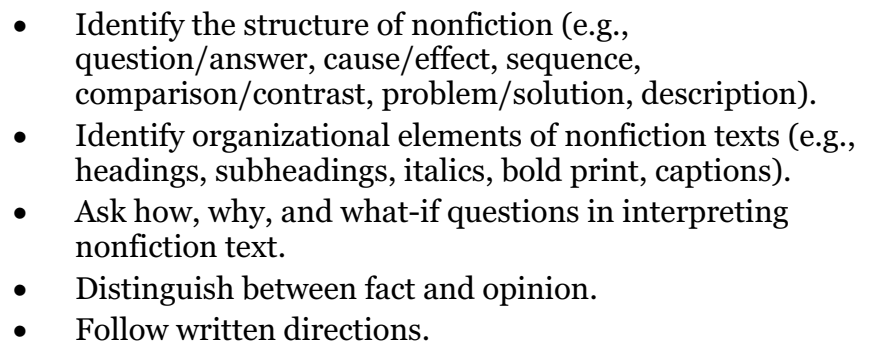 \\
\hline $\begin{array}{l}\text { Students will identify similarities and } \\
\text { differences between two fourth- } \\
\text { grade-level reading selections. }\end{array}$ & $\begin{array}{l}\text { - Compare and contrast reading selections across } \\
\text { geographic regions, cultures, and time periods. } \\
\text { Compare and contrast reading selections to students' } \\
\text { present-day lives. }\end{array}$ \\
\hline $\begin{array}{l}\text { Students will write using Standard } \\
\text { English (conventions) for sentence } \\
\text { structure, usage, punctuation, } \\
\text { capitalization and spelling. }\end{array}$ & $\begin{array}{l}\text { Identify and use correct capitalization, punctuation, } \\
\text { spelling, and paragraph indentation. } \\
\text { - Identify and use nouns, verbs, and personal pronouns. }\end{array}$ \\
\hline
\end{tabular}


Table BB1. (cont)

Students will write paragraphs/reports with focus, related ideas, and supporting details.

Students will revise and edit narrative compositions.

Students will demonstrate the use of multiple forms to write for different audiences and purposes.

Students will demonstrate the use of self-generated questions, note taking, and summarizing while learning.

Students will participate in group discussions by asking questions and contributing information and ideas.

Students will deliver organized oral presentations using complete sentences, clear enunciation, adequate volume, and eye contact.

Students will identify information gained and complete tasks through listening.
- Use a variety of strategies to generate and organize ideas.

- Write several paragraphs on the same topic.

- Write compositions with a beginning, middle and end.

- Revise to improve organization, content, word choice, voice, and sentence fluency.

- $\quad$ Edit using Standard English conventions.

- Use legible cursive writing and/or a word processor when publishing written work.

- Use established criteria to evaluate their own writing.

- Write descriptive and narrative compositions about experiences, stories, people, objects, and events.

- Write poems of varied forms.

- Write letters.

- Generate questions in exploration of a topic.

- Record important ideas from information provided by others.

- Use summarization methods including outlining and webbing.

- Contribute information and ask questions relevant to the topic discussed.

- Use subject-related vocabulary in discussions.

- $\quad$ Provide accurate directions.

- Stay on topic or create appropriate transitions to new topics.

- Gain the floor in appropriate ways.

- Give oral presentations of prose and poetry with fluency and expression.

- $\quad$ Listen to and follow multiple-step oral directions.

- Use active listening, showing consideration of others' contributions to discussions.

Source: http://nelinks.nde.state.ne.us/ViewReports.aspx

\section{Test Content and Format}

Because districts administer local assessments in reading, we cannot describe the content of a statewide test in reading. However, a statewide writing assessment was given to students in grade 4 in 2001-02 and to students in grade 8 in 2002-03. In these assessments, students wrote in response to one prompt. Students in grade 4 wrote in a narrative mode, and students in grade 8 wrote in a descriptive mode. In 2003-04, students in grade 11 will write in the persuasive mode. Students completed the writing assessment during a timed session on two consecutive days. On the first day, students were allocated 40 minutes for prewriting activities, such as note taking, outlining, or mapping, and generating preliminary drafts. On the second day, students had 40 minutes to revise, edit, and write the final draft. Student responses were assessed on Nebraska's six traits of writing: ideas, organization, voice, word choice, sentence fluency, and 
conventions (see Table BB2). Two readers scored students' writings holistically. The scores from the two readers were added together to determine the final score

(http://www.nde.state.ne.us/stars/updates/update7.pdf;

http://www.nde.state.ne.us/stars/updates/update9.pdf).

\section{Table BB2. Writing-Assessment Scoring Criteria}

\begin{tabular}{ll}
\hline Ideas & Has clarity, fresh perspective, important details that go beyond the obvious \\
Organization & Has order and logic, clear connections to the main idea, inviting, attention-getting \\
& lead, graceful ending \\
Voice & Is appropriate for the topic, audience, and purpose; brings topic to life, has the mark \\
& of a particular writer \\
Word Choice & Creates word pictures, relies on strong verbs and precise nouns; does not try to \\
& impress with jargon or overblown language; avoids redundancy \\
Sentence Fluency & Is easy to read aloud, inviting; has varied sentence length and structure, purposeful \\
& sentence beginnings \\
Conventions & Looks clean, edited, proofread; has no glaring errors that distract the reader; \\
& specifically: \\
& - spelling correct on simple words, correct or close on difficult words \\
& - ending punctuation correct; internal punctuation not misleading \\
& - paragraphs for new topics, new speakers \\
& - quotation marks to denote dialogue \\
& - capital letters to begin all proper nouns and all sentences \\
& - noun-verb agreement \\
& - no arbitrary shifts in tense
\end{tabular}

Source: http://www.nde.state.ne.us/stars/updates/update10.pdf

\section{Achievement-Level Definitions}

On the writing assessment, each rater gives a score ranging from 1 to 4 (including plus and minus score points), with 1 being the lowest and 4 being the highest. A minimum combined score from the two raters of 4.33 (out of a possible 8 points) is considered proficient (http://www.nde.state.ne.us/stars/writing/statewidesummaryo3.pdf).

\section{Performance Results}

\section{Student Performance}

Nebraska did not provide writing scores broken down by student characteristics.47 In 2001-02, 73 percent of $4^{\text {th }}$-grade students met or exceeded standards on the state writing assessment. In

47 Approximately 82 percent of students in Nebraska are white; 8 percent are Hispanic; and 7 percent are African American. No other racial/ethnic group comprises 2 percent of the population. About 31 percent of students are eligible for the free and reduced-price lunch program; 4 percent are in limited-Englishproficiency programs; and 16 percent have Individual Education Programs (IEPs). 
2002-03, 75 percent of $8^{\text {th }}$-grade students met or exceeded standards on the state writing assessment

(http://reportcard.nde.state.ne.us/DownloadFiles/ReportCard20022003_Inside_4.pdf).

$\underline{\text { School Performance }}$

School-level scores are not available for Nebraska. 



\section{APPENDIX CC. NEVADA}

\section{State Assessment System}

Nevada's system for assessing students, the Nevada Proficiency Examination Program (NPEP), includes criterion-referenced and norm referenced tests, diagnostic assessments, and a high school proficiency examination. Specifically, Nevada's assessments include:

- Criterion-Referenced Tests (CRT) in Reading and Mathematics in grades 3, 5, and 8 and Science in grades 5 and 8

- Writing Assessments in grades 4 and 8

- Norm-Referenced Tests (NRT): Iowa Tests of Basic Skills (ITBS) in grades 4 and 7, and Iowa Tests of Educational Development (ITED) in grade 10

- High School Proficiency Examination (HSPE) in Reading, Mathematics, and Writing

- The Skills and Competencies Alternative Assessment of Nevada (SCAAN), alternate assessment system (manual and electronic format) in grades 3-8 and grade 10

- English Language Development Assessment (ELDA) in grades 3-12

- Pre-Language Assessment Scales (Pre-LAS) in grades K-2

During the 2003-04 school year, the Nevada Department of Education is expanding its testing program by developing and piloting math and reading tests for grades 4,6 , and 7 . Test scores from the CRTs, the writing assessments, and the HSPE will be used to track Adequate Yearly Progress (AYP) under No Child Left Behind, because these are the assessments that measure students' progress in meeting the state's content and performance standards. Students must pass the HSPE in reading, mathematics, and writing in order to earn a high school diploma (see http://www.doe.nv.gov/sca/testing/index.html for additional details regarding assessment and accountability).

Nevada has set content and performance standards for English language arts for grades 1-8 and grade 12. Each of the 11 broad content standards in Table CC1 have sub-standards, delineated by grade, which further define the standard. Table $\mathrm{CC} 2$ provides an example of these sub-standards for Content Standard 4 in grades 4, 8, and 12. In addition, Nevada has established performance standards for the broad content standards by grades (see example in Table $\mathrm{CC}_{3}$ ) (http://www.doe.nv.gov/sca/standards/standardsfiles/ela/index.html). 


\section{Table CC1. English Language Arts Content Standards}

Content Standard 1.0: Students know and use word-analysis skills and strategies to comprehend new words encountered in text.

Content Standard 2.0: Students use reading process skills and strategies to build comprehension.

Content Standard 3.0: Students read to comprehend, interpret, and evaluate literature from a variety of authors, cultures, and times.

Content Standard 4.0: Students read to comprehend, interpret, and evaluate informational texts for specific purposes

Content Standard 5.0: Students write a variety of texts that inform, persuade, describe, evaluate, or tell a story and are appropriate to purpose and audience.

Content Standard 6.o: Students write with a clear focus and logical development, evaluating, revising, and editing for organization, style, tone, and word choice.

Content Standard 7.0: Students write using Standard English grammar, usage, punctuation, capitalization, and spelling.

Content Standard 8.0: Students listen to and evaluate oral communications for content, style, speaker's purpose, and audience appropriateness.

Content Standard 9.0: Students speak using organization, style, tone, voice, and media aids appropriate to audience and purpose.

Content Standard 10.0: Students participate in discussions to offer information, clarify ideas, and support a position.

Content Standard 11.0: Students formulate research questions, use a variety of sources to obtain information, weigh the evidence, draw valid conclusions, and present findings.

Source: http://www.doe.nv.gov/sca/standards/standardsfiles/ela/index.html 
Table CC2. Sub-standards for Content Standard 4: Students Read to Comprehend, Interpret, and Evaluate Informational Texts for Certain Specific Purposes, by $4^{\text {th }}, 8^{\text {th }}$, and $1^{\text {th }}$ Grades

\begin{tabular}{lll}
\hline \multicolumn{1}{c}{$\mathbf{4}^{\text {th }}$ Grade } & \multicolumn{1}{c}{$\mathbf{8}^{\text {th }}$ Grade } & \multicolumn{1}{c}{ 12 $^{\text {th }}$ Grade } \\
\hline $\begin{array}{l}\text { Use information from titles, } \\
\text { tables of contents, chapter } \\
\text { headings, glossaries, indexes, } \\
\text { diagrams, charts, and maps to } \\
\text { comprehend text. }\end{array}$ & $\begin{array}{l}\text { Use knowledge of text features } \\
\text { and common expository structures } \\
\text { such as cause/effect and } \\
\text { comparison/contrast to } \\
\text { comprehend text. }\end{array}$ & $\begin{array}{l}\text { Analyze text features and } \\
\text { rhetorical strategies of different } \\
\text { types of primary sources }\end{array}$ \\
$\begin{array}{l}\text { Compare main ideas and } \\
\text { important concepts of various } \\
\text { tests. }\end{array}$ & $\begin{array}{l}\text { Locate, interpret, organize, and } \\
\text { synthesize information from texts } \\
\text { to answer specific questions and } \\
\text { support ideas. }\end{array}$ & $\begin{array}{l}\text { Locate, organize, interpret, and } \\
\text { synthesize information in } \\
\text { multiple primary and secondary } \\
\text { sources to support ideas and } \\
\text { positions. }\end{array}$ \\
$\begin{array}{l}\begin{array}{l}\text { Develop hypotheses based upon } \\
\text { prior knowledge and information } \\
\text { from text. }\end{array} \\
\begin{array}{l}\text { Identify and assess the validity, } \\
\text { accuracy, and adequacy of } \\
\text { evidence that supports an author's }\end{array}\end{array}$ & $\begin{array}{l}\text { Critique the power, logic, } \\
\text { reasonableness, and audience } \\
\text { appeal of arguments advanced in } \\
\text { texts. }\end{array}$ \\
$\begin{array}{l}\text { Draw conclusions about text and } \\
\text { support them with evidence from } \\
\text { a variety of sources. }\end{array}$ & $\begin{array}{l}\text { Summarize authors' ideas and } \\
\text { information in texts, including }\end{array}$ & $\begin{array}{l}\text { Analyze how historical and } \\
\text { cultural contexts influence the } \\
\text { advertisements and public } \\
\text { documents. }\end{array}$ \\
$\begin{array}{l}\text { Identify authors' purposes for } \\
\text { informational texts. }\end{array}$ \\
$\begin{array}{l}\text { Read and follow multistep } \\
\text { directions to complete a task. }\end{array}$ & $\begin{array}{l}\text { Read and follow multistep } \\
\text { directions to complete a complex } \\
\text { task. }\end{array}$ & $\begin{array}{l}\text { Read and apply multistep } \\
\text { directions to perform complex } \\
\text { procedures and tasks }\end{array}$ \\
\hline
\end{tabular}

Source: http://www.doe.nv.gov/sca/standards/standardsfiles/ela/index.html 


\section{Table CC3. Achievement-Level Descriptors for English Language Arts, $8^{\text {th }}$ Grade,}

Content Standard 4.o

\section{Content Standard 4.o. Students read to comprehend, interpret, and evaluate informational texts for specific purposes.}

\begin{tabular}{ll}
\hline Exceeds Standard & Consistently apply knowledge of text features and complex expository structures to a \\
& variety of materials to comprehend text. \\
& Independently locate, interpret, organize, and synthesize information from a variety of \\
& texts. \\
& Evaluate and critique authors' arguments. \\
& Concisely analyze and summarize information from a variety of texts, including \\
& advertisements and public documents. \\
& Read and follow multistep directions effectively to complete an increasingly complex \\
& task. \\
& Use knowledge of text features and common expository structures to comprehend text. \\
& Locate, interpret, organize, and synthesize information in text to answer specific \\
& questions and support ideas. \\
& Evaluate the validity, accuracy, and adequacy of evidence behind authors' ideas and cite \\
& supporting evidence. \\
& Summarize ideas and information in text, including advertisements and public \\
& documents. \\
& Read and follow multistep directions to complete a complex task. \\
& Have knowledge of some text features and expository structures, but may not use them \\
& to comprehend text. \\
& Locate and interpret information in text, but may not be able to organize and synthesize \\
& information. \\
Identify the authors' arguments, but do not assess validity, accuracy, and adequacy of \\
supporting evidence. \\
Restate information from text. \\
Require assistance to read and follow multistep directions to complete a complex task. \\
Have little or no knowledge of text features and/or expository structures. \\
Have difficulty locating information in a text. \\
Sometimes identify authors' arguments, but fail to identify supporting evidence. \\
Restate minimal information from text. \\
Do not read and/or follow multistep directions to complete a complex task. \\
Below Standard & Standard \\
&
\end{tabular} Source: http://www.doe.nv.gov/sca/standards/standardsfiles/ela/index.html

\section{Test Content and Format}

Below we describe the criterion-referenced assessments that provide information about adolescent literacy levels: the reading CRTs in grades 5 and 8; the writing assessments in grades 4 and 8; and the High School Proficiency Exams in reading

(http://www.doe.nv.gov/sca/testing/crt/).

\section{CRT and High School Proficiency Examination}

The CRT and HSPE reading assessment measures word-analysis skills and both comprehension and interpretation of literary and informational text of varying difficulty. The CRT and HSPE are 
primarily multiple-choice items; however, the CRTs in grades 4 through 8 also include at least two constructed-response items. Readings may be literary, informational, or functional text. Passage length will range from 500 to 690 words for grade 5; 900 to 1,080 words for grade 8; and 1,000 to 1,200 words for grade $10 / 11$. Poems may be shorter than the minimum number of words designated, and pairing of two short passages may occur.

The items that are used to evaluate understanding of these passages fall into three cognitive domains-form an initial understanding; develop an interpretation; and demonstrate a critical stance-and three content clusters-word analysis and skills; comprehend, interpret, and evaluate literature; and comprehend, interpret, and evaluate informational texts. Table $\mathrm{CC}_{4}$ describes how much emphasis the assessments place on each of the cognitive domains and content clusters. The percentage of items that test demonstrating a critical stance increases a bit by grade level as does the emphasis on comprehending and evaluating information text, while forming an initial understanding and word analysis and skills are emphasized a bit less in the later grades.

Table CC4. Assessed Content Clusters and Cognitive Domains

\begin{tabular}{lccc}
\hline & $\mathbf{5}^{\text {th }}$ Grade & $\mathbf{8}^{\text {th }}$ Grade & HSPE \\
\cline { 2 - 4 } & \multicolumn{3}{c}{ Percentage of Items } \\
\hline Content Cluster & 29 & 20 & 24 \\
Word analysis and skills & 24 & 35 & 32 \\
$\begin{array}{l}\text { Comprehend, interpret, and evaluate } \\
\text { literature }\end{array}$ & & & 44 \\
Comprehend, interpret, and evaluate & 37 & 45 & \\
informational text & & & 30 \\
Cognitive Domains & 37 & 33 & 46 \\
Form an initial understanding & 48 & 48 & 24 \\
Develop an interpretation & 15 & 19 & \\
Demonstrate a critical stance & & & \\
\hline
\end{tabular}

Source: http://www.doe.nv.gov/sca/testing/crt/

\section{Writing Assessment}

In Nevada, the $4^{\text {th- }}$ and the $8^{\text {th }}$-grade writing prompts assess narrative/descriptive writing. These writings are assessed on analytic trait scoring for ideas, organization, voice, and convention. The

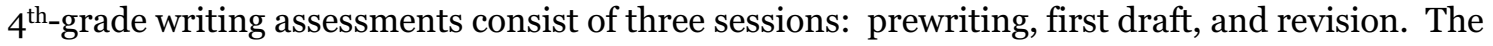
$8^{\text {th }}$-grade assessment consists of two sessions: first draft and final draft.

The $11^{\text {th }}-/ 12^{\text {th }}$-grade writing assessment uses two prompts; one is narrative/descriptive and the other is expository/persuasive. This assessment is scored using a holistic rubric that reflects the 
overall impression of the writing with a balance of the strengths and weaknesses

(http://www.doe.nv.gov/sca/standards/writing/index.html).

\section{Achievement-Level Definitions}

Nevada reports scores by four achievement levels: emerging/developing, approaching standard, meeting standard, or exceeding standard. Scores that meet or exceed standards are considered "proficient” for accountability under NCLB.

\section{Performance Results}

\section{Student Performance}

Table $\mathrm{CC}_{5}$ provides performance results disaggregated by disability status, English-proficiency status, socioeconomic status, and racial/ethnic groups for $5^{\text {th }}$-graders on the 2003 NCRT reading assessment. 48 Because 2003 was the field test for the grade 8 NCRT reading assessment, these results are not available. Writing results were considered diagnostic and are not available. Forty-six percent of students scored at or above meeting standards level, but only 8 percent reached the exceeding standards level. Over half ( 56 percent) of students with disabilities scored at or above the approaching standards level; only 16 percent met standards; and only 2 percent scored at the exceeding standards level.

While almost one-fourth of students with limited-English proficiency scored at or above the meeting standards level, 77 percent scored at or above the approaching standards level. Thus, only 23 percent scored at the lowest achievement level.

Economically disadvantaged students scored far below their peers. The achievement gap was 27 percentage points at the meeting standards level and 8 percent at the exceeding standards level. African American and Hispanic students scored far below white and Asian students at all achievement levels. For example, only 30 percent of African American and Hispanic students scored at or above the meeting standards level, compared with 56 percent of Asian students and 59 percent of white students.

${ }^{48}$ Approximately 55 percent of students in Nevada are white; 27 percent are Hispanic; 10 percent are African American; and 6 percent are Asian/Pacific Islander. About 30 percent are eligible for the free and reducedprice lunch program; 11 percent are in limited-English-proficiency programs; and 11 percent have Individual Education Programs (IEPs). 


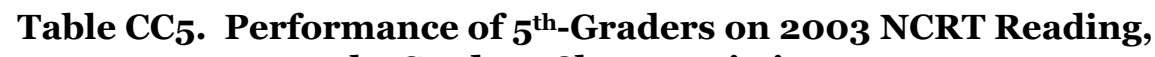
by Student Characteristics

\begin{tabular}{lccc}
\hline & $\begin{array}{c}\text { Approaching } \\
\text { Standard and } \\
\text { Above }\end{array}$ & $\begin{array}{c}\text { Meeting } \\
\text { Standard } \\
\text { and Above }\end{array}$ & $\begin{array}{c}\text { Exceeding } \\
\text { Standard }\end{array}$ \\
\cline { 2 - 4 } Percentage \\
\hline $\mathbf{5}^{\text {th }}$ Grade & \multicolumn{3}{c}{} \\
All students & 88 & 46 & 8 \\
Students with disabilities & 56 & 16 & 2 \\
Students with limited-English proficiency & 77 & 24 & 3 \\
Economically disadvantaged students & 82 & 31 & 3 \\
Non-economically disadvantaged students & 93 & 57 & 11 \\
African American students & 83 & 30 & 3 \\
Asian students & 94 & 56 & 9 \\
Hispanic students & 81 & 30 & 3 \\
White students & 94 & 59 & 12 \\
\hline
\end{tabular}

Source: http://www.nevadatestreports.com/

School Data

School-level data on the 2002 NRCT were not available. 



\section{APPENDIX DD. NEW HAMPSHIRE}

\section{State Assessment System}

Under the New Hampshire Educational Improvement and Assessment Program (NHEIAP), students in grades 3, 6, and 10 take criterion-referenced end-of-grade assessments in English language arts, mathematics, science, and social studies. Results provide information on how students are progressing in gaining the knowledge and skills outlined in New Hampshire's curriculum frameworks. While the tests are used to evaluate school performance under NCLB, assessment results do not have consequences for individual students or teachers.

In 2002, New Hampshire entered into the New England Compact with Rhode Island and Vermont to work on cross-state collaborative initiatives focused on the implementation of the NCLB. As part of the compact's federally funded Enhanced Assessment Project, Rhode Island, New Hampshire and Vermont have developed a set of common grade-level expectations (GLEs) the Tri-State GLEs - that identify the content knowledge and skills expected of students for largescale assessment. The GLEs will be reviewed for alignment with the states' own standards and for quality, and will be used as the basis for a new large-scale assessment to be developed collaboratively by the three states. A draft version of the GLEs and draft test specifications were posted on the compact's Web site in early 2004 (http://www.ed.state.nh.us/ Assessment/GradeLevel/GLE.htm).

\section{Test Content and Format}

The English language arts NHEIAP assessments consist of multiple-choice and open-response items that require students to use higher-order thinking skills, such as evaluation, analysis, and summarization. While there are suggested time limits for the assessments, students are provided additional time to complete the test if needed.

The tests include both common and matrix-sampled items. However, beginning with the May 2002 administration, the test design was modified so that student, school, and district scores were based on common items only. Prior to that time, results were based on both common and matrix-sampled items.

In grades 6 and 10, the English language arts assessment includes a reading section, a writing section, and a videotaped section that tests listening and viewing.

Approximately one-third of the possible points for reading are based on each of the three passage types: literary and narrative works, informational or content pieces, and practical sources: 
- Literary passages are represented by a variety of genres, including fiction, fantasy, poetry, drama, fables, folktales, legends, and historical fiction.

- Informational or content passages include nonfiction, essays, biographies, autobiographies, informational articles, and factual presentations.

- Practical passages are functional materials that instruct or advise the reader, including directions and how-to-do-it books.

Reading passages on the assessment include both long and short texts. None of the passages is written specifically for the assessment; passages are collected from published works. Passages are selected to be grade-appropriate, with the ideas expressed becoming increasingly complex in the later grades. The items related to these passages require students to demonstrate their skills in both literal comprehension (where the answer is stated explicitly in the text) and inferential comprehension (where the answer is implied by the text and/or the text must be connected to relevant prior knowledge to determine an answer). In addition, some questions require students to use the skills and strategies of reading to answer items-for example, how to identify the author's principal purpose, such as to persuade, entertain, or to inform-and to demonstrate their understanding of how words and images communicate to readers.

The writing portion of the English language arts assessment includes writing prompts and multiple-choice items. The writing prompts are scored on a scale of 1-6 points; the final writing score is the sum of two independent readers' ratings. Multiple-choice items are worth 1 point each and assess editing and grammar.

The prompts used in the 2001-02 NHEIAP were:

- Grade 6 prompt: If you could travel anywhere, where would you go and why? Describe what you would do when you got there.

- Grade 10 prompt: Choose a book or a movie that you think other people should read or view. Explain your choice.

Listening and viewing are assessed through the use of videotaped programs. The subject matter of the videotaped programs varies from year to year and includes literary and informational programs. These programs are approximately 10-15 minutes long. Each student responds to six multiple-choice items and one open-response item based on a common videotaped selection for that grade level. One common multiple-choice item about the cover art on the test booklet is also included (http://www.ed.state.nh.us/Assessment/2002/Tech\%20Report_02.pdf). 


\section{Achievement-Level Definitions}

New Hampshire defines four performance categories: advanced, proficient, basic, and novice.

For accountability purposes, students performing at basic and above are considered to be moving

forward toward appropriate learning goals. Table DD1 provides achievement-level definitions for grades 6 and 10.

Table DD1. Achievement-Level Definitions, $6^{\text {th }}$ and $10^{\text {th }}$ Grades

\begin{tabular}{|c|c|c|}
\hline $\begin{array}{l}\text { Achievement } \\
\text { Level }\end{array}$ & $6^{\text {th }}$ Grade & 10 $^{\text {th }}$ Grade \\
\hline Advanced & $\begin{array}{l}\text { Students at this level demonstrate a } \\
\text { thorough understanding of literary, } \\
\text { narrative, factual, informational, and } \\
\text { practical works. They extract main and } \\
\text { subordinate ideas, supporting details, and } \\
\text { information from materials they read, hear, } \\
\text { and view. They draw conclusions, make } \\
\text { critical judgments, and develop meaningful } \\
\text { connections between and among ideas and } \\
\text { concepts. They explain and support their } \\
\text { inferences and interpretations. Their } \\
\text { writing is clear, effective, and fluent. They } \\
\text { organize ideas, develop a topic, add } \\
\text { supporting details, and vary both sentence } \\
\text { structure and vocabulary. They make few, } \\
\text { if any, mechanical errors. }\end{array}$ & $\begin{array}{l}\text { Students at this level demonstrate a broad } \\
\text { and in-depth understanding of a wide } \\
\text { range of literary, narrative, factual, } \\
\text { informational, and practical works. They } \\
\text { make complex connections between and } \\
\text { among ideas and concepts in materials } \\
\text { they read, hear, and view. They analyze } \\
\text { text and make critical judgments. They } \\
\text { provide extensive evidence for inferences } \\
\text { and interpretations. They persuasively } \\
\text { present, explain, and defend positions. } \\
\text { Their writing shows logic, clarity, } \\
\text { organization, fluency, and style. They use } \\
\text { language to communicate effectively. }\end{array}$ \\
\hline Proficient & $\begin{array}{l}\text { Students at this level demonstrate an } \\
\text { overall understanding of literary, narrative, } \\
\text { factual, informational, and practical works. } \\
\text { They extract main ideas, analyze text, } \\
\text { evaluate and organize information, draw } \\
\text { conclusions, and make inferences and } \\
\text { interpretations. They critically evaluate } \\
\text { materials they read, hear, and view. They } \\
\text { effectively organize, develop, and support } \\
\text { ideas so that a reader can easily understand } \\
\text { the intent of their writing. They } \\
\text { demonstrate a firm grounding in the } \\
\text { mechanics of written expression; however, } \\
\text { they may still make some errors. }\end{array}$ & $\begin{array}{l}\text { Students at this level demonstrate a solid } \\
\text { understanding of a wide range of literary, } \\
\text { narrative, factual, informational, and } \\
\text { practical works. They make meaningful } \\
\text { connections between and among ideas } \\
\text { and concepts in materials they read, hear, } \\
\text { and view. They evaluate and organize } \\
\text { information, make and communicate } \\
\text { informed judgments, and provide } \\
\text { evidence for inferences and } \\
\text { interpretations. Their writing is clear, } \\
\text { logical, and shows evidence of fluency and } \\
\text { style. They effectively control the } \\
\text { mechanics of language, including spelling, } \\
\text { capitalization, grammar, and punctuation. }\end{array}$ \\
\hline
\end{tabular}


Table DD1. (cont.)

\begin{tabular}{|c|c|c|}
\hline Basic & $\begin{array}{l}\text { Students at this level demonstrate a reasonable } \\
\text { understanding of literary, narrative, factual, } \\
\text { informational, and practical works. They } \\
\text { recognize main ideas and identify supporting } \\
\text { details. They gather information from } \\
\text { materials they read, hear, and view and use it to } \\
\text { make obvious conclusions. Their responses } \\
\text { often include appropriate examples. They } \\
\text { employ sufficient organization, development, } \\
\text { and support of ideas to satisfactorily } \\
\text { communicate the intent of their writing. While } \\
\text { they demonstrate a fundamental control of the } \\
\text { mechanics of written expression, they may } \\
\text { make errors in spelling, capitalization, } \\
\text { grammar, and/or punctuation. }\end{array}$ & $\begin{array}{l}\text { Students at this level demonstrate a general } \\
\text { understanding of literary, narrative, factual, } \\
\text { informational, and practical works. They } \\
\text { form reasoned conclusions and make } \\
\text { straightforward connections among ideas and } \\
\text { concepts. They use information obtained by } \\
\text { reading, viewing, and listening to solve } \\
\text { problems and complete tasks. Their writing } \\
\text { successfully communicates straightforward } \\
\text { ideas, but is limited in organization, focus, } \\
\text { and details. They may make errors in the } \\
\text { mechanics of language. }\end{array}$ \\
\hline Novice & $\begin{array}{l}\text { Students at this level demonstrate some } \\
\text { understanding of literary, narrative, factual, } \\
\text { informational, and practical works. They } \\
\text { recognize clearly stated topics and details in } \\
\text { materials they read, hear, and view. For the } \\
\text { most part, their responses to questions are } \\
\text { literal. Their writing shows rudimentary } \\
\text { organization, development, and use of detail. } \\
\text { Errors in capitalization, punctuation, spelling, } \\
\text { and/or grammar may interfere with a reader's } \\
\text { ability to understand the text. }\end{array}$ & $\begin{array}{l}\text { Students at this level demonstrate some } \\
\text { understanding of literary, narrative, factual, } \\
\text { informational, and practical works. They } \\
\text { recognize clearly stated information in } \\
\text { materials they read, hear, and view. They } \\
\text { display a rudimentary ability to use language } \\
\text { to solve problems and complete well-defined } \\
\text { tasks. Their writing shows limited focus, } \\
\text { organization, and development and may } \\
\text { contain errors in the use of conventional } \\
\text { language, mechanics, and sentence structure. }\end{array}$ \\
\hline
\end{tabular}

Source: http://www.ed.state.nh.us/Assessment/grade6-2003.pdf;

http://www.ed.state.nh.us/Assessment/grade10-2003.pdf

\section{Performance Results}

\section{Student Performance}

The New Hampshire Department of Education provides student-level data on student

performance for all students, students with disabilities, economically disadvantaged students, and major racial/ethnic 49 groups by two achievement levels - basic and above and proficient and above. Table DD2 presents scores for $6^{\text {th }}$ and $10^{\text {th }}$-graders on the NHEIAP English Language Arts assessment.

Seventy-one percent of $6^{\text {th }}$-graders and 69 percent of $10^{\text {th }}$-graders scored at or above the basic level, and 30 percent and 33 percent, respectively, scored at the proficient and above level. There

49 Approximately 95 percent of students in New Hampshire are white, and 2 percent are Hispanic. No other racial/ethnic group comprises more than 2 percent of the student population. About 15 percent of students are eligible for the free and reduced-price lunch program; less than 2 percent are in limited-Englishproficiency programs; and 14 percent have Individual Education Programs (IEPs). 
were large differences in the passing rates of students with and without disabilities-over 50 percentage points at the basic level and over 30 percentage points at the proficient level.

Hispanic students scored well below white students, with passing rates at the basic level that were between 18 and 24 percentage points lower. About 16-17 percent of Hispanic students scored at the proficient level compared with 31-35 percent of white students. Economically disadvantaged students also tended to score below their counterparts by 20-23 percentage points in the $6^{\text {th }}$ grade at the two achievement levels and by $16-20$ percentage points in the $10^{\text {th }}$ grade. A little over half of economically disadvantaged students scored at the basic level compared with over 70 percent of students who were not economically disadvantaged. Only 14-19 percent of them scored at the proficient level, compared with 34-35 percent of their peers.

Table DD2. Performance of $6^{\text {th }}$ - and $10^{\text {th }}$-Graders on 2003 English Language Arts Performance NHEIAP, by Student Characteristics

\begin{tabular}{|c|c|c|}
\hline & $\begin{array}{c}\text { Basic and } \\
\text { Above }\end{array}$ & $\begin{array}{c}\text { Proficient and } \\
\text { Above }\end{array}$ \\
\hline & \multicolumn{2}{|c|}{ Percentage } \\
\hline \multicolumn{3}{|l|}{$6^{\text {th }}$ Grade } \\
\hline All students & 71 & 30 \\
\hline Students with disabilities & 26 & 4 \\
\hline Students without disabilities & 80 & 35 \\
\hline Economically disadvantaged students & 53 & 14 \\
\hline Non-economically disadvantaged students & 76 & 34 \\
\hline Hispanic students & 54 & 16 \\
\hline White students & 72 & 31 \\
\hline \multicolumn{3}{|l|}{$10^{\text {th }}$ Grade } \\
\hline All students & 69 & 33 \\
\hline Students with disabilities & 25 & 5 \\
\hline Students without disabilities & 77 & 38 \\
\hline Economically disadvantaged students & 51 & 19 \\
\hline Non-economically disadvantaged students & 71 & 35 \\
\hline Hispanic students & 47 & 17 \\
\hline White students & 71 & 35 \\
\hline
\end{tabular}

Source: http://www.ed.state.nh.us/Assessment/grade6-2003.pdf;

http://www.ed.state.nh.us/Assessment/grade10-2003.pdf

\section{$\underline{\text { School-Level Performance }}$}

School-level data disaggregated by urbanicity are available for the 2002 NHEIAP administration for grades 6 and 10 reading (Table DD3). Over half (53 percent) of schools in New Hampshire are rural, 36 percent are suburban, and 11 percent are urban. Only 3 percent of schools in New 
Hampshire are high-poverty schools. About 10 percent of urban schools served such high proportions of economically disadvantaged students, as did 3 percent of rural schools. No suburban schools were classified as being high-poverty.

Table DD3. Average School Performance, $6^{\text {th }}$ and $10^{\text {th }}$-Grade 2002 NHEIAP English Language Arts Performance (Reading Only), by Urbanicity

\begin{tabular}{|c|c|c|}
\hline & $\begin{array}{c}\text { Basic and } \\
\text { above }\end{array}$ & $\begin{array}{l}\text { Proficient } \\
\text { and above }\end{array}$ \\
\hline & \multicolumn{2}{|c|}{ Average Percentage } \\
\hline \multicolumn{3}{|l|}{$6^{\text {th }}$ Grade } \\
\hline Rural schools & 68 & 27 \\
\hline Suburban schools & 72 & 31 \\
\hline Urban schools & 61 & 24 \\
\hline \multicolumn{3}{|l|}{$1^{\text {th }}$ Grade } \\
\hline Rural schools & 77 & 36 \\
\hline Suburban schools & 77 & 38 \\
\hline Urban schools & $*$ & $*$ \\
\hline
\end{tabular}




\section{APPENDIX EE. NEW JERSEY}

\section{State Assessment System}

As of 2003, New Jersey's assessment system consisted of:

- The NJ ASK 4 in grade 4 in language arts literacy and mathematics

- The Grade Eight Proficiency Assessment (GEPA) in language arts literacy, mathematics, and science

- The High School Proficiency Assessment (HSPA) in grade 11, which tests language arts literacy and mathematics.

These assessments are used to hold schools accountable. In addition, students must pass all sections of the HSPA in order to obtain a diploma. Students failing the first time have up to three chances to pass this assessment. New Jersey is currently expanding its assessment system in order to meet the requirements under NCLB. In spring 2004, New Jersey will add NJ ASK 3 and a science portion to NJ ASK 4. By 2005-2006, New Jersey will have a testing program for grades 3-8 as required by federal law (http://www.nj.gov/njded/assessment/history.shtml).

The assessments are designed to align with New Jersey's Core Curriculum Content Standards (CCCS), which enumerate what all New Jersey students should know and be able to do by the end of the $4^{\text {th }}$ and $8^{\text {th }}$ grades, and upon completion of a New Jersey public school education. These standards, along with their Cumulative Progress Indicators (CPIs), define expected achievement in seven core content areas: visual and performing arts, comprehensive health and physical education, language arts literacy, mathematics, science, social studies, and world languages. In addition, all areas of instruction include the cross-content workplace readiness standards. There are five language arts literacy standards:

1. Reading-All students will understand and apply the knowledge of sounds, letters, and words in written English to become independent and fluent readers, and will read a variety of materials and texts with fluency and comprehension.

2. Writing-All students will write in clear, concise, organized language that varies in content and form for different audiences and purposes.

3. Speaking-All students will speak in clear, concise, organized language that varies in content and form for different audiences and purposes.

4. Listening-All students will listen actively to information from a variety of sources in a variety of situations. 
5. Viewing and media literacy-All students will access, view, evaluate, and respond to print, nonprint, and electronic texts and resources (http://www.state.nj.us/njded/cccs/s3_lal.htm\#31).

Each standard is further defined through content strands. For example, the reading content standard is divided into the following strands: concepts about print, phonological awareness, decoding and word recognition, fluency, reading strategies, vocabulary and concept development, comprehension skills and response to text, and inquiry and research. For each of these standards and strands, New Jersey has developed CPIs around concepts for each grade level in grades $\mathrm{K}-8$, as well as a combined cluster for grades 9-12. Table EE1 provides an example of cumulative progress indicators for the grade 8 English language arts reading content standard in the area of comprehension skills and response to text.

\section{Table EE1. Grade-Level Expectations for $8^{\text {th }}$ Grade for Reading Comprehension Skills and Response to Text}

\section{Building upon knowledge and skills gained in the preceding grades, by the end of}

$8^{\text {th }}$ Grade, students:

1. differentiate between fact, opinion, bias, and propaganda in newspapers, periodicals, and electronic texts

2. compare and analyze several authors' perspectives of a character, personality, topic, setting, or event

3. analyze ideas and recurring themes found in texts, such as good versus evil, across traditional and contemporary works

4. locate and analyze the elements of setting, characterization, and plot to construct understanding of how characters influence the progression and resolution of the plot

5. read critically by identifying, analyzing, and applying knowledge of the purpose, structure, and elements of nonfiction and providing support from the text as evidence of understanding

6. read critically by identifying, analyzing, and applying knowledge of the theme, structure, style, and literary elements of fiction and providing support from the text as evidence of understanding

7. respond critically to text ideas and the author's craft by using textual evidence to support interpretations

8. identify and analyze literary techniques and elements, such as figurative language, meter, and rhetorical and stylistic features of text

9. identify and analyze recurring themes across literary works

10. read critically and analyze poetic forms (e.g., ballad, sonnet, couplet)

11. identify and understand the author's use of idioms, analogies, metaphors, and similes in prose and poetry

12. understand perspectives of authors in a variety of interdisciplinary works

13. interpret text ideas through journal writing, discussion, and enactment

14. demonstrate the use of everyday texts (e.g., train schedules, directions, brochures) and make judgments about the importance of such documents

15. compare and analyze the various works of writers through an author's study.

Source: http://www.state.nj.us/njded/cccs/s3_lal.htm\#31 


\section{Test Format and Content}

For purposes of examining adolescent literacy, we now focus on the language arts ESPA, GEPA, and HSPA (see http://www.nj.gov/njded/assessment for additional information).

The tests assess students' skills in writing, speaking, reading, listening, viewing, extending understanding of text, working with or interpreting text, and analyzing and critiquing text. On the ESPA, students read everyday text and narrative text. On the GEPA and HSPA, students read narrative and persuasive texts. For writing, $4^{\text {th }}$-grade students are asked to explain a poetrylinked prompt and to speculate for a picture prompt. Students in $8^{\text {th }}$ and $11^{\text {th }}$ grades are also asked to speculate based on a picture prompt, to analyze a poetry-linked prompt, and to persuade. They are also assessed on revising and editing.

In all three assessments, students encounter multiple-choice and open-ended items for reading, listening, and viewing. Most open-ended items will ask students to write a paragraph or more in response. However, for fourth-grade students, at least one open-ended question requires students to work with a graphic organizer. For all three tests, students' responses to open-ended items are scored using a rubric designed to measure students' levels of understanding. The speaking section is administered separately from the paper-and-pencil portion of the test. Students are given 60 minutes to prepare a speech on a given topic. Students are allowed to create notes for their speaking and/or to construct viewing materials to support their presentations. Student speeches are scored on a holistic rubric.

The section on extending understanding of the text is designed as an integrated unit based on a central idea or theme. Students taking the ESPA read an informational article, respond to multiple-choice and open-ended items, and complete a writing project. Students taking the GEPA and the HSPA are given both informational and everyday texts. For all three assessments, students will be expected to use information from the reading selection(s) to complete a textlinked writing project. As they work on their project, students will make decisions, solve problems, and create original work that may include visual materials as well as their own written text. Students' writing projects will be scored using a zero-to-five-point rubric (http://www.njpep.org/assessment/TestSpecs/LangArts/TOC.html).

\section{Achievement-Level Definitions}

New Jersey has adopted three performance categories-partial, proficient, and advanced. Proficient scores are considered "passing” under NCLB. 


\section{Performance Results}

\section{$\underline{\text { Student Performance }}$}

The New Jersey Department of Education provides student-level data on performance for all students, students with disabilities, economically disadvantaged students, and major racial/ethnic $5^{\circ}$ groups; however, at the writing of this report, only 2002 data were available. Table EE2 presents scores for $4^{\text {th }}$, $8^{\text {th }}$, and $11^{\text {th }}$-graders on the 2002 language arts assessments (ESPA, GEPA, and HSPA, respectively).

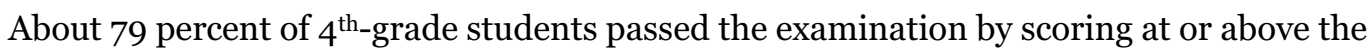
proficient level, and about 6 percent scored at the advanced level. Less than half of $4^{\text {th }}$-grade students with disabilities (43 percent) or students with limited-English proficiency (45 percent) reached the proficient level. Only 62 percent of economically disadvantaged $4^{\text {th }}$-grade students reached the proficient level.

Asian students outperformed white students by small margins (3 percentage points at the proficient level) and African American students and Hispanic students by much larger margins (29 percentage points and 23 percentage points, respectively, in the $4^{\text {th }}$ grade).

We find similar trends for $8^{\text {th }}$-graders on the GEPA; however, achievement gaps among groups of students were greater. While 73 percent of all students reached the proficient level, only 26 percent of students with disabilities and 21 percent of students with limited-English proficiency did so. Asian students outperformed white students by small margins (3 percentage points at the proficient level); however, Asian students outscored African American and Hispanic students by very large margins at the proficient level-41 percentage points and 33 percentage points, respectively.

Eighty-one percent of students passed the HSPA, and 15 percent scored at the advanced level. Trends for student group performance were consistent with those found on the ESPA and GEPA.

$5^{\circ}$ Approximately 60 percent of students in New Jersey are white; 18 percent are African American; 16 percent are Hispanic; and 7 percent are Asian/Pacific Islander. About 28 percent of students are eligible for the free and reduced-price lunch program; 4 percent are in limited-English-proficiency programs; and 16 percent have Individual Education Programs (IEPs). 
Table EE2. Performance of $4^{\text {th }}$, $8^{\text {th }}$, and $1^{\text {th }}$-Graders on Language Arts 2002 Assessments, by Student Characteristics

\begin{tabular}{|c|c|c|}
\hline & $\begin{array}{l}\text { Proficient } \\
\text { and Above }\end{array}$ & Advanced \\
\hline & \multicolumn{2}{|c|}{ Percentage } \\
\hline \multicolumn{3}{|l|}{$4^{\text {th }}$ Grade (ESPA assessment) } \\
\hline All students & 79 & 6 \\
\hline General education & 86 & 7 \\
\hline Students with disabilities & 43 & 1 \\
\hline Students with limited-English proficiency & 45 & o \\
\hline Economically disadvantaged students & 62 & 1 \\
\hline African American students & 61 & 1 \\
\hline Asian/Pacific Islander students & 90 & 12 \\
\hline Hispanic students & 67 & 2 \\
\hline White students & 87 & 8 \\
\hline \multicolumn{3}{|l|}{$8^{\text {th }}$ Grade (GEPA assessment) } \\
\hline All students & 73 & 8 \\
\hline General education & 83 & 10 \\
\hline Students with disabilities & 26 & o \\
\hline Students with limited-English proficiency & 21 & o \\
\hline Economically disadvantaged students & 47 & 1 \\
\hline African American students & 46 & 1 \\
\hline Asian/Pacific Islander students & 87 & 19 \\
\hline Hispanic students & 54 & 2 \\
\hline White students & 84 & 11 \\
\hline \multicolumn{3}{|l|}{$1^{\text {th }}$ Grade (HSPA assessment) } \\
\hline All students & 81 & 15 \\
\hline General education & 90 & 17 \\
\hline Students with disabilities & 38 & 1 \\
\hline Students with limited-English proficiency & 21 & o \\
\hline Economically disadvantaged students & 59 & 3 \\
\hline African American students & 63 & 4 \\
\hline Asian/Pacific Islander students & 87 & 26 \\
\hline Hispanic students & 64 & 5 \\
\hline White students & 88 & 18 \\
\hline
\end{tabular}

Source: http://education.state.nj.us/rc/2002/index.html

\section{School Performance}

School-level data, disaggregated by urbanicity, are available for the 2002 reading ESPA and GEPA administrations for grades 4 and 8 in reading (Table EE3). Eighty-eight percent of schools in New Jersey are suburban, and 12 percent are urban; none is rural. Urban schools are 
disproportionately high-poverty schools: 84 percent of urban schools are high-poverty, compared with 16 percent of suburban schools. Due to the small number of rural schools in New Jersey, we do not report scores for these schools.

The average percentage of students reaching proficiency in suburban schools is substantially higher than in urban schools-a 22-30-percentage-point difference at the proficient level and a 5-8-percentage-point difference at the advanced level.

Table EE3. Average School Performance on $4^{\text {th- }}$ and $8^{\text {th }}$-Grade 2002 Language Arts ESPA and GEPA, by Urbanicity

\begin{tabular}{lcc}
\hline & $\begin{array}{c}\text { Proficient } \\
\text { and Above }\end{array}$ & Advanced \\
\cline { 2 - 3 } & Average Percentage \\
\hline $\mathbf{4}^{\text {th }}$ Grade (ESPA) & 81 & 7 \\
Suburban schools & 59 & 2 \\
Urban schools & & \\
$\mathbf{8}^{\text {th }}$ Grade (GEPA) & 76 & 9 \\
Suburban schools & 46 & 1 \\
Urban schools & & \\
\hline
\end{tabular}




\section{APPENDIX FF. NEW MEXICO}

\section{State Assessment System}

In 2000, the State Board of Education implemented a statewide accountability program for public schools, testing students in grades 3-9 in mathematics, language arts, science, and social studies, using a norm-referenced test. However, New Mexico is transitioning from this norm-referenced system to a criterion-referenced system in order to comply with NCLB. The transition to the criterion-referenced assessment will occur over school years 2003-04 and 2004-05. In 2002-03 and 2003-04, New Mexico administered norm-referenced tests in grades 3, 5, 6, 7, and 9 and a criterion-referenced assessment in grades 4 and 8 in mathematic, language arts, science, and social studies. (The criterion-referenced test used in 2002-03 and 2003-04 will be phased out.) A criterion-referenced assessment for grade 11 was field-tested in 2002-03 as well. By 2004-05, new criterion-referenced tests will be fully implemented in grades $3-9$ and 11 in English and Spanish (http://www.ped.state.nm.us/resources/ downloads/2003.annual.report.pdf).

In addition, New Mexico administers a high school competency examination (NMHSCE) that tests student in reading, language arts, mathematics, science, social studies, and writing. Students take the tests for the first time in the $10^{\text {th }}$ grade and must pass all subject areas in order to receive a high school diploma. Sophomores who fail any part of the NMHSCE have another chance to take the exam in their junior year and two chances in their senior year.

New Mexico's new criterion-referenced examinations are designed to measure state standards. New Mexico has developed content standards, benchmarks, and performance standards for language arts, mathematics, science, social studies, and a number of other subject areas. Each general standard is divided into grade-span benchmarks, which are further delineated by gradelevel-specific performance standards. For example, Table FF1 presents the benchmark and performance standards for grades $5 \mathbf{- 8}$ for the content standard: Students will apply strategies and skills to comprehend information that is read, heard, and viewed. 
Table FF1. $5^{\text {th }}-8^{\text {th }}-$ Grade Benchmark and Performance Standards for Content Standard: Students Will Apply Strategies and Skills to Comprehend Information That Is Read, Heard, and Viewed

5-8 Benchmark: Gather and use information for research and other purposes

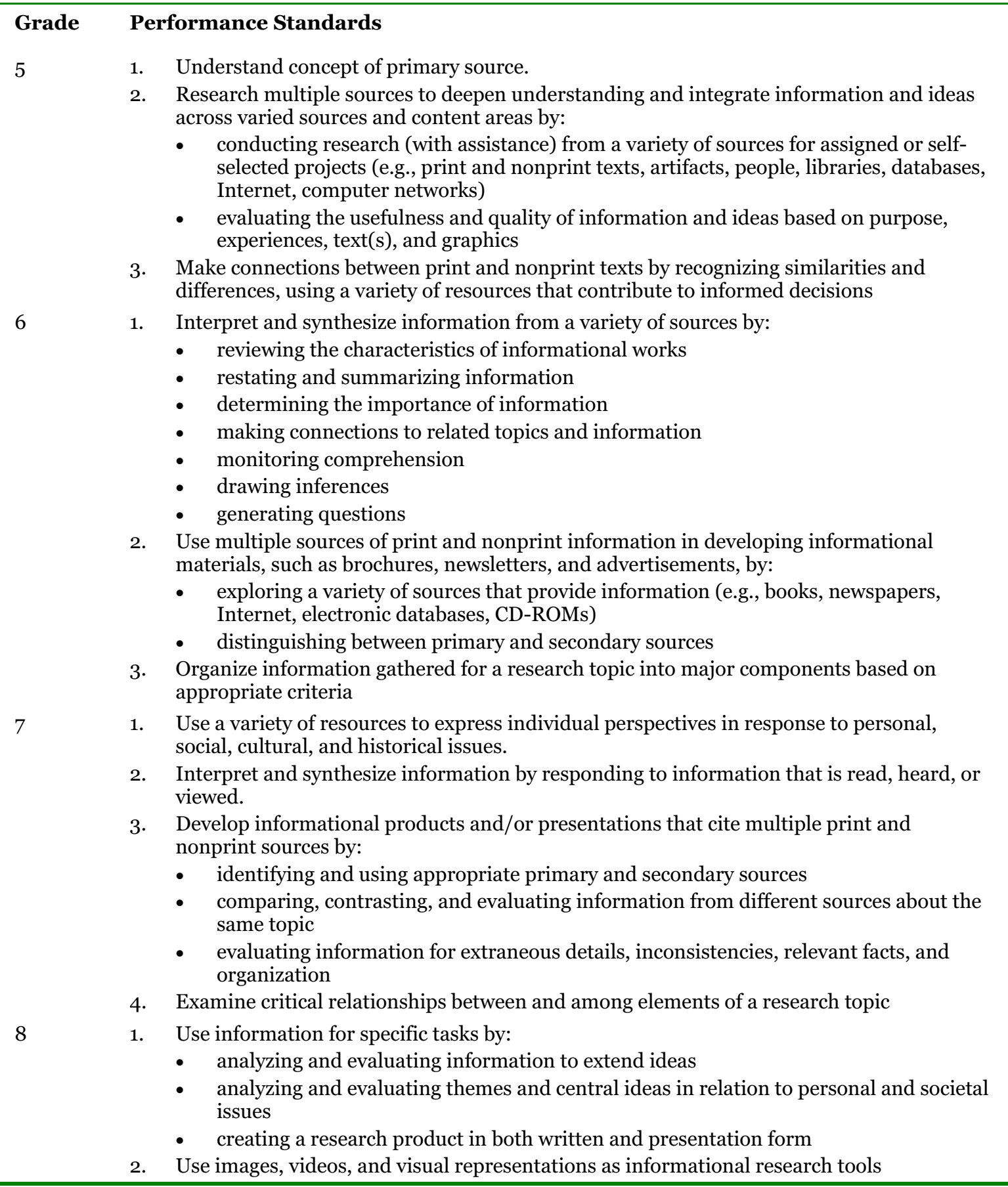

Source: http://164.64.166.11/cilt/downloads/standards/stand_la.doc 


\section{Test Format and Content}

We now turn to a discussion of the criterion-referenced tests in grades 4 and 8 and the NMHSCE in reading, language arts, and writing.

\section{$\underline{\text { CRTs }}$}

The language arts assessments in grades 4 and 8 consist of multiple-choice and constructedresponse items; each of these categories counts for approximately 50 percent of the assessment score. Constructed-response items are either short responses, which take approximately three to five minutes to answer, or extended-response items, which require anywhere from five to 15 minutes to answer. The language arts test also contains three writing prompts that require students to write a minimum of one paragraph for each. Reading passages on the assessment include literary, informational, and functional passages (http://www.ped.state.nm.us/div/ais/ assess/dl/reading.test.and.item.specifications.3.17.03.draft.pdf).

The tests sample the performance standards that are appropriate for inclusion on a statewide, paper-and-pencil test. All other performance standards are tested at the classroom level. For instance, for grade 8, students may be tested on reading comprehension; gathering and using information for research and other purposes; applying critical-thinking skills to analyze information; communicating effectively through writing; applying grammatical and language conventions to communicate; demonstrating competence in the skills and strategies of the writing process; using literature to develop an understanding of people, societies, and the self and to understand various social and cultural perspectives; and identifying ideas and making connections among literary works (http://www.ped.state.nm.us/div/ais/ (assess/dl/crt.descriptors.pdf).

\section{NMHSCE}

The NMHSCE includes reading and language arts tests with both multiple-choice and constructed-response questions. For the writing section, students answer one writing prompt that is scored on a six-point rubric.

\section{Achievement-Level Definitions}

For the CRTs, New Mexico established four achievement levels-beginning step, nearing proficiency, proficient, and advanced. Scores of proficient and above are considered "passing" under New Mexico's new accountability program and NCLB. Table FF2 provides definitions of these achievement levels for grade-8 language arts. 


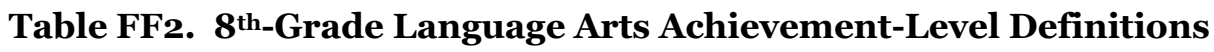

\begin{tabular}{|c|c|}
\hline Beginning Step & $\begin{array}{l}\text { Students: } \\
\text { - can comprehend forms, simple poems, and narratives } \\
\text { - demonstrate reading strategies, including recalling details and interpreting } \\
\text { story characters' feelings } \\
\text { - can interpret meaning of vocabulary from context } \\
\text { - use commas and quotation marks correctly } \\
\text { - can combine simple sentences and identify sentences with correct verb tense } \\
\text { - identify some correctly spelled words } \\
\text { - can read map legends } \\
\text { - identify major reference materials for information } \\
\text { - identify supporting details for an outline. }\end{array}$ \\
\hline Nearing Proficiency & $\begin{array}{l}\text { Students: } \\
\text { - } \text { use context clues to predict or draw conclusions regarding events and/or } \\
\text { feelings of a character } \\
\text { - demonstrate reading strategies, including identifying main idea, conclusion, } \\
\text { cause and effect, identifying author's mood in short and long narratives, poems } \\
\text { and interviews } \\
\text { - understand some idiomatic and figurative language } \\
\text { - derive the meaning of some words in context } \\
\text { - can read forms and charts for details } \\
\text { - identify sentences with correct use of commas, quotation marks, and } \\
\text { - capitalization } \\
\text { - can sequence events and ideas in a paragraph } \\
\text { - can idetermine correct capitalization and punctuation in letters }\end{array}$ \\
\hline Proficient & $\begin{array}{l}\text { Students: } \\
\text { - can generalize, extend, and apply author's meaning } \\
\text { - demonstrate reading strategies, including main idea and prediction } \\
\text { - show understanding of descriptive language, literary genres, text types, story } \\
\text { structure, author's style, and paragraph development } \\
\text { - can explain their answers and strategies } \\
\text { - identify multi-meaning words for different contexts } \\
\text { - select appropriate use of pronouns } \\
\text { - choose appropriate synonyms and antonyms in context and in isolation } \\
\text { - can determine correct use of apostrophes and appropriate punctuation in } \\
\text { - addresses } \\
\text { - can complete an outline. }\end{array}$ \\
\hline Advanced & $\begin{array}{l}\text { Students: } \\
\text { - demonstrate reading strategies, including inferential reasoning, analogy, and } \\
\text { application } \\
\text { - identify plot, theme, and outcome in a narrative } \\
\text { - define more difficult words, and edit writing for grammar, punctuation, } \\
\text { capitalization. }\end{array}$ \\
\hline
\end{tabular}

Source: http://www.ped.state.nm.us/div/ais/assess/dl/grade468.pdf 
For the NMHSCE, performance is reported as a scale score, with a mean of 200 and a standard deviation of 40. A scale score of 175 represents adequate performance on the reading and language arts tests. For the writing section, a score of three on the six-point rubric is considered passing.

\section{Performance Results}

\section{Student Performance}

Table FF3 presents data on student performance on the $4^{\text {th- }}$ and $8^{\text {th }}$-grade language arts assessments, disaggregated by disability status, English-proficiency status, socioeconomic status, and racial/ethnic groups. ${ }^{51}$ Data for the standardized administration of the assessments are presented.

A little over half of $4^{\text {th }}$-grade students (53 percent) passed the examination by reaching the proficient level. Eight percent scored at the advanced level, while 82 percent scored at or above the nearing proficiency level. Scores of $8^{\text {th }}$-grade students were a bit higher -85 percent scored at or above the nearing proficiency level, 58 percent reached proficiency, and 14 percent scored at the advanced level. However, $4^{\text {th }}$-grade special education students were a bit more likely to reach the proficient level than were the $8^{\text {th }}$-grade special education students -42 percent compared with 34 percent.

In $4^{\text {th }}$ and $8^{\text {th }}$ grades, 65 percent of English-language learners scored at or above the nearing proficiency level, while 28-30 percent scored at the proficient level, and 2 percent scored at the advanced level. Economically disadvantaged students scored far below their peers-about 21-22 percentage points lower at the proficient level. White students scored 20-26 percentage points above Hispanic students and African American students at the proficient level.

Table FF4 presents scale scores for student groups on the reading and language arts NMHSCE, as well as the percentage of students who passed all of the tests in the NMHSCE battery in spring 2003. The mean scale scores on the tests were 200, with a standard deviation of 40 . A scale score of 175 represents adequate performance on the reading and language arts tests.

${ }^{51}$ Approximately 51 percent of students in New Mexico are Hispanic; 34 percent are white; 11 percent are American Indian; and 2 percent are African American. About 55 percent of students are eligible for the free and reduced-price lunch program; 21 percent are in limited-English-proficiency programs; and 20 percent have Individual Education Programs (IEPs). 
About 69 percent of all students passed the battery of NMHSCE tests. However, only 27 percent of special education students, 36 percent of English-language learners, and 51 percent of economically disadvantaged students did so.

Table FF3. $4^{\text {th- }}$ and $8^{\text {th }}$-Grade Language Arts 2003 Standards-Based Assessment (SBA), by Student Characteristics

\begin{tabular}{|c|c|c|c|}
\hline & $\begin{array}{c}\text { Nearing } \\
\text { Proficiency } \\
\text { and Above }\end{array}$ & $\begin{array}{l}\text { Proficient and } \\
\text { Above }\end{array}$ & Advanced \\
\hline & \multicolumn{3}{|c|}{ Percentage } \\
\hline \multicolumn{4}{|l|}{$4^{\text {th }}$ Grade } \\
\hline All students & 82 & 53 & 8 \\
\hline General education students & 82 & 53 & 8 \\
\hline Special education students & 69 & 42 & 10 \\
\hline English-language learners & 65 & 30 & 2 \\
\hline Non-English-language learners & 78 & 50 & 8 \\
\hline Economically disadvantaged students & 69 & 36 & 4 \\
\hline Non-economically disadvantaged students & 83 & 58 & 11 \\
\hline African American students & 76 & 45 & 4 \\
\hline Hispanic students & 78 & 45 & 5 \\
\hline White students & 91 & 69 & 14 \\
\hline \multicolumn{4}{|l|}{$8^{\text {th }}$ Grade } \\
\hline All students & 85 & 58 & 14 \\
\hline General education students & 86 & 59 & 14 \\
\hline Special education students & 63 & 34 & 9 \\
\hline English-language learners & 65 & 28 & 2 \\
\hline Non-English-language learners & 81 & 55 & 13 \\
\hline Economically disadvantaged students & 72 & 40 & 6 \\
\hline Non-economically disadvantaged students & 84 & 61 & 17 \\
\hline African American students & 82 & 55 & 11 \\
\hline Hispanic students & 81 & 49 & 8 \\
\hline White students & 93 & 75 & 24 \\
\hline
\end{tabular}

Source: http://www.ped.state.nm.us/div/acc.assess/assess/dl/sba.executive.summary.pdf

Note: The table reports scores from standardized administrations of the assessments. 
Table FF4. Performance of $10^{\text {th }}$-Graders on 2003 NMHSCE, by Student Characteristics

\begin{tabular}{lccc}
\hline & $\begin{array}{c}\text { Reading } \\
\text { Average } \\
\text { Scale Score }\end{array}$ & $\begin{array}{c}\text { Language } \\
\text { Arts Average } \\
\text { Scale Score }\end{array}$ & $\begin{array}{c}\text { Percentage } \\
\text { Passing All } \\
\text { Tests }\end{array}$ \\
\hline All students & 209 & 201 & 69 \\
General education students & 211 & 203 & 72 \\
Special education students & 180 & 166 & 27 \\
English-language learners & 185 & 175 & 36 \\
Economically disadvantaged students & 195 & 186 & 51 \\
Non-economically disadvantaged students & 210 & 202 & 71 \\
African American students & 202 & 192 & 58 \\
Hispanic students & 203 & 195 & 61 \\
White students & 221 & 213 & 85 \\
\hline
\end{tabular}

Source: http://www.ped.state.nm.us/div/acc.assess/assess/dl/nm.exec.summary.2003.pdf

Note: Standardized score results presented.

Turning to the reading and language arts scale scores, we can see that economically

disadvantaged students perform about 4 of a standard deviation below their non-economically disadvantaged peers, and Hispanic and African American students perform about half a standard deviation below white students.

$\underline{\text { School Performance }}$

No school-level data are available for New Mexico. 



\section{APPENDIX GG. NEW YORK}

\section{State Assessment System}

New York assesses students in English, mathematics, and science in grades 4 and 8, social studies in grade 5 , and technology education in grade 8 . At the high school level, students must complete a series of Regents examinations that test students in English, mathematics, social studies, science, the arts, and languages other than English. High school students must pass the high school examinations in order to graduate from high school. Students have multiple testing opportunities to pass the high school examination. New York is planning to expand its series of assessments to meet requirements under NCLB and plans to administer assessments in grades 38 in English language arts and mathematics in 2005-2006 (additional information can be found through http://www.emsc.nysed.gov/nyc/accountability.html).

New York's assessments are intended to measure state standards. New York established four content standards in English language arts:

- Standard 1: Students will read, write, listen, and speak for information and understanding. As listeners and readers, students will collect data, facts, and ideas; discover relationships, concepts, and generalizations; and use knowledge generated from oral, written, and electronically produced texts. As speakers and writers, they will use oral and written language to acquire, interpret, apply, and transmit information.

- Standard 2: Students will read, write, listen, and speak for literary response and expression. Students will read and listen to oral, written, and electronically produced texts and performances, relate texts and performances to their own lives, and develop an understanding of the diverse social, historical, and cultural dimensions the texts and performances represent. As speakers and writers, students will use oral and written language for self-expression and artistic creation.

- Standard 3: Students will read, write, listen, and speak for critical analysis and evaluation. As listeners and readers, students will analyze experiences, ideas, information, and issues presented by others using a variety of established criteria. As speakers and writers, they will present, in oral and written language and from a variety of perspectives, their opinions and judgments on experiences, ideas, information, and issues.

- Standard 4: Students will read, write, listen, and speak for social interaction. Students will use oral and written language for effective social communication with a wide variety of people. As readers and listeners, they will use the social communications of others to enrich their understanding of people and their views (http://www.emsc.nysed.gov/ciai/ pub/standards). 
In addition, New York has published performance indicators by school levels for the standards; each standard is linked to a key idea that defines the standard, along with performance indicators that describe the required expectations for students at the elementary, intermediate, and commencement levels (see Table GG1 for example).

\section{Table GG1. Performance Indicators and Evidence for Listening and Reading, by School Level}

Listening and reading to acquire information and understanding involve collecting data, facts, and ideas; discovering relationships, concepts, and generalizations; and using knowledge from oral, written, and electronic sources.

\begin{tabular}{|c|c|c|c|}
\hline & Elementary & Middle & Commencement \\
\hline $\begin{array}{l}\text { Performance } \\
\text { indicator }\end{array}$ & $\begin{array}{l}\text { - Gather and interpret } \\
\text { information from } \\
\text { children's reference books, } \\
\text { magazines, textbooks, } \\
\text { electronic bulletin boards, } \\
\text { audio and media } \\
\text { presentations, and oral } \\
\text { interviews, and from such } \\
\text { forms as charts, graphs, } \\
\text { maps, and diagrams } \\
\text { - Select information } \\
\text { appropriate to the purpose } \\
\text { of their investigation and } \\
\text { relate ideas from one text } \\
\text { to another } \\
\text { - Select and use strategies } \\
\text { they have been taught for } \\
\text { note taking, organizing, } \\
\text { and categorizing } \\
\text { information } \\
\text { - Ask specific questions to } \\
\text { clarify and extend } \\
\text { meaning } \\
\text { Make appropriate and } \\
\text { effective use of strategies } \\
\text { to construct meaning from } \\
\text { print, such as prior } \\
\text { knowledge about a } \\
\text { subject, structural and } \\
\text { context clues, and an } \\
\text { understanding of letter- } \\
\text { sound relationships to } \\
\text { decode difficult words } \\
\text { - Support inferences about } \\
\text { information and ideas } \\
\text { with reference to text } \\
\text { features, such as } \\
\text { vocabulary and } \\
\text { organizational patterns. }\end{array}$ & $\begin{array}{l}\text { - Interpret and analyze } \\
\text { information from } \\
\text { textbooks and nonfiction } \\
\text { books for young adults, as } \\
\text { well as reference } \\
\text { materials, audio and } \\
\text { media presentations, oral } \\
\text { interviews, graphs, charts, } \\
\text { diagrams, and electronic } \\
\text { databases intended for a } \\
\text { general audience } \\
\text { - Compare and synthesize } \\
\text { information from different } \\
\text { sources } \\
\text { - Use a wide variety of } \\
\text { strategies for selecting, } \\
\text { organizing, and } \\
\text { categorizing information } \\
\text { Distinguish between } \\
\text { relevant and irrelevant } \\
\text { information and between } \\
\text { fact and opinion } \\
\text { - Relate new information to } \\
\text { prior knowledge and } \\
\text { experience } \\
\text { - Understand and use the } \\
\text { text features that make } \\
\text { information accessible and } \\
\text { usable, such as format, } \\
\text { sequence, level of diction, } \\
\text { and relevance of details. }\end{array}$ & $\begin{array}{l}\text { - Interpret and analyze } \\
\text { complex informational } \\
\text { texts and presentations, } \\
\text { including technical } \\
\text { manuals, professional } \\
\text { journals, newspaper and } \\
\text { broadcast editorials, } \\
\text { electronic networks, } \\
\text { political speeches and } \\
\text { debates, and primary } \\
\text { source material in their } \\
\text { subject-area courses } \\
\text { - Synthesize information } \\
\text { from diverse sources and } \\
\text { identify complexities and } \\
\text { discrepancies in the } \\
\text { information } \\
\text { - Use a combination of } \\
\text { techniques (e.g., } \\
\text { previewing, use of advance } \\
\text { organizers, structural } \\
\text { cues) to extract salient } \\
\text { information from texts } \\
\text { - Make distinctions about } \\
\text { the relative value and } \\
\text { significance of specific } \\
\text { data, facts, and ideas } \\
\text { - Make perceptive and well- } \\
\text { developed connections to } \\
\text { prior knowledge } \\
\text { - Evaluate writing strategies } \\
\text { and presentational } \\
\text { features that affect } \\
\text { interpretation of the } \\
\text { information. }\end{array}$ \\
\hline
\end{tabular}


Table GG1. (cont.)

\begin{tabular}{llll}
\hline Evidence & - Students accurately & - Students produce a & - Students incorporate \\
paraphrase what they have & summary of the & information from several \\
heard or read & information about a & noted experts to support a \\
- Students follow directions & famous person found in a & thesis in a research paper \\
that involve a few steps & biography, encyclopedia, & - Students assemble notes \\
- Students ask for & and textbook & for historical and artistic \\
clarification of a & - Students use facts and data & tables \\
classmate's idea in a group & from news articles and & - Students use an electronic \\
discussion & television reports in an oral & database and other graphic \\
- Students use concept maps, & report on a current event & presentations to find \\
semantic webs, or outlines & - Students compile a & evidence of trends for a \\
to organize information & bibliography of sources & sociological study \\
they have collected. & that are used in a research & - Students produce flow \\
& project & charts and diagrams to \\
& Students take notes that & show the relationships \\
& record the main ideas and & among information from \\
& most significant supporting & different sources \\
& details of a lecture or & - Students determine the \\
& speech. & relative value of different \\
& & reference materials for a \\
& & particular research \\
& & question.
\end{tabular}

Source: http://www.emsc.nysed.gov/ciai/ela/pub/elalearn.pdf

\section{Test Format and Content}

The $20024^{\text {th }}$-grade English language arts test consists of three sessions. In the first session, students answer 28 multiple-choice items. Session 2 contains a listening passage, followed by two short-response items and one extended-response item, and an independent writing prompt linked thematically with the listening prompt. Session 3 contains two linked passages (one informational and one literary, or two literary), accompanied by three short-response items and one extended-response item.

The $8^{\text {th }}$-grade English language arts test has two sessions. The first consists of 25 multiple-choice items and three short-response items and one extended-response item. The four open-response items follow a listening passage. Session 2 contains linked information stimuli, accompanied by three short-response items and one extended-response item, and an independent writing prompt that is followed by an extended-response item.

The High School Regents Comprehensive Examination in English assesses student achievement of the learning standards at the commencement level. The examination is administered in two three-hour sessions on separate days. In Session 1, students are required to: 
- listen to a speech, answer six multiple-choice questions, and use information from the speech to write a response for a specific purpose and audience

- read a text and a related graphic, answer ten multiple-choice questions, and use information from both documents to write a response for a specific purpose and audience.

In Session 2, students are required to:

- read two literary texts, answer ten multiple-choice questions, and write an essay discussing a controlling idea and the authors' use of literary elements and techniques

- interpret a written statement given to them about some aspect of literature (http://emsc32.nysed.gov/osa/inform/DET\%20541E\%200604.pdf).

\section{Achievement-Level Definitions}

New York measures achievement at four levels:

- Level 4-exceeds the standards

- Level 3-meets all the standards

- Level 2-meets some of the standards or partially meets the standards

- Level 1-shows serious academic difficulties.

Performance at or above level 3 is considered "proficient" under NCLB.

\section{Performance Results}

\section{Student Performance}

Student-level data were not publicly available for New York.

School Performance

Table GG2 presents data on the 2002 administration of the $4^{\text {th- }}$ and $8^{\text {th }}$-grade reading section of the English language arts tests by school urbanicity, poverty, and racial/ethnic demographics. Forty-nine percent of schools in New York were suburban, 38 percent urban, and 13 percent rural. About 38 percent of schools were high-poverty. Urban schools were disproportionately high-poverty schools. $5^{2}$ Eighty-four percent of urban schools are high-poverty, compared with 15

\footnotetext{
${ }^{52}$ Approximately 55 percent of students in New York are white; 20 percent are African American; 19 percent are Hispanic, and 6 percent are Asian/Pacific Islander. About 43 percent of students are eligible for the free and reduced-price lunch program; 7 percent are in limited-English-proficiency programs; and 15 percent have Individual Education Programs (IEPs).
} 
percent of rural schools and 11 percent of suburban schools. Forty-six percent of schools are highminority schools, defined as 50 percent minority students and above.

For all schools, on average, 63 percent of students passed the $4^{\text {th }}$-grade reading assessment by scoring at or above level 3 , compared with 43 percent of students on the $8^{\text {th }}$-grade assessment. For both grades, average performance in high-poverty schools was lower than in low-poverty schools (30-31 percentage points at level 3 and above); and high-minority schools trailed lowminority schools (22-25 percentage points at level 3 and above). Average student performance in suburban schools was higher than in rural or urban schools, and rural schools outperformed urban schools. For instance, on the $8^{\text {th }}$-grade assessment, average performance at level 3 or above was 54 percent in suburban schools, compared with 47 percent in rural schools and 27 percent in urban schools.

Table GG2. Average School Performance on $4^{\text {th- }}$ and $8^{\text {th }}$-Grade 2002 Reading Assessment, by Urbanicity, Poverty Status, and Minority Status

\begin{tabular}{lccc}
\hline & $\begin{array}{c}\text { Level 2 } \\
\text { and Above }\end{array}$ & $\begin{array}{c}\text { Level 3 } \\
\text { and Above }\end{array}$ & Level 4 \\
\cline { 2 - 4 } & \multicolumn{3}{c}{ Average Percentage } \\
\hline $\mathbf{4}^{\text {th }}$ Grade & 92 & 63 & 21 \\
All schools & 85 & 45 & 11 \\
High-poverty schools & 97 & 75 & 27 \\
Low-poverty schools & 87 & 51 & 15 \\
High-minority schools & 97 & 73 & 26 \\
Low-minority schools & 95 & 64 & 17 \\
Rural schools & 97 & 75 & 28 \\
Suburban schools & 85 & 47 & 13 \\
Urban schools & & & \\
8 $^{\text {th }}$ Grade & 92 & 43 & 10 \\
All schools & 83 & 23 & 4 \\
High-poverty schools & 97 & 54 & 13 \\
Low-poverty schools & 85 & 29 & 6 \\
High-minority schools & 97 & 54 & 12 \\
Low-minority schools & 96 & 47 & 9 \\
Rural schools & 96 & 54 & 13 \\
Suburban schools & 84 & 27 & 5 \\
Urban schools & & & \\
\hline
\end{tabular}





\section{APPENDIX HH. NORTH CAROLINA}

\section{State Assessment System}

Under its testing program, North Carolina administers a number of assessments, including:

- End-of-grade assessments to students in grades 3-8 in reading and mathematics

- Writing assessments to students in grades 4,7 , and 10

- High school comprehensive tests to students in grade 10 in reading and mathematics (reinstated in 2002-2003 for compliance under NCLB)

- End-of-course assessments for a variety of mathematics, English, science, and history courses taken in high school (grades 9-12), including: English I; Algebra I; Algebra II; Geometry; Physical Science; Biology; Chemistry; Physics; Economic, Legal, and Political Systems; and World History

- Computer-skills test to students in grade 8

- Competency test in reading and mathematics to students in grade 9

- High school exit exam that measures communication, problem solving, processing information, and using numbers and data to students in grade 11.53

The end-of grade tests and the high school comprehensive tests are used for measuring adequate yearly progress under NCLB; all the end-of-grade tests, end-of-course tests, computer-skills test, and writing assessments are used for North Carolina's accountability system, which tracks schools' absolute performance and performance growth. Schools can receive rewards or sanctions for performance on the assessments. In addition, North Carolina public school students are required to meet statewide standards, as measured by the end-of-grade assessments in grades 3,5 , and 8 , to be automatically promoted to the next grade. For high school graduation, students will need a passing score on an exit exam of essential skills (additional information on assessment and accountability can be found through http://abcs.ncpublicschools.org/abcs/).

North Carolina's assessments are intended to measure the competency goals and objectives of the Standard Course of Study, which are delineated by discipline and grade level. Table HH1 presents an example for one competency goal for $8^{\text {th }}$-grade students in English language arts.

53The test was field-tested in 2002-2003 and is expected to replace the current competency tests in reading and mathematics, once implemented in 2004 for the graduates of 2005. 


\section{Table HH1. Competency Goal 1 in Standard Course of Study for $8^{\text {th }}$-Grade English Language Arts}

Competency Goal 1: The learner will use language to express individual perspectives through analysis of personal, social, cultural, and historical issues.

1.01 Narrate a personal account which:

- creates a coherent, organizing structure appropriate to purpose, audience, and context

- establishes a point of view and sharpens focus

- uses remembered feelings

- selects details that best illuminate the topic

- connects events to self and society

1.02 Explore expressive materials that are read, heard, and viewed by:

- generating a learning log or journal

- maintaining an annotated list of works that are read or viewed, including personal reactions

- taking an active role in and/or leading formal and informal book and media talks

1.03 Interact in group activities and/or seminars in which the student:

- shares personal reactions to questions raised

- gives reasons and cites examples from text in support of expressed opinions

- clarifies, illustrates, or expands on a response when asked to do so, and asks classmates for similar expansion

1.04 Reflect on learning experiences by:

- evaluating how personal perspectives are influenced by society, cultural differences, and historical issues

- appraising changes in self throughout the learning process

- evaluating personal circumstances and background that shape interaction with text

Source: http://www.ncpublicschools.org/curriculum/languagearts/gradeeight.htm

\section{Test Format and Content}

We now turn to a discussion of assessments that speak to adolescent literacy-the end-of-grade tests, the high school comprehensive test in reading, and the writing assessments. We selected $4^{\text {th }}$ and $8^{\text {th }}$ grades as our examples for the end-of-grade reading tests (see

http://www.dpi.state.nc.us/

accountability/testing/eog/TIS.htm for additional details on the assessments).

End-of-Grade Reading Comprehension Assessments

For $4^{\text {th }}$ grade, the reading comprehension test consists of 50 multiple-choice questions

administered during a 115-minute block. The test consists of eight reading selections with three to nine associated questions for each selection. Each student is asked to read five literary selections (two fiction, one nonfiction, one drama, one poem) and three informational selections (two content and one consumer). The variety of selections allows for the assessment of reading for various purposes: for literary experience, to gain information, and to perform a task. 
Students in $8^{\text {th }}$ grade answer 56 multiple-choice questions in the 115 -minute block, based on six literary selections (two fiction, one nonfiction, one drama, two poems) and three informational selections (two content and one consumer).

The end-of-grade tests are organized by category, with each item falling into one of four categories: cognition, interpretation, critical stance, or connections. A description of each category and the average percentage of items per form for each category are shown in Table HH2. We see that developing a critical stance is weighted more heavily in the $8^{\text {th }}$ grade than in the $4^{\text {th }}$, while cognition is given less weight in the higher grade. While making connections (a higher-level skill) is tested, it is given little weight, only $5-6$ percent, in either grade.

Table HH2. Descriptive Information for the North Carolina End-of-Grade Test of Reading Comprehension $-4^{\text {th }}$ and $8^{\text {th }}$ Grades

\begin{tabular}{|c|c|c|c|}
\hline Category & Description of Category & $\begin{array}{l}4^{\text {th }} \text { Grade } \\
\text { Average } \\
\text { Percentage } \\
\text { of Score } \\
\end{array}$ & $\begin{array}{l}\text { 8 }^{\text {th }} \text { Grade } \\
\text { Average } \\
\text { Percentage } \\
\text { of Score }\end{array}$ \\
\hline Cognition & $\begin{array}{l}\text { Refers to the initial strategies a reader uses to } \\
\text { understand the selection. It is about purpose and } \\
\text { organization of the selection. It considers the text } \\
\text { as a whole or in a broad perspective. Cognition } \\
\text { includes strategies such as using context clues to } \\
\text { determine meaning or summarizing to include } \\
\text { main points. }\end{array}$ & 38 & 29 \\
\hline Interpretation & $\begin{array}{l}\text { Requires the student to develop a more complete } \\
\text { understanding. It may ask students to clarify, } \\
\text { explain the significance of, extend, and/or adapt } \\
\text { ideas and concepts. }\end{array}$ & 39 & 40 \\
\hline Critical stance & $\begin{array}{l}\text { Refers to tasks that ask the student to stand apart } \\
\text { from the selection and consider it objectively. It } \\
\text { involves processes such as comparing, contrasting, } \\
\text { and understanding the impact of literary } \\
\text { elements. }\end{array}$ & 18 & 25 \\
\hline Connections & $\begin{array}{l}\text { Refers to connecting knowledge from the selection } \\
\text { with other information and experiences. It } \\
\text { involves the student being able to relate the } \\
\text { selection to events beyond or outside the selection. } \\
\text { In addition, the student will make associations } \\
\text { outside the selection and between selections. }\end{array}$ & 5 & 6 \\
\hline
\end{tabular}




\section{$\underline{\text { High School Comprehensive Reading Comprehension Assessment }}$}

The high school comprehensive reading comprehension test requires students to answer 72 multiple-choice questions based on eight passages students read-three passages are literary texts; three are content-based (e.g., science, history); and two are practical (e.g., form, brochure, recipe). Students have 115 minutes to complete the assessment (http://www.ncpublicschools.org/student_promotion/raisebar.html).

\section{Writing Assessments}

In March 2003, North Carolina piloted new writing assessments in grades 4, 7, and 10. Students in grades 4 and 7 were provided 75 minutes to respond to a prompt, while students in grade 10 received 100 minutes. Students in grade 4 wrote an extended narrative response (personal or imaginative); students in grade 7 wrote an extended argumentative response (problem solution or evaluative); and students in grade 10 wrote an extended information response (definition, cause and effect, or problem solution). These responses were graded using a four-point rubric (http://www.ncpublicschools.org/student_promotion/mgwriting.html).

\section{Achievement-Level Definitions}

North Carolina has established four achievement levels for its end-of-grade and high school comprehensive assessments:

- Level I: Students performing at this level do not have sufficient mastery of knowledge and skills in the subject area to be successful in the next grade.

- Level II: Students performing at this level demonstrate inconsistent mastery of knowledge and skills in the subject area and are minimally prepared to be successful at the next grade level.

- Level III: Students performing at this level consistently demonstrate mastery of the gradelevel subject matter and skills and are well prepared for the next grade level.

- Level IV: Students performing at this level consistently perform in a superior manner clearly beyond that required to be proficient at grade-level work.

Students performing at or above Level III are considered to be achieving at or above grade level, and this level is used as the proficiency level for adequate yearly progress (AYP) under NCLB. 


\section{Performance Results}

\section{$\underline{\text { Student Performance }}$}

North Carolina provides student-level data disaggregated by disability status, English-proficiency status, socioeconomic status, and racial/ethnic groups. 54 Table HH3 provides data on student performance on the $4^{\text {th- }}$ and $8^{\text {th }}$-grade reading comprehension assessment for these student groups.

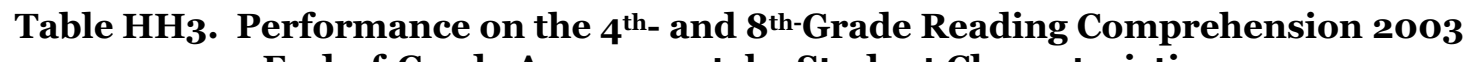
End-of-Grade Assessment, by Student Characteristics

\begin{tabular}{lcc}
\hline & $4^{\text {th }}$ Grade & $\mathbf{8}^{\text {th }}$ Grade \\
\cline { 2 - 3 } & Percent Proficient and Above \\
\hline All students & 81 & 86 \\
Students with disabilities & 48 & 50 \\
Students with no disabilities & 87 & 91 \\
Students with limited-English proficiency & 48 & 41 \\
Students with English proficiency & 83 & 87 \\
Economically disadvantaged students & 70 & 74 \\
Non-economically disadvantaged students & 91 & 93 \\
African American students & 71 & 76 \\
Asian/Pacific Islander students & 83 & 87 \\
Hispanic students & 64 & 65 \\
White students & 89 & 92 \\
\hline
\end{tabular}

Source: http://disag.ncpublicschools.org/2003/

Eighty-one percent of $4^{\text {th }}$-graders and 86 percent of $8^{\text {th }}$-graders reached the proficient level on the reading comprehension end-of-grade assessment. About half (48-50 percent) of students with disabilities did so, and 41-48 percent of students with limited-English proficiency reached this level. Over 90 percent of non-economically disadvantaged students scored at the proficient level, compared with 70-74 percent of economically disadvantaged students.

A larger percentage of white students scored at or above the proficient level than did any other racial/ethnic group. The achievement gap between white and Asian students was small-only 5-6 percentage points; however, it was much larger between white and African American students (16-18 percentage points) and white and Hispanic students (25-27 percentage points).

54Approximately 60 percent of students in North Carolina are white; 31 percent are African American; 5 percent are Hispanic; and 2 percent are Asian/Pacific Islander. About 38 percent are eligible for the free and reduced-price lunch program; 4 percent are in limited-English-proficiency programs; and 14 percent have Individual Education Programs (IEPs). 
Table $\mathrm{HH} 4$ provides data on the $10^{\text {th }}$-grade reading-comprehension HSCA. About 64 percent of all students reached the proficient level. However, only 25 percent of students with limitedEnglish proficiency and 21 percent of students with disabilities reached this level. Similar to what we found on the end-of-grade tests, economically disadvantaged students scored lower than their peers (29 percentage points) and white students outperformed Asian students (9 percentage points), African American students (32 percentage points), and Hispanic students (31 percentage points).

\section{Table HH4. Performance on the $10^{\text {th }}$-Grade Reading Comprehension 2003 High} School Comprehensive Assessment, by Student Characteristics

\begin{tabular}{lc}
\hline & $\begin{array}{c}\text { Percentage } \\
\text { Proficient and } \\
\text { Above }\end{array}$ \\
\hline $\mathbf{1 0}^{\text {th }}$ Grade & 64 \\
All students & 25 \\
Students with limited-English proficiency & 65 \\
Students with English proficiency & 21 \\
Students with disabilities & 69 \\
Students with no disabilities & 43 \\
Economically disadvantaged students & 72 \\
Non-economically disadvantaged students & 49 \\
American Indian/Alaskan Native students & 66 \\
Asian/Pacific Islander students & 43 \\
African American students & 44 \\
Hispanic students & 75 \\
White students & \\
\hline
\end{tabular}

Source: http://disag.ncpublicschools.org/2003/

\section{$\underline{\text { School Performance }}$}

School-level data disaggregated by urbanicity are available for the 2002 administration of the $5^{\text {th }}$

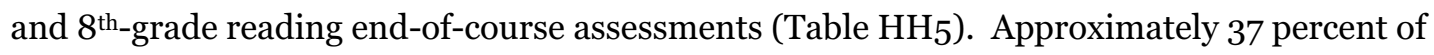
schools in North Carolina were rural, 35 percent were suburban, and 28 percent were urban. A larger proportion of rural and urban schools were high-poverty schools, compared with suburban schools (58 percent, 48 percent, and 26 percent, respectively).

Suburban schools outperformed rural schools by 3 percentage points, and urban schools by 6 percentage points in $5^{\text {th }}$ and $8^{\text {th }}$ grades at level III. For the school level, we also have data on performance at the highest performance category. Again, suburban schools outperformed their rural and urban counterparts. However, urban schools at level IV perform slightly better than 
rural schools did in both grades. For instance, on average, suburban schools in the $5^{\text {th }}$ grade had 42 percent of students performing at level IV, compared with urban schools with 38 percent of students performing at this level, and rural schools with 36 percent of students performing at this level.

Table HH5. Average School Performance on $5^{\text {th }}$ and $8^{\text {th }}$-Grade 2002 Reading Comprehension End-of-Grade Assessment, by Urbanicity

\begin{tabular}{lcc}
\hline & $\begin{array}{c}\text { Level III } \\
\text { and Above }\end{array}$ & Level IV \\
\cline { 2 - 3 } & \multicolumn{1}{c}{ Average Percentage } \\
\hline $\mathbf{5}^{\text {th }}$ Grade & 83 & 36 \\
Rural schools & 86 & 42 \\
Suburban schools & 80 & 38 \\
Urban schools & & \\
$\mathbf{8}^{\text {th }}$ Grade & 81 & 35 \\
Rural schools & 84 & 39 \\
Suburban schools & 78 & 36 \\
Urban schools & \\
\hline
\end{tabular}





\section{APPENDIX II. NORTH DAKOTA}

\section{State Assessment System}

The North Dakota State Assessment (NDSA) is a criterion-referenced exam designed to align with state content standards in English language arts and mathematics. Currently, students in grades 4, 8, and 12 take the assessment, although the state plans to expand the assessment to include students in grades $3,5,6$, and 7 in 2005-06 (for additional information regarding the state assessment system, see http://www.dpi.state.nd.us/grants/NCLB.shtm).

The North Dakota Curriculum Frameworks lay out the state's content standards. The framework lists seven content standards that apply across all grade levels:

- Standard 1: Students gather and organize information

- Standard 2: Students engage in the reading process

- Standard 3: Students comprehend literature

- Standard 4: Students engage in the writing process

- Standard 5: Students write for a variety of purposes and audiences

- Standard 6: Students engage in speaking and listening processes

- Standard 7: Students understand and use principles of language.

Each standard is further broken down into a set of benchmarks that describe what students should know and be able to do to meet the standard in grades 4,8 , and 12. Each benchmark is augmented by examples of specific supporting knowledge and performance activities. The content standards are supplemented by the state's achievement standards, which provide fourpoint rubrics describing levels of performance for each benchmark. Table II1 shows one content standard, with associated benchmarks and achievement standards for grade 8 , as an example (http://www.dpi.state.nd.us/standard/content/english96.pdf).

The state department of education has released professional-development materials, called calibration packets, which help teachers learn about the standards and how to assess students' progress on them.

North Dakota released a draft version of a revision of the state English language arts content standards in January 2004. The six standards in the draft are engaging in the research process, engaging in the reading process, engaging in the writing process, engaging in the speaking and listening process, understanding media, and understanding and using principles of language. Benchmarks for the new standards are defined for all grades levels, $\mathrm{K}-12$. 
Table II 1. North Dakota English Language Arts Curriculum Framework, $8^{\text {th }}$ Grade

\begin{tabular}{|c|c|}
\hline \multicolumn{2}{|r|}{ Standard 3: Students Comprehend Literature } \\
\hline Benchmark & Achievement Standards \\
\hline \multirow{4}{*}{$\begin{array}{l}\text { Understand that } \\
\text { events and themes in } \\
\text { literature parallel and } \\
\text { often impact events in } \\
\text { their lives }\end{array}$} & $\begin{array}{l}\text { Level 4: The student identifies and relates to multiple themes and clearly expresses and } \\
\text { creatively uses these themes through writing or speaking. }\end{array}$ \\
\hline & $\begin{array}{l}\text { Level 3: The student makes connections between his/her own life and literature and } \\
\text { expresses these connections through writing or speaking. }\end{array}$ \\
\hline & $\begin{array}{l}\text { Level 2: The student sees a connection, but vaguely expresses it through writing or } \\
\text { speaking. }\end{array}$ \\
\hline & Level 1: The student is unable to understand the connection. \\
\hline \multirow{4}{*}{$\begin{array}{l}\text { Use specific aspects of } \\
\text { literature to better } \\
\text { understand their own } \\
\text { and/or others' } \\
\text { thoughts and actions }\end{array}$} & $\begin{array}{l}\text { Level 4: The student thoroughly describes the protagonist, antagonist, point of view, and } \\
\text { type of characterization used. }\end{array}$ \\
\hline & Level 3: The student describes the protagonist, antagonist, and other characters. \\
\hline & $\begin{array}{l}\text { Level 2: The student identifies and describes characters, but cannot describe their } \\
\text { function. }\end{array}$ \\
\hline & Level 1: The student shows little or no understanding of characterization. \\
\hline \multirow{4}{*}{$\begin{array}{l}\text { Understand that a } \\
\text { single text may elicit a } \\
\text { wide variety of } \\
\text { reactions }\end{array}$} & Level 4: The student thoughtfully elicits, discusses, and acknowledges other viewpoints. \\
\hline & Level 3: The student acknowledges a variety of viewpoints in addition to his/her own. \\
\hline & Level 2: The student expresses his/her own opinion, but is unaware of other viewpoints. \\
\hline & Level 1: The student is unable to express any point of view. \\
\hline \multirow{4}{*}{$\begin{array}{l}\text { Understand the } \\
\text { characteristics of a } \\
\text { wide variety of genres }\end{array}$} & $\begin{array}{l}\text { Level 4: The student identifies and understands several specific literary elements of } \\
\text { different genres. }\end{array}$ \\
\hline & Level 3: The student identifies and understands some elements of different genres. \\
\hline & Level 2: The student identifies limited elements of different genres. \\
\hline & Level 1: The student is unable to identify specific elements of different genres. \\
\hline
\end{tabular}

Source: http://www.dpi.state.nd.us/standard/content/english96.pdf

\section{Test Format and Content}

The NDSA is produced by CTB/McGraw-Hill and features the company's TerraNova exam augmented with uniquely aligned state test items. The reading/language arts assessment uses both multiple-choice and constructed-response items. Reading standards tested on the exam include gathering and organizing information, engaging in the reading process, comprehending literature, and understanding and using language; language arts standards tested include engaging in the writing process, writing for a variety of purposes, and understanding and using language (http://www.dpi.state.nd.us/testing/index.shtm). 


\section{Achievement-Level Definitions}

Student scores on the NDSA are reported in four categories: advanced, proficient, partially proficient, and novice. Students scoring at the proficient level or higher are considered to have met academic requirements under NCLB.

In addition to defining the achievement levels broadly and setting cut scores, the state has also published grade-by-grade achievement-level descriptors for both reading/language arts and mathematics. Table II2 shows the descriptors for $8^{\text {th }}$-grade reading/language arts as an example.

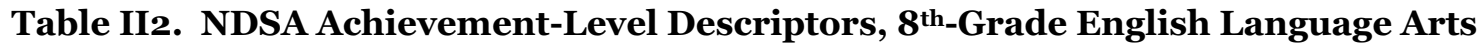

\begin{tabular}{ll}
\hline Advanced & Students identify story elements, interpret context clues, and explain abstract \\
ideas in complex texts. They transfer information from one format to another. \\
Students read critically, making inferences about characters and main ideas, \\
analyzing information to draw conclusions, and interpreting point of view, style, \\
and tone. They scan and reread for clarification. Students distinguish between \\
different types of texts, rationalize the effects of persuasive techniques, and \\
determine the meaning of cultural slang. \\
Students interpret multiple context clues to determine word meaning, analyze \\
texts to determine main idea, and scan to locate specific information. They follow \\
detailed directions and identify appropriate resources. Students read critically to \\
determine setting and to draw conclusions. They analyze characters' \\
development, make predictions, and draw conclusions based on characters' \\
thoughts and actions. Students distinguish main idea from specific details. They \\
interpret simile, metaphor, and slang in different types of texts. \\
Students sort events in chronological order, use context clues to determine word \\
meaning, follow directions, draw conclusions based on evidence in the text, and \\
scan to locate information. They use plot to understand characters' actions. \\
Profially \\
Students use context clues to determine word meaning in simple texts. They \\
identify the narrator, read for detail, and identify persuasive techniques in simple \\
texts.
\end{tabular}

Source: http://www.dpi.state.nd.us/testing/assess/120602.pdf

\section{Performance Results}

\section{Student Performance}

North Dakota provides data on student performance for all students and by a variety of student characteristics, including disability, economic disadvantage, English fluency, and racial/ethnic group. 55 Table II3 shows results from the 2003 NDSA reading/language arts exam for students in grades 4,8 , and 12

55Approximately 89 percent of students in North Dakota are white, and 8 percent are American Indian. No other racial/ethnic group comprises 2 percent of the student population. About 28 percent of students are eligible for the free and reduced-price lunch program, and 13 percent have Individual Education Programs (IEPs). 


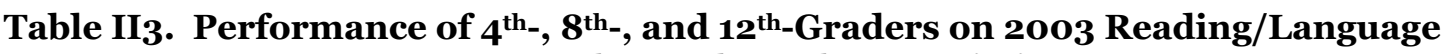
Arts NDSA, by Student Characteristics

\begin{tabular}{|c|c|c|c|}
\hline & $\begin{array}{l}\text { Partially } \\
\text { Proficient } \\
\text { and Above }\end{array}$ & $\begin{array}{l}\text { Proficient } \\
\text { and Above }\end{array}$ & Advanced \\
\hline & \multicolumn{3}{|c|}{ Percentage } \\
\hline \multicolumn{4}{|l|}{$4^{\text {th }}$ Grade } \\
\hline All students & 93 & 74 & 21 \\
\hline Students with IEPs & 74 & 38 & 4 \\
\hline Students without IEPs & 95 & 79 & 24 \\
\hline English-language-learner students & 75 & 39 & 3 \\
\hline $\begin{array}{l}\text { Non-English-language-learner } \\
\text { students }\end{array}$ & 93 & 75 & 22 \\
\hline $\begin{array}{l}\text { Economically disadvantaged } \\
\text { students }\end{array}$ & 88 & 64 & 13 \\
\hline $\begin{array}{l}\text { Non-economically disadvantaged } \\
\text { students }\end{array}$ & 95 & 79 & 26 \\
\hline Native American students & 81 & 50 & 5 \\
\hline White students & 94 & 77 & 23 \\
\hline \multicolumn{4}{|l|}{$8^{\text {th }}$ Grade } \\
\hline All students & 88 & 69 & 15 \\
\hline Students with IEPs & 57 & 22 & 1 \\
\hline Students without IEPs & 93 & 75 & 17 \\
\hline English-language-learner students & 40 & 22 & 2 \\
\hline $\begin{array}{l}\text { Non-English-language-learner } \\
\text { students }\end{array}$ & 89 & 69 & 16 \\
\hline $\begin{array}{l}\text { Economically disadvantaged } \\
\text { students }\end{array}$ & 80 & 55 & 8 \\
\hline $\begin{array}{l}\text { Non-economically disadvantaged } \\
\text { students }\end{array}$ & 92 & 75 & 19 \\
\hline Native American students & 68 & 34 & 3 \\
\hline White students & 90 & 72 & 17 \\
\hline \multicolumn{4}{|l|}{$1^{\text {th }}$ Grade } \\
\hline All students & 79 & 52 & 18 \\
\hline Students with IEPs & 30 & 9 & 1 \\
\hline Students without IEPs & 83 & 56 & 19 \\
\hline English-language-learner students & 24 & 7 & 2 \\
\hline $\begin{array}{l}\text { Non-English-language-learner } \\
\text { students }\end{array}$ & 80 & 53 & 18 \\
\hline $\begin{array}{l}\text { Economically disadvantaged } \\
\text { students }\end{array}$ & 66 & 36 & 9 \\
\hline $\begin{array}{l}\text { Non-economically disadvantaged } \\
\text { students }\end{array}$ & 82 & 56 & 20 \\
\hline Native American students & 54 & 24 & 6 \\
\hline White students & 81 & 54 & 19 \\
\hline
\end{tabular}

Source: http://www.dpi.state.nd.us/dpi/reports/profile/index.shtm 
Fourth-grade students performed at higher levels on the reading NDSA than did $8^{\text {th }}$-grade or $12^{\text {th }}$ grade students. For example, at the $4^{\text {th }}$ grade, 74 percent of students scored at or above the proficient level, compared with 69 percent of $8^{\text {th }}$-graders, and 52 percent of $12^{\text {th }}$-graders. While 38 percent of students with disabilities reached the proficient level in $4^{\text {th }}$ grade, only 22 percent did so in $8^{\text {th }}$ grade, and only 9 percent did so in $12^{\text {th }}$ grade. Results for English-language learners were similar.

At all grades and achievement levels, economically disadvantaged students performed below their peers. Across the three grades, the achievement gap ranged from 15 to 20 percentage points at the proficient level and 11-13 percentage points at the advanced level. An even larger achievement gap exists between white students and Native American students. Across the grades, white students scored 27-38 percentage points higher than did Native American students at the proficient level and 13-18 percentage points higher at the advanced level.

North Dakota also provides information regarding how all students progressed, broken down by the four reading standards (not shown in table). Interestingly, there was little or no difference within grade regarding how students performed on the standards. For instance, 74-75 percent of

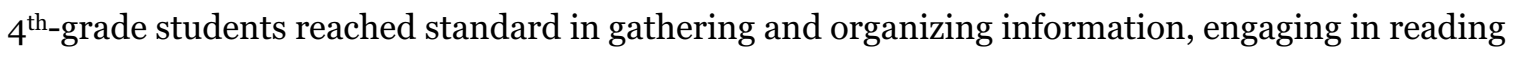
process, comprehending literature, and understanding and use of language principles.

\section{$\underline{\text { School Performance }}$}

School-level data are not available for North Dakota. 



\section{APPENDIX JJ. OHIO}

\section{State Assessment System}

As of the 2001-02 school year, Ohio's state assessment system consisted of the Ohio Proficiency Tests (OPT) exams in reading, writing, mathematics, science, and social studies, defined by the state's learning outcomes. The tests are given in $4^{\text {th }}, 6^{\text {th }}$, and $9^{\text {th }}$ grades. Students must pass all

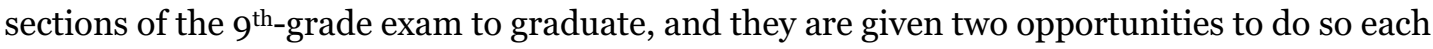
year from $8^{\text {th }}$ grade through $12^{\text {th }}$ grade (http://www.ode.state.oh.us/Accountability/default.asp). The learning outcomes in the OPT are based on the state's Model Competency-Based Programs, adopted in the early 1990s. However, in 2001 the state adopted academic content standards in reading, writing, and mathematics. Paragraph-length descriptions of each standard define what all students should know and be able to do. The ten standards in English language arts for grades $\mathrm{K}-12$ are related to:

- Phonemic awareness, word recognition, and fluency

- Acquisition of vocabulary

- Reading process, concepts of print, comprehension strategies, and self-monitoring strategies

- Reading applications, literary text

- Writing process

- Writing applications

- Writing conventions

- Research

- Communication, oral and visual.

For each standard, a set of benchmarks defines key checkpoints to help monitor students' progress at various grade clusters $(\mathrm{K}-3,4-7,8-10$, and 11-12 in reading; and $\mathrm{K}-2,3-4,5-7,8-$ 10, and 11-12 in writing). Finally, grade-level indicators describe what all students should know and be able to do at each grade level

(http://www.ode.state.oh.us/academic_content_standards/acsenglish.asp?\#Draft\%20of\%20the \%20Academic\%20Content\%20Standards).

The state is developing and phasing in new state assessments, which will be aligned with the new academic content standards. The Ohio Graduation Test is a criterion-referenced exam in reading, writing, mathematics, science, and social studies for students in grade 10. Beginning with the class of 2007, students must pass all sections of the test in order to graduate. Students in grades 3-8 will take the new Ohio Achievement Tests in reading and mathematics. Students in grades 4 
and 7 will also take the test in writing, and students in grades 5 and 8 will take the test in science and social studies. Subject areas not tested on the achievement test at a given grade level will be assessed using the state's diagnostic test to help teachers check on students' progress and adjust their instruction. Students in grades 1 and 2 will also take the diagnostic test in reading, writing, and mathematics.

\section{Test Format and Content}

To examine recent trends in adolescent literacy, in the rest of the discussion we will focus on the OPT in reading and writing for grades 4,6 , and 9 (additional information can be found through http://www.ode.state.oh.us/proficiency/default.asp).

The $4^{\text {th }}$ - and $6^{\text {th }}$-grade reading assessments consist of 41 and 35 items, respectively, including 2028 multiple-choice questions, five to nine short-answer questions, and two extended- response questions. Multiple-choice questions count for 1 point each, short-answer items are scored on a two-point scale, and extended-response items are scored on a four-point scale. The questions are divided evenly between those based on fiction and poetry selections and those based on a nonfiction selection. Approximately half the items on the $4^{\text {th }}$-grade exam assess students' ability to construct meaning (e.g., summarize the text), while the other half assess their ability to examine and extend meaning (e.g., infer from the text). The $6^{{ }^{\text {th }}}$-grade exam emphasizes extending meaning (e.g., critique or evaluate aspects of the text) approximately twice as much as constructing and examining meaning.

The $9^{\text {th }}$-grade reading assessment consists of 40 multiple-choice questions, of which 16 relate to fictional passages, 16 to nonfiction passages, and eight to everyday functional passages. The questions address both constructing and extending meaning.

The writing assessment for all three grade levels consists of two writing tasks that require students to respond to prompts in specified modes. Modes for $4^{\text {th }}$ - and $6^{\text {th }}$-grade students include summaries, fictional narratives, personal-experience narratives, informational pieces, or communications. Prompts on the $9^{\text {th }}$-grade test elicit expository, narrative, or descriptive writing. Student responses are scored using grade-specific four-point holistic rubrics that address the state's learning outcomes related to content, organization, language, and writing conventions.

\section{Achievement-Level Definitions}

Student scores on the $4^{\text {th- }}$ and $6^{\text {th-grade }}$ Ohio Proficiency Tests are reported using four achievement levels: advanced, proficient, basic, and below basic, while scores on the $9^{\text {th }}$-grade test are reported as proficient or not proficient. Students scoring at the proficient level or above are considered to have met academic requirements under NCLB. 


\section{Performance Results}

\section{Student Performance}

Ohio provides data on student performance for all students, for the two major racial/ethnic groups (white and African American), and for students with disabilities, although only the proficient level and above is reported. ${ }^{6}$ Table JJ1 shows results from the 2002 Ohio Proficiency Tests for students in grades 4,6 , and 9 .

Table JJ1. Performance of $4^{\text {th-, }} 6^{\text {th-}}$, and $9^{\text {th }}$-Graders on 2002 Reading and Writing Ohio Proficiency Test, by Student Characteristics

\begin{tabular}{lcc}
\hline & \multicolumn{1}{c}{ Reading } & Writing \\
\cline { 2 - 3 } & \multicolumn{2}{c}{$\begin{array}{c}\text { Percent Proficient and } \\
\text { Above }\end{array}$} \\
\hline $\mathbf{4}^{\text {th }}$ Grade & \multicolumn{2}{c}{} \\
All students & 68 & 81 \\
Students with disabilities & 48 & 64 \\
African American students & 38 & 63 \\
White students & 75 & 84 \\
6 $^{\text {th }}$ Grade & & \\
All students & 58 & 87 \\
Students with disabilities & 31 & 64 \\
African American students & 26 & 74 \\
White students & 65 & 90 \\
9 $^{\text {th }}$ Grade & & \\
All students & 92 & 90 \\
Students with disabilities & 70 & 66 \\
African American students & 79 & 78 \\
White students & 95 & 93 \\
\hline www.ode.state.oh.us/proficiency/default.asp & &
\end{tabular}

Source: http://www.ode.state.oh.us/proficiency/default.asp

Sixty-eight percent of $4^{\text {th }}$-graders and 58 percent of $6^{\text {th }}$-graders scored at the proficient level and above in reading, but over 81 percent of them did so in writing. There were large differences in the proficiency rates of white and African American students, particularly in reading. For

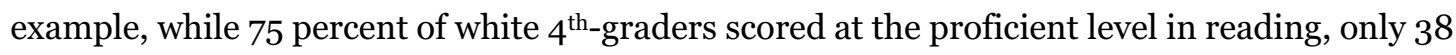
percent of African American students did so. There was a 39-percentage-point difference at the

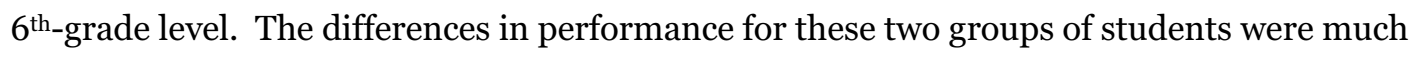

${ }^{56}$ About 80 percent of students in Ohio are white; 17 percent are African American; and 2 percent are Hispanic. About 27 percent are eligible for the free and reduced-price lunch program; 1 percent are in limited-English-proficiency programs; and 12 percent have Individual Education Programs (IEPs). 
smaller in writing-21 percentage points in the $4^{\text {th }}$ grade and 16 percentage points in the $6^{\text {th }}$ grade. About 48 percent of $4^{\text {th }}$-grade students with disabilities were judged proficient in reading; the number was much smaller in the $6^{\text {th }}$ grade, 31 percent. About 64 percent of these students passed the writing test in both grades.

At the $9^{\text {th }}$-grade level, between 90 and 92 percent of students passed in both reading and writing. The difference in the passing rates of African American and white students was smaller than in lower grades, particularly in reading-16 percentage points compared with 37-39 percentage points in the lower grades. Seventy percent of students with disabilities passed the reading test at the $9^{\text {th }}$-grade level, and 66 percent did so in writing.

\section{$\underline{\text { School Performance }}$}

School-level data disaggregated by urbanicity are available for the 2002 Ohio Proficiency Test administration for grades 4, 6, and 9 (Table JJ2). Approximately 53 percent of schools in Ohio were suburban, 25 percent rural, and 22 percent urban. A much larger proportion of urban schools were high-poverty schools, compared with rural and suburban schools (66 percent, 14 percent, and 10 percent, respectively). Given these demographics, it is not surprising that urban schools performed far below suburban and rural schools in reading and writing across all three grade levels, particularly for $4^{\text {th }}$ and $6^{\text {th }}$-grade reading, at which the achievement gap ranges between 24 and 28 percentage points.

Table JJ2. Average School Performance for $4^{\text {th- }}, 6^{\text {th }}$, and $9^{\text {th }}$-Grade 2002 Reading and Writing Ohio Proficiency Test, by Urbanicity

\begin{tabular}{lcc}
\hline & \multicolumn{1}{c}{ Reading } & Writing \\
\cline { 2 - 3 } & \multicolumn{2}{c}{$\begin{array}{c}\text { Average Proficient and Above } \\
\text { Percentage }\end{array}$} \\
\hline $\mathbf{4}^{\text {th }}$ Grade & 72 & 83 \\
Rural schools & 74 & 84 \\
Suburban schools & 48 & 69 \\
Urban schools & & \\
$\mathbf{6}^{\text {th }}$ Grade & 62 & 90 \\
Rural schools & 65 & 90 \\
Suburban schools & 37 & 79 \\
Urban schools & & \\
$\mathbf{9}^{\text {th }}$ Grade & 95 & 93 \\
Rural schools & 95 & 93 \\
Suburban schools & 82 & 82 \\
Urban schools & & \\
\hline
\end{tabular}




\section{APPENDIX KK. OKLAHOMA}

\section{State Assessment System}

As of 2002-03, the Oklahoma School Testing Program consisted of two sets of student assessments:

- The Oklahoma Core Curriculum Tests (OCCT) are criterion-referenced exams designed to measure the state content standards in mathematics, reading, writing, science, and social studies for students in grades 5 and 8 . Students are required to pass the $8^{\text {th-grade reading }}$ assessment in order to be issued a driver's license or instructional permit before the age of 18 .

- The Oklahoma End of Instruction Tests are criterion-referenced exams designed to measure state content standards for several high school courses, including Algebra, Biology, English II, and U.S. History. All students who take these courses are required to take the tests in order to graduate, and scores are reported on students' transcripts.

The state is developing and phasing in new criterion-referenced state assessments in reading and writing for all grades from 3 through 8 to meet testing requirements under NCLB. Tests will be introduced for grades 3 and 4 in 2004-05, and for grades 6 and 7 in 2005-06 (for additional information on state accountability and assessment, see http://www.sde.state.ok.us/NCLB/). Oklahoma's Priority Academic Student Skills (PASS) contain the state content standards in language arts; mathematics; science; social studies; the arts; languages; health, safety, and physical education; information literacy; instructional technology; and technical education. The language arts PASS addresses reading and literature; writing, grammar, usage, and mechanics; oral language, listening, and speaking; and visual literacy. The standards define broad goals for all students in these areas and are shown in Table KK1.

Each standard is further defined by a set of performance objectives for each grade level from $\mathrm{K}$ through 12. For example, at the $8^{\text {th }}$-grade level, the reading comprehension standard includes performance objectives related to literal understanding, inferences and interpreting, summary and generalization, analysis and evaluation, and monitoring and correction strategies. The PASS document designates with an asterisk those standards and objectives that should be assessed by the local school district; all other standards and objectives will be assessed by the state assessment program. 
Table KK1. Oklahoma Priority Academic Student Skills, Language Arts

\begin{tabular}{|c|c|}
\hline Strand & Standards \\
\hline \multirow[t]{8}{*}{ Reading and literature } & $\begin{array}{l}\text { Print awareness-The student will develop and demonstrate knowledge of print } \\
\text { awareness. }\end{array}$ \\
\hline & $\begin{array}{l}\text { Phonological and phonemic awareness-The student will develop and demonstrate } \\
\text { knowledge of phonological/phonemic awareness. }\end{array}$ \\
\hline & $\begin{array}{l}\text { Phonics decoding-The student will apply sound-symbol relationships to decode } \\
\text { unknown words. }\end{array}$ \\
\hline & $\begin{array}{l}\text { Vocabulary-The student will develop and expand knowledge of words and word } \\
\text { meanings to increase vocabulary. }\end{array}$ \\
\hline & $\begin{array}{l}\text { Fluency-The student will identify words rapidly so that attention is directed at the } \\
\text { meaning of the text. }\end{array}$ \\
\hline & $\begin{array}{l}\text { Comprehension and critical literacy-The student will interact with the words and } \\
\text { concepts in a text to construct an appropriate meaning. }\end{array}$ \\
\hline & $\begin{array}{l}\text { Literature-The student will read to construct meaning and respond to a wide } \\
\text { variety of literary forms. }\end{array}$ \\
\hline & $\begin{array}{l}\text { Research and information-The student will conduct research and organize } \\
\text { information. }\end{array}$ \\
\hline \multirow{3}{*}{$\begin{array}{l}\text { Writing, grammar, } \\
\text { usage, and mechanics }\end{array}$} & Writing process-The student will use the writing process to write coherently. \\
\hline & $\begin{array}{l}\text { Modes and forms of writing-The student will communicate through a variety of } \\
\text { written forms and for various purposes and to a specific audience or person. }\end{array}$ \\
\hline & $\begin{array}{l}\text { Grammar, usage, and mechanics-The student will demonstrate appropriate } \\
\text { practices in writing by applying Standard English conventions to the revising and } \\
\text { editing stages of writing. }\end{array}$ \\
\hline \multirow{3}{*}{$\begin{array}{l}\text { Oral language, } \\
\text { listening, and } \\
\text { speaking }\end{array}$} & Listening-The student will listen for information and for pleasure. \\
\hline & $\begin{array}{l}\text { Speaking-The student will express ideas and opinions in a group or individual } \\
\text { situation. }\end{array}$ \\
\hline & $\begin{array}{l}\text { Group interactions-The student will use effective communication strategies in } \\
\text { pair and small-group contexts. }\end{array}$ \\
\hline \multirow[t]{2}{*}{ Visual literacy } & $\begin{array}{l}\text { Interpret meaning-The student will interpret and evaluate various ways visual } \\
\text { image-makers, including graphic artists, illustrators, and news photographers, } \\
\text { represent meaning. }\end{array}$ \\
\hline & $\begin{array}{l}\text { Evaluate media-The student will evaluate visual and electronic media such as film } \\
\text { as compared with print messages. }\end{array}$ \\
\hline
\end{tabular}

Source: http://sde.state.ok.us/acrob/pass/languagearts.pdf

\section{Test Format and Content}

We now turn to a discussion of the OCCT reading assessments in grades 5 and 8 and the English II assessment (for additional information, see

http://title3.sde.state.ok.us/studentassessment).

The OCCT reading assessment for grades 5 and 8 consists of 55 multiple-choice questions, five of which are field-test items that do not count toward students' scores. The reading and literature section of the English II End-of-Instruction Test consists of approximately 60 multiple-choice 
items, ten of which are field-test items. The items are distributed among different depth-ofknowledge levels, with 20-25 percent assessing recall and reproduction, 60-65 percent testing skills and concepts, and 10-15 percent assessing strategic and extended thinking. Table KK2 shows the percentage of items for each standard and achievement level for both tests.

Passages on the OCCT exam are divided evenly between authentic literary selections and expository selections; the end-of-instruction test contains primarily authentic literature selections. One passage on the OCCT is task-oriented, and there is at least one set of paired passages on both exams to allow comparisons and connections. The reading/literature tests are given in one session lasting approximately 90-95 minutes.

Table KK2. Percentage of Items by Standard, Reading and Literature OCCT and End-of-Instruction Exams

\begin{tabular}{|c|c|c|c|}
\hline & $\begin{array}{c}5^{\text {th-Grade }} \\
\text { OCCT }\end{array}$ & $\begin{array}{c}8^{\text {th }} \text {-Grade } \\
\text { OCCT }\end{array}$ & $\begin{array}{c}\text { English II } \\
\text { EOI }\end{array}$ \\
\hline Vocabulary & 24 & 12 & 13 \\
\hline Words in context & 8 & & \\
\hline Affixes, roots, and stems & 8 & & \\
\hline $\begin{array}{l}\text { Synonyms, antonyms, and } \\
\text { homonyms }\end{array}$ & 8 & & \\
\hline $\begin{array}{l}\text { Comprehension and critical } \\
\text { literacy }\end{array}$ & 42 & 42 & 33 \\
\hline Literal understanding & 8 & 8 & 8 \\
\hline Inferences and interpretation & $10-14$ & $8-12$ & 8 \\
\hline Summary and generalization & $12-16$ & $10-14$ & 8 \\
\hline Analysis and evaluation & $12-16$ & $12-16$ & 8 \\
\hline Literature & 22 & 30 & 42 \\
\hline Literary genres & & 8 & 8 \\
\hline Literary elements & $12-16$ & $12-10$ & 13 \\
\hline $\begin{array}{l}\text { Figurative language and sound } \\
\text { devices }\end{array}$ & $10-14$ & $10-14$ & 10 \\
\hline Literary works & & & 10 \\
\hline Research and information & 12 & 16 & 13 \\
\hline Assessing information & 12 & 8 & \\
\hline Interpreting information & & 8 & \\
\hline
\end{tabular}

Source: http://title3.sde.state.ok.us/studentassessment/\#blueprints

For the $5^{\text {th- }}$ and $8^{\text {th }}$-grade OCCT writing test, students respond to specific topics, using any appropriate writing mode. Students' responses are scored using a set of six four-point analytic rubrics that judge them on word choice; organization, unity, and coherence; ideas and development; mechanics; grammar and usage; and sentences and paragraphs. These scores are 
combined into a weighted score that helps determine the composite score-ideas and development are 30 percent of the weighted score; organization, unity, and coherence are 25 percent; word choice is 15 percent; sentences and paragraphs are 15 percent; mechanics are 10 percent; and word choice is 5 percent. A linear transformation is applied to the weighted score to arrive at a final composite score on a scale of $1-6$, with 1 corresponding to unsatisfactory performance, 2 and 3 to limited knowledge, 4 to satisfactory performance, and 5 and 6 to advanced performance. The writing section of the English II end-of-instruction exam is administered and scored similarly to the OCCT writing test, except that students write two essays, and receive composite scores that combine both responses and range from 1-12.

\section{Achievement-Level Definitions}

Student scores on the OCCT and the End of Instruction test are reported using four achievement levels: advanced, satisfactory, limited knowledge, and unsatisfactory. Achievement levels are defined separately for each grade level and subject area. Table KK3 shows the achievement-level

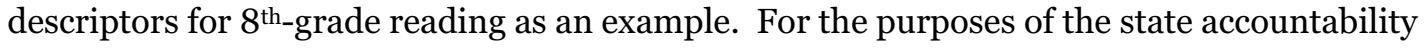
system under the NCLB, students scoring at the satisfactory or advanced levels are considered "proficient."

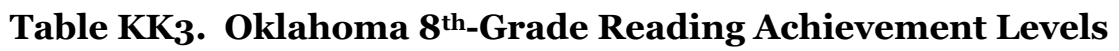

Advanced

Satisfactory

Limited Knowledge

Unsatisfactory
Students consistently demonstrate a thorough understanding of the knowledge and skills expected of all students at this grade level. These skills are broadly demonstrated in reading processes, response to text, and in acquisition of information through research. In addition to demonstrating a broad and in-depth understanding of the application of all skills at the satisfactory achievement level, students scoring at the advanced level typically: use a wide range of strategies to interpret and evaluate texts; regularly demonstrate a thorough and comprehensive understanding of literary forms; and consistently apply many different strategies for assessing, organizing, analyzing, synthesizing, and paraphrasing information.

Students demonstrate a general understanding of the reading knowledge and skills expected of students at this grade level. Students scoring at the satisfactory level typically read and comprehend grade-level reading material, using the following skills: determine literal and nonliteral word meanings using a variety of strategies; analyze informational text, poetry, short stories, novels, dramas; determine main idea and themes (stated or implied) and recognize relevance of details; interpret figurative language and elements of poetry; infer, predict, and generalize ideas; judge author's purpose or point of view, accuracy of text, fact and opinion; and use appropriate strategies to organize and summarize information.

Students demonstrate a partial understanding of the reading knowledge and skills expected of all students at this grade level. Students scoring at the limited knowledge level are inconsistent in demonstrating satisfactory level competencies and typically demonstrate reading skills within more explicit and concrete contexts.

Students do not demonstrate at least a limited knowledge level of the skills expected of all students at this grade level. Students scoring at the unsatisfactory level should be given comprehensive reading instruction. 
Source:

http://title3.sde.state.ok.us/studentassessment/perf\%2olevel\%2odescriptors/Grade\%208\%20Reading\%20

Performance.pdf

\section{Performance Results}

\section{Student Performance}

Oklahoma provided data on student performance for all students and by student poverty, language proficiency, disability, and race/ethnicity. ${ }^{57}$ Table KK4 shows results from the 2003

Oklahoma Core Curriculum Test for students in grades 5 and 8 , by a variety of student characteristics.

In $5^{\text {th }}$ grade, 64 percent of students passed the reading exam by scoring at or above the satisfactory level, as did 71 percent of $8^{\text {th }}$-grade students, and 5-6 percent of students scored at the advanced level. Student scores in writing were a bit higher: 77 percent of students scored at or above the satisfactory level, and 13-22 percent reached the advanced level.

Only 19-21 percent of students with disabilities reached the satisfactory level in reading, and 3637 percent did so in writing. About half of students with disabilities scored at the unsatisfactory level (the lowest proficiency level, not shown in table).

In reading, 38-42 percent of students with limited-English proficiency scored at or above the satisfactory level; however, 55-65 percent did so in writing. Approximately 30 percent of these students scored at the lowest level of proficiency (not shown).

Among general education students across both grades, the achievement gap between economically disadvantaged students and non-economically disadvantaged students was much larger in reading than in writing, 17-19 percentage points compared with 7-10 percentage points at the satisfactory level. White students performed better than African American, Hispanic, and American Indian students. In reading, these gaps were relatively large, particularly between white students and African American students (28 percentage points at the satisfactory level) and white students and Hispanic students (21-22 percentage points at the satisfactory level). The achievement gaps by race/ethnicity were far smaller in writing-between 2 and 9 percentage points at the satisfactory level.

57Approximately 64 percent of students in Oklahoma are white; 18 percent are American Indian; 11 percent are African American; and 7 percent are Hispanic. Almost half (49 percent) of students are eligible for the free and reduced-price lunch program; 6 percent are in limited-English-proficiency programs; and 14 percent have Individual Education Programs (IEPs). 
Table KK4. Performance of $5^{\text {th }}$-and $8^{\text {th }}$-Graders on 2003 Reading and Writing Oklahoma Core Curriculum Test, by Student Characteristics

\begin{tabular}{|c|c|c|c|c|}
\hline & \multicolumn{2}{|c|}{ Reading } & \multicolumn{2}{|c|}{ Writing } \\
\hline & $\begin{array}{l}\text { Satisfactory } \\
\text { and Above }\end{array}$ & Advanced & $\begin{array}{l}\text { Satisfactory } \\
\text { and Above }\end{array}$ & Advanced \\
\hline & \multicolumn{4}{|c|}{ Percentage } \\
\hline \multicolumn{5}{|l|}{$5^{\text {th }}$ Grade } \\
\hline All students & 64 & 5 & 77 & 13 \\
\hline General education students & 74 & 6 & 84 & 15 \\
\hline Students with IEPs & 19 & 1 & 37 & 2 \\
\hline English-language learners & 38 & 1 & 65 & 7 \\
\hline Non-English-language learners & 65 & 5 & 77 & 13 \\
\hline $\begin{array}{l}\text { Economically disadvantaged } \\
\text { students1 }\end{array}$ & 64 & 3 & 79 & 11 \\
\hline $\begin{array}{l}\text { Non-economically disadvantaged } \\
\text { students }{ }^{1}\end{array}$ & 83 & 9 & 89 & 20 \\
\hline African American students ${ }^{1}$ & 52 & 2 & 79 & 12 \\
\hline American Indian students ${ }^{1}$ & 69 & 4 & 80 & 11 \\
\hline Hispanic students ${ }^{1}$ & 59 & 2 & 81 & 12 \\
\hline White students ${ }^{1}$ & 80 & 8 & 86 & 17 \\
\hline \multicolumn{5}{|l|}{ 8th Grade } \\
\hline All students & 71 & 6 & 77 & 22 \\
\hline General education students & 79 & 6 & 85 & 26 \\
\hline Students with IEPs & 21 & o & 36 & 4 \\
\hline English-language learners & 42 & 3 & 55 & 11 \\
\hline Non-English-language learners & 72 & 6 & 79 & 23 \\
\hline $\begin{array}{l}\text { Economically disadvantaged } \\
\text { students1 }\end{array}$ & 68 & 3 & 81 & 19 \\
\hline $\begin{array}{l}\text { Non-economically disadvantaged } \\
\text { students }^{1}\end{array}$ & 85 & 8 & 88 & 30 \\
\hline African American students ${ }^{1}$ & 57 & 2 & 78 & 17 \\
\hline American Indian students ${ }^{1}$ & 75 & 4 & 84 & 22 \\
\hline Hispanic students ${ }^{1}$ & 63 & 3 & 78 & 19 \\
\hline White students ${ }^{1}$ & 85 & 8 & 86 & 28 \\
\hline
\end{tabular}

Note: ${ }^{1}$ Scores for these groups are for regular education students only.

Source: State Summary Reports from Oklahoma Department of Education

Table KK 5 presents results for the English II End-of-Instruction exam for the two sections of the exam-reading and literature, and writing. Over half of students reached the satisfactory level on the reading and literature section, and 28 percent reached the advanced level of the End-ofInstruction exam; 68 percent and 49 percent, respectively, did so on the writing section. Few students with disabilities or English-language learners reached the satisfactory level in reading (11 
percent and 20 percent, respectively) or writing (23 percent and 37 percent, respectively).

Because the End-of-Instruction examination tests English literature content as well as general reading and writing proficiency, it is unclear what proportion of these scores can be attributed to lack of content skills and what proportion can be attributed to lack of literacy skills.

\section{Table KK5. Performance of High School Students on 2003 English II End-of- Instruction Exam, by Student Characteristics}

\begin{tabular}{|c|c|c|c|c|}
\hline & \multicolumn{2}{|c|}{ Reading and Literature } & \multicolumn{2}{|c|}{ Writing } \\
\hline & $\begin{array}{l}\text { Satisfactory } \\
\text { and Above }\end{array}$ & Advanced & $\begin{array}{l}\text { Satisfactory } \\
\text { and Above }\end{array}$ & Advanced \\
\hline & \multicolumn{4}{|c|}{ Percentage } \\
\hline All students & 56 & 28 & 68 & 49 \\
\hline General education students & 62 & 31 & 74 & 54 \\
\hline Students with IEPs & 11 & 3 & 23 & 10 \\
\hline English-language learners & 20 & 7 & 37 & 18 \\
\hline Non-English-language learners & 57 & 28 & 68 & 49 \\
\hline Economically disadvantaged students & 41 & 16 & 58 & 37 \\
\hline $\begin{array}{l}\text { Non-economically disadvantaged } \\
\text { students }\end{array}$ & 63 & 33 & 73 & 54 \\
\hline African American students & 32 & 11 & 52 & 32 \\
\hline American Indian students & 48 & 21 & 62 & 41 \\
\hline Hispanic students & 37 & 14 & 58 & 36 \\
\hline White students & 63 & 33 & 73 & 54 \\
\hline
\end{tabular}

Source: State Summary Reports from Oklahoma Department of Education

As with the $5^{\text {th- }}$ and $8^{\text {th-grade }}$ assessments, we find that achievement gaps exist among students by economic status and race/ethnicity.

Oklahoma also provided data on student performance, broken down by skills. On the writing section, students generally tend to score less well on mechanics and sentences and paragraphs, and do better on ideas and development and word choice (not shown in table).

$\underline{\text { School Performance }}$

School-level data are not available for Oklahoma. 



\section{APPENDIX LL. OREGON}

\section{State Assessment System}

The Oregon Statewide Assessment System consists of three assessment tools: state knowledge and skills tests, which are criterion-referenced exams designed to measure state content standards in mathematics, reading and literature, science, and social studies; state performance tests, which are criterion-referenced exams linked to state performance standards in mathematics and writing; and work samples in writing, speaking, and mathematics. Students take the knowledge and skills tests in reading and literature and in mathematics at three benchmark grades $-3,5$, and 8 -and in grade 10 to receive a Certificate of Instructional Mastery (CIM). Students in grades 5,8 , and 10 also take the writing and mathematics state performance tests and the science and social studies knowledge and skills tests. Tenth-grade students who pass all portions of the CIM-level exams may receive the Certificate of Advanced Mastery (additional information on assessment and accountability can be found through http://www.ode.state.or.us/nclb/).

Oregon's state content standards were adopted in 1996 and revised in 1998. The English standards cover four broad strands: reading, literature, writing, and communication. Standards within each strand define what all students should know and be able to do, and are linked to the state's Common Curriculum Goals. Each standard is accompanied by progressive expectations for each of the three benchmarks and CIM. Table LL1 shows the reading content standards and the Benchmark 3 (grade 8) expectations, as an example. 
Table LL1. Oregon State English Content Standards, Reading Strand

\begin{tabular}{|c|c|}
\hline $\begin{array}{l}\text { Content } \\
\text { Standard }\end{array}$ & Benchmark 3 (8 (th $\left.^{\text {trade }}\right)$ \\
\hline \multirow{2}{*}{$\begin{array}{l}\text { Recognize, } \\
\text { pronounce, and } \\
\text { know the } \\
\text { meaning of words } \\
\text { in text by using } \\
\text { phonics, language } \\
\text { structure, } \\
\text { contextual clues, } \\
\text { and visual clues }\end{array}$} & $\begin{array}{l}\text { Determine meanings of words using contextual and structural clues and other reading } \\
\text { strategies }\end{array}$ \\
\hline & $\begin{array}{l}\text { Students will: } \\
\text { - use context clues to choose the correct meaning for words or phrases } \\
\text { - use prefixes and suffixes to help define words in context } \\
\text { - use grammatical elements--e.g., conjunctions, referent pronouns, prepositional } \\
\text { phrases, dependent clauses, modifying words such as adjectives and adverbs that } \\
\text { may be more commonly recognized in the noun or verb form--to determine the } \\
\text { meaning of words used in the passage } \\
\text { - recognize how figurative language--e.g., colloquial expressions, idioms, metaphors- } \\
\text {-expresses implied meanings } \\
\text { - use punctuations and print conventions that signal specific meanings or significant } \\
\text { situations--e.g., question and exclamation marks or punctuation such as } \\
\text { parentheses, underlining, and/or italicized print that indicate titles or emphases } \\
\text { - use knowledge of contractions and possessives to help determine the meaning of } \\
\text { words in the passage. }\end{array}$ \\
\hline \multirow{4}{*}{$\begin{array}{l}\text { Locate } \\
\text { information and } \\
\text { clarify meaning } \\
\text { by skimming, } \\
\text { scanning, close } \\
\text { reading, and } \\
\text { other reading } \\
\text { strategies }\end{array}$} & $\begin{array}{l}\text { Locate information and clarify meaning by using tables of contents, glossaries, indexes, } \\
\text { headings, graphs, charts, diagrams, and/or tables }\end{array}$ \\
\hline & $\begin{array}{l}\text { Students will: } \\
\text { - use tables of contents and indexes to locate specific information } \\
\text { - use information in illustrations, graphs, charts, diagrams, and tables to help } \\
\text { understand a reading passage }\end{array}$ \\
\hline & - use a glossary to locate words and/or help clarify meaning \\
\hline & - use headings to locate where needed information is likely to be found. \\
\hline \multirow{7}{*}{$\begin{array}{l}\text { Demonstrate } \\
\text { literal } \\
\text { understanding of } \\
\text { a variety of } \\
\text { printed materials }\end{array}$} & $\begin{array}{l}\text { Identify sequence of events, main ideas, facts, supporting details, and opinions in } \\
\text { literary, informative, and practical selections. }\end{array}$ \\
\hline & Students will identify or summarize: \\
\hline & - the order of events or a specific event from a sequence of events \\
\hline & - a statement or sentence that best indicates the main ideas of the selection \\
\hline & $\begin{array}{l}\text { - directly stated facts--e.g., actions or events; directions for an experiment or } \\
\text { problem-solving exercise; information from charts and graphs; names of } \\
\text { characters, places, or things in the selection; special circumstances relevant to the } \\
\text { story }\end{array}$ \\
\hline & $\begin{array}{l}\text { - details such as key words, phrases, or sentences that explicitly state important } \\
\text { characteristics, circumstances, or similarities and differences in characters, times, } \\
\text { or places }\end{array}$ \\
\hline & - directly stated opinions, including those introduced by transitional phrases. \\
\hline
\end{tabular}


Table LL1. (cont.)

\section{Demonstrate inferential comprehension of a variety of printed materials}

Demonstrate evaluative comprehension of a variety of printed materials
Draw connections between reading selections and other texts, experiences, issues, and events
Examine relationships, images, patterns, or symbols to draw conclusions about their meanings in printed materials

Students will:

- examine implicit relationships, such as cause and effect, sequence-time relationships, comparisons, classifications, and generalizations

- predict probable future outcomes or actions

- infer an author's meaning by drawing conclusions based on facts, events, images, patterns, or symbols in the text

- infer the main idea of a selection when it is not explicitly stated

- identify unstated reasons for actions or beliefs based on explicitly stated information.

Analyze and evaluate whether a conclusion is validated by the evidence in a selection. Students will:

- draw conclusions about the author's motivation or purpose for writing a passage or story based on evidence in the selection

- draw a conclusion that is validated by the evidence in the selection

- determine whether the information used by the author to support a conclusion is accurate and/or credible

- differentiate between conclusions that are based on fact and those that are based on opinion

- draw parallels between the selections and issues and situations relevant to the text.

Extend and deepen comprehension by relating text to other texts, experiences, issues, and events

Source: http://www.ode.state.or.us/teachlearn/subjects/elarts/standards/contentstandards.pdf

Oregon adopted new content standards for English language arts in January 2003. These standards are also grouped into four content strands: reading, literature, writing, and speaking and listening. Within each strand, grade-level standards are listed under a set of domains common to all grade levels. In reading, for example, the domains are

- Decoding and word recognition

- Listen to and read informational and narrative text

- Vocabulary

- Read to perform a task

- Informational text: demonstrate general understanding

- Informational text: develop and interpret

- Informational text: examine content and structure.

Specific standards in each domain are defined by grades 4-10. In its standards documents, Oregon notes those standards that may be assessed on the state exams and how the new 
standards align with the old standards and the Common Curriculum Goals. Although the new standards have been in place since January 2003, students will not be assessed on them until the 2005-06 school year.

\section{Test Format and Content}

Oregon's state assessments are somewhat unique, because they consist of "level tests" as opposed to single grade-level exams. At each benchmark grade, the state administers three different level tests that overlap in difficulty but are tailored to the achievement level of the student. The academic content on all three tests is similar, and each test allows students the opportunity to meet the standards for the benchmark. Level A has the least-difficult questions, Level $\mathrm{C}$ has the most-difficult questions, and Level B falls between the two. Classroom teachers determine which level test to give each student, based on classroom work, the student's history, and a short pretest. The level tests are intended to both refine the precision of the statewide assessment and to extend the range of achievement that can be measured.

The reading and literature Knowledge and Skills Test consists of 60-70 multiple-choice questions. For grades $5-10$, approximately 16 percent of the items are related to each of word meaning, literal comprehension, inferential comprehension, evaluative comprehension, and literary elements and devices. Eleven percent relates to finding information, and 9 percent to literary forms. Reading selections on the tests include passages serving different purposes, including reading for literary experience, reading to gain information, and reading to perform a task. Each selection will have three to ten related questions. The scoring procedure takes into account the difficulty of the questions on each level test, and produces a scale score for each student (http://www.ode.state.or.us/asmt/).

\section{Achievement-Level Definitions}

Student scores from the Oregon Statewide Assessment System are reported in three categories: Does Not Meet Standard, Meets Standard, and Exceeds Standard. Students scoring at the Meets Standard level or higher are considered to have met academic requirements under the NCLB. The state has defined performance standards that specify the minimum scores on the state assessments to meet or exceed the standards in each subject area for each grade level. Since reading/language arts scores are reported on a continuous scale for all four grades, the cut-scores overlap somewhat; the standard for exceeding the standard at each benchmark level is the same as the standard for meeting the standard at the next higher benchmark. Table LL2 shows the reading and literature performance standards for the four grade levels. 
Table LL2. Oregon State Reading and Literature Performance Standards

\begin{tabular}{|c|c|c|c|c|}
\hline & $\begin{array}{c}\text { Benchmark } \\
1 \\
\left(3^{\text {rd }} \text { Grade) }\right.\end{array}$ & $\begin{array}{c}\text { Benchmark } \\
2 \\
\left(5^{\text {th }} \text { Grade) }\right.\end{array}$ & $\begin{array}{c}\text { Benchmark } \\
3 \\
\left(8^{\text {th }} \text { Grade) }\right.\end{array}$ & $\begin{array}{c}\text { CIM } \\
\text { (10 } \\
\text { Grade) }\end{array}$ \\
\hline Meets the Standard & 201 & 215 & 231 & 239 \\
\hline Exceeds the Standard & 215 & 231 & 239 & 249 \\
\hline
\end{tabular}

Source: http://www.ode.state.or.us/asmt/results/2002/reports/readmath2002.pdf

\section{Performance Results}

\section{Student Performance}

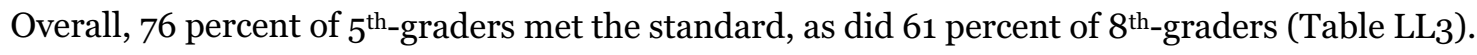
About one-fourth of $5^{\text {th }}$-graders exceeded the standard, as did 29 percent of $8^{\text {th }}$-graders. The percentage of students reaching both these achievement levels was lower in $10^{\text {th }}$ grade, in which only 52 percent of students met the standard and only 17 percent exceeded it. Data disaggregated by student characteristics were not available. $5^{8}$

Table LL3. Performance of $5^{\text {th- }}, 8^{\text {th-}}$, and $10^{\text {th }}$-Graders on 2003 Oregon Reading and Literature Knowledge and Skills Test Performance

\begin{tabular}{lcc}
\hline & $\begin{array}{c}\text { Meets } \\
\text { Standard } \\
\text { or Above }\end{array}$ & $\begin{array}{c}\text { Exceeds } \\
\text { Standard }\end{array}$ \\
\cline { 2 - 3 } & \multicolumn{2}{c}{ Percentage } \\
\hline All $5^{\text {th }}$-grade students & 76 & 25 \\
All $8^{\text {th }}$-grade students & 61 & 29 \\
All $10^{\text {th-grade students }}$ & 52 & 17 \\
\hline
\end{tabular}

Source: http://www.ode.state.or.us/asmt/results/2003/downloads/distscores2002\%202003.xls

School Data

School-level performance data for the 2002 administration of the reading/language arts Knowledge and Skills Test for reading and writing were available by school poverty level and by urbanicity (Table LL4). Overall, 31 percent of schools in Oregon were high-poverty schools; 43 percent were suburban; 36 percent were rural; and 21 percent were urban. Urban and rural schools were more likely than suburban schools to be high-poverty schools - 41 percent and 39 percent, respectively, versus 20 percent.

${ }^{8}$ Approximately 79 percent of students in Oregon are white; 12 percent are Hispanic; 4 percent are Asian/Pacific Islander; 3 percent are African American; and 2 percent are American Indian/Alaskan Native. About 36 percent of students are eligible for the free and reduced-price lunch program; 8 percent are in limited-English-proficiency programs; and 13 percent have Individual Education Programs (IEPs). 
At all grade and achievement levels, low- and medium-poverty schools outperformed highpoverty schools. For instance, in $5^{\text {th }}$ and $8^{\text {th }}$ grades, on average, high-poverty schools scored 11-12 percentage points lower than low- and medium-poverty schools at or above the meets standards level and 13 percentage points lower at the exceeds standards level.

Suburban schools did outperform rural and urban schools at all grade and achievement levels (typically by small margins), with two exceptions: At the $8^{\text {th }}$ grade, the average percentage exceeding standards was 3 percentage points higher in urban schools than in suburban schools, and at the $10^{\text {th }}$ grade, the average performance of suburban and urban schools at the exceeds standards level was the same.

Table LL4. Average School Performance on $5^{\text {th }}$, $8^{\text {th }}$, and $10^{\text {th }}$-Grade 2002 Oregon Reading and Literature Knowledge and Skills Test Performance, by Poverty Level and Urbanicity

\begin{tabular}{lcc}
\hline & $\begin{array}{c}\text { Meets } \\
\text { Standard or } \\
\text { Above }\end{array}$ & $\begin{array}{c}\text { Exceeds } \\
\text { Standard }\end{array}$ \\
\cline { 2 - 3 } & Average Percentage \\
\hline $5^{\text {th }}$ Grade & 83 & 30 \\
Low- and medium-poverty schools & 72 & 17 \\
High-poverty schools & 78 & 21 \\
Rural schools & 81 & 27 \\
Suburban schools & 77 & 28 \\
Urban schools & & \\
$\mathbf{8}^{\text {th }}$ Grade & 66 & 35 \\
Low- and medium-poverty schools & 53 & 22 \\
High-poverty schools & 60 & 27 \\
Rural schools & 64 & 33 \\
Suburban schools & 62 & 36 \\
Urban schools & & \\
10 & & \\
Low- and medium-poverty schools & 53 & 16 \\
High-poverty schools & 34 & 8 \\
Rural schools & 50 & 14 \\
Suburban schools & 52 & 16 \\
Urban schools & 43 & 16 \\
\hline
\end{tabular}




\section{APPENDIX MM. PENNSYLVANIA}

\section{State Assessment System}

The Pennsylvania System of School Assessment (PSSA) consists of criterion-referenced exams designed to align with state content standards in reading, mathematics, and writing. Students in grades 5,8 , and 11 take the PSSA in reading and mathematics; students in grades 6, 9, and 11 take the PSSA in writing. Students in $\mathbf{1 1}^{\text {th }}$ grade who score well on the PSSA may receive special seals on their diplomas to signify that they have met levels of excellence on the state assessment. Pennsylvania is currently expanding its assessment system to meet the testing requirements under NCLB (http://www.pde.state.pa.us/pas/site/default.asp?g=o\&k12Nav=|1141|).

Pennsylvania's academic standards define what students should know and be able to do in reading, writing, speaking, listening, and mathematics in grades $3,5,8$, and 11 . The reading, writing, speaking, and listening standards are grouped into eight standards categories:

- Learning to read independently

- Reading critically in all content areas

- Reading, analyzing, and interpreting literature

- Types of writing

- Quality of writing

- Speaking and listening

- Characteristics and function of the English language

- Research

Within each category, specific standards define what students should know and be able to do at each grade level $(3,5,8$, and 11). For most standards, grade-specific content descriptors define specific expectations related to the broader standard. Table MM1 shows the standards for $8^{\text {th }}$ grade under the categories related to reading, as an example (http://www.pde.state.pa.us/k12/lib/k12/Reading.pdf). 


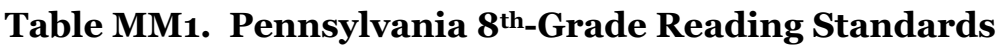

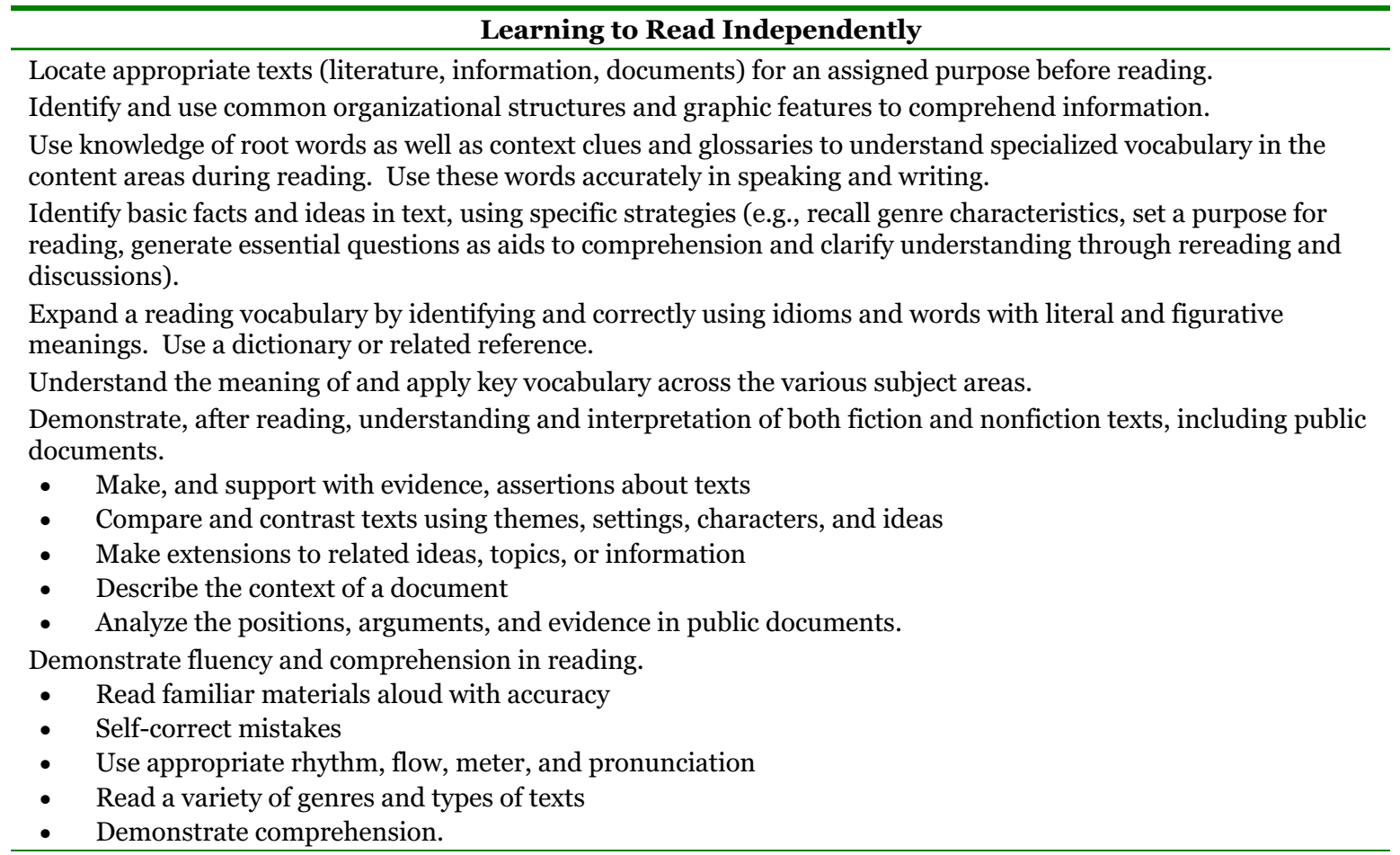

Reading Critically in All Content Areas

Read and understand essential content of informational texts and documents in all academic areas.

- Differentiate fact from opinions, utilizing resources that go beyond traditional text (e.g., newspapers, magazines, and periodicals) to electronic media

- Distinguish between essential and nonessential information across texts and going beyond texts to a variety of media; identify bias and propaganda where present

- Draw inferences based on a variety of sources

- Evaluate text organization and content to determine the author's purpose and effectiveness according to the author's theses, accuracy, and thoroughness.

Use and understand a variety of media and evaluate the quality of material produced.

- $\quad$ Compare and analyze how different media offer a unique perspective on the information presented

- Analyze the techniques of particular media messages and their effect on a target audience

- Use, design, and develop a media project that expands understanding (e.g., authors and works from a particular historical period.

Produce work in at least one literary genre that follows the conventions of the genre.

\section{Reading, Analyzing, and Interpreting Literature}

Read and understand works of literature.

Analyze the use of literary elements by an author, including characterization, setting, plot, theme, point of view, tone, and style.

Analyze the effects of various literary devices:

- $\quad$ Sound techniques (e.g., rhyme, rhythm, meter, alliteration)

- $\quad$ Figurative language (e.g., personification, simile, metaphor, hyperbole, allusion.

Identify poetic forms (e.g., ballad, sonnet, couplet).

Analyze drama to determine the reasons for a character's actions, taking into account the situation and basic motivations of the character.

Read and respond to nonfiction and fiction, including poetry and drama. 
Table MM1. (cont.)

\section{Characteristics and Functions of the English Language}

Describe the origins and meanings of common, learned, and foreign words used frequently in English language (e.g., carte blanche, faux pas).

Analyze the role and place of standard American English in speech, writing, and literature.

Identify new words that have been added to the English language over time.

Select and refine a topic for research.

Source: http://www.pde.state.pa.us/k12/lib/k12/Reading.pdf

\section{Test Format and Content}

To examine trends in adolescent literacy, the rest of the discussion will focus on the PSSA reading exams for grades 5,8 , and 11, and the writing assessment for grades 6, 9, and 11 (for additional information on assessment format and content, see http://www.pde.state.pa.us/a_and_t/site/default.asp?g=o\&a_and_tNav=|630 $|\& k 12 N a v=| 1141)$. The reading portion of the PSSA includes both multiple-choice and open-response items, called performance tasks. The six reading passages are divided evenly between informational or nonfiction texts and narrative or fiction passages. Multiple-choice questions for all the passages assess the same five standard categories: reading independently; reading critically in all content areas; reading, analyzing, and interpreting literature; identifying characteristics and function of the English language; and performing research. The $11^{\text {th }}$-grade test contains an equal percentage of items for each standard, while the $5^{\text {th- }}$ and $8^{\text {th }}$-grade tests place slightly less emphasis on characteristics and functions of the English language and research.

Three of the reading passages have associated performance tasks, which are scored using a fourpoint rubric that considers students' understanding, comprehension level, and ability to make connections to the text. The tests use both census testing, in which all students answer the same questions, and matrix sampling, in which a large set of test items is divided into several different test forms. Students in $5^{\text {th }}$ grade complete 54 census items and 27 matrix items. The $8^{\text {th }}$-grade test includes 74 census items and 37 matrix items, and the $11^{\text {th }}$-grade test includes 82 census items and 41 matrix items. The PSSA reading test is administered over three sessions and lasts a total of four hours.

The writing portion of the PSSA consists of a number of writing tasks that require students to respond to specific prompts. Prompts may ask students to write in an informational, narrative, or persuasive mode. Students in grades 6 and 9 respond to two prompts, while $11^{\text {th }}$-grade students respond to three prompts, one for each mode of writing. Students have one hour to complete 
each essay. Students' essays are judged in the domains of focus, content, organization, style, and conventions, using a set of four-point analytic rubrics. Students also fill out a questionnaire about writing-process strategies as part of the assessment. The questionnaire does not count toward individual student scores, but schools receive summary information about their students' responses. The state content standards for writing are for grades 5,8 , and 11 , but the assessment is administered in grades 6,9 , and 11 . Students in $6^{\text {th }}$ and $9^{\text {th }}$ grades take the PSSA writing assessment in the fall, while students in $11^{\text {th }}$ grade take the PSSA in the early spring.

\section{Achievement-Level Definitions}

Student scores on the PSSA are reported using four achievement levels: advanced, proficient, basic, and below basic. Pennsylvania has also published detailed grade- and subject-specific achievement-level descriptors that define what students should know and do at each level for each standard. Table MM2 shows the performance-level descriptors for the $8^{\text {th-grade }}$ standards related to reading independently, as an example. Students scoring at the proficient level or higher are considered to have met academic requirements under NCLB. 


\section{Table MM2. PSSA Achievement-Level Descriptors, $8^{\text {th }}$-Grade Reading, Reading Independently}

\begin{tabular}{|c|c|c|c|c|}
\hline Standard & Below Basic & Basic & Proficient & Advanced \\
\hline $\begin{array}{l}\text { Locate appropriate texts (literature, } \\
\text { information, documents) for an } \\
\text { assigned purpose before reading. }\end{array}$ & $\begin{array}{l}\text { Identify limited types of text for an } \\
\text { assigned purpose }\end{array}$ & $\begin{array}{l}\text { Find some different types of text for an } \\
\text { assigned purpose }\end{array}$ & $\begin{array}{l}\text { Locate appropriate text for an assigned } \\
\text { purpose }\end{array}$ & $\begin{array}{l}\text { Examine and evaluate texts for an } \\
\text { assigned purpose }\end{array}$ \\
\hline $\begin{array}{l}\text { Identify and use common } \\
\text { organizational structures and graphic } \\
\text { features to comprehend information. }\end{array}$ & Recognize limited text formats & $\begin{array}{l}\text { Identify some text formats and retell } \\
\text { information }\end{array}$ & $\begin{array}{l}\text { Identify and use common } \\
\text { organizational structures and graphic } \\
\text { features to comprehend information }\end{array}$ & $\begin{array}{l}\text { Combine text and graphic formats to } \\
\text { synthesize information }\end{array}$ \\
\hline $\begin{array}{l}\text { Use knowledge of root words as well as } \\
\text { context clues and glossaries to } \\
\text { understand specialized vocabulary in } \\
\text { the content areas during reading. Use } \\
\text { these words accurately in speaking and } \\
\text { writing. }\end{array}$ & $\begin{array}{l}\text { Use strategies, with assistance, to } \\
\text { understand content area vocabulary }\end{array}$ & $\begin{array}{l}\text { Use limited strategies to understand } \\
\text { specialized vocabulary in content areas }\end{array}$ & $\begin{array}{l}\text { Use knowledge of root words as well as } \\
\text { context clues and glossaries to read, } \\
\text { write, and understand specialized } \\
\text { vocabulary in the content areas }\end{array}$ & $\begin{array}{l}\text { Use multiple strategies to understand } \\
\text { vocabulary in the content areas }\end{array}$ \\
\hline $\begin{array}{l}\text { Identify basic facts and ideas in text } \\
\text { using specific strategies (e.g., recall } \\
\text { genre characteristics, set a purpose for } \\
\text { reading, generate essential questions } \\
\text { as aids to comprehension, and clarify } \\
\text { understanding through rereading an } \\
\text { discussion. }\end{array}$ & $\begin{array}{l}\text { Recall basic facts and ideas and } \\
\text { predict, with assistance }\end{array}$ & $\begin{array}{l}\text { Restate basic facts to make limited } \\
\text { predictions }\end{array}$ & $\begin{array}{l}\text { Identify the basic ideas and facts in } \\
\text { text and information from other } \\
\text { sources to make predictions about text }\end{array}$ & $\begin{array}{l}\text { Connect basic ideas and facts in text } \\
\text { with information from other sources to } \\
\text { make predictions about text }\end{array}$ \\
\hline $\begin{array}{l}\text { Expand a reading vocabulary by } \\
\text { identifying and correctly using idioms } \\
\text { and words with literal and figurative } \\
\text { meanings. Use a dictionary or related } \\
\text { reference. }\end{array}$ & $\begin{array}{l}\text { Recognize a reading vocabulary that } \\
\text { includes idioms and words with literal } \\
\text { meanings }\end{array}$ & $\begin{array}{l}\text { Develop a reading vocabulary that } \\
\text { includes idioms and words with literal } \\
\text { meaning; use a dictionary or related } \\
\text { reference }\end{array}$ & $\begin{array}{l}\text { Expand a reading vocabulary by } \\
\text { identifying and correctly using idioms } \\
\text { and words with literal and figurative } \\
\text { meanings; use a dictionary or related } \\
\text { resource }\end{array}$ & $\begin{array}{l}\text { Establish an extensive reading } \\
\text { vocabulary of literal and figurative } \\
\text { words, and understand their } \\
\text { relationship to other words }\end{array}$ \\
\hline $\begin{array}{l}\text { Understand the meaning of and apply } \\
\text { key vocabulary across the various } \\
\text { subject areas. }\end{array}$ & $\begin{array}{l}\text { Recognize a minimal number of key } \\
\text { vocabulary words from across subject } \\
\text { areas }\end{array}$ & $\begin{array}{l}\text { Identify and understand key } \\
\text { vocabulary in various subject areas }\end{array}$ & $\begin{array}{l}\text { Understand the meaning of and apply } \\
\text { key vocabulary across the various } \\
\text { subject areas }\end{array}$ & $\begin{array}{l}\text { Analyze and appropriately use a } \\
\text { variety of key vocabulary words across } \\
\text { subject areas }\end{array}$ \\
\hline $\begin{array}{l}\text { Demonstrate, after reading, } \\
\text { understanding and interpretation of } \\
\text { both fiction and nonfiction texts, } \\
\text { including public documents. }\end{array}$ & $\begin{array}{l}\text { Retell the major ideas of the text; } \\
\text { Compare ideas within a text; Restate } \\
\text { ideas through rereading and } \\
\text { discussion; Recognize that there are } \\
\text { different contexts in documents; } \\
\text { Recognize a position, argument, or } \\
\text { evidence in a public document }\end{array}$ & $\begin{array}{l}\text { Summarize the major ideas of a text; } \\
\text { Compare and contrast texts using } \\
\text { some literary elements; Clarify ideas } \\
\text { through rereading and discussion; } \\
\text { Identify, with assistance, the context of } \\
\text { a document; Identify and cite evidence } \\
\text { or position or arguments in public } \\
\text { documents }\end{array}$ & $\begin{array}{l}\text { Make assertions about text and } \\
\text { support with evidence; Compare and } \\
\text { contrast text using themes, characters, } \\
\text { settings, and ideas; Make extensions to } \\
\text { related ideas, topics, or information; } \\
\text { Describe the content of a document; } \\
\text { Analyze the positions, arguments, and } \\
\text { evidence in public documents }\end{array}$ & $\begin{array}{l}\text { Analyze assertions about text and } \\
\text { support with evidence; Evaluate } \\
\text { themes, setting, characters, and ideas } \\
\text { in text; Synthesize related ideas, } \\
\text { topics, or information to make } \\
\text { extensions; Compare and contrast the } \\
\text { context of several documents; Defend } \\
\text { the positions and arguments in public } \\
\text { documents, using evidence }\end{array}$ \\
\hline $\begin{array}{l}\text { Demonstrate fluency and } \\
\text { comprehension in reading. }\end{array}$ & $\begin{array}{l}\text { Read familiar materials aloud, with } \\
\text { minimal accuracy; Self-correct with } \\
\text { prompts; Use rhythm, flow, meter, and } \\
\text { pronunciation with prompting; Read } \\
\text { at least one genre; Demonstrate } \\
\text { minimal comprehension }\end{array}$ & $\begin{array}{l}\text { Read familiar materials aloud, with } \\
\text { marginal accuracy; Self-correct some } \\
\text { mistakes; Use rhythm, flow, meter, } \\
\text { and pronunciation; Read a limited } \\
\text { number of genres; Demonstrate } \\
\text { marginal comprehension }\end{array}$ & $\begin{array}{l}\text { Read familiar materials aloud, with } \\
\text { accuracy; Self-correct mistakes; Use } \\
\text { appropriate rhythm, flow, meter, and } \\
\text { pronunciation; Read a variety of } \\
\text { genres and types of text; Demonstrate } \\
\text { comprehension }\end{array}$ & $\begin{array}{l}\text { Read familiar materials with superior } \\
\text { accuracy; Self-correct independently; } \\
\text { Use exemplary rhythm, flow, meter, } \\
\text { and pronunciation; Read sophisticated } \\
\text { texts; Demonstrate superior } \\
\text { comprehension }\end{array}$ \\
\hline
\end{tabular}




\section{Performance Results}

\section{$\underline{\text { Student Performance }}$}

Pennsylvania provides data on student performance for all students and by race/ethnicity, disability status, and economic status.59 Table MM3 shows results from the 2002 PSSA reading exam for students in grades 5,8 , and 11 , by a variety of student characteristics.

About 57-59 percent of $5^{\text {th- }}, 8^{\text {th-}}$, and $11^{\text {th }}$-graders scored at or above the proficient level on the reading test, and between 16 and 20 percent were categorized as advanced. The lowest percentage of students scoring at the advanced level was in the $11^{\text {th }}$ grade.

There were marked differences in the performance of students with different racial/ethnic backgrounds. For example, while 66 percent of white $5^{\text {th }}$-graders scored at the proficient level, only 22 percent of African American students and 29 percent of Hispanic students did sodifferences of 44 and 37 percentage points, respectively. Very few of these students scored at the advanced level-3-6 percent-compared with 22 percent of white students and 24 percent of Asian students. There were equally large differences at the $8^{\text {th }}$ and $11^{\text {th }}$-grade levels at the proficient and advanced levels in the relative performance of different racial/ethnic groups. At the $11^{\text {th }}$ grade, the proportion of white students scoring at the advanced level was smaller than in the lower grades: 17 percent compared with 22-24 percent.

Students from low-income households tended to perform at a lower level than their counterparts. For example, in $5^{\text {th }}$ grade, only 32 percent of them passed the reading test compared with 67 percent of those who were not economically disadvantaged. The differences were similar across the higher grades (35-37 percentage points at the proficient level and 14-19 percentage points at the advanced level).

Not surprisingly, the percentage of students with disabilities scoring at the proficient level was much lower than that of students without disabilities, with differences between 48 and 52 percentage points. For example, 15 percent of $5^{\text {th }}$-grade students with disabilities passed the reading test compared with 63 percent of students without disabilities.

Table MM4 presents results from the 2002 PSSA writing performance for grades 6, 9, and 11. Data disaggregated by student groups were available for only the $11^{\text {th }}$ grade. Overall, $56-61$ percent of $6^{\text {th }}$ and $9^{\text {th }}$-graders passed the writing test by scoring at the proficient and higher level,

\footnotetext{
${ }^{59}$ Approximately 78 percent of students in Pennsylvania are white; 15 percent are African American; 5 percent are Hispanic; and 2 percent are Asian/Pacific Islander. About 28 percent of students are eligible for the free and reduced-price lunch program and 13 percent have IEPs.
} 
Table MM3. Performance of $5^{\text {th }}$, $8^{\text {th }}$, and $1^{\text {th }}$-Graders on 2002 Reading PSSA, by Student Characteristics

\begin{tabular}{|c|c|c|c|}
\hline & $\begin{array}{c}\text { Basic and } \\
\text { Above }\end{array}$ & $\begin{array}{l}\text { Proficient } \\
\text { and Above }\end{array}$ & Advanced \\
\hline & \multicolumn{3}{|c|}{ Percentage } \\
\hline \multicolumn{4}{|l|}{$5^{\text {th }}$ Grade } \\
\hline All students & 80 & 57 & 18 \\
\hline Students with IEPs & 37 & 15 & 4 \\
\hline Students without IEPs & 86 & 63 & 20 \\
\hline Economically disadvantaged students & 60 & 32 & 6 \\
\hline Non-economically disadvantaged students & 88 & 67 & 23 \\
\hline African American students & 51 & 22 & 3 \\
\hline Asian students & 83 & 60 & 24 \\
\hline Hispanic students & 57 & 29 & 6 \\
\hline White students & 87 & 66 & 22 \\
\hline \multicolumn{4}{|l|}{$8^{\text {th }}$ Grade } \\
\hline All students & 80 & 59 & 20 \\
\hline Students with IEPs & 32 & 13 & 2 \\
\hline Students without IEPs & 86 & 65 & 23 \\
\hline Economically disadvantaged students & 58 & 31 & 6 \\
\hline Non-economically disadvantaged students & 87 & 68 & 25 \\
\hline African American students & 52 & 24 & 4 \\
\hline Asian students & 83 & 63 & 29 \\
\hline Hispanic students & 56 & 30 & 6 \\
\hline White students & 86 & 67 & 24 \\
\hline \multicolumn{4}{|l|}{$1^{\text {th }}$ Grade } \\
\hline All students & 80 & 59 & 16 \\
\hline Students with IEPs & 31 & 14 & 2 \\
\hline Students without IEPs & 85 & 63 & 17 \\
\hline Economically disadvantaged students & 56 & 29 & 4 \\
\hline Non-economically disadvantaged students & 84 & 64 & 18 \\
\hline African American students & 53 & 26 & 3 \\
\hline Asian students & 80 & 61 & 22 \\
\hline Hispanic students & 55 & 29 & 4 \\
\hline White students & 85 & 64 & 17 \\
\hline
\end{tabular}

Source: http://www.pde.state.pa.us/pas/lib/pas/correctachievemento12604.pdf

a passing rate that was comparable to that on the reading test. The proportion of students in the $11^{\text {th }}$ grade who passed the writing test was higher than on the reading test -70 percent versus 59 percent. Fourteen percent of $11^{\text {th }}$-grade students scored at the advanced level on the writing test, 2 percentage points more than on the reading test. 
Table MM4. Performance of $6^{\text {th }}-, 9^{\text {th }}$, and $1^{\text {th }}$-Graders on 2002 Writing PSSA, by Student Characteristics

\begin{tabular}{lccc}
\hline & Basic and Above & $\begin{array}{c}\text { Proficient and } \\
\text { Above }\end{array}$ & Advanced \\
\cline { 2 - 4 } & & Percentage & \\
\hline $\mathbf{6}^{\text {th }}$ Grade & 87 & 56 & 11 \\
All students & & & \\
$\mathbf{9}^{\text {th }}$ Grade & 79 & 61 & 15 \\
All students & & & \\
$\mathbf{1 1}^{\text {th }}$ Grade & 86 & 70 & 14 \\
All students & 42 & 21 & 2 \\
Students with IEPs & 90 & 75 & 15 \\
Students without IEPs & 67 & 43 & 4 \\
Economically disadvantaged & & & 15 \\
$\quad$ students & 89 & 75 & 4 \\
Non-economically & & & \\
$\quad$ disadvantaged students & 69 & 44 & 23 \\
African American students & 87 & 74 & 13 \\
Asian students & 67 & 43 & 15 \\
Hispanic students & 83 & 65 & 75 \\
Multiracial students & 89 & & \\
White students & & & \\
\hline
\end{tabular}

Source: http://www.pde.state.pa.us/pas/lib/pas/correctachievemento12604.pdf;

http://www.pde.state.pa.us/a_and_t/lib/a_and_t/stateaverage6\&9writing2002.pdf

Note: Scores were not disaggregated by student groups for grades 6 and 9.

The remainder of the discussion focuses on the $11^{\text {th }}$-grade results. The differences in pass rates between white students and Hispanic and African American students were 31-32 percentage points at the proficient level and 10-11 percentage points at the advanced level (a little smaller than the 35-44 percentage points that we had seen on the reading test). There was a similar gap between the achievement levels of economically disadvantaged students and those who were not disadvantaged. Only 21 percent of students with disabilities passed the writing test compared with 75 percent of students without disabilities.

\section{$\underline{\text { School Performance }}$}

School-level data disaggregated by urbanicity are available for the 2002 PSSA reading administration for grades 5, 8, and 11 (Table MM5) and for the 2002 grade-11 writing assessment (Table MM6). Writing data for grades 6 and 9 were not available. Approximately 60 percent of schools in Pennsylvania were suburban, and the remaining 40 percent were split evenly between rural and urban locales. Urban schools were far more likely to be high-poverty than were rural or suburban schools, 64 percent compared with 11 percent and 8 percent, respectively. 
Table MM5. Average School Performance on $5^{\text {th }}$, $8^{\text {th }}$, and $1^{\text {th }}$-Grade 2002 Reading PSSA, by Urbanicity

\begin{tabular}{lccc}
\hline & $\begin{array}{c}\text { Basic and } \\
\text { Above }\end{array}$ & $\begin{array}{c}\text { Proficient } \\
\text { and Above }\end{array}$ & Advanced \\
\cline { 2 - 4 } & \multicolumn{3}{c}{ Average Percentage } \\
\hline $\mathbf{5}^{\text {th Grade }}$ & 82 & 57 & 15 \\
Rural schools & 86 & 65 & 22 \\
Suburban schools & 59 & 31 & 7 \\
Urban schools & & & \\
$\mathbf{8}^{\text {th }}$ Grade & 80 & 57 & 16 \\
Rural schools & 83 & 63 & 23 \\
Suburban schools & 59 & 33 & 8 \\
Urban schools & & & 12 \\
$\mathbf{1 1}^{\text {th }}$ Grade & 81 & 57 & 16 \\
Rural schools & 81 & 60 & 6 \\
Suburban schools & 56 & 33 & \\
Urban schools & & & \\
\hline
\end{tabular}

Table MM6. Average School Performance on $1^{\text {th }}$-Grade 2002 Writing PSSA, by Urbanicity

\begin{tabular}{lccc}
\hline & Basic and Above & $\begin{array}{c}\text { Proficient and } \\
\text { Above }\end{array}$ & Advanced \\
\cline { 2 - 4 } & \multicolumn{4}{c}{ Average Percentage } \\
\hline Rural schools & 84 & 65 & 9 \\
Suburban schools & 86 & 70 & 13 \\
Urban schools & 67 & 45 & 6 \\
\hline
\end{tabular}

Suburban schools outperformed rural schools by small margins $-3-8$ percentage points at the proficient level-and urban school by large margins-30-34 percentage points at the proficient level. Differences in performance persisted at the advanced level. Similar differences are found for $11^{\text {th }}$-grade writing. For instance, on average, suburban schools had 70 percent of students performing at or above the proficient level, compared with rural schools with 65 percent of students performing at this level and urban schools with 45 percent of students performing at this level. 



\section{APPENDIX NN. RHODE ISLAND}

\section{State Assessment System}

Rhode Island currently administers the New Standards Reference Exam (NSRE) to students in grades 4, 8, and 10 in English language arts and mathematics. NSRE is a criterion-referenced exam, published by Harcourt Educational Measurement and referenced to the New Standards Performance Standards and aligned with state standards. Both the exam and the reference standards were developed by the New Standards Project, a collaborative initiative between the National Center for Education and the Economy and the Learning Research and Development Center at the University of Pittsburgh that promoted standards-based reform in the 1990s. The NSRE is used as a supplemental assessment in numerous districts and schools nationwide, especially as part of the America's Choice comprehensive school-reform model.

Scores from the NSRE are used for school accountability in Rhode Island. In addition, the Rhode Island Skills Commission issues Certificates of Initial Mastery to high school students based in part on their scores on the NSRE.

Rhode Island also administers the Rhode Island Writing Assessment in grades 3, 7, 10, and 11 and the Rhode Island Health Education Assessment in grades 5 and 9. Neither of these assessments is used in the state accountability system (http://www.ridoe.net/schoolimprove/Default.htm).

Rhode Island's Common Core of Learning defines what students should know and be able to do at all grade levels and in all subject areas. A set of curriculum frameworks in English language arts, mathematics, science, social studies, arts, health education, and family-consumer science refine these broad competencies into specific content and performance standards for the various subject areas. The state also has standards for early childhood education and for school libraries and information literacy. The English language arts framework outlines nine broad standards that define general areas of competency for all grade levels:

- Standard 1: Communication-All students will be effective communicators in varied settings and for varied purposes.

- Standard 2: Response to Text-All students will demonstrate the ability to understand and respond to a wide variety of texts.

- Standard 3: Creation and Presentation of Text-All students will compose clear text in a variety of forms for many purposes.

- Standard 4: Student Voice-All students will demonstrate the power and effectiveness of voice through the language arts. 
- Standard 5: Awareness and Evaluation of the Learning Process-All students will know the processes used to construct and convey meaning through text and will develop and apply criteria for the evaluation and appreciation of their own and others' texts.

- Standard 6: Inquiry and Technology-All students will investigate issues and problems using a variety of current and emerging technologies in school and work settings.

- Standard 7: Enduring Themes-All students will use themes and topics from text to make connections and demonstrate an understanding of commonalities and diversity through exploration of universal issues.

- Standard 8: Literacy and the Community-All students will develop and apply their language skills, using the community as a learning laboratory.

- Standard 9: Language Arts and Citizenship-All students will use language effectively and responsibly as members of a democratic society.

Each standard is further defined by a set of descriptors, and specific expectations related to each descriptor are identified for four grade clusters--K-4, 5-8, 9-10, and 11-12 (http://www.ridoe.net/standards/frameworks/english/default.htm). Table NN1 shows the descriptors and expectations for the "Response to Text" standard at the $9^{\text {th }}-10^{\text {th }}$-grade level, as an example.

\section{Table NN 1. Rhode Island English Language Arts Curriculum Framework Standards, $9^{\text {th }}-1^{\text {th }}-$ Grade Expectations for Response to Text}

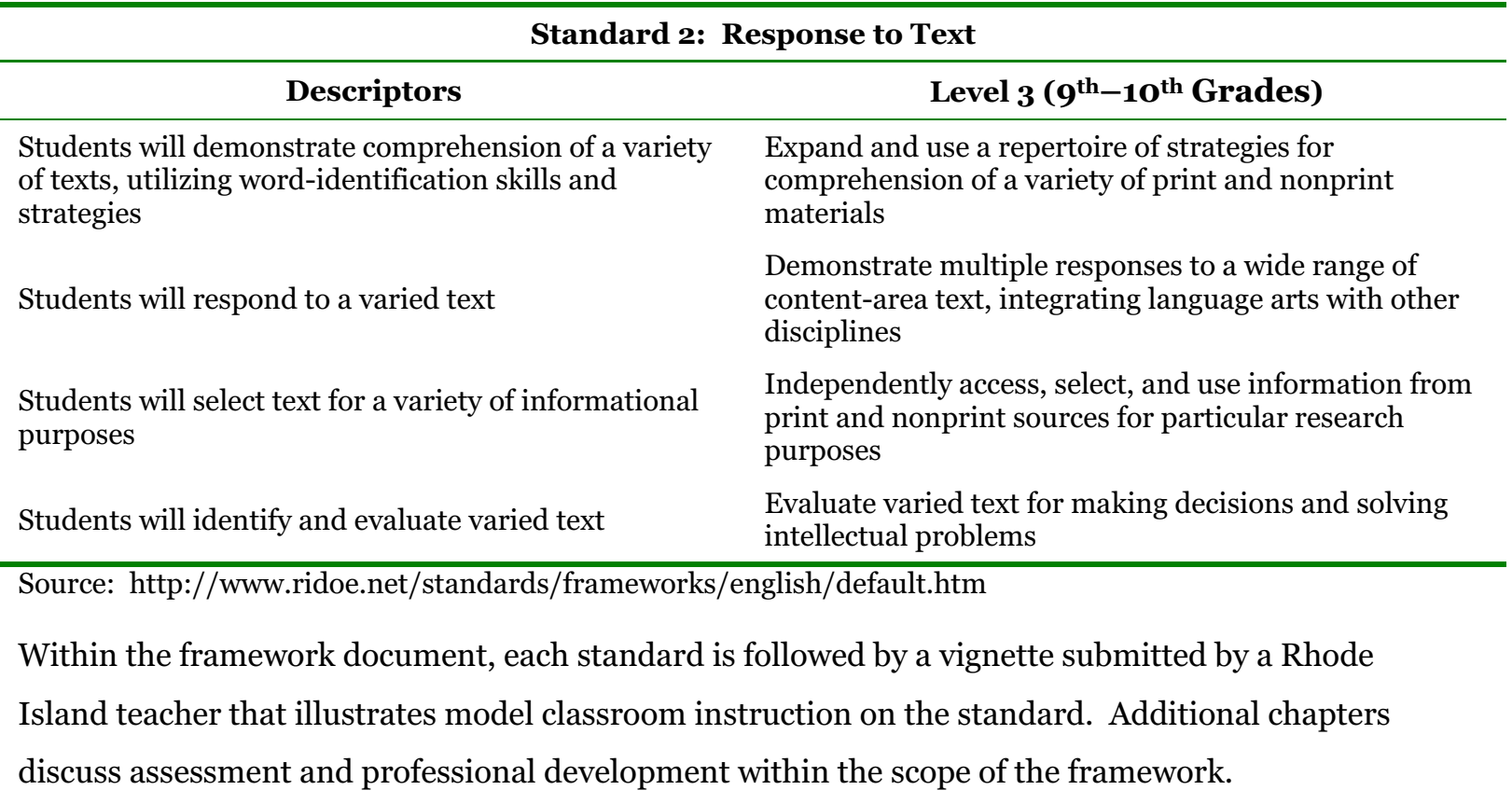


In 2002, Rhode Island entered into the New England Compact with New Hampshire and Vermont to work on cross-state collaborative initiatives focused on the implementation of the NCLB. As part of the compact's federally funded Enhanced Assessment Project, Rhode Island, New Hampshire, and Vermont have developed a set of common grade-level expectations (GLEs)-the Tri-State GLEs--that identify the content knowledge and skills expected of students for largescale assessment. The GLEs will be reviewed for alignment with the states' own standards and for quality, and will be used as the basis for a new large-scale assessment to be developed collaboratively by the three states. A draft version of the GLEs and draft test specifications were posted on the compact's Web site in early 2004. According to Rhode Island's NCLB workbook, the new assessment will be ready for statewide use in the 2005-2006 school year.

\section{Test Format and Content}

To examine trends in adolescent literacy, the rest of the discussion will focus on the NSRE in English language arts for grades 4, 8, and 10, and the Rhode Island Writing Assessment for grades 7 and 10 (see http://www.ridoe.net/standards/stateassessment/default.htm for additional detail).

The NSRE includes multiple-choice, short-answer, extended-response, and essay items. Areas tested include basic understanding, analysis and interpretation, writing effectiveness, and English-language conventions. Extended-response and essay items are scored using a number of four-, five-, and six-point rubrics. The exam is administered over three 55-minute testing sessions.

The Rhode Island Writing Assessment consists of one assigned-writing prompt that students respond to in an essay composition. Students in $7^{\text {th }}$ grade write expository essays, and students in $11^{\text {th }}$ grade write persuasive essays. Students in $7^{\text {th }}$ grade take the assessment in two 50 -minute sessions on consecutive days, with the first session devoted to prewriting and drafting and the second to revising and editing. Students in $11^{\text {th }}$ grade complete all steps of the writing process in a single 85-minute testing session. Students are provided with an editing checklist and a list of questions to guide reflection and revision. Only the final composition is handed in at the end of the test. Student responses are scored by two readers, using a holistic six-point rubric that focuses on ideas and development, organization, use of language, sentence structure, and grammar. For the $11^{\text {th }}$-grade test, students' use of supporting details and awareness of audience are also considered. If the two readers' scores differ by more than one point, the chief reader settles the discrepancy. Scores from the two readers are added together to reach a final score. 


\section{Achievement-Level Definitions}

Student scores on the NSRE are reported using five achievement levels: little evidence of achievement, below the standard, nearly achieved the standard, achieved the standard, and achieved the standard with honors. Students scoring at the achieved the standard level or higher are considered to have met academic requirements under NCLB.

\section{Performance Results}

\section{Student Performance}

Rhode Island provides data on student performance on the NSRE for all students and for students disaggregated by race/ethnicity, by English-proficiency status, disability status, and poverty status. ${ }^{60}$ Table NN2 shows the results from the 2003 NSRE English language arts assessment for students in grades 4,8 , and 10, disaggregated by student characteristics.

A much larger percentage of $4^{\text {th }}$-graders scored at or above the achieved the standard level, compared with $8^{\text {th- }}$ and $10^{\text {th }}$-graders -62 percent compared with 41 percent and 43 percent, respectively--although more than three-quarters of students in all three grades reached the nearly achieved the standard level. Few students $-3-8$ percent-reached the achieved the standard with honors level. There were marked differences in the pass rates of different racial/ethnic student groups, and this was true across all grade levels-23-29 percentage points between white and African American students and 27-31 percentage points between white and Hispanic students. For example, while 50 percent of white $10^{\text {th }}$-graders passed the test, only 26 percent of African American and 23 percent of Hispanic students did so.

About 22 percent of students with limited-English proficiency scored at or above the achieved the standard level in $4^{\text {th }}$ grade, and only 10 percent and 7 percent did so in $8^{\text {th }}$ grade and $10^{\text {th }}$ grade, respectively. The proportion of students with limited-English proficiency scoring at or above the nearly achieved the standard level ranged from 28 percent in $10^{\text {th }}$ grade to 43 percent in $4^{\text {th }}$ grade. The pass rates of students with disabilities were between 26 and 32 percentage points lower than those of all students at the achieved the standard level. About half of students with disabilities in all three grades scored at or above the nearly achieved the standard level.

Economically disadvantaged students achieved below their peers in all grade levels. This achievement gap was 18-20 percentage points at the achieved the standard level.

\footnotetext{
${ }^{60}$ Approximately 73 percent of students in Rhode Island are white; 15 percent are Hispanic; 8 percent are African American; and 3 percent are Asian/Pacific Islander. About 34 percent of students are eligible for the free and reduced-price lunch program; 6 percent are in limited-English-proficiency programs; and 20 percent have Individual Education Programs (IEPs).
} 
Table NN2. Performance of $4^{\text {th }}$, $8^{\text {th-, }}$ and $10^{\text {th }}$-Graders on 2003 English Language Arts NSRE, by Student Characteristics

\begin{tabular}{|c|c|c|c|}
\hline & $\begin{array}{c}\text { Nearly } \\
\text { Achieved the } \\
\text { Standard and } \\
\text { Above }\end{array}$ & $\begin{array}{l}\text { Achieved the } \\
\text { Standard and } \\
\text { Above }\end{array}$ & $\begin{array}{l}\text { Achieved the } \\
\text { Standard } \\
\text { with Honors }\end{array}$ \\
\hline & \multicolumn{3}{|c|}{ Percentage } \\
\hline \multicolumn{4}{|l|}{$4^{\text {th }}$ Grade } \\
\hline All students & 78 & 62 & 8 \\
\hline Students with disabilities & 50 & 30 & 2 \\
\hline $\begin{array}{l}\text { Students with limited-English } \\
\text { proficiency }\end{array}$ & 43 & 22 & 1 \\
\hline Economically disadvantaged students & 65 & 44 & 3 \\
\hline African American students & 64 & 42 & 2 \\
\hline Hispanic students & 61 & 40 & 2 \\
\hline White students & 85 & 71 & 11 \\
\hline \multicolumn{4}{|l|}{$8^{\text {th }}$ Grade } \\
\hline All students & 78 & 41 & 3 \\
\hline Students with disabilities & 50 & 14 & 1 \\
\hline $\begin{array}{l}\text { Students with limited-English } \\
\text { proficiency }\end{array}$ & 37 & 10 & o \\
\hline Economically disadvantaged students & 62 & 23 & 1 \\
\hline African American students & 64 & 26 & 1 \\
\hline Hispanic students & 59 & 22 & 1 \\
\hline White students & 86 & 49 & 3 \\
\hline \multicolumn{4}{|l|}{$1^{\text {th }}$ Grade } \\
\hline All students & 76 & 43 & 5 \\
\hline Students with disabilities & 48 & 17 & 1 \\
\hline $\begin{array}{l}\text { Students with limited-English } \\
\text { proficiency }\end{array}$ & 28 & 7 & o \\
\hline Economically disadvantaged students & 60 & 23 & 1 \\
\hline African American students & 63 & 26 & 1 \\
\hline Hispanic students & 59 & 23 & 1 \\
\hline White students & 84 & 50 & 7 \\
\hline
\end{tabular}

Source: http://131.109.26.242/reportcard/o3/rcSchools.asp?rcType=stateRC

Table NN3 presents the results of the 2003 writing assessment for students in the $7^{\text {th }}$ and $11^{\text {th }}$ grades. Disaggregated data were not available. The proportion of students reaching the achieved the standard level in writing was 34 percent in $7^{\text {th }}$ grade and 24 percent in $11^{\text {th }}$ grade. These pass rates were lower than those seen earlier in the English language arts test. However, similar to English language arts scores, about three-fourths of students achieved at or above the nearly achieved the standard level. 
Table NN3. Performance of $7^{\text {th- }}$ and $11^{\text {th }}$-Graders on 2003 Rhode Island Writing Assessment

\begin{tabular}{lcccc}
\hline & $\begin{array}{c}\text { Below the } \\
\text { Standard } \\
\text { and Above }\end{array}$ & $\begin{array}{c}\text { Nearly } \\
\text { Achieved the } \\
\text { Standard } \\
\text { and Above }\end{array}$ & $\begin{array}{c}\text { Achieved } \\
\text { the } \\
\text { Standard } \\
\text { and Above } \\
\text { and }\end{array}$ & $\begin{array}{c}\text { Achieved the } \\
\text { Standard } \\
\text { with Honors }\end{array}$ \\
\hline \multicolumn{5}{c}{ Percentage } \\
\hline $7^{\text {th }}$ Grade & 91 & 73 & 34 & 4 \\
$11^{\text {th }}$ Grade & 89 & 76 & 24 & 3 \\
\hline
\end{tabular}

Source: http://infoworks.ride.uri.edu/2004/state/assessments.pdf

\section{$\underline{\text { School Performance }}$}

School-level performance data by urbanicity are available for the $4^{\text {th }}$ and $8^{\text {th }}$-grade administration of the English language arts NSRE ${ }^{61}$ (Table NN4) and the $7^{\text {th }}$ - and $11^{\text {th }}$-grade writing assessments (Table NN5). Because of the small number of rural schools in Rhode Island, scores for these schools are not reported. Sixty-one percent of schools in Rhode Island were suburban, 35 percent urban, and 4 percent rural. While the majority of urban schools were highpoverty (63 percent), only 7 percent of suburban schools and no rural schools were high-poverty.

Table NN4. Average School Performance on $4^{\text {th- }}$ and $8^{\text {th }}$-Grade 2002 English Language Arts NSRE, by Urbanicity

\begin{tabular}{lc}
\hline & $\begin{array}{c}\text { Average Percentage at the Nearly Achieved } \\
\text { the Standard Level and Above }\end{array}$ \\
\hline $\mathbf{4}^{\text {th }}$ Grade & $*$ \\
Rural schools & 70 \\
Suburban schools & 52 \\
Urban schools & \\
$\mathbf{8}^{\text {th }}$ Grade & $*$ \\
Rural schools & 52 \\
Suburban schools & 27 \\
Urban schools & 27 \\
rural schools are not reported due to small sample size.
\end{tabular}

${ }^{*}$ Scores for rural schools are not reported due to small sample size.

${ }^{61}$ Data were available only at the nearly achieved the standard level. 
Table NN5. Average School Performance on $7^{\text {th- }}$ and $11^{\text {th }}-$ Grade 2002 Rhode Island Writing Assessment, by Urbanicity

\begin{tabular}{lc}
\hline & $\begin{array}{c}\text { Percentage at the Achieved the } \\
\text { Standard Level and Above }\end{array}$ \\
\hline $7^{\text {th }}$ Grade & $*$ \\
Rural schools & 33 \\
Suburban schools & 10 \\
Urban schools & \\
$\mathbf{1 1}^{\text {th }}$ Grade & $*$ \\
Rural schools & 35 \\
Suburban schools & 17 \\
Urban schools & \\
\hline
\end{tabular}

*Scores for rural schools are not reported due to small sample size.

Suburban schools outperformed urban schools by large margins in all grades and subjectsanywhere from 18 to 25 percentage points. For example, on average, suburban schools had 52 percent of students nearly meeting the standard on the $8^{\text {th }}$-grade English language arts assessment, compared with 27 percent in urban schools. 



\section{APPENDIX OO. SOUTH CAROLINA}

\section{State Assessment System}

For the 2002-03 school year, South Carolina's statewide assessment system included two components:

- The Palmetto Achievement Challenge Test (PACT) is a criterion-referenced test that aims to measure state content standards in English language arts, math, science, and social studies. The test is administered annually to students in grades $3-8$.

- The Basic Skills Assessment Program (BSAP) is a criterion-referenced high school exit exam designed to measure state content standards in reading, writing, and mathematics. Students take the BSAP in $10^{\text {th }}$ grade and must pass the exam in order to graduate. Students have four opportunities to retake portions they do not pass in their first attempt.

South Carolina recently adopted a new high school exit exam, the High School Assessment Program, which replaced the BSAP for the 2003-04 school year. Beginning with the class of 2006, students will be required to pass both the English language arts and math sections of the HSAP to graduate. South Carolina is also introducing new End-of-Course Examinations over the next several years for high school students enrolled in certain courses, including English I, Algebra I, Math for Technologies II, Physical Science, Biology I, Applied Biology II, and U.S. History and Constitution. The English I exam was administered for the first time in the spring of 2004 (for additional information on assessment and accountability, see http://www.myscschools.com/nclb/).

South Carolina has defined state curriculum standards in English language arts, mathematics, science, social studies, foreign language, physical education, health and safety education, and visual and performing arts. The English language arts standards are organized under four broad content strands-reading, writing, communication, and research-and by more specific topics within each strand. Standards for each topic are defined separately by grade level from PK through grade 8, and for courses taken in the 9-12 grade-span. Each standard begins with one of three descriptors-"begin," "continue," or "demonstrate"-that indicate progression through the standards at different grade levels. Table OO1 shows the standards for $8^{\text {th }}$ grade under the reading strand. 


\section{Table OO1. South Carolina English Language Arts Curriculum Standards, $8^{\text {th }}$-Grade}

Reading Strand

Reading process and
comprehension
The student will
integrate various cues
and strategies to
comprehend what he or
she reads.
she reads.
Analysis of texts The student will use knowledge of the purposes, structures, and elements of writing to analyze and interpret various types of texts.
Word study and analysis The student will use knowledge of semantics, syntax, and structural analysis to determine the meaning of unfamiliar words and to read texts with understanding.

\section{Standards for Reading}

Demonstrate the ability to read a variety of texts fluently

Demonstrate the ability to read independently for extended periods of time to derive pleasure and gain information

Demonstrate the ability to make connections between a text read independently and his or her prior knowledge, other texts, and the world

Demonstrate the ability to summarize, paraphrase, analyze, and evaluate what he or she read Demonstrate the ability to identify the details that support the thesis of a particular text Demonstrate the ability to make predictions about stories

Demonstrate the ability to analyze the main idea of a particular text

Demonstrate the ability to draw conclusions and make inferences

Demonstrate the ability to describe and analyze cause and effect and their impact on the plot, character, and theme

Demonstrate the ability to recognize when statements of fact are not documented and when opinions are not adequately supported

Demonstrate the ability to follow multistep directions, such as those for preparing applications and completing forms

Demonstrate the ability to use graphic representations, such as charts, graphs, pictures, and graphic organizers, as information sources and as a means of organizing information and events logically

Demonstrate the ability to use skimming and scanning techniques

Demonstrate the ability to compare and contrast his or her findings on a particular topic after having extracted that information from two or more pieces of graphic or written material

Demonstrate the ability to detect bias and identify propaganda techniques

Demonstrate the ability to analyze an author's use of static, dynamic, round, and flat characters; the structural elements of plot; flashback and foreshadowing; and point of view and tone

Demonstrate the ability to compare and contrast conflict in a variety of literary works

Demonstrate the ability to identify the speaker in a literary work and recognize the difference between first- and third-person narration and between the omniscient and the limited omniscient point of view and explain how they affect the overall theme of the work

Demonstrate the ability to compare and contrast theme in a variety of texts

Demonstrate the ability to identify elements of style, such as word choice and sentence structure (syntax), in a variety of texts

Demonstrate the ability to identify imagery and symbolism

Demonstrate the ability to identify the characteristics of genres, such as fiction, poetry, drama, and informational texts

Demonstrate the ability to identify elements of poetry, such as rhyme scheme, stanza, and refrain

Demonstrate the ability to identify the author's purpose in texts in a variety of genres Demonstrate the ability to develop and apply objective criteria for evaluating texts in a variety of genres

Demonstrate the ability to determine pronunciations, meanings, alternate word choices, the parts of speech, or the etymologies of words by using a dictionary and thesaurus

Demonstrate the ability to use knowledge of roots and affixes to analyze the meaning of complex words

Demonstrate the ability to use sentence structure (syntax) and context to determine the meaning of unfamiliar words and multiple-meaning words

Demonstrate the ability to make simple and complex analogies

Begin distinguishing between denotation and connotation of words and interpreting the connotative power of words

Source: http://www.myscschools.com/offices/cso/standards/ela/documents/standards.pdf 
South Carolina publishes bridge documents for each grade level to help teachers and students understand the relationship between the standards and the PACT. The document specifies PACT measurement guidelines (e.g., direct or indirect assessment, possible item and text types), as well as the eligible cognitive domains (e.g., factual, conceptual, analytical).

\section{Test Format and Content}

To examine trends in adolescent literacy, the rest of the discussion will focus on the PACT in English language arts for grades 5 and 8, and the reading and writing portions of the BSAP for grade 10 (for additional information regarding test format and content, see http://www.myscschools.com/offices/assessment/).

The English language arts PACT includes a mix of constructed-response items, worth 2-4 points each; extended-response items, worth 15 points in $5^{\text {th }}$ grade and 30 points in $8^{\text {th }}$ grade; and multiple-choice items, worth 1 point each. The $5^{\text {th }}$-grade exam consists of three to four constructed-response, one extended-response, and 23-33 multiple-choice questions, while the $8^{\text {th }}$-grade exam includes four to five constructed-response, one extended-response, and 43-55 multiple-choice items. On the $5^{\text {th }}$-grade exam, 54-57 percent of the available points are for reading, 33-37 percent are for writing, and 7-11 percent are for research. For the $8^{\text {th }}$-grade exam, 49-52 percent of the points are for reading, 39-41 percent are for writing, and 9-11 percent are for research. Skills and knowledge tested include applying knowledge of vocabulary; completing and/or interpreting graphic organizers; comprehending classical and contemporary literature; evaluating real-world text, such as charts, signs, advertisements, schedules, and brochures; editing samples of writing; and writing essays when given a topic. Constructed-response items are scored using a three-point rubric, and the extended-response items are scored using three four-point and one three-point analytic rubrics (http://www.myscschools.com/offices/assessment/PACT/Rubrics.htm).

The reading portion of the BSAP consists entirely of multiple-choice items, focused on objectives including decoding and word meaning, details, main idea, reference usage, inference, and analysis of literature. The test is not timed, but should take approximately two and a half hours. The writing portion of the exam requires students to compose an essay in response to an assigned topic. The writing portion is also not timed, but is estimated to take approximately an hour and 20 minutes.

\section{Achievement-Level Definitions}

Student scores on the PACT are reported using four achievement levels-below basic, basic, proficient, and advanced. Table $\mathrm{OO} 2$ shows the state's descriptor for each achievement level. 
Scores on the BSAP are reported as "meeting standards" or "not meeting standards." Students scoring at the proficient level and above on the PACT and at the meeting standards level on the BSAP are considered to have met academic requirements under NCLB.

\section{Table 002. PACT Achievement-Level Descriptors}

\begin{tabular}{ll}
\hline Advanced & $\begin{array}{l}\text { A student who performs at the "Advanced" level on the PACT has exceeded expectations for } \\
\text { student performance based on the curriculum standards approved by the state board of } \\
\text { education. The student is very well prepared for work at the next grade. }\end{array}$ \\
Proficient & $\begin{array}{l}\text { A student who performs at the "Proficient" level on the PACT has met expectations for } \\
\text { student performance based on the curriculum standards approved by the state board of } \\
\text { education. The student is well prepared for work at the next grade. The "Proficient" level } \\
\text { represents the long-term goal for student performance in South Carolina }\end{array}$ \\
Basic & $\begin{array}{l}\text { A student who performs at the "Basic" level on the PACT has met minimum expectations } \\
\text { for student performance on the curriculum standards as approved by the state board of } \\
\text { education. The student is minimally prepared for work at the next grade level. }\end{array}$ \\
Below Basic & $\begin{array}{l}\text { A student who performs at the "Below Basic" level on the PACT has not met expectations } \\
\text { for student performance on the curriculum standards approved by the state board of } \\
\text { education. The student is not prepared for work at the next grade. }\end{array}$
\end{tabular}

Source: http://www.myscschools.com/offices/assessment/Publications/Usersguide2003.pdf

\section{Performance Results}

\section{Student Performance}

South Carolina provides data on student performance on the PACT and BSAP for all students and for students disaggregated by race/ethnicity, by English-proficiency status, disability status, and poverty status. ${ }^{62}$ Table $\mathrm{OO}_{3}$ presents the results of the 2003 PACT English language arts assessment for students in grades 4 and 8 , disaggregated by these students' characteristics. Although $67-76$ percent of students in the $4^{\text {th }}$ and $8^{\text {th }}$ grades scored at the basic level, only 33 percent of $4^{\text {th }}$-graders reached the proficient level, as did 21 percent of $8^{\text {th }}$-graders. Only 2 percent of $4^{\text {th- }}$ and $8^{\text {th }}$-graders scored at the advanced level.

Only 2-18 percent of students with disabilities scored at the proficient level, and 50 percent of $4^{\text {th }}$-graders and 72 percent of $8^{\text {th }}$-graders with disabilities scored at the lowest level of proficiency, below basic.

There was a 21-28-percentage-point difference in the pass rates of white and African American students in the two grades. At the $4^{\text {th }}$-grade level, only 18 percent of African American students

\footnotetext{
${ }^{62}$ Approximately 55 percent of students in South Carolina are white; 42 percent are African American; and 2 percent are Hispanic. About 49 percent of students are eligible for the free and reduced-price lunch program; 1 percent are in limited-English-proficiency programs; and 15 percent have Individual Education Programs (IEPs).
} 
scored at the proficient level or higher in both grades, compared with 45 percent of white students. There also were large differences in the pass rates of economically disadvantaged students and their counterparts who were not economically disadvantaged-21-30 percentage points at the proficient level.

Table $\mathrm{OO}_{4}$ presents figures for the percentages of students meeting the standard in reading and writing on the $10^{\text {th }}$-grade 2003 BSAP. Overall, $83-84$ percent of $10^{\text {th }}$-graders met the standards in both subjects. A little over half of the students with disabilities met the reading and writing standards (52-53 percent). While 92 percent of white students met the reading and writing standards, the pass rate for African American students was much lower-72 percent in reading and 69 percent in writing. There was a 19-20-percentage-point difference in the performance of students from economically disadvantaged backgrounds and their counterparts.

Table 003. Performance of $4^{\text {th- }}$ and $8^{\text {th }}$-Graders on 2003 English Language Arts PACT, by Student Characteristics

\begin{tabular}{|c|c|c|c|}
\hline & $\begin{array}{l}\text { Basic and } \\
\text { Above }\end{array}$ & $\begin{array}{l}\text { Proficient } \\
\text { and Above }\end{array}$ & Advanced \\
\hline & \multicolumn{3}{|c|}{ Percentage } \\
\hline \multicolumn{4}{|l|}{$4^{\text {th }}$ Grade } \\
\hline All students & 76 & 33 & 2 \\
\hline Students with IEPs & 56 & 18 & 1 \\
\hline Students without IEPs & 79 & 35 & 2 \\
\hline Economically disadvantaged students & 66 & 19 & 1 \\
\hline $\begin{array}{l}\text { Non-economically disadvantaged } \\
\text { students }\end{array}$ & 88 & 49 & 4 \\
\hline African American students & 65 & 18 & 1 \\
\hline White students & 86 & 45 & 4 \\
\hline \multicolumn{4}{|l|}{$8^{\text {th }}$ Grade } \\
\hline All students & 67 & 21 & 2 \\
\hline Students with IEPs & 28 & 2 & $\mathrm{O}$ \\
\hline Students without IEPs & 70 & 22 & 3 \\
\hline Economically disadvantaged students & 52 & 9 & 1 \\
\hline $\begin{array}{l}\text { Non-economically disadvantaged } \\
\text { students }\end{array}$ & 79 & 30 & 4 \\
\hline African American students & 51 & 8 & o \\
\hline White students & 79 & 30 & 4 \\
\hline
\end{tabular}

Source: https://www.myscschools.com/tracks/testscores/pact/2003/\#StateD 
Table OO4. Performance of $10^{\text {th }}$-Graders on 2003 Reading and Writing BSAP

\begin{tabular}{lcc}
\hline & \multicolumn{1}{c}{ Reading } & Writing \\
\cline { 2 - 3 } & Percentage & Meeting the Standard \\
\hline All students & 84 & 83 \\
Students without IEPs & 86 & 85 \\
Students with IEPs & 53 & 52 \\
Economically disadvantaged students & 71 & 69 \\
Non-economically disadvantaged students & 90 & 89 \\
African American students & 72 & 69 \\
White students & 92 & 92 \\
\hline
\end{tabular}

Source: https://www.myscschools.com/reports/exitexam/2003/Exit2003.PDF

Note: Economically disadvantaged students refers solely to students receiving free lunch.

$\underline{\text { School Data }}$

School-level performance data by urbanicity are available for the $5^{\text {th }}$ and $8^{\text {th }}$-grade administration of the English language arts PACT (Table OO5) and the $10^{\text {th }}$-grade BSAP (Table O06). Forty-nine percent of schools in South Carolina were suburban, while 36 percent were rural and 15 percent were urban. Almost half of all schools were high-poverty schools, and threefourths of rural schools were high-poverty schools, compared with 53 percent of urban schools and 44 percent of suburban schools.

Table 005. Average School Performance on $5^{\text {th- }}$ and $8^{\text {th }}$-Grade 2002 English Language Arts, by Urbanicity

\begin{tabular}{lccc}
\hline & $\begin{array}{c}\text { Basic or } \\
\text { Higher }\end{array}$ & $\begin{array}{c}\text { Proficient } \\
\text { or Higher }\end{array}$ & $\begin{array}{c}\text { Advanced } \\
\text { or Higher }\end{array}$ \\
\cline { 2 - 4 } & \multicolumn{3}{c}{ Average Percentage } \\
\hline $\mathbf{5}^{\text {th Grade }}$ & 68 & 18 & 1 \\
Rural schools & 77 & 27 & 1 \\
Suburban schools & 71 & 23 & 1 \\
Urban schools & & & \\
$\mathbf{8}^{\text {th Grade }}$ & 63 & 19 & 3 \\
Rural schools & 73 & 29 & 5 \\
Suburban schools & 68 & 27 & 5 \\
Urban schools & & & \\
\hline
\end{tabular}


Table OO6. Average School Performance on $10^{\text {th }}-$ Grade 2002 Reading and Writing BSAP, by Urbanicity

\begin{tabular}{lcc}
\hline & Reading & Writing \\
\cline { 2 - 3 } & $\begin{array}{c}\text { Average Percentage } \\
\text { Meeting the Standard }\end{array}$ \\
\hline Rural schools & 77 & 79 \\
Suburban schools & 82 & 84 \\
Urban schools & 81 & 83 \\
\hline
\end{tabular}

Suburban and urban schools outperformed their rural counterparts at all grade levels and in all subjects. For instance, at the $8^{\text {th }}$ grade, on average, 19 percent of students in rural schools reached the proficient level, compared with 73 percent in suburban schools and 68 percent in urban schools. 



\section{APPENDIX PP. SOUTH DAKOTA}

\section{State Assessment System}

For the 2002-03 school year, South Dakota's statewide assessment system included two mandatory components for regular education students:

- The Dakota State Test of Educational Progress (STEP) is a norm- and criterion-referenced test that intends to link to state content standards in reading, math, science, social science, and language arts. The test is administered annually to students in grades $3-8$ and 11 .

- The Stanford Writing Assessment is a performance-based writing exam for students in grades 5 and 9 (see http://www.state.sd.us/deca/NCLB/index.htm for additional information regarding state assessment and accountability).

South Dakota has defined state content standards in reading, communication arts, mathematics, science, social studies, world language, physical education, health education, fine arts, family and consumer science, technology education, business and marketing, trade and industrial education, and agriculture education. The reading standards are organized around one broad state goal: students will read at increasing levels of complexity for a variety of purposes. Four indicators define important components of the goal. For each indicator, the state has defined benchmarks for grade clusters $-\mathrm{K}-2,3-5,6-8,9-12-$ as well as grade-by-grade standards in grades $\mathrm{K}-8$. The indicators, benchmarks for grades $6-8$, and standards for $8^{\text {th }}$-grade reading are shown in Table $\mathrm{PP} 1$, as an example.

South Dakota recently revised its reading and communication arts standards, and the new standards will be in place beginning with the 2004-05 school year. The goals and indicators are very similar to the previous version, but they have been elaborated and retooled slightly. The grade-cluster benchmarks have been removed, and the grade-level standards have been rewritten and reorganized. Each standard has been filled out with supporting skills and examples. Finally, the new standards document includes grade-specific performance descriptors for both regular education students and for English-language learners (http://www.state.sd.us/deca/OCTA/contentstandards/reading/standards/68.htm). 
Table PP1. South Dakota Reading Standards, $8^{\text {th }}$ Grade

\begin{tabular}{|c|c|c|}
\hline Indicator & Benchmarks & Grade-Level Standards \\
\hline \multirow[t]{4}{*}{$\begin{array}{l}\text { Students will use various } \\
\text { reading cues and } \\
\text { strategies to comprehend } \\
\text { text (e.g., context, } \\
\text { semantic, syntactic, and } \\
\text { graphophonic cues) }\end{array}$} & $\begin{array}{l}\text { Use specific cues and strategies to } \\
\text { make connections with, predict } \\
\text { meaning of, and comprehend } \\
\text { information within a text } \\
\text { Determine when a specific cue or }\end{array}$ & $\begin{array}{l}\text { Recognize and use direct, implied, } \\
\text { and inferential meaning to extend } \\
\text { understanding of materials read (e.g., } \\
\text { denotation, connotation, and } \\
\text { reasoning) }\end{array}$ \\
\hline & $\begin{array}{l}\text { strategy can be used most effectively } \\
\text { to read for comprehension }\end{array}$ & \multirow{2}{*}{$\begin{array}{l}\text { Use context clues to determine the } \\
\text { meanings of unfamiliar words (e.g., } \\
\text { antonyms, homonyms) }\end{array}$} \\
\hline & \multirow{2}{*}{$\begin{array}{l}\text { Use prior knowledge and experience } \\
\text { to interpret and construct meaning } \\
\text { from various texts }\end{array}$} & \\
\hline & & $\begin{array}{l}\text { Make reasonable predictions about } \\
\text { the content or message of various } \\
\text { reading materials before reading }\end{array}$ \\
\hline \multirow{3}{*}{$\begin{array}{l}\text { Students will evaluate the } \\
\text { patterns of organization, } \\
\text { literary elements, and } \\
\text { literary devices within } \\
\text { various texts. }\end{array}$} & $\begin{array}{l}\text { Compare and contrast various } \\
\text { organizational techniques authors use } \\
\text { to create reader interest (e.g., } \\
\text { sequence, cause and effect) }\end{array}$ & $\begin{array}{l}\text { Evaluate the structural elements of } \\
\text { plot development and how conflicts } \\
\text { are addressed and resolved (e.g., } \\
\text { subplot, parallel episodes) }\end{array}$ \\
\hline & $\begin{array}{l}\text { Explain literary elements and/or } \\
\text { devices used in various texts (e.g., } \\
\text { plot, setting, character, imagery, } \\
\text { alliteration) }\end{array}$ & \multirow[t]{2}{*}{$\begin{array}{l}\text { Compare and contrast the use of } \\
\text { poetic elements of word choice, } \\
\text { dialogue, rhyme, rhythm, and voice }\end{array}$} \\
\hline & $\begin{array}{l}\text { Describe the effects authors create by } \\
\text { using a combination of literary } \\
\text { elements and devices (e.g., theme, } \\
\text { imagery, point of view, anecdote) }\end{array}$ & \\
\hline \multirow{3}{*}{$\begin{array}{l}\text { Students will interpret and } \\
\text { respond to a diversity of } \\
\text { works representative of a } \\
\text { variety of cultures and } \\
\text { time periods. }\end{array}$} & $\begin{array}{l}\text { Examine various literary works to } \\
\text { understand how authors present } \\
\text { different perspectives }\end{array}$ & $\begin{array}{l}\text { Compare and contrast literature from } \\
\text { different eras or cultures that deal } \\
\text { with similar situations or conflicts }\end{array}$ \\
\hline & $\begin{array}{l}\text { Compare and contrast a variety of } \\
\text { literary works to confirm or refute } \\
\text { personal interpretations }\end{array}$ & \multirow{2}{*}{$\begin{array}{l}\text { Analyze the relationship between a } \\
\text { work of literature and the context in } \\
\text { which it was created (e.g., period, } \\
\text { ideas, customs, and outlooks of a } \\
\text { people) }\end{array}$} \\
\hline & $\begin{array}{l}\text { Use personal criteria to defend the } \\
\text { choice of independent-reading } \\
\text { materials }\end{array}$ & \\
\hline \multirow{5}{*}{$\begin{array}{l}\text { Students will access, } \\
\text { synthesize, and evaluate } \\
\text { information from a variety } \\
\text { of sources }\end{array}$} & \multirow{2}{*}{$\begin{array}{l}\text { Select and use suitable information } \\
\text { sources for a variety of purposes (e.g., } \\
\text { Internet, CD-ROM, print and video } \\
\text { materials, library) }\end{array}$} & $\begin{array}{l}\text { Analyze and synthesize information } \\
\text { to make informed decisions }\end{array}$ \\
\hline & & \multirow{2}{*}{$\begin{array}{l}\text { Compare original text to summary for } \\
\text { accuracy (e.g., inclusion of main ideas } \\
\text { and critical details, extent to which it } \\
\text { conveys the original meaning) }\end{array}$} \\
\hline & $\begin{array}{l}\text { Analyze the validity and/or } \\
\text { appropriateness of various technical }\end{array}$ & \\
\hline & and practical materials & \multirow{2}{*}{$\begin{array}{l}\text { Determine the appropriate } \\
\text { technology to gather, organize, and } \\
\text { retrieve information (e.g., computer } \\
\text { software, Internet) }\end{array}$} \\
\hline & $\begin{array}{l}\text { Collect and summarize information to } \\
\text { make reasonable and informed } \\
\text { decisions }\end{array}$ & \\
\hline
\end{tabular}

Source: http://www.state.sd.us/deca/OCTA/contentstandards/reading/standards/68.htm

\section{Test Format and Content}

To examine trends in adolescent literacy, the rest of the discussion will focus on the Dakota STEP in language arts and reading for grades 5 and 8, and the Stanford Writing Assessment for grades 5 
and 9 (see http://www.state.sd.us/deca/OCTA/testing/index.htm for additional test information).

The Dakota STEP is based on the Stanford Achievement Test, $10^{\text {th }}$ edition (SAT10), with additional items on the reading and mathematics portions that are aligned with state content standards. The test consists entirely of multiple-choice items. Each of the $5^{\text {th- }}, 8^{\text {th-}}$, and $11^{\text {th- }}$ grade exams includes $45-56$ reading-comprehension items, of which approximately one-third on the $5^{\text {th-grade }}$ exam and half on the $8^{\text {th }}$ and $11^{\text {th }}$-grade exams are augmentation components geared specifically toward the state content standards. The exam also includes 20 reading vocabulary items at all three grade levels. The language arts exam consists of 30 multiple-choice items. Neither section is timed, but the reading portion takes approximately one hour and the language section approximately 20 minutes.

For the Stanford Writing Assessment, students respond to a prompt in one of four modesdescriptive, narrative, expository, or persuasive-in an extended essay. Students are provided with a writer's checklist to guide them through the writing process. Students' responses are scored using both a six-point holistic rubric and a set of four-point analytic rubrics that judge ideas and development; organization, unity, and coherence; word choice; sentences and paragraphs; grammar and usage; and mechanics.

\section{Achievement-Level Definitions}

Student scores on the Dakota STEP are reported in several ways. Students receive scaled scores and national percentiles based on the norm-referenced portion of the test, and are also assigned one of four achievement levels:

- Advanced-Signifies superior performance beyond grade-level mastery

- Proficient-Represents solid academic performance, indicating that students are prepared for the next grade or responsible adulthood

- Basic-Denotes partial mastery of the knowledge and skills that are fundamental for satisfactory work

- Below Basic-Denotes little (if any) mastery of the most elementary knowledge and scores.

The state has defined cutoffs for the achievement levels in terms of both raw and scaled scores. Students scoring at the proficient level or higher are considered to have met academic requirements under NCLB. 


\section{Performance Results}

\section{Student Performance}

South Dakota provides data on student performance on the Dakota STEP for all students and for students disaggregated by race/ethnicity, -English-proficiency status, disability status, and poverty status. ${ }^{63}$ Table PP2 shows the results of the 2003 Dakota STEP reading assessment for students in grades 5,8 , and 11, disaggregated by a variety of student characteristics.

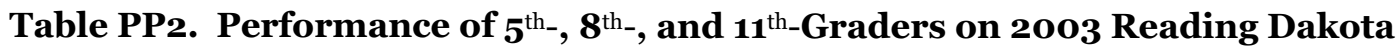
STEP, by Student Characteristics

\begin{tabular}{|c|c|c|c|}
\hline & $\begin{array}{l}\text { Basic and } \\
\text { Above }\end{array}$ & $\begin{array}{l}\text { Proficient and } \\
\text { Above }\end{array}$ & Advanced \\
\hline & \multicolumn{3}{|c|}{ Percentage } \\
\hline \multicolumn{4}{|l|}{$5^{\text {th }}$ Grade } \\
\hline All students & 90 & 51 & 3 \\
\hline Students with disabilities & 63 & 15 & 1 \\
\hline $\begin{array}{l}\text { Students with limited-English } \\
\text { proficiency }\end{array}$ & 64 & 10 & o \\
\hline Economically disadvantaged students & 84 & 37 & 1 \\
\hline Native American students & 77 & 22 & o \\
\hline White students & 94 & 57 & 4 \\
\hline \multicolumn{4}{|l|}{$8^{\text {th }}$ Grade } \\
\hline All students & 99 & 78 & 23 \\
\hline Students with disabilities & 90 & 26 & o \\
\hline $\begin{array}{l}\text { Students with limited-English } \\
\text { proficiency }\end{array}$ & 98 & 34 & o \\
\hline Economically disadvantaged students & 98 & 64 & 12 \\
\hline Native American students & 98 & 52 & 5 \\
\hline White students & 99 & 81 & 25 \\
\hline \multicolumn{4}{|l|}{ 11 $^{\text {th }}$ Grade } \\
\hline All students & 89 & 55 & o \\
\hline Students with disabilities & 46 & 8 & o \\
\hline $\begin{array}{l}\text { Students with limited-English } \\
\text { proficiency }\end{array}$ & 29 & 8 & o \\
\hline Economically disadvantaged students & 84 & 43 & o \\
\hline Native American students & 49 & 32 & o \\
\hline White students & 89 & 56 & o \\
\hline
\end{tabular}

63Approximately 86 percent of students in South Dakota are white, and 10 percent are American Indian/Alaska Native. No other racial/ethnic group comprises 2 percent of the population. About 30 percent are eligible for the free and reduced-price lunch program; 3 percent are in limited- Englishproficiency programs; and 13 percent have Individual Education Programs (IEPs). 
Source: http://sis.ddncampus.net:8081/nclb/index.html

The performance across grades varied considerably. Although 89-100 percent of students in grades 5,8 , and 11 scored at the basic level, only 51 and 55 percent of $5^{\text {th- }}$

and $11^{\text {th }}$-graders passed the reading assessment by scoring at or above the proficient level. The proportion passing the test was much higher in the $8^{\text {th }}$ grade -78 percent. Only 3 percent of $5^{\text {th }}$ graders and none of the $11^{\text {th }}$-graders scored at the advanced level compared with 23 percent of $8^{\text {th }}$ graders.

There was a 35-percentage-point difference in the pass rates of white and Native American students in the $5^{\text {th }}$ grade ( 57 percent versus 22 percent), but this gap decreased in magnitude across the grades. By the $11^{\text {th }}$ grade, the performance gap decreased to 24 percentage points (56 percent versus 32 percent). In contrast to the very small numbers in the $5^{\text {th }}$ and $11^{\text {th }}$ grades $(0-4$ percent), 25 percent of white students in $8^{\text {th }}$ grade scored at the advanced level. Students with disabilities scored 36 percentage points lower in pass rates compared with all students in the $5^{\text {th }}$ grade; in the $8^{\text {th }}$ and $11^{\text {th }}$ grades, this gap increased to between 47 and 52 percentage points.

Economically disadvantaged students scored 12-14 percentage points lower than all students at the proficient level across all three grade levels. Students with limited-English proficiency trailed well behind all students. For example, only 8-10 percent of these students passed the reading assessment in the $5^{\text {th }}$ and $11^{\text {th }}$ grades. The percentage was much higher in the $8^{\text {th }}$ grade, 34 percent, but the gap in relative performance was large (41-47 percentage points) and increased across the grades.

Table $\mathrm{PP}_{3}$ presents the percentage of students who scored at or above the proficient level on the 2003 writing assessment for grades 5 and 9 . The pass rate of $5^{\text {th }}$-graders was markedly lower

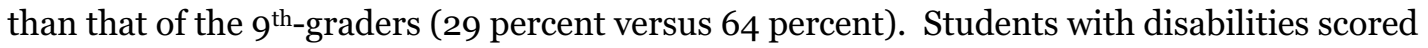
lower than all students, with pass rates of 14 percent in the $5^{\text {th }}$ grade and 21 percent in the $9^{\text {th }}$ grade. As seen earlier, the difference in performance was larger in the higher grade. South Dakota also provides data on student performance on the content areas of writing that are assessed-ideas and development; organization, unity, and coherence; word choice; sentences and paragraphs; grammar and usage; and mechanics (not shown in table). While the performance of $9^{\text {th }}$-graders was relatively uniform across these areas, $5^{\text {th }}$-graders tended to score higher on ideas and development and lower on organization, unity, and coherence. 


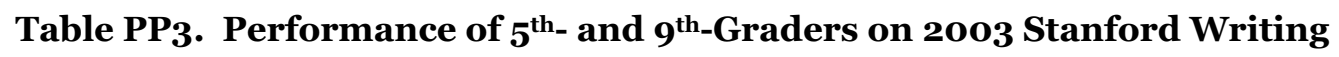
Assessment

\begin{tabular}{lc}
\hline & $\begin{array}{c}\text { Percentage } \\
\text { Proficient and } \\
\text { Advanced }\end{array}$ \\
\hline $\mathbf{5}^{\text {th }}$ Grade & \\
All students & 29 \\
Students with disabilities & 14 \\
$\mathbf{9}^{\text {th }}$ Grade & \\
All students & 64 \\
Students with disabilities & 21 \\
\hline
\end{tabular}

Source: http://www.state.sd.us/deca/Finance/Data/o3digest/o2-o3StateProfile.pdf

$\underline{\text { School Data }}$

Comparable school-level data were not available for South Dakota. 


\section{APPENDIX QQ. TENNESSEE}

\section{State Assessment System}

The Tennessee Comprehensive Assessment System (TCAP) consists of the TCAP Achievement Test, the End-of-Course tests, and the Direct Writing Assessments.

The TCAP Achievement Test is a norm- and criterion-referenced test designed to measure state content standards in various subject areas. Students take the test in the following subject areas at each grade level:

- Kindergarten - reading, language arts, mathematics

- $\quad 1^{\text {st }}$ Grade - reading, language arts, mathematics, science, social studies, word analysis, vocabulary, math computation

- $\quad 2^{\text {nd }}$ Grade - reading, language arts, mathematics, science, social studies, word analysis, vocabulary, language mechanics, math computation, spelling

- $\quad 3^{\text {rd }}$ Grade - reading, language arts, mathematics, science, social studies, word analysis

- $\quad 4^{\text {th }}-8^{\text {th }}$ Grades - reading, language arts, mathematics, science, social studies.

The End-of-Course Tests are criterion-referenced exams the state reports as linked to state content standards for various high school courses in mathematics, science, English, and history. Students enrolled in each of the ten courses that are part of the assessment program--Algebra I, Algebra II, Geometry, Math Foundations I, Biology I, Physical Science, Chemistry, English I, English II, and U.S. History--take the test in the spring. A student's score on the End-of-Course test counts as at least 15 percent of his or her semester grade for the course. Of the ten End-ofCourse Tests, three-English II, Algebra I, and Biology I-have been designated at Gateway Tests: Students are required to pass each of these three gateway tests in order to graduate, and are given additional opportunities to retake any that they do not pass on their first attempt. The English II Gateway Test was administered for the first time in 2002-03.

The Tennessee Writing Assessment is a performance-based test of writing skills for students in grade 5,8 , and 11 (additional assessment and accountability information can be found through http://www.state.tn.us/education/mnclb.htm).

Tennessee has defined state curriculum standards in English language arts, mathematics, science, social studies, foreign language, dance, music, theatre, visual arts, physical education and lifetime wellness, and computer technology. The state also has specific Gateway Test and End-of-Course standards for each of the courses in these assessment programs. Three broad content standards communicate the state's vision of literacy: 
- $\quad$ Reading - The student will develop the reading and listening skills necessary for word recognition, comprehension, interpretation, analysis, evaluation, and appreciation of print and nonprint text.

- Writing - The student will develop the structural and creative skills of the writing process necessary to produce written language that can be read, presented to, and interpreted by various audiences.

- Elements of Language - The student will use Standard English conventions and proper spelling as appropriate to speaking and writing.

A set of learning expectations identify the core of learning for each standard within three grade clusters $-\mathrm{K}-3,4-5$, and 6-8-while grade-specific accomplishments define the knowledge and skills needed in each grade to master the learning expectations (http://www.state.tn.us/education/ci/cistandards2001/la/cilag8all.htm). Table QQ1 shows the learning expectations and accomplishments for the reading standard in grade 8 , as an example.

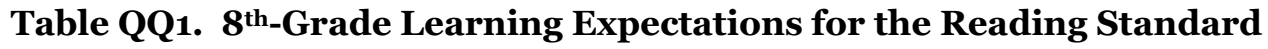

\begin{tabular}{|c|c|}
\hline $\begin{array}{c}\text { Learning } \\
\text { Expectations }\end{array}$ & Accomplishments \\
\hline \multirow{8}{*}{$\begin{array}{l}\text { Continue to develop } \\
\text { oral language and } \\
\text { reading skills }\end{array}$} & Continue to model active listening in both formal and informal settings \\
\hline & Continue to adhere to rules for public conversations \\
\hline & Continue to formulate and respond to questions from teachers and classmates \\
\hline & $\begin{array}{l}\text { Continue to organize and share information, stories, experiences, ideas, and feelings } \\
\text { with others in both formal and informal settings }\end{array}$ \\
\hline & Participate in creative responses to text (e.g., debates, dramatizations, speeches) \\
\hline & $\begin{array}{l}\text { Deliver a focused, well-organized oral presentation, using multiple sources of } \\
\text { information from any content areas, utilizing visual aids for contextual support }\end{array}$ \\
\hline & $\begin{array}{l}\text { Incorporate into oral reading, discussions, and presentations the use of correct stress, } \\
\text { pitch, and juncture }\end{array}$ \\
\hline & $\begin{array}{l}\text { Analyze a variety of nonverbal communication techniques and how they impact the } \\
\text { audience and speaker }\end{array}$ \\
\hline \multirow[t]{3}{*}{$\begin{array}{l}\text { Develop an } \\
\text { understanding of the } \\
\text { concepts of print }\end{array}$} & $\begin{array}{l}\text { Recognize the defining characteristics of a variety of texts (e.g., identify differences } \\
\text { between poetry and narration, between plays and essays, between biography and } \\
\text { historical fiction) }\end{array}$ \\
\hline & $\begin{array}{l}\text { Approach texts according to their type, using appropriate skills and prior knowledge } \\
\text { (e.g., read poetry aloud, determine how the form/genre informs meaning) }\end{array}$ \\
\hline & $\begin{array}{l}\text { Recognize the structure and organization of various text features to locate information } \\
\text { (e.g., sidebars, questions at the end of chapter/unit, footnotes, endnotes) }\end{array}$ \\
\hline \multirow{3}{*}{$\begin{array}{l}\text { Expand reading skills } \\
\text { through phonemic } \\
\text { awareness }\end{array}$} & $\begin{array}{l}\text { Continue to develop an awareness of sounds of language through repeated exposure to a } \\
\text { variety of auditory experiences (e.g., poems, music lyrics, books on tape, read-alouds) }\end{array}$ \\
\hline & Evaluate patterns of rhyme and rhythm and how they affect understanding \\
\hline & $\begin{array}{l}\text { Evaluate the effects of sound in language (e.g., alliteration [assonance and consonance], } \\
\text { onomatopoeia, slant rhyme, internal rhyme, accent, repetition) }\end{array}$ \\
\hline \multirow[t]{4}{*}{ Use decoding strategies } & Recognize and identify the base/root from words having affixes \\
\hline & Determine the meaning of prefixes and suffixes through identification and usage \\
\hline & Use context clues to determine multiple-meaning words \\
\hline & $\begin{array}{l}\text { Decode unknown grade-level words utilizing previously learned strategies and verify the } \\
\text { word's meaning within the context of the selection }\end{array}$ \\
\hline
\end{tabular}




\section{Table QQ1. (cont.)}

Read to develop fluency, expression, accuracy, and confidence

Expand reading vocabulary
Develop independent pre-reading strategies to facilitate comprehension
Demonstrate the ability to read with expression, accuracy, and poise from a variety of texts (e.g., paired reading, choral reading, and read-alongs)

Continue to participate in guided reading

Continue to read using appropriate pronunciation, expression, and rate

Continue to adjust speed based on the purpose for reading

Continue to read independently on a daily basis

Build vocabulary by listening to literature, viewing films and documentaries, participating in class discussions, and reading self-selected and assigned texts

Build vocabulary by reading and viewing from a wide variety of print and nonprint texts, and literary and media genres and modes

Analyze word meanings, using roots, prefixes, and suffixes

Continue to determine the meaning of unfamiliar words, using context clues, dictionaries, electronic sources, glossaries, and other resources

Evaluate the use of synonyms, antonyms, homonyms, and multiple-meaning words, and determine how their use assists with understanding

Continue to foster word consciousness (e.g., word play, word walls, graphic organizers, nuances of words, power words)

Analyze and use useful mnemonic devices (e.g., rhyming words, vocabulary cartoons, kinesthetic) to acquire new vocabulary

Select the correct word or phrase to complete an analogy

Recognize the historical influences on and changes to the English language

Consider word etymology and semantic change as part of vocabulary study

Recognize and interpret widely used foreign phrases (e.g., e pluribus unum, c'est la vie)

Use connotation and denotation for vocabulary studies

Recognize that word choices create a mood to set a tone

Discover ways by which a language acquires new words (e.g., brand names, acronyms)

Identify words and phrases that serve as clues to reveal time periods, cultures, and regions represented (e.g., use of vocabulary associated with a particular time period, region, or country

Continue to establish a purpose for reading and viewing (e.g., to understand, to interpret, to enjoy, to solve problems, to answer specific questions, to discover information/facts, to discover models of writing)

Continue to utilize reference sources to build background knowledge for reading

Continue to use previously learned strategies to front-load text (e.g., skimming and scanning, connecting to prior knowledge)

Preview text, using supports such as illustrations/pictures, captions, graphs, diagrams, headings, subheadings, and footnotes

Relate the importance and the significance of the reading, listening, and viewing selections to learning and life

Analyze significant words to be encountered in the text

Make predictions about print and nonprint text

Relate print and nonprint text to prior personal experiences or opinions, historical knowledge, current events and cultural background, as well as to previously read print and nonprint texts 


\section{Table QQ1. (cont.)}

Use active comprehension strategies to derive meaning while reading and check for understanding after reading
Derive meaning while reading by:

- Continuing to formulate clarifying questions

- Evaluating predictions made in prereading and making adjustments

- Continuing to predict outcomes, state reasonable generalizations, and draw conclusions based on prior knowledge and information gained while reading

- Using metacognitive and self-monitoring strategies while reading (e.g., pausing, rereading, consulting other sources, reading ahead, asking for help)

- Engaging in reading between the lines (i.e., changing perspective among characters to determine thoughts, imagining parallel events, stating implied information)

- Continuing to create mental pictures from abstract information

- Continuing to relate text to prior personal experiences or opinions, as well as to previously read print and nonprint texts

- Making inferences and recognizing unstated assumptions

- Verifying or modifying pre-reading purpose as additional information is obtained

- Exploring ways to interact with text (e.g., mark the text, use Post-It notes, ask questions, and make comments within the text)

Derive meaning after reading by:

- Indicating, analyzing, and evaluating the sequence of events

- Recognizing and stating the main idea/central element in a given reading selection, noting details that support the main idea/central element

- Identifying the author's purpose and analyzing to determine whether the purpose is met

- Discussing similarities and differences in events and characters, using evidence cited from the text or various texts

- Analyzing and evaluating the text to find contextual support for responses to questions, for assistance in formulating ideas and opinions, and for supporting personal responses

- Assessing the accuracy and appropriateness of an author's details to support claims and assertions, noting instances of bias and stereotyping

- Evaluating cause-and-effect relationships

- Evaluating statements as fact or opinion

- Analyzing the use of figurative language (idioms, similes, metaphors, personification, imagery, puns)

- Analyzing themes, whether stated or implied

- Evaluating and reflecting upon comprehension strategies utilized to make meaning from texts

- Making connections among print and nonprint texts

- Making connections among the various literary genres and themes with personal, historical, and cultural experiences

- Evaluating reading selections for their application to daily life (e.g., extend and apply meaning derived from text to different situations 


\section{Table QQ1. (cont.)}

Refine study skills and develop methods of research to enhance learning
Apply vocabularydevelopment and comprehension skills to facilitate reading to learn in content areas
Determine appropriate reference sources in various formats (e.g., encyclopedias, card/electronic catalogs, almanacs, periodicals, Internet)

Use media (e.g., films, videos, the visual and performing arts, on-line catalogs, nonfiction books, encyclopedias, CD-ROMs, references, Internet) to view, read, and represent information

Use current technology (e.g., the Internet, CD-ROMs, on-line catalogs) as a research and communication tool

Analyze a variety of reference sources (e.g., biographical sketches, letters, diaries, encyclopedias, periodicals)

Distinguish between and use primary- and secondary-source documents

Evaluate resources for validity and reliability

Continue to refine skimming and scanning skills

Retrieve, organize, represent, analyze, and evaluate information to demonstrate knowledge effectively acquired

Develop and use notes that include important concepts, summaries, and identification of reference sources

Investigate and evaluate the impact of bias/persuasive devices on daily life

Recognize and identify a statement as an example of persuasive and/or propaganda techniques (e.g., false generalizations, loaded words, snob appeal, name-calling, bandwagon, testimonials, and inconsistencies of logic)

Use and evaluate a variety of sources to prepare a research paper that includes a title page, outline, notes, and a bibliography

Define and apply internal (subjective) and external (objective) criteria in making critical evaluations of given statements

Expand and maintain vocabulary specific to content areas and to current events

Continue to locate information, using available text features (e.g., maps, charts, timelines, graphics, indexes, glossaries, footnotes, author's biography, and table of contents)

Apply, analyze, and evaluate comprehension skills and strategies used to obtain meaning from informational text in the content areas

Continue to use self-correction strategies while reading (e.g., pausing, rereading, consulting other sources)

Continue to interact with the text and analyze its effectiveness

Determine the reliability of sources by exploring the author's background, intentions, and motives

Read independently for Read for literary experience a variety of purposes
Read to gain information

Read to perform a task

Read for enjoyment

Read to expand vocabulary

Read to build fluency 


\section{Table QQ1. (cont.)}

Experience and explore the elements of various literary and media genres
Develop and sustain a motivation for reading

Continue to read, view, and recognize various literary (e.g., novels, science fiction, plays, suspense, poetry, autobiographies, nonfiction of high interest) and media (e.g., music, films, videos)

Recognize and analyze the elements of various literary and media genres

Explore the elements that determine types of fiction (e.g., suspense/mystery, comedy/humor, drama, historical fiction, romance, legends and myth)

Identify and evaluate stated or implied themes and connect recurring themes to previously read materials and current readings

Evaluate how the author develops characters (e.g., though words, speech, action, thoughts, narrator, interaction, motivation) and evaluate whether the characters are stereotypical or realistic

Evaluate words, phrases, and other devices used by authors to create mood to establish a tone

Determine the elements of the plot and trace them, using graphic organizers (i.e., exposition, rising action, climax, falling action, resolution, denouement)

Distinguish among varying types of conflict (i.e., man v. man, man v. nature, man v. himself)

Explore subplots in literary selections and films

Compare and contrast between or among stories/events/the elements of the plot

Determine the narrator's/author's point of view (i.e., first person, third person, limited, or omniscient)

Explore and explain how a story changes or an event is perceived if the point of view is changed

Summarize, paraphrase, and evaluate selected passages for discussion and/or written assignments or presentations

Make inferences about print and nonprint text

Use deductive reasoning to facilitate and to extend understanding of texts

Determine the differences among nonfiction materials (e.g., letters, memoirs, diaries, journals, documentaries, autobiographies, biographies, and educational, informational, and technical texts)

Demonstrate knowledge of similes, metaphors, personification, symbolism, idioms, puns, hyperbole, flashback, foreshadowing, and irony

Explore the concept of allusion

Visit libraries/media centers, book fairs, bookstores, and other print-rich environments to explore books

Use personal criteria to select reading material (e.g., personal interest, knowledge of authors, text difficulty, text genres, recommendation of others)

Read daily from self-selected materials

Relate literary experiences (e.g., book discussions, literary circles, writing, oral presentations, artistic expressions)

Experience and develop an awareness of literature that reflects a diverse society Maintain a personal reading list/reading $\log /$ journal to reflect reading gains and accomplishments

Source: http://www.state.tn.us/education/ci/cistandards2001/la/cilag8all.htm

Each of the content standards is also broken down into benchmark performance indicators, which define the specific skills and knowledge expected of students at different levels of achievement within each grade cluster. The performance indicators include both state-assessed and teacherobserved indicators, and are divided into three levels: Below Proficient, Proficient, and Advanced. 
For English I End-of-Course and English II Gateway Tests, there are four broad content standards: writing, reading, viewing and representing, and speaking and listening. Similar to the $\mathrm{K}-8$ standards, each of these four is broken down into learning expectations for the course, and is accompanied by performance indicators for the three levels of achievement.

\section{Test Format and Content}

The TCAP Achievement Test consists entirely of multiple-choice items. The test includes both norm-referenced and criterion-referenced items. Table QQ2 shows the objectives and sub-skills tested by the norm-referenced items, and their approximate relative emphasis on the 2004 exam, as an example.

Table QQ2. TCAP Reading and Language Arts Achievement Test Objectives and Subskills, by Relative Weight

\begin{tabular}{|c|c|c|c|c|c|}
\hline & $\begin{array}{c}5^{\text {th }} \\
\text { Grade }\end{array}$ & $\begin{array}{c}\text { 8 }^{\text {th }} \\
\text { Grade }\end{array}$ & & $\begin{array}{c}5^{\text {th }} \\
\text { Grade }\end{array}$ & $\begin{array}{c}8^{\text {th }} \\
\text { Grade }\end{array}$ \\
\hline Basic Understanding & 18 & 21 & Evaluate and Extend Meaning & 10 & 13 \\
\hline Stated information & 5 & 9 & Generalize & $\mathrm{O}$ & 3 \\
\hline Sequence & 3 & 4 & Author purpose & 4 & 1 \\
\hline Vocabulary & 6 & 9 & Author point of view/Bias & 1 & 1 \\
\hline Initial understanding & 4 & $\mathrm{O}$ & Critical assessment & 1 & 3 \\
\hline Analyze Text & 19 & 20 & Predict/Hypothesize & 1 & 3 \\
\hline Main idea/Theme & 4 & 3 & Extend/Apply meaning & o & 3 \\
\hline Conclusions & 6 & 5 & Fact/Opinion & 3 & $\mathrm{O}$ \\
\hline Story elements/Character & 5 & 3 & Identify Reading Strategies & 12 & 6 \\
\hline Story elements/Plot & 1 & $\mathrm{O}$ & Summarize & 3 & 1 \\
\hline Supporting evidence & 1 & o & Apply genre criteria & $\mathrm{O}$ & 1 \\
\hline Literary techniques & 1 & 1 & Vocabulary strategies & 5 & 3 \\
\hline Cause/Effect & o & 3 & Self-monitor & 1 & 1 \\
\hline Compare/Contrast & $\mathrm{O}$ & 1 & Make connections & 1 & $\mathrm{O}$ \\
\hline Story elements/Setting & o & 3 & Synthesize across texts & 1 & $\mathrm{O}$ \\
\hline Nonfiction elements & o & 3 & Sentence Structure & 12 & 9 \\
\hline Writing Strategies & 16 & 16 & Complete/Fragment/Run-on & 6 & 4 \\
\hline Topic Sentence & 3 & 1 & Sentence combining & 3 & 4 \\
\hline Relevance & 5 & 8 & Misplaced modifier & 3 & 1 \\
\hline Supporting sentences & 6 & 5 & Editing Skills & 13 & $\mathbf{1 5}$ \\
\hline Connective/Transitional words & $\mathrm{O}$ & 1 & Punctuation & & 1 \\
\hline Information sources & 1 & 1 & Usage & 13 & 14 \\
\hline
\end{tabular}

The criterion-referenced items on the TCAP Achievement Test assess students on content, grammar conventions, meaning, techniques and skills, vocabulary, writing/organization, and 
writing process. The exam is broken into thee tests, one of which has two parts, which take between 20 and 60 minutes each.

The Tennessee Writing Assessment consists of one extended-writing task. Students compose an essay in response to an assigned prompt. On the $5^{\text {th }}$-grade exam, the prompt asks for a narrative essay, while $8^{\text {th }}$-grade students write an expository essay and $11^{\text {th }}$-graders compose a persuasive essay. Fifth- and $8^{\text {th }}$-grade students have 35 minutes to complete their response, and $11^{\text {th }}$-grade students have 25 minutes. The essays are scored holistically using a six-point rubric.

The Language Arts Gateway Test consists of 62 multiple-choice items that assess grammar conventions, content, meaning, word choice, organization, and technique.

\section{Achievement-Level Definitions}

Tennessee is in the process of developing achievement levels and setting standards for the state assessment. Student test scores for the TCAP Achievement Test will be reported in three levels: Basic, Proficient, and Advanced. Students scoring at or above the proficient level will be considered to have met academic requirements under NCLB. The state will set standards for the TCAP Achievement Test during the summers of 2003 and 2004, based on the previous school year's test results; these achievement levels will be fully operational for all grade levels for the 2005 assessment. However, at the time of this report, assessment data were available through only the 2002-03 school year, when test scores were reported as national percentiles.

Scores on the writing assessment are reported in six achievement levels that correspond to the six-point rubric. Scores at the "competent" level (4 points) or above are considered "passing."

\section{Performance Results}

\section{Student Performance}

Table QQ3 presents data on student performance on the TCAP Achievement Test and Writing Assessment for all students and for students disaggregated by race/ethnicity, disability status, and eligibility for the free- or reduced-price lunch program (proxy for poverty). ${ }^{64}$ Although the Writing Assessment is currently administered in grades 5, 8, and 11, it was administered in grades 4, 7, and 11 until 2002-03. As the most recent test score data available are for the 2001-02 administration, we report scores for grades 4, 7, and 11 rather than for 5, 8, and 11 (Table QQ4).

\footnotetext{
64Approximately 72 percent of students in Tennessee are white; 25 percent are African American; and 3 percent are Hispanic. Forty-two percent were eligible for the free and reduced-price lunch program; 2 percent were enrolled in limited-English-proficiency programs; and about 16 percent of students have Individual Education Programs (IEPs).
} 
In $5^{\text {th }}$ and $8^{\text {th }}$ grades, on average, all students scored slightly above the national average in reading and language arts ( $54^{\text {th }}$ percentile to $61^{\text {st }}$ percentile), and students with disabilities scored at the $12^{\text {th }}-16^{\text {th }}$ percentile. Economically disadvantaged students scored substantially below their noneconomically disadvantaged peers across all grades and subjects. For example, in reading, economically disadvantaged $5^{\text {th }}$-grade student performance averaged at the $37^{\text {th }}$ percentile, compared with that of peers whose average score was at the $66^{\text {th }}$ percentile. Large achievement gaps also existed between white and African American students (24-31-percentile-rank difference) and white and Hispanic students (20-30-percentile-rank difference) in all grades and subjects. Table QQ3. Performance of $5^{\text {th }}$ and $8^{\text {th }}-$ Graders on 2003 Reading TCAP
Achievement Test, by Student Characteristics

\begin{tabular}{|c|c|c|c|c|}
\hline & \multicolumn{2}{|c|}{$5^{\text {th }}$ Grade } & \multicolumn{2}{|c|}{$8^{\text {th }}$ Grade } \\
\hline & & anguage & & Language \\
\hline & Reading & Arts & Reading & Arts \\
\hline & \multicolumn{4}{|c|}{ National Percentile Rank } \\
\hline All students & 54 & 56 & 56 & 61 \\
\hline Students with disabilities & 12 & 15 & 16 & 12 \\
\hline Students without disabilities & $5^{8}$ & 63 & 60 & 66 \\
\hline $\begin{array}{l}\text { Economically disadvantaged } \\
\text { students }\end{array}$ & 37 & 42 & 41 & 41 \\
\hline $\begin{array}{l}\text { Non-economically } \\
\text { disadvantaged students }\end{array}$ & 66 & 70 & 66 & 73 \\
\hline African American students & 31 & 39 & 38 & 38 \\
\hline Hispanic students & 35 & 44 & 37 & 39 \\
\hline White students & 62 & 64 & 62 & 69 \\
\hline
\end{tabular}

Source: http://www.state.tn.us/education/testing/o2tstcapstatewide.pdf

On the writing assessment, 72 percent of $4^{\text {th }}$-graders, 82 percent of $7^{\text {th }}$-graders, and 70 percent of $11^{\text {th }}$-graders reached the competent level. Similar to the performance of all students, $7^{\text {th }}$-grade students with disabilities performed the better, with 37 percent reaching the competent level, than did those in either $4^{\text {th }}$ grade, 27 percent, or in $11^{\text {th }}$ grade, 24 percent. Similar to the language arts and reading assessments, achievement gaps exist across the grades between noneconomically disadvantaged students and economically disadvantaged students (15-18 percentage points); white and African American students (10-11 percentage points); and white and Hispanic students (8-15 percentage points). 
Table QQ4. Performance of $4^{\text {th }}$, $7^{\text {th }}$ - and $1^{\text {th }}$ Graders on 2002 TCAP Writing Assessment, by Student Characteristics

\begin{tabular}{llcc}
\hline & $4^{\text {th }}$ Grade & $7^{\text {th }}$ Grade & $\mathbf{1 1}^{\text {th }}$ Grade \\
\cline { 2 - 4 } & \multicolumn{3}{c}{ Percentage Competent } \\
\hline All students & 72 & 82 & 70 \\
Students with disabilities & 27 & 37 & 24 \\
Students without disabilities & 77 & 88 & 74 \\
Economically disadvantaged students & 62 & 73 & 56 \\
Non-economically disadvantaged students & 79 & 88 & 74 \\
African American students & 64 & 74 & 62 \\
Hispanic students & 66 & 72 & 58 \\
White students & 74 & 85 & 73 \\
\hline
\end{tabular}

Source: http://www.state.tn.us/education/testing/o2tswastatewide.pdf

\section{School Performance}

School-level data by urbancity are available for the 2002 TCAP administration for grades 5 and 8 for reading and language arts (Table QQ5). Schools in Tennessee are relatively evenly distributed across rural, suburban, and urban area-36 percent of schools are located in rural areas, 34 percent in suburban areas, and 30 percent in urban areas. A much higher percentage of urban schools are high-poverty schools-31 percent-compared with 11 percent of rural schools and 5 percent of suburban schools.

In all grades and subjects, suburban schools had average test scores that were higher than those of students in rural schools (4-6-percentile-rank points) and substantially higher than those of urban schools (12-16-percentile-rank points). Given the distribution of these schools by poverty, these findings are not surprising.

Table QQ5. Average School Performance on $5^{\text {th- }}$ and $8^{\text {th-Grade } 2002 \text { TCAP }}$ Achievement Test Reading and Language Arts, by Urbanicity

\begin{tabular}{lcccc}
\hline & \multicolumn{2}{c}{$\mathbf{5}^{\text {th }}$ Grade } & \multicolumn{2}{c}{$\mathbf{8}^{\text {th }}$ Grade } \\
\cline { 2 - 5 } & \multicolumn{2}{c}{$\begin{array}{c}\text { Language } \\
\text { Arts }\end{array}$} \\
\cline { 2 - 5 } & \multicolumn{2}{c}{$\begin{array}{c}\text { Arts } \\
\text { Reading }\end{array}$} & $\begin{array}{c}\text { Reading } \\
\text { Average National Percentile Rank }\end{array}$ \\
\hline Rural schools & 55 & 55 & 54 & 58 \\
Suburban schools & 61 & 59 & 59 & 64 \\
Urban schools & 45 & 47 & 43 & 48 \\
\hline
\end{tabular}




\section{APPENDIX RR. TEXAS}

\section{State Assessment System}

The Texas Assessment of Knowledge and Skills (TAKS) was first administered in the 2002-03 school year. The TAKS is a new testing program that replaced the state's previous assessment program, the Texas Assessment of Academic Skills (TAAS). Grades and subjects are currently tested as follows:

- $\quad$ Grade 3 - Reading, Mathematics

- Grade 4-Reading, Writing, Mathematics

- Grade 5 - Reading, Mathematics, Science

- Grade 6 - Reading, Mathematics

- $\quad$ Grade 7 - Reading, Writing, Mathematics

- Grade 8 - Reading, Mathematics, Social Studies

- Grade 9 - Reading, Mathematics

- Grade 10 - English Language Arts (English language arts), Mathematics, Science, Social Studies

- Grade 11 - English Language Arts, Mathematics, Science, Social Studies

Spanish TAKS tests are administered for all subjects in grades 3 through 6 (for English-language learners).

The TAKS tests more of the Texas Essential Knowledge and Skills (TEKS), the state standards, than did the TASS (http://www.tea.state.tx.us/student.assessment/taks/booklets/index.html). Texas has developed TEKS in 18 subject areas, including English language arts and reading; mathematics; science; and social studies. The TEKS are grade-specific for $\mathrm{K}-8$ and are coursespecific at the high school level. Many of the TEKS student expectations are written in similar language from grade to grade, although the expected level of student performance increases across grades.

\section{Test Format and Content}

For the purposes of examining trends in adolescent literacy, the rest of the discussion will focus on the TAKS reading and English language arts tests administered in grades 4, 7, and 10 (additional information on the assessments can be found through http://www.tea.state.tx.us/student.assessment/taks/booklets/index.html). 
The TAKS reading assessments evaluate a subset of the TEKS, the state-mandated curriculum. The TEKS student expectations for the $3^{\text {rd- through }} 8^{\text {th }}$-grade TAKS reading assessments are grouped under four TAKS objectives:

- Objective 1: The student will demonstrate a basic understanding of culturally diverse written texts.

- Objective 2: The student will apply knowledge of literary elements to understand culturally diverse written texts.

- Objective 3: The student will use a variety of strategies to analyze culturally diverse written texts.

- Objective 4: The student will apply critical-thinking skills to analyze culturally diverse written texts.

The items on the fourth-grade and the seventh-grade reading tests are all multiple-choice, requiring students to demonstrate their mastery of each of the above objectives. Four kinds of reading selections are utilized by the TAKS: narrative selections, expository selections, mixed selections (combining two types of writing into a single passage), and paired selections (two selections to be read together). Word counts for the reading selections vary according to grade level. Selections for third and fourth grades are approximately 500 to 700 words, and selections for the middle grades (6th, 7 th, and $8^{\text {th }}$ grades) are approximately 700 to 1,000 words.

The fourth-grade and seventh-grade writing tests assess the following TEKS objectives:

- Objective 1: The student will, within a given context, produce an effective composition for a specific purpose.

- Objective 2: The student will produce a piece of writing that demonstrates a command of the conventions of spelling, capitalization, punctuation, grammar, usage, and sentence structure.

- Objective 3: The student will recognize appropriate organization of ideas in written text.

- Objective 4: The student will recognize correct and effective sentence construction in written text.

- Objective 5: The student will recognize standard usage and appropriate word choice in written text.

- Objective 6: The student will proofread for correct punctuation, capitalization, and spelling in written text.

The tests consist of a written composition and a revising and editing multiple-choice section. The first two objectives are assessed through the written composition, and the remaining objectives are assessed through the multiple-choice section. On that section, students read passages 
designed to resemble students' writing. Passages at fourth grade are approximately 175 to 225 words, while passages at seventh grade are 250 to 300 words in length.

At the high school level, the ninth-grade reading test, tenth-grade English language arts test, and eleventh-grade exit-level English language arts test all share the same TAKS objectives:

- Objective 1: The student will demonstrate a basic understanding of culturally diverse written texts.

- Objective 2: The student will demonstrate an understanding of the effects of literary elements and techniques in culturally diverse written texts.

- Objective 3: The student will demonstrate the ability to analyze and critically evaluate culturally diverse written texts and visual representations.

The three objectives are assessed through multiple-choice items based on a set of three thematically linked reading pieces, called a "triplet." The components of a triplet include the following: a published literary section, a published expository (informational) section, and a onepage viewing and representing piece. Objectives 2 and 3 are assessed through several shortanswer (open-ended) items. The short-answer items test two skills. Students must be able to generate clear, reasonable, thoughtful ideas or analyses about some aspect of the published literary and expository selections. They must also be able to support these ideas or analyses with relevant, strongly connected textual evidence. The open-ended items focus on the literary or expository pieces only.

The tenth-grade English language arts test also includes a writing component, which tests the following objectives:

- Objective 4: The student will, within a given context, produce an effective composition for a specific purpose.

- Objective 5: The student will produce a piece of writing that demonstrates a command of the conventions of spelling, capitalization, punctuation, grammar, usage, and sentence structure.

- Objective 6: The student will demonstrate the ability to revise and proofread to improve the clarity and effectiveness of a piece of writing.

Objectives 4 and 5 are assessed through students' response to a writing prompt, thematically linked to the triplet. To assess Objective 6, students read passages designed to represent student writing and respond to multiple-choice questions that require students to indicate how a particular sentence might be corrected or improved or how the organization of a paragraph might be improved. 


\section{Achievement-Level Definitions}

In November 2002, the State Board of Education adopted three performance standards for the TAKS: Commended Performance, Met Standard, and Did Not Meet Standard. Students scoring at or above the met standard level are considered to have met the requirements for academic performance under NCLB. However, the state is in the process of developing four achievement levels - exemplary, recognized, academically acceptable, and academically unacceptable/lowperforming, where academically acceptable will be considered having met the standard.

Because the new TAKS is, by design, more challenging than its predecessor, the TAAS, the state is phasing in the "met standard" level over three years. Thus, in 2002, the number of questions a student needs to correctly answer to have met the standard will be lower than the number of questions a student will need to get correct in 2005 to have met the standard (http://www.tea.state.tx.us/perfreport/aeis/2003/glossary.html).

\section{Performance Results}

\section{Student Performance}

Table RR1 reports performance data for all students, economically disadvantaged students, students with limited-English proficiency, and students from different racial/ethnic backgrounds ${ }^{65}$ on the $4^{\text {th- }}$ and $8^{\text {th }}$-grade reading TAKS, while Table RR2 presents $4^{\text {th- }}$ and $7^{\text {th }}$ grade student performance on writing TAKS, and Table RR3 presents student performance data on the $10^{\text {th }}$-grade English language arts TAKS.

Overall, 85-88 percent of students in grades 4 and 8 met the standard in reading, while 17-25 percent reached the commended achievement level. Special education students had fairly high pass rates: 64-79 percent reached the met standard level across both grades and subjects.

Students with limited-English proficiency had the lowest performance of the student groups-6569 percent met the standard in $4^{\text {th }}$-grade reading and writing, but only $43-47$ percent did so in the $7^{\text {th }}$ grade. The percentage of economically disadvantaged students meeting the standard was 5-6 percentage points below that of all students meeting the standard.

\footnotetext{
65 About 42 percent of students in Texas are Hispanic; 41 percent are white; 14 percent are African American; and 3 percent are Asian/Pacific Islander. About 45 percent of students are eligible for the free and reduced-price lunch program; 15 percent are in limited-English-proficiency programs; and 12 percent have Individual Education Programs (IEPs).
} 
Table RR1. Performance of $4^{\text {th- }}$ and $8^{\text {th }}$-Graders on 2003 Reading TAKS, by Student Characteristics

\begin{tabular}{|c|c|c|c|c|}
\hline & \multicolumn{2}{|c|}{$4^{\text {th }}$ Grade } & \multicolumn{2}{|c|}{$8^{\text {th }}$ Grade } \\
\hline & $\begin{array}{c}\text { Met } \\
\text { Standard } \\
\text { and above }\end{array}$ & $\begin{array}{l}\text { Commended } \\
\text { Performance }\end{array}$ & $\begin{array}{c}\text { Met } \\
\text { Standard } \\
\text { and above }\end{array}$ & $\begin{array}{l}\text { Commended } \\
\text { Performance }\end{array}$ \\
\hline & \multicolumn{4}{|c|}{ Percentage } \\
\hline All students & 85 & 17 & 88 & 25 \\
\hline Special education students & 79 & 11 & 71 & 8 \\
\hline $\begin{array}{l}\text { Students with limited- } \\
\text { English proficiency }\end{array}$ & 65 & 3 & 45 & 2 \\
\hline $\begin{array}{l}\text { Economically disadvantaged } \\
\text { students }\end{array}$ & 79 & 8 & 82 & 14 \\
\hline African American students & 76 & 8 & 82 & 13 \\
\hline Hispanic students & 80 & 9 & 83 & 15 \\
\hline White students & 93 & 27 & 94 & 37 \\
\hline
\end{tabular}

Table RR2. Performance of $4^{\text {th- }}$ and $7^{\text {th-Graders on }} 2003$ Writing TAKS, by Student Characteristics

\begin{tabular}{lcccc}
\hline & \multicolumn{2}{c}{$\mathbf{4}^{\text {th }}$ Grade } & \multicolumn{2}{c}{$7^{\text {th }}$ Grade } \\
\cline { 2 - 5 } & $\begin{array}{c}\text { Met } \\
\text { Standard } \\
\text { and above }\end{array}$ & $\begin{array}{c}\text { Met } \\
\text { Commended } \\
\text { Performance }\end{array}$ & $\begin{array}{c}\text { Standard } \\
\text { and above }\end{array}$ & $\begin{array}{c}\text { Commended } \\
\text { Performance }\end{array}$ \\
\cline { 2 - 5 } & \multicolumn{4}{c}{ Percentage } \\
\hline All students & 86 & 13 & 85 & 13 \\
Special education students & 76 & 6 & 64 & 3 \\
Students with limited- & 69 & 3 & 43 & 0 \\
$\quad$ English proficiency & 81 & 7 & 79 & 6 \\
Economically & & & & 6 \\
$\quad$ disadvantaged students & 80 & 6 & 80 & 6 \\
African American students & 83 & 8 & 80 & 7 \\
Hispanic students & 91 & 19 & 92 & 20 \\
White students & & & & \\
Source: www.tea.state.tx.us/student.assessment/reporting/results/swresults/taks/2003/index.html
\end{tabular}

Source: www.tea.state.tx.us/student.assessment/reporting/results/swresults/taks/2003/index.html

White students outperformed African American students by 11-15 percentage points and

Hispanic students by 12-13 percentage points across grades and subjects at the met standard

level; there are similar gaps at the commended level as well.

On the $10^{\text {th }}$-grade English language arts assessment, 72 percent of student met the standard and 3 percent obtained a score at the commended achievement level. The proportion of special education students meeting the standard was 32 percent, and the proportion of students with 
limited-English proficiency meeting the standard was 23 percent. None of these students scored at the commended achievement level.

Table RR3. Performance of $10^{\text {th }}-$ Graders on 2003 English Language Arts TAKS, by Student Characteristics

\begin{tabular}{lcc}
\hline & $\begin{array}{c}\text { Met Standard } \\
\text { and Above }\end{array}$ & $\begin{array}{c}\text { Commended } \\
\text { Performance }\end{array}$ \\
\cline { 2 - 3 } & \multicolumn{2}{c}{ Percentage } \\
\hline 10 $^{\text {th Grade }}$ & 72 & 5 \\
All students & 32 & 0 \\
Special education students & 23 & 0 \\
Students with limited-English proficiency & 61 & 2 \\
Economically disadvantaged students & 64 & 2 \\
African American students & 63 & 2 \\
Hispanic students & 80 & 8 \\
White students & \multicolumn{2}{c}{. } \\
\hline www.tea.state.tx.us/student.assessment/reporting/results/swresults/taks/2003/index.html
\end{tabular}

Economically disadvantaged students scored 11 percentage points below all students, and African American and Hispanic students scored 16-17 percentage points below white students.

Texas also reports statewide information on the average percentage of items that students answer correctly in the four reading objectives and writing objectives for grades 4 and 7 (Basic Understanding; Applying Knowledge of Literary Elements; Using Strategies to Analyze; and Applying Critical-Thinking Skills) (Table RR4). The performance results on the reading objectives show that both $4^{\text {th- }}$ and $7^{\text {th }}$-grade students perform worst on questions that ask them to apply their critical-thinking skills. This gap was larger at the $7^{\text {th }}$-grade level than it is at the $4^{\text {th }}$ grade level. In writing, $4^{\text {th }}$ and $7^{\text {th }}$-grade students had comparative difficulty with correct and effective sentence construction; however, $7^{\text {th }}$-grade students scored a bit lower on appropriate organization of ideas, as well.

\section{School Performance}

Because the TAKS was first administered in 2002-03, no school-level urbanicity data for 200102 were available. 
Table RR4. Performance of $4^{\text {th- }}$ and $7^{\text {th }}$-Graders, by TAKS Reading and Writing Objectives

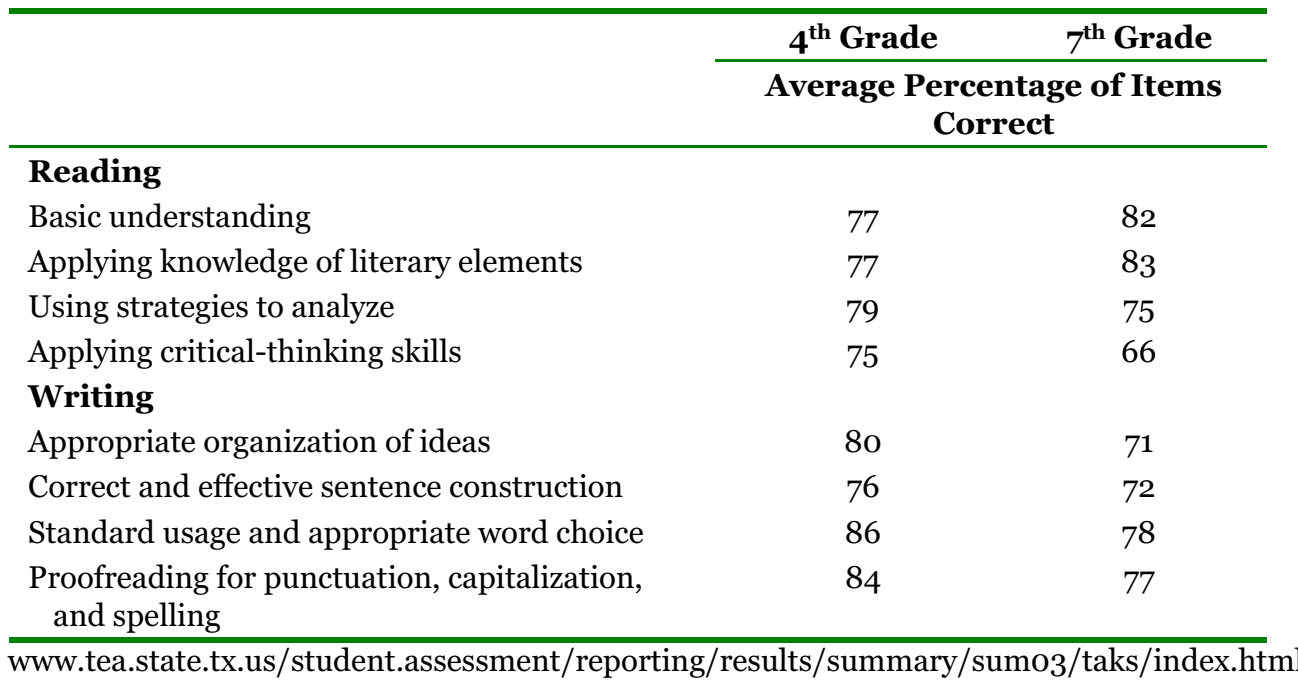





\section{APPENDIX SS. UTAH}

\section{State Assessment System}

The Utah Performance Assessment System for Students (U-PASS) consists of a number of state assessments, including:

- Core Assessment Criterion-Referenced Tests in reading/language arts for grades 1-11; mathematics for grades 1-10 (through geometry); and science for grades 4-11 (through biology).

- Reading Diagnostic Instruments (used in conjunction with CRTs to determine grade-level performance)

- $\quad$ Direct Writing Assessment (DWA) in grades 6 and 9

- A Norm-Referenced Achievement Test (currently the Stanford Achievement Test, 9th Edition) in reading, language arts, mathematics, science, and social studies in grades $3,5,8$, and 11.

- Utah Basic Skills Competency Test in reading, writing, and mathematics for high school. Beginning with the class of 2005, students must pass every section of the Basic Skills Competency Test, as well as complete all other graduation requirements, in order to receive a basic high school diploma. Tenth-graders will take the test for the first time in the spring of their tenth-grade year; however, students may retake sections they do not pass as many times as they need to.

The Core Assessment Criterion-Referenced Tests are designed to measure progress toward state content and performance standards and are used for school accountability purposes (for additional assessment information, see http://www.usoe.k12.ut.us/eval/). Utah has established content standards and objectives for many subjects including language arts, mathematics, social studies, science, and fine arts. For language arts, Utah has established grade-specific standards for grades 3-12. As an example, the objectives for grade 8 for the first reading content standardstudents use comprehension strategies before reading-are presented in Table SS1. 


\section{Table SS1. Students Use Comprehension Strategies Before Reading, Objectives for}

$8^{\text {th }}$ Grade

Establish a purpose prior to reading.

a. Read to learn.

b. Read for enjoyment.

c. Read to gather information for decisionmaking.

d. Read to perform a task.

Preview the text.

a. Identify the author's purpose.

b. Skim the text for general understanding.

c. Scan for specific information.

d. Determine text format by noting key features--e.g., headlines, captions, bold-faced print.

e. Choose strategies to suit identified purpose-e.g., functional, informational, literary. Activate and build upon prior knowledge.

a. Access and review prior knowledge of content.

b. Build interest or understanding by relating prior knowledge to the main topic.

Source: http://www.uen.org/core/core.do?courseNum=4080

\section{Test Format and Content}

For the purposes of examining trends in adolescent literacy, we now turn to discussing the Core Assessment Test in reading/language arts and the direct writing assessment.

The reading/language arts tests include multiple-choice and constructed-response questions and are untimed. The tests are constructed in a multiple-choice format. Passages at all grade levels include three types of reading: literary, informational, and functional.

The writing assessment requires students to write an essay in response to a writing prompt that focuses on a school or social issue of interest to students their age. There are separate topics for the sixth- and ninth-grade students, to address their different developmental levels. A writing checklist is provided to help students compose their response. The DWA is scored using a fivepoint analytic scoring rubric upon which student responses are scored along six writing traits: ideas and content, organization, voice, word choice, sentence fluency, and conventions (http://www.usoe.k12.ut.us/eval/SecondaryLA2003/default.dwt).

\section{Proficiency Levels}

The Core Assessment Criterion Referenced Test in reading/language arts has set four proficiency levels:

- Mastery. A student at this level is prepared to be successful at the next grade level (or sequential course) in this subject. 
- Near Mastery. A student at this level is prepared to be successful at the next grade level (or sequential course) in this subject, with some additional tutoring or practice with the few concepts or skills that have not been mastered.

- Partial Mastery. A student at this level may be prepared to be successful at the next grade level (or sequential course) in this subject, with significant and specific tutoring/remediation with the concepts or skills that have not been mastered.

- Minimal Mastery. A student at this level will not be prepared to be successful at the next grade level (or sequential course) in this subject without extensive intervention with most or all of the concepts or skills (http://www.usoe.k12.ut.us/eval/ UPASSLink/UPASSexplan.htm).

Students scoring at or above the Near Mastery level are considered to have met academic requirements under NCLB.

\section{Performance Results}

\section{Student Performance}

Student-level data by different student characteristics was not available for the Core CRTs, so Table SS2 presents performance data for all students on the reading/language arts assessment in grades 4,8 , and 10 for the 2002 administration. ${ }^{66}$ Eighty percent of $4^{\text {th }}$-grade students passed the reading/language arts assessment by scoring at or above the near mastery level, as did 62 percent of $8^{\text {th }}$-graders, and 74 percent of $10^{\text {th }}$-graders. The percentage of $8^{\text {th }}$-grade students scoring at the mastery level also was lower than in the other grades, 17 percent compared with 47 percent of $4^{\text {th-graders }}$ and 46 percent of $10^{\text {th }}$-graders.

\section{$\underline{\text { School Performance }}$}

No school-level data were available for the Core Assessment Criterion-Referenced Tests.

\footnotetext{
${ }^{66}$ Approximately 85 percent of students in Utah are white; 10 percent are Hispanic; and 3 percent are Asian/Pacific Islander. About 29 percent of students are eligible for the free and reduced-price lunch program; 9 percent are in limited-English-proficiency programs; and 11 percent have Individual Educational Programs (IEPs).
} 
Table SS2. Performance of $4^{\text {th-}}$, $8^{\text {th }}$-, and $10^{\text {th }}$-Graders on the 2002 Reading/Language Arts Core Assessment Criterion-Referenced Test

\begin{tabular}{lccc}
\hline & $\begin{array}{c}\text { Partial } \\
\text { Mastery } \\
\text { and } \\
\text { Above }\end{array}$ & $\begin{array}{c}\text { Near } \\
\text { Mastery } \\
\text { and } \\
\text { Above }\end{array}$ & Mastery \\
\cline { 2 - 4 } & 98 & Percentage \\
\hline $4^{\text {th }}$ Grade & 90 & 60 & 47 \\
$8^{\text {th }}$ Grade & 88 & 74 & 17 \\
$10^{\text {th }}$ Grade & \multicolumn{3}{|c}{46} \\
\hline
\end{tabular}

Source: http://www.usoe.k12.ut.us/eval/CRT/2002a/crt2002schoolsDBo01.HTM 


\section{APPENDIX TT. VERMONT}

\section{State Assessment System}

Established in 1996, the Vermont Comprehensive Assessment System (CAS) evaluates student performance in the state's schools, based on Vermont's Framework of Standards and Learning Opportunities. Statewide assessments include:

- Vermont Developmental Reading Assessment (DRA), administered in grade 2

- New Standards Reference Exams (NSRE) in English language arts and mathematics, administered in grades 4,8 , and 10

- VT-PASS (science assessment), administered in grades 5, 9, and 11.

Schools also assess student performance in additional subject areas and at additional grade levels, using portfolios (collections of student work), norm-referenced standardized tests, and locally developed assessments (http://www.state.vt.us/educ/new/html/pgm_assessment.html).

Vermont's Framework for Standards and Learning Opportunities provides a structure from which curriculum can be developed, organized, implemented, and assessed. Vermont has established standards for three grade ranges-PreK-4, 5-8, and 9-12-for the following subjects: communication (listening, expressing, reading, and writing), mathematics, personal development civic/social responsibility, arts, language, literacy, history and social sciences, mathematics, science, and technology. Table TT1 presents an example of standards for reading strategies.

\section{Table TT1. Standards for Learning Opportunities, Communications, Reading Strategies}

Students use a variety of strategies to help them read. This is evident when students use a combination of strategies including:

\begin{tabular}{|c|c|c|}
\hline PreK-4 & $5-8$ & 9-12 \\
\hline $\begin{array}{l}\text { - } \quad \text { Sounds, syllables, and letter } \\
\text { patterns (e.g. phonological, } \\
\text { phonic, and graphic } \\
\text { knowledge); } \\
\text { - } \quad \text { Syntax } \\
\text { - } \quad \text { Meaning in context } \\
\text { A range of cueing systems to } \\
\text { discover pronunciation and } \\
\text { meaning; } \\
\text { - Self-correcting when } \\
\text { subsequent reading } \\
\text { indicates an earlier miscue; } \\
\text { - } \quad \text { Puestioning; and } \\
\text { Prior knowledge of the topic } \\
\text { and sense of story. }\end{array}$ & 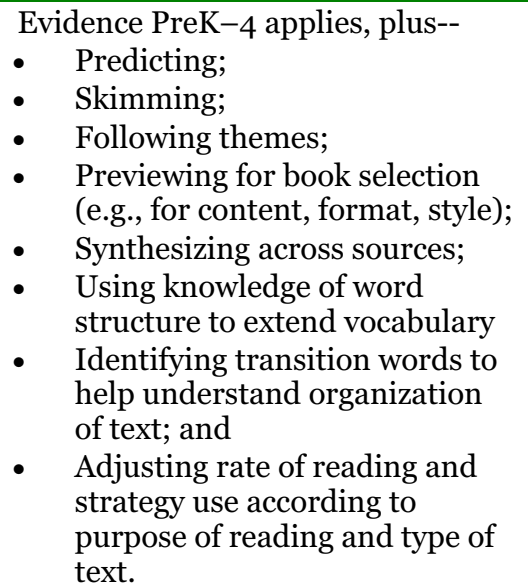 & $\begin{array}{l}\text { Evidence PreK-8 applies, plus-- } \\
\text { - } \quad \text { Using knowledge of word } \\
\text { origins and other resources } \\
\text { to extend vocabulary } \\
\text { development across all } \\
\text { content areas. }\end{array}$ \\
\hline
\end{tabular}

Source: http://www.state.vt.us/educ/new/html/pubs/framework.html 
To meet the new testing requirements under NCLB, in 2002, Vermont entered into the New England Compact with New Hampshire, Maine, and Rhode Island to work on cross-state collaborative initiatives. As part of the Compact's federally funded Enhanced Assessment project, Rhode Island, New Hampshire and Vermont have developed a set of common grade-level expectations (GLEs) - the Tri-State GLEs - that identify the content knowledge and skills expected of students for large-scale assessment. The GLEs will be reviewed for alignment with the states' own standards and for quality, and will be used as the basis for a new large-scale assessment to be developed collaboratively by the three states. A draft version of the GLEs and draft test specifications were posted on the Compact website in early 2004. The new assessment will be ready for statewide use in the 2005-06 school year (http://www.state.vt.us/educ/new/html/pgm_assessment.html).

\section{Test Format and Content}

To examine trends in adolescent literacy, the rest of the discussion will focus on the NSRE in English language arts for grades 4, 8, and 10. The NSRE includes multiple-choice, short-answer, extended-response, and essay items. Areas tested include the following:

- $\quad$ Reading: Basic Understanding: Students must demonstrate the ability to comprehend a variety of materials of varying length and complexity.

- Reading: Analysis and Interpretation: Students must demonstrate the ability to analyze and interpret what they read in the process of becoming critical readers.

- Writing Effectiveness: Students must demonstrate the ability to write effectively in a variety of formats for a variety of purposes, audiences, and contexts.

- Writing Conventions: Students must demonstrate control of the conventions (usage, spelling, and punctuation) of the English language according to current standards of correctness.

\section{Proficiency Levels}

Student scores on the NSRE are reported using five achievement levels:

- Achieved the Standard with Honors: A student who "Achieved the Standard with Honors" performs at a higher level than the standard on a consistent basis.

- Achieved the Standard: A student who "Achieved the Standard" performs at the level of the standard on a consistent basis.

- Nearly Achieved the Standard: A student who "Nearly Achieved the Standard" shows some evidence of performing at the level of the standard, but overall the performance does not consistently meet the standard. 
- Below the Standard. A student who is "Below the Standard" shows some attempt to respond, but the number of responses is minimal and, all too often, the responses are incomplete.

- Little Evidence of Achievement: A student who shows "Little Evidence of Achievement" shows almost no attempt to respond, as evidenced by numerous blank answers, entirely unsuccessful answers, and incomplete answers.

Students scoring at or above the Achieved the Standard level are considered to have met academic requirements under NCLB.

\section{Performance Results}

\section{Student Performance}

Table TT2 reports performance data disaggregated by special needs status and socioeconomic status on the reading NSRE, which includes an analysis score and a basic-understanding score. ${ }^{67}$ Due to the small percentages of racial/ethnic groups other than white students and the small percentage of students with limited-English proficiency, these scores are not reported.

In $4^{\text {th }}$ grade, 70 percent of students scored at or above the achieved the standard level, and 10 percent scored at the honors level in reading analysis. Students performed better on the reading basic understanding section, on which 81 percent of $4^{\text {th }}$-graders scored at or above the achieved the standard level and 23 percent scored at the honors level.

While students also scored higher on the basic understanding section in $8^{\text {th }}$ and $10^{\text {th }}$ grades, overall achievement on both reading sections was lower than that of $4^{\text {th }}$-grade students. For instance, 62 percent of $8^{\text {th }}$-graders and 54 percent of $10^{\text {th }}$-graders achieved the standard in reading basic understanding, and 36 percent of $8^{\text {th }}$-graders and 44 percent of $10^{\text {th }}$-graders did so in reading analysis.

Thirty-two percent of $4^{\text {th }}$-grade students with special needs achieved the standard in reading analysis, and 48 percent did so in reading basic understanding. These percentages were far lower in $8^{\text {th }}$ grade ( 6 percent and 24 percent, respectively) and $10^{\text {th }}$ grade ( 6 percent and 14 percent, respectively). The percentage of students with special needs scoring at or above the nearly achieving the standards level was lower in the higher-grade levels than in $4^{\text {th }}$ grade as well, particularly in reading analysis.

\footnotetext{
${ }^{67}$ Approximately 96 percent of students in Vermont are white; no other racial/ethnic group comprises 2 percent of the student population. About 24 percent are eligible for the free and reduced-price lunch program; 1 percent are in limited-English-proficiency programs; and 13 percent have Individual Education Programs (IEPs).
} 
Table TT2. Performance of $4^{\text {th }}$, $8^{\text {th }}$, and $10^{\text {th }}$-Graders on 2003 NSRE, English and Language Arts Reading Analysis and Basic Understanding NSRE, by Student

\section{Characteristics}

\begin{tabular}{|c|c|c|c|c|c|c|}
\hline & \multicolumn{3}{|c|}{ Reading: Analysis } & \multicolumn{3}{|c|}{ Reading: Basic Understanding } \\
\hline & $\begin{array}{c}\text { Nearly } \\
\text { Achieved } \\
\text { the } \\
\text { Standard } \\
\text { and Above }\end{array}$ & $\begin{array}{c}\text { Achieved } \\
\text { the } \\
\text { Standard } \\
\text { and Above }\end{array}$ & Honors & $\begin{array}{c}\text { Nearly } \\
\text { Achieved } \\
\text { the } \\
\text { Standard } \\
\text { and Above }\end{array}$ & $\begin{array}{c}\text { Achieved } \\
\text { the } \\
\text { Standard } \\
\text { and Above }\end{array}$ & Honors \\
\hline & \multicolumn{6}{|c|}{ Percentage } \\
\hline \multicolumn{7}{|l|}{$4^{\text {th }}$ Grade } \\
\hline All students & 93 & 70 & 10 & 92 & 81 & 23 \\
\hline Special needs students & 72 & 32 & 1 & 71 & 48 & 6 \\
\hline $\begin{array}{l}\text { Non-special needs } \\
\text { students }\end{array}$ & 95 & 74 & 11 & 94 & 84 & 25 \\
\hline $\begin{array}{l}\text { Economically } \\
\text { disadvantaged } \\
\text { students }\end{array}$ & 87 & 55 & 4 & 86 & 70 & 12 \\
\hline $\begin{array}{l}\text { Non-economically } \\
\text { disadvantaged } \\
\text { students }\end{array}$ & 95 & 77 & 12 & 94 & 85 & 28 \\
\hline \multicolumn{7}{|l|}{$8^{\text {th }}$ Grade } \\
\hline All students & 84 & 36 & 7 & 91 & 62 & 2 \\
\hline Special needs students & 46 & 6 & o & 67 & 24 & o \\
\hline $\begin{array}{l}\text { Non-special needs } \\
\text { students }\end{array}$ & 87 & 39 & 7 & 94 & 66 & 2 \\
\hline $\begin{array}{l}\text { Economically } \\
\text { disadvantaged } \\
\text { students }\end{array}$ & 70 & 20 & 3 & 84 & 46 & 1 \\
\hline $\begin{array}{l}\text { Non-economically } \\
\text { disadvantaged } \\
\text { students }\end{array}$ & 88 & 42 & 8 & 94 & 67 & 2 \\
\hline \multicolumn{7}{|l|}{ 10 $^{\text {th }}$ Grade } \\
\hline All students & 82 & 44 & 1 & 89 & 55 & 4 \\
\hline Special needs students & 38 & 6 & o & 60 & 14 & o \\
\hline $\begin{array}{l}\text { Non-special needs } \\
\text { students }\end{array}$ & 86 & 47 & 1 & 92 & 59 & 5 \\
\hline $\begin{array}{l}\text { Economically } \\
\text { disadvantaged } \\
\text { students }\end{array}$ & 68 & 24 & o & 81 & 36 & 1 \\
\hline $\begin{array}{l}\text { Non-economically } \\
\text { disadvantaged } \\
\text { students }\end{array}$ & 85 & 48 & 1 & 91 & 59 & 5 \\
\hline
\end{tabular}

Source: http://data.ed.state.vt.us/performance/o3/STATE_03.pdf 
Table TT3. Performance of $4^{\text {th- }}, 8^{\text {th-}}$, and $10^{\text {th }}$-Graders on 2003 English and Language Arts Writing Conventions and Effectiveness NSRE, by Student Characteristics

\begin{tabular}{|c|c|c|c|c|c|c|}
\hline & \multicolumn{3}{|c|}{ Writing Conventions } & \multicolumn{3}{|c|}{ Writing Effectiveness } \\
\hline & $\begin{array}{c}\text { Nearly } \\
\text { Achieved } \\
\text { the } \\
\text { Standard } \\
\text { and Above }\end{array}$ & $\begin{array}{l}\text { Achieved the } \\
\text { Standard } \\
\text { and Above }\end{array}$ & Honors & $\begin{array}{c}\text { Nearly } \\
\text { Achieved } \\
\text { the } \\
\text { Standard } \\
\text { and Above }\end{array}$ & $\begin{array}{c}\text { Achieved } \\
\text { the } \\
\text { Standard } \\
\text { and Above }\end{array}$ & Honors \\
\hline & \multicolumn{6}{|c|}{ Percentage } \\
\hline \multicolumn{7}{|l|}{$4^{\text {th }}$ Grade } \\
\hline All students & 74 & 63 & 4 & 77 & 60 & 3 \\
\hline Special needs students & 38 & 24 & o & 43 & 25 & o \\
\hline $\begin{array}{l}\text { Non-special needs } \\
\text { students }\end{array}$ & 77 & 66 & 5 & 80 & 63 & 4 \\
\hline $\begin{array}{l}\text { Economically } \\
\text { disadvantaged } \\
\text { students }\end{array}$ & 62 & 49 & 1 & 66 & 45 & 1 \\
\hline $\begin{array}{l}\text { Non-economically } \\
\text { disadvantaged } \\
\text { students }\end{array}$ & 78 & 68 & 6 & 81 & 66 & 4 \\
\hline \multicolumn{7}{|l|}{$8^{\text {th }}$ Grade } \\
\hline All students & 88 & 52 & 4 & 95 & 66 & 2 \\
\hline Special needs students & 53 & 12 & o & 78 & 25 & o \\
\hline $\begin{array}{l}\text { Non-special needs } \\
\text { students }\end{array}$ & 91 & 56 & 5 & 97 & 70 & 2 \\
\hline $\begin{array}{l}\text { Economically } \\
\text { disadvantaged } \\
\text { students }\end{array}$ & 78 & 35 & 2 & 91 & 49 & 1 \\
\hline $\begin{array}{l}\text { Non-economically } \\
\text { disadvantaged } \\
\text { students }\end{array}$ & 91 & 58 & 5 & 97 & 72 & 3 \\
\hline \multicolumn{7}{|l|}{$1^{\text {th }}$ Grade } \\
\hline All students & 94 & 77 & 24 & 87 & 43 & 5 \\
\hline Special needs students & 74 & 35 & 2 & 54 & 10 & o \\
\hline $\begin{array}{l}\text { Non-special needs } \\
\text { students }\end{array}$ & 96 & 81 & 26 & 90 & 47 & 5 \\
\hline $\begin{array}{l}\text { Economically } \\
\text { disadvantaged } \\
\text { students }\end{array}$ & 89 & 62 & 10 & 77 & 24 & 1 \\
\hline $\begin{array}{l}\text { Non-economically } \\
\text { disadvantaged } \\
\text { students }\end{array}$ & 95 & 80 & 27 & 89 & 47 & 5 \\
\hline
\end{tabular}


There was an achievement gap between non-economically disadvantaged students and economically disadvantaged students that ranged from 15-24 percentage points.

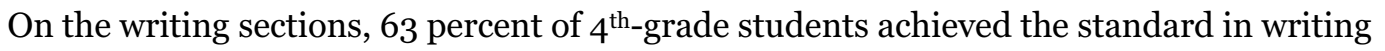
conventions and 60 percent achieved the standard in writing effectiveness. Few students scored at the honors level (3-4 percent). About one-fourth of students with special needs met the standard, and 38-43 percent scored at or above the nearly achieving standards level.

In $8^{\text {th }}$ grade, 52 percent of students achieved the standard in writing conventions and 66 percent did so in writing effectiveness. Students with special needs did better on writing effectiveness: 25 percent achieved the standard and 78 percent nearly achieved the standard, compared with 12 percent and 53 percent, respectively, on writing conventions.

Unlike $8^{\text {th }}$-graders, $10^{\text {th }}$-graders performed better in writing effectiveness than in writing conventions (77 percent compared with 43 percent at or above the achieved standards level). Students with special needs also scored better on writing conventions (35 percent achieved the standard, and 74 percent scored at or above the nearly achieved the standard level) than on writing effectiveness (10 percent achieved the standard, and 54 percent scored at or above the nearly achieved the standard level).

Similar to what we found in reading, there were large achievement gaps between economically disadvantaged students and their peers (19-21 percentage points in $4^{\text {th }}$ grade, 23 percentage points in $8^{\text {th }}$ grade, and $18-23$ percentage points in $10^{\text {th }}$ grade).

$\underline{\text { School Performance }}$

School-level data by urbanicity are available for the 2002 administration of the NSRE in reading and writing (Table TT4). The majority of schools in Vermont were rural (83 percent); 14 percent were suburban; and 3 percent were urban. While only 11 percent of schools in Vermont were high-poverty, urban schools were far more likely to be high-poverty than rural and suburban schools, 22 percent compared with 12 percent and 2 percent, respectively. Because of the small number of urban schools in the state (there were only nine in the entire state), we do not report school-level data for this group of schools. 
Table TT4. School Performance on $4^{\text {th- }}, 8^{\text {th }}$, and $10^{\text {th }}$-Grade 2002 English and Language Arts NSRE, by Urbanicity

\begin{tabular}{|c|c|c|c|c|}
\hline & \multicolumn{2}{|c|}{ Reading } & \multicolumn{2}{|c|}{ Writing } \\
\hline & Analysis & $\begin{array}{c}\text { Basic } \\
\text { Understanding }\end{array}$ & Conventions & Effectiveness \\
\hline & \multicolumn{4}{|c|}{ Average Percentage } \\
\hline \multicolumn{5}{|l|}{$4^{\text {th }}$ Grade } \\
\hline Rural schools & 67 & 80 & 59 & 55 \\
\hline Suburban schools & 74 & 84 & 65 & 63 \\
\hline Urban schools & $*$ & * & * & $*$ \\
\hline \multicolumn{5}{|l|}{$8^{\text {th }}$ Grade } \\
\hline Rural schools & 39 & 65 & 52 & 60 \\
\hline Suburban schools & 43 & 64 & 55 & 65 \\
\hline Urban schools & $*$ & * & $*$ & $*$ \\
\hline \multicolumn{5}{|l|}{$1^{\text {th }}$ Grade } \\
\hline Rural schools & 45 & 51 & 73 & 41 \\
\hline Suburban schools & 47 & 52 & 76 & 42 \\
\hline Urban schools & $*$ & $*$ & $*$ & $*$ \\
\hline
\end{tabular}

* Sample size too small to report.

In general, suburban schools outperformed rural schools; however, the differences among the average school scores were only $4-8$ percentage points at the $4^{\text {th }}$ grade, $1-5$ percentage points at the $8^{\text {th }}$ grade, and $1-3$ percentage points at the $10^{\text {th }}$ grade. 



\section{APPENDIX UU. VIRGINIA}

\section{State Assessment System}

Virginia's student assessment system consists of a number of tests, including the Stanford Achievement Test - 9 in grades 4, 6, and 9; the Literacy Passport Test, a basic-skills test that examines competence in reading, writing, and mathematics that students must pass in order to advance to the ninth grade or above and be awarded a regular or advanced diploma; and the Standards of Learning (SOL) tests, which are criterion-referenced tests Virginia developed to measure student progress in achieving the state standards. Students take the SOL tests in English, mathematics, science, and history/social science in grades 3, 5, and 8 and computer technology in grades 5 and 8. In addition, Virginia administers a number of end-of-course SOL tests at the high school level:

- English: reading, literature, and research, which measures performance on the 9-11 English SOLs; and writing

- Mathematics: Algebra I; Algebra II; and Geometry

- History/Social Science: World History to 1000 A.D. plus World Geography; World History from 1000 A.D. to Present plus World Geography; U. S. History; and World Geography

- Science: Earth Science; Biology; and Chemistry

- Computer technology.

SOL assessment scores are used for school accountability. In addition, the state requires that a student's test performance on the SOL tests for grades 3, 5 , and 8 be considered as one factor for determining whether a student should be retained in grade. For the SOL end-of-course tests, a student who takes the course must also take the test. Virginia does not require that schools use the end-of-course test performance data for promotion or retention decisions. The state allows but does not require that students' SOL test performance be considered in grading at the high school level. However, beginning with the graduating class of 2003-04, students need to pass a specific number of SOL tests in order to receive a standard or advanced studies diploma (http://www.pen.k12.va.us/VDOE/Parents/parentshandbook.pdf).

According to the state, the SOL test program is based on the revised 1995 Standards of Learning, which describe Virginia's expectations for student learning and achievement in grades $\mathrm{K}-12$ in English, mathematics, science, history/social science, technology, the fine arts, foreign language, health and physical education, and driver education. In English, mathematics, science, and history/social science, Virginia also provides a curriculum framework that details the specific knowledge and skills students must possess to meet the standards for these subjects. Standards 
for kindergarten through $8^{\text {th }}$ grade are organized in three related strands: oral language, reading, and writing. Standards for $9^{\text {th }}$ through $12^{\text {th }}$ grades are organized in four related strands: oral language, reading analysis, writing, and research. Table UU1 provides an example of English language arts standards for grade 8.

\section{Table UU1. English Language Arts Standards of Learning, $8^{\text {th }}$ Grade}

The eighth-grade student will learn and apply interviewing techniques. The student will demonstrate correct use of language, spelling, and mechanics by applying grammatical conventions in writing and speaking. The student will plan, draft, revise, and edit writing, with emphasis on exposition and persuasion. The student will apply reading and writing skills in all subjects, as well as respond critically to literature. The student will continue development of vocabulary, with attention to connotations and figurative language. The student will become a skillful interpreter of the persuasive strategies used in print and mass media. The student will continue to develop an appreciation for literature through a study of a wide variety of selections. The student will describe themes or inferred main ideas, interpret cause-effect relationships, and draw conclusions from a variety of literary and informational selections.

\section{Oral Language}

8.1 The student will use interviewing techniques to gain information:

a) Prepare and ask relevant questions for the interview.

b) Make notes of responses.

c) Compile and report responses.

d) Evaluate the effectiveness of the interview.

8.2 The student will develop and deliver oral presentations in groups and individually:

a) Choose topic and purpose appropriate to the audience.

b) Choose vocabulary and tone appropriate to the audience, topic, and purpose.

c) Use appropriate verbal and nonverbal presentation skills.

d) Respond to audience questions and comments.

e) Use grammatically correct language.

f) Critique oral presentations.

8.3 The student will analyze mass-media messages:

a) Evaluate the persuasive technique being used.

b) Describe the possible cause-effect relationships between mass-media coverage and public-opinion trends.

c) Evaluate sources, including advertisements, editorials, and feature stories, for relationships between intent and factual content.

\section{Reading}

8.4 The student will apply knowledge of word origins, derivations, inflections, analogies, and figurative language to extend vocabulary development:

a) Identify simile, metaphor, personification, hyperbole, and analogy.

b) Use context, structure, and connotations to determine meaning of words and phrases.

8.5 The student will read and analyze a variety of narrative and poetic forms.

a) Explain the use of symbols and figurative language.

b) Describe inferred main ideas or themes, using evidence from the text as support.

c) Describe how authors use characters, conflict, point of view, and tone to create meaning.

d) Compare and contrast the use of the poetic elements of word choice, dialogue, form, rhyme, rhythm, and voice.

e) Compare and contrast authors styles.

8.5 The student will read and analyze a variety of narrative and poetic forms:

a) Explain the use of symbols and figurative language.

b) Describe inferred main ideas or themes, using evidence from the text as support.

c) Describe how authors use characters, conflict, point of view, and tone to create meaning.

d) Compare and contrast the use of the poetic elements of word choice, dialogue, form, rhyme, rhythm, and voice. 
Table UU1. (cont)

e) Compare and contrast authors styles.

8.6 The student will read, comprehend, and analyze a variety of informational sources:

a) Draw on background knowledge and knowledge of text structure to understand selections.

b) Analyze the author's credentials, viewpoint, and impact.

c) Analyze the author's use of text structure and word choice.

d) Analyze details for relevance and accuracy.

e) Read and follow instructions to complete an assigned task.

f) Summarize and critique text.

g) Evaluate and synthesize information to apply in written and oral presentations.

h) Draw conclusions based on explicit and implied information.

i) Make inferences based on explicit and implied information.

Writing

8.7 The student will write in a variety of forms, including narrative, expository, persuasive, and informational:

a) Use prewriting strategies to generate and organize ideas.

b) Organize details to elaborate the central idea.

c) Select specific vocabulary and information.

d) Revise writing for word choice, sentence variety, and transitions among paragraphs.

e) Use available technology.

8.8 The student will edit writing for correct grammar, capitalization, punctuation, spelling, sentence structure, and paragraphing.

a) Use a variety of graphic organizers, including sentence diagrams, to analyze and improve sentence formation and paragraph structure.

b) Use and punctuate correctly varied sentence structures to include conjunctions and transition words.

c) Choose the correct case and number for pronouns in prepositional phrases with compound objects.

d) Maintain consistent verb tense across paragraphs.

e) Use comparative and superlative degrees in adverbs and adjectives.

Source: http://www.pen.k12.va.us/VDOE/Superintendent/Sols/2002/EnglishK-12.pdf

\section{Test Format and Content}

For the purposes of examining trends in adolescent literacy, the remainder of this section will focus on the English SOLs in grades 5 and 8 and the end-of-course English SOL that students take in high school. All of these English SOL tests consist of a reading, literature, and research section, and a writing section. Sections of the test are not timed (see

http://www.pen.k12.va.us/VDOE/Assessment/soltests/ for additional format and content information).

For the reading, literature, and research section, the tests consist of reading passages followed by multiple-choice questions. Tests include a variety of types of reading selections, including fiction, nonfiction, and poetry. Fiction selections may be contemporary fiction, historical fiction, folklore, science fiction, or mysteries. Nonfiction selections may be biographies, autobiographies, historyrelated articles, or science-related articles. On this section, four primary skills are assessed: use 
of word-analysis strategies; understanding a variety of printed materials; understanding elements of literature; and use of information from a variety of resource materials (Table UU2).. Use of word-analysis strategies is tested only at the fifth grade, and use of information from a variety of resource materials is tested only at the high school level. The eighth-grade test is split evenly between testing on understanding elements of literature and understanding a variety of printed materials.

Table UU2. Skills Tested in the English Standard of Learning Assessments, $5^{\text {th-}}$ 8 $^{\text {th-}}$, and High School Grades

\begin{tabular}{lccc}
\hline Skills & $\begin{array}{c}\mathbf{5}^{\text {th }} \\
\text { Grade }\end{array}$ & $\begin{array}{c}\mathbf{8}^{\text {th }} \\
\text { Grade }\end{array}$ & $\begin{array}{c}\text { High } \\
\text { School }\end{array}$ \\
\hline Use word-analysis strategies & $14 \%$ & NT & NT \\
Understand a variety of printed materials/resource materials. & $48 \%$ & $50 \%$ & $29 \%$ \\
Understand elements of literature. & $38 \%$ & $50 \%$ & $57 \%$ \\
Use information from a variety of resource materials & NT & NT & $14 \%$ \\
\hline
\end{tabular}

Source: http://www.pen.k12.va.us/VDOE/Assessment/soltests/english.html $\mathrm{NT}=$ not tested.

As part of the English language arts SOL in grades 5, 8, and high school, students take a two-part writing test. The first section of the test requires students to answer multiple-choice questions about a given writing sample; the second asks students to construct a writing sample in response to a given prompt. The papers are scored on a four-point rubric for three domains: composition; written expression (style); and usage/mechanics (http://www.pen.k12.va.us/VDOE/Instruction/English/writing/vasolwti.pdf).

\section{Proficiency Levels}

Virginia reports scores using three proficiency levels: advanced; passing; and not passing. Students scoring at or above the passing level are considered to have met the academic requirements under NCLB. Table UU3 presents the percentage of items students must get correct in order to pass or be considered advanced for the reading, literature, and research portion and the writing portion. The percentage correct needed to pass is a bit lower in $8^{\text {th }}$ grade and high school than it is in $5^{\text {th }}$ grade. 
Table UU3. Proficiency Levels for English SOL Assessment Sections, Grades 5, 8, and High School

\begin{tabular}{lcccc}
\hline & \multicolumn{2}{c}{$\begin{array}{c}\text { Reading/literature and } \\
\text { Research }\end{array}$} & \multicolumn{2}{c}{ Writing } \\
\cline { 2 - 5 } & Passing & Advanced & Passing & Advanced \\
\cline { 2 - 5 } & 67 & 93 & 73 & 93 \\
\hline Grade 5 & 64 & 88 & 68 & 93 \\
Grade 8 & 57 & 88 & 69 & 91 \\
High School & \multicolumn{4}{c}{ Percentage of Items Correct } \\
\hline
\end{tabular}

Source: http://www.pen.k12.va.us/VDOE/News/solpass.html

\section{Performance Results}

\section{Student Performance}

Virginia provides results for all students and for students disaggregated by race/ethnicity, disability, and limited-English proficiency. ${ }^{68}$ Table UU4 presents the results for the 2003 SOL reading and writing assessments given in grades 5 and 8 and at the end of grade in high school. The table shows the percentage of students who passed the test and those who scored at the advanced level.

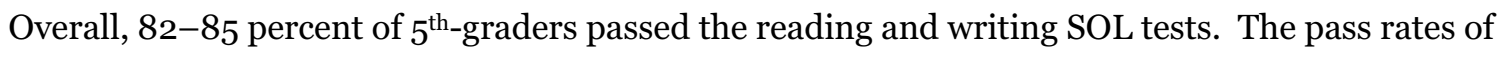

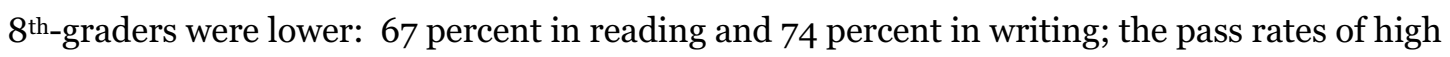
school students were higher: 91-93 percent. The percentage of students scoring at the advanced level in reading was higher in the higher grades, rising from 9 percent in grade 5 to 34 percent in

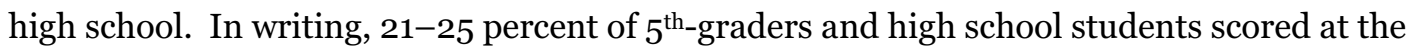
advanced level compared with 10 percent of $8^{\text {th }}$-graders.

The pass rates of students with limited-English proficiency were lower than those of all students in both reading and writing, but the gap was much higher in the $8^{\text {th }}$ grade. For example, $65^{-66}$ percent of limited-English-proficiency students in the $5^{\text {th }}$ grade passed the reading and writing tests compared with $82-85$ percent of all students. In the $8^{\text {th }}$ grade, the difference in pass rates increased to 32 percentage points in reading (35 percent versus 67 percent) and 26 percentage points in writing (48 percent versus 74 percent). At the high school level, the gap had narrowed to 13 percentage points in reading and 19 percentage points in writing.

\footnotetext{
68 Approximately 63 percent of students in Virginia are white; 27 percent are African American; 6 percent are Hispanic; and 4 percent are Asian/Pacific Islander. About 29 percent of students are eligible for the free and reduced-price lunch program; 4 percent are in limited-English-proficiency programs; and 14 percent have Individual Education Programs (IEPs).
} 
Students with disabilities scored below all students by 19-39 percentage points. For example, 28 percent of them passed the $8^{\text {th }}$-grade reading test compared with 67 percent of all students, and there was a similar gap in writing. However, the difference in passing rates was somewhat smaller at the $5^{\text {th }}$ and $11^{\text {th }}$ grades. Generally, the gap was larger in writing than in reading. Asian students' scores were very close to those of white students. For example, 88 percent of both these groups passed the $5^{\text {th }}$-grade reading test and 89-91 percent of them passed the writing test. Between 20 and 25 percent of Asian and white students scored at the advanced level in reading, and 26-30 percent of them did so in writing.

African American and Hispanic students trailed students from other racial/ethnic groups, especially in the lower grades. For example, the differences in pass rates of Hispanic and white students ranged from 15 to 26 percentage points in reading and 13 to 27 percentage points in writing in grades 5 and 8. The performance gap between African Americans and whites was slightly smaller (18-19 percentage points in reading and 14-23 percentage points in writing). However, by high school, the difference in passing rates was considerably reduced. For example, 83-85 percent of Hispanic and African American students passed the high school writing exam compared with 94 percent of white students. However, at the higher achievement level, there were still differences of 20-25 percentage points in reading and 17-21 percentage points in writing.

\section{$\underline{\text { School Performance }}$}

Table UU5 presents school-level data for urbanicity and school poverty (since they were not available at the student level) for the $20025^{\text {th- }}$ and $8^{\text {th }}$-grade reading and writing SOLs. 69 Approximately 49 percent of schools in Virginia were suburban; 27 percent were rural; and 24 percent were urban. About a quarter (26 percent) of Virginia schools were high-poverty schools. Almost half of urban schools (48 percent) were high-poverty schools, as were 35 percent of rural schools and only 10 percent of suburban schools.

On average, the proportion of students in high-poverty schools who passed the SOLs in both grades and subjects was 6-16 percentage points lower than that in low- and medium-poverty schools. The differences by urbanicity were a bit smaller-suburban schools outperformed urban schools by 6-10 percentage points, and rural schools by 7-8 percentage points.

\footnotetext{
69 High school scores were not available.
} 
Table UU4. Performance of $5^{\text {th }}$, $8^{\text {th }}$, and High School Grade Students on the 2003 English SOL Assessments, by Student Characteristics

\begin{tabular}{|c|c|c|c|c|}
\hline & \multicolumn{2}{|c|}{ Reading } & \multicolumn{2}{|c|}{ Writing } \\
\hline & $\begin{array}{l}\text { Passing and } \\
\text { Above }\end{array}$ & Advanced & $\begin{array}{l}\text { Passing and } \\
\text { Above }\end{array}$ & Advanced \\
\hline & \multicolumn{4}{|c|}{ Percentage } \\
\hline \multicolumn{5}{|l|}{$5^{\text {th }}$ Grade } \\
\hline All students & 82 & 9 & 85 & 21 \\
\hline Students with disabilities & 58 & 6 & 56 & 5 \\
\hline $\begin{array}{l}\text { Students with limited-English } \\
\text { proficiency }\end{array}$ & 65 & 5 & 66 & 8 \\
\hline African American students & 70 & 7 & 75 & 10 \\
\hline $\begin{array}{l}\text { Asian/Pacific Islander } \\
\text { students }\end{array}$ & 88 & 20 & 91 & 30 \\
\hline Hispanic students & 73 & 9 & 76 & 13 \\
\hline White students & 88 & 25 & 89 & 26 \\
\hline \multicolumn{5}{|l|}{$8^{\text {th }}$ Grade } \\
\hline All students & 67 & 16 & 74 & 10 \\
\hline Students with disabilities & 28 & 3 & 35 & 2 \\
\hline $\begin{array}{l}\text { Students with limited-English } \\
\text { proficiency }\end{array}$ & 35 & 3 & 48 & 2 \\
\hline African American students & 49 & 5 & 58 & 3 \\
\hline $\begin{array}{l}\text { Asian/Pacific Islander } \\
\text { students }\end{array}$ & 74 & 19 & 84 & 18 \\
\hline Hispanic students & 50 & 7 & 62 & 5 \\
\hline White students & 76 & 21 & 81 & 13 \\
\hline \multicolumn{5}{|l|}{ High School } \\
\hline All students & 93 & 34 & 91 & 25 \\
\hline Students with disabilities & 74 & 10 & 61 & 6 \\
\hline $\begin{array}{l}\text { Students with limited-English } \\
\text { proficiency }\end{array}$ & 80 & 9 & 72 & 5 \\
\hline African American students & 88 & 16 & 83 & 10 \\
\hline $\begin{array}{l}\text { Asian/Pacific Islander } \\
\text { students }\end{array}$ & 95 & 37 & 94 & 29 \\
\hline Hispanic students & 77 & 21 & 85 & 14 \\
\hline White students & 96 & 41 & 94 & 31 \\
\hline
\end{tabular}

Source: http://www.pen.k12.va.us/VDOE/src/SOLassessments.shtml 
Table UU5. Average School Performance on $5^{\text {th }}$ and $8^{\text {th }}$-Grade 2002 English SOL Assessments, by Urbanicity

\begin{tabular}{lcc}
\hline & Reading & Writing \\
\cline { 2 - 3 } & \multicolumn{2}{c}{ Average Passing Percentage } \\
\hline $\mathbf{5}^{\text {th }}$ Grade & 66 & 75 \\
High-poverty schools & 82 & 87 \\
Low- and medium-poverty schools & 74 & 79 \\
Rural schools & 81 & 86 \\
Suburban schools & 71 & 80 \\
Urban schools & & \\
$\mathbf{8}^{\text {th }}$ Grade & 54 & 58 \\
High-poverty schools & 60 & 74 \\
Low- and medium-poverty schools & 55 & 66 \\
Rural schools & 63 & 74 \\
Suburban schools & 57 & 65 \\
Urban schools & & \\
\hline
\end{tabular}




\section{APPENDIX VV. WASHINGTON}

\section{State Assessment System}

Washington State's assessment system consists of two state assessments. The Washington Assessment of Student Learning (WASL), a set of standards-based tests, is at the center of the program. The WASL tests students in mathematics, reading, and writing in grades 4,7 , and 10 and in science in grade 5 and 8.70 The state also administers a norm-referenced test (the ITBS or ITED) in reading/language arts and mathematics to students in grades 3, 6, and 9. However, most school districts also select and administer exams beyond those provided by the state. In addition to standardized tests, the state provides teachers with classroom-based assessments for use throughout the school year that can be tailored to the varying developmental needs and learning styles of students and enable teachers to measure student progress over time.

The WASL is used for school and district accountability. Beginning with the graduating class of 2006, the highest scale score and level achieved in each content area on the high school WASL will be displayed on a student's transcript. In addition, successful completion of the reading, writing, and mathematics assessments will become a statewide graduation requirement in 2008 (http://www.k12.wa.us/assessment/default.aspx).

The WASL is intended to measure achievement on the Essential Academic Learning Requirements (EALRs), which are Washington's content standards. Washington has developed EALRs for reading, writing, mathematics, science, communications, social studies, the arts, and health fitness. Table VV1 provides the EARLs for reading. The EARLs are further defined by grade-level expectations (GLEs) for each grade level for grades $\mathrm{K}-\mathbf{8}$ and for the 9-12 grade range. Table VV2 provides an example of the GLE for grade 7 for EARL 1.

\footnotetext{
${ }_{70}$ The grade-5 science assessment will be required in 2004-05. It was optional in 2003-04.
} 
Table VV1. Essential Academic Learning Requirements, Reading

1. The student understands and uses different skills and strategies to read:

1.1 Uses word recognition skills and strategies to read and comprehend text.

1.2 Uses vocabulary (word-meaning) strategies to comprehend text.

1.3 Builds vocabulary through wide reading.

1.4 Applies word-recognition skills and strategies to read fluently.

2. The student understands the meaning of what is read:

2.1 Demonstrates evidence of reading comprehension.

2.2 Understands and applies knowledge of text components to comprehend text.

2.3 Expands comprehension by analyzing, interpreting, and synthesizing information and ideas in literary and informational text.

2.4 Thinks critically and analyzes author's use of language, style, purpose, and perspective in informational and literary text.

3. The student reads different materials for a variety of purposes:

3.1 Reads to learn new information.

3.2 Reads to perform a task.

3.3 Reads for career application.

3.4 Reads for literary/narrative experience in a variety of genres.

4. The student sets goals and evaluates progress to improve reading:

4.1 Assesses reading strengths and need for improvement.

4.2 Develops interests and shares reading experiences.

Source: http://www.k12.wa.us/curriculumInstruct/reading/ealrs.aspx

Table VV2. $7^{\text {th }}$-Grade Expectations for EARL 1: The Student Understands and Uses Different Skills and Strategies to Read

Uses vocabulary (wordmeaning) strategies to comprehend text.

\section{Understands and applies dictionary skills and other reference skills:}

- Uses dictionaries, thesauruses, and glossaries to find or confirm word meanings, pronunciations, syllabication, synonyms, antonyms, parts of speech, and/or to clarify shades of meaning.

- Uses text evidence to verify meaning from reference source.

Applies a variety of strategies to comprehend words and ideas in complex text:

- Uses word origins to determine the meaning of unknown words.

- Uses abstract, derived root words, prefixes, and suffixes from Greek and Latin to analyze the meaning of complex words (e.g., expose, exposition).

- Uses structural analysis and concept-building vocabulary strategies to understand new words and concepts in informational/expository text and literary/narrative text.

- Uses prior knowledge, the text, context clues, and graphic features of text to predict, clarify, and/or expand word meanings and concepts.

- Self-corrects, re-reads, reads on, and/or slows down to gain meaning when encountering unknown words in literary/narrative and informational/expository text. 
Table VV2. (cont.)

Builds vocabulary through wide reading.
Understands and applies new vocabulary:

- Integrates new vocabulary from informational/expository text and literary/narrative text, including text from a variety of cultures and communities, into written and oral communication.

Understands and applies content/academic vocabulary critical to the meaning of the text.

- Identifies and defines content/academic vocabulary critical to the meaning of the text and uses that knowledge to interpret the text.

- Identifies words that have different meanings in different content areas and determines the correct meaning from the context (e.g., property in science or social studies).

- Selects, from multiple choices, the meanings of words or phrases identified in the text.

Uses new vocabulary in oral and written communication.

Applies word-recognition skills and strategies to read fluently.

\section{Applies fluency to enhance comprehension:}

- Reads aloud grade-level informational/expository text and literary/narrative text accurately, using appropriate pacing, phrasing, and expression.

- Reads aloud unpracticed grade-level text with fluency in a range of $145^{-}$ $155^{+}$words correct per minute.

\section{Applies different reading rates to match text.}

- Adjusts reading rate by speeding up or slowing down based on purpose (e.g., pleasure, informational reading, task-oriented reading), text level of difficulty, form, and style.

\section{Test Format and Content}

We now turn our focus to the reading and writing WASL assessments administered in grades 4, 7, and 10.

\section{Reading}

The WASL reading assessments incorporate three item types: selected response (multiple choice); short constructed response; and extended constructed response. For the three grades, approximately 50 percent of the total score comes from multiple-choice questions. None of the WASL assessments is timed. On every reading WASL, there are five passages: two literary passages, two informational passages, and one linked pair, comprising a literary passage and an informational passage (the pair counts as one passage due to its linked content). The passages vary in length; however, the total word count is about 1,500 words for $4^{\text {th }}$ grade, 2,200 words for $7^{\text {th }}$ grade, and 2,500 words for $10^{\text {th }}$ grade. Literary passages may be poems, stories, biographies, autobiographies, or literary essays. Informational passages may be textbook entries, informational essays, instructional tasks, charts, graphs, maps, and/or timelines. Each reading 
WASL typically includes a "science-like" passage and a "social studies-like" passage

(http://www.k12.wa.us/assessment/WASL/testspec.aspx).

\section{Writing}

The writing assessment administered in grades 4,7 , and 10 asks students to respond to two writing prompts. Students in grade 4 respond to a narrative and an expository prompt, while students in grades 7 and 10 respond to one expository prompt and one persuasive prompt. On each essay, students can earn four points for content, organization, and style and two points for convention, for a total of 12 possible points. Students must earn 9 points in order to meet the standard (http://www.k12.wa.us/assessment/

WASL/testspec.aspx).

\section{Proficiency Levels}

Washington set four achievement levels for the WASL assessments: above standard, met standard, below standard, and well below standard. Students scoring at or above the met standard level are considered to have met the academic requirements under NCLB.

\section{Performance Results}

\section{$\underline{\text { Student Performance }}$}

Washington reports student performance for all students and for students grouped by selected characteristics: special education status, limited-English proficiency, low income, and race/ethnicity. ${ }^{71}$ Table VV3 presents the results of the 2003 WASL Reading Assessment for students in grades 4,7 , and 10 , disaggregated by the above characteristics.

The discussion focuses on the percentage at or above the meeting the standard level. Two-thirds of $4^{\text {th }}$-grade students and 60 percent of $10^{\text {th }}$-graders met the standard compared with only 48 percent of students in grade 7. The proportion scoring above standard rose dramatically, from 19-24 percent in the lower grades to 43 percent in grade 10.

Students with limited-English proficiency trailed far behind all students with passing rates that were 41-48 percentage points lower than those of all students. For example, while 60 percent of $10^{\text {th }}$-graders met the standard, only 12 percent of limited-English-proficiency students were able

${ }^{71}$ Approximately 74 percent of students in Washington are white; 11 percent are Hispanic; 8 percent are Asian/Pacific Islander; and 5 percent are African American. About 31 percent are eligible for the free or reduced-price lunch program; 7 percent are in limited-English-proficiency programs; and 12 percent have Individual Education Programs (IEPs). 
to do so, and only 1-5 percent of them scored above the standard. There were equally large differences between the proficiency rates of special education students and all students, and the

Table VV3. Performance of $4^{\text {th-, }} 7^{\text {th-, }}$ and $10^{\text {th }}$-Graders on 2003 Reading WASL, by Student Characteristics

\begin{tabular}{|c|c|c|c|}
\hline & $\begin{array}{c}\text { Below } \\
\text { Standard } \\
\text { and } \\
\text { Above }\end{array}$ & $\begin{array}{c}\text { Met } \\
\text { Standard } \\
\text { and } \\
\text { Above }\end{array}$ & $\begin{array}{c}\text { Above } \\
\text { Standard }\end{array}$ \\
\hline & \multicolumn{3}{|c|}{ Percentage of Students } \\
\hline \multicolumn{4}{|l|}{$4^{\text {th }}$ Grade } \\
\hline All students & 92 & 67 & 24 \\
\hline Special education students & 70 & 31 & 7 \\
\hline Students with limited-English proficiency & 72 & 24 & 3 \\
\hline Low-income students & 88 & 52 & 14 \\
\hline African American students & 88 & 52 & 13 \\
\hline American Indian students & 87 & 52 & 12 \\
\hline Asian students & 94 & 68 & 26 \\
\hline Hispanic students & 82 & 41 & 9 \\
\hline White students & 94 & 73 & 28 \\
\hline \multicolumn{4}{|l|}{$7^{\text {th }}$ Grade } \\
\hline All students & 84 & 48 & 19 \\
\hline Special education students & 45 & 10 & 2 \\
\hline Students with limited-English proficiency & 42 & 7 & 1 \\
\hline Low-income students & 72 & 30 & 10 \\
\hline African American students & 73 & 28 & 8 \\
\hline American Indian students & 72 & 30 & 8 \\
\hline Asian students & 87 & 53 & 24 \\
\hline Hispanic students & 67 & 24 & 7 \\
\hline White students & 88 & 53 & 22 \\
\hline \multicolumn{4}{|l|}{ 10 $^{\text {th }}$ Grade } \\
\hline All students & 79 & 60 & 43 \\
\hline Special education students & 35 & 12 & 5 \\
\hline Students with limited-English proficiency & 36 & 12 & 5 \\
\hline Low-income students & 67 & 43 & 27 \\
\hline African American students & 61 & 37 & 21 \\
\hline American Indian students & 66 & 43 & 25 \\
\hline Asian students & 83 & 64 & 47 \\
\hline Hispanic students & 60 & 35 & 21 \\
\hline White students & 83 & 65 & 47 \\
\hline
\end{tabular}


difference increased across the grades, from 36 percentage points in grade 4 to 48 percentage points in grade 10. Low-income students also scored below all students, but the performance gap was smaller, 15-18 percentage points. For example, 30 percent of low-income students met the standard in grade 7 compared with 48 percent of all students.

Among the racial/ethnic groups, white and Asian students scored the highest and Hispanic students scored the lowest. About 68-73 percent of white and Asian students met the standard in grade 4, 53 percent in grade 7, and 64-65 percent in grade 10. The passing rate for Hispanic students was 41 percent in grade 4, 24 percent in grade 7 , and 35 percent in grade 10-29-32 percentage points below the passing rate of whites. The performance gap between African American and white students ranged from 21 percentage points in grade 4 to 28 percentage points in grade 10, somewhat smaller than the gap between Hispanic and white students. American Indian students ranked in the middle, with passing rates of 52 percent in grade 4,30 percent in grade 7, and 43 percent in grade 10. About 26-28 percent of white and Asian students scored above standard in grade 4, increasing to 47 percent in grade 10. The percentages of African American and Hispanic students who scored above standard were 14-19 percentage points lower in the lower grades and 26 percentage points lower in grade 10.

Table VV4 shows the percentage of students in grades 4, 7, and 10 on the 2003 WASL writing assessment that met the standard. Overall, between 54 and 61 percent of students passed the writing test, and these passing rates were, with one exception, generally lower than those on the reading test.

Table VV4. Performance of $4^{\text {th }}-, 7^{\text {th }}$, and $10^{\text {th }}$-Graders on 2003 Writing WASL, by Student Characteristics

\begin{tabular}{lccc}
\hline & $\mathbf{4}^{\text {th }}$ Grade & $7^{\text {th }}$ Grade & 10 $^{\text {th }}$ Grade \\
\cline { 2 - 4 } & \multicolumn{3}{c}{ Percentage } \\
\hline All students & 54 & 55 & 61 \\
Special education students & 24 & 12 & 12 \\
Students with limited-English proficiency & 22 & 15 & 11 \\
Low-income students & 41 & 37 & 45 \\
American Indian students & 37 & 35 & 41 \\
Asian students & 64 & 65 & 66 \\
African American students & 44 & 41 & 39 \\
Hispanic students & 34 & 33 & 34 \\
White students & 58 & 59 & 66 \\
\hline ce: http://reportcard.ospi.k12.wa.us/Reports/WASLTrend.aspx?\&schoolId=1\&reportLevel=State
\end{tabular}


Limited-English-proficiency and special education students had very low passing rates, comparable with those on the reading test. For example, the passing rate for limited-Englishproficiency students was 22 percent in grade 4, 15 percent in grade 7, and 11 percent in grade 10. The performance gap between these students and all students increased across the grades, from 32 percentage points in grade 4 to 50 percentage points in grade 10. Between $37-45$ percent of low-income students met the writing standard; the gap between their passing rates and those of all students was the largest in grade $7-18$ percentage points, compared with $13-16$ percentage points in the other grades.

Between 39 and 44 percent of African American students met the writing standard, as did 33-34 percent of Hispanic students and 35-41 percent of American Indian students. The rates were lower than the 58-66 percent passing rate of white and Asian students, and the performance gap ranged from 14-27 percentage points for African American students to 24-32 percent for Hispanic students.

\section{$\underline{\text { School Level Performance }}$}

School-level data by urbanicity are available for student performance on the 2002 WASL in reading and writing for $4^{\text {th }}, 7^{\text {th }}$, and $10^{\text {th }}$ grades (Tables VV5 and VV6). Approximately 54 percent of schools in Washington were suburban; 24 percent were rural; and 21 percent were urban. Urban schools and rural schools were significantly more likely to be high-poverty schools than suburban schools, 37 percent compared with 15 percent.

In reading and writing, suburban schools outperformed rural and urban schools (with one exception). For instance, on the $4^{\text {th }}$ - and $7^{\text {th }}$-grade reading WASL, the average performance of rural schools was 7-8 percentage points lower than that of suburban schools at the met standard level and an average of 4-7 percentage points lower at the above standard level. The gap between suburban schools and urban schools was smaller, an average 3-4 percentage points at the met standard level and $\mathrm{o}-3$ percentage points at the above standard level.

At the $10^{\text {th }}$-grade level in reading, schools performed at about the same level (1-2-percentagepoint difference at the met standard level); however, at the above standard level, the gap was quite large--30 percentage points between suburban and rural schools and 19 percentage points between suburban and urban schools. 
Table VV5. Average School Performance on $4^{\text {th }}-, 7^{\text {th }}$, and $10^{\text {th }}-$ Grade 2002 Reading WASL, by Urbanicity

\begin{tabular}{lcc}
\hline & $\begin{array}{c}\text { Met } \\
\text { Standard } \\
\text { and Above }\end{array}$ & $\begin{array}{c}\text { Above } \\
\text { Standard }\end{array}$ \\
\cline { 2 - 3 } Average Percentage \\
\hline $\mathbf{4}^{\text {th }}$ Grade & 60 & 22 \\
Rural schools & 68 & 29 \\
Suburban schools & 64 & 26 \\
Urban schools & & \\
$7^{\text {th }}$ Grade & 39 & 11 \\
Rural schools & 46 & 15 \\
Suburban schools & 43 & 15 \\
Urban schools & & \\
$\mathbf{1 0}^{\text {th }}$ Grade & 56 & 10 \\
Rural schools & 55 & 40 \\
Suburban schools & 53 & 39 \\
$\quad$ Urban schools & & \\
\hline
\end{tabular}

Table VV6. Average School Performance on $4^{\text {th-, }} 7^{\text {th-}}$, and $10^{\text {th }}-$ Grade 2002 Writing WASL, by Urbanicity

\begin{tabular}{lccc}
\hline & $\mathbf{4}^{\text {th }}$ Grade & $7^{\text {th }}$ Grade & $\mathbf{1 0}^{\text {th }}$ Grade \\
\cline { 2 - 4 } & Average Meeting Standard Percentage \\
\hline Rural schools & 41 & 47 & 48 \\
Suburban schools & 52 & 54 & 50 \\
Urban schools & 49 & 50 & 46 \\
\hline
\end{tabular}




\section{APPENDIX WW. WEST VIRGINIA}

\section{State Assessment System}

West Virginia's Statewide Assessment Program consists of a number of assessments. Included in the 2002-03 Statewide Assessment Program are the following:

- The Metropolitan Readiness Test (MRT) is used to evaluate the progress of students in kindergarten.

- The Stanford Achievement Test, Ninth Edition (SAT-9) in grades 1-11 in reading, mathematics, language, spelling, listening, study skills, science, and social studies. However, 2002-03 was the last administration of the SAT-9.

- A writing assessment in grades 4, 7, and 11.

- WESTEST, a criterion-referenced test in reading, mathematics, science, and social studies for students in grades 3-8 and 10. WESTEST was field-tested in spring 2003 and will be fully operational in spring 2004 (http://osa.k12.wv.us/index.html).

WESTEST was developed specifically to meet the requirements of NCLB and will be used for state and federal accountability. WESTEST is intended to measure student progress toward mastery of West Virginia's Content Standards and Objectives (CSOs). West Virginia has developed CSOs in 15 subject areas, including reading and language arts, mathematics, science, social studies, health, foreign languages, and technology. The CSOs are further defined by performance standards, which define indicators of levels of mastery. The three broad reading and language arts standards are

- Standard 1. Reading: Students will use skills to read for literacy experiences, read to inform, and read to perform a task by

○ identifying and using the dimensions of reading (phonemic awareness, phonics, background knowledge/vocabulary, high-frequency words/fluency, comprehension, writing, and motivation to read)

- employing a wide variety of literature in developing independent readers.

- Standard 2. Writing: Students will employ a wide range of writing strategies to communicate effectively for different purposes by developing the writing process; applying grammatical and mechanical properties in writing; and gathering and using information for research purposes.

- Standard 3. Listening, Speaking, and Viewing: Students will apply their use of spoken, written, and/or visual language to communicate with a variety of audiences and for different purposes. 
Table WW1 provides the grade-level expectations for the reading standard for $9^{\text {th }}$ grade, as an example.

\section{Table WW1. Reading Objectives for $9^{\text {th }}$ Grade}

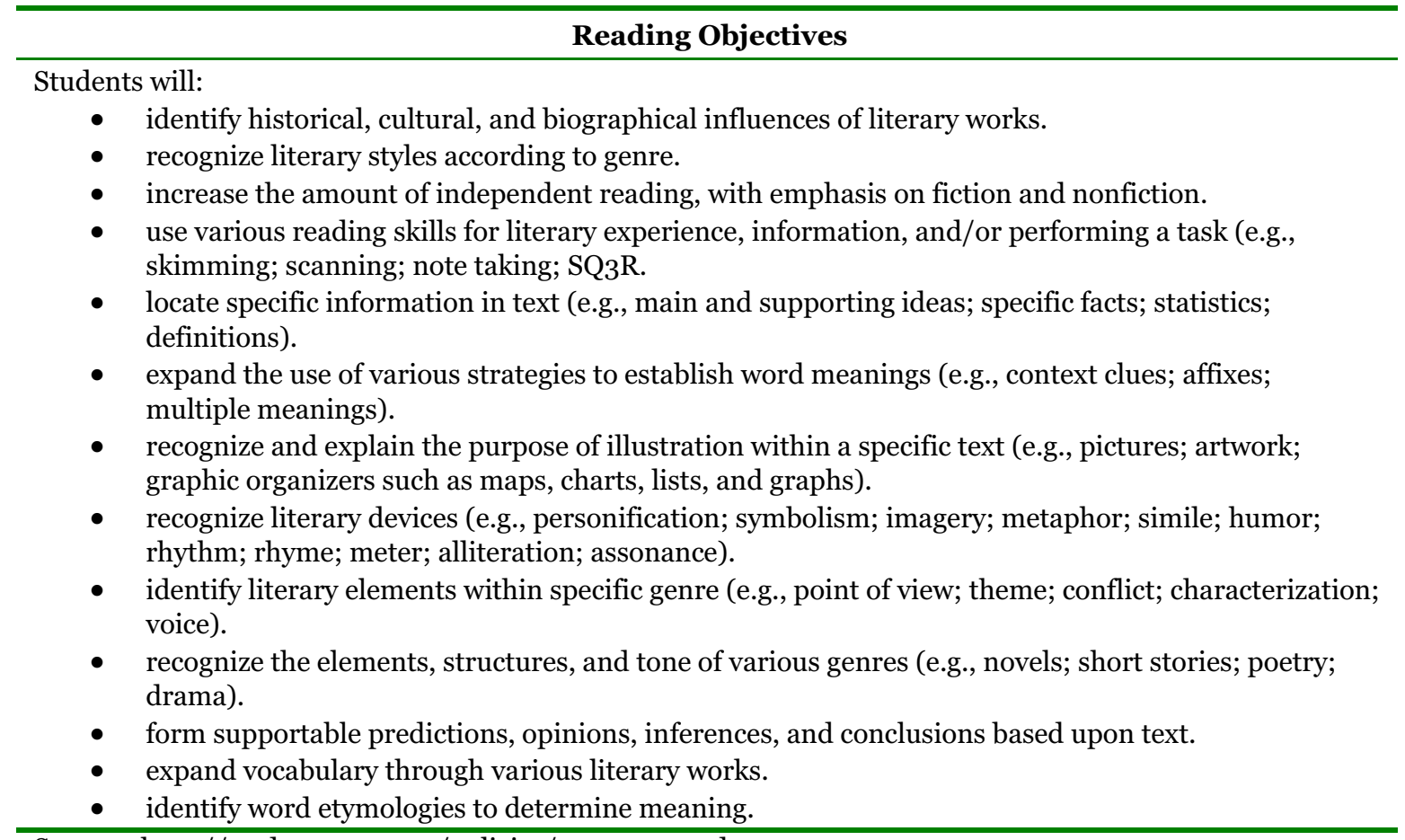

Source: http://wvde.state.wv.us/policies/p2520.1_ne.doc

\section{Test Format and Content}

We now turn to examine the test format and content of the WESTEST reading/language arts assessment 72 and the writing assessment.

WESTEST contains multiple-choice and short-answer/constructed-response items. The WESTEST reading/language arts test measures vocabulary, reading-comprehension skills for gaining information, performing tasks, and reading for literary experience. Additionally, the test measures writing skills to include language mechanics and language expression. About $35-40$ percent of the total reading/language arts score is from the writing section.

For the writing assessment, students in $4^{\text {th }}, 7^{\text {th }}$, and $10^{\text {th }}$ grades respond to a given prompt. Students in the $4^{\text {th }}$ grade write a first draft within a 60-minute period during the morning. Later in the morning, students are given another 60-minute period to edit, revise, and write a final

${ }^{72}$ While the SAT-9 was administered to students in 2003, we do not have data to report on this administration. As a result, we present information regarding the new state test that has been developed. 
draft. In grades 7 and 10, students are asked to plan, write, revise, edit, and proofread a first draft before writing a final draft within 60 minutes. A modified holistic scoring based on a 4-point rubric is used to judge the writing samples (http://westest.k12.wv.us/).

\section{Proficiency Levels}

West Virginia has defined five achievement levels for the WESTEST: distinguished, above mastery, mastery, partial mastery, and novice. Students scoring at or above the mastery level are considered to have met the academic requirements under NCLB.

\section{Performance Results}

In 2003, West Virginia did not report student scores by grade level. As a result, performance results are not reported. 



\section{APPENDIX XX. WISCONSIN}

\section{State Assessment System}

Wisconsin administers the Wisconsin Knowledge and Concepts Examination (WKCE) each year to students in grades 4,8 , and 10 . The assessment measures student achievement in reading, language arts, mathematics, science, and social studies. The WKCE is a commercially developed test (the TerraNova), which includes questions specifically developed for Wisconsin in order to improve coverage of Wisconsin's academic standards and to meet the requirements of NCLB. For the 2002-03 school year, Wisconsin administered the WKCE in late fall to ensure that the state could meet the reporting requirements for NCLB. To meet testing requirements under NCLB, Wisconsin will be expanding annual assessments in mathematics and reading to grades $3-8$. In addition, Wisconsin has developed a customized writing assessment that will be administered at grades 4, 8, and 10; it was included in the WKCE starting in the fall of 2002 (http://www.dpi.state.wi.us/dpi/oea/wsas_intro.html).

WKCE scores are used for school and district accountability. Further, WKCE scores are used as one of several criteria for advancing students from fourth to fifth grade and from eighth to ninth grade.

Wisconsin has developed academic standards for its tested content areas-English language arts, mathematics, science, and social studies-and for a number of subject areas, such as foreign languages, technology, business, and the arts. Academic standards specify what students should know and be able to do, what they might be asked to do to give evidence of standards, and how well they must perform. They include content, performance, and proficiency standards. Content standards refer to what students should know and be able to do; performance standards define how students will show that they are meeting a standard; and proficiency standards indicate how well students must perform. Wisconsin has established six major content areas for English language arts: reading and literature; writing; oral language; language; media and technology; and research and inquiry. Table XX1 provides an example of grade- 8 performance standards for reading/literature. 
Table XX1. Performance Standards for Reading and Literature, Grade 8

\section{By the end of $8^{\text {th }}$ grade, students will:}

Use effective reading strategies to achieve their purposes in reading:

- Use knowledge of sentence and word structure, word origins, visual images, and context clues to understand unfamiliar words and clarify passages of text

- Use knowledge of the visual features of texts, such as headings and boldface print, and structures of texts, such as chronology and cause and effect, as aids to comprehension

- Establish purposeful reading and writing habits by using texts to find information, gain understanding of diverse viewpoints, make decisions, and enjoy the experience of reading

- Select, summarize, paraphrase, analyze, and evaluate, orally and in writing, passages of texts chosen for specific purposes

Read, interpret, and critically analyze literature:

- Identify the defining features and structure of literary texts, such as conflict, representation of character, and point of view

- Analyze the effect of characters, plot, setting, language, topic, style, purpose, and point of view on the overall impact of literature

- Draw on a broad base of knowledge about the genres of literature, such as the structure and conventions of essays, epics, fables, myths, plays, poems, short stories, and novels, when interpreting the meaning of a literary work

- Develop criteria to evaluate literary merit and explain critical opinions about a text, either informally in conversation or formally in a well-organized speech or essay

Read and discuss literary and nonliterary texts in order to understand human experience.

- Provide interpretive responses, orally and in writing, to literary and nonliterary texts representing the diversity of American cultural heritage and cultures of the world

- Identify common historical, social, and cultural themes and issues in literary works and selected passages

- Draw on a broad base of knowledge about the themes, ideas, and insights found in classical literature while reading, interpreting, and reflecting on contemporary texts

- Evaluate the themes and main ideas of a work considering its audience and purpose

Read to acquire information:

- Interpret and use technical resources, such as charts, tables, travel schedules, timelines, and manuals

- Compare, contrast, and evaluate the relative accuracy and usefulness of information from different sources

- Identify and explain information, main ideas, and organization found in a variety of informational passages

- Distinguish between the facts found in documents, narratives, charts, maps, tables and other sources and the generalizations and interpretations that are drawn from them.

Source: http://www.dpi.state.wi.us/dpi/standards/elaa8.html

\section{Test Format and Content}

The remainder of this discussion focuses on the WKCE reading and writing assessments.

\section{Reading}

The reading WCKE is a version of the TerraNova that includes additional state-specific items.

Students respond to selected response and short constructed-response items

(http://www.dpi.state.wi.us/dpi/oea/kce.html). 


\section{Writing}

In the writing portion of the WKCE, students plan, write, and edit a composition on a specific topic within a specified time frame. Beginning in fall 2002, students' essays will be scored using anchor and training papers written by Wisconsin students under standardized testing conditions. The writing prompts that may be used on the WKCE include the following purposes and modes: expressive writing (narrative or descriptive); informative or expository writing; and persuasive writing. The writing sample is scored with two holistic rubrics. A six-point composing rubric evaluates students' ability to control purpose/focus, organization/coherence, development of content, sentence fluency, and word choice. A three-point conventions rubric evaluates students' ability to control punctuation, grammar, capitalization, and spelling. Points received on these two rubrics are combined to produce a single score, with a maximum of nine points possible. During the fall 2002 administration of the WKCE, the points earned on the impromptu essay at grade 10 were incorporated into the same scoring scale as all other points earned on the reading/language arts portion of the examination. At grades 4 and 8, however, the points earned on the impromptu essay were not incorporated into the same scoring scale as the other points on the reading and language arts assessment (http://www.dpi.state.wi.us/dpi/oea/kcwriting.html).

\section{Proficiency Levels}

Scores from the WKCE are reported using proficiency categories of advanced, proficient, basic, and minimal, based on standards for mastery of academic content. Scores in the advanced category show in-depth understanding in the academic content area tested. Proficient scores show evidence that students have the skills necessary to progress in the academic content area tested. Students who score in the basic category are considered somewhat competent, but their scores show evidence of at least one major flaw in understanding the academic content area tested. Scores that are in the minimal category indicate major misconceptions or gaps in the knowledge and skills tested (http://www.dpi.state.wi.us/dpi/oea/kce.html).

Wisconsin also further defines each achievement level by grade and subject. Table XX2 delineates the achievement levels for grade- 8 reading.

Students obtaining scores at or above the proficient level are considered to have met the academic requirements under NCLB. 
Table XX2. Achievement Levels for $8^{\text {th }}$-Grade Reading on WKCE

\begin{tabular}{|c|c|}
\hline $\begin{array}{l}\text { Proficiency } \\
\text { Level }\end{array}$ & WKCE Proficiency-Level Descriptions and Scale-Score Ranges \\
\hline $\begin{array}{l}\text { Advanced } \\
698 \text { and above }\end{array}$ & $\begin{array}{l}\text { Students at the Advanced level demonstrate in-depth understanding of academic } \\
\text { knowledge and skills tested on the WKCE by: } \\
\text { - extracting and organizing essential information from text } \\
\text { - interpreting and inferring from figurative and descriptive language } \\
\text { - interpreting, explaining, or comparing information in text and using text-based } \\
\text { information to support interpretations }\end{array}$ \\
\hline $\begin{array}{l}\text { Proficient } \\
654-697\end{array}$ & $\begin{array}{l}\text { Students at the Proficient level demonstrate competency in the academic knowledge } \\
\text { and skills tested on the WKCE by: } \\
\text { - interpreting and analyzing figurative and descriptive language } \\
\text { - interpreting idiomatic expressions } \\
\text { - making inferences or predictions based on information in a text } \\
\text { - analyzing plot structure in a narrative text } \\
\text { - demonstrating literal understanding of complex text by inferring, predicting, or } \\
\text { restructuring } \\
\text { - interpreting and explaining imagery in poetry } \\
\text { - interpreting informational text and identifying relationships among ideas } \\
\text { presented } \\
\text { - identifying essential information in technical or other informational text and } \\
\text { evaluating the usefulness of information in different sources } \\
\text { - analyzing characters in literary text by making inferences from text or } \\
\text { connections with prior knowledge } \\
\text { - drawing conclusions and making inferences from text information, including } \\
\text { cause-effect relationships } \\
\text { - using contextual information to understand text } \\
\text { - evaluating the appropriateness or likely effectiveness of reading strategies to aid } \\
\text { comprehension } \\
\text { - using prior knowledge and context clues to determine the meaning of words } \\
\text { used in grade-level reading passages }\end{array}$ \\
\hline $\begin{array}{l}\text { Basic } \\
633-653\end{array}$ & $\begin{array}{l}\text { Students at the Basic level demonstrate some academic knowledge and skills tested on } \\
\text { the WKCE by: } \\
\text { - using context clues to identify synonyms for familiar words and using context } \\
\text { clues to determine which word best completes a sentence } \\
\text { - using information in text to make inferences or draw conclusions } \\
\text { - reading and interpreting informational text, and using text features to aid } \\
\text { comprehension } \\
\text { - identifying the main idea of a text and recalling specific details } \\
\text { - understanding imagery used in poetry } \\
\text { - using contextual information to understand text } \\
\text { - organizing information in a text } \\
\text { - demonstrating literal understanding of complex text by recalling specific details }\end{array}$ \\
\hline $\begin{array}{l}\text { Minimal } \\
\text { Performance } \\
632 \text { and below }\end{array}$ & $\begin{array}{l}\text { Students at the Minimal Achievement level demonstrate very limited academic } \\
\text { knowledge and skills tested on the WKCE. }\end{array}$ \\
\hline
\end{tabular}




\section{Performance Results}

\section{$\underline{\text { Student Performance }}$}

Wisconsin reports scores on the reading and language arts assessments for students, disaggregated by several characteristics including English-proficiency status, disability status, race/ethnicity, and socioeconomic status.73 Table $\mathrm{XX}_{3}$ presents the results from the 2002-03 Reading and Language Arts WKCE assessment for various groups of students. The discussion that follows focuses on the percentages of students scoring at or above the proficient level.

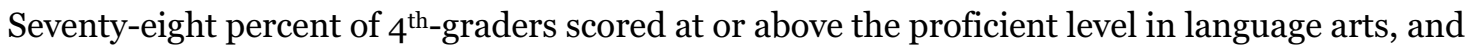
80 percent did so in language arts. While 83 percent of $8^{\text {th }}$-graders were at the proficient level in reading, only 62 percent of them scored at the proficient level in language arts. At the $10^{\text {th }}$ grade, 70-71 percent of students passed both the reading and language arts assessment by scoring at the proficient level. The percentages scoring at the advanced level were somewhat higher in reading than in language arts. For example, 39-40 percent of $4^{\text {th }}$ and $8^{\text {th }}$-graders and 52 percent 0 f $10^{\text {th }}$ graders were judged as advanced in reading, compared to 35 percent of $4^{\text {th-graders, } 20 \text { percent of }}$

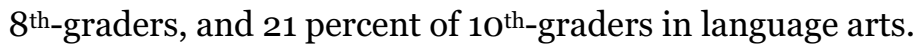

There were large differences in the pass rates of students with limited-English proficiency and English-proficient students. For example, $46-51$ percent of $4^{\text {th }}$-graders with limited-English proficiency were judged proficient compared with 79-82 percent of English-proficient studentsa difference of 31-33 percentage points. The performance gap between the two groups increased across the grades, and in the $10^{\text {th }}$ grade the difference in pass rates was between 53 and 54 percentage points. Very few of these students-between 1 and 9 percent-scored at the advanced level.

Not surprisingly, we find equally large or larger differences in proficiency levels of students with disabilities and students without disabilities, ranging from 44 to 54 percentage points in the two subjects. The proportion of students with disabilities who scored at the advanced level was between 2 and 12 percent.

\footnotetext{
73 Approximately 80 percent of students in Wisconsin are white; 10 percent are African American; 5 percent are Hispanic; and 3 percent are Asian/Pacific Islander. About 26 percent of students are eligible for the free and reduced-price lunch program; 3 percent are in limited-English-proficiency programs; and 14 percent have Individual Education Programs (IEPs).
} 
Table XX3. Performance of $4^{\text {th- }}, 8^{\text {th-}}$, and $1^{\text {th }}$-Graders on Fall $2002-03$ Reading and Language Arts WKCE, by Student Characteristics

\begin{tabular}{|c|c|c|c|c|c|c|}
\hline & \multicolumn{3}{|c|}{ Reading } & \multicolumn{3}{|c|}{ Language Arts } \\
\hline & $\begin{array}{l}\text { Basic } \\
\text { and } \\
\text { Above }\end{array}$ & $\begin{array}{l}\text { Proficient } \\
\text { and } \\
\text { Above }\end{array}$ & Advanced & $\begin{array}{l}\text { Basic } \\
\text { and } \\
\text { Above }\end{array}$ & $\begin{array}{c}\text { Proficient } \\
\text { and } \\
\text { Above }\end{array}$ & Advanced \\
\hline & \multicolumn{6}{|c|}{ Percentage } \\
\hline \multicolumn{7}{|l|}{$4^{\text {th }}$ Grade } \\
\hline All students & 92 & 80 & 40 & 93 & 78 & 35 \\
\hline Students with disabilities & 69 & 44 & 10 & 67 & 39 & 8 \\
\hline Nondisabled students & 96 & 86 & 45 & 97 & 84 & 39 \\
\hline $\begin{array}{l}\text { Students with limited- } \\
\text { English proficiency }\end{array}$ & 76 & 51 & 9 & 74 & 46 & 8 \\
\hline $\begin{array}{l}\text { English-proficient } \\
\text { students }\end{array}$ & 94 & 82 & 42 & 93 & 79 & 36 \\
\hline $\begin{array}{l}\text { Economically } \\
\text { disadvantaged } \\
\text { students }\end{array}$ & 87 & 67 & 22 & 86 & 62 & 18 \\
\hline $\begin{array}{l}\text { Non-economically } \\
\text { disadvantaged } \\
\text { students }\end{array}$ & 96 & 87 & 49 & 95 & 84 & 42 \\
\hline $\begin{array}{l}\text { African American } \\
\text { students }\end{array}$ & 85 & 61 & 17 & 82 & 54 & 14 \\
\hline $\begin{array}{l}\text { Asian/Pacific Islander } \\
\text { students }\end{array}$ & 90 & 69 & 22 & 91 & 67 & 22 \\
\hline Hispanic students & 81 & 62 & 19 & 79 & 57 & 17 \\
\hline White students & 95 & 86 & 47 & 95 & 83 & 40 \\
\hline \multicolumn{7}{|l|}{$8^{\text {th }}$ Grade } \\
\hline All students & 92 & 83 & 39 & 85 & 62 & 20 \\
\hline Students with disabilities & 65 & 43 & 6 & 47 & 16 & 2 \\
\hline $\begin{array}{l}\text { Students with limited- } \\
\text { English proficiency }\end{array}$ & 63 & 39 & 6 & 54 & 20 & 2 \\
\hline $\begin{array}{l}\text { English-proficient } \\
\text { students }\end{array}$ & 93 & 85 & 40 & 87 & 64 & 21 \\
\hline Nondisabled students & 97 & 90 & 44 & 92 & 70 & 23 \\
\hline $\begin{array}{l}\text { Economically } \\
\text { disadvantaged } \\
\text { students }\end{array}$ & 82 & 65 & 18 & 71 & 39 & 7 \\
\hline $\begin{array}{l}\text { Non-economically } \\
\text { disadvantaged } \\
\text { students }\end{array}$ & 96 & 90 & 46 & 91 & 71 & 25 \\
\hline $\begin{array}{l}\text { African American } \\
\text { students }\end{array}$ & 75 & 54 & 10 & 62 & 29 & 4 \\
\hline $\begin{array}{l}\text { Asian/Pacific Islander } \\
\text { students }\end{array}$ & 86 & 69 & 22 & 82 & 48 & 12 \\
\hline Hispanic students & 77 & 60 & 17 & 67 & 36 & 6 \\
\hline White students & 95 & 89 & 45 & 91 & 70 & 24 \\
\hline
\end{tabular}


Table XX3. (cont.)

\begin{tabular}{|c|c|c|c|c|c|c|}
\hline & \multicolumn{3}{|c|}{ Reading } & \multicolumn{3}{|c|}{ Language Arts } \\
\hline & $\begin{array}{l}\text { Basic } \\
\text { and } \\
\text { Above }\end{array}$ & $\begin{array}{l}\text { Proficient } \\
\text { and } \\
\text { Above }\end{array}$ & Advanced & $\begin{array}{l}\text { Basic } \\
\text { and } \\
\text { Above }\end{array}$ & $\begin{array}{l}\text { Proficient } \\
\text { and } \\
\text { Above }\end{array}$ & Advanced \\
\hline & \multicolumn{6}{|c|}{ Percentage } \\
\hline \multicolumn{7}{|l|}{$10^{\text {th }}$ Grade } \\
\hline All students & 85 & 71 & 52 & 88 & 70 & 21 \\
\hline Students with disabilities & 52 & 27 & 12 & 58 & 22 & 2 \\
\hline Nondisabled students & 91 & 78 & 58 & 91 & 76 & 23 \\
\hline $\begin{array}{l}\text { Students with limited- } \\
\text { English proficiency }\end{array}$ & 41 & 20 & 8 & 44 & 17 & 1 \\
\hline $\begin{array}{l}\text { English-proficient } \\
\text { students }\end{array}$ & 87 & 73 & 53 & 89 & 71 & 21 \\
\hline $\begin{array}{l}\text { Economically } \\
\text { disadvantaged } \\
\text { students }\end{array}$ & 71 & 50 & 30 & 73 & 46 & 7 \\
\hline $\begin{array}{l}\text { Non-economically } \\
\text { disadvantaged } \\
\text { students }\end{array}$ & 88 & 76 & 57 & 92 & 76 & 24 \\
\hline $\begin{array}{l}\text { African American } \\
\text { students }\end{array}$ & 60 & 36 & 19 & 62 & 34 & 4 \\
\hline $\begin{array}{l}\text { Asian/Pacific Islander } \\
\text { students }\end{array}$ & 77 & 55 & 36 & 80 & 52 & 11 \\
\hline Hispanic students & 64 & 45 & 27 & 66 & 42 & 7 \\
\hline White students & 91 & 78 & 58 & 92 & 76 & 24 \\
\hline
\end{tabular}

Source: http://www2.dpi.state.wi.us/wsas/statewkce.asp

Among racial/ethnic groups, white students scored the highest and African American students the lowest. Somewhat surprisingly, Asian students' scores (which in other states tended to be comparable with those of white students) were lower than those of white students in every grade and at both the proficient and advanced levels. For example, 67-69 percent of Asian students scored at the proficient level in the $4^{\text {th }}$ grade in reading and language arts compared with $83-86$ percent of white students. Twenty-two percent scored at the advanced level in the two subjects compared with 40-47 percent of white students. The differences ranged from 17-25 percentage points across the grades. The passing rates of African American and Hispanic students declined across the grades in reading, falling from $61-62$ percent in the $4^{\text {th }}$ grade to $36-45$ percent in the $10^{\text {th }}$ grade. The gap in the performance of African American and Hispanic and white students also increased, from 24-25 percentage points in the $4^{\text {th }}$ grade to $33^{-42}$ percentage points in the $10^{\text {th }}$ grade. This pattern held true in language arts as well. The proportions of African American and Hispanic students scoring at the advanced level were between 28 and 39 percentage points lower than those of white students in reading and 17-26 percentage points lower in language arts. 
Economically disadvantaged students trailed their more advantaged peers by 20-27 percentage points in the $4^{\text {th }}$ grade at the two achievement levels. However, at the $8^{\text {th }}$ grade, the differences in performance became even more marked at the proficient level, increasing to $32-35$ percentage points. At the $10^{\text {th }}$ grade, $46-50$ percent of economically disadvantaged students passed both assessments, compared with 76 percent of their counterparts.

\section{$\underline{\text { School Performance }}$}

School year 2002-03 was the first year the WKCE was administered; thus, we do not report school year 2001-02 school-level scores disaggregated by urbanicity for Wisconsin. 


\section{APPENDIX YY. WYOMING}

\section{State Assessment System}

The Wyoming Comprehensive Assessment System (WyCAS) tests students in the following grades and subjects:

- Grade 4-Reading, writing, and mathematics

- Grade 8-Reading, writing, and mathematics

- Grade 11-Reading, writing, and mathematics.

The WyCAS assessments are intended to measure student performance toward mastering state content standards. The English language arts (ELA) curriculum framework is based on a single standard in each of three content areas:

- Reading: Students use the reading process to demonstrate understanding of literary and informational texts.

- Writing: Students regularly use the writing process and use appropriate strategies to write a variety of expressive and expository pieces.

- Speaking and Listening: Students use listening and speaking skills for a variety of purposes and audiences.

The standards are further articulated by grade-level benchmarks and achievement-level descriptions, which define how well students must perform to meet those benchmarks in $\mathrm{K}-8$ and 11 (http://www.k12.wy.us/eqa/nca/pubs/standards/lang.pdf). Table YY1 presents the $8^{\text {th-grade }}$ benchmarks for reading, as an example.

\section{Test Format and Content}

For the purposes of examining what the WyCAS reveals about adolescent literacy, the rest of the discussion will focus on the reading and writing tests that students take in the spring in grades 4 , 8 , and 11.

The WyCAS contains two tests: the standards-based test developed specifically for the WyCAS program and the norm-referenced CTB TerraNova test. The standards-based tests include three reading sessions and two writing sessions; the TerraNova test includes one reading session.

There are eight possible tests forms, each including common items, matrix-sampling items, and field-test items. The reading test requires students to read a total of six passages: three common and three matrix-sampled passages. Students are given 50 minutes to answer 46 multiple-choice questions and 25 minutes to answer five constructed-response items. 
The writing test allocates 60-90 minutes and requires each student to respond to a total of two writing prompts. One prompt is common by grade, one prompt is matrix-sampled, and there are no field-test writing prompts.

\section{Table YY1. Reading Benchmarks, Grade 8}

I. Students use the reading process to apply a variety of comprehension strategies before, during, and after reading:

A. Students use word origins, context clues, and personal connections to develop vocabulary and understand grade-level-appropriate technical and subject-specific terms.

B. Students comprehend main idea and supporting details in grade-level-appropriate text.

C. Students use strategies, such as setting a purpose, predicting, cause and effect, comparing and contrasting, drawing conclusions, visualizing, and inferring, to interpret and analyze text.

II. Students read and interpret a variety of literary texts:

A. Students make inferences about events, setting, style, tone, mood, and meaning.

B. Students understand and identify significant literary elements, such as author's purpose and style, point of view, symbolism, dialect, figurative language (metaphor, simile, personification), flashback, foreshadowing, and common themes.

C. Students understand the historical, social, and cultural influences on literary works, such as how a text reflects the period ideas, customs, and outlook of a particular group of people in history.

III. Students read and demonstrate understanding of informational texts:

A. Students conduct research using multiple resources.

B. Students analyze data or make generalizations based on explicitly stated information.

C. Students support conclusions with facts and/or citations.

D. Students are familiar with a variety of informational texts modes, such as documentaries, essays, interviews, speeches, newspapers, and Internet Web sites.

E. Students summarize and paraphrase information in chronological, sequential, or logical order.

Source: http://www.k12.wy.us/eqa/nca/pubs/standards/lang.pdf).

\section{Achievement-Level Definitions}

Scores for the standards-based assessments are reported in terms of achievement levelsadvanced, proficient, partially proficient, and novice. Definitions for the reading levels are

- Advanced-Students demonstrate the ability to extend applications and connections beyond the obvious. These students understand complex ideas and are insightful. They make strong, complex, and sophisticated connections among a variety of texts and themselves, other texts, and the world. They cite extensive, appropriate evidence for their inferences.

- Proficient-Students demonstrate an accurate understanding of a variety of gradeappropriate texts. Their comprehension extends beyond the literal level. They make relevant connections among texts, themselves, and other sources. They support inferences with textual evidence. 
- Partially Proficient-Students demonstrate a better understanding of some types of texts than others. Comprehension is mostly at the literal level. They make some obvious personal connections.

- Novice-Students demonstrate minimal understanding of the text. They restate phrases from questions or text, making no connections or generalizations.

Definitions for the writing levels are

- Advanced-Students write with a clearly intended purpose and audience, successfully integrating voice and format. Their writing shows logical and sophisticated organization. Ideas are presented clearly and supported by specific and precise details. Sentence structure is varied and complex, the language is rich and engaging, and the writer uses sophisticated control of conventions.

- Proficient-Students write with an intended purpose and audience, with evidence of voice and format. Their writing shows logical organization. Ideas are supported with sufficient, relevant details. Sentence structure is varied and correct, language is effective throughout and the student demonstrates reasonable control of conventions.

- Partially Proficient-Students write with limited evidence of intended purpose and audience. Their writing shows some organization, with minimal awareness of voice. Ideas are evident, but supporting details may be minimal or irrelevant. Sentences have some variety, with few errors in structure. Word choice is generally correct, and the student demonstrates some control of conventions.

- Novice-Students write with an inconsistent development and focus. Their writing shows lack of awareness of purpose, audience, format, and/or voice.

Students scoring at or above the proficient level are considered to have met the academic requirements under NCLB.

\section{Performance Results}

\section{$\underline{\text { Student Performance }}$}

Table YY2 presents data on student performance, disaggregated by disability status, Englishproficiency status, and racial/ethnic groups for the $4^{\text {th }}$, $8^{\text {th }}$, and $11^{\text {th }}$-grade reading WyCAS.74

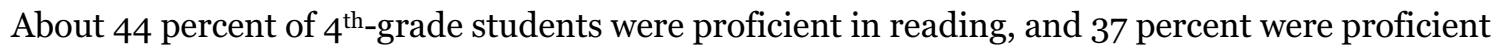
in writing. While results in reading were relatively similar in $8^{\text {th }}$ and $11^{\text {th }}$ grade (39 percent and 47

\footnotetext{
74Approximately 87 percent of students in Wyoming are white; 7 percent are Hispanic; and 3 percent are American Indian/Alaska Native. About 3 percent of students are in limited-English-proficiency programs, and 13 percent have Individual Education Programs (IEPs).
} 
percent, respectively), there was a much greater proportion of students at these grade levels that reached the proficient level in writing -48 percent in $8^{\text {th }}$ grade and 62 percent in $11^{\text {th }}$ grade.

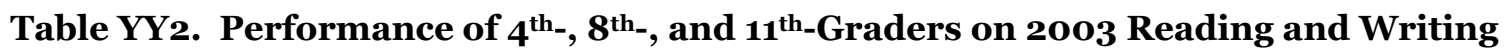
WyCAS, by Student Characteristics

\begin{tabular}{|c|c|c|}
\hline & Reading & Writing \\
\hline & \multicolumn{2}{|c|}{ Percentage Proficient and Above } \\
\hline \multicolumn{3}{|l|}{$4^{\text {th }}$ Grade } \\
\hline All students & 44 & 37 \\
\hline Students with disabilities & 13 & 9 \\
\hline Students with limited-English proficiency & 13 & 11 \\
\hline Economically disadvantaged students & 31 & 25 \\
\hline Non-economically disadvantaged students & 51 & 44 \\
\hline American Indian students & 18 & 12 \\
\hline Hispanic students & 30 & 30 \\
\hline White students & 47 & 39 \\
\hline \multicolumn{3}{|l|}{$8^{\text {th }}$ Grade } \\
\hline All students & 39 & 48 \\
\hline Students with disabilities & 5 & 7 \\
\hline Students with limited-English proficiency & 8 & 13 \\
\hline Students with English proficiency & 40 & 49 \\
\hline Economically disadvantaged students & 23 & 32 \\
\hline Non-economically disadvantaged students & 44 & 53 \\
\hline American Indian students & 15 & 22 \\
\hline Hispanic students & 23 & 31 \\
\hline White students & 42 & 52 \\
\hline \multicolumn{3}{|l|}{ 11 $^{\text {th }}$ Grade } \\
\hline All students & 47 & 62 \\
\hline Students with disabilities & 7 & 15 \\
\hline Students with limited-English proficiency & 15 & 36 \\
\hline Students with English proficiency & 47 & 62 \\
\hline Economically disadvantaged students & 31 & 47 \\
\hline Non-economically disadvantaged students & 49 & 64 \\
\hline American Indian students & 22 & 39 \\
\hline Hispanic students & 31 & 47 \\
\hline White students & 49 & 64 \\
\hline
\end{tabular}

Only a small percentage of students with disabilities reached the proficient level across grade levels and subjects -5 to 15 percent. In $4^{\text {th }}$ and $8^{\text {th }}$ grades, only a small proportion of students with limited-English, 8-13 percent, were proficient in reading or writing. In $11^{\text {th }}$ grade, reading 
results for this group of students were similar (15 percent proficient), but the percentage at the proficient level in writing was much larger-36 percent.

There were large achievement gaps between economically disadvantaged students and their peers, ranging from 17 to 21 percentage points. The achievement gap between white students and Hispanic students ranged from 9 to 21 percentage points across grades and subjects. The achievement gap between white students and Native American students was even larger-25-30 percentage points.

\section{$\underline{\text { School Performance }}$}

Data for school performance by urbanicity is available for the 2002 administration of the WyCAS (Table YY3). Approximately 76 percent of schools in Wyoming were rural; 16 percent were urban; and 8 percent were suburban. Twenty-six percent of urban and suburban schools were highpoverty schools, as were 12 percent of rural schools.

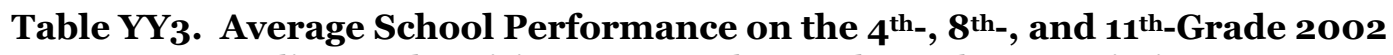
Reading and Writing WyCAS, by Student Characteristics

\begin{tabular}{lcccc}
\hline & \multicolumn{2}{c}{ Reading } & \multicolumn{2}{c}{ Writing } \\
\cline { 2 - 5 } & $\begin{array}{l}\text { Proficient } \\
\text { and Above }\end{array}$ & Advanced & $\begin{array}{c}\text { Proficient } \\
\text { and Above }\end{array}$ & Advanced \\
\cline { 2 - 5 } & \multicolumn{5}{c}{ Average Percentage } \\
\hline $\mathbf{4}^{\text {th }}$ Grade & 45 & 15 & 43 & 8 \\
Rural schools & 42 & 9 & 39 & 7 \\
Suburban schools & 42 & 13 & 45 & 8 \\
Urban schools & & & & \\
$\mathbf{8}^{\text {th }}$ Grade & 40 & 7 & 54 & 9 \\
Rural schools & $*$ & $*$ & $*$ & $*$ \\
Suburban schools & 43 & 8 & 53 & 11 \\
Urban schools & & & & \\
$\mathbf{1 1}^{\text {th }}$ Grade & 44 & 11 & 55 & 10 \\
Rural schools & $*$ & $*$ & $*$ & $*$ \\
Suburban schools & $*$ & $*$ & $*$ & $*$ \\
Urban schools & & & & \\
\hline resents a data point for which there are fewer than seven schools.
\end{tabular}

There were no consistent trends in the relative performance of rural and urban schools, when compared to one another. In some grades and subjects, rural schools outperformed urban schools; in others, urban schools outperformed rural schools, but all these differences were relatively small (o-3 percentage points). Suburban schools tended to perform a bit lower than 
rural and urban schools at the $4^{\text {th }}$-grade level. Because of the small number of suburban schools for grades 8 and 11, we do not report data for suburban schools at these grade levels. 